DANIELLE FERNANDA MORAIS DE MELO

COMPORTAMENTO REOLÓGICO DE SOLOS SUJEITOS A CORRIDAS DE LAMA POR LIQUEFAÇÃO ESTÁTICA 
DANIELLE FERNANDA MORAIS DE MELO

\section{COMPORTAMENTO REOLÓGICO DE SOLOS SUJEITOS A CORRIDAS DE LAMA POR LIQUEFAÇÃO ESTÁTICA}

Dissertação apresentada à Escola Politécnica da Universidade de São Paulo para obtenção do título de Mestre em Engenharia

Área de Concentração: Engenharia Geotécnica

Orientador: Prof. Dr. Marcos Massao Futai 
Autorizo a reprodução e divulgação total ou parcial deste trabalho, por qualquer meio convencional ou eletrônico, para fins de estudo e pesquisa, desde que citada a fonte.

Este exemplar foi revisado e corrigido em relação à versão original, sob responsabilidade única do autor e com a anuência de seu orientador.

São Paulo, de abril de 2014.

Assinatura do autor

Assinatura do orientador

Melo, Danielle Fernanda Morais de

Comportamento reológico de solos sujeitos a corridas de lama por liquefação estática / D.F.M. de Melo. -- versão corr. -São Paulo, 2014.

$253 \mathrm{p}$.

Dissertação (Mestrado) - Escola Politécnica da Universidade de São Paulo. Departamento de Engenharia de Estruturas e Geotécnica.

1.Solos (Comportamento) 2.Reologia 3.Liquefação estática 4.Corridas de lama I.Universidade de São Paulo. Escola Politécnica. Departamento de Engenharia de Estruturas e Geotécnica II.t. 
Dedico este trabalho aos meus pais e minha irmã, que sempre me apoiaram e estiveram ao meu lado e ao Marcos pelo amor e companheirismo. 


\section{AGRADECIMENTOS}

Agradeço a toda a minha família pelo apoio durante essa fase, especialmente:

Às minhas avós, Lourdes e Maria, que são minha inspiração para tudo na vida, por serem mulheres fortes que encaram a vida com coragem e sabedoria. Aos meus avôs, Laudegário (in memorian) e Aguinaldo, pelas histórias, pelos momentos de diversão e pelos ensinamentos.

Aos meus pais, Everaldo e Elzi, que sempre me incentivaram em todos os aspectos da minha vida, me encorajando, me apoiando e me ensinando a seguir sempre em frente. À minha irmã Denise, por estar do meu lado desde o dia em que nasci, minha eterna companheira, com quem sempre posso contar.

Ao meu noivo Marcos, por me apoiar nessa empreitada me dando paciência e esperança nas horas difíceis e de desespero, quando as previsões não eram boas, e principalmente por ser sempre meu companheiro.

Agradeço também ao meu orientador, Prof. Dr. Marcos Massao Futai, por todo apoio na elaboração desse trabalho, e antes até, durante meus últimos anos da graduação.

Aos demais professores do departamento de geotecnia da Escola Politécnica, com os quais tive a felicidade de conviver, principalmente aos professores Carlos Pinto, Nader, Cláudio Wolle, Maria Eugênia, Heloísa, Marinho, especialmente ao professor Waldemar Hachich que me encaminhou para a mecânica dos solos. Aos demais professores da Escola pela formação acadêmica.

Aos professores Vanderley Moacyr John e Rafael Pileggi por ceder à utilização dos equipamentos no Laboratório de Microestrutura. E principalmente ao César Romano por toda ajuda na utilização dos equipamentos reológicos.

Aos professores Cláudio Wolle e Rafael Pileggi pela participação na minha banca de qualificação, pelas correções e sugestões que enriqueceram esse trabalho.

Aos colegas da escola que, passando pela mesma situação são um consolo e um exemplo. Pelas risadas e também pelas conversas sérias agradeço aos colegas: 
Talita, Lia, Milagros, William, Veroska, Brian, Pedro, Letícia, Gonzalo e Normam. Obrigada pela convivência durante esses anos.

Agradecimento especial ao Lauro que sempre esteve disposto a ensinar e ajudar em qualquer assunto durante nosso convívio, principalmente pela ajuda na coleta das amostras no Rio de Janeiro.

Aos professores da UFRJ André Avelar e Ana Luísa Coelho, por me receberem no Rio de Janeiro e pelo suporte para a coleta das minhas amostras de solo.

Aos técnicos do LMS. Ao Antônio pela ajuda na realização de ensaios e pela paciência de sempre me explicar mais uma vez. Ao Joaquim pelas diversas conversas, sempre paciente para ouvir e com bons conselhos e ensinamentos de vida como resposta.

Por fim agradeço ao CNPq pelo auxílio financeiro e a Reageo pelo apoio na coleta das amostras em Nova Friburgo. 
Concede-me, Senhor, a serenidade necessária para aceitar as coisas que não posso modificar; coragem para modificar as que posso e sabedoria para distinguir a diferença. 
MELO, D. F. M. Comportamento reológico de solos sujeitos a corridas de lama por liquefação estática. 2014. 253p. Dissertação (Mestrado em Engenharia Geotécnica) - Escola Politécnica da Universidade de São Paulo, São Paulo, 2014.

\section{RESUMO}

Os escorregamentos causados por precipitação intensa ocasionam grandes prejuízos a cada estação chuvosa no sudeste brasileiro. Essa dissertação estudou 2 amostras de solos da região serrana do Rio de Janeiro sob uma nova ótica de análise para escorregamentos. As amostras foram coletadas 4 meses após a ocorrência do megadesastre, onde chuvas com precipitação de $325 \mathrm{~mm}$ em 48 horas causaram mais de 1500 mortes.

Em relatos e vídeos obtidos de movimentos de massa que ocorreram nesse evento foi possível observar que o solo apresentou comportamento de um líquido denso e viscoso, escoando pelas encostas da cidade, ou seja, o solo, encharcado pelas chuvas intensas que ocorreram na região, sofreu liquefação. Esse material viscoso formado pela mistura de solo+água que foi caracterizado através da utilização da reologia.

Para isso foram apresentados os conceitos da reologia e dos ensaios reométricos, e as possíveis aplicações para solos e na caracterização de corridas de lama. Foram utilizados três ensaios para caracterizar o solo no estado fluido, que foi o squeeze flow, o reômetro de torque com reometria planetária, e o reômetro de placas paralelas. O principal objetivo para utilização desses ensaios é a praticidade para realização dos ensaios, que tem como características: a rapidez na execução, a coleta de dados é realizada automaticamente, apresentam receptibilidade e a facilidade na execução.

Com os resultados obtidos foi possível observar a mudança de comportamento do solo (de um material com comportamento elástico para um material como um fluxo de lama) com a elevação da umidade, para os dois ensaios. Os resultados demonstram que o valor do limite de liquidez calculado através do aparelho de Casagrande é confirmado com esses novos aparelhos, 
sendo que, para esses aparelhos é visível a mudança de comportamento que define o limite de liquidez.

Através dos resultados também foi possível determinar que o solo em estado fluido tem seu comportamento regido pelo modelo de Herschel Bulkley.

Para tornar os resultados obtidos aplicáveis foi apresentado um capítulo ligando os resultados obtidos da reometria com a possibilidade do solo sofrer liquefação, aliado com os resultados obtidos dos ensaios de caracterização geotécnica. Sendo realizadas análises de estabilidade com os resultados obtidos, correlacionando a inclinação do talude, o nível d'água e a ocorrência da liquefação.

Palavras-chave: reometria de solos, liquefação estática, corridas de lama, reologia em solos. 
MELO, D. F. M. Rheological behavior of soils subjected to mudflow by static liquefaction. 2014. 253 p. Thesis (Master of Sciences in Geotechnical Engineering) - Polytechnic School, São Paulo University, São Paulo, Brazil, 2014.

\begin{abstract}
Landslide caused by rainfalls cause major damage each rainy season in southeastern Brazil. This dissertation studied two soil samples from the mountainous region of Rio de Janeiro in a new light analysis for landslides. Samples were collected four months after the occurrence of disaster, when rainfall with intensity of $325 \mathrm{~mm}$ in 48 hours caused more than 1,500 deaths .

In reports and video obtained from mass movements that occurred at this event was observed that the soil responded as a dense liquid, viscous draining the city's landscape. The drenched soil, by heavy rains that occurred in the region, suffered liquefaction. This viscous material formed by mixture of soil and water that was characterized by the use of rheology.

In this dissertation was presented the concepts of rheology and rheometric tests for application in soils and characterization of fluid movements.

Tree different rheometric tests were performed to characterize the soil in the fluid state, which was the squeeze flow, torque rheometer with planetary geometry and parallel plate rheometer. The main objective of these tests is to use the convenience for the tests, that presents the follow characteristics: the speed of execution, data collection is performed automatically and the testes present repeatability apart from ease of application.

With the results we observed the change of soil behavior (of a material with elastic properties for a material that presents the behavior as a mud flow) with increasing humidity for the tests. The results show that the value of the liquidity limit calculated by the Casagrande apparatus is confirmed with these new devices, furthermore with the use of these devices is visible the behavior change that defines the liquid limit.
\end{abstract}


Was determined that the Herschel Bulkley model is the one that best represents the behavior of the soil in the fluid state.

Was presented a chapter with an application of the results obtained by adding the results of the rheometer with the results of geotechnical characterization tests to determine the possibility of soil suffer liquefaction. To this aim, were performed stability analysis considering the results obtained, correlating the slope inclination, the water level and the occurrence of liquefaction.

Keywords: rheometry of soils, static liquefaction, mudflow, rheology in soils. 


\section{LISTA DE FIGURAS}

Figura 2.1 Solo em fluxo na Região Serrana do Rio de Janeiro (Youtube) 12

Figura 2.2 Mapa de Regiões Administrativas do RJ (http://mapasblog.blogspot.com.br)

Figura 2.3 Mapa Geológico Simplificado do Estado do Rio de Janeiro com destaque em Nova Friburgo (DMR - RJ, 2008) 15

Figura 2.4 Vista geral dos escorregamentos em Nova Friburgo (Google Earth) 16

Figura 2.5 Vista de deslizamentos ocorridos em Nova Friburgo (Reprodução/ TV Globo)

Figura 2.6 Foto do Bairro Caleme, Teresópolis, demonstrando os detritos transportados (Avelar, 2011)

Figura 2.7 Escorregamentos na Serra das Araras em 1967 (JONES, 1973) __ 18

Figura 2.8 Situação climática no evento (BAGGIO e HORN, 2011) _ 19

Figura 2.9 Precipitação da Estação de Teresópolis 83744 (INMET)_ 20

Figura 2.10 Localização da estação de dados de precipitação (INMET) __ 21

Figura 2.11 Intensidade de chuva em quatro estações nos dias 11 e 12 de janeiro de 2011 (Coelho Neto et al., 2011)

Figura 2.12 Evidência do aumento da densidade do fluxo, Teresópolis 14- jan (Avelar,

2011)

Figura 2.13 Lama escoando pela encosta mesmo após o cessar das chuvas (Youtube)

Figura 2.14 Movimento de solo em estado fluidificado, Santa Catarina, 2011 (Youtube)

Figura 3.1 Vista geral dos escorregamentos ocorridos na Itália e em Nova Friburgo ((a)

Cascini e Sorbino, 2003 e (b) Google Earth)

Figura 3.2 Perfil típico de Cervinara (Damiano e Olivares, 2010)

Figura 3.3 Estado de tensões na ruptura (a) taludes íngremes e (b) taludes muito íngremes (Olivares e Damiano, 2007)

Figura 3.4 Vista de escorregamentos (a) Cervinara (b) Monte Spina (Olivares e Damiano, 2007)

Figura 3.5 Possibilidades de resposta de solo granular (Olivares e Damiano, 2007)_32 Figura 3.6 Escorregamentos em Quindicu - correlação entre inclinação do talude e número de flowslides (Olivares e Damiano, 2007)

Figura 3.7 Fotografias de Nova Friburgo demonstrando os cortes realizados nas encostas

Figura 3.8 Mecanismo de Ruptura Saprólito (AVELAR et al., 2011)

Figura 3.9 Desenvolvimento da ruptura de talude de grandes dimensões 38

Figura 4.1.1 Faixas de distribuição granulométricas suscetíveis à liquefação (ISHIARA

et al., 1980) 42

Figura 4.1.2 Recomendações sobre avaliação de tipos de solo com potencial para sofrer liquefação (SEED et al., 2003)

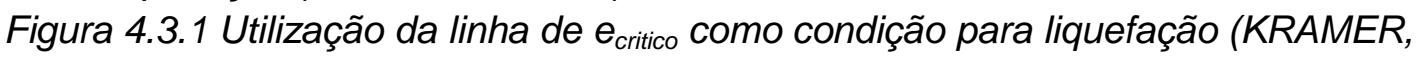
1996)

Figura 4.3.2 Linha de índice de vazios crítico e comportamento das amostras (KRAMER, 1996) 
Figura 4.3.3 Conceito de iniciação da ruptura por liquefação (KRAMER, 1996)__ 47

Figura 4.3.4 Zonas de suscetibilidade à liquefação (modificado de KRAMER, 1996) 48

Figura 5.1 Lama escoando da encosta no centro de Nova Friburgo (Youtube) __ 50

Figura 5.2 Experiência das placas paralelas___ 54

Figura 5.3 Definição de viscosidade baseada num fluxo laminar entre duas placas

paralelas de extensão infinita (VAN WAZER et al., 1966)__ 55

Figura 5.4 Tensão de escoamento estática e dinâmica (STEFFE, 1996)___ 59

Figura 5.5 Principais modelos reológicos de comportamento de fluxos (SETOR1, 2012)

Figura 5.6 Comportamento reológico dos fluidos (Pileggi, 2001) ___ 64

Figura 5.7 Exemplo de comportamento tixotrópico e reopético ___ 65

Figura 5.8 Instrumentos reométricos comuns (STEFFE, 1996) __ 69

Figura 5.9 Reômetro rotacional de torque __ 72

Figura 5.10 Exemplo de curva obtida no reômetro___ 73

Figura 5.11 Esquema representativo do ensaio de fluxo __ 74

Figura 5.12 Aparelho do ensaio de fluxo___ 75

Figura 5.13 Resultado típico de ensaio de squeeze flow __ 77

Figura 5.14 Suavização da curva obtida por squeeze flow (Cardoso, 2009) ___ 78

Figura 5.15 Procedimento geométrico para obtenção da tensão de escoamento para 0

squeeze flow (Betioli et al., 2009) _ 79

Figura 5.16 Fluxo entre placas lubrificadas e não lubrificadas (STEFFE, 1996)__ 79

Figura 5.17 Configurações das placas paralelas___ 81

Figura 5.18 Prensa utilizada nos ensaios de squeeze flow___ 84

Figura 5.19 Esquema seção transversal reômetro utilizado por Philipes e Davies

(1991) 88

Figura 5.20 Representação das amostras ensaiadas por Philips e Davies (1991)__ 89

Figura 5.21 Curvas médias de fluxo obtidas no reômetro de Philips e Davies (1991) 90

Figura 5.22 Resultado teórico e experimental obtido (Coussot et al., 1992)____ 91

Figura 5.23 Diagrama esboço do reômetro de cilindro coaxial (Coussot e Piau, 1994)

Figura 5.24 Distribuição granulométrica das amostras de debris flow ensaiadas

(Coussot e Piau, 1994)

92

Figura 5.25 Mistura entre água e debris flow para diferentes concentrações de sólidos:

curva de fluxo (Coussot e Piau, 1994)

Figura 5.26 Misturas argila-água (Cv=21,5\%): comparação das curvas de fluxo obtidas através de reômetro cone-placa e reômetro de grandes dimensões (Coussot e Piau, 1994)

Figura 5.27 Posição do fluido em duas fases do ensaio (a) após o início e (b) final do ensaio (COUSSOT e BOYER, 1995)

Figura 5.28 Comparação das curvas de cisalhamento obtidas nos reômetros com geometria de placas paralelas e cone - placa (COUSSOT e BOYER, 1995) 98

Figura 5.29 Erro relativo da tensão de escoamento obtida no plano inclinado (COUSSOT E BOYER, 1995)

Figura 5.30 Curvas de fluxo de quatro amostras intermediárias (Coussot et al., 1998)

Figura 5.31 Relação entre tensão de escoamento e concentração de sólidos (Coussot

et al., 1998) _ 100

Figura 5.32 Variação dos dados obtidos em campo e laboratório (Whipple, 1997) _ 101 
Figura 5.33 Reologia do debris flow de Black Canyon (Whipple, 1997) __ 102

Figura 5.34 Distribuição granulométrica da amostra (Melo et al., 2012)___ 103

Figura 5.35 Reômetro Rotacional utilizado por Melo et al. (2012) ___ 104

Figura 5.36 Programação do ensaio de reometria rotacional (Melo et al., 2012) __ 105

Figura 5.37 Resultado do ensaio de Reometria rotacional (Melo et al., 2012) ___ 105

Figura 5.38 Relação entre: (a) viscosidade aparente e (b) estimativa de torque de escoamento com a umidade (Melo et al., 2012) __ 106

Figura 5.39 Perfil obtido no ensaio de squeeze flow (Melo et al., 2012)___ 107

Figura 5.40 Relação entre umidade e carga em deformação constante (Melo et al., 2012)

Figura 5.41 Novos resultados de squeeze flow de Vila Albertina __ 109

Figura 5.42 Variação da tensão de escoamento com a umidade para Vila Albertina 110 Figura 5.43 Relação entre umidade e carga em deformação constante para Vila

Albertina

Figura 5.44 Aproximação por modelos dos dados obtidos por Melo et al. (2012), para a umidade de $25,7 \%$

Figura 5.45 Aproximação por modelos dos dados obtidos por Melo et al. (2012), para a umidade de $39,2 \%$

Figura 5.46 Aproximação por modelos dos dados obtidos por Melo et al. (2012), para a umidade de $57,8 \%$

Figura 5.47 Aproximação por modelos dos dados obtidos por Melo et al. (2012), para a umidade de $64,6 \%$

Figura 5.48 Variação da tensão de escoamento e do k coma umidade - Bingham 116

Figura 5.49 Variação da tensão de escoamento e do k coma umidade - HB 117

Figura 5.50 Variação da tensão de escoamento e do k coma umidade - HB modificado

Figura 5.51 Variação da tensão de escoamento para os modelos estudados 118

Figura 5.52 Taxa de deformação cisalhante $(N)$ versus esforço cisalhante $\left(G^{2}\right)$

(TAKAHASHI, 1991) 120

Figura 5.53 Relação da velocidade com a viscosidade na corrida do Papagaio segundo o modelo de Johnson (1970) (MACIAS et al., 1997)

Figura 5.54 Relação da velocidade com a viscosidade na corrida do Quitite segundo o modelo de Johnson (1970) (MACIAS et al., 1997) ___ 123

Figura 6.1 Diversos escorregamentos observados na rodovia RJ-130_ 125

Figura 6.2 Solos predominantes nos escorregamentos (a) residual e (b) colúvio_ 126

Figura 6.3 Procedimento de retirada de amostra indeformada - solo residual __ 127

Figura 6.4 Amostragem do segundo bloco indeformado - colúvio ___ 128

Figura 6.5 Localização dos pontos de coleta de amostra___ 128

Figura 6.6 Distribuição granulométrica das amostras ___ 129

Figura 6.7 Prensa e componentes para o ensaio de cisalhamento direto___ 131

Figura 6.8 Recalque durante o ensaio de cisalhamento - Solo Residual___ 132

Figura 6.9 Tensão de cisalhamento obtida no ensaio - Solo Residual____ 132

Figura 6.10 Recalque durante o ensaio de cisalhamento - Colúvio ___ 132

Figura 6.11 Tensão de cisalhamento obtida no ensaio - Colúvio ___ 133

Figura 6.12 Resultado gráfico ensaio de cisalhamento___ 133

Figura 6.13 Comparação dos resultados obtidos com os de Avelar et al (2011) _ 134

Figura 6.14 Corpos de prova: (a) residual e (b) colúvio __ 134 
Figura 6.15 Umidade das amostras utilizadas em (a) o Solo Residual e em (b) o Colúvio

Figura 6.16 Diagrama com apresentação das amostras

Figura 6.17 Esquema do ensaio no reômetro rotacional de torque____ 137

Figura 6.18 Ciclo de velocidade utilizado no reômetro rotacional____ 138

Figura 6.19 Apresentação das amostras de Solo Residual com diferentes umidades

Figura 6.20 Apresentação das amostras do colúvio

Figura 6.21 Resultado obtido no reômetro de torque para o Solo Residual 139

Figura 6.22 Resultado obtido no reômetro de torque para o Colúvio 140

Figura 6.23 Aproximação de região do gráfico do resultado obtido no reômetro de torque para o Colúvio

Figura 6.24 Variação da estimativa da viscosidade em relação à rotação para o Solo

Residual

Figura 6.25 Variação da estimativa da viscosidade em relação à rotação para 0 Colúvio

Figura 6.26 Resultado obtido para o solo Residual

Figura 6.27 Resultado obtido para o Colúvio 144

Figura 6.28 Posicionamento da AR 550 para ensaio

Figura 6.29 Procedimento de posicionamento da amostra para ensaio ___ 145

Figura 6.30 Esquema ensaio de reometria com placas paralelas___ 146

Figura 6.31 Curva de fluxo - Solo Residual - Ciclo $1 \_147$

Figura 6.32 Corpo de prova pronto para ser ensaiado ___ 149

Figura 6.33 Resultado do squeeze flow realizado em $0,1 \mathrm{~mm} / \mathrm{s}$ para o Solo Residual

Figura 6.34 Resultado do squeeze flow realizado em $3,0 \mathrm{~mm} / \mathrm{s}$ para o Solo Residual

Figura 6.35 Fotos do ensaio squeeze flow - Solo Residual ___ 151

Figura 6.36 Resultado do squeeze flow realizado em 0,1 mm/s para o Colúvio__ 152

Figura 6.37 Resultado do squeeze flow realizado em 3,0 mm/s para o Colúvio__ 152

Figura 6.38 Fotos do ensaio squeeze flow - Colúvio___ 153

Figura 7.1 GP - Colúvio - Aproximação por Bingham - w =64,3\% 155

Figura 7.2 GP - Residual - Aproximação por Bingham - $w=42,3 \%$

Figura 7.3 Variação dos parâmetros com a umidade - Bingham Colúvio___ 157

Figura 7.4 Variação dos parâmetros com a umidade - Bingham Residual___ 157

Figura 7.5 GP - Colúvio - Aproximação por Herschel Bulkley - w =64,3\%__ 158

Figura 7.6 GP - Residual - Aproximação por Herschel Bulkley - w = 42,3\%__ 159

Figura 7.7 Variação dos parâmetros com a umidade - HB Colúvio ___ 160

Figura 7.8 Variação dos parâmetros com a umidade - HB Residual ___ 160

Figura 7.9 GP - Viscosidade aparente modelo de HB - Colúvio ___ 161

Figura 7.10 GP - Viscosidade aparente modelo de HB - Residual__ 161

Figura 7.11 GP - Colúvio - Aproximação por Herschel Bulkley modificado - $w=64,3 \%$

Figura 7.12 GP - Colúvio - Aproximação por Herschel Bulkley modificado - $w=42,3 \%$

Figura 7.13 GP - Viscosidade aparente modelo de HB modificado - Colúvio ___ 163

Figura 7.14 GP - Viscosidade aparente modelo de HB modificado - Residual ___ 163

Figura 7.15 Variação dos parâmetros com a umidade - HB mod. Colúvio___ 164 
Figura 7.16 Variação dos parâmetros com a umidade - HB mod. Residual___ 164

Figura 7.17- Tensão de escoamento - Colúvio _ 165

Figura 7.18- Tensão de escoamento - Residual __ 165

Figura 7.19 Área de histerese das amostras___ 166

Figura 7.20 Colúvio - Comparação entre os modelos utilizados $-w=64,3 \%$

Figura 7.21 Residual - Comparação entre os modelos utilizados - $w=42,3 \%$

Figura 7.22 GP - Variação da tensão de escoamento - carregamento ___ 168

Figura 7.23 Variação da tensão de escoamento - descarregamento___ 168

Figura 7.24 GP - Variação da Tensão de escoamento com a umidade - Colúvio _ 170

Figura 7.25 GP - Variação da tensão de escoamento com a umidade - Residual__ 170

Figura 7.26 GP - Variação da viscosidade com a umidade para cinco taxas de cisalhamento

Figura 7.27 Variação da viscosidade em relação à umidade - Bingham ___ 171

Figura 7.28 Perda de contato entre a amostra e a punção no final do ensaio ___ 174

Figura 7.29 Linhas de fluxo observadas no final do ensaio___ 174

Figura 7.30 PP - Colúvio - Aproximação por Bingham - $w=80 \%$

Figura 7.31 PP - Residual - Aproximação por Bingham $-w=61 \%$

Figura 7.32 PP - Colúvio - Aproximação por Herschel Bulkley - $w=80 \% \_177$

Figura 7.33 PP - Residual - Aproximação por Herschel Bulkley $-w=61 \%$

Figura 7.34 PP - Colúvio - Aproximação por Herschel Bulkley modificado - $w=80 \%$

Figura 7.35 PP - Residual - Aproximação por Herschel Bulkley modficado - $w=61 \%$

Figura 7.36 Comparação entre as velocidades de $0,1 \mathrm{~mm} / \mathrm{s}$ e $3,0 \mathrm{~mm} / \mathrm{s}$ - Colúvio _ 181 Figura 7.37 Comparação entre as velocidades de $0,1 \mathrm{~mm} / \mathrm{s}$ e $3,0 \mathrm{~mm} / \mathrm{s}$ - Solo Residual

Figura 7.38 Variação da tensão de escoamento em relação à umidade - colúvio 184

Figura 7.39 Variação da tensão de escoamento em relação à umidade - residual_ 185

Figura 7.40 Esquema ilustrativo comportamento do colúvio___ 185

Figura 7.41 Carga necessária para deformação fixa - colúvio ___ 186

Figura 7.42 Carga necessária para deformação fixa - residual 187

Figura 7.43 Variação da viscosidade elongacional com a taxa de cisalhamentocolúvio

Figura 7.44 Variação da viscosidade elongacional com a taxa de cisalhamento -

residual

Figura 7.45 Variação da viscosidade elongacional para 4 taxas de cisalhamento colúvio

Figura 7.46 Variação da viscosidade elongacional para 4 taxas de cisalhamento residual

Figura 8.1 Análise de suscetibilidade: curva granulométrica

Figura 8.2 Análise de suscetibilidade: Limites de Atteberg

Figura 8.3 Local de coleta do Colúvio

Figura 8.4 Perfil de elevação do local de coleta do solo residual (Google Earth, 2011)

Figura 8.5 Fluxograma modificado com a contribuição da pesquisa (modificado de

Olivares e Damiano, 2007)

Figura 8.6 Resumo dos teores de umidade para os solos

Figura A.1 Curva de fluxo - Solo Residual - Ciclo 1 
Figura A.2 Curva de fluxo - Solo Residual - Ciclo 2 212

Figura A.3 Variação da viscosidade com taxa de cisalhamento - Solo Residual - Ciclo 1 213

Figura A.4 Variação da viscosidade com taxa de cisalhamento - Solo Residual - Ciclo 2

Figura A.5 Curva de fluxo - Colúvio - Ciclo 1 214

Figura A.6 Curva de fluxo - Colúvio - Ciclo 2 215

Figura A.7 Variação da viscosidade com taxa de cisalhamento-Colúvio-Ciclo 1217

Figura A.8 Variação da viscosidade com taxa de cisalhamento - Colúvio - Ciclo 2218

Figura A.9 GP - Bingham - colúvio - $w=21,0 \%$

Figura A.10 GP - Bingham - colúvio - $w=29,3 \%$

Figura A.11 GP - Bingham - colúvio - $w=35,7 \%$

Figura A.12 GP - Bingham - colúvio - $w=41,7 \%$

Figura A.13 GP - Bingham - colúvio - $w=49,7 \%$

Figura A.14 GP - Bingham - colúvio - $w=54,0 \%$ _ 222

Figura A.15 GP - Bingham - colúvio - $w=58,0 \% \quad 223$

Figura A.16 GP - Bingham - colúvio - $w=64,3 \%$ 223

Figura A.17 GP - Bingham - residual - w =22,9\%_ 223

Figura A.18 GP - Bingham - residual - $w=26,0 \% \quad 224$

Figura A.19 GP - Bingham - residual - $w=28,2 \% \quad 224$

Figura A.20 GP - Bingham - residual - $w=31,2 \% \quad 224$

Figura A.21 GP - Bingham - residual - $w=33,0 \% \quad 225$

Figura A.22 GP - Bingham - residual - $w=36,2 \%$ _ 225

Figura A.23 GP - Bingham - residual $-w=42,3 \% \quad 225$

Figura A.24 GP - Herschel Bulkley - colúvio - $w=21,0 \%$

Figura A.25 GP - Herschel Bulkley - colúvio - $w=29,3 \% \_226$

Figura A.26 GP - Herschel Bulkley - colúvio - $w=35,7 \% \_226$

Figura A.27 GP - Herschel Bulkley - colúvio - w = 41,7\%__ 227

Figura A.28 GP - Herschel Bulkley - colúvio - w = 49,7\%__ 227

Figura A.29 GP - Herschel Bulkley - colúvio - $w=54,0 \% \_227$

Figura A.30 GP - Herschel Bulkley - colúvio - $w=58,0 \%$

Figura A.31 GP - Herschel Bulkley - colúvio - $w=64,3 \%$

Figura A.32 GP - Herschel Bulkley - residual - w =22,9\%_ 228

Figura A.33 GP - Herschel Bulkley - residual - $w=26,0 \%$

Figura A.34 GP - Herschel Bulkley - residual - $w=28,2 \% \quad 229$

Figura A.35 GP - Herschel Bulkley - residual - $w=31,2 \%$

Figura A.36 GP - Herschel Bulkley - residual - $w=33,0 \% \quad 230$

Figura A.37 GP - Herschel Bulkley - residual - $w=36,2 \% \_230$

Figura A.38 GP - Herschel Bulkley - residual - $w=42,3 \%$

Figura A.39 GP - Herschel Bulkley modificado- colúvio - $w=21,0 \%$

Figura A.40 GP - Herschel Bulkley modificado- colúvio - $w=29,3 \% \quad 231$

Figura A.41 GP - Herschel Bulkley modificado- colúvio - $w=35,7 \% \quad 232$

Figura A.42 GP - Herschel Bulkley modificado- colúvio - $w=41,7 \%$

Figura A.43 GP - Herschel Bulkley modificado- colúvio - $w=49,7 \%$

Figura A.44 GP - Herschel Bulkley modificado- colúvio - $w=54,0 \% \quad 233$

Figura A.45 GP - Herschel Bulkley modificado- colúvio - $w=58,0 \% \quad 233$

Figura A.46 GP - Herschel Bulkley modificado- colúvio - $w=64,3 \% \_233$

Figura A.47 GP - Herschel Bulkley modificado- residual - $w=22,9 \% \_234$ 
Figura A.48 GP - Herschel Bulkley modificado- residual $-w=26,0 \%$ 234

Figura A.49 GP - Herschel Bulkley modificado- residual - $w=28,2 \%$ 234

Figura A.50 GP - Herschel Bulkley modificado- residual $-w=31,2 \%$ 235

Figura A.51 GP - Herschel Bulkley modificado- residual - $w=33,0 \%$ 235

Figura A.52 GP - Herschel Bulkley modificado- residual - $w=36,2 \%$ 235

Figura A.53 GP - Herschel Bulkley modificado- residual - $w=42,3 \%$ 236

Figura A.54 PP - Bingham - colúvio - $w=61 \%$ 240

Figura A.55 PP - Bingham - colúvio $-w=67 \%$ 241

Figura A.56 PP - Bingham - colúvio $-w=69 \%$ 241

Figura A.57PP - Bingham - colúvio - $w=71 \%$ 241

Figura A.58 PP - Bingham - colúvio - $w=74 \%$ 242

Figura A.59 PP - Bingham - colúvio - $w=76 \%$ 242

Figura A.60 PP - Bingham - colúvio - $w=79 \%$ 242

Figura A.61 PP - Bingham - colúvio - $w=80 \%$

Figura A.62 PP - Bingham - residual $-w=46 \%$ 243

Figura A.63 PP - Bingham - residual $-W=52 \%$ 243

Figura A.64 PP - Bingham - residual $-w=54 \%$ 243

Figura A.65 PP - Bingham - residual $-w=55 \%$ 244

Figura A.66 PP - Bingham - residual $-w=57 \%$ 244

Figura A.67 PP - Bingham - residual - $w=59 \%$ 244

Figura A.68 PP - Bingham - residual $-w=61 \%$ 245

Figura A.69 PP - Herschel Bulkley - colúvio - $w=67 \%$ 245

Figura A.70 PP - Herschel Bulkley - colúvio - $w=69 \%$ 246

Figura A.71 PP - Herschel Bulkley - colúvio - $w=71 \%$ 246

Figura A.72 PP - Herschel Bulkley - colúvio - $w=74 \%$ 246

Figura A.73 PP - Herschel Bulkley - colúvio - $w=76 \%$ 247

Figura A.74 PP - Herschel Bulkley - colúvio - $w=78 \%$ 247

Figura A.75 PP - Herschel Bulkley - colúvio - $w=80 \%$

Figura A.76 PP - Herschel Bulkley - residual - $w=54 \%$ 248

Figura A.77PP - Herschel Bulkley - residual $-w=55 \%$ 248

Figura A.78 PP - Herschel Bulkley - residual - $w=59 \%$ 248

Figura A.79 PP - Herschel Bulkley - residual $-w=61 \%$ 249

Figura A.80 PP - Herschel Bulkley modificado- colúvio - $w=67 \%$ 249

Figura A.81 PP - Herschel Bulkley modificado- colúvio - $w=69 \%$ 249

Figura A.82 PP - Herschel Bulkley modificado- colúvio - $w=71 \%$ 250

Figura A.83 PP - Herschel Bulkley modificado- colúvio - $w=74 \%$ 250

Figura A.84 PP - Herschel Bulkley modificado- colúvio - $w=76 \%$ 250

Figura A.85 PP - Herschel Bulkley modificado- colúvio - $w=78 \%$ 251

Figura A.86 PP - Herschel Bulkley modificado- colúvio - $w=80 \%$ 251

Figura A.87 PP - Herschel Bulkley modificado- residual - $w=54 \%$ 251

Figura A.88 PP - Herschel Bulkley modificado- residual - $w=55 \%$ 252

Figura A.89 PP - Herschel Bulkley modificado- residual - $w=59 \%$ 252

Figura A.90 PP - Herschel Bulkley modificado- residual - $w=61 \%$ 252 253 


\section{LISTA DE TABELAS}

Tabela 2.1 Sistema de Classificação de Varnes (1978) 8

Tabela 2.2 Sistema de Classificação de Augusto Filho (1992)

Tabela 2.3 Principais casos documentados de debris flows no Brasil (Kanji et al, 2003)

Tabela 5.1 Valores característicos obtidos para Debris Flow (Iverson, 1997) __ 56

Tabela 5.2 Modelos Reológicos fluidos independentes do tempo (STEFFE, 1996) _ 67

Tabela 5.3 Exemplos de comportamento de fluidos (SETOR1, 2012) __ 68

Tabela 5.4 Características dos materiais utilizados (COUSSOT e BOYER, 1995)_ 96

Tabela 5.5 Parâmetros obtidos para debris flow de Black Canyon (Whipple, 1997)_ 102

Tabela 5.6 Variação dos parâmetros dos modelos com a umidade ___ 116

Tabela 5.7 Parâmetros e Resultados da Aproximação segundo Mears (1981) (MACIAS et al., 1997)

Tabela 5.8 Parâmetros e resultados da análise segundo Bagnold (1954) (MACIAS et al., 1997)

Tabela 5.9 Parâmetros e resultados da análise segundo Johnson (1970) (MACIAS et al., 1997)

Tabela 6.1 Resumo dos dados obtidos 130

Tabela 6.2 Parâmetros do ensaio de cisalhamento direto 131

Tabela 6.3 Programação da umidade das amostras 136

Tabela 6.4 Valores de umidade utilizados no reômetro com geometria placas paralelas

Tabela 7.1 GP - Parâmetro obtidos - Colúvio - Aproximação por Bingham 155

Tabela 7.2 GP - Parâmetro obtidos - Residual - Aproximação por Bingham___ 156

Tabela 7.3 GP - Parâmetro obtidos - Colúvio - Aproximação por Herschel Bulkley 158

Tabela 7.4 GP - Parâmetro obtidos - Residual - Aproximação por Herschel Bulkley 159

Tabela 7.5 GP - Parâmetro obtidos - Colúvio - Aproximação por Herschel Bulkley modificado

Tabela 7.6 GP - Parâmetro obtidos - Residual - Aproximação por Herschel Bulkley modificado

Tabela 7.7 Resultado numérico ensaio.

Tabela 7.8 PP - Parâmetro obtidos - Colúvio - Aproximação por Bingham __ 176

Tabela 7.9 PP - Parâmetro obtidos - Residual - Aproximação por Bingham ___ 176

Tabela 7.10 PP - Parâmetro obtidos - Colúvio - Aproximação por Herschel Bulkley

Tabela 7.11 PP - Parâmetro obtidos - Residual - Aproximação por Herschel Bulkley

Tabela 7.12 PP - Parâmetro obtidos - Colúvio - Aproximação por Herschel Bulkley modificado

Tabela 7.13 PP - Parâmetro obtidos - Residual - Aproximação por Herschel Bulkley

modificado

Tabela 7.14 Tensão de escoamento obtida pelo squeeze flow

Tabela 8.1 Valores obtidos para coeficiente de seguança 198

Tabela A.1 Valores de Torque( $\mathrm{Nm}$ ) obtidos ensaio com Geometria Planetária - Colúvio 
Tabela A.2 Valores de Viscosidade( $\mathrm{Nm} / \mathrm{rpm})$ obtidos ensaio com Geometria Planetária - Colúvio 219

Tabela A.3 Valores de Torque( $\mathrm{Nm})$ obtidos ensaio com Geometria Planetária -

Residual 220

Tabela A.4 Valores de Viscosidade $(\mathrm{Nm} / \mathrm{rpm})$ obtidos ensaio com Geometria Planetária

- Residual 220

Tabela A.5 Dados Reômetro Placa a Placa - solo residual $-w=46 \%$ e $w=52 \%$ 236

Tabela A. 6 Dados Reômetro Placa a Placa - solo residual $-w=54 \%$ e $w=55 \%$ 237

Tabela A. 7 Dados Reômetro Placa a Placa - solo residual $-w=57 \%$ e $w=59 \%$ 237

Tabela A.8 Dados Reômetro Placa a Placa - solo residual $-w=61 \%$ 238

Tabela A.9 Dados Reômetro Placa a Placa - colúvio - $w=61 \%$ e $w=67 \%$ 238

Tabela A.10 Dados Reômetro Placa a Placa - colúvio - $w=69 \%$ e $w=71 \%$ 239

Tabela A.11 Dados Reômetro Placa a Placa - colúvio - $w=74 \%$ e $w=76 \%$ 239

Tabela A. 12 Dados Reômetro Placa a Placa - colúvio - $w=78 \%$ e $w=80 \%$ 240 
Lista de Figuras

v

Lista de Tabelas xii

1. INTRODUÇÃO 1

1.1. Objetivos 5

1.2. Organização do trabalho 5

2. MOVIMENTOS DE MASSA 7

2.1. Introdução 7

2.2. Região Serrana do Rio de Janeiro 2011 13

3. MECANISMOS DE RUPTURA EM ESCORREGAMENTOS 26

3.1. Desenvolvimento do Escorregamento - Caso Italiano 26

3.2. Mecanismo Ruptura - Nova Friburgo 34

3.3. Mecanismo Pós-Ruptura - Nova Friburgo 38

4. LIQUEFAÇÃO DE SOLOS 41

4.1. Materiais suscetíveis à liquefação 42

4.2. Condição de Saturação 44

4.3. Comportamento em solicitação 44

5. REOLOGIA 50

5.1. Introdução 50 
5.2. Parâmetros Reológicos 53

5.2.1. Viscosidade 53

5.2.2. Tensão de escoamento 57

5.3. Aspectos Conceituais 60

5.4. Equipamentos de ensaio 68

5.4.1. Reômetro Rotacional de Torque 70

5.4.2. Reômetro Rotacional com geometria de Placas Paralelas 74

5.4.3. Reometria Compressiva (Squeeze Flow) 75

5.4.3.1. Configuração do ensaio 81

5.4.3.2. Dimensão da amostra 82

5.4.3.3. Tipo de solicitação 83

5.5. Reologia na Mecânica dos Solos 85

5.6. Reometria na Mecânica dos Solos 87

5.7. Parâmetro de suavização 111

5.8. Aplicação na Geotecnia 118

6. ENSAIOS E RESULTADOS 124

6.1. Área de Estudo 124

6.2. Amostragem 125

6.3. Ensaios de Caracterização 129

6.4. Resistência ao Cisalhamento Direto 130

6.5. Reometria Rotacional de Torque 135 
6.5.1. Reometria Rotacional - Umidade Constante 135

6.5.2. Reometria Rotacional - Umidade variável 142

6.6. Reometria Rotacional - Placas Paralelas 144

6.7. Reometria Compressiva (Squeeze-Flow) 148

7. ANÁLISE DOS RESULTADOS DOS ENSAIOS REOLÓGICOS 154

7.1. Análise do ensaio Reometria Rotacional 154

7.1.1. Ajuste dos modelos reológicos para os resultados dos ensaios de Geometria Planetária 154

7.1.2. Conclusões do Ensaio de Geometria Planetária 166

7.2. Reometria Rotacional - Geometria Placas Paralelas (PP) 173

7.2.1. Placas Paralelas (PP) - Aproximação por Modelos Reológicos 174

7.2.2. Conclusões Ensaio de Placas Paralelas 179

7.3. Reometria Compressiva - Squeeze flow 181

7.3.1. Conclusões Reometria Compressiva 189

7.4. Conclusões da reometria aplicada a solos 190

8. APLICAÇÃO À GEOTECNIA 193

9. CONCLUSÕES E SUGESTÕES 199

10. REFERÊNCIAS BIBLIOGRÁFICAS 202

A. ANEXOS 210

A.1. Resultados obtidos no Reômetro Rotacional de Placas Paralelas 211 
A.2. Reômetro de Torque com Geometria Planetária - Aproximação por Modelos Reológicos 219

A.2.1. Modelo de Bingham 221

A.2.2. Modelo de Herschel Bulkley 225

A.2.3. Modelo de Herschel Bulkley modificado por Papanastasiou 231

A.3. Reômetro Placa a Placa - Aproximação por Modelos Reológicos 236

A.3.1. Modelo de Bingham 240

A.3.2. Modelo de Herschel Bulkley 245

A.3.3. Modelo de Herschel Bulkley corrigido por Papanastasiou 249 


\section{INTRODUÇÃO}

No país, especialmente na região da Serra do Mar, a cada estação chuvosa ocorrem diversos eventos de movimentações de massa que causam um grande prejuízo social, financeiro e econômico. O movimento de massa causa risco de morte à população que se encontra em áreas passíveis da ocorrência de eventos desse tipo, além da possibilidade de destruir parcialmente ou completamente a infraestrutura local, tais como: residências, pontes, barragens, ruas, etc., que demandam tempo e investimento para sua reconstrução.

Durante o último século ocorreram mudanças climáticas causadas, principalmente, pela emissão de gases poluentes na atmosfera. De acordo com o relatório do IPCC de 2007, um dos efeitos dessa mudança climática é a alteração do regime de precipitações que será sentida na região sudeste especialmente de duas maneiras: (a) aumento dos índices pluviométricos e (b) aumento da intensidade das chuvas, resultando em um maior número de dias secos e eventos de precipitação mais intensos. Esse novo regime de precipitações deve levar a um maior número de problemas de instabilidade de taludes. Além das mudanças climáticas, está sendo previsto que o número de eventos extremos relativos ao clima, como os de precipitação, aumente.

O desenvolvimento econômico de grandes cidades brasileiras, como São Paulo e Rio de Janeiro, atrai um elevado número de pessoas para essas regiões que já são altamente ocupadas. Com o crescimento das cidades, as áreas que antes estavam desocupadas, por não terem uma topografia favorável, estão hoje sendo alvo de novas moradias construídas, geralmente, por pessoas de baixa renda que não têm condição técnica nem financeira para preparar um projeto adequado à localidade, sendo construídas moradias irregulares com cortes e aterros sem a devida consideração, em locais desfavoráveis e, alguns deles, sem coleta das águas servidas. Ocorre uma junção entre o crescimento desordenado das cidades e a inexistência de uma política habitacional eficaz.

Wolle (1980) defendeu que a água é o agente deflagrador de maior importância nos processos de instabilização, atuando das seguintes maneiras: (1) o 
fluxo de água em meios terrosos ou rochosos provoca forças de percolação; (2) a ocorrência de água em trincas e fissuras gera o aparecimento de pressões que leva à abertura das descontinuidades e rupturas nos taludes; (3) através de erosão interna, pipping, pode provocar alteração da geometria instabilizando o talude; (4) através da saturação do solo pela infiltração da água de chuva levando a diminuição da resistência induzindo a instabilização, e (5) do aumento do peso específico causado pela retenção de parte da água infiltrada.

Aliando os fatores expostos, uma maior concentração de chuvas, a ocupação de áreas inadequadas e a influência da água na estabilidade, é possível julgar o porquê, a cada estação chuvosa ocorrem tantos desastres naturais deflagrados pelas chuvas e porque tantas famílias são afetadas por esses eventos, sendo que é possível estimar que tanto o número de pessoas afetadas quanto o número desse tipo de evento aumentem nos próximos anos.

Os movimentos de massa são também um agente de formação do relevo, e como agentes atuantes do processo de modificação do relevo os movimentos de massa são fenômenos naturais extremamente comuns, que acontecem há milhares de anos sendo processos recorrentes e previsíveis. As movimentações de massa, muitas vezes denominados através do uso da palavra escorregamento, que é definido como um dos tipos de movimentos, causam enormes prejuízos econômicos e sociais ao país. (GUIDICINI \& NIEBLE, 1983).

Do ponto de vista geológico e geotécnico, e considerada a alta pluviosidade da região, a Serra do Mar constitui a região brasileira mais suscetível a escorregamentos de solos e rochas. Estende-se por cerca de 1.500 quilômetros do estado do Espírito Santo ao estado de Santa Catarina, apresentando largura média de 10 quilômetros. Segundo Wolle (1988), o processo de escorregamento na Serra do Mar faz parte da dinâmica natural das escarpas causando a regressão das escarpas ao longo do continente em uma escala geológica de tempo.

Apesar dos movimentos de massa serem um evento geologicamente recorrente, os danos às populações estão se tornando cada vez mais mensuráveis devido à facilidade de comunicação existente atualmente, o que faz com que ocorra uma demanda de atenção para esse tipo de problema, principalmente quando ocorrem eventos de grandes magnitudes como em Santa Catarina em 2008, e no 
Rio de Janeiro em 2011.

Em janeiro de 2011, a região Serrana do estado do Rio de Janeiro foi atingida por fortes chuvas que causaram milhares de escorregamentos. Esses escorregamentos causaram um prejuízo estimado de $\mathrm{R} \$ 469$ milhões no comércio e R\$ 153 milhões na indústria (Fecomércio - RJ e Firjan), sendo que até hoje é possível visualizar as cicatrizes dessas movimentações. Durante esse evento houve mais de 1500 mortes (Avelar et al. 2011), além de milhares de desabrigados e desalojados. Vários desses escorregamentos ocorridos no Rio de Janeiro evoluíram para movimentos em forma de corridas, também conhecidos como debris flow.

Diversas pesquisas já foram realizadas para determinar a ocorrência de movimentos de massa relacionada à ocorrência de chuvas na região da Serra do Mar, nas quais foram determinadas correlações entre índices pluviométricos e a ocorrência de escorregamentos (Tatizana et al., 1987; Guidicini e Iwasa, 1976), os agentes deflagradores dos movimentos (Guidicini e Nieble, 1983; etc.) e o mecanismo de ruptura da massa instável (Wolle, 1980; entre outros). Em relação ao desenvolvimento pós-ruptura desses escorregamentos pode-se citar Wolle (1980 e 1988) e Futai et al. (2011), entre outros.

Em casos de escorregamentos causados por precipitação intensa, como os ocorridos na região da Serra do Mar, o excesso de água no solo pode fazer com que a massa instável se liquefaça. Quando isso ocorre, existe a formação de corridas, com maior energia cinética, que causam danos maiores que escorregamentos, devido ao seu maior alcance e poder destrutivo. As corridas podem ser consideradas como fluxos compostos inicialmente por grãos de solo e água, sendo que podem agregar materiais soltos ou que são arrancados pela força do movimento, blocos de rocha, troncos de árvores e entulhos de construções destruídas.

Esse trabalho propõe estudar as características reológicas da massa de solo liquefeita que pode se desenvolver imediatamente após a ruptura, causada pela infiltração de precipitação e, consequentemente, saturação do solo. Esse estudo será realizado através da determinação dessas características em solos da Região Serrana do Estado do Rio de Janeiro. Para isso, foram utilizados tanto ensaios tradicionais (caracterização e cisalhamento direto) quanto equipamentos mais 
modernos e não empregados na geotecnia (ensaios reométricos).

Na busca de soluções para problemas práticos, a mecânica dos solos tem, geralmente, assumindo que o solo é um material perfeitamente plástico, quando são considerados problemas de estabilidade e um material pseudo-plástico na estimativa de deformação sob carregamento. Considerando, por exemplo, o modelo elástico linear que é bastante adequado para fins de projeto, existe um problema de credibilidade na análise de dados de um ensaio de carga axial, já que o solo apresenta uma curva como resposta no gráfico de tensão versus deformação quando, de acordo com a teoria, deveria apresentar uma reta (KEEDWELL, 1984). O comportamento do solo nos ensaios é diferente da resposta observada em campo, porque o solo apresenta diferentes respostas às diversas solicitações a que é submetido além da porcentagem de deformação ser menor do que no campo. É importante que existam diferentes modelos de previsões de comportamento e que seja utilizado o que fornece melhor aproximação ao comportamento real.

Oliveira et al. (2000) apresentou a ideia de que em sólidos e líquidos perfeitos, onde a deformação independente da direção de aplicação da solicitação mecânica, a relação entre a tensão aplicada e a deformação resultante é simples e conhecida, contudo grande parte dos materiais apresenta características reológicas intermediárias de maior complexidade. O solo tem seu comportamento aproximado pelo de um corpo sólido, porém quando em estado liquefeito esse modelo não fornece bons resultados, sendo necessário que se adote outro modelo que consiga representar o comportamento.

Diversos pesquisadores estão realizando estudos de caracterização reológica em debris flow (Phillips e Davies, 1991; Coussot et al., 1992 e 1998; Coussot e Piau, 1994; Whipple, 1997; Iverson, 1997; entre outros). Considerar a corrida de solo como um fluido e estudá-la através da reologia é um assunto recente (Melo et al., 2012), o que torna necessário que se busque os conceitos da reologia; ciência que estuda os materiais em seu estado fluido, a partir da relação entre a deformação aplicada e a força obtida como resposta. Através da reologia é possível estudar o comportamento, em relação à deformação, das corridas em seu estado liquefeito.

Assim a dissertação assume a tarefa de analisar o comportamento de corridas em seu estado liquefeito e apresentará os procedimentos utilizados nesse 
primeiro contato entre o solo e alguns ensaios reométricos que foram adotados para que novos estudos nesse sentido possam ser realizados.

\subsection{Objetivos}

O presente trabalho tem como objetivo geral estudar a evolução de um movimento de massa do tipo escorregamento para um movimento do tipo corrida de solo, adotando o ponto de vista da reologia.

Como objetivos intermediários estão sendo propostos:

- Introduzir a utilização de alguns equipamentos de reometria em solos;

- Determinar o comportamento reológico de amostras coletadas em Nova Friburgo;

- Comparar os resultados reológicos obtidos com modelos de comportamento que são previstos para solos;

- Associar o comportamento reológico com as características do solo no estado fluido e a liquefação.

Para isso, o solo coletado foi ensaiado em diversas umidades, com o objetivo de esclarecer a resposta do comportamento do solo ao aumento da umidade causado pela infiltração da precipitação.

\subsection{Organização do trabalho}

\section{- Capítulo 1 - Introdução}

Nesse primeiro capítulo é apresentada uma breve introdução contendo a justificativa e a descrição dos objetivos da dissertação.

\section{- Capítulo 2 - Movimentos de Massa}

Apresenta os movimentos de massa do ponto de vista da Geotecnia, sendo realizada uma revisão do caso que serviu de motivação para o estudo, ocorrido em Janeiro de 2011 no Rio de Janeiro.

\section{- Capítulo 3 - Mecanismos de ruptura em Escorregamentos}


Resumo dos mecanismos de ruptura observados na Região Serrana do Rio de Janeiro, com caracterização dos mecanismos observados no evento de Janeiro de 2011, comparação com um caso italiano para compreensão do mecanismo de ruptura ocorrido, além da apresentação do mecanismo de pós-ruptura.

- Capítulo 4 - Liquefação de Solos

Revisão bibliográfica do fenômeno de liquefação de solos, com apresentação dos requisitos para ocorrência do fenômeno.

- Capítulo 5 - Reologia

Apresentação da Reologia como ciência e seus principais conceitos. Introdução aos equipamentos e a forma de apresentação dos resultados dos ensaios que serão utilizados na dissertação. Apresenta também uma revisão bibliográfica dos principais estudos reológicos que estão sendo realizados em solos.

- Capítulo 6 - Ensaios e Resultados

São apresentadas as amostras coletadas para a realização dos ensaios e os resultados obtidos.

- Capítulo 7 - Análise dos Resultados

Nesse capítulo são analisados os resultados obtidos em relação ao comportamento esperado e aos modelos reológicos mais comuns.

- Capítulo 8 - Aplicação à Geotecnia

Nesse capítulo é apresentada uma aplicação dos resultados obtidos para a geotecnia.

\section{- Capítulo 9 - Conclusões e Sugestões para pesquisas futuras}

- Referências bibliográficas

- Anexos

No anexo estão apresentados os dados de todos os ensaios realizados, assim como os gráficos para cada um desses ensaios. 


\section{MOVIMENTOS DE MASSA}

\subsection{Introdução}

Movimentos de massa denominados, genericamente, como escorregamentos, causam grandes prejuízos e, devido a suas consequências desastrosas, demandam diversos estudos sobre seu comportamento, suas causas e agentes deflagradores. A ocorrência desses movimentos no Brasil é comum e o aumento no número de eventos é o resultado da intensiva urbanização, do uso impróprio do solo e da falta de um programa público permanente de moradia. (AUGUSTO FILHO, 2004)

O termo escorregamento é usado para descrever uma grande variedade de processos que resultam em movimentos de massa. Magalhães Freire (1965), através da síntese de diversos especialistas, classificou os movimentos em três tipos: os escoamentos, os escorregamentos e as subsidências; sua proposta é bastante adequada à utilização no país. (GUIDICINI E NIEBLE, 1983)

O escoamento é definido como um movimento contínuo que pode ou não apresentar superfície de movimentação, contém as classes de corridas e rastejo. $O$ escorregamento (propriamente dito) apresenta deslocamento finito, tem superfície de deslocamento bem definida e pode ser do tipo rotacional ou translacional. As subsidências são deslocamentos verticais, como recalques abruptos ou desabamentos. As quedas são movimentos que ocorrem em taludes íngremes ou pedaços de blocos de penhascos verticais. Para cada categoria são discriminados vários grupos e subgrupos, tratando se o material é solo, rocha ou detritos, se os movimentos são lentos ou rápidos, da existência ou não de uma superfície definida de movimentação, da cinemática do movimento, além de causas e agentes das instabilizações. (GUIDICINI e NIEBLE, 1983; WOLLE, 1988)

O sistema de classificação de Varnes (1978) é o mais utilizado em âmbito mundial e está apresentado na Tabela 2.1. O sistema de Augusto Filho (1992), Tabela 2.2, será apresentado também por ser bastante adequado aos casos brasileiros. 
Tabela 2.1 Sistema de Classificação de Varnes (1978)

\begin{tabular}{|c|c|c|c|c|c|}
\hline \multirow{3}{*}{\multicolumn{3}{|c|}{ Tipo de movimento }} & \multicolumn{3}{|c|}{ Tipo de material } \\
\hline & & & \multirow{2}{*}{ Rocha } & \multicolumn{2}{|c|}{ Solo (engenharia) } \\
\hline & & & & Grosseiro & Fino \\
\hline \multicolumn{3}{|c|}{ Quedas } & de rocha & de detritos & de terra \\
\hline \multicolumn{3}{|c|}{ Tombamentos } & de rocha & de detritos & de terra \\
\hline \multirow[t]{2}{*}{ Escorregamentos } & Rotacional & $\begin{array}{l}\text { Poucas } \\
\text { unidades }\end{array}$ & \multirow{2}{*}{$\begin{array}{c}\text { Abatimento de } \\
\text { rocha } \\
\text { De blocos } \\
\text { rochosos } \\
\text { De rocha }\end{array}$} & \multirow{2}{*}{$\begin{array}{c}\text { Abatimento de } \\
\text { detritos } \\
\text { De blocos } \\
\text { de detritos } \\
\text { De detritos }\end{array}$} & \multirow{2}{*}{$\begin{array}{c}\text { Abatimento de } \\
\text { terra } \\
\text { De blocos } \\
\text { de terra } \\
\text { De terra }\end{array}$} \\
\hline & Translacional & $\begin{array}{c}\text { Muitas } \\
\text { unidades }\end{array}$ & & & \\
\hline \multicolumn{3}{|c|}{ Expansões laterais } & de rocha & de detritos & de terra \\
\hline \multirow{2}{*}{\multicolumn{3}{|c|}{ Corridas/escoamentos }} & \multirow{2}{*}{$\begin{array}{c}\text { de rocha (rastejo } \\
\text { profundo) }\end{array}$} & de detritos & de terra \\
\hline & & & & \multicolumn{2}{|c|}{ (rastejo de solo) } \\
\hline
\end{tabular}

Tabela 2.2 Sistema de Classificação de Augusto Filho (1992)

\begin{tabular}{|c|c|}
\hline Processos & Características do movimento, material e geometria \\
\hline \multirow{5}{*}{$\begin{array}{l}\text { Rastejo ou } \\
\text { Fluência }\end{array}$} & Vários planos de deslocamento (internos) \\
\hline & $\begin{array}{l}\text { Velocidades de muito baixas (cm/ano) a baixas e decrescente com a } \\
\text { profundidade }\end{array}$ \\
\hline & Movimentos constantes, sazonais ou intermitentes \\
\hline & Solo, depósitos, rocha alterada/fraturada \\
\hline & Geometria indefinida \\
\hline \multirow{7}{*}{ Escorregamentos } & Poucos planos de deslocamento (externos) \\
\hline & Velocidades médias $(\mathrm{km} / \mathrm{h})$ a altas $(\mathrm{m} / \mathrm{s})$ \\
\hline & Pequenos a grandes volumes de material \\
\hline & Geometria e materiais variáveis \\
\hline & $\begin{array}{l}\text { Planares } \rightarrow \text { solos pouco espessos, solos e rochas com um plano de } \\
\text { fraqueza }\end{array}$ \\
\hline & Circulares $\rightarrow$ solos espessos homogêneos e rochas muito fraturadas \\
\hline & Em cunha $\rightarrow$ solos e rochas com dois planos de fraqueza \\
\hline \multirow{8}{*}{ Quedas } & Sem planos de deslocamento \\
\hline & Movimentos tipo queda livre ou em plano inclinado \\
\hline & Velocidades muito altas (vários m/s) \\
\hline & Material rochoso \\
\hline & Pequenos a médios volumes de material \\
\hline & Geometria variável: lascas, placas, blocos, etc \\
\hline & Rolamento de matacão \\
\hline & Tombamento \\
\hline \multirow{7}{*}{ Corridas } & $\begin{array}{l}\text { Muitas superfícies de deslocamento (internas e externas à massa em } \\
\text { movimentação) }\end{array}$ \\
\hline & Movimento semelhante ao de um líquido viscoso \\
\hline & Desenvolvimento ao longo das drenagens \\
\hline & Velocidades de médias a altas \\
\hline & Mobilização do solo, rocha, detritos e água \\
\hline & Grandes volumes de material \\
\hline & Extenso raio de alcance, mesmo em áreas planas \\
\hline
\end{tabular}


Varnes (1978) baseou sua classificação em duas frentes: o tipo de material envolvido no movimento e o tipo predominante de movimento observado. Os materiais considerados foram rocha, solo grosseiro e solo fino. Os tipos de movimentos adotados foram as quedas, os tombamentos, os escorregamentos, expansões laterais e corridas, sendo ainda considerada uma categoria de movimentos complexos que envolvem a combinação de dois ou mais dos tipos mencionados.

Augusto Filho (1992) apresentou sistema de classificação bastante adequado aos casos brasileiros, baseou-se em parâmetros como natureza da superfície de movimentação, velocidade do movimento, volume de material mobilizado além de características qualitativas do movimento.

Os escorregamentos, em determinadas condições que serão discutidas adiante, podem se desenvolver e passarem a um movimento no qual ocorre fluxo de materiais. A ocorrência desses eventos envolvendo fluxos eleva muito os prejuízos financeiros e sociais. Znamensky (2001) relatou que a passagem do estado sólido para o fluido é um processo que envolve um grande aumento no teor de água, uma desestruturação da fase sólida, aliados a um progressivo enfraquecimento dos vínculos existentes entre os componentes sólidos individuais. Esse vínculo enfraquecido pode ser considerado a coesão do solo.

Avelar et al. (2006) observaram que alguns autores utilizam o termo "corridas de massa ou de detritos", porém, adverte que o termo corrida não se refere a um processo físico enquanto o termo fluxo sim, por isso a preferência da utilização de "fluxo de detritos". Além disso, a utilização do termo fluxo é mais adequada à tradução do termo em inglês que é debris flow. A denominação adotada por cada um dos autores está mantida nessa revisão, sendo utilizadas tanto as expressões fluxo, quanto corridas e debris.

As corridas são formas rápidas de escoamento de caráter essencialmente hidrodinâmico, ocasionadas pela insuficiência de atrito interno devido à quebra da estrutura em presença de excesso de água. O tipo de material encontrado em corridas é extremamente variado, de densos e muito viscosos a outros tão fluidos como águas barrentas (Guidicini e Nieble, 1983). 
A Tabela 2.3 apresenta os principais casos de fluxos de detritos ocorridos no país até 2003. A maioria dos casos apresentados ocorreu na região da Serra do Mar, sendo consequência de precipitações intensas que causaram escorregamentos e fluxos. A região da Serra do Mar é propícia a sofrer com movimentações de solo, porque está sujeita a altos volumes de precipitações e possui um relevo acidentado, com encostas inclinadas.

Tabela 2.3 Principais casos documentados de debris flows no Brasil (Kanji et al, 2003)

\begin{tabular}{|c|c|c|c|c|c|c|}
\hline Caso & $H / L$ & $\begin{array}{c}\text { Área da } \\
\text { Bacia }\left(\mathrm{km}^{2}\right)\end{array}$ & Chuva & $\begin{array}{c}\text { Velocidade } \\
(\mathrm{m} / \mathrm{s})\end{array}$ & $\begin{array}{c}\text { Volume } \\
\left(\mathrm{m}^{3}\right)\end{array}$ & Perdas \\
\hline $\begin{array}{l}\text { Serra das Araras, RJ, } \\
23 \text { de Janeiro de } 1967\end{array}$ & & & $\begin{array}{l}114 \mathrm{~mm} / 1 \mathrm{~h} \\
275 \mathrm{~mm} / 24 \mathrm{~h}\end{array}$ & - & $>10^{7}$ & $\begin{array}{l}1200 \text { mortes, mais de } 100 \\
\text { casas destruídas, danos a } \\
\text { estradas }\end{array}$ \\
\hline $\begin{array}{l}\text { Caraguatatuba, SP, } 18 \\
\text { de Março de } 1967\end{array}$ & 0,07 & & $\begin{array}{l}420 \mathrm{~mm} / 24 \mathrm{~h} \\
586 \mathrm{~mm} / 48 \mathrm{~h}\end{array}$ & - & \begin{tabular}{|c|}
$7 \times 10^{6}$ \\
toneladas de \\
sólidos \\
\end{tabular} & $\begin{array}{l}120 \text { mortes, } 400 \text { casas } \\
\text { destruídas, danos a estradas }\end{array}$ \\
\hline Tubarão, SC, 1974 & & & $\begin{array}{l}394 \mathrm{~mm} / 72 \mathrm{~h} \\
742 \mathrm{~mm} / 16 \mathrm{~d}\end{array}$ & - & - & $\begin{array}{l}\text { Cidade inundada com } \\
\text { detritos }\end{array}$ \\
\hline Petrópolis, RJ, 1988 & - & - & $\begin{array}{c}145 \mathrm{~mm} / 24 \mathrm{~h} \\
414 \mathrm{~mm} / 144 \mathrm{~h}\end{array}$ & - & - & $\begin{array}{l}171 \text { mortes, } 5000 \text { casas } \\
\text { afetadas }\end{array}$ \\
\hline $\begin{array}{l}\text { Cubatão - RPBC, SP, } \\
1994\end{array}$ & 0,27 & 2,64 & $60 \mathrm{~mm} / 1 \mathrm{~h}$ & $10 \mathrm{~m} / \mathrm{s}$ & $3 \times 10^{5}$ & $\begin{array}{l}\text { Refinaria da Petrobras } \\
\text { inundada com detritos, } \\
\text { prejuízo de US } \$ 44 \text { mi de } \\
\text { interrupção de operação e } \\
\text { limpeza }\end{array}$ \\
\hline $\begin{array}{l}\text { Timbé do Sul, SC/RS, } \\
\text { Dezembro de } 1995\end{array}$ & 0,12 & 23,1 & $>500 \mathrm{~mm} / 1 \mathrm{~h}$ & $>5 \mathrm{~m} / \mathrm{s}$ & $3 \times 10^{6}$ & $\begin{array}{l}29 \text { mortes, } 20 \text { casas } \\
\text { destruidas, perdas na } \\
\text { agricultura e pecuária }\end{array}$ \\
\hline $\begin{array}{l}\text { Cubatão - RPBC, SP, } \\
1996\end{array}$ & 0,27 & 2,64 & - & $10 \mathrm{~m} / \mathrm{s}$ & $1,6 \times 10^{4}$ & $\begin{array}{l}\text { Limpeza da Refinaria de } \\
\text { Petrobras, protegida por } \\
\text { obras de contenção }\end{array}$ \\
\hline Ubatuba, SP, 1996 & - & - & $\begin{array}{l}>10 \mathrm{~mm} / 10 \mathrm{~min} \\
442 \mathrm{~mm} / 13 \mathrm{~h}\end{array}$ & - & - & $\begin{array}{l}\text { Danos severos à rodovia, } \\
\text { sendo necessário trabalhos } \\
\text { de estabilização }\end{array}$ \\
\hline $\begin{array}{l}\text { Quitute e Papagaio, } \\
\text { RJ, } 1996\end{array}$ & 0,47 & $\begin{array}{l}2,13(\mathrm{Q}) \\
2,53(P)\end{array}$ & $202 \mathrm{~mm} / 24 \mathrm{~h}$ & $2,5 \mathrm{~m} / \mathrm{s}$ & $\begin{array}{l}9 \times 10^{4}(\mathrm{Q}) \\
4 \times 10^{4}(\mathrm{P})\end{array}$ & $\begin{array}{l}1 \text { morte, centenas de casas } \\
\text { destruídas }\end{array}$ \\
\hline $\begin{array}{l}\text { Rodovia Anchieta, Dez } \\
1999\end{array}$ & 0,18 & - & $\begin{array}{l}128 \mathrm{~mm} / 24 \mathrm{~h} \\
274 \mathrm{~mm} / 72 \mathrm{~h}\end{array}$ & - & $3 \times 10^{5}$ & $\begin{array}{l}\text { Rodovia afetada em trecho } \\
\text { de } 200 \mathrm{~m} \text {, tráfego } \\
\text { interrompido por semanas }\end{array}$ \\
\hline
\end{tabular}

Em relação à geração de corridas na Serra das Araras, que está englobada na Serra do Mar, ocorrido em 1966, Costa Nunes (1969) sugeriu que poderiam ser formadas a partir de um fenômeno de erosão violenta (violent erosion or hydraulicking) causadas por trombas de água. Em relação às corridas ocorridas em Cubatão, Wolle (1988) concluiu que primeiro ocorria o escorregamento e depois se desenvolviam as corridas, através da consideração das seguintes observações realizadas em fotos e na Serra de Cubatão: as encostas apresentavam as cicatrizes 
de escorregamentos definidas e não tinham sinais de erosão; o fenômeno de desmonte hidráulico é produzido por jatos de água ou por escoamento diretamente sobre o solo erodível, o que não aconteceu porque o solo susceptível ao desmonte ocorre sob uma camada de solo argiloso; a erosão não conseguiria arrancar todas as árvores, algumas restariam, o que não foi observado; e as cicatrizes deveriam apresentar larguras mais variadas, desde centímetros até muitos metros, sendo que as cicatrizes observadas apresentavam largura de, aproximadamente, $5 \mathrm{~m}$.

O objeto desse trabalho não é estudar o fluxo de detritos, ou debris flow, mas sim o fluxo de lama, ou mudflows. A principal diferença entre essas duas definições de movimentos é o tipo de material envolvido, sendo que os fluxos de detritos apresentam material grosseiro, os detritos, enquanto que o fluxo de lama apresenta apenas o solo. O fluxo de lama, assim como o fluxo de detritos, não é um evento isolado, normalmente diversos escorregamentos desses tipos são iniciados num mesmo evento deflagrador. Por exemplo, nos mesmos locais onde ocorreram os fluxos de detritos, indicados na Tabela 2.3, podem ter ocorridos diversos fluxos de lama se os materiais envolvidos fossem diferentes.

De acordo com Guidicini e Nieble (1983), uma massa de solo no estado sólido pode se tornar fluida pela simples adição de água, efeito de vibração (como terremoto ou cravação de estaca) ou ainda pelo amolgamento de argilas muito sensitivas. O primeiro ponto apontado acima, se aplica aos fluxos de solo, onde a massa é formada basicamente por solo em umidade natural inicialmente em estado sólido e, sob a influência da adição de água por precipitação ou escoamento superficial, flui. No estudo proposto na dissertação será analisada a ocorrência da liquefação em massas de solo que sofreram escorregamentos causados pela infiltração de água através de precipitação intensa.

Segundo Znamensky (2001), os debris flow são movimentos de uma massa conjugada (sólidos e fluidos) atuando através da ação da gravidade que se iniciam no estado físico sólido e apresentam inicialmente as características de um corpo sólido (embora saturado ou mesmo supersaturado) para rapidamente se transformar em um corpo líquido capaz de escoar e, ao cessar o movimento, retorna ao estado sólido. Ainda segundo o autor, o debris flow é um fenômeno que transita entre 0 domínio geotécnico, sob a forma de escorregamentos, e o domínio hidráulico, sob o transporte de sedimentos por arraste e/ou em suspensão. 
Avelar (2003) realizou uma compilação de dados da literatura e apresentou os seguintes mecanismos para a iniciação de fluxos detríticos: a) devido à erosão fluvial em canais de drenagem, b) devido à ocorrência de deslizamentos geradores de liquefação, c) devido ao aumento de pressão neutra por mecanismos de infiltração e d) devido ao aumento da pressão neutra provocado por carregamento muito rápido. Outra maneira de ocorrência de fluxos detríticos é quando ocorrem escorregamentos que barram pequenos fluxos de água, esse barramento faz com que se acumule uma grande quantidade de água e, quando esses barramentos rompem, a água represada se junta ao solo escorregado gerando fluxos. (Wolle, 1980)

O mecanismo (b) é o mais comum de ocorrer, sendo que na maioria das vezes o que ocorre é a transformação do comportamento sólido em fluido devido à liquefação da massa de solo que iniciou sua movimentação por deslizamento e, para que isso ocorra, é necessário um elevado grau de saturação de modo que haja água suficiente para a produção do fluxo (AVELAR, 2003). A Figura 2.1 demonstra a ocorrência de fluxos na Região Serrana do estado do Rio de Janeiro, evento de estudo dessa dissertação.

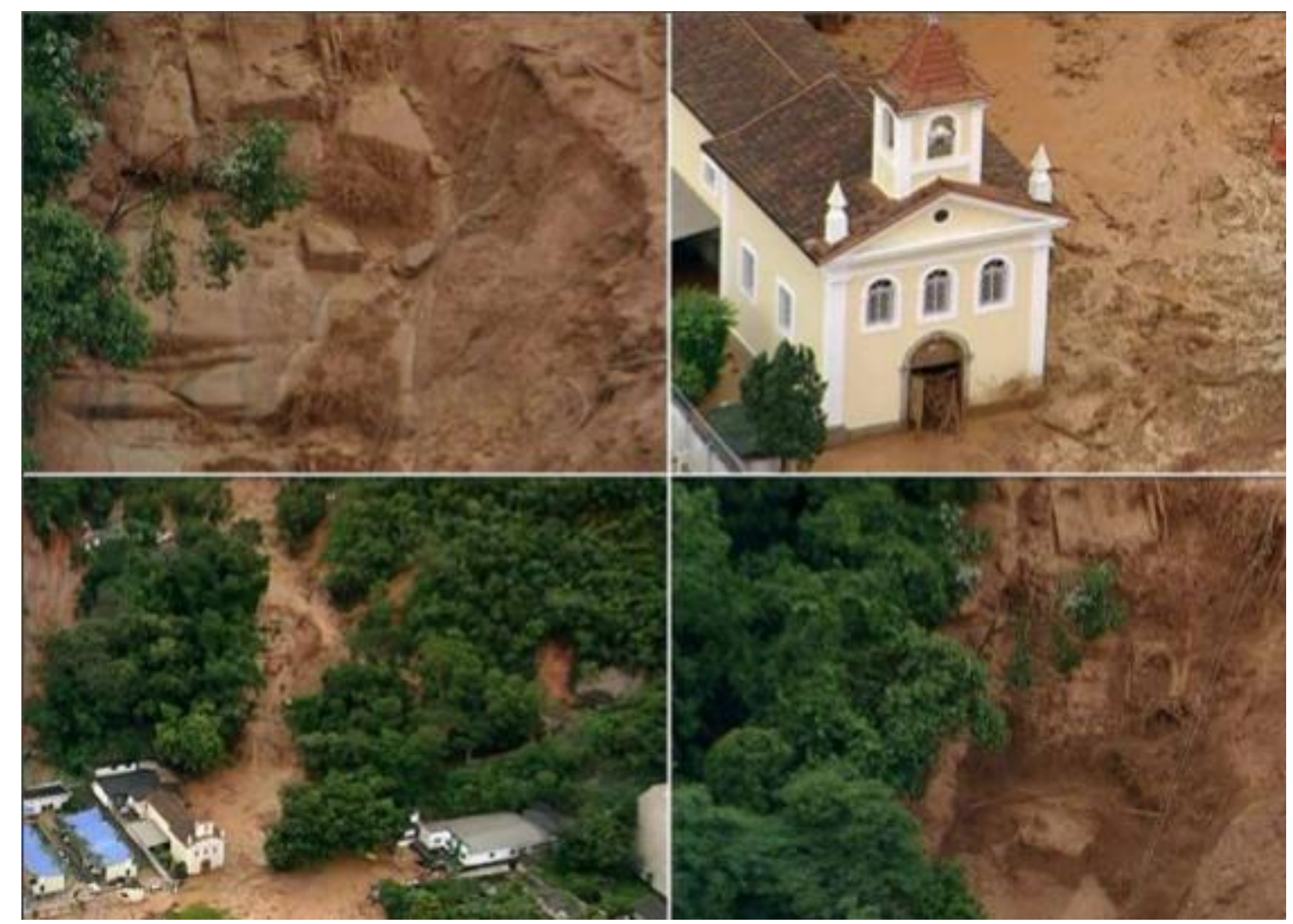

Figura 2.1 Solo em fluxo na Região Serrana do Rio de Janeiro (Youtube) 
A dificuldade existente hoje é diferenciar quais são os escorregamentos que vão se desenvolver em corridas, sofrendo o fenômeno da liquefação e quais os escorregamentos nos quais a massa rompida tem um deslocamento finito e se mantêm estável após a ocorrência da ruptura.

\subsection{Região Serrana do Rio de Janeiro 2011}

A região serrana é composta por 16 municípios: Bom Jardim, Cachoeira de Macacu, Cantagalo, Carmo, Cordeiro, Duas Barras, Guapimirim, Macuco, Nova Friburgo, Petrópolis, Santa Maria Madalena, São José do Rio Preto, São Sebastião do Alto, Sumidouro, Teresópolis e Trajano de Moraes, que estão representados na Figura 2.2. As principais atividades econômicas da região são as industriais, o turismo e a produção de hortigranjeiros.

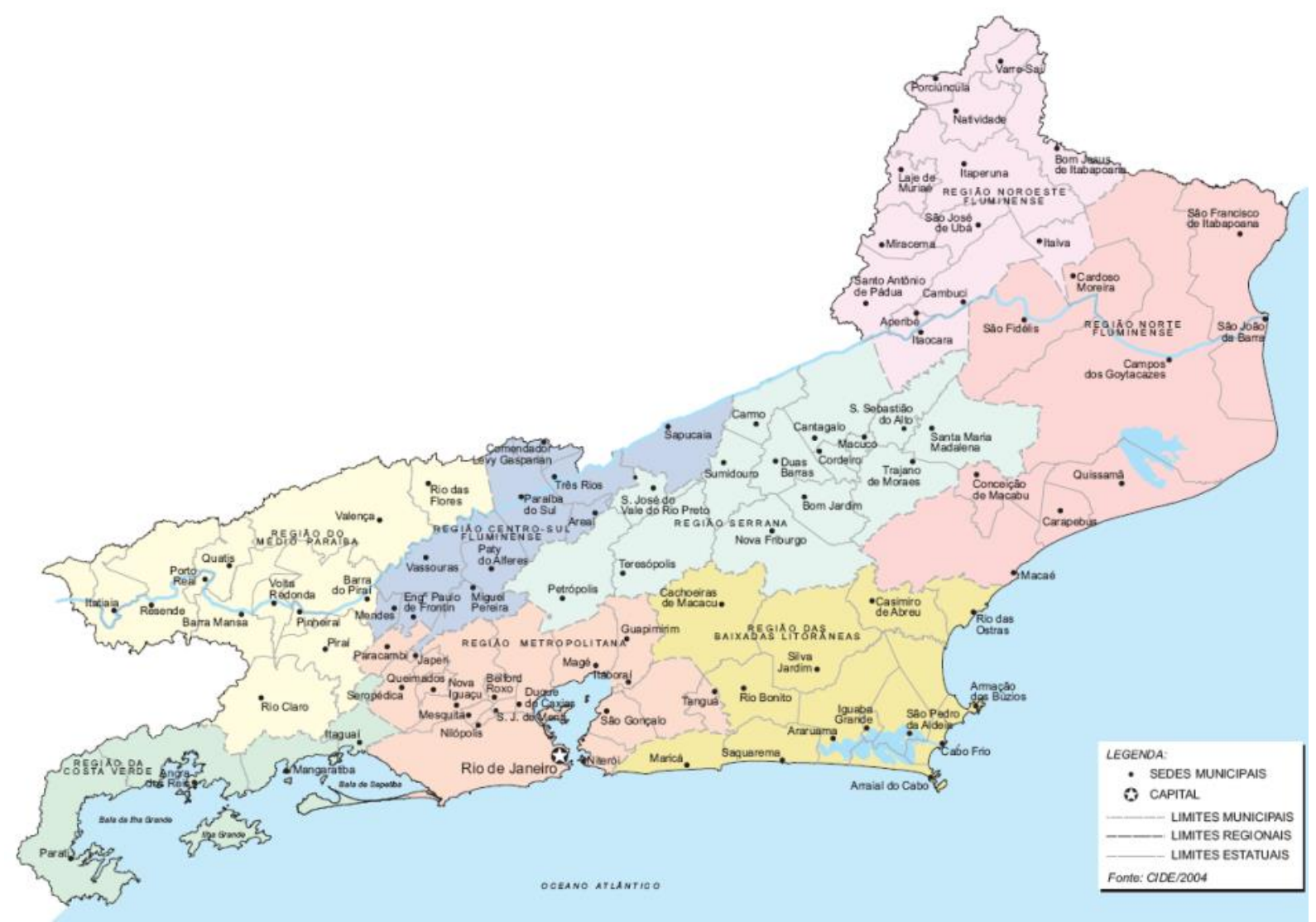

Figura 2.2 Mapa de Regiões Administrativas do RJ (http://mapasblog.blogspot.com.br) 
A região era originalmente coberta continuamente pela Mata Atlântica, que foi significadamente removida para uso de plantações de vegetais, grama para pastos e centros urbanos com ocupação humana. Ainda resta alguma parte com a floresta original e, em várias localidades, houve uma recuperação da área com florestas secundárias, ocorrido por causa da impraticabilidade de atividades agrícolas. Durante o crescimento urbano e rural foram realizados cortes nos taludes para construção de rodovias e residências. Esses fatores aumentam a vulnerabilidade aos escorregamentos, como observado em várias situações desse tipo (AVELAR et al., 2011).

A Figura 2.3 apresenta o mapa geológico simplificado do estado do Rio de Janeiro, onde o contorno em linha preta representa o município de Nova Friburgo, local onde foram coletadas as amostras. Através do mapa é possível verificar a formação geológica que é um dos fatores de predisposição a riscos de acidentes geológicos (deslizamentos, por exemplo). Estes mapas podem ser usados como base de planejamento para uso e ocupação do solo, indicando a vulnerabilidade natural dos terrenos para implantação de construções, disposição de resíduos perigosos e lixo doméstico, entre outros. (DMR - RJ 2008)

Através da Figura 2.3 é observado que o município de Nova Friburgo, assim como toda a região serrana, apresenta predominância nas cores rosa, azul claro e vermelho que são correspondentes a: (DMR - RJ, 2008)

Rosa: Rochas ortoderivadas - formadas a partir do metamorfismo sobre rochas ígneas. As rochas ortoderivadas mais comuns no Estado são os chamados ortognaisses, que possuem uma composição semelhante ao granito, mas que mostram uma estrutura planar bem desenvolvida que são as foliações, gnaisse.

Azul claro: Rochas paraderivadas - formadas a partir do metamorfismo das rochas sedimentares, podendo ser também chamadas de metassedimentares. As mais comuns no Estado do Rio de Janeiro são os paragnaisses, que possuem minerais típicos de metamorfismo sobre sedimentos, como a sillimanita e a granada (mineral vermelho ou rosa, com brilho de vidro). Os mármores de Cantagalo e Italva são rochas metassedimentares que indicam ter havido um grande depósito de corais num mar existente na região há cerca de 1 bilhão de anos. 


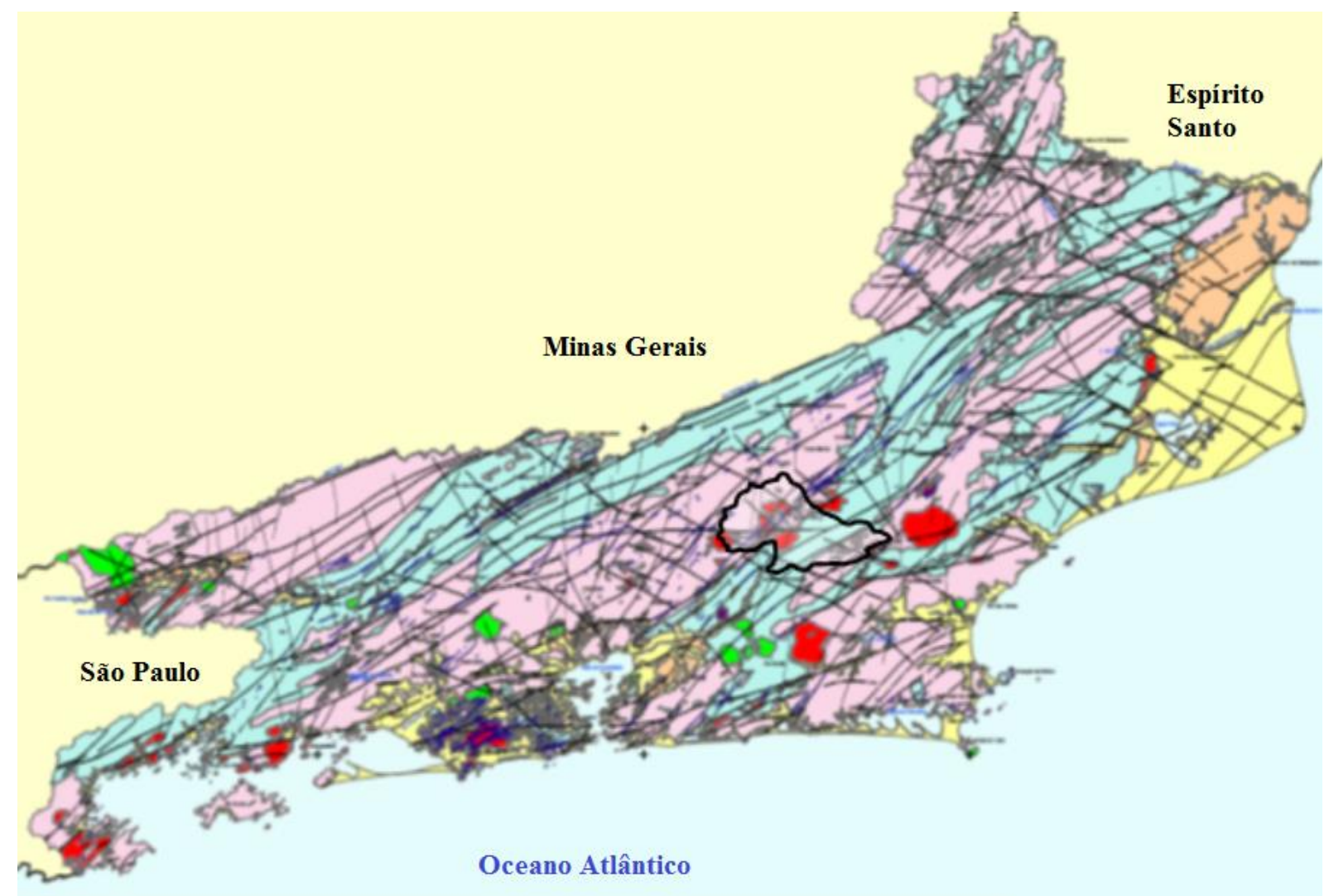

Figura 2.3 Mapa Geológico Simplificado do Estado do Rio de Janeiro com destaque em Nova Friburgo (DMR - RJ, 2008)

Vermelho: Granitos homogêneos - dentre as rochas ígneas que não sofreram metamorfismo no Estado, os granitos são as mais comuns. São constituídos basicamente pelos minerais: quartzo, feldspato e biotita, que podem ocorrer em proporções variadas.

Para os padrões brasileiros, a geomorfologia do Rio de Janeiro é extremamente acidentada. A Serra do Mar forma uma barreira montanhosa, paralela à costa e claramente voltada para o Atlântico, sendo sua face quase sempre abrupta, podendo chegar até a verticalidade. Rochas do Pré-Cambriano médio e tardio (principalmente granito e gnaisse) constituem-na e a altitude média de sua crista fluminense gira em torno de $1.000 \mathrm{~m}$, com picos de altitude bem elevados, como a Pedra do Sino $(2.263 \mathrm{~m})$ e da Caledônia $(2.284 \mathrm{~m})$. A Serra do Mar Fluminense é a continuação dessa importante formação montanhosa iniciada em Santa Catarina (DRUMMOND, 1997).

Em janeiro de 2011, a região serrana do estado do Rio de Janeiro foi atingida por fortes chuvas que causaram milhares de escorregamentos, a Figura 2.4 apresenta uma vista geral dos escorregamentos e a Figura 2.5 num dos bairros 
atingidos. Os municípios mais afetados foram Teresópolis, Nova Friburgo, Petrópolis e Sumidouro. De acordo com Avelar et al. (2011) foram contabilizados 3.562 escorregamentos em uma área de $160 \mathrm{~km}^{2}(20 \times 80 \mathrm{~km})$ que causaram mais de 1500 mortes e danos severos à infraestrutura rural e urbana dos municípios atingidos, sendo que as chuvas que atingiram a região tiveram intensidade de 325 $\mathrm{mm}$ em 48 horas.

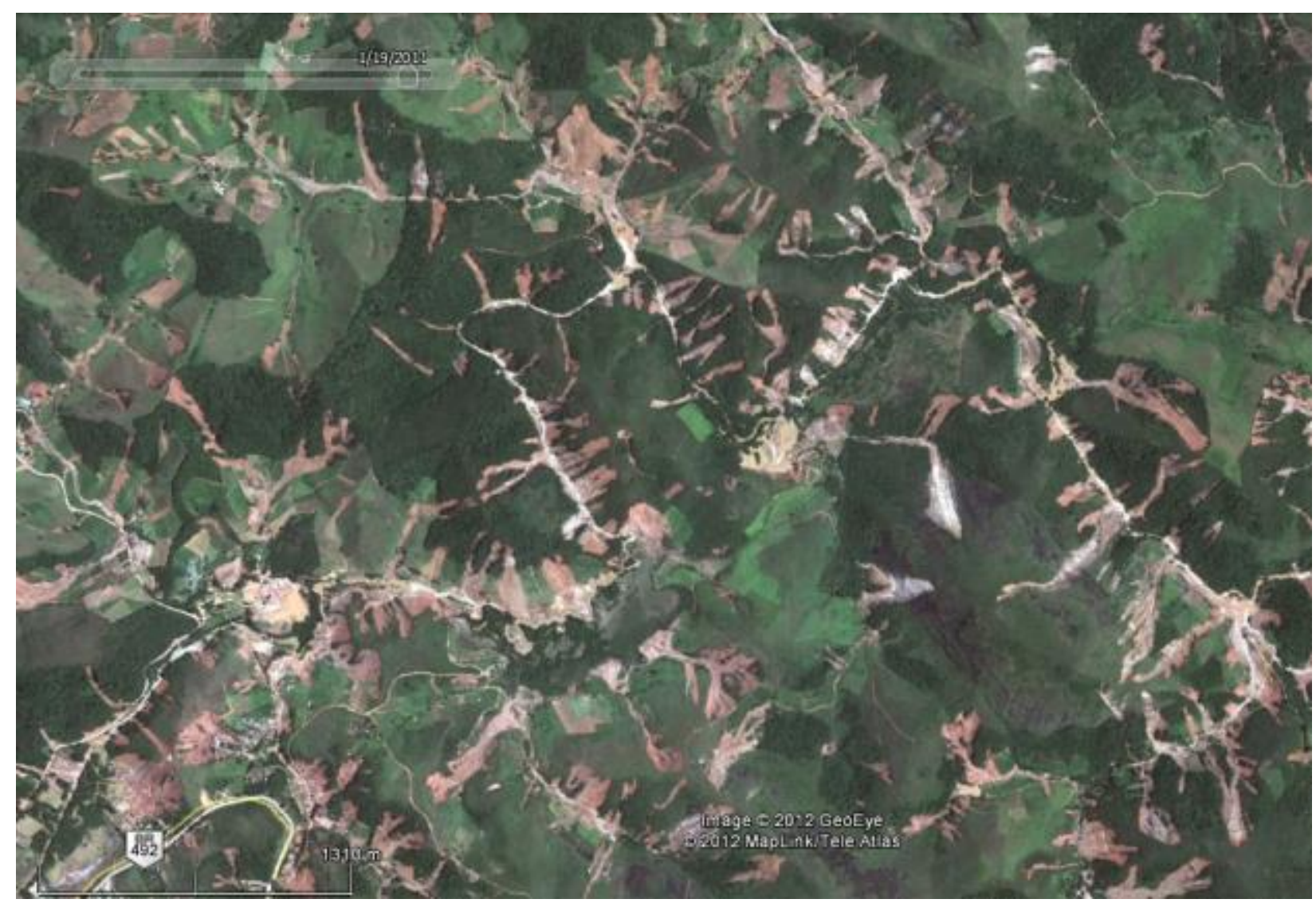

Figura 2.4 Vista geral dos escorregamentos em Nova Friburgo (Google Earth)

Coelho Neto et al. (2011) descreveram que os materiais mobilizados nas encostas alimentaram as avalanches ricas em blocos e detritos orgânicos ao longo do fundo do vale, formando torrentes de grande magnitude que transbordavam os canais fazendo com que esses tivessem sua morfologia e várzea modificadas. A Figura 2.6 ilustra esse fenômeno, no qual os deslizamentos a montante, indicados pelas setas, se uniram com os fluxos de detritos fazendo com que grandes blocos de rocha e troncos fossem transportados por vários quilômetros no fluido denso. 


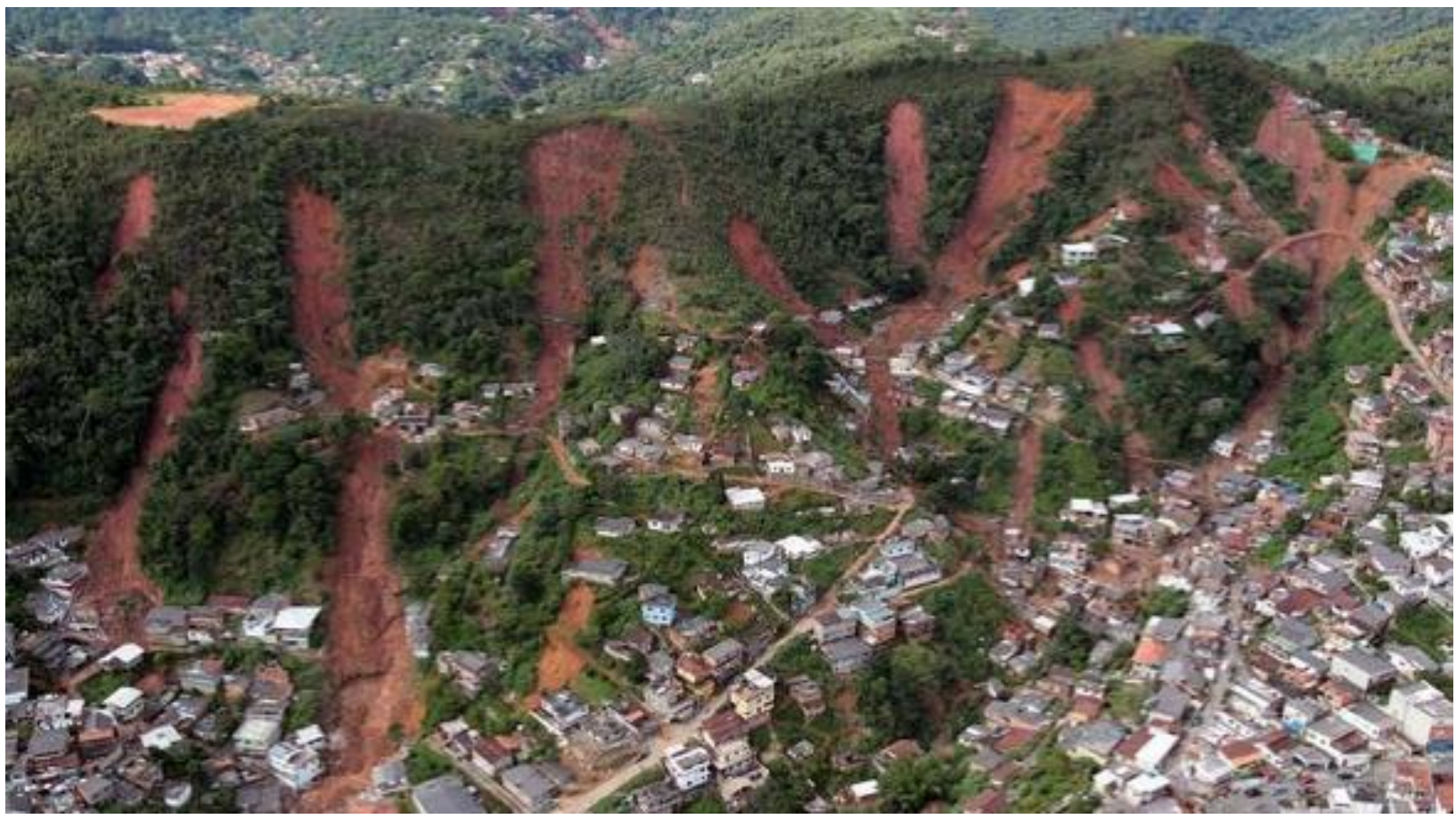

Figura 2.5 Vista de deslizamentos ocorridos em Nova Friburgo (Reprodução/ TV Globo)

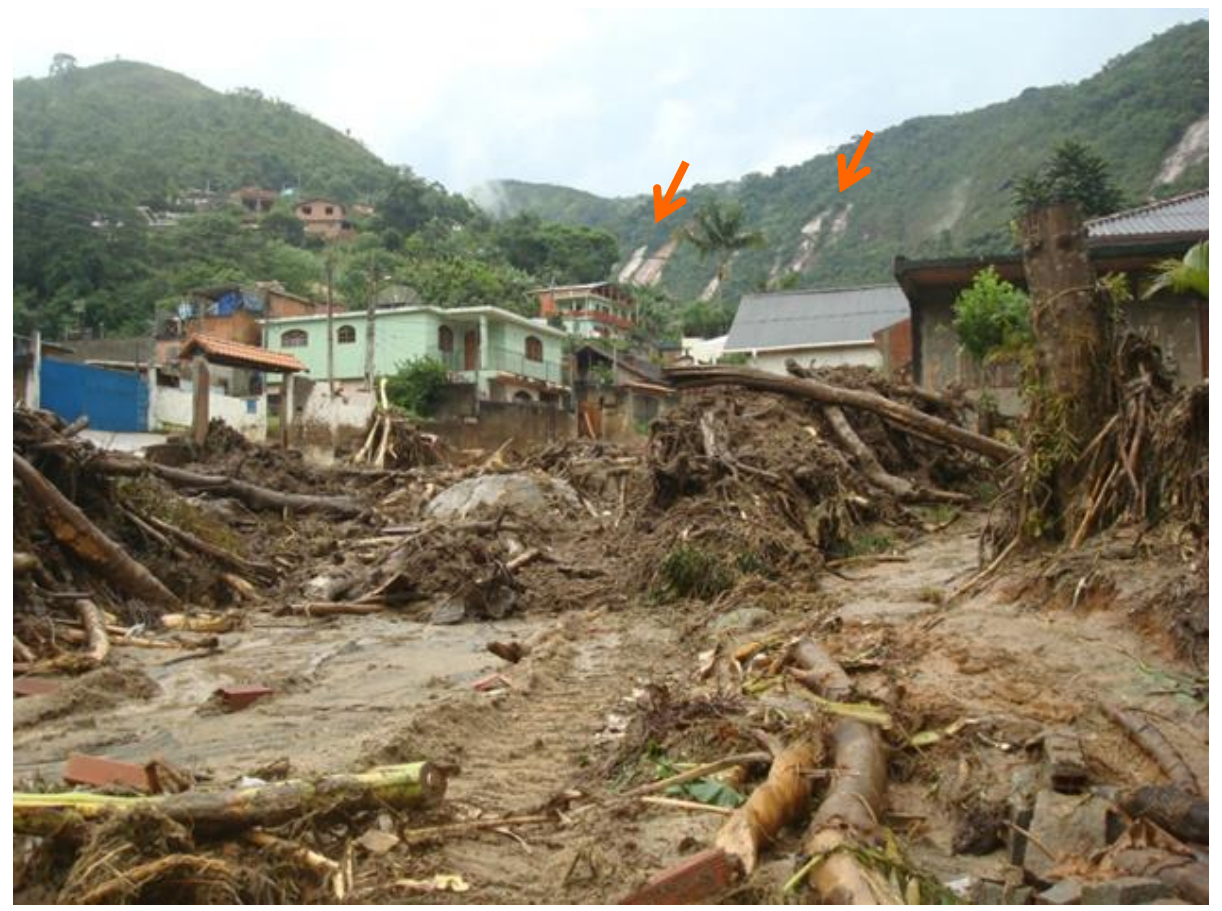

Figura 2.6 Foto do Bairro Caleme,Teresópolis, demonstrando os detritos transportados

(Avelar, 2011)

Não foi a primeira vez que um evento dessa magnitude atingiu o Estado do Rio de Janeiro. Nos anos de 1966 e 1967, nos meses de janeiro e fevereiro, fortes trombas d'água atingiram outra região do Estado causando diversos escorregamentos. Na noite do dia 22 para o dia 23 de janeiro de 1967 o Estado foi 
atingido por uma tempestade que começou às 21 horas e durou por 2 horas e 10 minutos apresentando intensidade de $70 \mathrm{~mm} / \mathrm{h}$, o período de retorno para essas chuvas que atingiram a região está entre 700 e 2000 anos. Os escorregamentos atingiram uma área de $7,5 \mathrm{~km}$ de largura e $24 \mathrm{~km}$ de comprimento, tanto nas áreas urbanas quanto em florestas, sendo estimado que ocorreram 1000 mortes decorrentes desse evento. A Figura 2.7 apresenta uma vista geral desse evento. (COSTA NUNES, 1969)

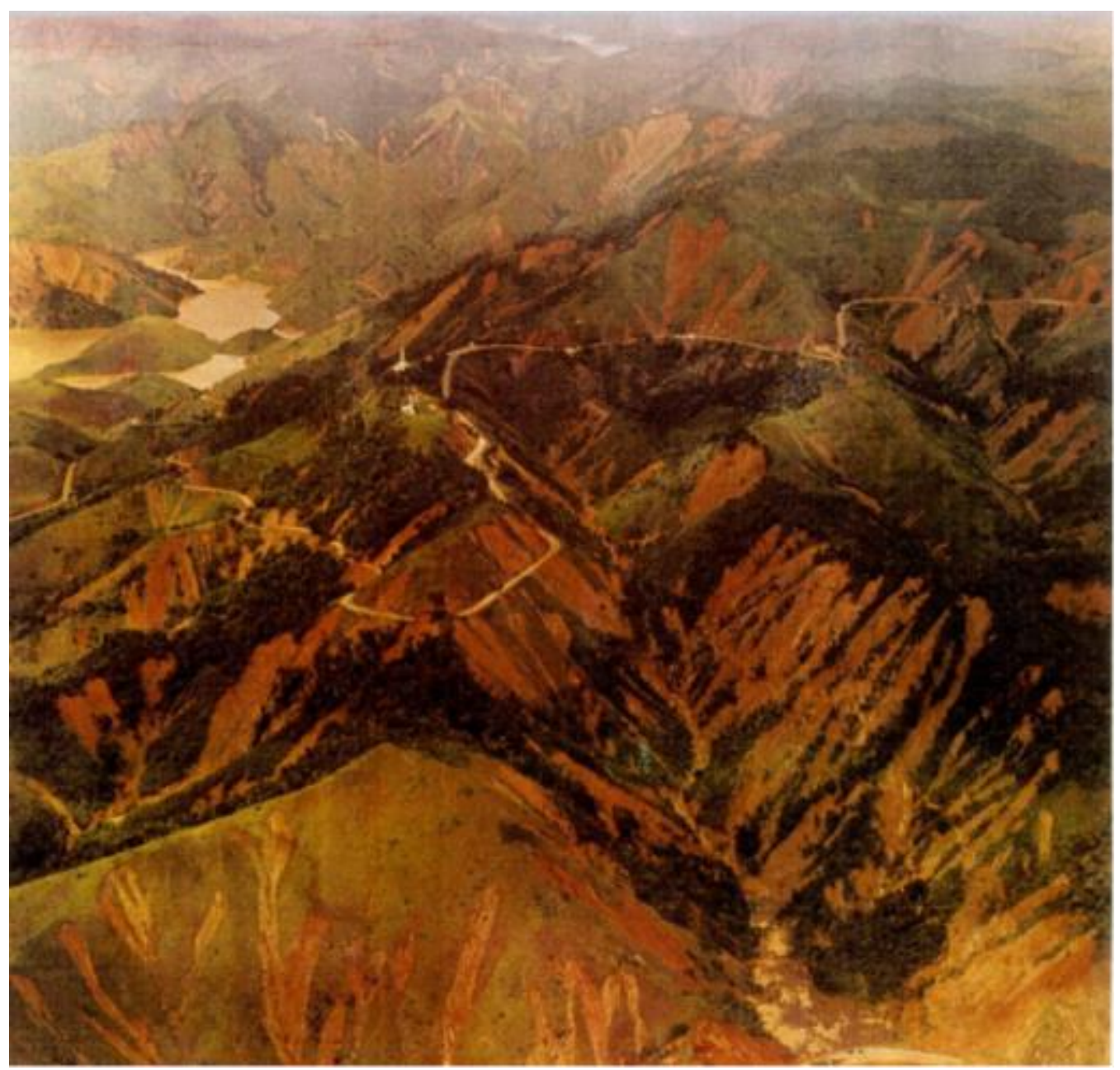

Figura 2.7 Escorregamentos na Serra das Araras em 1967 (JONES, 1973)

Barata (1969) descreveu que muitos dos movimentos observados em $1966 \mathrm{e}$ 1967 foram fluxos com rápida velocidade, que ocorreram durante eventos chuvosos - durante ou depois de chuvas fortes -, em encostas de média a alta inclinação, com cobertura superficial, tendo seu início na forma de escorregamento que acelerou devido a duas condições: 1) a camada de solo jovem era muito permeável e a massa de solo se tornou saturada com facilidade, assim quando o movimento 
começou a massa se tornou fluida muito rapidamente e 2) o talude tem inclinação média a alta e é longo, o que permite o desenvolvimento e aceleração da corrida.

Além das fotografias impressionantes, os dois eventos apresentam outras características em comum, como o alto número de vítimas, a chuva intensa como agente deflagrador e a grande extensão da área atingida. Entretanto, não é válido realizar uma comparação direta entre esses dois eventos, tendo em vista que o Rio de Janeiro de 2011 apresenta condições ocupacionais, ambientais e climáticas muito diferentes das condições existentes em 1966/1967.

Durante o início do ano de 2011 toda a região sudeste foi atingida por fortes chuvas, sendo o principal agente deflagrador dos escorregamentos observados. De fato, em janeiro de 2011, os eventos extremos que ocorreram sobre a Região Sudeste foram modulados pela Zona de Convergência do Atlântico Sul (ZCAS), principal sistema responsável pelas chuvas nos meses de verão, e também pelo sinal da Oscilação Intrassazonal Madden-Julian, como pode ser observado na Figura 2.8. O sinal favorável desta oscilação persistiu até meados de janeiro, intensificando o episódio de ZCAS e, consequentemente, as chuvas em parte da Região Sudeste. As chuvas também excederam os valores médios históricos em grande parte das Regiões Norte e Centro-Oeste, no norte e extremo leste da Região Nordeste e no leste da Região Sul. (CPTEC/INPE)

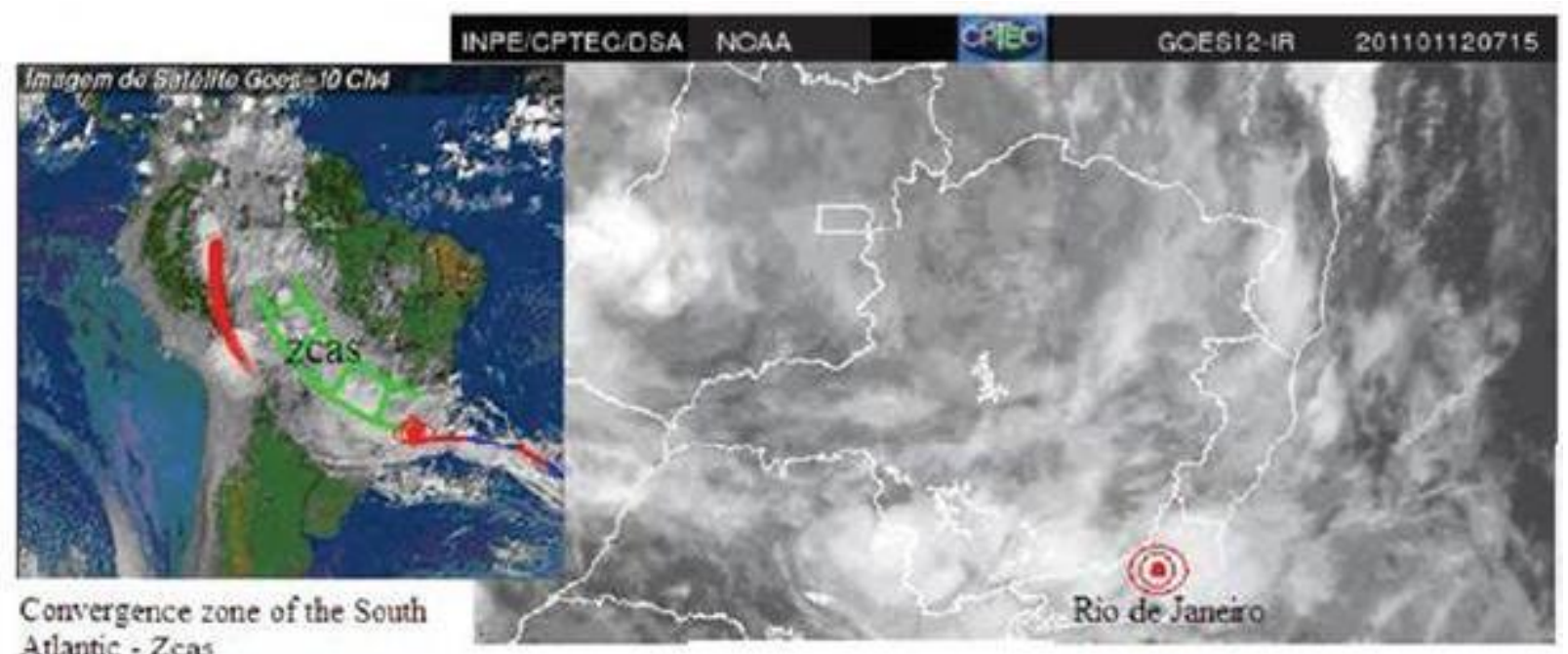

Figura 2.8 Situação climática no evento (BAGGIO e HORN, 2011)

A média das chuvas de Nova Friburgo, para o mês de Janeiro é de 232,1 mm e, somente nos dias 11 e 12 de janeiro, foram registrados $170 \mathrm{~mm}$ de chuva (INMET). Apesar das fortes chuvas que atingiram a região, apenas essas chuvas, 
provavelmente, não seriam capazes de causar um evento tão extremo como o observado na região. A chuva intensa nos dois dias foi deflagradora das movimentações observadas, no entanto também é possível predizer que os solos da região estavam saturados, devido ao período chuvoso da região de novembro à janeiro. As precipitações diárias e a acumulada de 30 dias, dos meses chuvosos da região, de novembro a dezembro, estão apresentadas na Figura 2.9. As chuvas médias mensais obtidas de dados de 1961-1990 para esses meses são de 169, 239 e $209 \mathrm{~mm}$ para novembro, dezembro e janeiro. Comparando com os valores medidos é possível afirmar que o mês de Janeiro foi atípico, com uma chuva $66 \%$ maior que a média, enquanto que em novembro a chuva foi $8 \%$ maior que a média e em dezembro foi $3 \%$ menor.

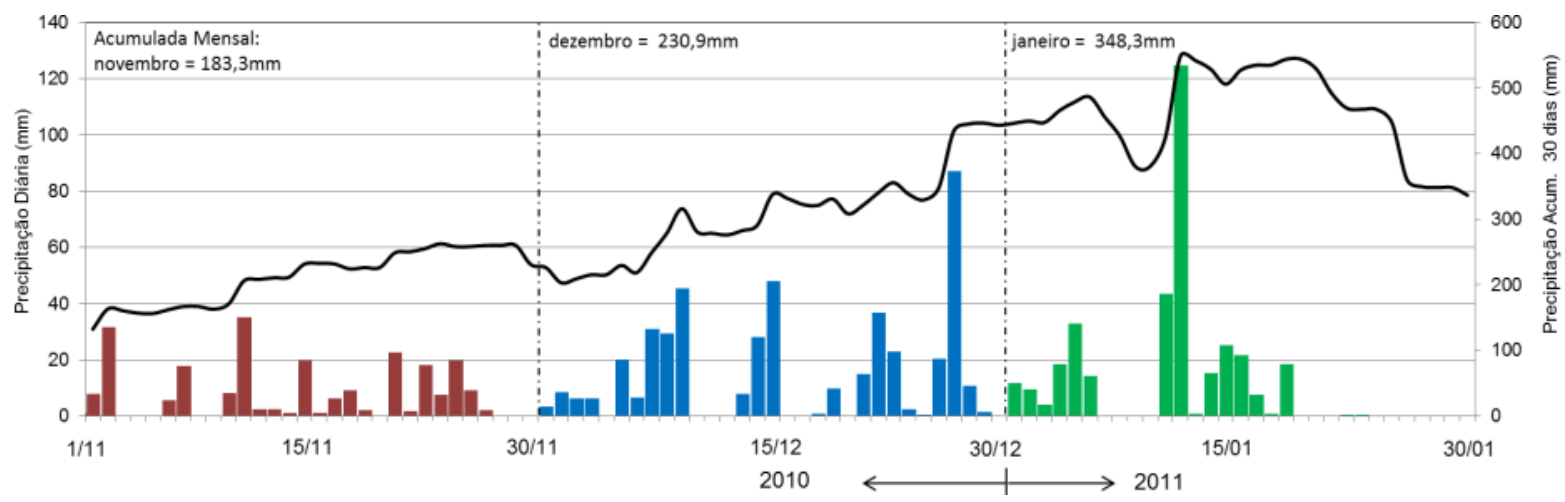

Figura 2.9 Precipitação da Estação de Teresópolis 83744 (INMET)

Os dados foram obtidos através do BDMEP (Banco de Dados Meteorológicos para Ensino e Pesquisa) do INMET (Instituto Nacional de Meteorologia). A estação utilizada foi a de Teresópolis-RJ (83744), sua localização está apresentada na Figura 2.10. Está a uma distância de, aproximadamente, $40 \mathrm{~km}$ do local de coleta das amostras, sinalizado pelo marcador preto. 


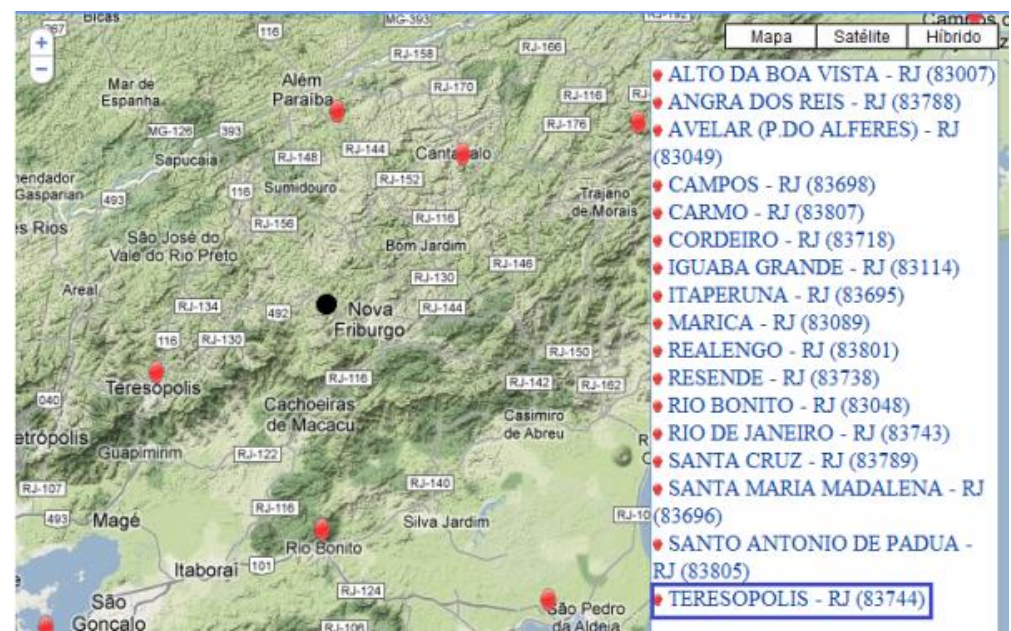

Figura 2.10 Localização da estação de dados de precipitação (INMET)

Nova Friburgo é a área que apresenta os maiores índices pluviométricos do estado do Rio de Janeiro, com uma média anual em torno de $2500 \mathrm{~mm}$ nas áreas mais altas, decrescendo progressivamente ao norte para $1300 \mathrm{~mm}$ (Coelho Neto et al., 2011). Através dos dados da Figura 2.9 é possível calcular que a precipitação acumulada dos três meses totalizou $1026 \mathrm{~mm}$.

Coelho Neto et al. (2011) apresentaram dados de precipitação versus tempo incluindo as ocorrências de escorregamentos para os locais de Olaria, Ypu, Nova Friburgo e Sítio Santa Paula, entre 20 horas do dia 11 e 08 horas do dia 12 de janeiro de 2011, com medidas a cada 30 minutos, reproduzida na Figura 2.11.

Através desses gráficos, é possível observar que a ocorrência de escorregamento não está vinculada apenas às máximas intensidades de chuva. Em Nova Friburgo, por exemplo, a intensidade de chuva não teve grandes variações durante o período, e as intensidades nas quais ocorreram escorregamentos apresentam média de $17 \mathrm{~mm} / \mathrm{h}$, nos dados apresentados, que não é um valor alto. Considerando a precipitação acumulada entre 10 e 11 de janeiro, é possível observar que 94\% dos escorregamentos ocorreram com precipitação acumulada dos dois dias acima de 120 mm, além disso, a cidade de Nova Friburgo, que apresentou as menores precipitações (acumulada e horária) dos dias 11 e 12, sofreu um número maior de escorregamentos do que os outros três locais estudados.

Coelho Neto et al. (2011), através da análise de isoietas do dia 12 de janeiro de 2011, verificaram que do número total de escorregamentos, estimados em 3622 , apenas 2,7\% ocorreram com intensidade entre 140 e $160 \mathrm{~mm}$ sendo que esse número cresce com a intensidade, nos locais onde a intensidade de precipitação foi 
entre 180 e 200 mm ocorreram 40,0\% dos escorregamentos. Os maiores escorregamentos, com área maior que $20.000 \mathrm{~m}^{2}$, ocorreram com intensidade entre 160 e 220 mm, sendo 20 ocorrências entre 160 e 180 mm, 64 ocorrências entre 180 e $200 \mathrm{~mm}$ e 56 ocorrências entre 200 e $220 \mathrm{~mm}$, totalizando 140 grandes escorregamentos. Sendo essas intensidades acumulada medida a partir das 20 horas da noite do dia 11 de janeiro. A maioria desses grandes escorregamentos (60\%) ocorreu em área com florestas 'naturais', não sendo realizada uma distinção se eram florestas primárias ou de reflorestamento.
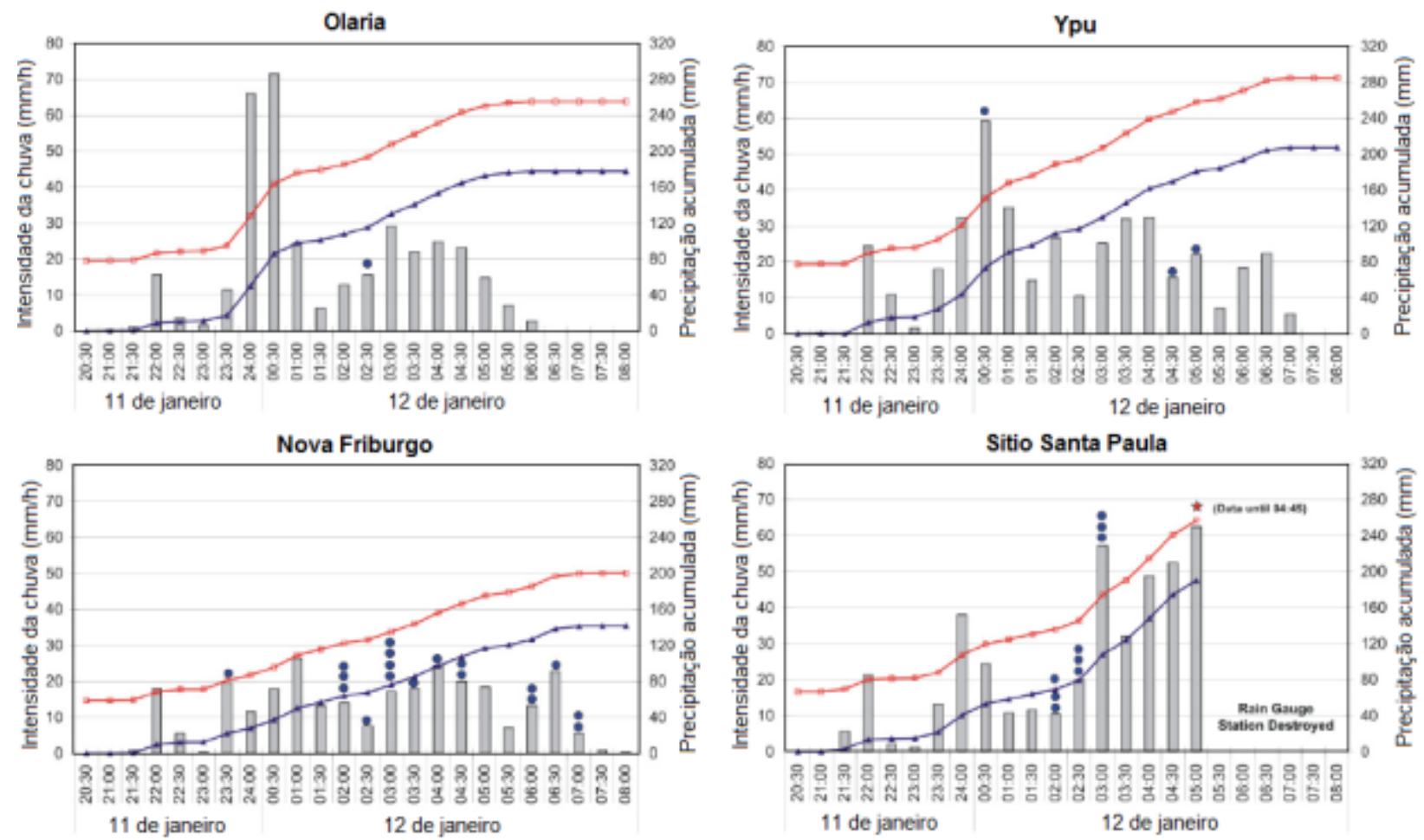

$\square$ Intensidade de precipitaçāo - Precipitaçăo acumulada dos dias 11 e 12 de Janeiro - - Precipitação acumulada dos dias 10 e 11 de Janeiro

Figura 2.11 Intensidade de chuva em quatro estações nos dias 11 e 12 de janeiro de 2011

(Coelho Neto et al., 2011)

Coelho Neto et al. (2011) determinaram as posições onde ocorreram os escorregamentos, através da sobreposição dos mapas de inclinação dos taludes com o mapa de deslizamentos, determinando que 55\% dos escorregamentos se localizam na parte mais alta da encosta. Em relação às inclinações dos taludes obtiveram uma inclinação média de $1^{\circ}$ na região, e que os escorregamentos ocorreram com inclinação média de 19ำ e máxima de 65ํ.

Avelar et al. (2011), observando os materiais envolvidos nos escorregamentos, determinou que são predominantes 4 tipos de solos nos 
escorregamentos: saprólitos de coloração cinza, que representa o estado inicial do intemperismo do granito; saprólitos de coloração rosa, que são o estado mais avançado de intemperismo do granito; colúvio de coloração vermelha e intensa laterização que cobre os taludes, e colúvio castanho com blocos de rocha arredondados, que preenchem os fundos de vale e que ocorrem, geralmente, nas depressões.

Através de imagens fotográficas feitas logo após o evento catastrófico, é possível observar algumas características dos fluxos que atingiram a região. $\mathrm{Na}$ Figura 2.12a pode-se ver a deposição de uma camada com cerca de $30 \mathrm{~cm}$ de espessura composta por material siltoso proveniente dos sólidos em suspensão existentes no fluxo detrítico e na Figura 2.12b pode-se observar a elevação de veículo devido ao aumento da densidade durante passagem de fluxo de detritos com depósito de cerca de $50 \mathrm{~cm}$ de espessura logo abaixo do veículo, ambas as fotos são do município de Teresópolis. Esses depósitos evidenciam a alta densidade do fluido durante a passagem do fluxo de detritos. (AVELAR, 2011)

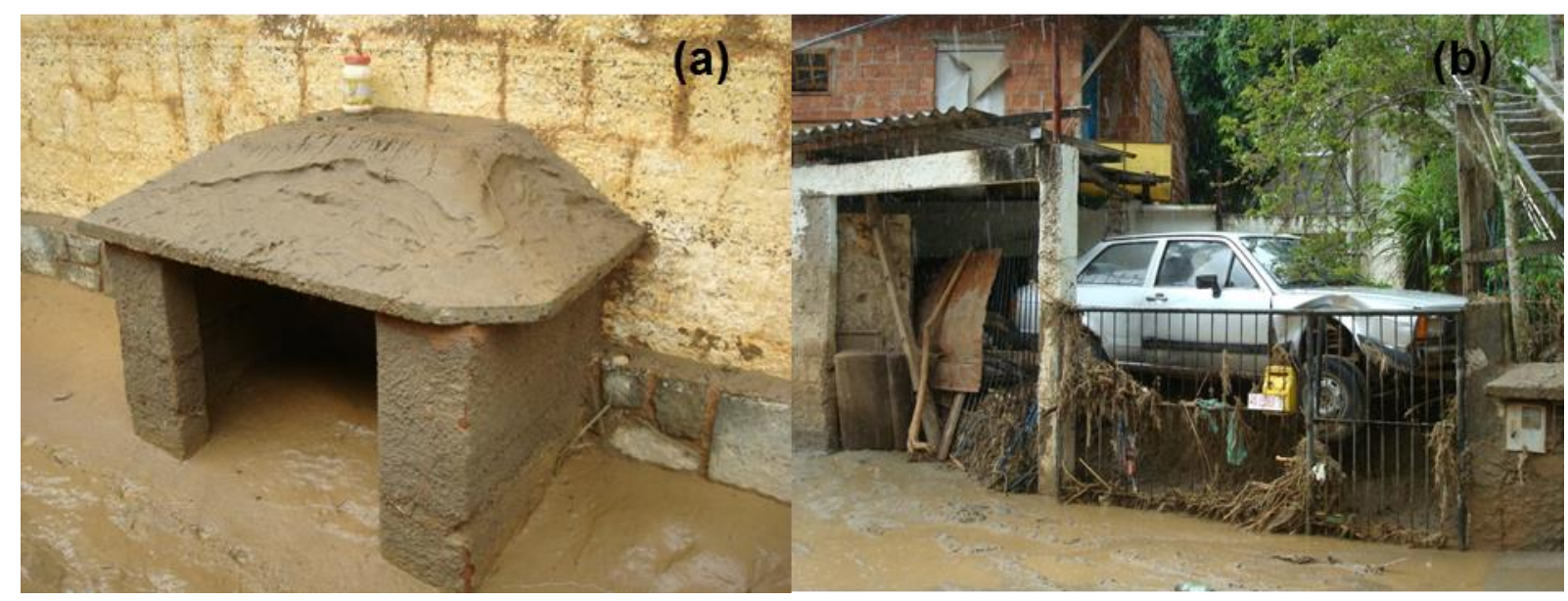

Figura 2.12 Evidência do aumento da densidade do fluxo, Teresópolis 14- jan (Avelar, 2011)

Durante esse evento ocorrido em Janeiro de 2011 foram observados alguns escoamentos, nos quais a movimentação do solo se deu em forma de fluxo, como pode ser visto na Figura 2.13 que apresenta a evolução da lama escoando em forma de um fluido barrento pela encosta no centro de Nova Friburgo, próximo de onde era localizado o teleférico, um dos pontos turísticos da cidade. Esse tipo de movimento que motivou o uso da reologia para o estudo do comportamento do solo em estado fluido. 
Esse fenômeno de liquefação do solo foi filmado em várias ocasiões tanto nesse evento ocorrido na Região Serrana do Rio de Janeiro quanto em outros eventos ocorridos no país. A Figura 2.14 apresenta o movimento do solo em estado fluidificado gravado durante uma reportagem, ocorrido em Santa Catarina em 2011.
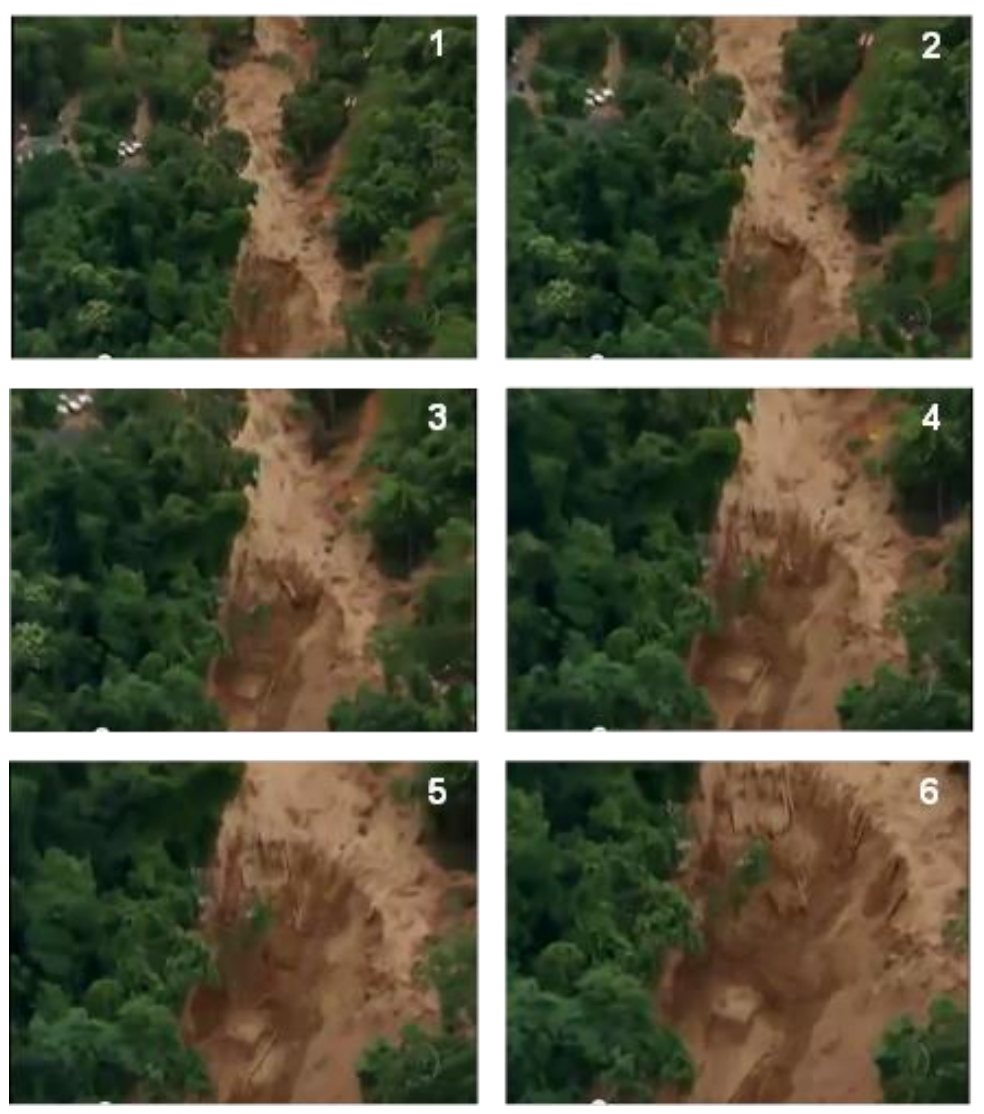

Figura 2.13 Lama escoando pela encosta mesmo após o cessar das chuvas (Youtube) 


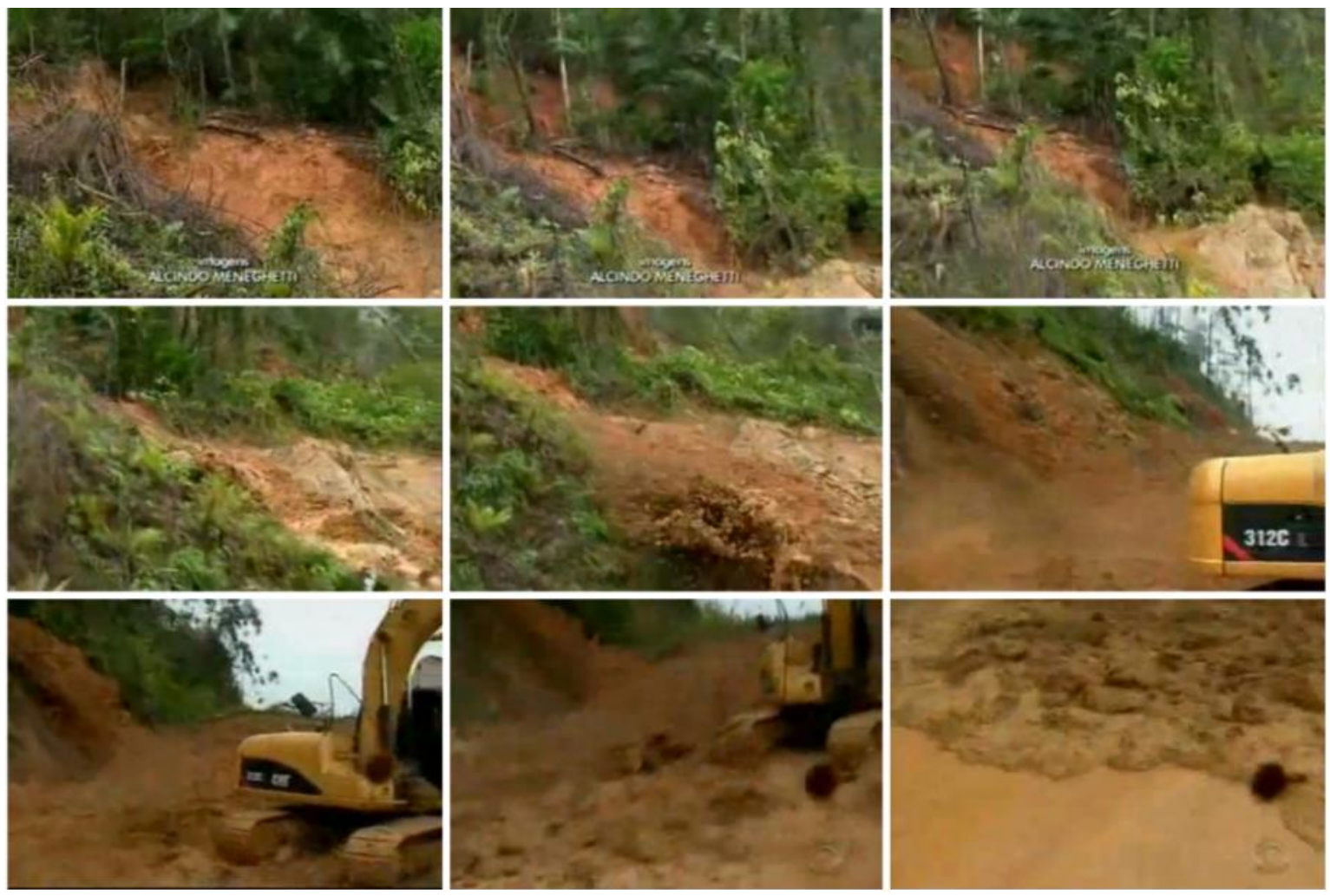

Figura 2.14 Movimento de solo em estado fluidificado, Santa Catarina, 2011 (Youtube)

Nos últimos anos a sociedade vem impondo um desafio em determinar causas e minimizar os impactos causados por movimentações de solo, principalmente em eventos catastróficos, como o ocorrido no Rio de Janeiro (2011). Como o solo apresenta um comportamento que está mais próximo de um líquido do que de um sólido, durante a ocorrência desses eventos catastróficos, a determinação de suas características reológicas pode ajudar na especificação do mecanismo de controle dessas corridas de solo. E auxiliar na forma de uma definição prévia da potencialidade de dano de cada encosta quanto ao desenvolvimento e mitigação do fluxo de solo. 


\section{MECANISMOS DE RUPTURA EM ESCORREGAMENTOS}

Na região de Campania no sul da Itália, próximo a Napoli e Salerno, ocorreram escorregamentos em condições similares às situações de desastres registrados no Brasil em 1966 e 1967 (Caraguatatuba, Serra das Araras e Rio de Janeiro), Serra de Cubatão (1985), Região Serrana do RJ (2011), dentre outros (FUTAl et al, 2011). A Figura 3.1 apresenta uma vista geral dos escorregamentos ocorridos em Campania em 1998 e na Região Serrana em 2011.

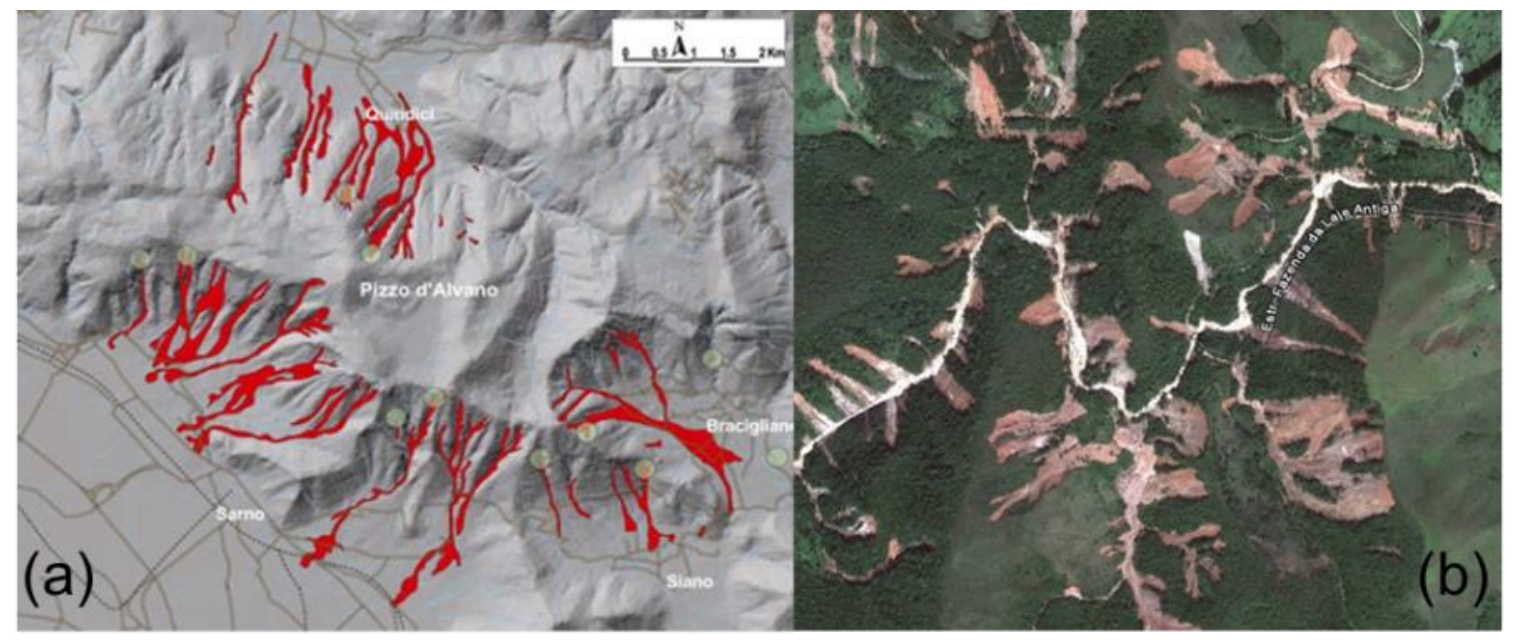

Figura 3.1 Vista geral dos escorregamentos ocorridos na Itália e em Nova Friburgo ((a) Cascini e Sorbino, 2003 e (b) Google Earth)

Um breve histórico da pesquisa desenvolvida para determinar os mecanismos de ruptura dos taludes no caso italiano e os principais resultados obtidos serão apresentados e com isso, pretende-se realizar uma comparação entre os mecanismos observados no caso Italiano e os que aconteceram no evento ocorrido na Região Serrana do Rio de Janeiro.

\subsection{Desenvolvimento do Escorregamento - Caso Italiano}

$\mathrm{Na}$ Itália, a infiltração de águas pluviais provocou escorregamentos catastróficos de depósitos de solos piroclásticos inicialmente insaturados, em encostas íngremes. Após a ocorrência da ruptura desencadeou-se um processo de colapso seguido por liquefação, culminando no deslocamento de uma massa totalmente saturada caracterizada por um alto grau de fluidez. Nestes casos, a 
análise do processo de geração do flowslide é bastante complexa e requer o conhecimento da mecânica dos solos não saturados. (OLIVARES \& DAMIANO, 2007)

O solo piroclástico é um produto vulcânico, formado por cinzas; material abundante no local por se tratar de área nas redondezas do Monte Vesúvio. Segundo Cascini et al. (2005), apesar do solo ser comumente encontrado nas proximidades de vulcões, também pode ser encontrado por áreas muito afastadas, graças a ação do vento no transporte de materiais durante a fase explosiva da atividade vulcânica. Esse tipo de cobertura representa 0,7\% da superfície terrestre (aproximadamente 1 milhão de $\mathrm{km}^{2}$ ) sendo grande parte ocupada como, por exemplo, no caso do Japão, Indonésia e América Central.

Num intervalo de 10 horas, em maio de 1998, ocorreram deslizamentos em quase toda a bacia de Pizzo d'Alvano, região de Campania. As áreas de início do movimento estão localizadas principalmente na parte superior da bacia. A inclinação média dos taludes varia entre $35^{\circ}$ e $45^{\circ}$ e a profundidade dos deslizamentos de 0,5 m a 5,0 m. O ângulo de atrito, nos casos examinados, é constante e a presença de uma superfície de deslizamento, que é praticamente paralela à formação calcária, permite que a análise através da hipótese de talude infinito seja bem empregada. (CASCINI \& SORBINO, 2003, OLIVARES \& DAMIANO, 2007). A Figura 3.1(a) apresenta uma vista geral dos flowslides ocorridos nesse evento.

Neste evento, após a ocorrência da ruptura, houve a formação de flowslides, provavelmente pelo fenômeno de liquefação estática. $O$ volume dos escorregamentos foi majorado devido à incorporação de solos erodidos de voçorocas e de pequenos escorregamentos. O volume total da massa de solo mobilizada foi de, aproximadamente, 3 milhões de $\mathrm{m}^{3}$. Através de retro análises dos danos sofridos pelas construções foi possível estimar as velocidades nas quais o fluxo atingiu as cidades próximas, que variaram de 1 a $20 \mathrm{~m} / \mathrm{s}$. Através de ensaios realizados com amostras indeformadas foi obtido que $\varphi^{\prime}$ varia de $30^{\circ}$ a $37^{\circ}$ e a coesão efetiva, c' é menor de 5 kPa. (CASCINI \& SORBINO, 2003)

Em dezembro de 1999 ocorreu um novo evento com diversos escorregamentos, novamente provocado por chuva intensa. No principal talude analisado, a inclinação é próxima a $40^{\circ}$ e a espessura média da cobertura é da 
ordem de 2,4 m. A partir de uma camada superficial do solo remoldado formada por cinzas vulcânicas (aproximadamente $60 \mathrm{~cm}$ de espessura), a camadas foram identificados de cima para baixo da seguinte forma: (A) uma camada superior (20 $\mathrm{cm}$ ) de púmices grosseiro; (B) uma camada $(100 \mathrm{~cm})$ de cinzas vulcânicas; (C) um horizonte $(20 \mathrm{~cm})$ de púmices mais fino misturado com cinzas; (D) uma camada inferior $(40 \mathrm{~cm})$ de cinzas em contato com a camada de calcário fraturado. A espessura total da cobertura de solo aumenta no pé do talude devido à presença de colúvio. (DAMIANO \& OLIVARES, 2010) A Figura 3.2 apresenta um esquema da encosta em Cervinara.

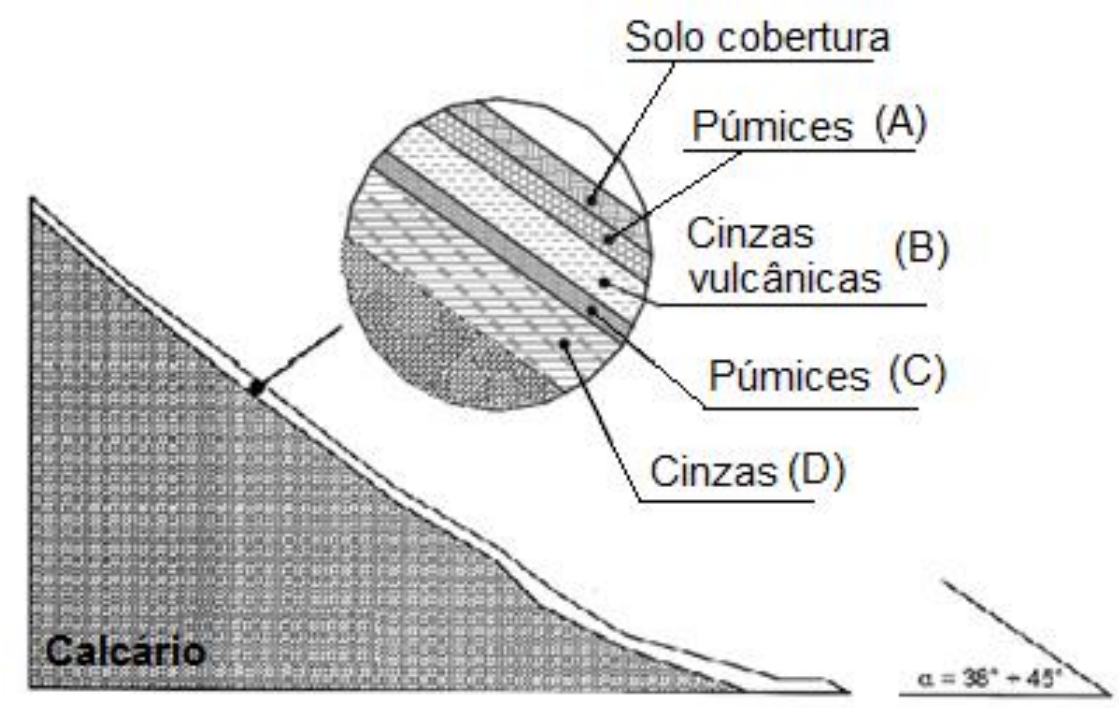

Figura 3.2 Perfil típico de Cervinara (Damiano e Olivares, 2010)

Os maciços da região de Campania, não apresentam nível d'água, sendo não saturados, e a resposta do solo na ruptura é mais difícil de ser prevista do que num solo saturado. A resistência, a rigidez e a condutividade hidráulica estão relacionadas com a sucção que, por sua vez, depende do grau de saturação. Com a infiltração de águas pluviais a sucção diminui e provoca um aumento da condutividade hidráulica e uma diminuição da resistência e da rigidez do maciço, o que pode levar à instabilidade.

Em solos granulares saturados a transição entre escorregamentos de terra e fluxos (ou corridas) é, essencialmente, atribuída ao desenvolvimento de um mecanismo de liquefação estática e não drenada. $O$ efeito da saturação na resistência pode ser analisado através de uma extensão da equação de MohrCoulomb, apresentada na Equação 3.1 proposta por Fredlund et al. (1978). De 
acordo com esse critério, a envoltória de resistência é paralela à envoltória em condição saturada, porém tem um ganho de resistência associado à parte não saturada. Ou seja, o início da instabilidade é causado pela redução do intercepto de coesão devido à saturação do solo.

$$
\tau=\left[c^{\prime}+\left(u_{a}-u_{w}\right) \operatorname{tg} \phi_{b}\right]+\left(\sigma-u_{a}\right) \operatorname{tg} \phi^{\prime}
$$

A trajetória de tensão correspondente pode ser caracterizada por um cisalhamento praticamente constante e um decréscimo na sucção, como pode ser visto na Figura 3.3. De acordo com Olivares \& Damiano (2007), podem ser discriminados dois cenários de processo de instabilização, a partir da infiltração, sendo que esses cenários dependem da morfologia dos taludes:

1. Encosta íngreme (a): ângulo de inclinação próximo ou ligeiramente maior que 0 ângulo de atrito - o ponto representativo das condições de tensões no início da instabilidade é próximo à envoltória de tensões cisalhantes para o material saturado.

2. Encosta muito íngreme (b): ângulo de inclinação significativamente maior que o ângulo de atrito - o ponto representante das condições iniciais de tensão no início da instabilidade está localizado bem acima da envoltória de resistência ao cisalhamento do material saturado.

No primeiro cenário, com menor inclinação, o solo no início da instabilidade está praticamente saturado quando ocorre a ruptura e, como será visto adiante, poderia se desenvolver tanto um escorregamento quanto um flowslide. No segundo cenário, a ruptura ocorre quando o solo ainda está longe de ter uma saturação completa e a evolução pós-ruptura para um flowslide não é provável. 


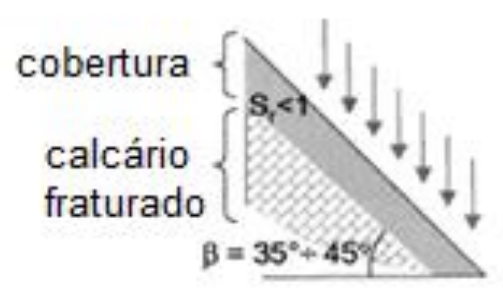

a)

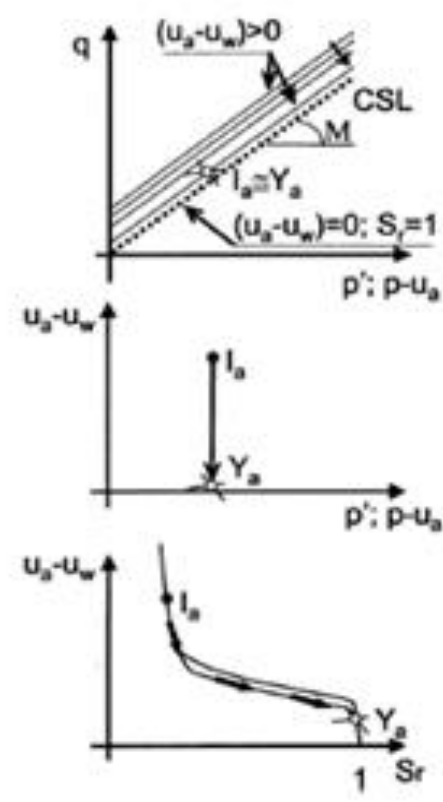

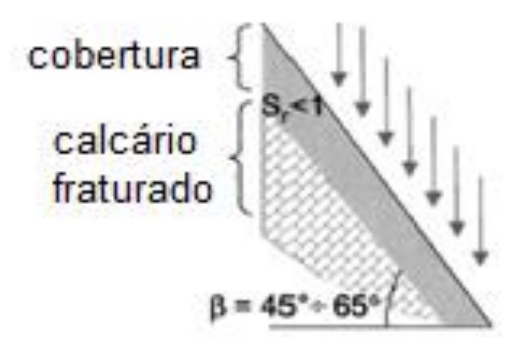

b) 2

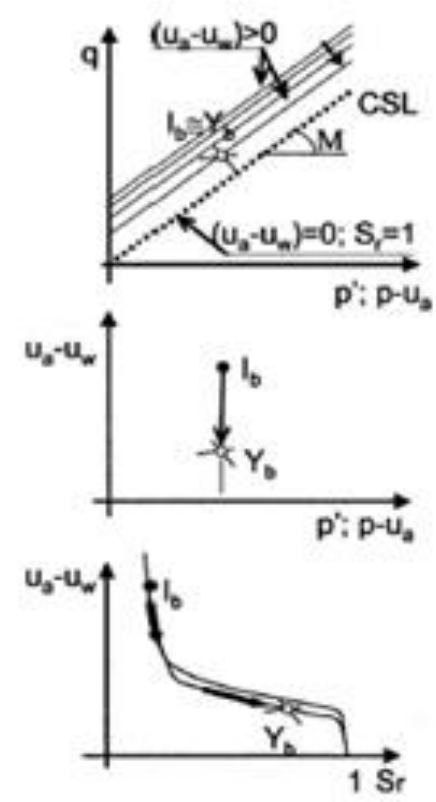

Figura 3.3 Estado de tensões na ruptura (a) taludes íngremes e (b) taludes muito íngremes (Olivares e Damiano, 2007)

Na Figura 3.4a, é apresentado um exemplo do caso de talude íngreme ocorrido em Cervinara, um flowslide catastrófico ocorrido em um talude com inclinação da ordem de $40^{\circ}$, com ângulo de atrito ligeiramente menor que $40^{\circ}$. O fenômeno de liquefação ocorreu com profundidade da ordem de 1,5 m, o solo correu pela encosta por vários quilômetros.

A Figura 3.4b, Monte Spina, é um caso de talude muito íngreme, onde ocorreu um escorregamento raso com espessura média de 1,2 m envolvendo cobertura piroclástica. $\mathrm{O}$ deslizamento começou em um declive de $48^{\circ}$ e ângulo de atrito de $35^{\circ}$. 


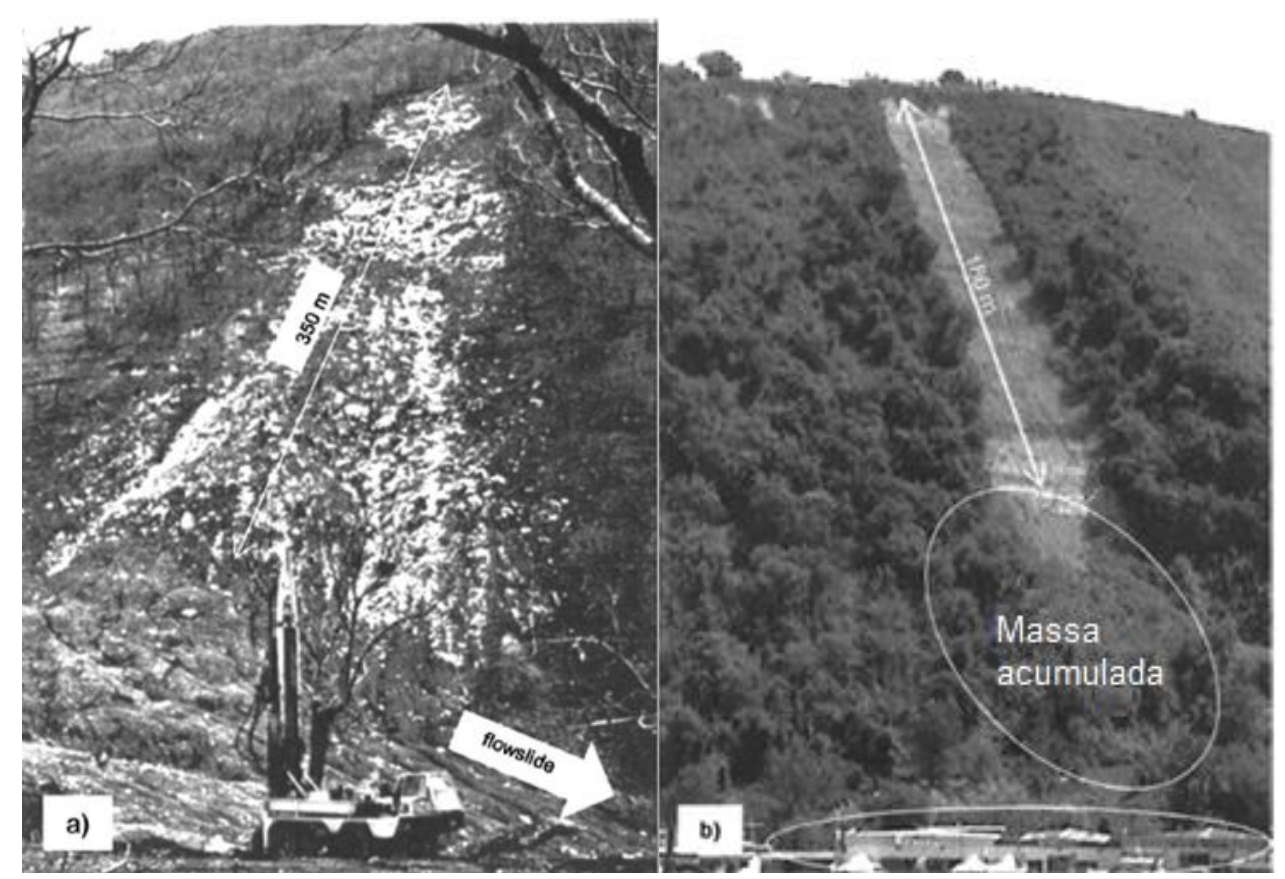

Figura 3.4 Vista de escorregamentos (a) Cervinara (b) Monte Spina (Olivares e Damiano, 2007)

No caso Cervinara, Olivares \& Damiano (2007), descreveram que a ruptura ocorreu em condições de saturação quase total, baseado no mecanismo apresentado na Figura 3.3a e no fato do valor da inclinação do talude ser próxima do ângulo de atrito. Quando a resistência disponível diminui, em consequência da diminuição da sucção, a ruptura quase que, instantaneamente, se torna não drenada, ou parcialmente drenada, para taxas de cisalhamento maiores do que a capacidade do solo de dissipar pressões neutras.

No caso do Monte Spina, Figura 3.4b, que apresenta uma inclinação muito maior que o ângulo de atrito, a ruptura ocorreu quando o solo ainda apresentava sucção e, portanto, com grau de saturação significativamente menor que a unidade. Desse modo, Olivares e Damiano (2007) afirmaram que a resposta do solo em relação aos mecanismos pós-ruptura são representadas pelas propriedades do estado do solo, principalmente o grau de saturação, no início da instabilidade. Para racionalizar o problema foi proposto o seguinte fluxograma, apresentado na Figura 3.5 , que resume as possibilidades de resposta de um talude infinito de solo granular exposto à água. 


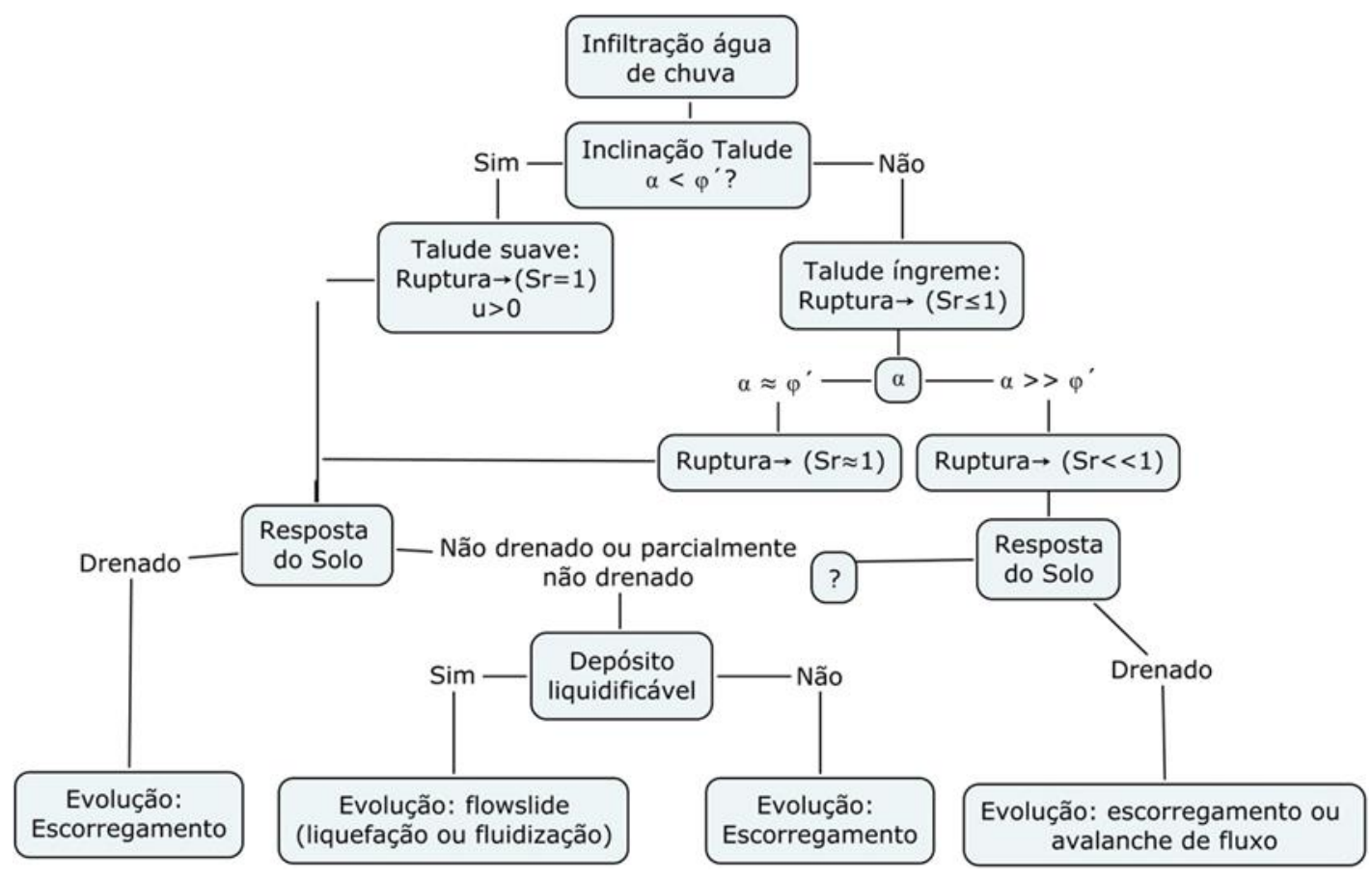

Figura 3.5 Possibilidades de resposta de solo granular (Olivares e Damiano, 2007)

Solos piroclásticos raramente são saturados, mesmo em encostas de inclinação baixa, quando a infiltração de água provoca a saturação ainda é necessário um aumento na pressão neutra para desencadear a instabilidade de taludes. Um flowslide ocorre somente se a resposta à pós-ruptura é não drenada e quando o solo é susceptível à liquefação.

Em ambos os casos (encostas íngremes e encostas muito íngremes) a infiltração de água provoca uma diminuição da sucção e, consequentemente, uma diminuição na resistência ao cisalhamento. Para uma dada sucção, a coesão verdadeira associada não é capaz de garantir a estabilidade dos taludes e ocorre a instabilidade.

Apenas a susceptibilidade à liquefação estática não é suficiente para obter uma evolução pós-ruptura em flowslide. Mesmo se a taxa de deformação, desenvolvida após a instabilidade, for suficiente para justificar uma resposta parcial ou totalmente não drenada, a condição de saturação também é necessária para obter uma resposta não drenada instável. Olivares \& Damiano (2007) admitiram que o mecanismo de liquefação estática ocorra apenas nos casos de encostas íngremes, em condição de saturação quase total e é necessário ainda que exista a condição de carregamento não drenado (ou parcialmente drenado), de acordo com a Figura 3.5. 
Olivares \& Damiano (2007) afirmaram que, para tornar esse quadro aplicável, é preciso saber a resposta do talude ao ciclo hidrológico, ou seja, relacionar a distribuição espaço-temporal da chuva com a saturação, $\mathrm{Sr}$, ou com a umidade, w, e com o estado de tensão dentro do solo. Em encostas reais (depósitos em camadas, geomorfologia complexa, etc) um papel fundamental é desempenhado pelas condições de contorno, pelas características intrínsecas hidráulicas de cada camada do solo e, acima de tudo, por variáveis de estado do solo no início da chuva.

O mecanismo de instabilização desse solo pode ser comparado com os descritos por Wolle (1988) no qual a infiltração das águas das chuvas provoca a redução ou até eliminação da coesão total, constatado da Serra do Mar nas rodovias adjacentes à Rodovia dos Imigrantes. Com a saturação, o solo instabiliza mesmo sem a presença de pressão neutra, apenas pela perda da sucção, ou coesão aparente.

Olivares \& Damiano (2007) obtiveram uma correlação entre a inclinação do talude e o número de ocorrência de flowslides, a partir dos mecanismos descritos previamente, para o local de Quindici depois do evento catastrófico de 1998, essa correlação está apresentada na Figura 3.6. Embora através da Figura 3.5 fosse possível confirmar que a probabilidade máxima de geração de um flowslide corresponde ao caso dos taludes com inclinação próxima ao ângulo de atrito em condições saturadas ou próximas à saturação, a Figura 3.6 comprova a hipótese.

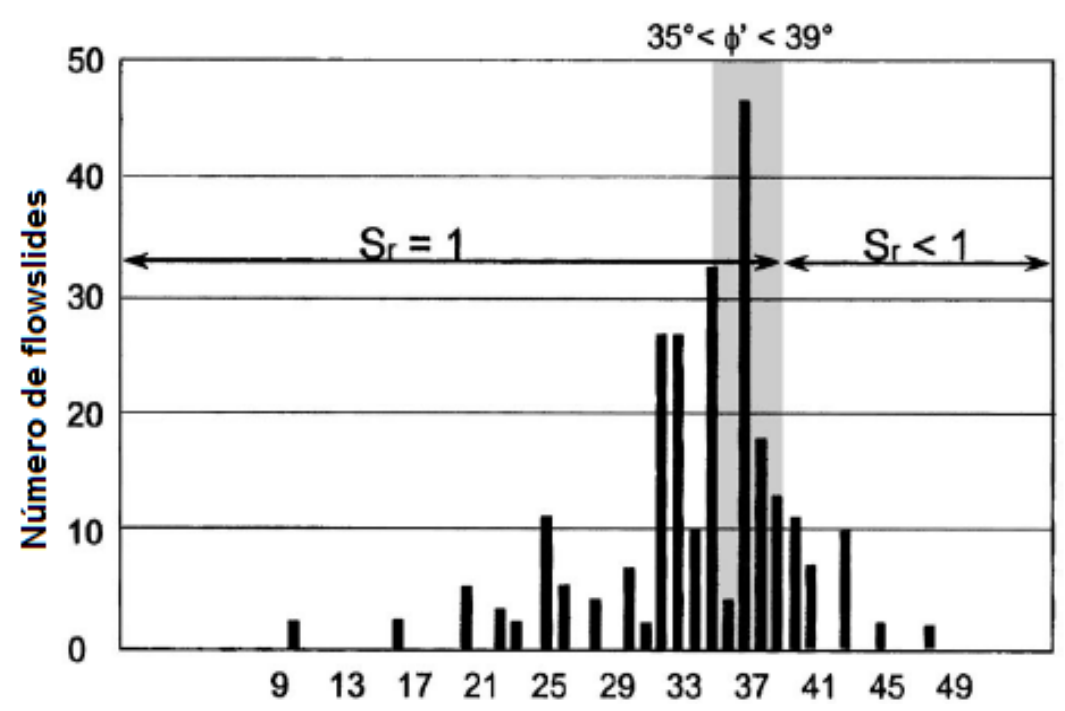

Figura 3.6 Escorregamentos em Quindicu - correlação entre inclinação do talude e número de flowslides (Olivares e Damiano, 2007) 
Essas pesquisas desenvolvidas na Itália indicam que o estudo dos solos não saturados pode ser importante para explicar os mecanismos que deflagram alguns tipos de corrida e que também deve ocorrer nos casos Brasileiros (FUTAl et al., 2011). Essa consideração é realizada levando em conta que as características das encostas analisadas são próximas das características das encostas brasileiras, principalmente da região da Serra do Mar.

Os movimentos de massa ocorridos na Itália apresentam características em comum com os movimentos observados na Região Serrana do Rio de Janeiro. Analisando a Figura 3.5 para determinar a resposta do solo de talude infinito exposto com as características do Rio de Janeiro os taludes tem $\alpha<\varphi$, sendo considerados de inclinação suave, nesse tipo de talude a ruptura ocorre com o grau de saturação igual a 1 e, quando a resposta do solo é um comportamento não drenado, dois tipos de ruptura podem ocorrer: uma liquefação ou um escorregamento. Para determinar o tipo de movimento que vai se desenvolver após a ruptura é preciso determinar se o solo é passível ou não de sofrer liquefação, que é objeto de estudo do capítulo 5.

\subsection{Mecanismo Ruptura - Nova Friburgo}

Devido às chuvas que atingiram a região serrana nos dias 11 e 12 de janeiro ocorreram milhares de movimentações de solo. Uma das primeiras publicações sobre o evento ocorrido na Região Serrana foi apresentada pelo DMR-RJ (Departamento de Recursos Minerais - Serviço Geológico do Estado do Rio de Janeiro). Nessa apresentação foram utilizadas as seguintes denominações para os movimentos de massa observados na região: (DMR-RJ, 2011)

\section{- Corridas de Massa de Detritos, Terra ou Lama}

Movimento semelhante à de um líquido viscoso, com desenvolvimento ao longo das drenagens, velocidade média a alta, grandes volumes de material, mobilização de blocos (pouca distância), solo ou detritos e água, com extenso raio de alcance sendo documentados $10 \mathrm{~km}$ no distrito de Vieira e $18 \mathrm{~km}$ no de Cuiabá.

Nos talvegues encontram-se depósitos que são, provavelmente, de corridas anteriores (sedimentos e blocos). A concentração de águas pluviais que provêm dos 
taludes laterais e de áreas a montante nestes canais pode levar ao escoamento superficial de água com altas velocidades, estas velocidades tem alto poder erosivo,

expondo e eventualmente movimentando blocos ali existentes. À água que escoa pode ser acrescido solo proveniente de instabilidades ocorridas nos taludes laterais, que podem provocar barramentos provisórios, criando reservatórios temporários que se rompem e o escoamento prossegue com maior energia.

\section{- Quedas}

Deslizamentos no contato solo/rocha, na parte superior da encosta, que promovem instabilidades em cotas mais baixas a partir da energia do choque das massas em movimento. Apresentam altas velocidades, volumes de material pequenos a grandes. Esse movimento de massa foi designado por deslizamento da Parroca por DMR-RJ (2011).

\section{- Escorregamentos}

O DMR-RJ (2011) denominou os escorregamentos através da denominação dos locais onde ocorreram os escorregamentos. O primeiro foi denominado por deslizamento tipo Catarina e suas características definidas foram: a velocidade alta; pequenas espessuras de solo na superfície de ruptura, deslizamentos controlados pelo solo residual jovem e pela subida da pressão neutra na base das depressões, e um movimento que ocorre de baixo para cima mobilizando a capa de solo maduro e vegetação. Também foi denominado o "deslizamento tipo rasteira" que apresentou altas velocidades, erosão fluvial intensa, se iniciou mobilizando capas de solo ou lascas de alívio (fraturadas e alteradas) no pé do talude e prosseguindo até a parte superior da encosta. Também foi utilizado o nome de "deslizamento tipo Vale Suspenso" para identificar os escorregamentos profundos, que atingiram pequenos alcances, mas com grandes volumes de material; ocorreram em vales ou drenagens fluviais afluentes com pronunciado desnível para o vale principal, apresentou formação de trincas à medida que ocorre o entalhamento da drenagem, obedecendo à evolução do relevo.

Assim como Guidicine e Nieble (1983), o DMR-RJ (2011) considerou que os fatores que levaram a esse evento podem ser divididos em três grupos sendo:

- Fatores Predisponentes: Geologia, Geomorfologia, Hidrologia de Superfície e Hidrogeologia e Clima. 
- Fatores efetivos: Uso e ocupação do solo - cortes e aterros-, chuvas antecedentes e erosão fluvial e pluvial.

Em Nova Friburgo, assim como na maioria das cidades limitadas por um relevo acidentado, é comum a utilização de cortes e aterros na construção de habitações, como pode ser observado na Figura 3.7. Wolle (1988) afirmou que o efeito da alteração geométrica é a modificação do estado de tensões que resulta na redução do coeficiente de segurança dessas encostas, assim como no aparecimento de trincas de tração.

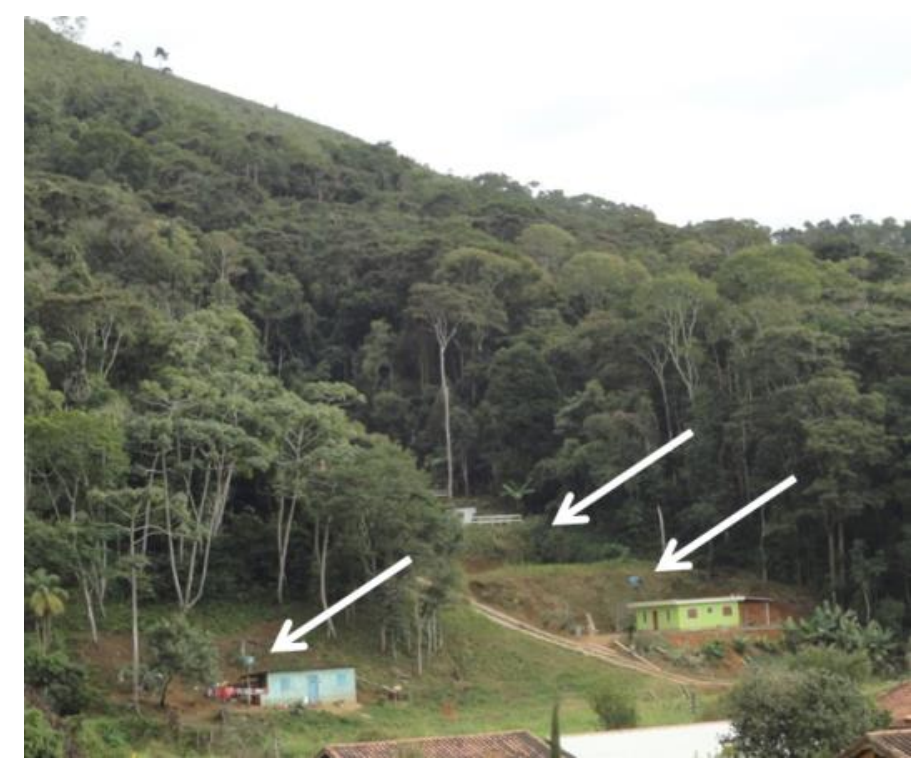

Figura 3.7 Fotografias de Nova Friburgo demonstrando os cortes realizados nas encostas

- Fator deflagrador: Chuvas com grande intensidade em 15 minutos.

A chuva como fator deflagrador dos movimentos de massa é assunto recorrente na geotecnia, diversos autores como: Guidicini e Iwasa (1976), Vargas Jr. et al. (1986), Tatizana et al. (1987), Wolle (1988), apresentaram a influência da precipitação como agente deflagrador de movimentos de massa. Wolle (1988) afirmou que os principais modos de atuação do fluxo de água no processo de instabilização são:

- Através das pressões neutras de percolação (ou forças de percolação),

- Através de pressões hidrostáticas, oriundas do preenchimento temporário de fendas e fissuras pela água em taludes de saprólitos e solos saprolíticos com descontinuidades.

- Através da erosão superficial e interna, provocada pelo escoamento da água sobre os taludes e através dos maciços, 
- Através da redução da sucção (devido à eliminação da parcela de coesão aparente).

Em relação ao Mecanismo de ruptura para encostas naturais relacionados com a precipitação, Wolle (1988) apresentou os seguintes mecanismos:

- Mecanismo Clássico - elevação do nível de água pré-existente, devido ao fluxo da água infiltrada: Admite-se a formação de uma rede de fluxo paralela ou subparalela ao talude que se eleva com a infiltração de água, ocorrendo aumento gradual da pressão neutra até que se atinja a ruptura.

- Mecanismo de redução ou eliminação da sucção - a infiltração de água causa uma frente de saturação no talude que tem sua coesão reduzida, chegando a se anular, o que causa a ruptura.

- Mecanismo de encontro de uma frente de saturação com um nível d'água pré-existente - ocorre um súbito aumento da pressão neutra com brusca elevação do nível d'água que deflagra a ruptura.

- Mecanismo de nível d'água suspenso no solo - ocorre quando existem camadas de solos menos permeáveis intercaladas com camadas mais permeáveis, formando um nível d'água suspenso no solo, que leva a ruptura.

Em relação ao evento ocorrido em Janeiro de 2011 no estado do Rio de Janeiro, Avelar et al. (2011) apresentaram artigo sobre os mecanismos de ruptura que aconteceram na Região Serrana. Como já mencionado, na região atingida pelos escorregamentos ocorre uma predominância de saprólito e colúvio. A presença do granito dificulta a ação do intemperismo o que permite estabilidade às encostas íngremes, que muitas vezes ainda apresentam afloramentos de rochas de grande porte. Esta situação foi revelada nos dados estatísticos sobre a declividade do talude, com um valor médio de 18,9 e desvio padrão de 10,9․ Por outro lado, com a ação do tempo geológico e o aumento progressivo de intemperismo químico, em geral mais acentuado com as fraturas no granito, a massa de rocha-mãe dá lugar a solos saprolíticos e saprólitos com uma graduação de intemperismo que reduz a coesão real e gera ruptura durante eventos prolongados de chuva ou durante chuvas intensas. (AVELAR et al., 2011) 
Para explicar o mecanismo de ruptura que atingiu os saprólitos, Avelar et al. (2011) partiram da formação de uma zona de saturação inicial, que se formou devido ao período chuvoso antecedente ao evento, e considerou que a infiltração gradual promoveu uma expansão das zonas de saturação no solo, levando a um aumento lento da pressão neutra na fronteira solo-rocha. Ao mesmo tempo, houve um aumento de umidade na parte superior desses solos (zonas insaturados) e a sucção foi suavemente reduzida. Nos dias 11 e 12 de janeiro com o advento de chuvas intensas, deve ter ocorrido uma elevação repentina do nível d'água com consequente redução significativa nas tensões efetivas, o que produziu as condições de ruptura nos saprólitos. Avelar et al. (2011) apresentaram na Figura 3.8 uma síntese deste mecanismo de ruptura dominante no talude.

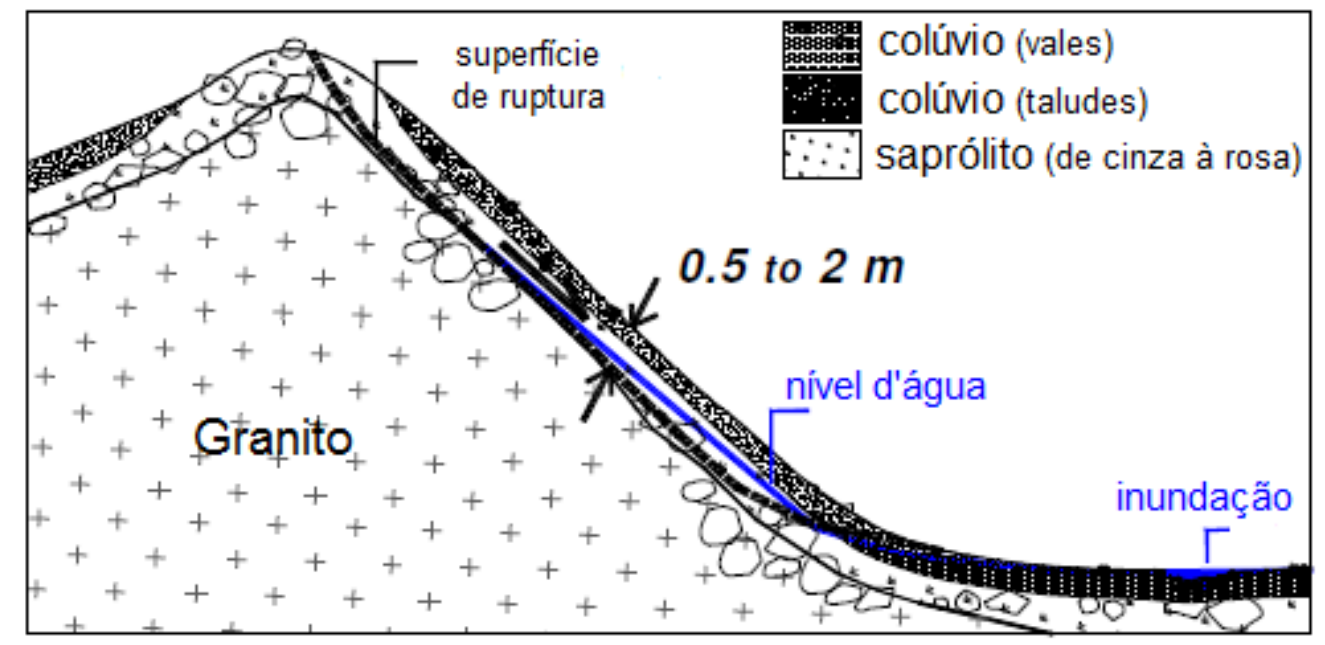

Figura 3.8 Mecanismo de Ruptura Saprólito (AVELAR et al., 2011)

Os solos coluvionares dos taludes da região não apresentam coesão verdadeira, portanto, como mecanismo de ruptura é provável que a durante a precipitação intensa de 11 e 12 de Janeiro houve infiltração suficiente para aumentar a umidade do solo sem a criação de uma zona saturada. Este aumento na umidade do solo pode ter causado redução significativa no valor da sucção e a consequente ruptura do solo. (AVELAR et al., 2011)

\subsection{Mecanismo Pós-Ruptura - Nova Friburgo}

Considerando o mecanismo de ruptura proposto por Avelar et al. (2011), no qual a infiltração da água saturou o solo residual fazendo com que houvesse uma diminuição da resistência é proposto o mecanismo pós ruptura para esse solo. Após 
a ruptura da massa de solo, houve liquefação fazendo com que o solo se comportasse como um líquido viscoso. Dessa forma aumentou-se o alcance da massa de solo e o grau de destruição do movimento.

Na Figura 3.9 está apresentado o mesmo talude estudado por Avelar et al. (2011) onde ocorreu a ruptura na parte superior do talude, como apresentado na Figura 3.8, e o fenômeno pós-ruptura fez com que a massa de solo tivesse um alcance bem maior, não sendo mais danoso pela topografia relativamente plana do pé do talude.

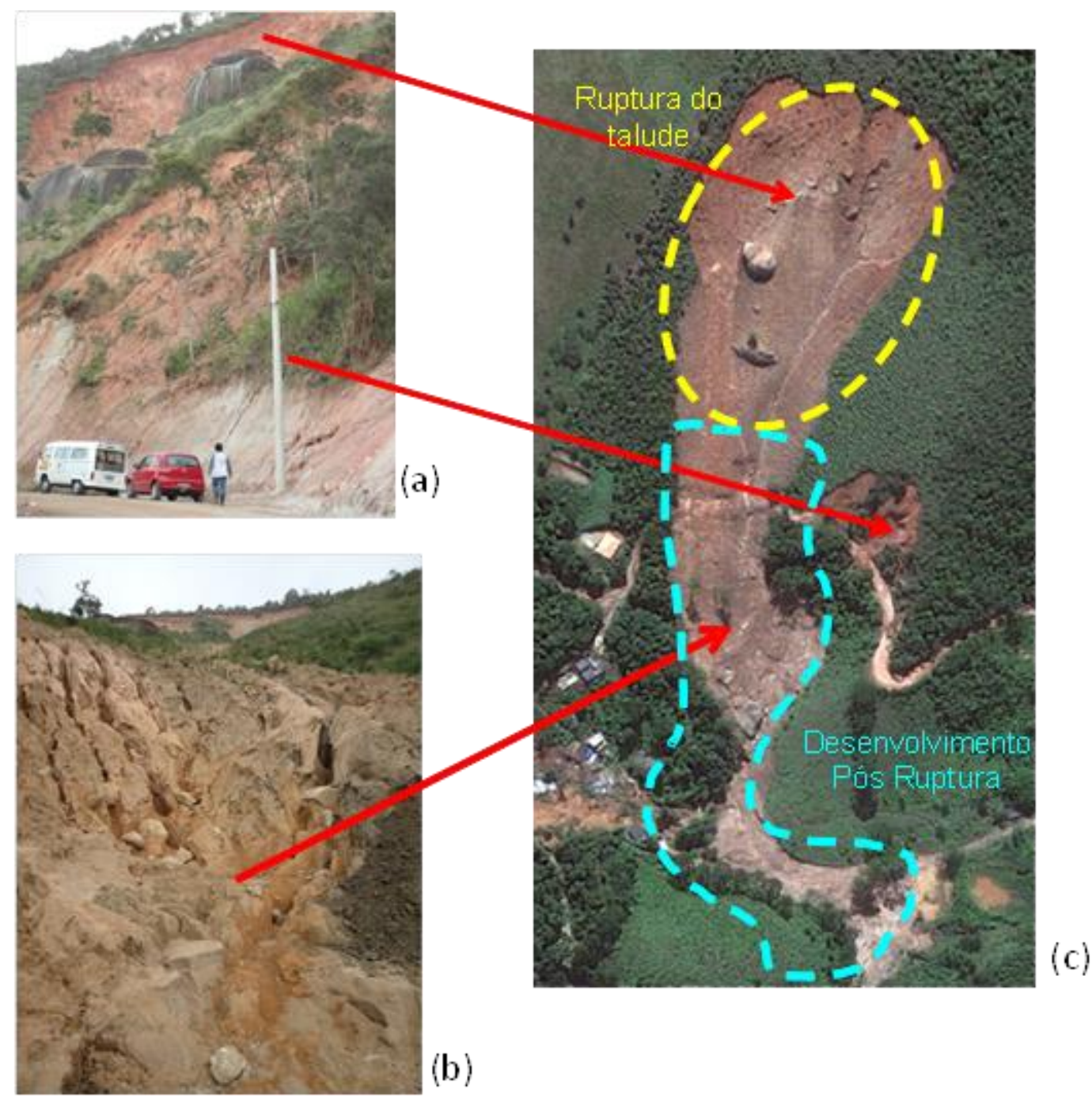

Figura 3.9 Desenvolvimento da ruptura de talude de grandes dimensões

A liquefação do solo após sofrer processo de escorregamento é objeto de estudo de diversos pesquisadores, como por exemplo, no caso Italiano apresentado, onde as precipitações intensas causam escorregamentos e corridas. Sendo que 
esse mesmo fenômeno foi observado na Região Serrana do Rio de Janeiro, no capítulo 5 será realizada uma revisão dos conceitos de liquefação de solos para avaliar a ocorrência desse tipo de fenômeno na região.

De acordo com o fluxograma da Figura 3.5, considerando a ruptura com o solo saturado e, considerando que a ruptura ocorre em condições de solo não drenado (ou parcialmente drenado), devido à rapidez do movimento, o desenvolvimento da ruptura será a liquefação ou o escorregamento. Para que ocorra a liquefação é necessário que o solo atenda aos requisitos que serão apresentados no Capítulo 4, caso contrário ocorrerá um escorregamento e esse solo rompido se acumulará na encosta.

Com a aplicação dos conceitos da reologia é possível definir um ensaio que seja representativo, e a partir dos dados do ensaio, um modelo para representar o comportamento do solo e assim definir a tensão de escoamento do solo. O valor da tensão de escoamento define se o solo vai ter um comportamento sólido, quando a tensão atuante é menor que a de escoamento, ou se apresenta comportamento de um líquido. Com os valores da tensão de cisalhamento atuante e da tensão de escoamento pode ser possível definir um fator de segurança para o talude.

A tensão de cisalhamento atuante no talude é determinável, considerando a hipótese de talude infinito. A velocidade do escorregamento, equivalente à taxa de cisalhamento, é um parâmetro que pode ser estimado a partir de fórmulas conhecidas baseadas em retro análises. Com as estimativas de velocidades do debris flow é possível também definir qual a viscosidade da massa em movimento, considerando o modelo adotado para cada umidade. 


\section{LIQUEFAÇÃO DE SOLOS}

Castro (1969) afirmou que a liquefação de areias saturadas é o fenômeno no qual a areia sofre uma substancial redução da resistência ao cisalhamento, se tornando uma massa fluida de solo, que flui até que as tensões cisalhantes atuantes na massa de solo se tornem tão pequenas quanto a sua reduzida resistência ao cisalhamento. Castro (1969) observou que a perda de resistência ao cisalhamento afeta uma porção importante da massa, e não apenas uma superfície de deslizamento.

Allen (1984) descreveu que o fenômeno de liquefação consiste na diminuição da resistência efetiva do solo, induzida por acréscimos de pressões neutras, causando a perda da rigidez da estrutura do solo sob a ação de forças externas, fazendo com que o solo se comporte como um líquido viscoso. Essa perda de estruturação faz com que os grãos passem a não mais se suportarem mutuamente, ficando dispersos no fluido.

O fenômeno da liquefação ocorre, geralmente, em materiais que se encontram em situação saturada (ou parcialmente saturada) e que apresentem tendência de contração de volume quando submetidos a tensões cisalhantes. A súbita perda de resistência resulta em rupturas potencialmente catastróficas que são caracterizadas por grandes deslocamentos de solo em velocidades elevadas.

A liquefação de solos pode ser classificada em liquefação estática, dinâmica e cíclica, denominados pelo tipo de esforço inicial que causa o fenômeno. Os esforços dinâmicos estão relacionados a carregamentos dinâmicos como movimentações sísmicas e a liquefação cíclica resulta da ação de aplicação de um ciclo de carregamento. O escopo dessa dissertação são as liquefações estáticas, que são aquelas associadas a eventos como: elevação do nível d'água em depósitos de materiais granulares; carregamentos rápidos; movimentos de massa na área de influência dos depósitos de materiais granulares e excessos de precipitação pluviométrica. (ALLEN, 1984)

Existem diversos fatores que influem se um determinado depósito de solo é ou não suscetível a sofrer liquefação, sendo os principais citados nos itens a seguir. 


\subsection{Materiais suscetíveis à liquefação}

Um fator que influencia no potencial de liquefação dos solos é a granulometria. Solos bem graduados são menos suscetíveis ao fenômeno devido à incorporação dos vazios pelas partículas menores, resultando numa menor variação volumétrica em condição drenada, e baixas gerações de pressão neutra na condição não drenada. Ishiara et al. (1980) apresentou a Figura 4.1.1 que é o critério proposto pelo código de projeto de Rodovias Japonês para as faixas de distribuição de granulometria de solos susceptíveis à liquefação.

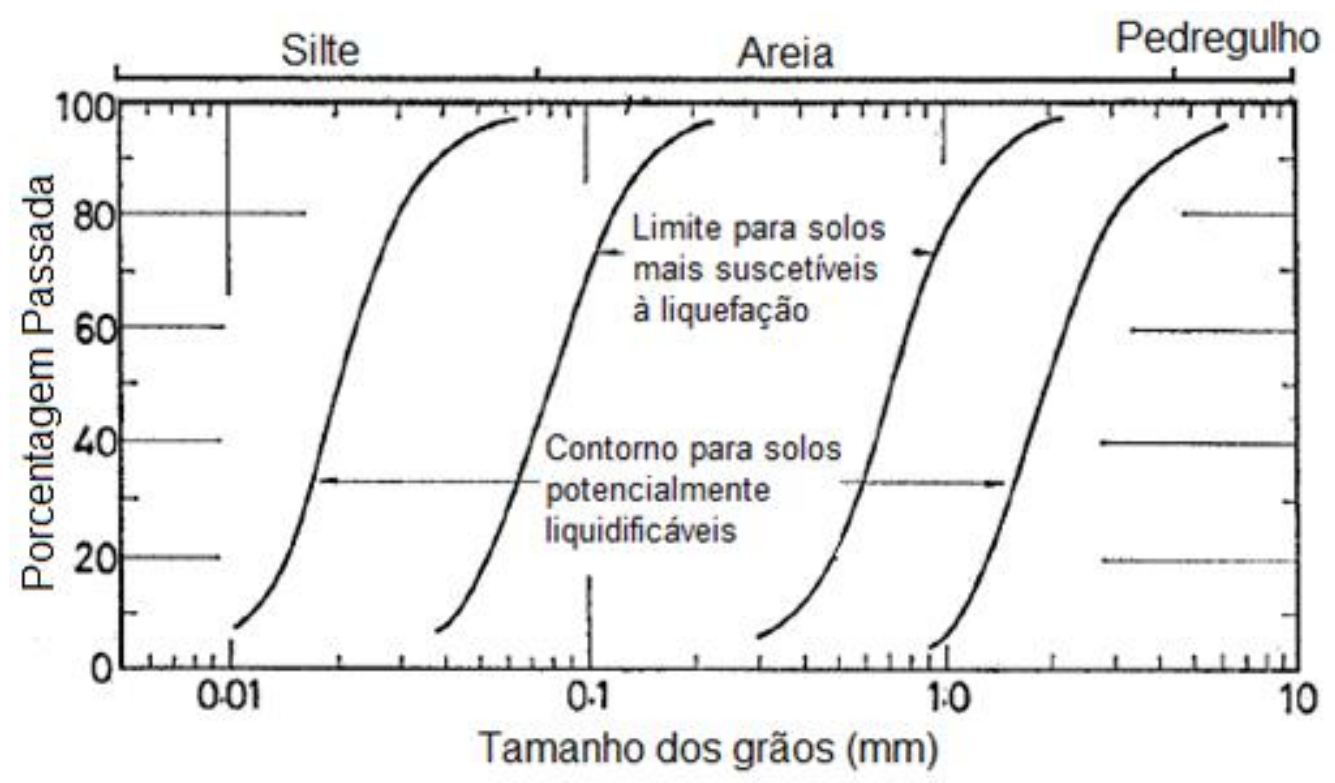

Figura 4.1.1 Faixas de distribuição granulométricas suscetíveis à liquefação (ISHIARA et al., 1980)

Inicialmente, era admitido que a liquefação só ocorresse em solos arenosos, e solos que apresentassem uma granulometria mais fina, com presença de partículas de argila e silte, não seriam passíveis de apresentar esse tipo de problema, porque não conseguiriam gerar grandes incrementos de pressão neutra devido à plasticidade, e solos mais grossos, como pedregulhos, não conseguiriam manter o acréscimo da pressão neutra por tempo suficiente para o surgimento do fenômeno. (SEED et al., 2003)

Seed et al. (2003) explicou que o teor de finos influencia de duas maneiras na susceptibilidade à liquefação de solos; de maneira negativa a presença de fração fina do solo, com características plásticas, contribui para a redução da condutividade 
hidráulica do solo e de maneira positiva contribui para o incremento da resistência ao cisalhamento devido ao acréscimo de coesão. No entanto, para solos formados por finos que apresentem baixa plasticidade, típico em solos tropicais, a influência dos finos no comportamento é apenas negativa. Ou seja, solos que apresentem teor de finos com baixo índice de plasticidade podem ser suscetíveis à liquefação, porém não são tão impermeáveis como as argilas plásticas.

Para definição de solos potencialmente liquificáveis diversos critérios foram aceitos e utilizados, porém não podem ser tomados como uma verdade irrefutável, tendo em vista que já ocorreram grandes eventos de liquefação em solos que não atendiam aos critérios propostos. A Figura 4.1.2 apresenta as recomendações sobre a determinação de solos liquificáveis, é um critério passível de modificação com base nos trabalhos que sejam futuramente apresentados, mas vale como um resumo do que é aceito até o momento. Na Figura 4.1.2 FF é a Fração de Finos e $\mathbf{w}_{\mathrm{c}}$ é a umidade de campo. (SEED et al., 2003)

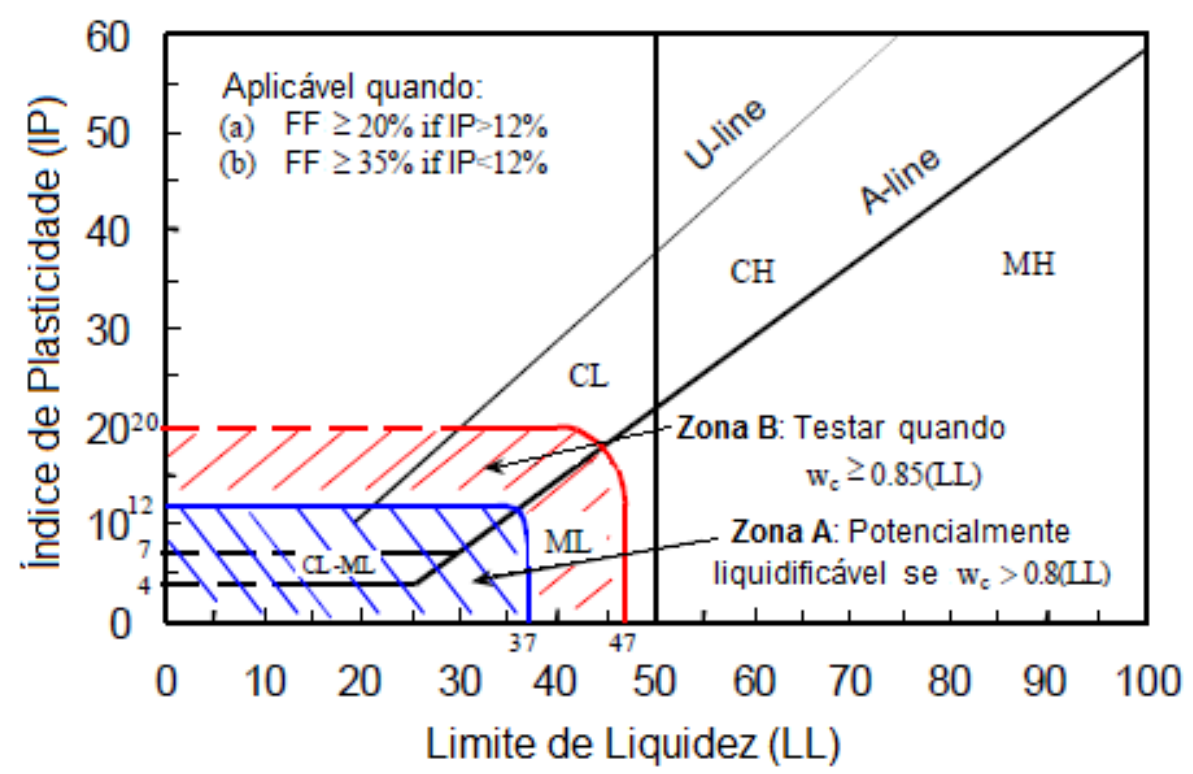

Figura 4.1.2 Recomendações sobre avaliação de tipos de solo com potencial para sofrer liquefação (SEED et al., 2003)

Para solos com um teor de finos suficientemente alto (maior que $20 \%$ ou $35 \%$, conforme critério), os finos se separam das partículas mais grosseiras e controlam o comportamento global apresentando os seguintes comportamentos (Figura 4.1.2): (1) Solos dentro da Zona A são considerados potencialmente suscetíveis a liquefação, (2) Solos na Zona B podem sofrer liquefação, e (3) Solos na Zona C (que são os que não estão das Zonas $A$ ou B) geralmente não são suscetíveis à 
liquefação, mas deve ser verificado em casos de perda de força com a amolgamento ou acúmulo de deformação cisalhante. Ressaltando que os critérios não cobrem integralmente todos os tipos de solos liquificáveis, sendo que continua sendo necessário um julgamento para avaliar o potencial de o solo ser liquificável. (SEED et al., 2003)

\subsection{Condição de Saturação}

Em relação à saturação do solo, Yoshimi et al. (1989) realizou ensaios de cisalhamento em areias com densidade relativa de $60 \%$ para avaliar o comportamento de solos que não estejam completamente saturados, obteve como resultado que esse solo apresentou liquefação com teores de saturação a partir de $80 \%$. Sobre isso, Martin (1999) afirma que um grau de saturação de $100 \%$ não é uma condição necessária para a ocorrência de ruptura não drenada, afirmando que um grau de saturação do solo entre 80 e 100\% já é suficiente para a ocorrência de liquefação, sendo preciso, no entanto, haver pressão de água positiva. Os critérios não são independentes, só a saturação não indica se o solo pode liquefazer, além da saturação é preciso observar o índice de vazios, critério apresentado a seguir.

\subsection{Comportamento em solicitação}

Outro fator que define o potencial liquificável de um solo é a condição inicial do índice de vazios. Solos que se encontram com índice de vazios acima da linha de estado crítica apresentam tendência à contração de volume e são suscetíveis ao fenômeno de liquefação, conforme apresenta a Figura 4.3.1.

Quando o solo se encontrar com um índice de vazios maior que o crítico tende a se comprimir ao ser carregado, expulsando água de seus vazios. Em função das condições de carregamento e das características de permeabilidade do solo, a água poderá ou não ser liberada de imediato do domínio do esqueleto sólido do solo, se não houver tempo para a liberação imediata ocorre o aparecimento de pressões neutras que diminuem a tensão efetiva e reduzem a resistência do solo, condição de carregamento não drenado, Figura 4.3.2. 


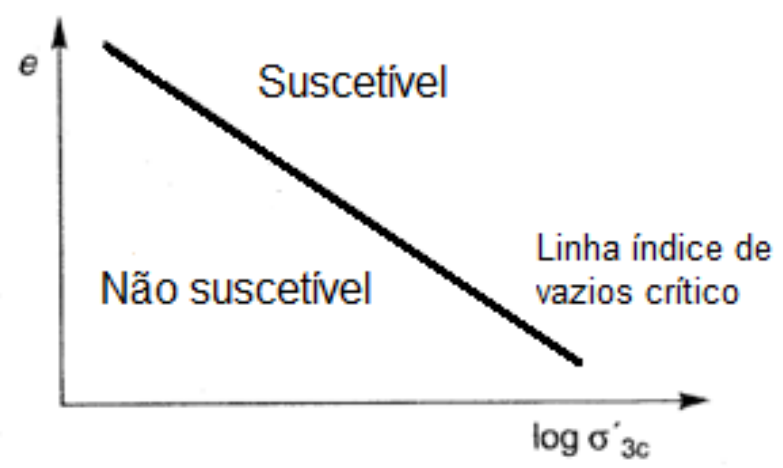

Figura 4.3.1 Utilização da linha de $e_{\text {critico }}$ como condição para liquefação (KRAMER, 1996)

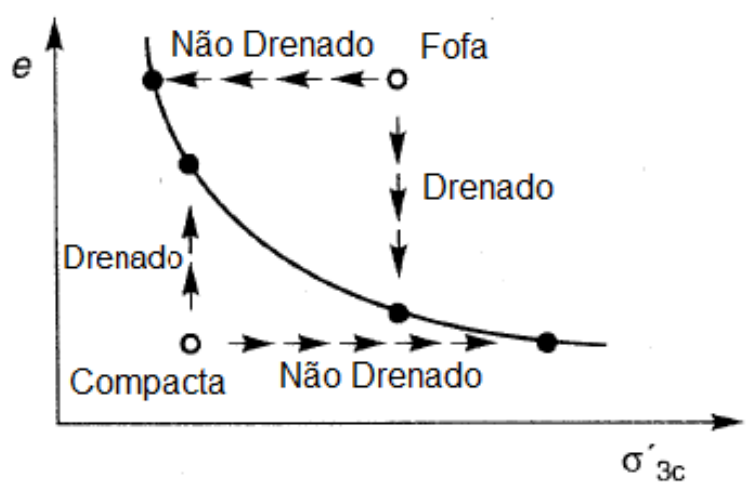

(a)

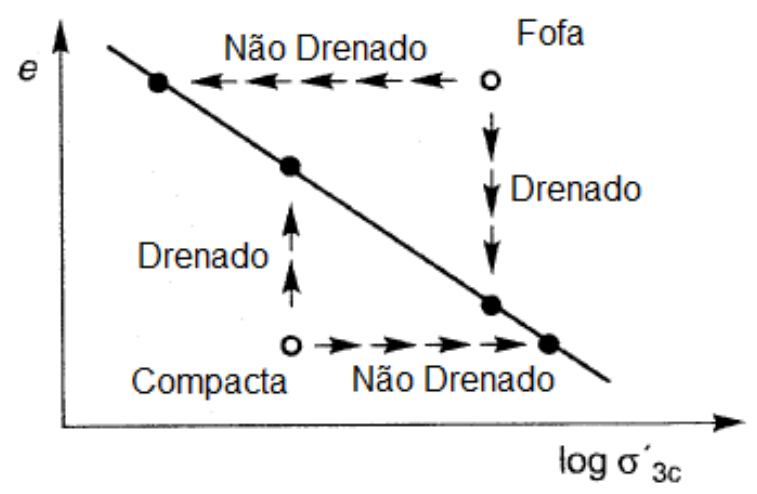

(b)

Figura 4.3.2 Linha de índice de vazios crítico e comportamento das amostras (KRAMER, 1996)

Durante o carregamento, quando a pressão neutra aumenta até um valor igual ao da tensão de confinamento, a tensão efetiva atuante no esqueleto do material é reduzida a zero e, em consequência, o material perde completamente sua resistência ao cisalhamento, comportando-se como líquido viscoso. Uma característica importante deste fenômeno é que este tipo de ruptura ocorre em regiões da massa de solo e não apenas ao longo de uma determinada superfície de ruptura. (Guillén, 2008)

Uma condição adicional necessária para que ocorra a liquefação do solo é o carregamento "rápido" (majoritariamente "não drenado"). As condições que determinam se o carregamento de um dado solo, com alto grau de saturação, será drenado ou não drenado são o coeficiente de permeabilidade do solo e a velocidade do carregamento, quando a velocidade do carregamento é suficientemente alta para que não exista tempo de ocorrer a expulsão da água do solo a condição é não drenada. 
Kramer (1996) afirmou que, o fato do depósito de solo ser suscetível à liquefação não significa que realmente vai liquefazer, é necessário que exista um carregamento suficientemente alto (como, por exemplo, uma chuva elevada) para que se inicie o fenômeno, corroborando com os resultados apresentados por Olivares e Damiano (2007). Entender a iniciação da liquefação requer identificação do estado do solo quando o fenômeno ocorre, essa condição será apresentada em uma estrutura que permita que os mecanismos de liquefação sejam claramente entendidos.

Kramer (1996) apresentou o gráfico da trajetória de tensões para ilustrar o mecanismo de início de fenômeno de liquefação, Figura 4.3.3, no qual a iniciação pode ser visualizada de forma mais clara mediante o uso da trajetória de tensões de um carregamento monotônico. A Figura 4.3.3 apresenta a resposta de uma série de amostras de areia saturadas submetidas a ensaios triaxiais não drenados. Todas as amostras de areia foram isotopicamente adensadas para um mesmo índice de vazios com diferentes tensões de confinamento e, seguindo diferentes trajetórias de tensão, os corpos de prova devem atingir o mesmo estado de tensão efetiva na condição permanente.

A linha denominada por SSL representa a envoltória de estado permanente. As amostras A e B encontram-se inicialmente abaixo da SSL, com comportamento dilatante sob cisalhamento, e as amostras C, D e E situadas acima da SSL apresentam comportamento contratível sob carregamento, apresentando um pico de resistência não drenada e deformando-se rapidamente em seguida até atingir a SSL. Os picos de resistência das amostras C, D e E definem pontos de início de liquefação que, unidos, formam uma linha reta que se projeta no plano p' x q, chamada de linha de fluxo por liquefação ou FLS (Flow Liquefaction Surface), que é a resistência de pico, a partir desses pontos correspondentes às resistências de pico ocorre o início da liquefação. (KRAMER, 1996) 


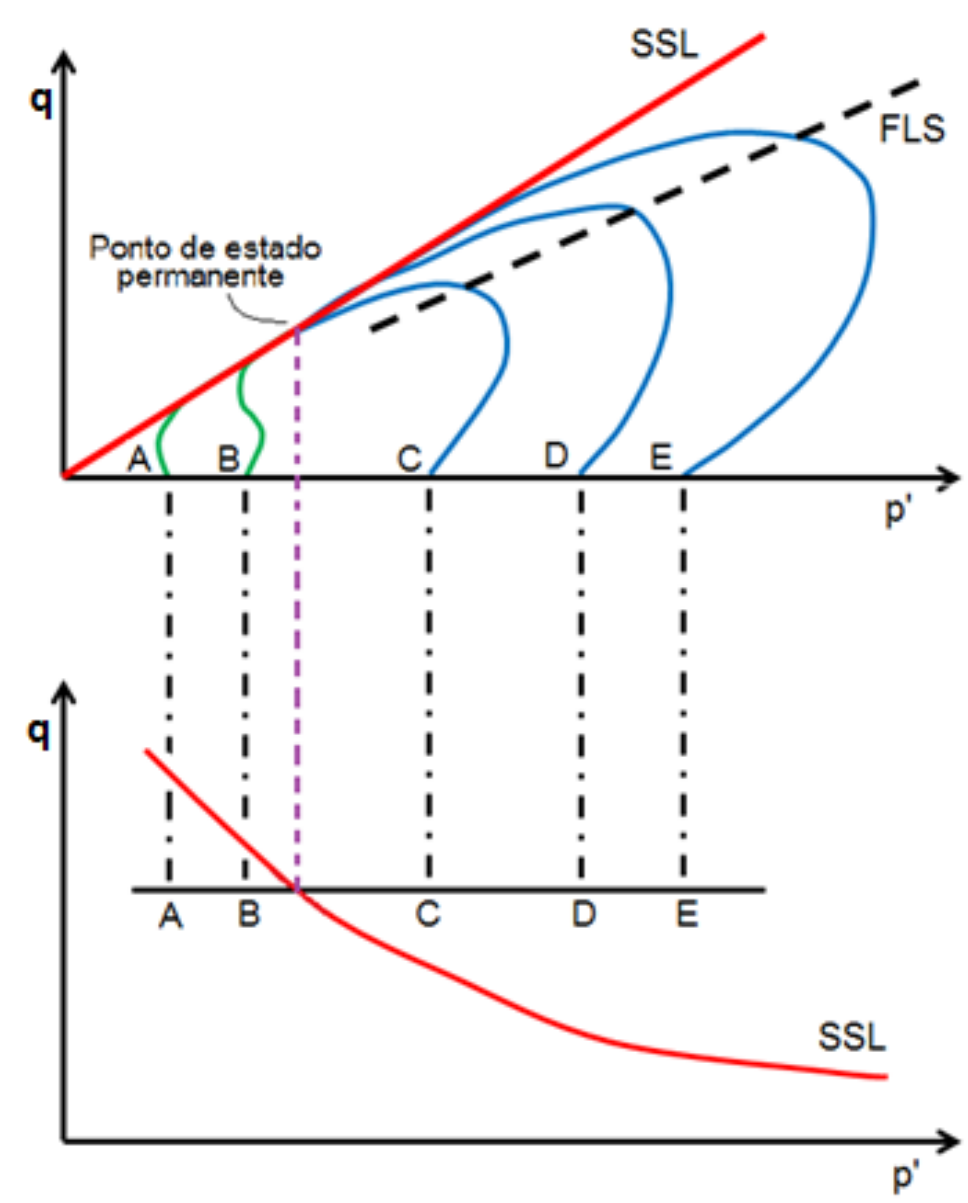

Figura 4.3.3 Conceito de iniciação da ruptura por liquefação (KRAMER, 1996)

Kramer (1996) explicou que a FLS marca uma fronteira entre estados estáveis e instáveis. Se o estado de tensão em um elemento de solo atingir a FLS em condição não drenada, quer em carregamento monotônico ou em carregamento cíclico, o fenômeno de liquefação será então iniciado. Portanto, a FLS descreve as condições em que o fluxo por liquefação é iniciado.

O fluxo por liquefação ocorre em duas fases. A primeira fase, ocorre sob pequenos níveis de deformação, envolve a geração de pressão neutra suficiente para mover o estado de tensão da sua posição inicial para a FLS. Esta pressão neutra em excesso pode ser gerada por carregamento monotônico ou cíclico não drenado. Quando a trajetória de tensões efetivas atinge a FLS, o solo torna-se instável e se inicia a segunda fase, que envolve o amolecimento (strain softening) e a geração adicional de pressão neutra com desenvolvimento de grandes deformações, enquanto a trajetória de tensões efetivas movimenta-se da FLS para a 
SSL. Se a primeira etapa leva o solo para a FLS em condição não drenada com condições de tensões controladas então a segunda fase é inevitável. (KRAMER, 1996)

A linha de estado permanente é obtida para areias fofas (contrativas) sob solicitação não drenada em ensaios triaxiais de tensão controlada, enquanto que a linha de estado crítico é geralmente obtida em ensaios com areias densas (dilatantes) sob solicitação drenada em ensaios de deformação controlada. Been, Jefferies e Hachey (1991), após análise dos resultados de extenso programa de ensaios triaxiais drenados e não drenados em areia, concluíram que as linhas de estado permanente e de estado crítico são coincidentes e independentes das trajetórias de tensões. (SCHOFIELD \& WROTH, 1968 )

O fluxo por liquefação pode ser iniciado sob carregamento dinâmico somente quando a tensão cisalhante no equilíbrio estático inicial for maior que a resistência do solo no estado residual, após aplicação do carregamento. No campo, estas tensões cisalhantes iniciais são causadas por forças gravitacionais e permanecem constantes até o final de ocorrência de grandes deformações. A ocorrência de fluxo por liquefação requer a aplicação de força suficientemente forte para mover a trajetória das tensões efetivas do ponto inicial para a FLS. A Figura 4.3.4 apresenta as regiões sujeitas a fluxo por liquefação.

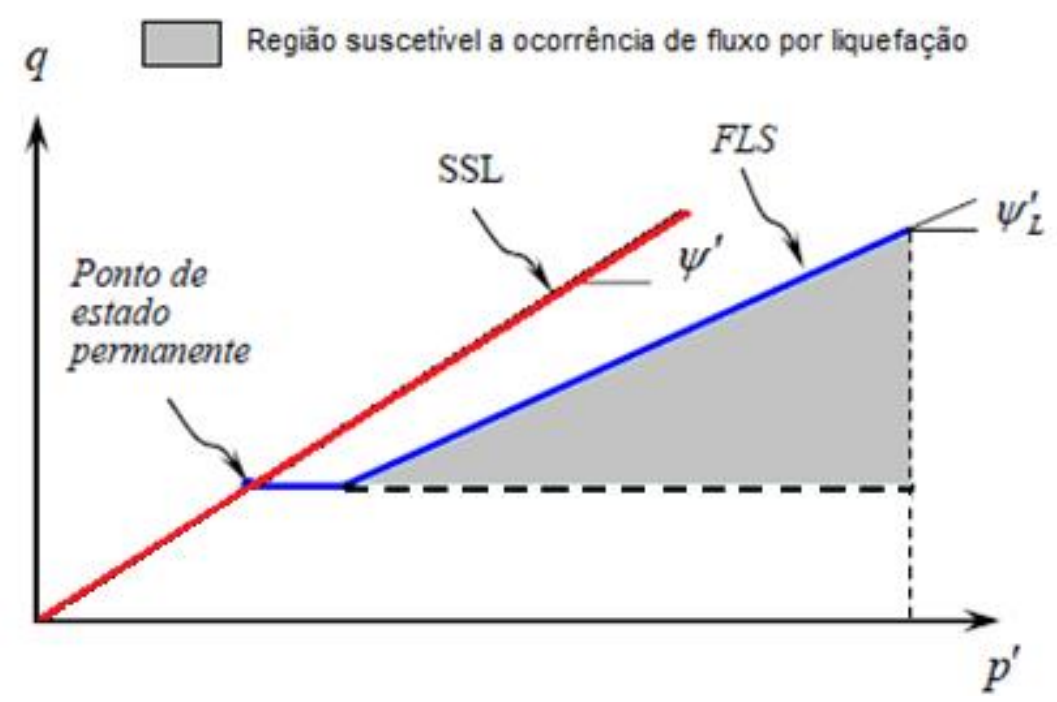

Figura 4.3.4 Zonas de suscetibilidade à liquefação (modificado de KRAMER, 1996)

A partir do momento que o solo é identificado como liquificável a utilização da reologia para o estudo e caracterização do comportamento é requisitada, já que o 
solo se comporta como um líquido viscoso e através da reologia é possível determinar o modelo de comportamento desse solo liquefeito. 


\section{REOLOGIA}

\subsection{Introdução}

Durante eventos de movimentos de massa que têm como agente deflagrador a precipitação intensa, é comum obter a expressão de que o solo estava fluindo como um líquido, através de relatos, fotos e vídeos, como apresentado na Figura 5.1. Essa descrição de fluido foi observada em janeiro de 2011, quando ocorreu o evento na Região Serrana do Rio de Janeiro e, é esse comportamento fluido do movimento de massa, que levou a busca de novas alternativas no estudo do comportamento de solos.

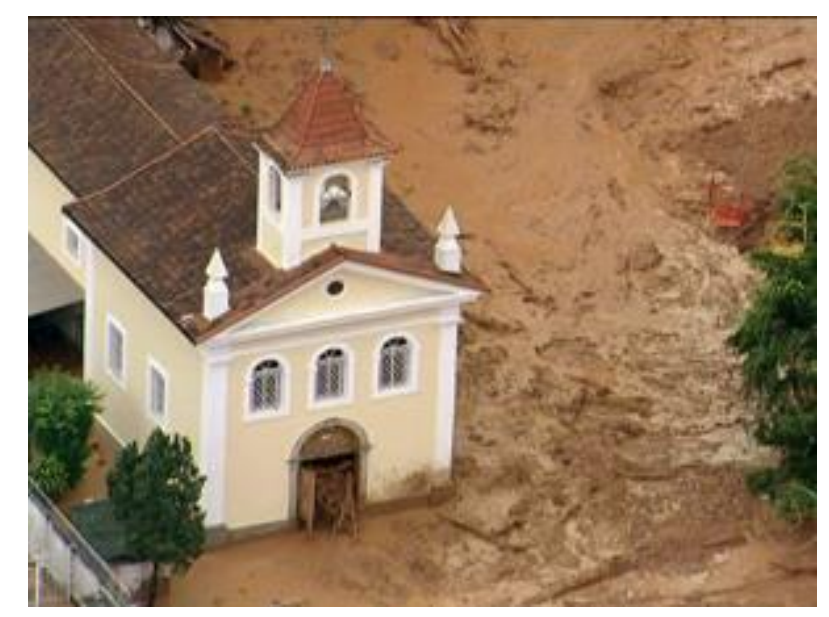

Figura 5.1 Lama escoando da encosta no centro de Nova Friburgo (Youtube)

Keedwell (1984) destacou que a principal motivação para a realização de ensaios em solos é a determinação de valores dos parâmetros de concepção, tensão - deformação - tempo, para que seja possível prever o comportamento do solo para utilização na análise de problemas geotécnicos. A interpretação bem sucedida dos resultados obtidos através de ensaio depende da qualidade da amostra e da validação do modelo utilizado para representar o comportamento do solo.

Keedwell (1984) afirmou que quando o resultado de um ensaio não apresenta resposta satisfatória o primeiro motivo seria a hipótese erros experimentais. Quando o palpite não se confirma é preciso levar em conta que o modelo utilizado na 
interpretação dos dados não se adequou ao comportamento observado. Quando isso ocorre a interpretação dos dados deve ser realizada a partir da escolha de outro modelo existente ou mesmo do desenvolvimento de um modelo que se adeque melhor ao comportamento do material.

O ideal é caracterizar o solo em condições próximas às de solicitação observada em campo. Em relação ao desenvolvimento pós-ruptura dos escorregamentos de solos é possível afirmar que, do ponto de vista macroscópico, a massa de solo flui como um líquido viscoso. Então a utilização da reologia, que estuda materiais em estado fluido, para a avaliação do comportamento do solo nessa condição é válida e pode apresentar resultados satisfatórios. (ZNAMENSKY, 2001; MESCHYAN, 1995)

De acordo com Meschyan (1995) a Reologia é a ciência da deformação e fluência de materiais destinada ao estudo de mudanças nos estados de tensão e deformação de materiais ao longo do tempo. Os objetos de estudo em reologia são materiais que apresentam propriedades reológicas, ou seja, elasticidade, plasticidade, viscosidade (fluência), relaxação de tensão e redução de resistência em longo prazo - que são características presentes em todos os corpos reais. As propriedades reológicas de cada material são manifestadas de formas diferentes e dependem do estado de tensão e deformação de um corpo, das suas características e de fatores (principalmente a tensão, o tempo e a temperatura) que influenciam o comportamento reológico.

Dentre as principais características que influenciam a reologia do sistema, podemos destacar: concentração volumétrica de sólidos; características do meio líquido (como a densidade); temperatura; características físicas das partículas (distribuição granulométrica, densidade, forma, etc.); o tipo de interação entre as partículas (repulsão, atração) e a concentração de moléculas de dispersante no meio líquido. (OLIVEIRA et al., 2000)

Meschyan (1995) expôs que a Reologia surgiu como ciência em resposta à necessidade de se compreender a fluidez dos líquidos viscosos. Num sentido mais amplo em que é aceito hoje, a reologia cobre todos os aspectos da mecânica de corpos rígidos deformáveis, sendo importante divisão da reologia a reologia experimental ou reometria, que lida com as leis que regem as propriedades reológicas e a determinação das características reológicas de materiais diversos. A 
reometria adquiriu grande importância e se tornou uma ciência independente, uma vez que lida com uma grande variedade de materiais, como alimentos, cosméticos, argamassas e concretos, entre outros.

Meschyan (1995) ainda destacou que há muito em comum entre as propriedades reológicas de vários materiais. Por isso a experiência adquirida com o estudo de um material pode ser útil para a realização de estudos experimentais e teóricos em outro material. Neste contexto, pode ser mencionado que os resultados obtidos a partir de estudos de determinação de propriedades reológicas de metais, plásticos, madeira, concreto e sistemas dispersos ajudam, consideravelmente, o preenchimento de lacunas na reologia de solos em gerais, e em particular contribuem para a solução de vários problemas complexos em solos argilosos, por exemplo sobre o papel de fluência do esqueleto do solo durante o adensamento de solos argilosos saturados.

Assim, para enfrentar com êxito os problemas da reologia de solos argilosos, é necessário seguir com os desenvolvimentos na reologia de outros materiais. Um material bastante estudado na reologia é o concreto fresco que apresenta estrutura e propriedades parecidas com as de solo em fluxo, por isso o conhecimento desse material é complementar. (PHILLIPS E DAVIES, 1991; MESCHYAN, 1995)

Diversos equipamentos podem ser utilizados para determinação das propriedades reológicas. Na mecânica dos solos, a reologia vem sendo utilizada na caracterização de fluxo de detritos através de medidas realizadas, principalmente, por viscosímetros e reômetros com geometria placa-cone e placas paralelas. $\mathrm{Na}$ dissertação serão utilizados três equipamentos na caracterização reológica, sendo realizadas análises de reometria compressiva, no aparelho de squeeze flow e também avaliação nos reômetros rotacionais que são o reômetro com geometria planetária e o reômetro com geometria de placas paralelas.

De acordo com Meschyan (1995), os estudos reométricos são sofisticados devido à natureza da deformação dos materiais reais e ao fato de que esses problemas são influenciados por diversos fatores. Por isso, é imprescindível que apenas um dos fatores que influenciam o comportamento reológico seja alterado para um resultado confiável. Na dissertação, o parâmetro de interesse adotado é a umidade que apresenta grande influência no comportamento dos solos. Nos trabalhos analisados na revisão bibliográfica, o parâmetro de controle para medir a 
mudança do comportamento do solo foi a concentração de sólidos, que teve seus valores variados a partir da adição de água.

A caracterização reológica de movimentos de solo é complexa por dois principais motivos. Primeiro que os solos, durante uma movimentação de massa, passam do estado solido, com comportamento elástico, para um estado fluido e, durante esse processo, o comportamento reológico apresenta grande alteração. Outra razão, relatada por Znamensky (2001), é que o solo é um material constituído por faixas granulométricas que interagem entre si e que podem ser constantemente modificadas no processo de movimentação.

\subsection{Parâmetros Reológicos}

Oliveira et al. (2000) afirmou que independentemente do grau de complexidade das características reológicas de um material, seu comportamento pode ser descrito através de relações matemáticas entre a tensão aplicada e sua respectiva deformação (ou fluxo), além de suas variações em relação ao tempo.

A relação matemática a qual Oliveira et al. (2000) se referiu é, geralmente, expressa em forma gráfica que representa o modelo comportamental do material analisado. Esses gráficos, denominados por curvas de fluxo, são dados em função de dois parâmetros, a viscosidade e a tensão de escoamento, que terão seus conceitos discutidos a seguir.

\subsubsection{Viscosidade}

A viscosidade é um parâmetro definido por Newton através da experiência das placas paralelas, exposta na Figura 5.2, na qual a tensão de cisalhamento é diretamente proporcional à variação da velocidade ao longo da direção normal às placas. 


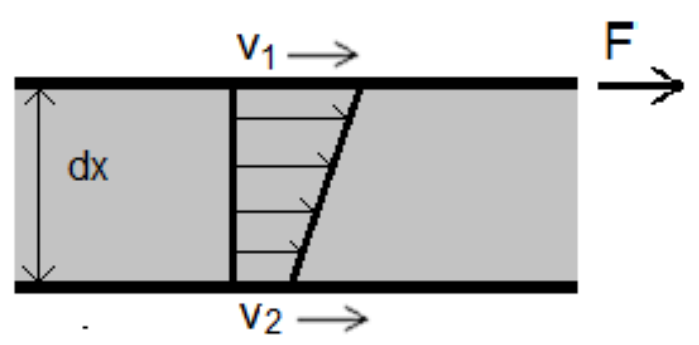

Figura 5.2 Experiência das placas paralelas

A experiência consiste em duas placas paralelas, planas e de mesma área, separadas por uma distância infinitesimal, $d x$, e movidas na mesma direção, com velocidades distintas, sendo $\mathrm{v}_{1}>\mathrm{v}_{2}$. $\mathrm{O}$ fluido localizado entre as placas é submetido a um cisalhamento simples devido à diferença de velocidade $(d v)$. A taxa de cisalhamento, $\dot{\gamma}$, equivale ao gradiente de velocidade ao longo da distância entre as placas, como expresso na Equação 5.1 .

$$
\dot{\gamma}=\frac{d v}{d x}
$$

A viscosidade caracteriza a resistência de um fluido ao escoamento sendo definida como a relação entre a taxa de cisalhamento e a tensão de cisalhamento, conforme descrito pela Equação 5.2. A viscosidade determinada é a viscosidade dinâmica que é, normalmente, descrita apenas como viscosidade.

$$
\tau=\frac{F}{a}=\eta \cdot \frac{d v}{d x}=\eta \cdot \dot{\gamma}
$$

Onde: $\tau$ é a tensão de cisalhamento $(\mathrm{Pa}), \mathrm{F}$ é a força aplicada $(\mathrm{N})$, a é a área de aplicação da força $\left(\mathrm{m}^{2}\right)$, $\eta$ é a viscosidade (Pa.s) e $\dot{\gamma}$ a taxa de cisalhamento $\left(\mathrm{s}^{-1}\right)$.

$\mathrm{Na}$ reologia, os materiais são classificados de acordo com seu comportamento em fluidos Newtonianos e fluidos Não Newtonianos. O primeiro caso representa os fluidos que obedecem à lei de Newton, ou seja, apresentam comportamento linear entre tensão e deformação, e o segundo caso no qual a relação entre essas duas variáveis é não linear. A água é um líquido newtoniano por excelência, porém quando misturada com o solo, apresenta um comportamento não newtoniano, sendo que quanto maior a concentração de sólidos, mais o comportamento se afasta do Newtoniano.

Para fluidos com adição de partículas formando uma suspensão ou pasta, o modelo definido por Newton não pode ser utilizado, visto que as partículas sólidas 
afetam a resistência que o fluido oferece ao escoamento, alterando a viscosidade do sistema. Nesses casos a viscosidade medida deixa de ser o coeficiente angular de uma relação linear, entre tensão e taxa de cisalhamento, e se torna uma propriedade, que é dependente das condições a que o fluido é submetido, e é denominada por viscosidade aparente. (LYRA, 2010)

Van Wazer et al. (1966), assim como Newton, define a viscosidade, também denominada por coeficiente de viscosidade, através de cisalhamento laminar simples entre dois planos paralelos, como sendo a razão entre a tensão de cisalhamento aplicada e a taxa de cisalhamento, como apresentado na Figura 5.3. Os autores ainda fazem uma separação entre viscosidade diferencial que é a inclinação de um dado ponto da curva de tensão de cisalhamento versus taxa de cisalhamento - e viscosidade aparente que é obtida através da inclinação de uma reta ligando um ponto com a origem, esse termo é mais usual para curvas de tensão de cisalhamento versus taxa de cisalhamento com comportamento não linear.

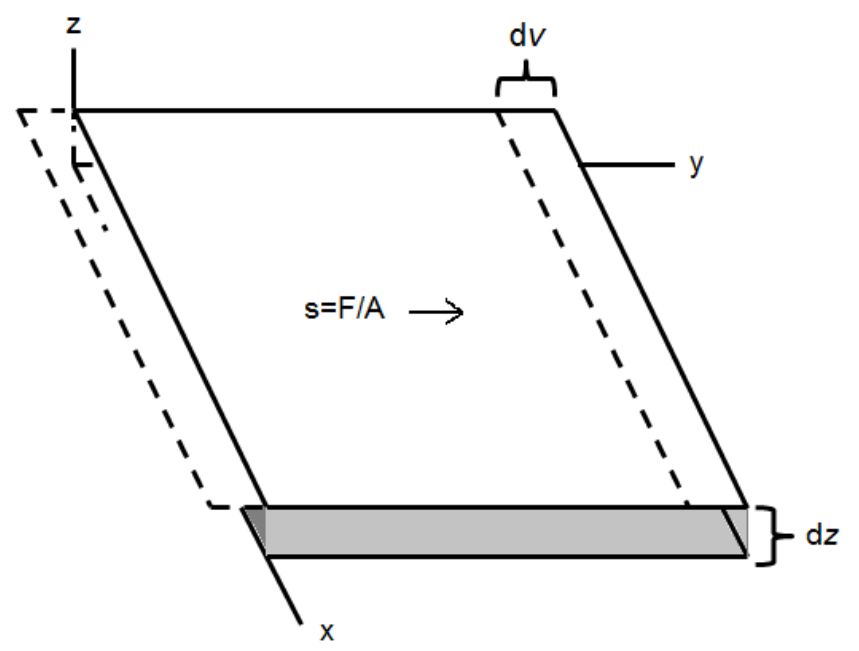

Figura 5.3 Definição de viscosidade baseada num fluxo laminar entre duas placas paralelas de extensão infinita (VAN WAZER et al., 1966)

Van Wazer et al. (1966) calculou a viscosidade através do gráfico da curva de fluxo admitindo que, para respostas lineares, a viscosidade é a mesma que a determinada por Newton e, para respostas não lineares, a viscosidade aparente é aquela onde é traçada uma reta entre o ponto no qual se deseja determinar a viscosidade e a secante por comportamento linear.

De acordo com Pileggi (2001), a viscosidade é uma medida da resistência do fluido ao escoamento. Considerando um sistema que contenha partículas sólidas em sua composição, a dificuldade imposta pelas partículas ao fluxo do líquido que as 
circundam aumenta a viscosidade do fluido. Os principais fatores que afetam a viscosidade de uma suspensão são: a concentração volumétrica de sólidos, as características do meio líquido (viscosidade, densidade, etc) e a temperatura.

Oliveira et al. (2000) exprimiu que a viscosidade é a principal propriedade reológica de um fluido por indicar a facilidade de escoar continuamente sob a ação de uma tensão de cisalhamento externa. Znamensky (2001) faz a mesma consideração em relação à debris flow, afirmando que a viscosidade é uma das suas características mais importantes, pois está intrinsicamente ligada à fluência e, assim, a mobilidade das massas que formam o sistema disperso.

Iverson (1997), no estudo de caracterização de fluxo de detritos considerou uma separação entre as propriedades de sólidos e líquidos de um fluxo, adotando as propriedades das fases $(L+S)$ separadas, os valores padrões encontrados para caracterizar cada uma das fases estão apresentados na Tabela 5.1. Sendo que para essa divisão entre as fases, considera que os grãos maiores que o silte representam os sólidos, e os menores se misturam com a água e fazem parte do fluido. Os dados apresentados foram estimados a partir de diferentes resultados obtidos através de retroanálises de debris flow.

Tabela 5.1 Valores característicos obtidos para Debris Flow (Iverson, 1997)

\begin{tabular}{|c|c|c|}
\hline Propriedade e Unidade & Símbolo & Valores Típicos \\
\hline \multicolumn{3}{|c|}{ Propriedades dos Grãos Sólidos } \\
\hline Densidade de massa, $\mathrm{kN} / \mathrm{m}^{3}$ & $\gamma_{s}$ & $25-30$ \\
\hline Diâmetro médio, m & $\delta$ & $10^{-5}-10$ \\
\hline Ângulo de atrito, $\stackrel{\circ}{ }$ & $\phi_{g}$ & $25-45$ \\
\hline \multicolumn{3}{|c|}{ Propriedades do Fluido dos Poros } \\
\hline Densidade de massa, $\mathrm{kN} / \mathrm{m}^{3}$ & $\gamma_{f}$ & $10-12$ \\
\hline Viscosidade, Pa s & $\mu$ & $0,001-0,1$ \\
\hline \multicolumn{3}{|c|}{ Propriedades da Mistura } \\
\hline Volume da fração Sólida (\%) & $v_{s}$ & $40-80$ \\
\hline Volume da fração Líquida (\%) & $v_{f}$ & $20-60$ \\
\hline Permeabilidade Hidráulica, $\mathrm{m} / \mathrm{s}$ & $k$ & $10^{-13}-10^{-9}$ \\
\hline Condutividade Hidráulica, m/s & K & $10^{-7}-10^{-2}$ \\
\hline Módulo de Deformabilidade, $\mathrm{Pa}$ & $\mathrm{E}$ & $10^{3}-10^{5}$ \\
\hline Ângulo de atrito,, & $\phi$ & $25-45$ \\
\hline
\end{tabular}

Como consequência dessa divisão, a viscosidade admitida por Iverson (1997) não é a viscosidade do sistema (que é o fluxo de detritos) e nem do fluido (no caso a 
água) e sim de um subsistema composto pela fração fina do solo (grãos de silte e argila) com a água.

Oliveira et al. (2000) reafirmou que a definição clássica de viscosidade dada por Newton não se aplica aos fluidos não newtonianos, uma vez que não há uma constante de proporcionalidade entre $\tau$ e $\dot{\gamma}$. Nesses casos a viscosidade deixa de ser uma característica intrínseca do fluido, em decorrência disso, outras expressões matemáticas devem ser utilizadas para descrever a viscosidade de fluidos não newtonianos, dentre estas expressões, as mais empregadas são a razão simples $(\tau / \dot{\gamma})$ denominada viscosidade aparente $\left(\eta_{a p}\right)$, e a derivada da curva entre $\tau$ e $\dot{\gamma}$, $d \tau / d \dot{\gamma}$, conhecida como a viscosidade diferencial.

Pileggi (2001) complementou afirmando que uma maneira de expressar a viscosidade que possibilite a comparação de suspensões formadas por diferentes tipos de meio líquido, é através da viscosidade relativa $\left(\eta_{R}\right)$, que definiu como a razão entre a viscosidade da suspensão e a viscosidade do meio $\left(\eta / \eta_{0}\right)$, sendo que neste caso a viscosidade da suspensão pode ser representada por quaisquer uma das outras definições empregadas.

A viscosidade é um parâmetro que representa uma medida de resistência ao fluxo para um determinado material. Esse conceito de viscosidade ainda não é aplicado em solos, embora seja um assunto com grande potencial de aplicação, para a determinação do tipo de desenvolvimento pós-ruptura, visto que a viscosidade é um parâmetro de fácil obtenção. No caso de solos com elevada umidade, um valor de viscosidade baixo indica que esse solo se encontra em um estado no qual é maior a probabilidade desse material sofrer um processo de corrida após a ruptura, enquanto solos que apresentem um valor mais elevado de viscosidade, mesmo com a umidade elevada, se mantém em estado sólido após a ruptura, ou seja, o solo rompe mas não ocorre o desenvolvimento para uma corrida.

\subsubsection{Tensão de escoamento}

Para definir a tensão de escoamento, Oliveira et al. (2000), explicou que alguns fluidos exigem a aplicação de uma tensão mínima de cisalhamento para que o seu escoamento se inicie, e quando são submetidos a valores de tensão inferiores 
à tensão de cisalhamento mínima esses fluidos se comportam como sólidos elásticos rígidos. Wallevik \& Wallevik (2011) complementaram a definição afirmando que os materiais que apresentam tensão de escoamento são aqueles tipicamente capazes de sustentar uma tensão aplicada sem entrar em movimentação.

Larrad \& Sedran (2002) explicaram que a tensão de escoamento é uma característica comum do concreto fresco e de materiais granulares secos (como solos), enquanto que a viscosidade plástica tende a relacionar concreto fresco à corpos viscosos como óleos ou a água e, portanto, pode-se assumir que a tensão de escoamento é o resultado do atrito intergranular durante o cisalhamento, enquanto que a viscosidade plástica é resultado da atuação da água na porosidade do sistema granular.

Oliveira et al. (2000) expôs que a tensão de escoamento das suspensões corresponde à tensão necessária para romper a estrutura tridimensional de partículas, formada pela aglomeração das partículas no fluido. Salientam que a formação desse tipo de estrutura exige que a suspensão apresente uma concentração de sólidos mínima, que possibilite a conexão entre as partículas por todo o volume do fluido, sendo que o principal fator para a formação dessas estruturas rígidas tridimensionais é a atração entre as partículas da suspensão. Acrescentam que a presença de partículas assimétricas e com alta rugosidade superficial também pode auxiliar a estruturação da suspensão, causada pela facilidade de ancoramento entre si.

Steffe (1996) definiu a tensão de escoamento como a tensão de cisalhamento mínima para iniciar o fluxo, afirma que existem diversos métodos para obtenção desse parâmetro não sendo possível preterir um, mas o método mais comum é obter a tensão de escoamento pela extrapolação da curva de taxa de cisalhamento versus tensão cisalhante, apesar do método apresentar forte influência do modelo reológico utilizado e da faixa de tensão de cisalhamento aplicada na amostra.

Para solos, assim como concretos, a tensão de escoamento demonstra que 0 material apresenta uma estrutura, que é capaz de suportar algum esforço sem sofrer deformação. Esse mesmo comportamento pode ser observado em outros ensaios utilizados na mecânica dos solos como o vane test, por exemplo. A tensão de escoamento nos solos deve variar, principalmente, segundo a umidade e a coesão 
da amostra ensaiada. Sendo intuitivo prever que quanto maior a umidade, menor a tensão de escoamento e ainda que deve existir uma umidade limite a partir da qual a tensão de escoamento se anule.

Cheng (1984) (apud Steffe, 1996) apresentou revisão sobre a obtenção da tensão de escoamento e introduziu o conceito de tensão de escoamento estática e dinâmica (Figura 5.4) assumindo que um fluido tixotrópico apresente duas diferentes estruturas. Para exemplificar esses conceitos, Steffe (1996) se utilizou de alimentos que se encontram em estado sólido quando em repouso e um estado líquido quando são agitados. Nesses alimentos, quando a tensão de escoamento é medida numa amostra inalterada resulta na tensão de escoamento estática, e quando é medida em amostra perturbada é a tensão de escoamento dinâmica. A tensão de escoamento estática é significativamente maior do que a dinâmica.

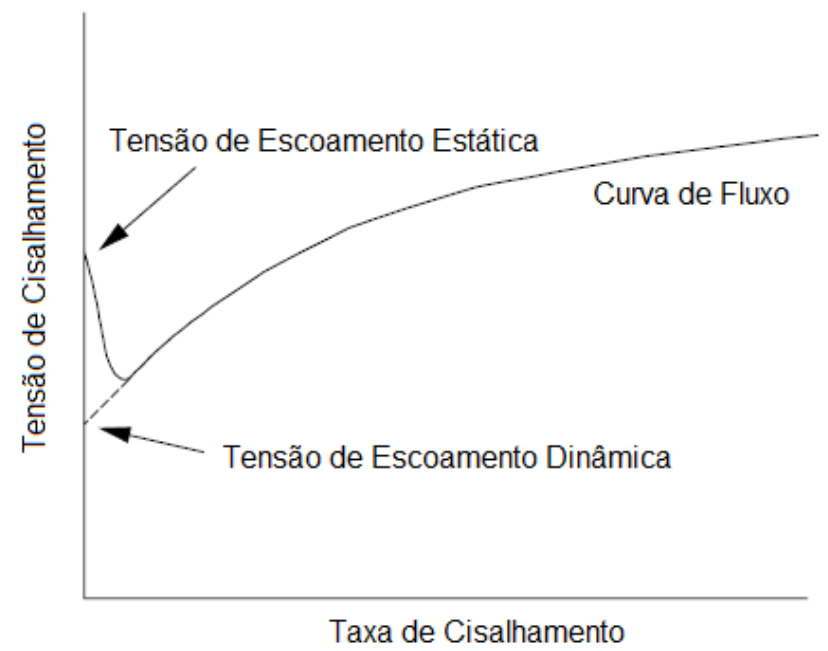

Figura 5.4 Tensão de escoamento estática e dinâmica (STEFFE, 1996)

Em relação às duas estruturas sugeridas para a tensão de escoamento, Steffe (1996) observou que uma das estruturas, dinâmica, é insensível a taxa de cisalhamento e serve para definir a tensão de escoamento dinâmica associada com a curva de fluxo. A segunda estrutura, estática, se forma sobre um determinado de período que a amostra fique em repouso. Steffe (1996) afirma que o valor real está mais próximo do valor dinâmico.

Essa separação da tensão de escoamento em estática e dinâmica deve ser válida para solos. Sendo que em amostras indeformadas a tensão de escoamento medida é a estática, que é a tensão de escoamento que ocorre em campo quando não são observadas movimentações. Já a tensão de escoamento dinâmica pode ser observada quando a massa está se movimentando. Enquanto o solo não se deforma 
e está estável a tensão atuante é a estática, no entanto, quando esse solo entra em movimento, a solicitação faz com que a tensão de escoamento passe a ser a dinâmica com um valor menor e o solo passa a suportar um esforço menor sem sofrer movimentação. Então, considerando um maciço de solo estável, sem ocorrência de deformações, submetido a uma determinada tensão. Se, por qualquer motivo, como o aumento da umidade, esse maciço passe a não suportar a tensão, então esse solo entra em movimento fazendo com que a tensão de escoamento passe a assumir o valor dinâmico e o maciço se instabiliza apresentado movimentações mais intensas.

\subsection{Aspectos Conceituais}

$\mathrm{Na}$ física fundamental os estados sólido $(\mathrm{S})$, líquido $(\mathrm{L})$ e gasoso $(\mathrm{G})$ são distintos, porém, os solos não são corpos tão simples quanto esses grupos, sendo, geralmente, compostos pela combinação dos estados sólido, líquido e gasoso. Esse sistema de três $(S+L+G)$ ou duas fases $(S+L$ ou $S+G)$ apresenta uma resposta às solicitações de uma maneira distinta de um sistema unifásico contínuo. Apesar de apresentar limitações, as soluções obtidas através da mecânica do contínuo são amplamente utilizadas na determinação de relação entre tensão e deformação (SUKLJE, 1969).

A utilização da reologia se apresenta como uma alternativa na obtenção de modelos para determinação do comportamento do solo sob solicitação. Modelagens matemáticas são utilizadas para tentar correlacionar uma característica real (medida) com uma avaliação teórica. A determinação do modelo representativo de comportamento leva em conta dois parâmetros: sua representatividade em relação ao comportamento medido e sua facilidade de aplicação. O comportamento reológico dos materiais é descrito através de relações matemáticas entre a tensão aplicada e a respectiva taxa de cisalhamento e suas variações em relação ao tempo.

Meschyan (1995) afirmou que, na reologia e na mecânica do contínuo, todos os materiais reais são substituídos por materiais idealizados, com certas propriedades atribuídas, em particular, homogeneidade e continuidade, e faz uma breve descrição do entendimento dessas propriedades para a reologia. $\mathrm{O}$ autor 
considerou que a homogeneidade descreve a equivalência em propriedades dos elementos constituintes do material, de diferentes tamanhos e tomados de pontos distintos de um corpo. Mesmo tendo conhecimento de que os corpos são constituídos por partículas individuais, essa simplificação pode ser adotada quando determinado corpo tem tamanho muito maior que as partículas e elementos individuais que o constituem.

A continuidade descreve que tudo está intimamente ligado, ou seja, não há partículas. Corpos reais rígidos e os solos, em particular, não possuem essa propriedade. No entanto, considerando válida a homogeneidade, um corpo é assumido como contínuo se as dimensões de um elemento do corpo rígido excedem em muito as dimensões dos seus elementos estruturais. Tal idealização de um corpo rígido é admissível porque a teoria em si se baseia em macro elementos, e a investigação sobre as leis que regem a sua deformação não se aprofunda nos processos que ocorrem no nível microscópico, entre as partículas e os agregados. (MESCHYAN, 1995)

Meschyan (1995) afirmou que, como a medida das propriedades de viscosidade, elasticidade e plasticidade podem aparecer em diversas combinações, a descrição da deformação de um corpo real torna-se uma tarefa complicada. Por isso, as deformações de corpos reais são descritas por modelos simplificados ou modelos idealizados, que servem para comparação e investigação das propriedades de corpos reais.

Ainda de acordo com Meschyan (1995) as propriedades reológicas de um solo argiloso podem variar consideravelmente dependendo de seu estado, que é determinado pela sua densidade, seu teor de umidade e sua resistência, mudando de um líquido ideal newtoniano viscoso até um corpo com comportamento plástico.

Znamensky (2001) afirmou que, em relação às corridas que ocorrem na natureza, a água do escoamento superficial (e de precipitação) é um fluido newtoniano por excelência, porém, ao receber sedimentos de diversos tamanhos e quantidades transforma-se num fluido não newtoniano. Coussot et al. (1988) observaram que a presença de grãos finos na fase sólida do sistema, mesmo em quantidade reduzida (concentração de $3 \%$ a $5 \%$ em volume) aumenta muito a viscosidade da matriz e confere ao sistema um comportamento coesivo-viscoso. 
Quanto maior a concentração de sólidos, mais o comportamento reológico se desvia do modelo newtoniano e passa a depender também de outras variáveis, em virtude disso, novas equações de estado reológico são necessárias para descrever o comportamento dessas suspensões. As propriedades de fluxo das suspensões são, normalmente, representadas por curvas de tensão de cisalhamento $(\tau)$ em função da taxa de cisalhamento $(\dot{\gamma})$ (PILEGGI, 2001).

Para uma compreensão mais objetiva, na Figura 5.5 estão apresentados os principais modelos de comportamento de fluidos sujeitos a ação de tensões cisalhantes, sendo realizada uma breve descrição de cada um deles a seguir de acordo com as definições obtidas em Tanner (1988) e Van Wazer et al. (1966).

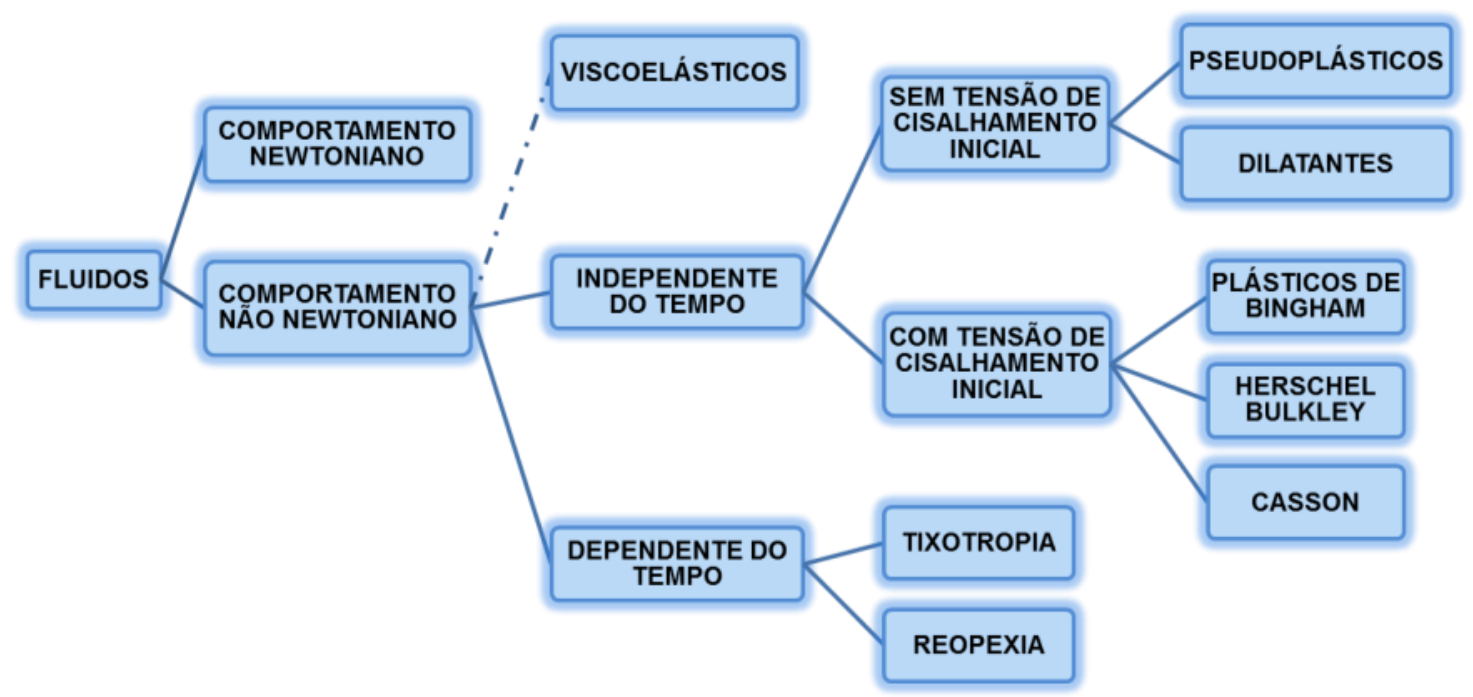

Figura 5.5 Principais modelos reológicos de comportamento de fluxos (SETOR1, 2012)

O comportamento dos fluidos se divide em dois grandes grupos, os newtonianos e os não newtonianos. O comportamento newtoniano indica que a viscosidade do material analisado independe da taxa de deformação a qual está submetido em uma dada temperatura. Já os sistemas não newtonianos possuem a relação entre taxa de deformação e tensão de cisalhamento mais complexa, pois a viscosidade varia com a taxa de deformação e existe ainda a necessidade da tensão de cisalhamento inicial. O comportamento não newtoniano é dividido em três grupos de modelos para a previsão do comportamento: os fluidos podem apresentar comportamento viscoelástico, comportamento dependente do tempo e comportamento independente do tempo.

Os fluidos viscoelásticos são aqueles que apresentam propriedades viscosas e elásticas acopladas e, quando a tensão de cisalhamento aplicada é retirada o 
fluido retorna parcialmente ao estado original após sofrer deformação. Os materiais viscoelásticos quando submetidos a solicitações, apresentam inicialmente um comportamento sólido e posteriormente líquido.

Os fluidos não newtonianos independentes do tempo são aqueles nos quais a taxa de cisalhamento em qualquer ponto é função apenas da tensão de cisalhamento no ponto, são divididos entre os que apresentam tensão de cisalhamento inicial, denominados por pseudoplásticos e dilatantes, e os que não apresentam que são os fluidos de Bingham, Herchel-Bukley e Casson, além de outros modelos.

A curva típica de um fluido pseudoplástico indica que a viscosidade aparente diminui progressivamente com o aumento da taxa (ou tensão) de cisalhamento e, para elevadas taxas de cisalhamento, a viscosidade se torna linear. A Equação 5.3 apresenta o comportamento reológico desse tipo de fluido, onde $k$ é uma constante e $n$ é um índice de comportamento do fluido que, para a pseudoplasticidade, é sempre menor que 1 .

$$
\tau=k(\dot{\gamma})^{n}
$$

Fluidos dilatantes são similares aos pseudoplásticos em relação a não apresentar tensão de cedência, mas a viscosidade para esse tipo de material aumenta com o aumento da taxa de cisalhamento. A lei da potência, apresentada na Equação 5.3, pode ser aplicada, sendo que nesse caso o coeficiente da potência é maior que a unidade.

Os plásticos de Bingham, Figura 5.6, são caracterizados por uma curva de fluxo que é uma reta com intercepto no eixo da tensão de cisalhamento. O material representativo desse modelo apresenta um comportamento mais parecido com um sólido do que com um fluido. A explicação para esse comportamento é que o fluido em repouso contém uma estrutura tridimensional, que é suficientemente rígida para resistir a qualquer tensão abaixo da tensão de escoamento.

Os fluidos de Herschel-Bulkley e de Casson apresentam o comportamento do tipo lei de potência com tensão de cisalhamento inicial. Outras equações empíricas são utilizadas para descrever o comportamento pseudoplástico com tensão de cisalhamento inicial e, normalmente, tem o nome dos seus inventores como PowerEyring, Ellis, entre outros. 
A partir dessas descrições é possível apresentar a Figura 5.6, que é um resumo gráfico dos conceitos vistos e apresenta a variação da viscosidade nos modelos discutidos.

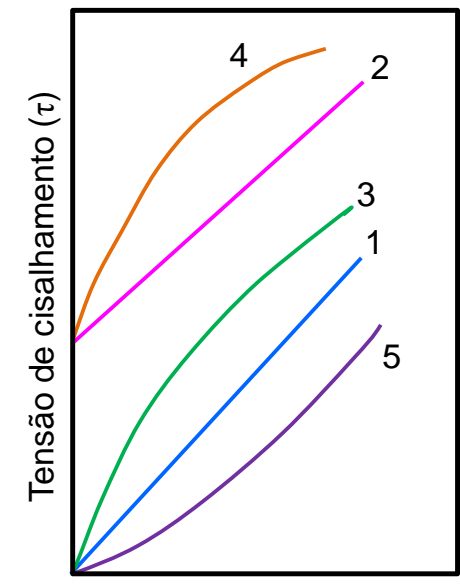

Taxa de cisalhamento $(\dot{\gamma})$

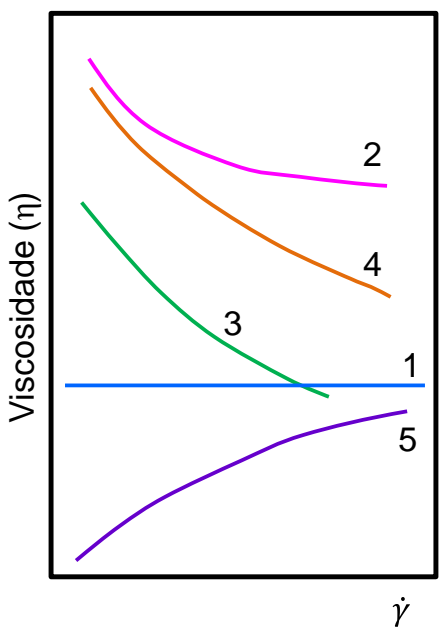

1 - Newtoniano

2 - Bingham

3 - Pseudoplástico

4 - Pseudoplástico com tensão de escoamento

5 - Dilatante

Figura 5.6 Comportamento reológico dos fluidos (Pileggi, 2001)

Os fluidos não newtonianos dependentes do tempo são divididos em dois grupos, os reopéticos e os tixotrópico (Figura 5.5), ou seja, a curva de carregamento e descarregamento não são coincidentes. Os fluidos reopéticos são os que apresentam um aumento da viscosidade aparente com o tempo de cisalhamento sob uma taxa de cisalhamento constante. Os ciclos de histereses destas substâncias dependem da velocidade de mudança da taxa de deformação. A área de histerese, área entre as curva de carregamento e descarregamento, é positiva nesse caso.

Os fluidos tixotrópicos são os que apresentam o fenômeno da diminuição da viscosidade aparente com o tempo sob uma taxa de cisalhamento constante. Assim como na pseudoplasticidade, a diminuição da viscosidade aparente com o tempo é devida à quebra de uma estrutura organizada no fluido. Esse tipo de fluido apresenta área de histerese negativa.

A Figura 5.7 apresenta exemplo de curvas de fluxo sendo que 0 comportamento tixotrópico ocorre quando se observa que o carregamento se dá pela parte superior da curva e o descarregamento pela curva inferior, como indicado pela cor vermelha. Já o comportamento reopético, também denominado de tixotropia negativa, ocorre quando o carregamento é observado pela parte inferior da curva e o descarregamento pela superior, como indicado pela cor azul. A maior parte dos materiais apresenta certo grau de tixotropia ou reopeticidade que pode ser desprezado. 


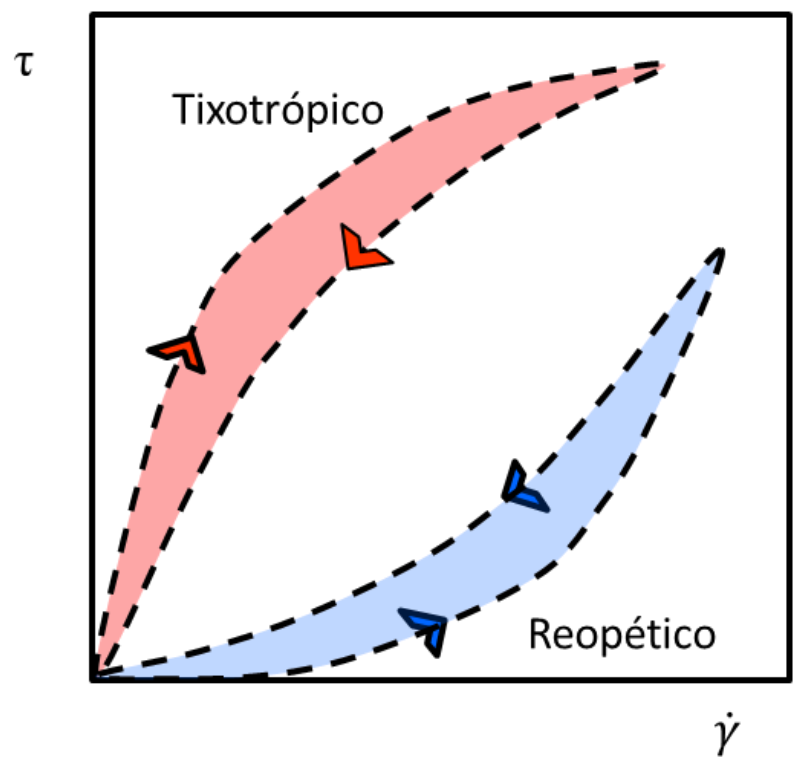

Figura 5.7 Exemplo de comportamento tixotrópico e reopético

Keedwell (1984) utilizou o termo tixotropia para descrever a tendência de alguns materiais a ficar no estado fluido facilmente quando são agitados e voltar ao estado "gel" quando a agitação é removida. Um exemplo é a mistura de bentonita e água. Essa mistura é utilizada como lama de perfuração em poços, quando é continuamente agitada pelas ferramentas de perfuração a mistura se mantêm na forma de lama, mas nos poros do solo onde é protegida de agitação, a mistura forma um gel.

Como relatado anteriormente, existem diversas equações para descrever o comportamento de fluidos que apresentam tensão de escoamento. Oliveira et al. (2000) exemplificaram apresentando as equações dos fluidos de Bingham, HerschelBulkley e Casson. Os fluidos com tensão de escoamento mais simples são os de Bingham, que obedecem a Equação 5.4, onde $\tau_{0}$ é a tensão de escoamento e $\eta_{p l}$ é a viscosidade plástica da suspensão.

$$
\tau=\tau_{0}+\eta_{p l} \dot{\gamma}
$$

Oliveira et al. (2000) afirmaram que a tensão de escoamento dos fluidos de Bingham equivale à tensão aplicada em condições muito próximas a taxas nulas de cisalhamento. É importante observar que, embora a viscosidade plástica desse tipo de fluido seja constante, sua viscosidade aparente se reduz em função da taxa de cisalhamento. A Equação 5.5 foi sugerida por Herschel e Bulkley, na qual $\tau_{y}$ é a tensão de escoamento de Herchel-Bulkley, $k$ é uma constante e $p$ é um índice de 
consistência do fluido obtido a partir do ajuste dos dados experimentais de $\tau_{y}$ e $\dot{\gamma}$. Representa a curva 4 na Figura 5.6.

$$
\tau=\tau_{y}+k(\dot{y})^{p}
$$

Outra equação bastante utilizada é a proposta por Casson, Equação 5.6, onde $\tau_{c}$ é a tensão de escoamento de Casson e $\eta_{c}$ é a viscosidade de Casson, também representada pela curva 4 na Figura 5.6.

$$
\tau^{1 / 2}=\tau_{c}{ }^{1 / 2}+\left(\eta_{c} \dot{\gamma}\right)^{1 / 2}
$$

Tanner (1988) afirmou que, em relação ao comportamento reológico, é possível apresentar a Equação 5.7 como a mais geral, que representa todas as curvas apresentadas na Figura 5.6 de acordo com os parâmetros adotados para $n$ e $\tau_{0}$.

$$
\tau=\tau_{0}+k \dot{\gamma}^{n}
$$

Sendo $k$ uma constante do material, $n$ o coeficiente que vale 1 para os fluidos que apresentem comportamento Newtoniano ou de Bingham, $n>1$ para fluidos dilatantes e $n<1$ para fluidos de Herschel Bulkley e Pseudoplásticos.

Steffe (1996) realizou uma compilação dos principais modelos reológicos utilizados para descrever o comportamento dos fluidos independentes do tempo apresentadas nas Equações 5.8 a 5.18, organizadas na Tabela 5.2. Onde $K_{1}, K_{2}$ e $K_{3}$ são constantes arbitrárias e $n_{1}$ e $n_{2}$ são índices de potência, todos determinados a partir dos dados experimentais. 
Tabela 5.2 Modelos Reológicos fluidos independentes do tempo (STEFFE, 1996)

\begin{tabular}{|c|c|c|}
\hline $\begin{array}{c}\text { Casson Modificado } \\
\text { (Mizrahi e Berk, 1972) }\end{array}$ & $\sigma^{0,5}=\left(\sigma_{0}\right)^{0,5}+K_{1}(\dot{\gamma})^{n_{1}}$ & 5.8 \\
\hline $\begin{array}{c}\text { Ellis } \\
\text { (Ellis, 1927) }\end{array}$ & $\dot{\gamma}=K_{1} \sigma+K_{2}(\sigma)^{n_{1}}$ & 5.9 \\
\hline $\begin{array}{c}\text { Herschel Bulkley } \\
\text { Generalizada } \\
\text { (Ofoli et al., 1987) }\end{array}$ & $\sigma^{n_{1}}=\left(\sigma_{0}\right)^{n_{1}}+K_{1}(\dot{\gamma})^{n_{2}}$ & 5.10 \\
\hline $\begin{array}{c}\text { Vocadlo } \\
\text { (Parzonka e Vorcadlo, } \\
\text { 1968) }\end{array}$ & $\sigma=\left[\left(\sigma_{0}\right)^{1 / n_{1}}+K_{1} \dot{\gamma}\right]^{n_{1}}$ & 5.11 \\
\hline $\begin{array}{l}\text { Série de Potências } \\
\text { (Whorlow, 1992) }\end{array}$ & $\begin{array}{l}\dot{\gamma}=K_{1} \sigma+K_{2}(\sigma)^{3}+K_{3}(\sigma)^{5} \ldots \\
\sigma=K_{1} \dot{\gamma}+K_{2}(\dot{\gamma})^{3}+K_{3}(\dot{\gamma})^{5} \ldots\end{array}$ & $\begin{array}{l}5.12 \\
5.13\end{array}$ \\
\hline $\begin{array}{c}\text { Carreau } \\
\text { (Carreau, 1968) }\end{array}$ & $\eta=\eta_{\infty}+\left(\eta_{0}-\eta_{\infty}\right)\left[1+\left(K_{1} \dot{\gamma}\right)^{2}\right]^{n-1 / 2}$ & 5.14 \\
\hline $\begin{array}{c}\text { Cross } \\
\text { (Cross, 1965) }\end{array}$ & $\eta=\eta_{\infty}+\frac{\eta_{0}-\eta_{\infty}}{1+K_{1}(\dot{\gamma})^{n}}$ & 5.15 \\
\hline $\begin{array}{c}\text { Van Wazer } \\
\text { (Van Wazer, 1966) }\end{array}$ & $\eta=\frac{\eta_{0}-\eta_{\infty}}{1+K_{1} \dot{\gamma}+K_{2}(\dot{\gamma})^{n_{1}}}+\eta_{\infty}$ & 5.16 \\
\hline $\begin{array}{c}\text { Powell-Eyring } \\
\text { (Powell e Eyring, 1944) }\end{array}$ & $\sigma=K_{1} \dot{\gamma}+\left(\frac{1}{K_{2}}\right) \operatorname{senh}^{-1}\left(K_{3} \dot{\gamma}\right)$ & 5.17 \\
\hline $\begin{array}{l}\text { Reiner-Philippoff } \\
\text { (Philippoff, 1935) }\end{array}$ & $\sigma=\left(\eta_{\infty}+\frac{\eta_{0}-\eta_{\infty}}{1+\left((\sigma)^{2} / K_{1}\right.}\right) \dot{\gamma}$ & 5.18 \\
\hline
\end{tabular}

Concluindo, o comportamento reológico apresenta um alto grau de complexidade para interpretação e entendimento, alguns dos fatores que afetam o comportamento reológico das suspensões são: características físicas do meio de dispersão (viscosidade, densidade, entre outros), concentração volumétrica de sólidos em suspensões, características físicas das partículas (área superficial específica, distribuição granulométrica, densidade, forma, entre outros), concentração de moléculas de dispersante no meio líquido, magnitude de interação entre as partículas (indicativo da eficiência do mecanismo de estabilização empregado), temperatura, pH, entre outros. (OLIVEIRA et al., 2000) 
A Tabela 5.3 apresenta alguns exemplos de fluidos e os modelos reológicos que são utilizados nas suas caracterizações. Como esse tipo de abordagem é bastante utilizado na indústria alimentícia grande parte dos exemplos se encaixam nessa categoria.

Tabela 5.3 Exemplos de comportamento de fluidos (SETOR1, 2012)

\begin{tabular}{|c|c|}
\hline Comportamento & Exemplos de materiais \\
\hline Newtoniano & Água, leite, soluções de sacarose, óleos vegetais. \\
\hline Pseudoplástico & Polpa de frutas, caldos de fermentação, melaço de cana. \\
\hline Dilatantes & $\begin{array}{l}\text { Suspensões de amido, soluções de farinha de milho e } \\
\text { açúcar, areia e silicato de potássio. }\end{array}$ \\
\hline Bingham & $\begin{array}{l}\text { Fluidos de perfuração de poços de petróleo, algumas } \\
\text { suspensões de sólidos granulares. }\end{array}$ \\
\hline Casson & Sangue, iogurte, purê de tomate. \\
\hline Viscoelástico & $\begin{array}{l}\text { Massas de farinha de trigo, gelatinas, queijos, líquidos } \\
\text { poliméricos, glicerina, plasma, biopolímeros, ácido } \\
\text { hialurônico, saliva, goma xantana. }\end{array}$ \\
\hline Tixotrópico & $\begin{array}{l}\text { Suspensões concentradas, emulsões, soluções protéicas, } \\
\text { petróleo cru, tintas, ketchup. }\end{array}$ \\
\hline Reopéticos & Argila bentonita. \\
\hline
\end{tabular}

\subsection{Equipamentos de ensaio}

A Reometria é a parte da reologia que estuda as técnicas experimentais para medir as propriedades reológicas e é responsável pelo estudo e desenvolvimento dos equipamentos (e sua geometria) utilizados para esse fim.

Os resultados experimentais das propriedades reológicas servem como base para determinar as equações reológicas de estado dos materiais. As equações de estado descrevem as propriedades de um corpo ideal. No entanto, ao incluir constantes que descrevem o comportamento do material real sob carga, essas equações servem para descrever as propriedades dos materiais reais. A precisão com que as propriedades reológicas dos materiais (reais) são representadas por 
estas equações depende da escolha adequada das equações de estado e da precisão na determinação dos parâmetros reológicos. (MESCHYAN, 1995)

Castro (2007) explicou que os ensaios de reometria são aqueles nos quais as propriedades reológicas são determinadas em laboratório, sendo que existem diversas técnicas experimentais disponíveis que variam de acordo com o material a ser ensaiado. Steffe (1996) apresentou os instrumentos mais comuns utilizados para medir propriedades reológicas fundamentais na indústria alimentícia, reproduzido na Figura 5.8.

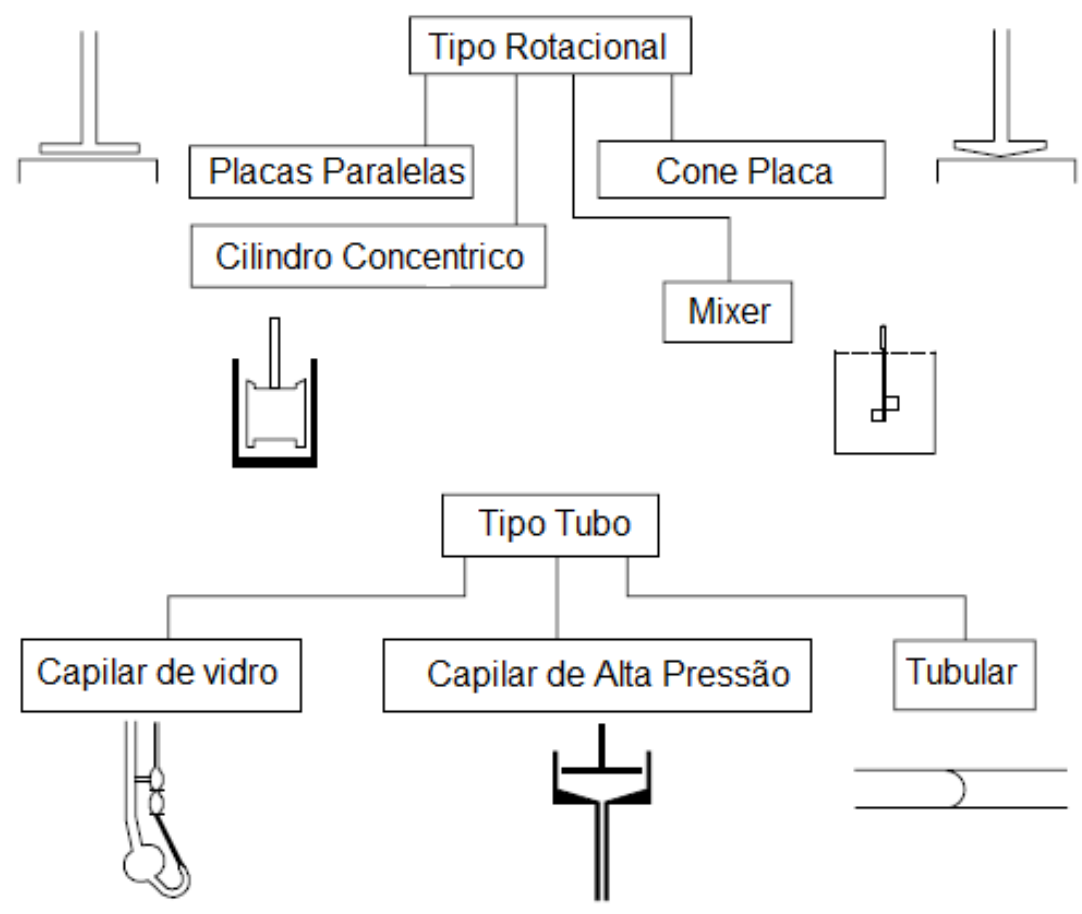

Figura 5.8 Instrumentos reométricos comuns (STEFFE, 1996)

Betioli et al. (2009) afirmaram que a maior dificuldade na caracterização de um material está na obtenção de uma única técnica capaz de simular todas as situações simultaneamente, ressaltando a importância da utilização de diferentes tipos de solicitações no material analisado.

A reometria não têm relação direta com os ensaios mais tradicionais de cisalhamento utilizados na Mecânica dos Solos, como o cisalhamento direto ou ring shear, porque esses ensaios utilizam uma única taxa de cisalhamento enquanto que nos ensaios reológicos ocorre a variação dessa tensão.

Nesse trabalho serão utilizados três equipamentos que são bastante utilizados na caracterização de concretos e argamassas, são eles: o aparelho de Squeeze flow, e os reômetros rotacionais sendo um deles com geometria tipo placas 
paralelas e outro com geometria tipo planetária, esses equipamentos serão apresentados a seguir.

$\mathrm{Na}$ reometria rotacional de torque com geometria planetária, é aplicado cisalhamento à amostra através de haste metálica. No reômetro de torque com geometria de placas paralelas a reometria se dá por cisalhamento aplicado na forma de fluxo de arraste. Já o equipamento de squeeze flow aplica compressão à amostra forcando a amostra a sofrer deformações elongacionais e cisalhantes.

\subsubsection{Reômetro Rotacional de Torque}

Reômetros são equipamentos direcionados à avaliação das propriedades reológicas de fluidos e suspensões, permitem estudar o comportamento da tensão de escoamento e da viscosidade plástica em função de outras variáveis, como tempo, temperatura, etc. Foram desenvolvidos visando diminuir a defasagem tecnológica de materiais, em relação às técnicas de caracterização reológicas convencionalmente empregadas para materiais como os concretos refratários. (PILEGGI, 2001)

O princípio básico de operação dos reômetros é avaliar a tensão de cisalhamento que é gerada pelo material analisado em decorrência da aplicação de esforços cisalhantes por raquetes, que em movimento rotacional, axial ou planetário, induzem-no a escoar. Ao impor um torque ao material ensaiado, através de velocidades angulares, que é representativo da taxa de cisalhamento, é medida a resistência ao escoamento quantificada na forma de tensão de cisalhamento. (PILLEGl et al., 2006)

Pileggi (2001) afirmou que os diversos equipamentos existentes no mercado se baseiam em dois princípios básicos de funcionamento: o primeiro é aquele no qual o torque aplicado ao fluido é controlado, sendo avaliado o cisalhamento resultante, e o segundo princípio é aquele no qual o cisalhamento aplicado ao material é controlado, sendo avaliada a força necessária para tal.

Pileggi (2001) expôs que o sistema de controle informatizado facilita e confere precisão na utilização do equipamento, além de possibilitar que a coleta de dados durante os experimentos registre uma elevada quantidade de informações (tempo, torque, rotação, $\mathrm{pH}$ e temperatura) em intervalos de tempo reduzidos (1 registro a 
cada segundo), acentuando ainda mais a confiabilidade dos resultados. Ressalta que as imprecisões associadas ao controle da rotação e às medidas de torque são pequenas, fornecendo credibilidade aos resultados obtidos, sendo que o limite inferior de rotação no equipamento é de 2 rpm no eixo central do planetário, pois abaixo desse valor o erro associado às medidas é bastante significativo. $O$ equipamento utilizado é todo automatizado, o que facilita o seu manuseio e a realização do ensaio, e permite que se tenha a menor interferência humana possível, fornecendo um resultado confiável e próximo do comportamento real da amostra ensaiada.

De acordo com Castro (2007), o primeiro reômetro desenvolvido especificamente para a caracterização de concretos foi concebido por Powers (1968), baseado no conceito de cilindros coaxiais e a partir desse nesse modelo, diversos outros equipamentos foram desenvolvidos. Com a evolução tecnológica dos reômetros, surgiram equipamentos que utilizam novos conceitos para o cisalhamento do material, dentre os quais se destaca o reômetro BTRHEOM -desenvolvido no Laboratoire Central des Ponts et Chaussées (LCPC), França. (LARRAD et al., 1997, apud CASTRO, 2007)

O reômetro rotacional de torque utilizado no trabalho foi desenvolvido no Departamento de Construção Civil da Escola Politécnica da USP, conforme Projeto FAPESP de Auxílio à Pesquisa número 03/12199-4 e pertence ao Laboratório de Microestrutura da Escola Politécnica da USP (LME). O princípio de funcionamento do aparelho é aplicar um torque, através da rotação da haste com geometria planetária, e medir uma estimativa de torque. O torque é aplicado através da definição prévia de velocidades de rotação. Na Figura 5.9 é possível visualizar os seguintes componentes do reômetro: (1) eixo através do qual o torque é aplicado, (2) haste com aletas em espiral que é a geometria do ensaio planetário, (3) cuba de aço inox que tem o papel de recipiente de ensaio e (4) base onde a cuba é encaixada e elevada para que toda a amostra fique em contato com a haste. As leituras são realizadas por computador acoplado ao sistema. A cuba de aço inox tem capacidade para, aproximadamente, quatro quilogramas de material.

De acordo com Pileggi (2001), a vantagem da consideração do modelo planetário é que este modelo permite que sejam avaliados tanto concretos com alta fluidez quanto concretos com fluidez reduzida e sem coesão, o que aumenta seu campo de utilização, portanto, em sua arquitetura final, o reômetro é um 
equipamento que possui força, velocidade e precisão suficientes para estudar os mais variados tipos de concretos, avaliando seu comportamento na etapa da mistura, além de simular suas diversas aplicações. E essa versatilidade faz com que seja interessante a utilização do reômetro em solos.

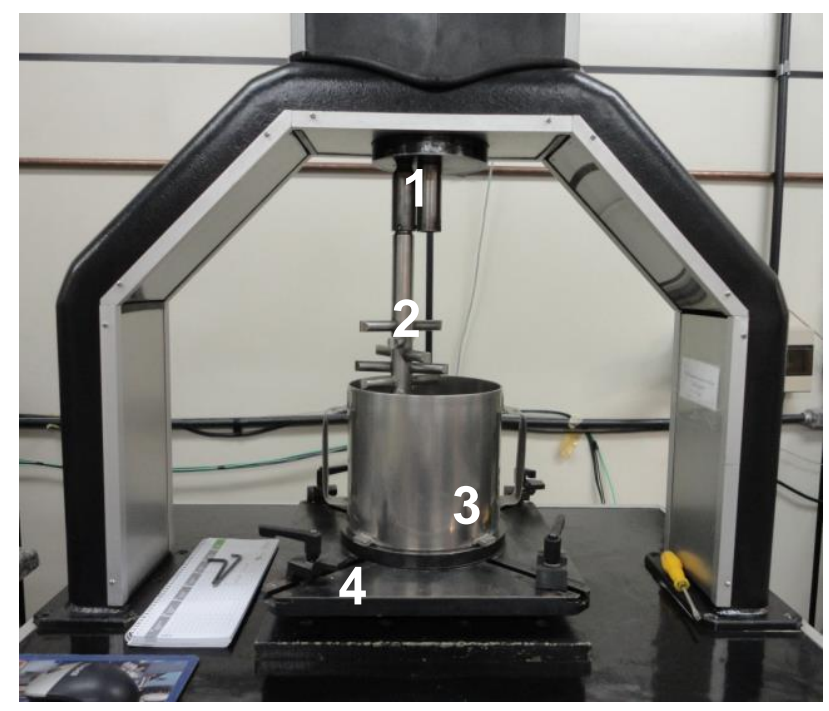

Figura 5.9 Reômetro rotacional de torque

A condição experimental, que é o ciclo de cisalhamento, deve ser definida antes do cálculo dos parâmetros reológicos. Wallevik e GjØrv (1990) (apud Castro, 2007) observam que, para uma suspensão à base de cimento, na qual certos fenômenos dependentes do tempo também estão envolvidos, a mudança na velocidade de rotação deve ser feita em escada e não continuamente. Definir a condição experimental significa definir qual a taxa de cisalhamento será aplicada por quanto tempo e como será realizado o aumento dessa taxa.

Esse tipo de ensaio gera curvas de torque versus velocidade de rotação, que fornecem duas informações fundamentais: primeiro, quanto menor a área de histerese (área entre as curvas ascendente e descendente do cisalhamento), maior a homogeneidade da amostra; e segundo, o formato da curva de cisalhamento indica a natureza reológica da mistura de concreto através da comparação com os modelos apresentados na Figura 5.6 (PILEGGI, 2001). Um exemplo de curva gerada está apresentado na Figura 5.10, na qual a área hachurada representa a histerese da amostra.

Wallevik e GjØrv (1990) (apud Castro (2007)) afirmaram que a análise dos resultados obtidos deve ser realizada pela parte descendente da curva, ou seja, o descarregamento, porque o tempo para obter o equilíbrio em cada taxa de cisalhamento será sempre menor partindo-se de uma maior para uma menor taxa de 
cisalhamento, o que significa de um maior para um menor grau de dispersão, então os dados analisados do descarregamento se estabilizam mais rapidamente.

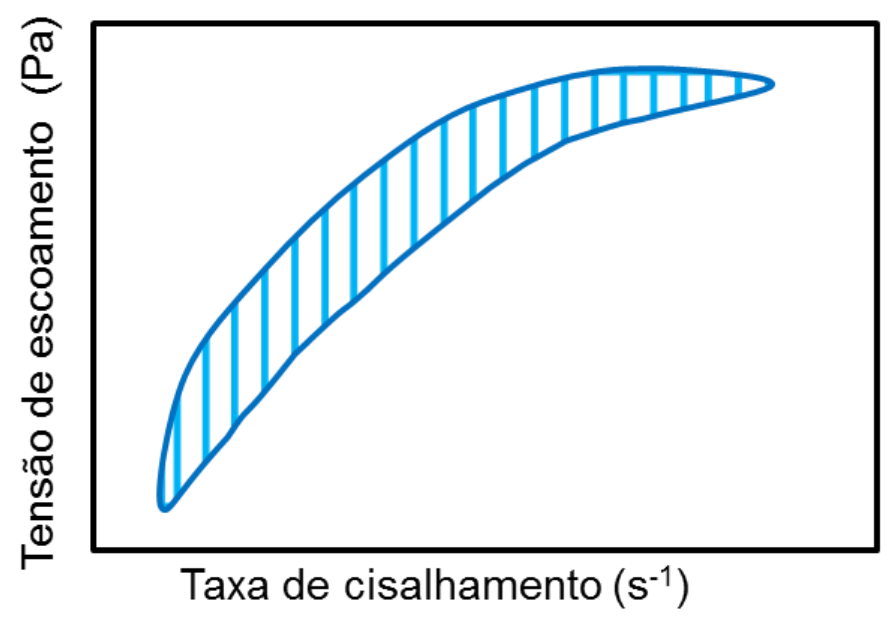

Figura 5.10 Exemplo de curva obtida no reômetro

Parâmetros reológicos são parâmetros que dependem do equipamento utilizado na medição. Banfil (1994) apresentou a Equação 5.19 para analisar os dados obtidos na forma de torque $(T)$ e velocidade de rotação $(N)$ para reômetros rotacionais.

$$
T=g+h N
$$

Onde g e h são constantes do material. Ao comparar essa equação com a equação do modelo de Bingham $\left(\tau=\tau_{0}+\eta_{p l} \dot{\gamma}\right)$ é possível admitir que g (N.m) corresponde ao torque de escoamento e h (N.m.s), inclinação da reta, à viscosidade.

Castro (2007) justificou que os parâmetros reológicos obtidos através do reômetro são dados em unidades de torque, ou seja, N.m e N.m.s, e, apesar de existirem equações que permitem a transformação das unidades de torque em unidades do SI, essa transformação não foi possível, pois as equações de transformação encontradas na literatura foram desenvolvidas para reômetros de cilindros coaxiais, essa mesma dificuldade foi encontrada na presente dissertação. (YEN et al. (1999); WALLEVIK (2006) apud CASTRO (2007)) 


\subsubsection{Reômetro Rotacional com geometria de Placas Paralelas}

O ensaio de fluxo, realizado no reômetro rotacional com geometria de placas paralelas, consiste na aplicação de força (ou deformação), através da aplicação de uma velocidade de rotação e da medida de resistência do material solicitado. Com a variação da taxa de cisalhamento é possível traçar a curva de escoamento, e obter valores de viscosidade e tensão de escoamento. O comportamento reológico pode ser apresentado por curvas de tensão versus taxa de cisalhamento ou de viscosidade versus taxa de cisalhamento.

O aparelho é composto por duas placas paralelas, concêntricas, e o diâmetro da amostra é definido pelo diâmetro da placa superior. Nesse tipo de reometria, a medida das propriedades reológicas é feita a partir da imposição de um fluxo de arraste, aplicado através da rotação da placa superior, enquanto a placa inferior permanece estática, como esquematizado na Figura 5.11 .

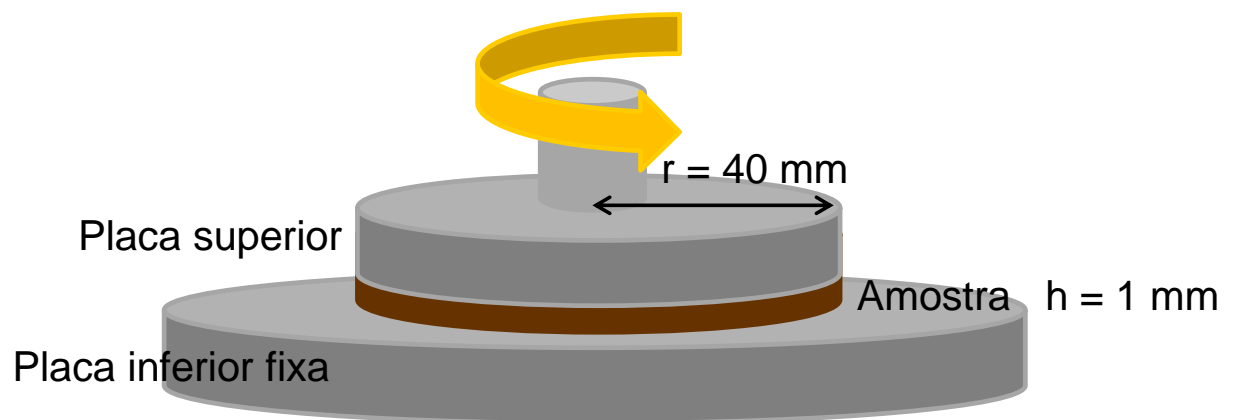

Figura 5.11 Esquema representativo do ensaio de fluxo

Nesse aparelho a tensão e a taxa de cisalhamento são obtidas diretamente, fazendo com que os cálculos sejam simples. Não é um equipamento apropriado para materiais com grandes partículas por causa da espessura da amostra, sendo o diâmetro máximo admitido para amostra, para garantir que não há interferência dos grãos, de um décimo da sua altura. Em relação aos solos, essa restrição na altura da amostra faz com que as amostras sejam compostas por grãos de até $0,1 \mathrm{~mm}$ de diâmetro, ou seja pela fração argila, silte e parte de areia fina. A amostra flui no espaço entre a placa superior e a inferior do equipamento, denominado de gap. A placa superior rotaciona com uma velocidade angular conhecida e é medido o torque resultante (STEFFE, 1996). 
Os ensaios realizados nessa dissertação foram em reômetro rotacional modelo AR 5500 da TA Intruments, apresentado na Figura 5.12, com tensão controlada, e com geometria de placas paralelas com diâmetro de $40 \mathrm{~mm}$ e espaçadas de $1 \mathrm{~mm}$. $\mathrm{O}$ aparelho também pertence ao Laboratório de Microestrutura da Escola Politécnica da USP (LME).

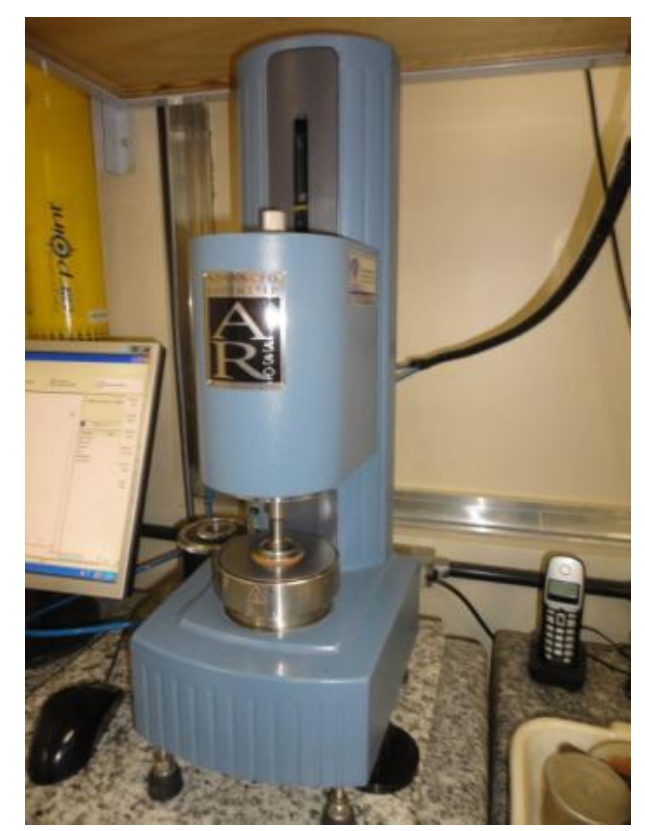

Figura 5.12 Aparelho do ensaio de fluxo

A espessura da amostra que pode ser utilizada nesse aparelho é muito pequena e pouco representativa do solo, no entanto, esse ensaio apresenta os resultados em unidades do sistema internacional, portanto, os resultados desse ensaio são passíveis de comparação com os dados encontrados na literatura. Além disso, essa geometria de ensaio já foi utilizada para a classificação reológica de solos por outros pesquisadores, como será visto adiante.

\subsubsection{Reometria Compressiva (Squeeze Flow)}

O ensaio de squeeze flow consiste na compressão de uma amostra entre duas placas paralelas, sendo que diversas configurações podem ser adotadas. Engmann et al. (2005) enfatizaram que o squeeze flow é uma técnica atrativa para medir propriedades reológicas de materiais viscosos, de fluidos que tendem a deslizar no contato com a parede do instrumento e de fluidos com grandes partículas. Cardoso (2009) considerou que um aspecto relevante refere-se ao 
potencial da ampla utilização técnica, visto que esta técnica dispensa o uso de reômetros especializados, pois pode ser facilmente adaptada em equipamentos do tipo máquina universal (prensas). Tais equipamentos são comumente utilizados em universidades, centros de pesquisas e desenvolvimento e, também, em laboratórios das indústrias destinados ao controle da qualidade. Além disso, a técnica é capaz de avaliar materiais com qualquer nível de consistência.

Independente do material a ser caracterizado, o princípio básico do ensaio é sempre a compressão entre duas placas paralelas através de prensas. Engmann et al. (2005) afirmaram que a técnica é geralmente utilizada devido à disponibilidade de equipamentos, facilidade de ensaio e pela semelhança apresentada em relação ao fluxo de processamento, o que se mostra vantajoso na indústria alimentícia, no entanto ressalta que é preciso estar ciente das dificuldades na interpretação dos dados.

No squeeze flow, a compressão pode se dar pela placa superior, pela placa inferior, ou por ambas; o ensaio pode ser realizado com controle de deslocamento ou controle de força e o diâmetro da placa superior pode ser menor, igual ou maior que o diâmetro da amostra. Cada uma das configurações é utilizada para especificar um determinado comportamento ou por ser mais adequada ao material ensaiado. $O$ ensaio gera os parâmetros reológicos fundamentais, a viscosidade e a tensão de escoamento.

A vasta gama de aplicação da técnica da reometria compressiva deve-se ao fato desta não apresentar alguns dos problemas mais comuns dos ensaios reológicos, como a perda de contato entre material e o elemento cisalhante que aplica o esforço na amostra (especialmente para materiais com características plásticas) ou o entrelaçamento de fibras no mesmo, o entupimento de capilares e as restrições por capacidade de torque em relação a outros equipamentos reométricos. (CARDOSO, 2009)

O resultado obtido em um ensaio de squeeze flow com controle por deslocamento é expresso na forma de uma curva de carga versus deslocamento, que apresenta um formato típico, conforme representado na Figura 5.13, com três regiões distintas. (MIN et al., 1994; CARDOSO, 2009) 


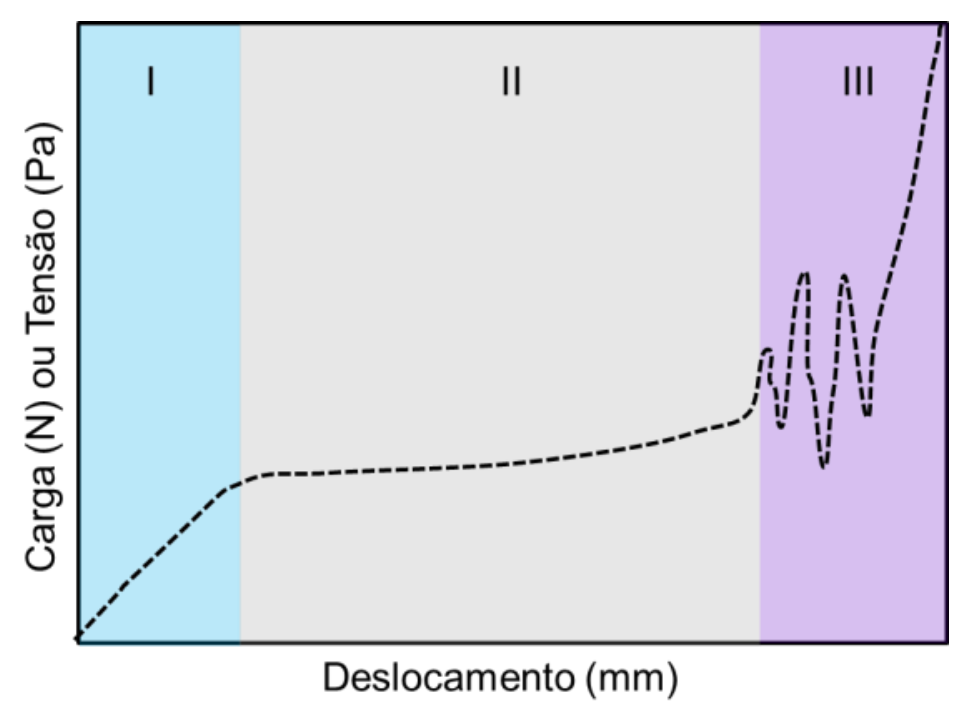

Figura 5.13 Resultado típico de ensaio de squeeze flow

O estágio I é a deformação elástica, no qual o material comporta-se como um sólido apresentando deformação elástica linear, esse estágio está relacionado à tensão de escoamento e ocorre sob pequenas deformações. O estágio II é denominado de deformação plástica e/ou fluxo viscoso, nesse estágio a compressão resulta em deformação radial elongacional e de cisalhamento, superando as forças que mantinham o material sob comportamento elástico e, assim, o mesmo flui por deformação. Nesta etapa, o material é capaz de sofrer grandes deformações sem aumento significativo da força necessária para o deslocamento. No estágio III, enrijecimento por deformação (strain hardening), ocorre um aumento exponencial da carga necessária para prosseguir a deformação do material, consequentemente, as forças de atrito são predominantes nessa situação. (MIN et al., 1994; CARDOSO et al., 2007)

É importante ressaltar que a faixa de deslocamento e a intensidade de cada estágio variam de acordo com a composição dos materiais (teores de água e de ar, dimensões mínima e máxima das partículas, presença de aditivos) e também com os parâmetros de ensaio utilizados. Entretanto, a análise da curva de carga ou tensão versus deslocamento possibilita a compreensão do comportamento reológico em diferentes situações durante sua aplicação, partindo de uma condição estacionária, representando o material em repouso, até um elevado nível de deformação, cisalhamento e restrição geométrica (CARDOSO et al., 2007).

Alguns ensaios podem apresentar comportamento como o demonstrado na Figura 5.14. Cardoso (2009) explicou que isso ocorre devido ao fluxo descontínuo do material durante o espalhamento radial, sendo que este fenômeno está relacionado 
ao atrito entre as placas e a amostra, e também aos mecanismos internos de deformação e fluxo do material, principalmente quando ocorre uma separação de fases que aumenta a concentração localizada de agregados em relação à mistura fazendo com que o atrito na região central seja ampliado.

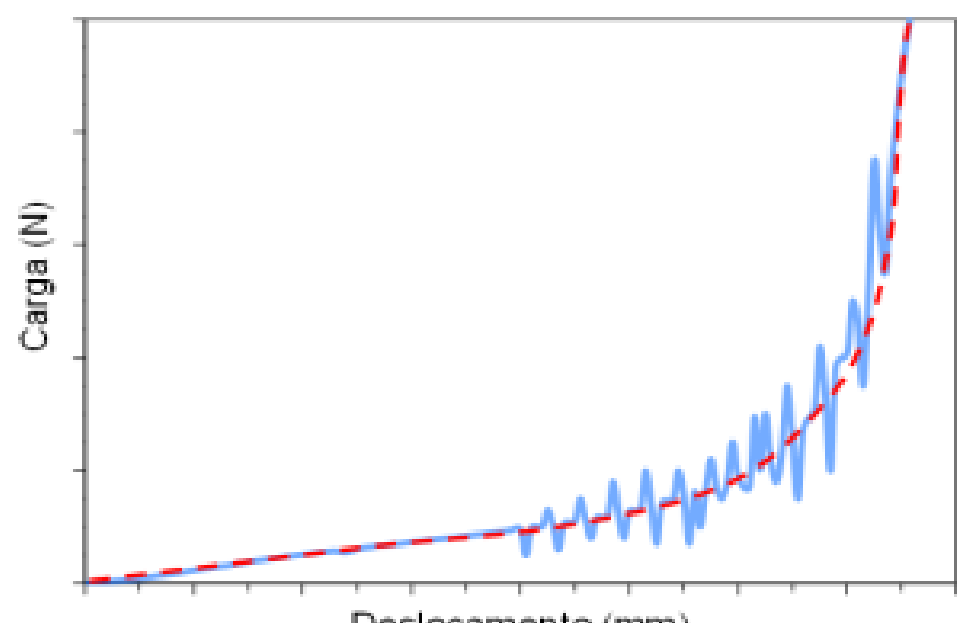

Deslocamento $(\mathrm{mm})$

Figura 5.14 Suavização da curva obtida por squeeze flow (Cardoso, 2009)

Melo et al. (2012) observaram esse comportamento em curvas de squeeze flow obtidas para solo argiloso, os autores justificaram o comportamento como parte de uma região onde foi encontrada maior resistência devido à presença de um aglomerado ou um grão de areia sob a punção, sendo que o maior diâmetro de grão encontrado na granulometria foi de $2 \mathrm{~mm}$, e após o rompimento da barreira a curva seguiu sua tendência normal. Cardoso (2009) explicou que a simples ocorrência dessas oscilações é uma informação que o teste fornece sobre o comportamento do material que está sendo avaliado, sugerindo a ocorrência de altos níveis de cisalhamento interno do material. Esse cisalhamento interno é causado pelo reposicionamento dos grãos da amostra durante a compressão.

A tensão de escoamento é determinada a partir da transição entre o estágio I e o estágio II, que pode ser calculada por meio de um artifício geométrico no gráfico obtido do ensaio. Esse procedimento consiste em se determinar a intersecção da extrapolação linear das curvas nos estágios I e II, como demonstrado na Figura 5.15 (BETIOLI et al., 2009). 


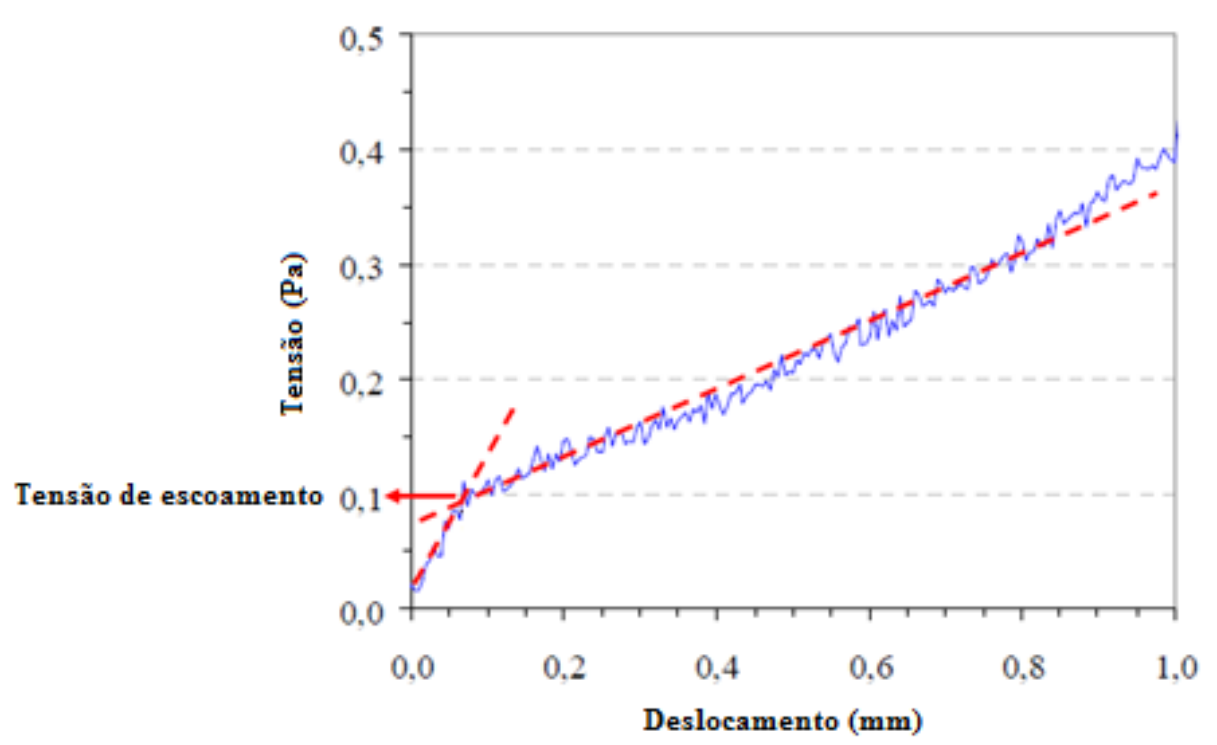

Figura 5.15 Procedimento geométrico para obtenção da tensão de escoamento para o squeeze flow (Betioli et al., 2009)

O ensaio de squeeze flow apresenta dois tipos de deformação: elongacional e viscométrica. A primeira se dá quando ocorre a condição de lubrificação entre as placa e a amostra, fazendo com que a deformação do corpo de prova se dê lateralmente (Figura 5.16a). A segunda ocorre na condição não lubrificada na qual não ocorre escorregamento entre o contato da amostra e a placa, como pode ser visto na Figura 5.16b. (STEFFE, 1996)
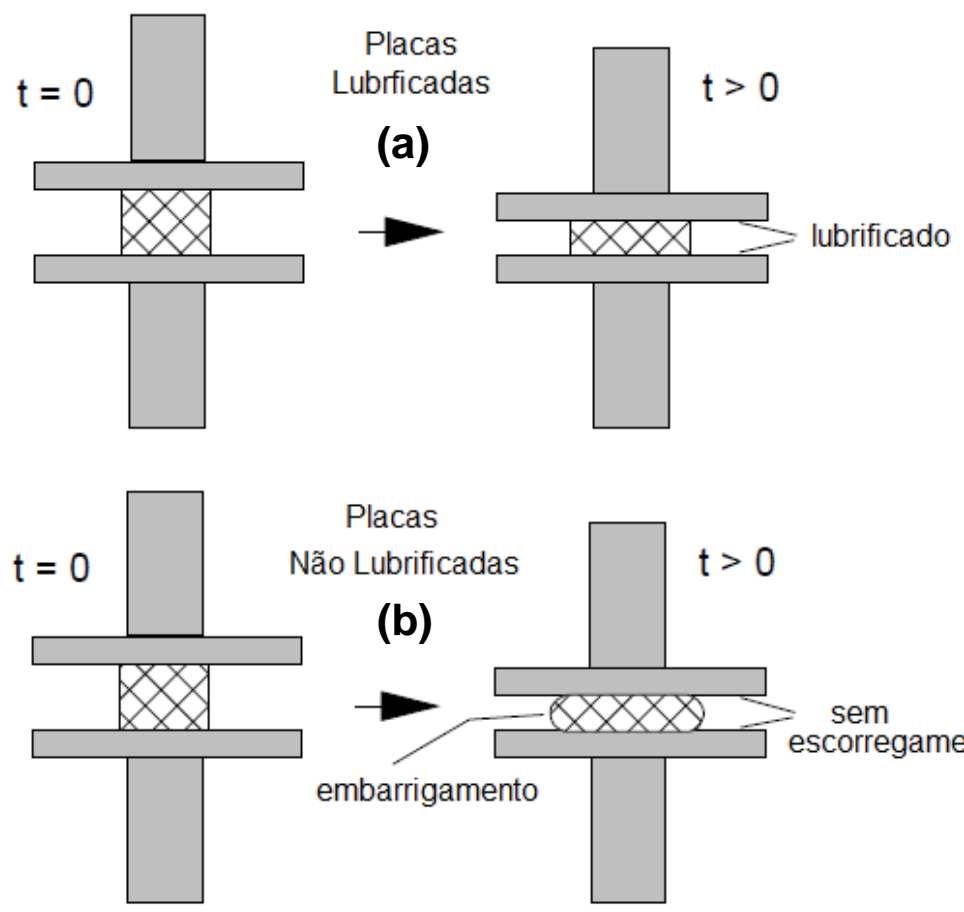

Placas

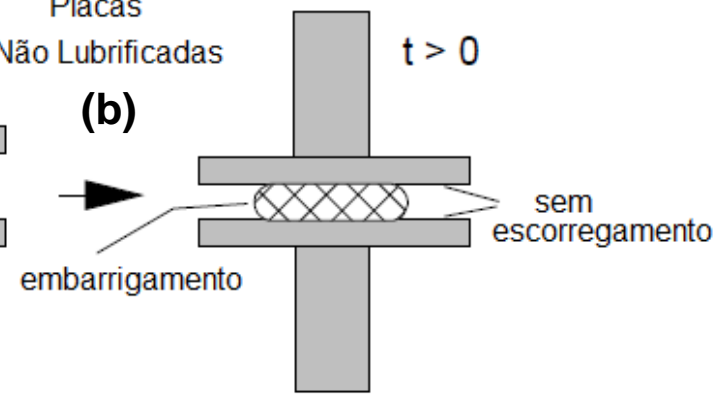

Figura 5.16 Fluxo entre placas lubrificadas e não lubrificadas (STEFFE, 1996) 
O resultado do ensaio de squeeze flow não é puramente viscométrico ou extensional, mas uma combinação entre esses. Cada uma dessas deformações (elongacional e cisalhante) apesentam parâmetros reológicos independentes. A condição não lubrificada é baseada na premissa que não ocorre deslizamento entre o material e a punção. Essa condição só pode ser alcançada através de artifícios, como colar uma lixa na punção. Nos ensaios realizados nenhum artifício desse tipo foi utilizado, então é suposto que os parâmetros obtidos sejam melhores analisados através da adoção dos parâmetros elongacionais.

A viscosidade elongacional $\left(\eta_{B}\right)$ é calculada conforme a Equação 5.20. Onde $\sigma_{B}$ é a tensão, $\dot{\varepsilon}$ é a taxa de deformação elongacional, $L$ é a carga, $h_{0}$ é a altura inicial da amostra, $t$ é o tempo, $v$ é a velocidade do punção, e $R$ é o raio do punção. (STEFFE, 1996)

$$
\eta_{B}=\frac{\sigma_{B}}{\dot{\varepsilon}}=2 L\left[\frac{h_{0}-(v t)}{v \pi R^{2}}\right]
$$

De acordo com Cardoso (2009) os modelos de viscosidade são válidos para fluxos homogêneos, o que ocorre apenas em determinadas situações, além disso, na prática ocorrem tanto solicitações elongacionais quanto cisalhantes durante o ensaio então, para analisar os resultados de squeeze flow, Cardoso (2009) utilizou os resultados na forma de gráfico de carga (ou tensão) em função do deslocamento, pois independente do número ou unidade utilizada esta é a resposta dos materiais frente às solicitações impostas.

Como o ensaio é passível de diversas configurações distintas, sendo possível controlar características das placas paralelas, como o diâmetro e a rugosidade da superfície que entra em contato com a amostra, também as dimensões da amostra e ainda o tipo de solicitação que será imposta na amostra, uma breve explicação sobre os efeitos de cada uma dessas mudanças no ensaio é realizada. 


\subsubsection{Configuração do ensaio}

As placas paralelas podem apresentar diferentes configurações, demonstradas na Figura 5.17. Além das mudanças de diâmetro, também é possível variar a rugosidade da superfície em contato com a amostra.

a
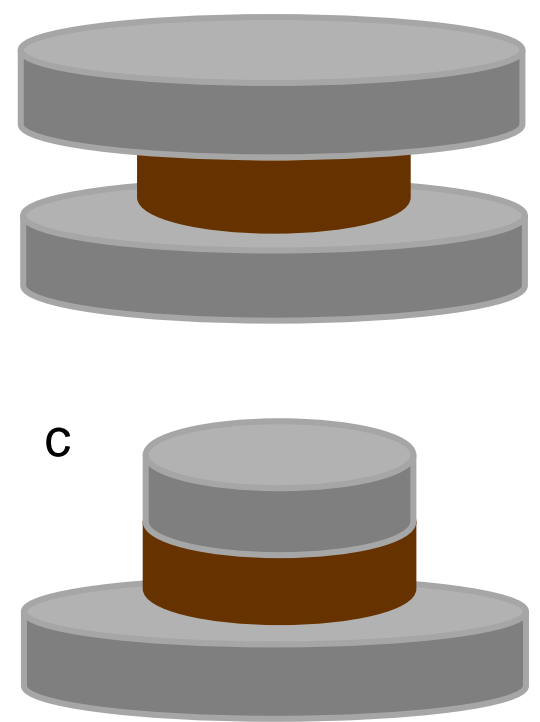

Figura 5.17 Configurações das placas paralelas b
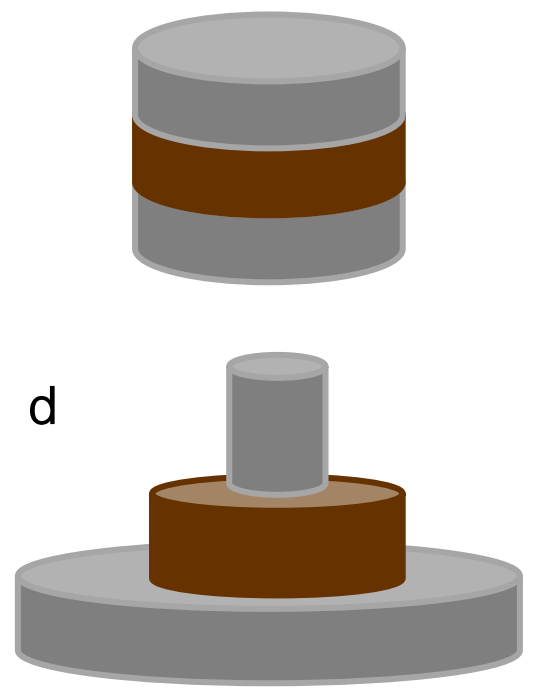

$\mathrm{Na}$ geometria de volume constante, Figura 5.17a, as placas são maiores do que a amostra e as interfaces radiais são livres. As vantagens desta geometria são que as tensões nas extremidades da amostra são claramente definidas, esta geometria também é mais próxima de processos industriais de compressão e de moldagem. As desvantagens são que a área de contato da amostra deve ser calculada, especialmente para materiais compressíveis, e que o contato entre placa - amostra - ar pode afetar os dados (ENGMANN et al., 2005).

A Figura 5.17b representa a configuração de área constante, onde o raio da amostra é maior ou igual ao raio das placas. Nesse modelo existe a vantagem de se conhecer a área de contato a qualquer tempo, e os erros de posicionamento da amostra são minimizados; as desvantagens são o tamanho da amostra necessária para a geometria inicial e as condições de contorno nas bordas das placas que são desconhecidas (ENGMANN et al., 2005).

A representação na Figura 5.17c é uma combinação entre as duas anteriores, na qual a área da amostra sob carregamento permanece constante e a área 
submetida aos fenômenos de escorregamento e atrito entre a base e a amostra é variável (CARDOSO et al., 2005).

A configuração apresentada na Figura 5.17 d é indicada para pastas com baixa viscosidade, ao término do ensaio com o punção penetrado na amostra, pode ocorrer transbordamento da pasta, assim como o diâmetro da amostra pode ocasionar fluxo turbulento devido à compressão na parede de confinamento (BARBOSA, 2010).

Engmann et al. (2005) afirmaram que é uma boa prática combinar dados teóricos e experimentais obtidos utilizando as geometrias de área constante e de volume constante. No entanto, como os resultados são influenciados pela configuração da placa não é recomendado que resultados com configurações diferentes sejam comparados.

Em relação à influência da rugosidade das placas, Cardoso (2009) apresentou resultados de ensaios realizados com argamassas nos quais foram observados que quanto maior a rugosidade, maior o cisalhamento interno da amostra, dificultando o fluxo.

Para realizar a avaliação reológica de líquidos viscosos, suspensões diluídas ou pastas com consistência inicial baixa, que apresentem pouca ou nenhuma tensão de escoamento, é utilizado um anel de PVC, para evitar o escoamento do material e manter a geometria adequada para a realização do ensaio; visto que esses materiais não são capazes de manter a forma sem o auxílio de um molde. A barreira imposta pelo molde exerce influência durante a solicitação do material, entretanto, esse efeito é minimizado utilizando amostra com diâmetro 3 vezes maior do que o diâmetro do punção que comprime o material, conforme avaliado por Min et al. (1994). (CARDOSO et al., 2005)

\subsubsection{Dimensão da amostra}

Para avaliar a influência da relação entre altura e diâmetro da amostra, Cardoso (2009) realizou ensaios em amostras com $10 \mathrm{~mm}$ de altura e diâmetros de $50,8 \mathrm{~mm}$ e $101 \mathrm{~mm}$. Analisando os resultados, observou que as amostras com maior área de contato apresentaram maiores tensões, para um mesmo valor de deslocamento. 
Barbosa (2010) observou que com o aumento do diâmetro pode ocorrer um acréscimo na carga medida. Esse acréscimo foi creditado à dificuldade que a partícula que está posicionada na região central da amostra encontra para se locomover. Essa dificuldade existe devido ao aumento do percurso, quando comparada com a amostra de menor diâmetro, o que pode gerar um aumento da carga medida.

\subsubsection{Tipo de solicitação}

A solicitação pode ser realizada com velocidade constante ou velocidade variável. Engmann et al. (2005) relata que os testes de squeeze flow originais, com velocidade constante, são os mais simples e ainda são os mais utilizados.

Cardoso et al. (2005) avaliaram a influência do aumento da velocidade de compressão em duas amostras de argamassa com 13\% e 15\% de água, os autores observaram um comportamento oposto entre as amostras, ensaiadas nas velocidades de $0,01 \mathrm{~mm} / \mathrm{s}, 0,1 \mathrm{~mm} / \mathrm{s}$ e $1,0 \mathrm{~mm} / \mathrm{s}$. Enquanto na composição com $13 \%$ de água as cargas necessárias para efetuar a deformação do material aumentam com a taxa utilizada, na argamassa com teor de água de $15 \%$ ocorre o inverso, ou seja, as cargas diminuem com o aumento da taxa. Porém, esse comportamento não pode ser tomado como regra, como o teor de água da argamassa é maior, pode haver condições de contorno diferentes entre os ensaios. Uma condição mais lubrificada (com menos atrito entre placas e material) pode ocorrer para a argamassa com teor de $15 \%$, sendo mais perceptível com a aplicação de deformações em taxas mais elevadas.

Independente dos resultados obtidos o importante é ressaltar que a velocidade possui influência sob o comportamento, por isso na comparação entre dois ensaios diferentes é preciso observar qual a velocidade utilizada.

Engmann et al. (2005) descreveu três tipos de variações de velocidades. O primeiro, para ensaios com a taxa de deformação constante nos quais a velocidade da placa e a altura devem diminuir exponencialmente com o tempo, ou seja, a velocidade da placa deve ser proporcional à separação das placas. Um segundo tipo é o ensaio de relaxação de tensão, onde a velocidade da placa se torna nula durante 
o ensaio e as medidas continuam a ser tomadas. O terceiro tipo de teste é aquele onde a velocidade é constante, que é o ensaio usual.

$\mathrm{Na}$ caracterização reológica de argamassas e concretos, a utilização do ensaio squeeze flow é interessante por ser capaz de avaliar os materiais com qualquer nível de consistência e também pela mudança geométrica inerente ao ensaio já que esses materiais em solicitações reais são constantemente comprimidos e cisalhados (CARDOSO, 2009). Esse mesmo tipo de solicitação, compressão e cisalhamento, acontece nos solos sujeitos a movimentação, justificando o ensaio reológico para caracterização de solos.

Como visto anteriormente, o squeeze flow aplica tanto tensões de cisalhamento quanto tensões elongacionais nas amostras. Para a análise dos resultados dos ensaios realizados, será adotado o mesmo padrão que foi por Cardoso (2009), em que foram analisados os resultados na forma de carga ou tensão em função do deslocamento.

Notaro (2012) apresentou trabalho sobre a utilização desse equipamento na classificação de solos e saibros da Região Metropolitana do Recife. Na realização dos ensaios será utilizada uma máquina universal de ensaios, Instron modelo 5569, com célula de carga de $1 \mathrm{kN}$, apresentada na Figura 5.18.

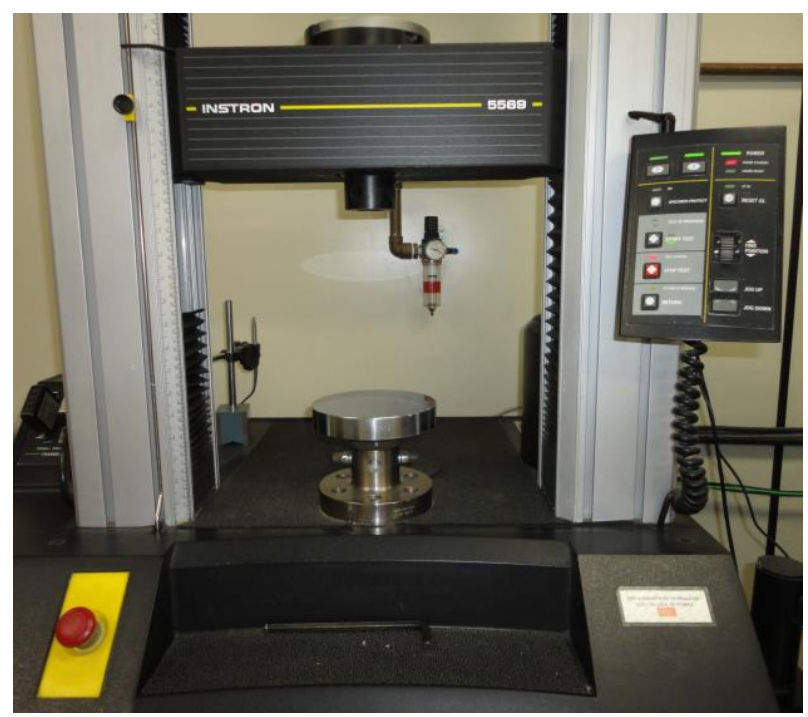

Figura 5.18 Prensa utilizada nos ensaios de squeeze flow 


\subsection{Reologia na Mecânica dos Solos}

A mudança de estado de um escorregamento de solo em um fluido denso pode ser visualizada facilmente, apesar disso, problemas de estabilidade e retroanálises de escorregamentos abordam o problema através da utilização de conceitos baseados na teoria da elasticidade ou plasticidade, que não são verificadas nesse tipo de situação. A utilização de ensaios reológicos dinâmicos, onde a energia é fornecida ao material, pode simular uma condição de escoamento e fornecer dados para uma interpretação da mudança de comportamento do solo.

$\mathrm{Na}$ Mecânica dos Solos, a reologia vem sendo utilizada, principalmente, na caracterização de fluxo de detritos. Os trabalhos pioneiros nesse campo foram apresentados por Johnson (1970), Coussot et al. (1992), Coussot e Piau (1994), Phillips e Davies (1991), Whipple et al. (1995), entre outros. Os fluxos de detritos, ou debris flows, podem ser definidos, de acordo com Guidicini e Nieble (1983) como formas rápidas de escoamentos com presença de detritos, com caráter hidrodinâmico que são ocasionadas pela perda de atrito interno, em virtude da destruição da estrutura em presença de excesso de água. Sua ocorrência raramente é isolada, sendo contabilizados diversos casos de movimentação a partir de um único evento deflagrador. Segundo Coussot e Meunier (1996), isso justifica importantes esforços de pesquisa sobre a sua iniciação, propagação e interrupção, em uma abordagem interdisciplinar envolvendo diversas especialidades como geologia, geografia, geomorfologia, reologia, mecânica dos fluidos e a engenharia civil.

Meschyan (1995) afirmou que qualitativamente há muito em comum entre as propriedades reológicas de vários materiais. Por isso, a experiência adquirida com o estudo de um material pode ser extremamente útil e até mesmo um pré-requisito essencial para a realização de estudos experimentais e teóricos em outro. Por essa razão serão apresentados alguns trabalhos e resultados obtidos no estudo reológico e reométrico de alguns debris flow, embora o material de estudo para esse trabalho seja o fluxo de lama. Alguns autores trabalharam com a caracterização de materiais obtidos de debris flow peneirados e os resultados obtidos devem ser próximos aos resultados que serão obtidos para as corridas de lama. 
As corridas de detritos representam um típico caso de material mutante, isto é, aquele que muda de estado e de consistência (dentro de cada estado). De fato, consideradas macroscopicamente, as corridas começam como um material sólido transforma-se em fluido e retornam ao estado sólido. Numa escala mais localizada, as alterações que se verificam durante o escoamento tornam os debris flow um material heterogêneo por excelência, e muito variável quanto a sua composição e consistência. (ZNAMENSKY, 2001)

Os debris flow podem ser vistos como fenômenos intermediários entre os fluxos hiperconcentrados e os escorregamentos, separados deles pelas transições de comportamento cisalhantes, que torna possível reconhecê-los ou os seus depósitos em campo, por isso a sua dinâmica não pode ser tratada com ferramentas usuais da hidráulica ou da mecânica dos solos. (COUSSOT \& MEUNIER, 1996)

Para o estudo dos debris flows através da reologia, são consideradas algumas simplificações, Coussot e Meunier (1996) adotam que, do ponto de vista macroscópico, toda a massa sofre deformações muito grandes e, aproximadamente, contínuas e que as propriedades mecânicas da massa não se alteram significadamente durante o cisalhamento. Assim, os fluxos envolvem uma mistura de água e detritos que pode ser considerado como um fluxo unifásico de um fluido viscoso. Essa mesma definição cabe às corridas de terra durante o escoamento.

Whipple (1997) apresentou a ideia de que uma melhoria no conhecimento da reologia dos fluxos de detritos, poderia ser uma ferramenta para ajudar os engenheiros na predição e no combate a esse fenômeno, afirmou que existem vários fatores que são negligenciados, como segregação, quebra de grãos, alteração de concentração, heterogeneidade e distribuição dos grãos, pelo fluxo ser considerado, em estudos teóricos, como fluido viscoso homogêneo em um meio aberto.

Segundo Coussout et al. (1992), na mecânica dos fluidos o primeiro passo para uma melhor compreensão de um fluxo é realizar um estudo reológico completo do material que flui. Existe uma grande diversidade de relações constitutivas propostas para descrever fluxos de detritos, há duas razões principais: primeiro as possibilidades de obter fluidos com comportamentos distintos a partir da composição de um fluxo de detritos são infinitos, em segundo lugar, as misturas de diversos e 
complexos materiais são muitas vezes difíceis de entender ou estudar com as técnicas usuais reométricas.

Essas dificuldades se justificam tendo em vista que um debris flow não é um material homogêneo e apresenta diferentes composições, mesmo que sejam coletadas amostras de um único movimento. Além disso, os detritos são distribuídos aleatoriamente durante esses movimentos. Cada amostra coletada de um debris flow é única. Por isso, para a caracterização reológica do debris flow ser única, seria necessário a utilização de diversas amostras com representatividade em um reômetro de dimensões suficientes para ensaiar todos os detritos que estão misturados com o solo.

Johnson (1970) (apud Whipple, 1997) apresentou trabalho pioneiro no qual propôs uma análise de um fluxo de detritos adotando o modelo de fluido de Bingham. Ainda segundo o autor diversos trabalhos conduzidos levaram a um resultado de que uma lama rica em suspensões de areia se comporta de acordo com fluidos de Bingham (Coussot et al. 1992; Coussot e Piau 1994; Major e Pierson, 1992; Phillips e Davies, 1991; Whipple et al 1995). Nesse trabalho será realizada uma análise para determinar se o solo estudade também apresenta comportamento modelado pelo fluido de bingham.

\subsection{Reometria na Mecânica dos Solos}

Primeiro é necessário fazer uma apresentação de dois conceitos que são muito explorados pelos autores estudados (Philips e Davies, 1991; Coussot e Piau, 1994, Coussot et al. 1998), que são a concentração de sedimentos por volume, Cv, e a concentração de sedimentos por peso, Cw, que estão apresentados pelas Equações 5.21 e 5.22, respectivamente.

$$
\begin{gathered}
C_{v}=\frac{\text { volume de sedimentos }}{\text { volume de sedimentos }+ \text { volume de água }} \\
C_{w}=\frac{C_{v} \gamma_{s}}{\gamma+C_{v}\left(\gamma_{s}-\gamma\right)}
\end{gathered}
$$


Philips e Davies (1991) explicaram que uma grande variedade de equipamentos (penetrômetros, viscosímetros e aparelhos de Vane test) está sendo utilizado sem serem adequados para medir todos os parâmetros reológicos de um fluxo, sendo a maioria deles limitada em relação às condições de operação ou não adequados em relação ao tamanho dos grãos e, geralmente, são obtidas apenas relações empíricas. Os autores ainda afirmaram que qualquer método que tenha intenção de medir propriedades reológicas tem que ser construído para acomodar uma quantidade razoável de material, deve produzir taxas de cisalhamento equivalentes as que ocorrem no debris flow em campo e apresentar resultados reproduzíveis e precisos. Os autores utilizaram um reômetro rotacional de grande dimensão com geometria do tipo cone - placa invertido com inclinação de $30^{\circ}$ para realizar ensaios em amostras de solo de debris flow. Na Figura 5.19 está representada a seção transversal do reômetro utilizado, onde as partes sombreadas são estacionárias e as partes claras são as que entram em rotação, nesse reômetro a amostra é contida entre o chão inclinado e com nervuras (cone) e a tampa (placa).

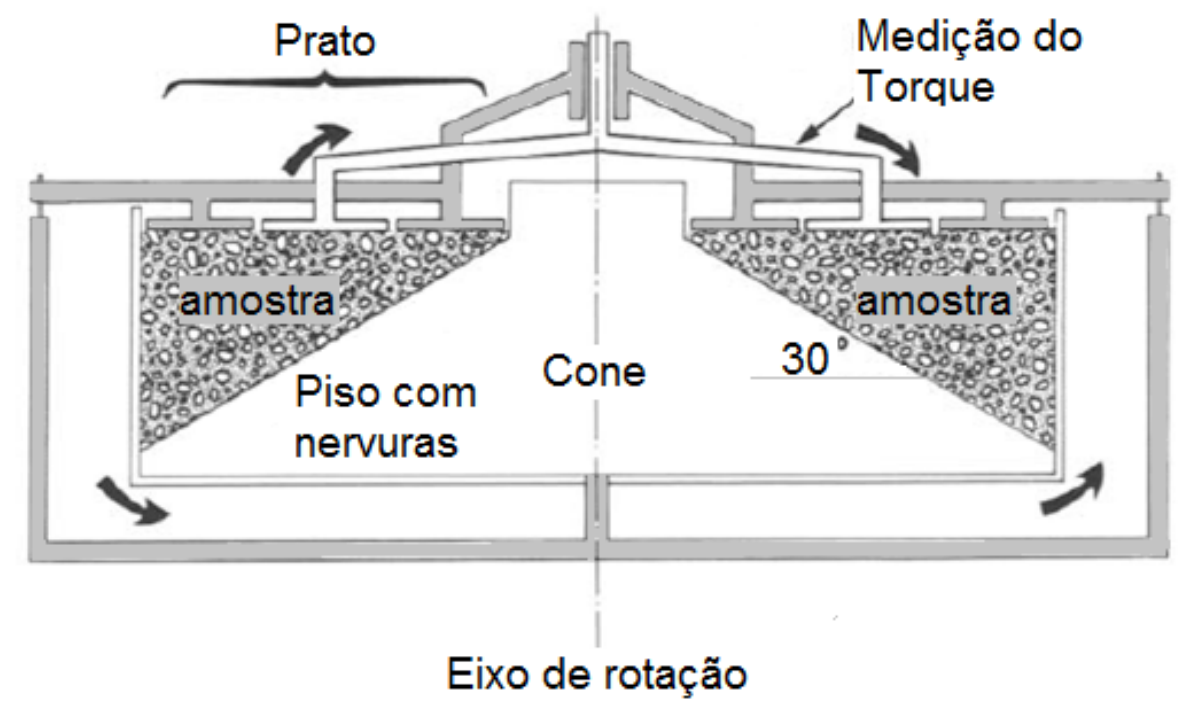

Figura 5.19 Esquema seção transversal reômetro utilizado por Philipes e Davies (1991)

Phillips e Davies (1991) utilizaram amostras de dois locais que frequentemente sofrem com debris flow na Nova Zelândia. O primeiro local de amostragem é Tarndale Slipe na North Island, onde chuvas com intensidade a partir de $25 \mathrm{~mm} / \mathrm{h}$, deflagram debris flow e o segundo é de Bullock Creek, Mt Thomas. As amostras do segundo local foram coletadas um dia após a ocorrência de debris flow em agosto de 1986, causado por chuva de $150 \mathrm{~mm}$ em 72 horas, apresentando fluxos com espessura de 0,3 a 1,0 m de profundidade. 
A parte mais grosseira das amostras, com diâmetro maior que $35 \mathrm{~mm}$, foi retirada. A quantidade de solo removida, que não foi utilizada no ensaio, representava menos de $1 \%$ do peso total da amostra. As curvas de fluxo e de viscosidade aparente foram determinadas após as amostras serem misturadas com um agitador de alimentação (remoldadas), carregadas na máquina, e testadas sobre uma taxa de cisalhamento de variou entre $1 \mathrm{~s}^{-1} \mathrm{e} 18 \mathrm{~s}^{-1}$.

Em relação às amostras de Tarndale, os teores de umidade variaram entre $17 \%$ e $25 \%$, com média de $21,3 \%$, os teores de argila variaram de $6 \%$ a $11 \%$ (média de $7,7 \%$ ), os autores consideram ainda um teor de finos, que representa a fração fina dos solos (argila + silte) e que apresentou variação de $12 \%$ a $23 \%$. As amostras de Bullock Creek apresentaram de $5 \%$ a $9 \%$ em peso de gravetos e a quantidade de finos variou entre $22 \%$ e $24 \%$. Uma representação baseada na terminologia de Pierson e Scott1 (1985) das amostras esta apresentada na Figura 5.20.

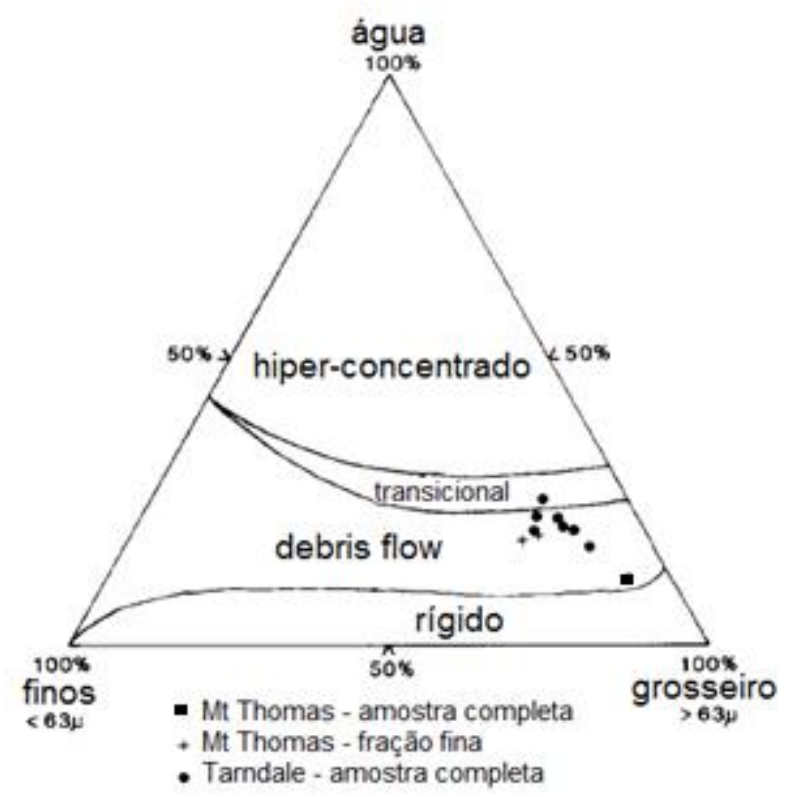

Figura 5.20 Representação das amostras ensaiadas por Philips e Davies (1991)

\footnotetext{
${ }^{1}$ Pierson e Scott (1985) consideram que o fluxo de solo ocorre em três fases que são: o debris flow, uma fase de transição e um fluxo hiperconcentrado. A fase debris flow é caracterizada por uma concentração de sólidos por volume entre $79 \%$ e $90 \%$ e partículas de diâmetros entre areia grossa e detritos; o fluxo hiperconcentrado apresenta concentração de sólidos entre $71 \%$ e $61 \%$ e partículas de areia média e grossa. A fase de transição apresenta os parâmetros entre essas duas fases.
} 
Os resultados obtidos no reômetro mostram as curvas médias dos fluxos de finos, Figura 5.21, em relação à $\mathrm{Cw}$, concentração de sedimentos por peso. As curvas apresentam comportamento no qual a viscosidade aparente é dependente da taxa de cisalhamento, sendo que o fluxo foi classificado como de transição entre o debris flow e um fluxo hiperconcentrado. Foi observado que as maiores viscosidades aparentes ocorreram nas menores taxas de cisalhamento. Realizando extrapolações nas curvas, são obtidos valores de tensão de escoamento na faixa de $15 \mathrm{kPa}$ a 300 $\mathrm{kPa}$.

a) Bullock Creek

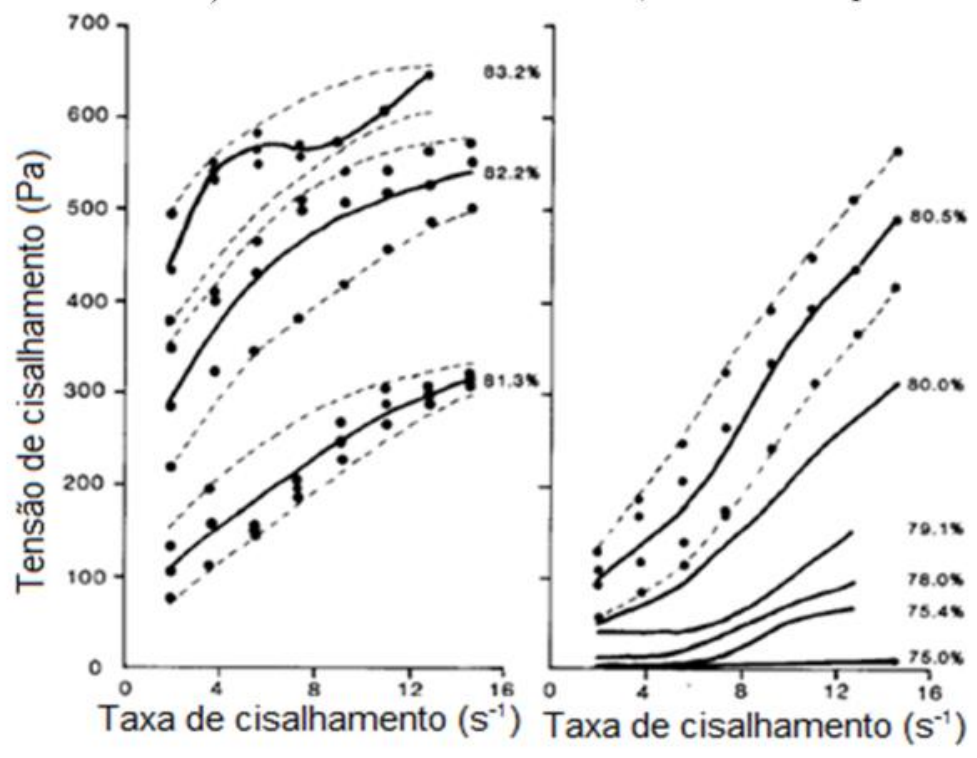

Figura 5.21 Curvas médias de fluxo obtidas no reômetro de Philips e Davies (1991)

Os resultados obtidos por Phillips e Davies (1991) mostram que a viscosidade aparente é extremamente sensível ao teor de água, uma alteração de apenas 1\% ou $2 \%$ em peso de água alterou as medições de tensão de cisalhamento por um fator de 2 e a viscosidade aparente por um fator que variou entre 1 e 2.

Phillips e Davies (1991) explicaram que o grau de dispersão dos resultados para as curvas de fluxo obtidos a partir do modelo de reômetro não é surpreendente, porque mesmo que as magnitudes da tensão de cisalhamento para altas taxas de cisalhamento apresentem variação de até $50 \%$, a forma de todas as curvas de fluxo foi consistente. Concluíram que a adoção de um único modelo reológico para descrever a gama completa de materiais e condições físicas que compõem o processo conhecido como debris flow ainda não é possível, entretanto, para parâmetros comuns observados em debris flow (Cw $>75 \%$, teor de finos $<10 \%$, densidades próximas ou superiores a $20 \mathrm{kN} / \mathrm{m}^{3}$, e geralmente mal distribuídos 
granulometricamente), o material apresenta um comportamento reológico viscoplástico ou plástico.

Major e Pierson (1992) (apud Coussot e Piau, 1994) construíram um reômetro coaxial cilíndrico de larga escala para ensaiar amostras de debris flow. Seus resultados relativos a amostras peneiradas indicaram um comportamento de fluido de Bingham, ressaltando a influência da concentração de partículas grosseiras na mudança do comportamento da suspensão. As amostras utilizadas no ensaio foram peneiradas devido à restrição de diâmetro do equipamento.

Coussout et al. (1992) construíram um reômetro especial grande, com cilindros coaxiais de 1,2 $\mathrm{m}$ de largura, para realizarem medições das propriedades reológicas em um fluido composto por bentonita e água em concentração de $4 \%$. Foram encontrados diversos problemas durante a execução dos ensaios como o faturamento no interior do material, a propagação de fissuras e o escorregamento das amostras no contato com a parede, que os autores creditaram a tixotropia e a alta tensão de cisalhamento. A partir de um estado inicial arbitrário (obtido após certo tempo de repouso), foram aplicadas e liberadas tensões de cisalhamento, carregamento e descarregamento, o resultado está apresentado na Figura 5.22, onde a linha cheia representa o modelo de Bingham.

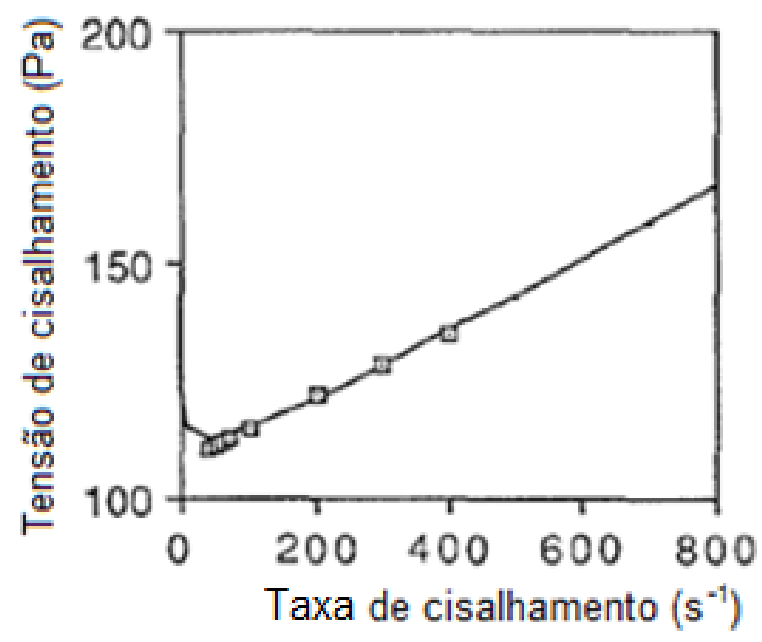

Figura 5.22 Resultado teórico e experimental obtido (Coussot et al., 1992)

Coussot e Piau (1994) realizaram uma melhor apresentação do equipamento utilizado. O reômetro, Figura 5.23, é composto essencialmente por uma plataforma com um eixo perpendicular capaz de obter diferentes velocidades angulares, sendo possível criar diferentes geometrias de rotação. No caso da geometria coaxial, o 
cilindro interno está ligado ao eixo central por barras de aço e o contato entre o cilindro e a plataforma é obtido através de uma junta de borracha. As dimensões escolhidas para a construção do reômetro foram de $0,8 \mathrm{~m}$ de diâmetro em relação ao cilindro interior, 1,2 $\mathrm{m}$ em relação ao cilindro exterior e profundidade de $0,8 \mathrm{~m}$. Os autores fizeram uma observação de que essas medidas são parecidas às propostas por Tattersall e Banfill (1983) para o reômetro construído com finalidade de estudar concreto fresco e concluem que os desenhos e dimensões análogos são esperados, porque os materiais são muito semelhantes.

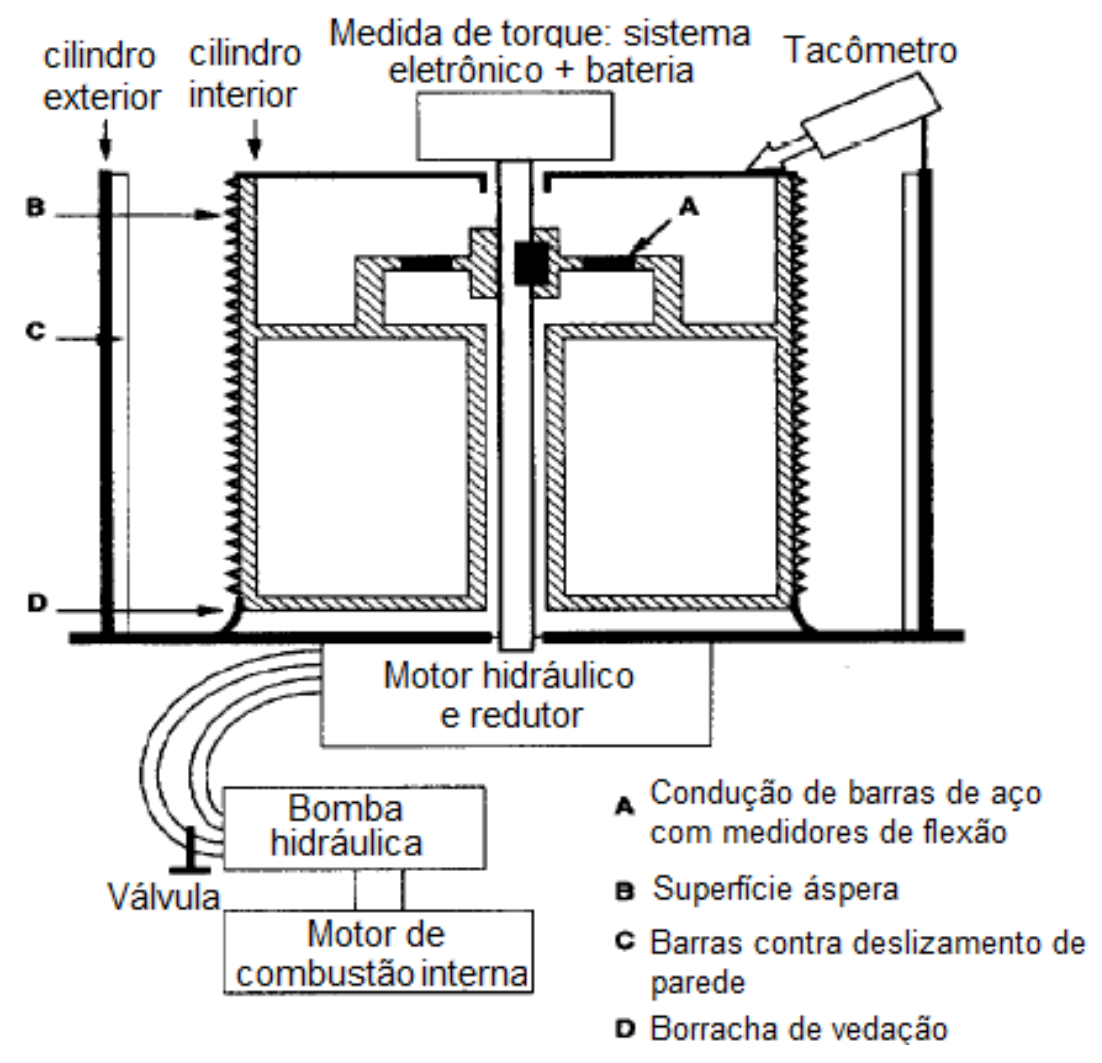

Figura 5.23 Diagrama esboço do reômetro de cilindro coaxial (Coussot e Piau, 1994)

Esse reômetro foi construído visando sua utilização em campo, e por se tratar de um protótipo apresenta sistemas de medidas bem simplificados. A medida do torque, aplicado pelo eixo central, é realizada através de medidores de flexão e a medida da velocidade de rotação através de um tacômetro fixado no cilindro exterior. Esses sistemas são calibrados independentes e, como não foi utilizado um computador, os dados experimentais tiveram que ser gravados pelos operadores. Esse método não é válido para medir propriedades que apresentam dependência do tempo (COUSSOT \& PIAU, 1994).

Para a realização dos ensaios, Coussot e Piau (1994) utilizaram amostras de debris flow misturadas com água e também argilas misturadas com água em 
diferentes concentrações. Foram ensaias duas suspensões de argila fina misturadas com água numa concentração volumétrica de sólidos de $21,5 \%$, sendo uma argila natural e um caulim natural, respectivamente, de Sinard e de Perazio na França. Também foram ensaiadas sete diferentes amostras coletadas em depósitos de debris flow nos Alpes. A Figura 5.24 apresenta uma distribuição granulométrica das amostras obtidas nos Alpes.

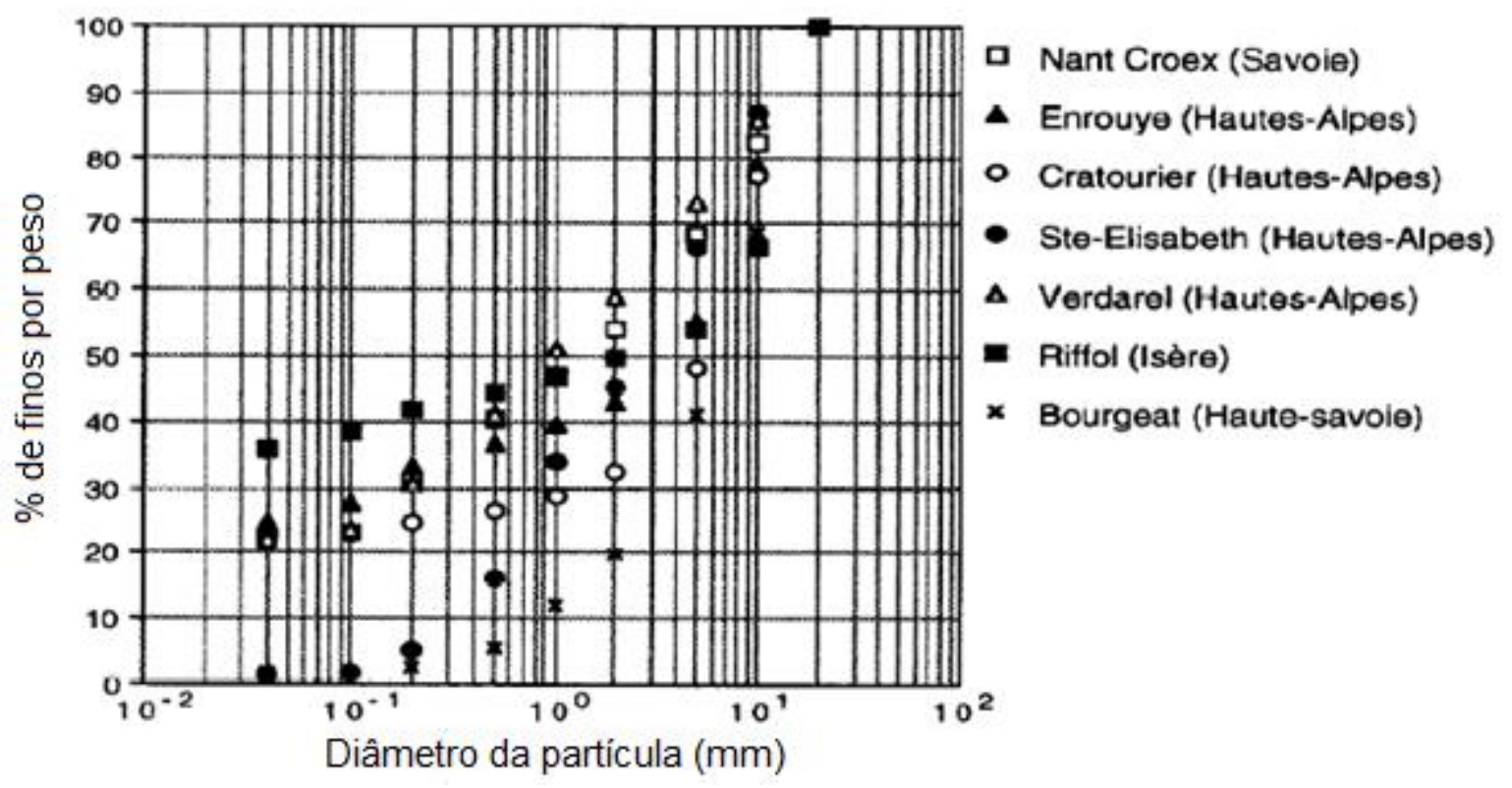

Figura 5.24 Distribuição granulométrica das amostras de debris flow ensaiadas (Coussot e Piau, 1994)

As curvas de fluxo obtidas para as amostras constituídas de depósitos de debris flow e adição de água estão apresentadas na Figura 5.25, onde é possível observar o rápido aumento da tensão de escoamento com a concentração de sólidos, que os autores creditaram ao fato da argila desempenhar um papel fundamental sobre o comportamento global. Foi observada grande concordância entre os ensaios e a teoria do modelo de Herschel-Bulkley (COUSSOT \& PIAU, 1994).

Objetivando aferir a confiabilidade do reômetro utilizado, foram realizados ensaios nas suspensões de argila pura e água, tanto no reômetro pequeno (de placas paralelas com $5 \mathrm{~cm}$ de diâmetro e profundidade de $3 \mathrm{~mm}$ ) quanto no reômetro de grandes dimensões, o resultado está apresentado na Figura 5.26. (COUSSOT \& PIAU, 1994) 

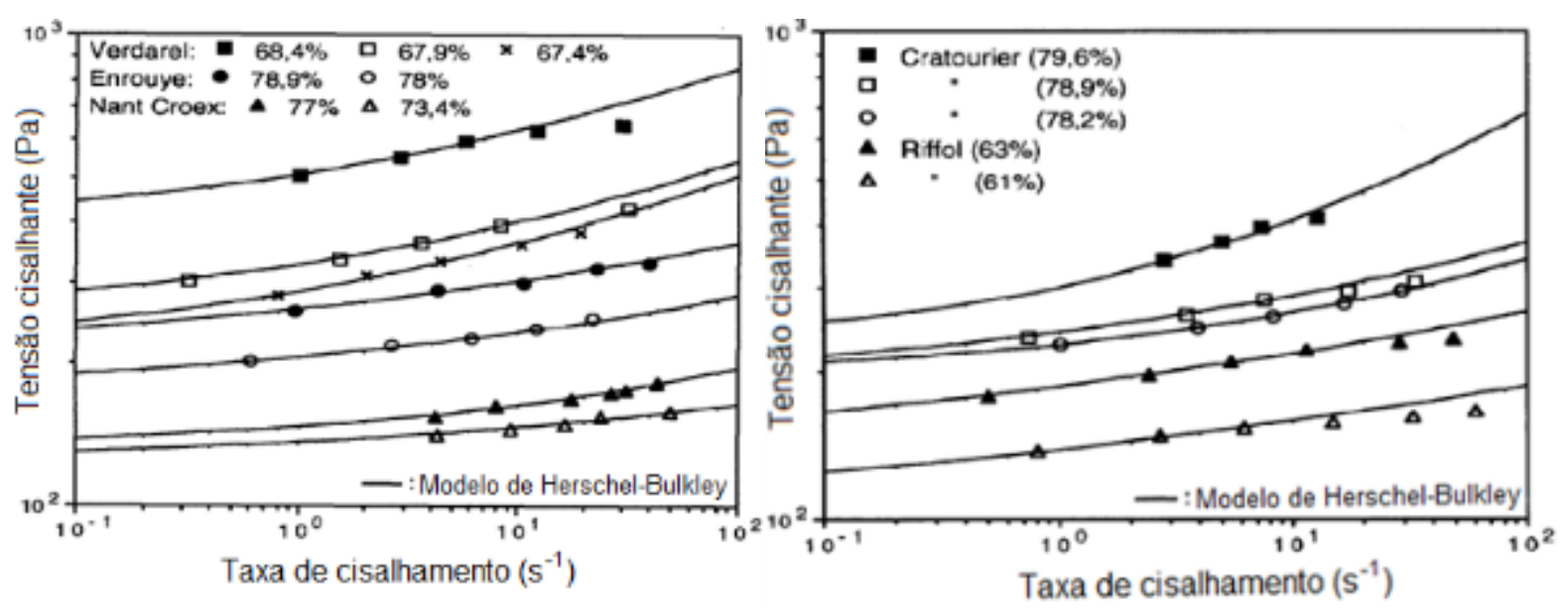

Figura 5.25 Mistura entre água e debris flow para diferentes concentrações de sólidos: curva de fluxo (Coussot e Piau, 1994)

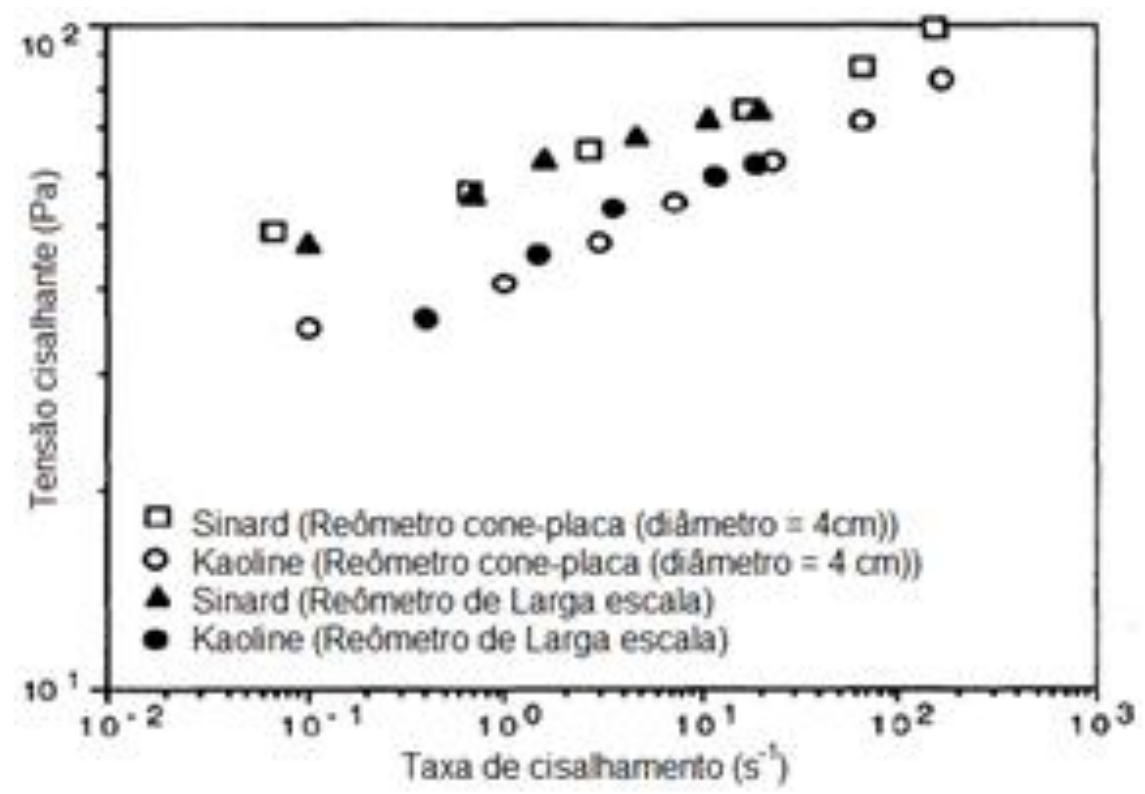

Figura 5.26 Misturas argila-água ( $C v=21,5 \%)$ : comparação das curvas de fluxo obtidas através de reômetro cone-placa e reômetro de grandes dimensões (Coussot e Piau, 1994)

Tendo em conta o resultado apresentado Figura 5.26, é possível afirmar que a parte mais fina do solo tem maior influência no seu comportamento reológico. Isso porque para a realização dos ensaios no reômetro as amostras foram peneiradas, devido a dimensão do equipamento. Coussot e Piau (1994) afirmaram que o espaçamento do equipamento deve ser significantemente maior que o diâmetro da partícula máxima, para reômetros com geometria tipo cone placa, placas paralelas ou de cilindros coaxiais, esse espaçamento deve ser de pelo menos 20 vezes o 
tamanho da maior partícula. Com isso, a amostra ensaiada no reômetro pequeno tem partículas de diâmetro menor que a amostra ensaiada no reômetro grande. Como os dois equipamentos produziram curvas concordantes, a existência das partículas de maior diâmetro na amostra utilizada no reômetro grande não alterou o comportamento apresentado para essa amostra. Não é possível afirmar que a utilização de apenas um dos equipamentos é recomendada, porque cada aparelho atinge diferentes níveis de taxas e tensões de cisalhamento, porém, é um indício que os resultados obtidos tanto com reômetro de grandes dimensões quanto com 0 de pequenas são compatíveis e passíveis de serem comparados.

Coussot e Boyer (1995) utilizaram um aparato de plano inclinado para avaliar o comportamento de misturas de solo com água em diferentes concentrações. A justificativa para a utilização do aparelho é que seria um aparato barato para ser construído e a sua utilização para determinação da tensão de escoamento simples, além disso, as medidas poderiam ser realizadas em campo. Afirmaram ainda que o plano inclinado poderia ser utilizado também para medições em concreto fresco, debris flow e na indústria de alimentos, porque seria capaz de medir a tensão de escoamento de suspensões com partículas grosseiras sem a utilização de reômetros de grandes escalas.

O ensaio em plano inclinado pode ser realizado de duas maneiras. A primeira consiste em, inicialmente, colocar o material em plano horizontal e ir inclinando esse plano até que se inicie o fluxo, esse método é demorado porque para cada inclinação é necessário esperar um grande período de tempo para confirmar que o material não entraria em movimento antes de aumentar a inclinação. A segunda maneira é já iniciar o ensaio com uma inclinação fixa e esperar o fluxo cessar para medir sua forma final (COUSSOT e BOYER, 1995).

Coussot e Boyer (1995) testaram duas misturas de solo com água em diferentes concentrações. Um dos solos é um caulim natural com uma distribuição granulométrica muito fina, em torno de $1 \mu \mathrm{m}$, coletada em Isère, França, e o outro solo, coletado em Grenoble, França, é denominado por argila de Sinard, e apresenta uma distribuição granulométrica que varia entre $0,1 \mu \mathrm{m}$ e $40 \mu \mathrm{m}$. Os solos foram secos e depois a água foi adicionada, sendo misturados manualmente ou através de bomba de recirculação por 25 minutos, os autores não fizeram referência de quando utilizaram um ou outro meio de homogeneização. 
Para comparar os resultados obtidos com resultados reométricos, Coussot e Boyer (1995), utilizaram também um reômetro com controle da taxa de cisalhamento e duas geometrias distintas, a geometria de placas paralelas, com diâmetro de $5 \mathrm{~cm}$ e espaçamento entre as placas de $3 \mathrm{~mm}$, e a geometria cone-placa, com diâmetro externo de $6 \mathrm{~cm}$ e inclinação de $5,7^{\circ}$. As características obtidas para as misturas utilizadas estão apresentadas na Tabela 5.4.

Tabela 5.4 Características dos materiais utilizados (COUSSOT e BOYER, 1995)

\begin{tabular}{|c|c|c|c|c|c|c|c|c|}
\hline Material & \multicolumn{5}{|c|}{ Mistura de Caulim e Água } & \multicolumn{3}{|c|}{ Mistura argila de Sinard e Água } \\
\hline Denominação & 1 & 2 & 3 & 4 & 5 & a & b & C \\
\hline$\rho\left(\mathrm{kg} / \mathrm{m}^{3}\right)$ & 1450 & 1478 & 1477 & 1492 & 1509 & 1424 & 1446 & 1484 \\
\hline $\operatorname{tesc}(\mathrm{Pa})$ & 36,2 & 51,3 & 62,3 & 79,5 & 90,3 & 36,2 & 39,5 & 68,1 \\
\hline $\mathrm{k}\left(\mathrm{Pa} \cdot \mathrm{s}^{1 / 3}\right)$ & 17,4 & 23,3 & 29,1 & 38,7 & 28,4 & 11,0 & 12,5 & 22,6 \\
\hline
\end{tabular}

A Figura 5.27 apresenta vistas laterais do esquema de funcionamento do aparelho de plano inclinado utilizado por Coussot e Boyer (1995) para a determinação da tensão de escoamento, com o posicionamento da amostra no início e final do ensaio.

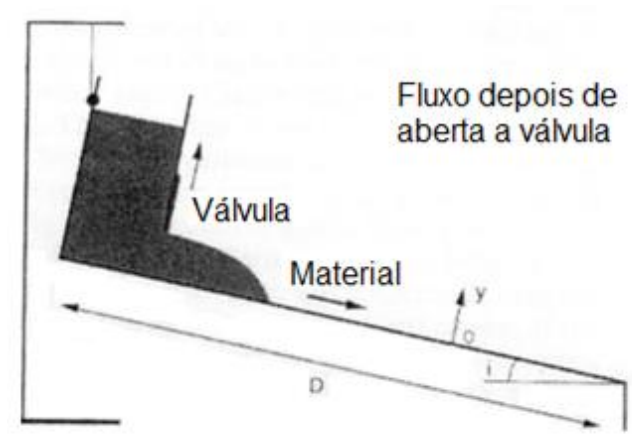

(a)

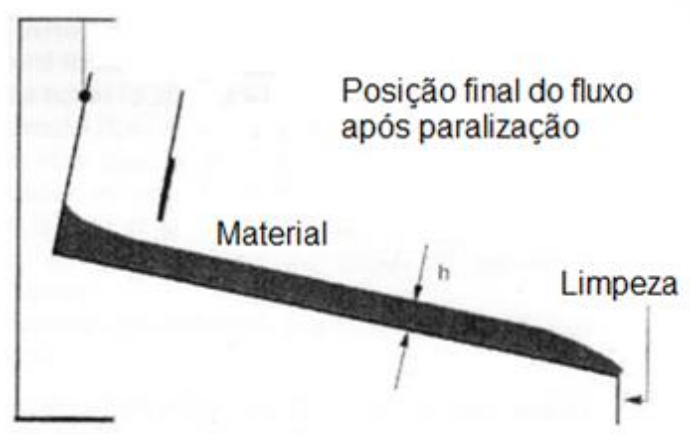

(b)

Figura 5.27 Posição do fluido em duas fases do ensaio (a) após o início e (b) final do ensaio (COUSSOT e BOYER, 1995) 
O equipamento consiste em um canal de $1 \mathrm{~m}$ de comprimento cuja largura poderia ser variada entre $5 \mathrm{~cm}$ e $25 \mathrm{~cm}$ e a inclinação entre $10^{\circ}$ e $30^{\circ}$, equipado com um sistema de represamento localizado a montante, que foi inicialmente cheio com o material. Em seguida, uma válvula inferior foi progressivamente aberta de modo que o fluido poderia fluir lentamente a jusante. $O$ volume total de material fornecido foi suficientemente grande para o fluido atingir a borda a jusante do canal. Após a abertura completa da válvula de fundo, o fluido flui sobre o canal e, em seguida, o material cai ao longo da borda vertical a jusante, para evitar qualquer influência por este último fluxo a borda inferior era regularmente limpa.

Para a determinação dos parâmetros reológicos é assumido que o fluido tem comportamento que é representado pelo modelo de Herschel Bulkley, representado pela Equação 5.23, onde $\tau$ é a magnitude da tensão cisalhante, $\dot{\gamma}$ a taxa de cisalhamento e $\tau_{c}$, k e m são parâmetros positivos.

$$
\tau=\tau_{c}+k \dot{\gamma}^{1 / m}
$$

Para descrever o fluxo foi adotada a hipótese de que os efeitos de inércia são desprezíveis, o que se verifica especialmente quando o fluxo é lento, ou seja, quando a profundidade do fluxo é próxima da profundidade de estado estacionário. Em seguida assume-se que, para cada instante, a profundidade do fluido, medida a partir das bordas, é constante, e que o fluxo uniforme correspondente à profundidade constante de fluido real, que é alcançado. A profundidade assintótica que correspondente ao estado estacionário, utilizada para calcular a tensão de escoamento utilizando o aparelho de plano inclinado, é apresentada na Equação 5.24 (COUSSOT e BOYER, 1995).

$$
\tau_{c}=\rho g h_{0}(\operatorname{sen} i)
$$

Coussot e Boyer (1995) afirmaram que os resultados do ensaio com plano inclinado foram bastante reprodutíveis, sendo registadas diferenças da ordem de $5 \%$ entre testes com condições idênticas.

Para obter um parâmetro de comparação confiável, Coussot e Boyer (1995) primeiro compararam os resultados obtidos no reômetro de pequenas dimensões com as duas geometrias diferentes, placas paralelas e cone placa, apresentado na Figura 5.28. A maior discrepância entre os resultados foi de $15 \%$, que os autores creditam a incerteza global nos testes reométricos. 
Para a comparação dos resultados obtidos no plano inclinado com os resultados reométricos mais conhecidos, apresentados na Figura 5.28, foi escolhida a tensão de escoamento como parâmetro de referência.

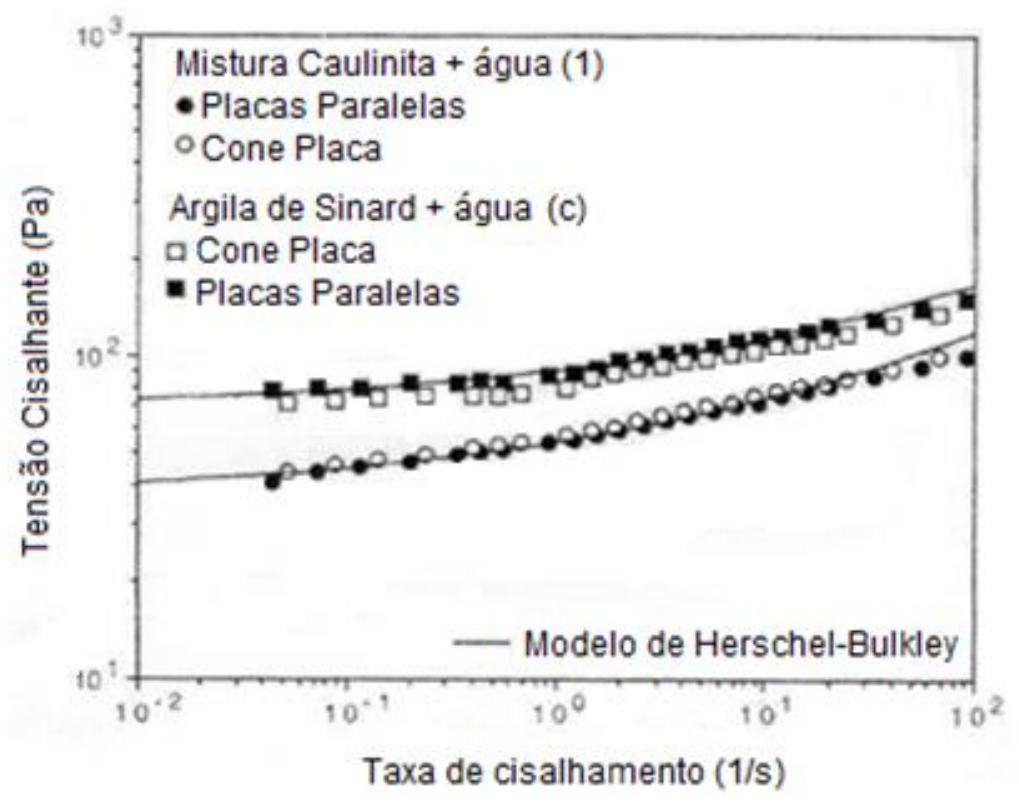

Figura 5.28 Comparação das curvas de cisalhamento obtidas nos reômetros com geometria de placas paralelas e cone - placa (COUSSOT e BOYER, 1995)

A Figura 5.29 apresenta o "erro relativo" da tensão de escoamento quando calculada pelo plano inclinado $(\Delta \tau / \tau)$ como função de um aspecto físico que foi a razão entre a profundidade do fluido em relação à largura do canal, foram calculados valores para as amostras apresentadas na Tabela 5.4, considerando ainda para cada amostra ensaiada uma variação na inclinação do equipamento.

Para cada relação de material, os resultados foram dispersos em torno de um valor médio. Se a única fonte de discrepância entre tensões de escoamento reométricas e as obtidas pelo ensaio com plano inclinado fossem a influência da largura do canal, cada curva que correspondente a determinado material deveria tender para zero quando $\mathrm{h} / \mathrm{L}$ tende para zero o que, na prática, não ocorreu. As diferentes curvas obtidas com um dado material para diferentes inclinações são próximas umas das outras, mas tendem para uma faixa de valores compreendidos entre $-10 \%$ e $+10 \%$. Estas flutuações podem ser devido a muitos efeitos, quatro deles listados a seguir: erro ao se utilizar o modelo de Herschel Bulkley como representativo do comportamento do solo, influência da parede lateral, efeitos de borda superior e inferior e uma situação de sedimentação ou drenagem a partir do início do teste. (COUSSOT e BOYER, 1995) 


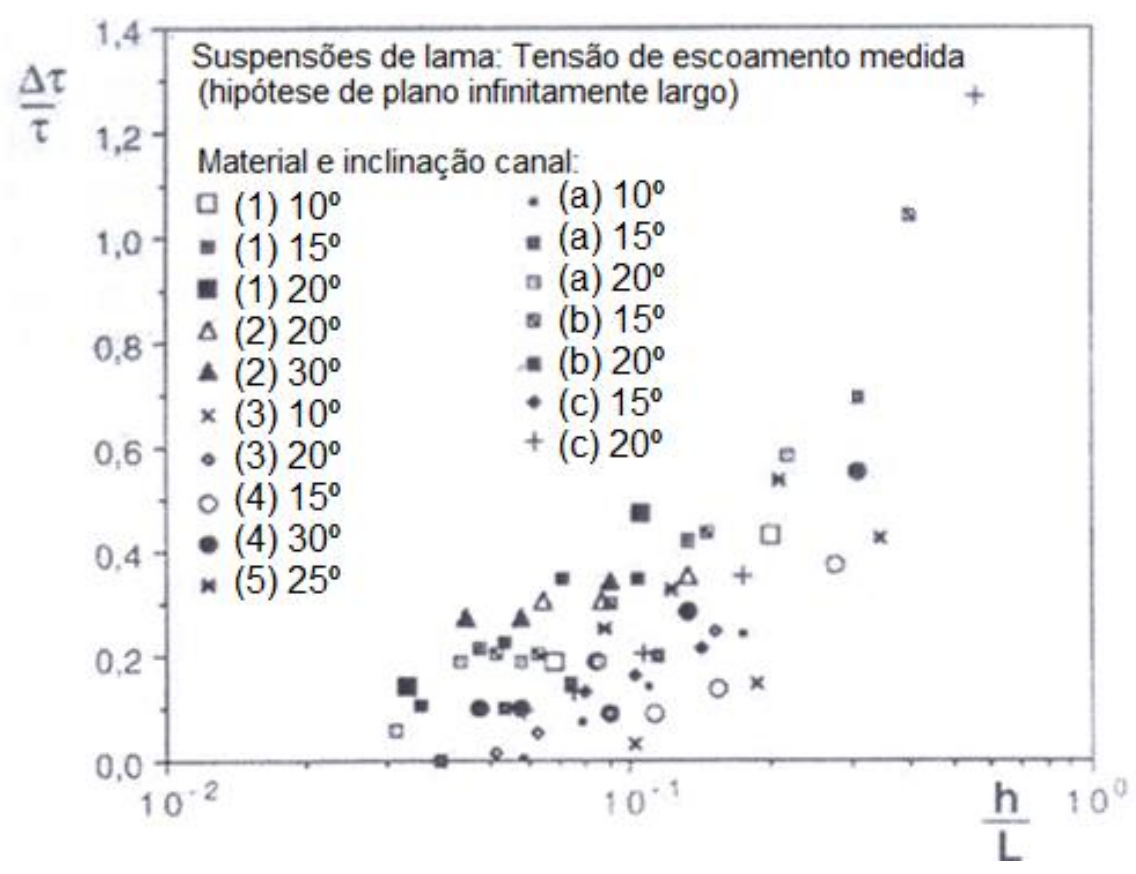

Figura 5.29 Erro relativo da tensão de escoamento obtida no plano inclinado (COUSSOT e BOYER, 1995)

Coussot et al. (1998) realizaram mais ensaios nos mesmos aparelhos utilizados por Coussot e Piau (1994) com amostra de solo coletada de um debris flow ocorrido em 05 de julho em Moscato Torrent, Itália. As amostras foram coletadas 40 horas após o evento. Diferentes suspensões foram geradas artificialmente, adicionando água às partículas de debris flow coletada. Os resultados do ensaio apresentaram relação com o modelo de Herschel-Bulkley, como pode ser visto na Figura 5.30.

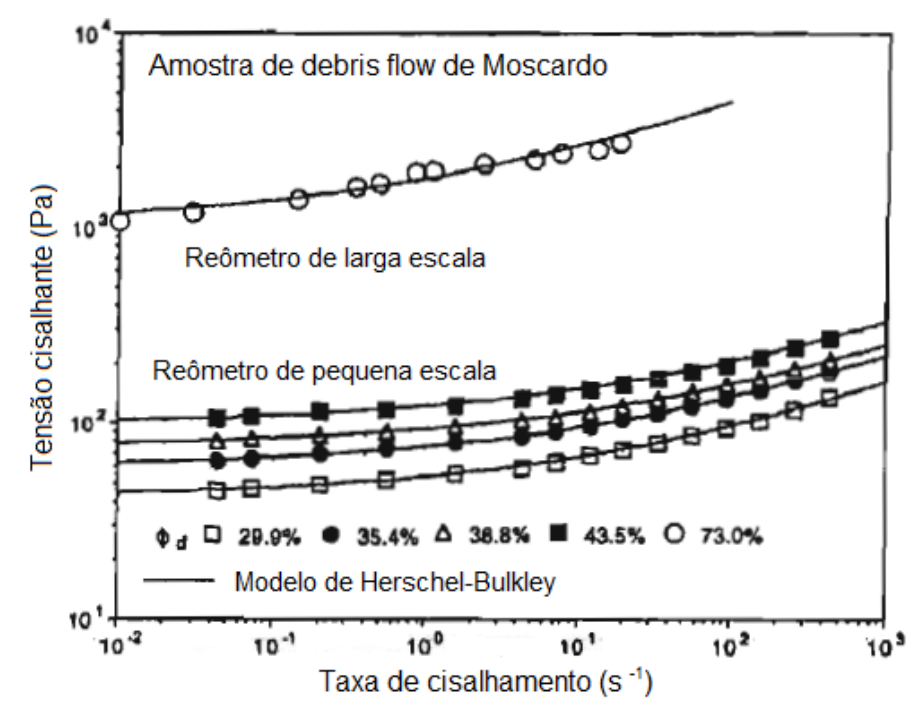

Figura 5.30 Curvas de fluxo de quatro amostras intermediárias (Coussot et al., 1998) 
Os autores obtiveram também uma relação entre a tensão de escoamento e a concentração de sólidos, supondo que com o aumento da concentração de sólidos haveria uma mudança de comportamento já que os contatos entre grãos passariam a interferir na tensão de escoamento, o que não foi verificado, o que pode ser visto na Figura 5.31.

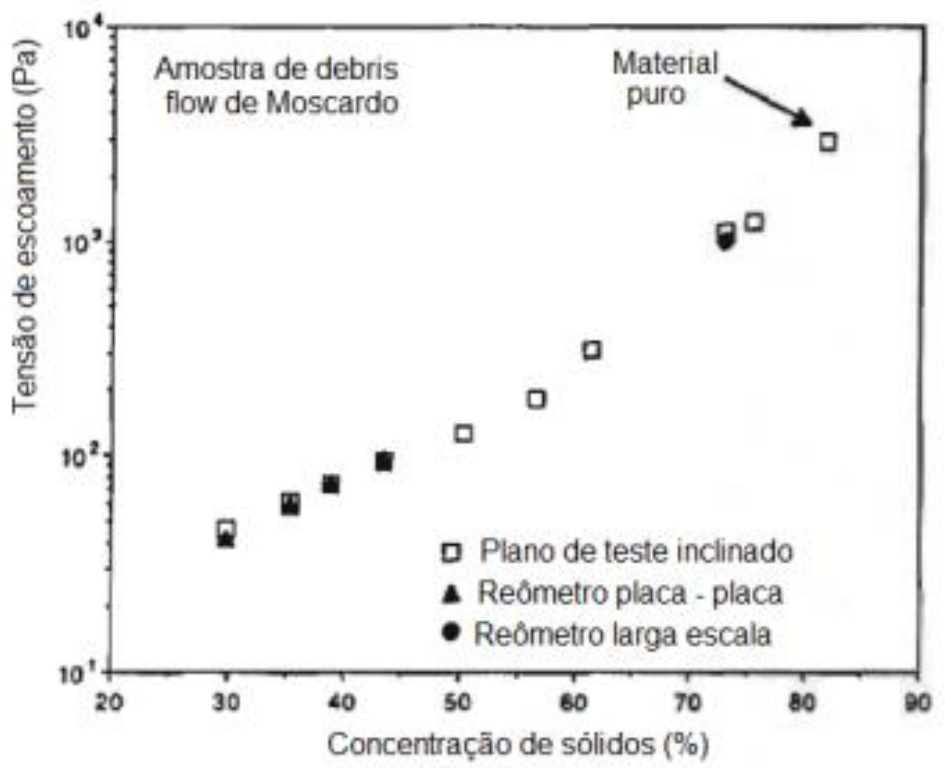

Figura 5.31 Relação entre tensão de escoamento e concentração de sólidos (Coussot et al., 1998)

Apesar de o aparelho apresentar uma facilidade e um baixo custo para construção, sua geometria pode não ser adequada para estudar solos porque existe influência do atrito entre o material que está escorregando e o fundo do aparelho, que não é retratada no artigo.

Whipple (1997) afirmou que uma previsão confiável dos riscos provocados por debris flow requer conhecimento quantitativo do processo de iniciação do fluxo, da mecânica do debris flow (dada pela reologia) e da utilização do modelo apropriado a sua caracterização, realizando um trabalho para validar a utilização do modelo de Bingham na classificação reológica de debris flow.

Whipple (1997) primeiro definiu a parte líquida de um debris flow como sendo aquela que age de maneira viscosa ou visco-plástica, o que pode ter diversos significados para um debris flow, dependendo da distribuição granulométrica. Para um debris flow de granulometria predominantemente fina, definiu o fluido como uma suspensão de partículas infinitesimais diluídas na água, e para um debris flow de material grosso o fluido incluiu a água misturada com argila, silte e até mesmo areia. 
Whipple (1997) afirmou que não há uma concordância entre os dados de viscosidade obtidos em laboratório e os obtidos em campo, para exemplificar apresenta a Figura 5.32 comparando dados de campo e de laboratório obtidos por diversos pesquisadores, na qual as amostras denominadas por $L_{i}$ representam os dados obtidos em laboratório e as amostras denominadas de $\mathrm{C}_{\mathrm{i}}$ os dados obtidos em campo, que foram obtidos através de um reômetro rotacional preparado para locomação, de menor precisão.

Na Figura 5.32, L1 se refere ao trabalho de Li et al. (1983) de Jiangjia Gully; L2 se refere as amostras de North Fork Toutle River, apresentada por Fairchild (1985), L3 se refere as de Major e Pierson (1992) e L4 são amostras de Mount Tomas apresentadas por Philips e Davies (1991). Os dados de campo são: C1 obtidos do mesmo local da L1 no mesmo trabalho, C2 de North Fork Toutle por Wigmosta (1983) e C3 de Mount Thomas por Pierson (1980). As barras de erro representam as incertezas, exceto para L2 que a incerteza é representada pela área sombreada. Com estes dados apresentados não é possível determinar relação entre a viscosidade e a tensão de escoamento.

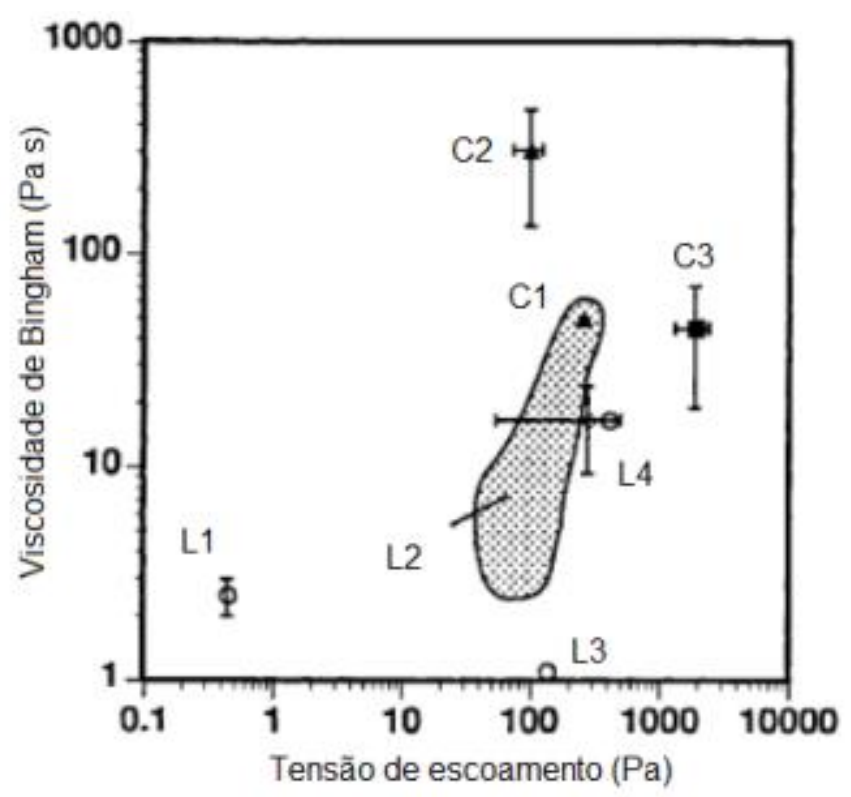

Figura 5.32 Variação dos dados obtidos em campo e laboratório (Whipple, 1997)

Whipple (1997) realizou uma simulação numérica através do programa computacional FIDAP (Fluid Dynamics Analysis Package) aplicado a um depósito de debris flow ocorrido em 1983 e 1990 no Black Canyon Fan, Califórnia. Considerando um fluxo estável, uniforme, retilíneo, em canal aberto, via análise regressa para 
obter a vazão e a velocidade em função da geometria e declividade do canal e das propriedades do material, os resultados obtidos estão apresentados na Tabela 5.5.

Tabela 5.5 Parâmetros obtidos para debris flow de Black Canyon (Whipple, 1997)

\begin{tabular}{|c|c|c|c|c|c|c|}
\hline Seção & $\begin{array}{c}\text { Área seção } \\
\text { transversal } \\
\left(\mathrm{m}^{2}\right)\end{array}$ & $\begin{array}{l}\text { Velocidade } \\
\text { média }(\mathrm{m} / \mathrm{s})\end{array}$ & $\begin{array}{l}\text { Vazão de } \\
\text { pico }\left(\mathrm{m}^{3} / \mathrm{s}\right)\end{array}$ & $\begin{array}{c}\text { Tensão de } \\
\text { escoamento } \\
\text { (Pa) }\end{array}$ & $\begin{array}{c}\text { Viscosidade } \\
\text { de Bingham } \\
\text { (Pa s) }\end{array}$ & $\begin{array}{c}\text { Viscosidade } \\
\text { Newtoniana } \\
\text { (Pa s) }\end{array}$ \\
\hline 1 & 56 & 7,8 & $435 \pm 15$ & $2150 \pm 150$ & $376 \pm 45$ & $876 \pm 31$ \\
\hline 2 & 19 & 5,2 & $95 \pm 15$ & $540 \pm 30$ & $300 \pm 55$ & $409 \pm 65$ \\
\hline 3 & 13 & 6,0 & $75 \pm 12$ & $540 \pm 30$ & $117 \pm 21$ & $179 \pm 29$ \\
\hline 4 & 6 & 4,8 & $22 \pm 8$ & $300 \pm 45$ & $25 \pm 11$ & $36 \pm 10$ \\
\hline 5 & 13 & 5,2 & $68 \pm 10$ & $340 \pm 80$ & $170 \pm 66$ & $224 \pm 75$ \\
\hline 6 & 2 & 4,5 & $8 \pm 1$ & $80 \pm 35$ & $13 \pm 3$ & $15 \pm 2$ \\
\hline
\end{tabular}

Na Figura 5.33 são apresentados os resultados obtidos para os debris flow de 1983 e 1990 ocorridos em Black Canyon, representados pelos quadrados com barras de erros. São apresentados também, para comparação, os resultados obtidos para North Fork Toutle, que apresenta uma distribuição granulométrica próxima a de Black Canyon, obtidas de dois estudos independentes, realizados anteriormente por Major e Pierson (1992), triângulo, e Fairchild (1985), região sombreada. As estimativas de campo para o debris flow de Black Canyon coincidem e seguem a mesma tendência das do laboratório para os depósitos que contém distribuições granulométricas similares. (WHIPPLE, 1997)

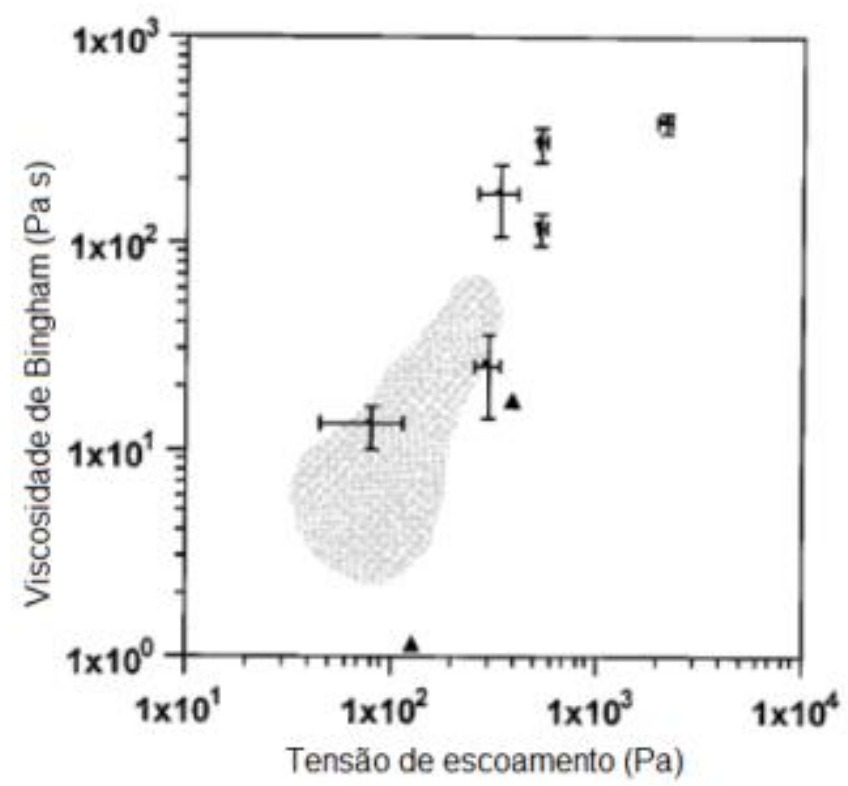

Figura 5.33 Reologia do debris flow de Black Canyon (Whipple, 1997) 
Whipple (1997) concluiu que a aplicação da equação constitutiva de Bingham para debris flow é mais razoável para suspensões que são ricas em finos. Isso porque a utilização dessa equação assume que a deformação da matriz governa o comportamento macroscópico do fluxo e que os efeitos dinâmicos (tais como colisões e fricção de partículas, a migração do fluido dos poros e a formação de redes e destruição de grão), ou são negligenciáveis ou são coletivamente manifestadas com, aproximadamente, o comportamento de Bingham.

Melo et al. (2012) utilizaram ensaios reométricos para caracterizar o solo de um aterro que apresenta escorregamento complexo com aceleração e desaceleração do movimento provocada pela oscilação do nível freático. O local analisado é um talude localizado em Vila Albertina, zona Norte da cidade de São Paulo, e foi objeto de estudos de uma dissertação de mestrado para a caracterização do movimento de massa complexo (GODOIS, 2011). A distribuição granulométrica do solo ensaiado é apresentada na Figura 5.34.

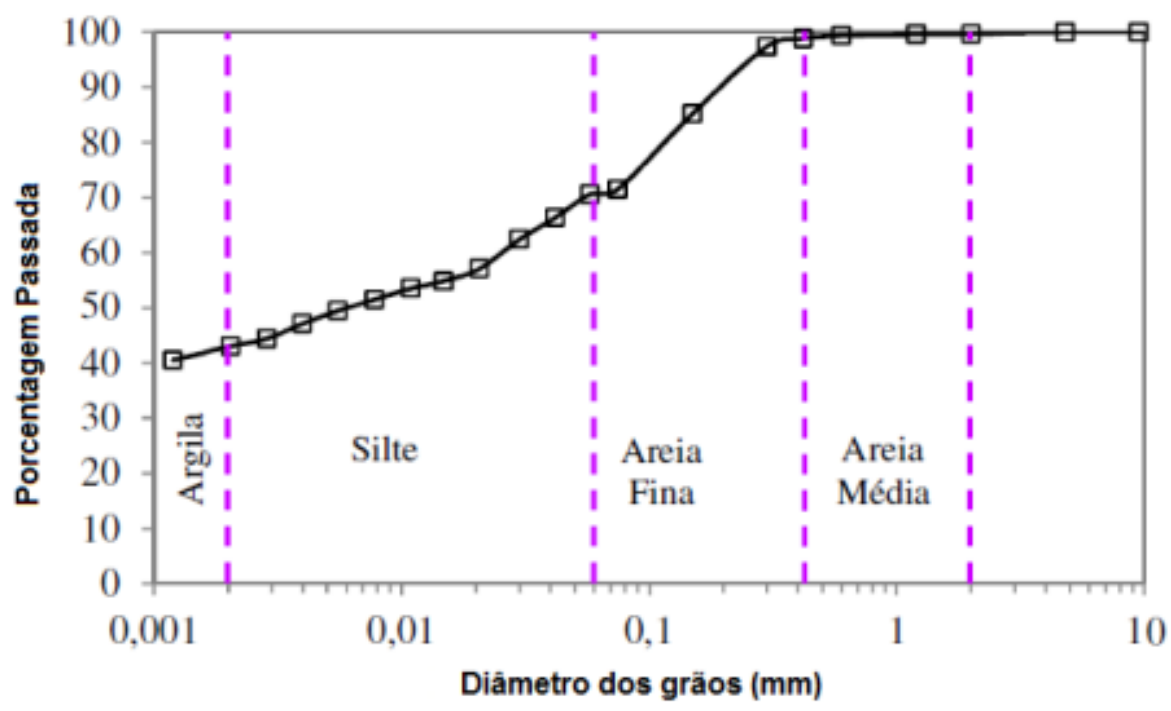

Figura 5.34 Distribuição granulométrica da amostra (Melo et al., 2012)

O limite de liquidez, $\mathrm{w}_{\mathrm{L}}$, foi de $49 \%$, o de plasticidade, $\mathrm{w}_{\mathrm{P}}$, de $25 \%$ e consequentemente, o índice de plasticidade foi de $24 \%$. O solo utilizado no trabalho foi umedecido e ensaiado com diferentes umidades. As umidades das amostras ensaiadas foram determinadas em relação a esses índices, sendo que foi adotada uma amostra com umidade próxima ao $\mathrm{w}_{\mathrm{P}}(26 \%)$, uma amostra entre o $\mathrm{W}_{\mathrm{P}}$ e $0 \mathrm{~W}_{\mathrm{L}}$ (39\%) e duas amostras com umidade superior ao $\mathrm{w}_{\mathrm{L}}(58 \%$ e $65 \%)$. (MELO et al., 2012) 
Foram realizados ensaios reométricos em dois aparelhos: o reômetro rotacional do tipo planetário e o squeeze flow. O reômetro rotacional está apresentado na Figura 5.35, pertence ao Laboratório de Microestrutura da EPUSP. Esse é o mesmo aparelho utilizado na realização dos ensaios dessa dissertação.

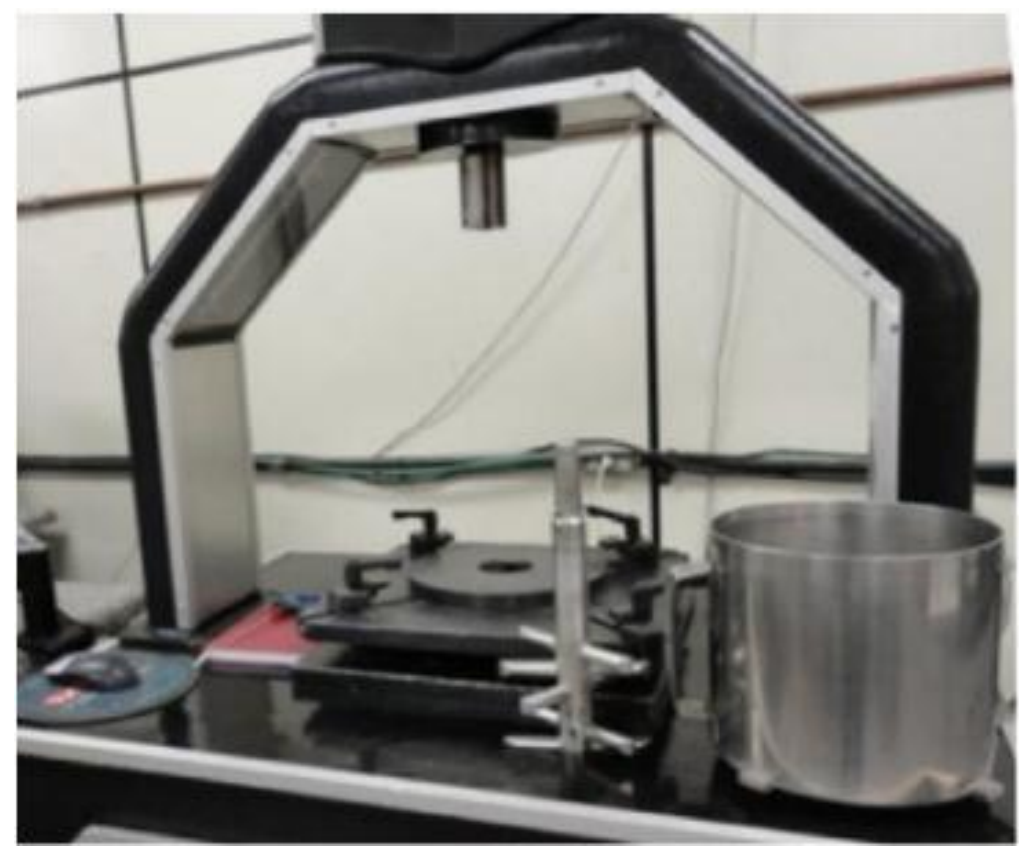

Figura 5.35 Reômetro Rotacional utilizado por Melo et al. (2012)

Para a realização dos ensaios foi determinado o ciclo de aplicação de velocidade apresentado na Figura 5.36. Esse ciclo de carga foi determinado com o objetivo de avaliar o comportamento do solo em diferentes taxas de cisalhamento correspondentes a velocidades de rotação de $50 \mathrm{rpm}$ à $1250 \mathrm{rpm}$. O estágio I corresponde ao posicionamento da mesa, no qual a amostra não está completamente em contato com o aparelho. No estágio II é aplicada uma rotação constante para que ocorra a homogeneização da amostra e o estágio III é o ciclo de cisalhamento, no qual são medidas as propriedades reológicas. (MELO et al., 2012)

O resultado obtido é apresentado na Figura 5.37 em forma de gráfico de rotação versus estimativa de torque, onde as setas vermelhas se referem à etapa de aceleração e as setas azuis à desaceleração. Todas as amostras apresentaram perfil de material pseudoplástico com torque de escoamento, comparando com as curvas da Figura 5.7. No entanto não foi realizada uma estimativa de modelo reológico nesse trabalho. 


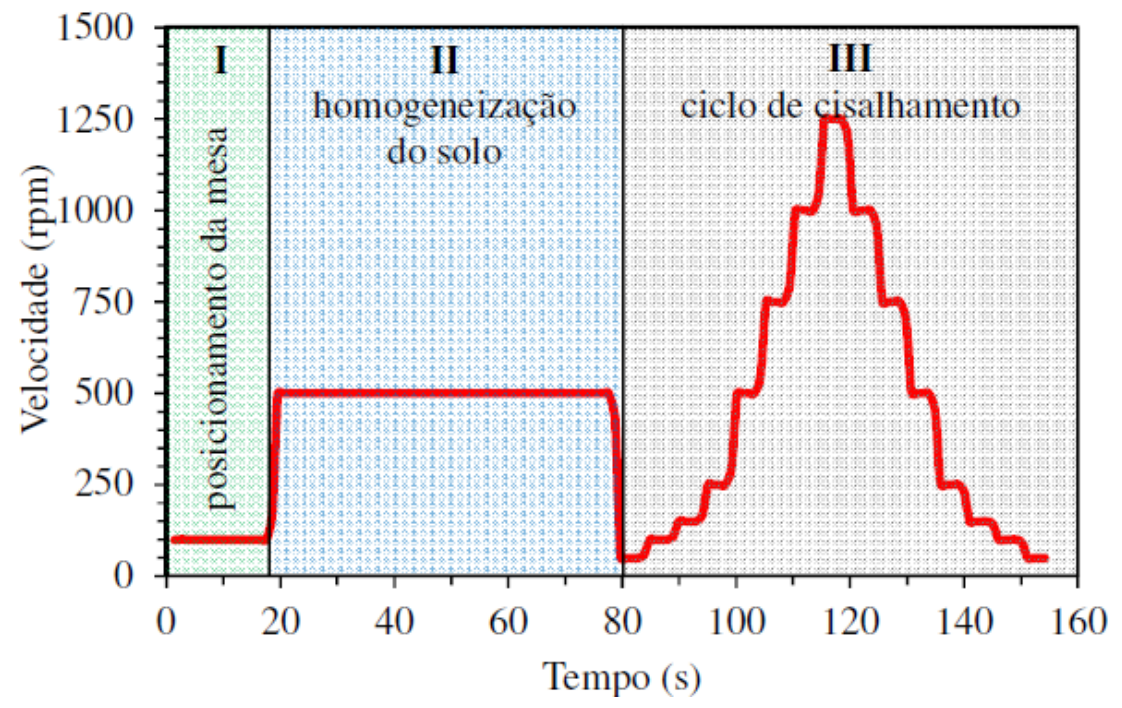

Figura 5.36 Programação do ensaio de reometria rotacional (Melo et al., 2012)

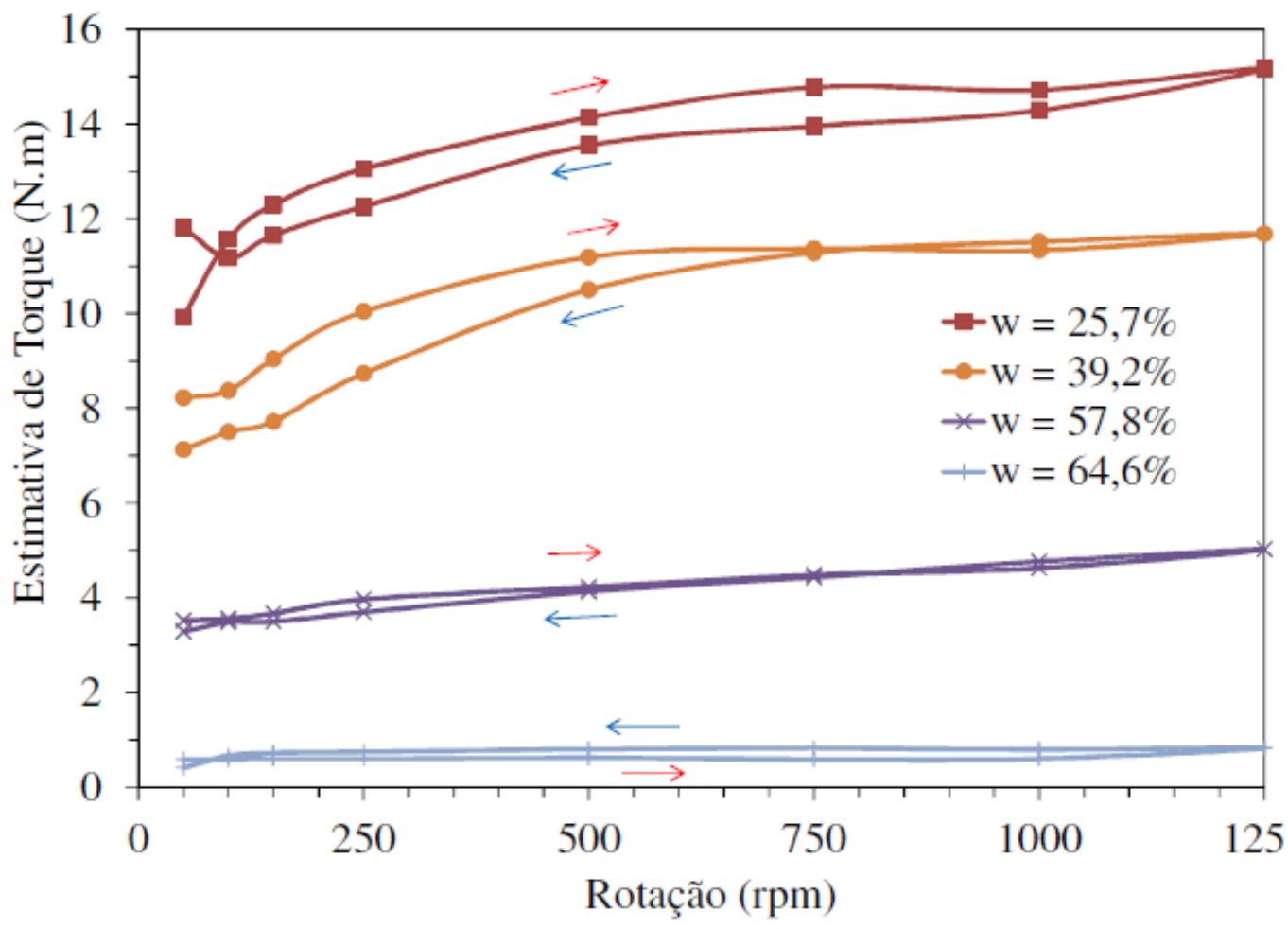

Figura 5.37 Resultado do ensaio de Reometria rotacional (Melo et al., 2012)

Ainda em relação à Figura 5.37, as amostras com maior umidade apresentaram tixotropia, enquanto a amostra mais úmida apresentou reopexia, ou tixotropia negativa, a diminuição da área de histerese com o aumento da umidade, indica que com o aumento da umidade as amostras ficam mais homogêneas. 
$\mathrm{Na}$ Figura 5.38 estão apresentadas as relações entre a umidade e as estimativas de características reológicas: viscosidade e torque de escoamento. Melo et al. (2012) afirmam que as alterações nos parâmetros reológicos foram diretamente proporcionais à umidade, que é o parâmetro de maior impacto nos ensaios.

Considerando os resultados apresentados na Figura 5.38 não foi possível relacionar os parâmetros obtidos com a definição do limite de liquidez, já que era esperada uma redução brusca dos parâmetros para as amostras nas quais a umidade fosse maior que o $\mathrm{w}_{\mathrm{L}}$, tendo em vista que a definição de limite de liquidez é justamente a umidade a partir da qual o solo apresenta comportamento líquido.

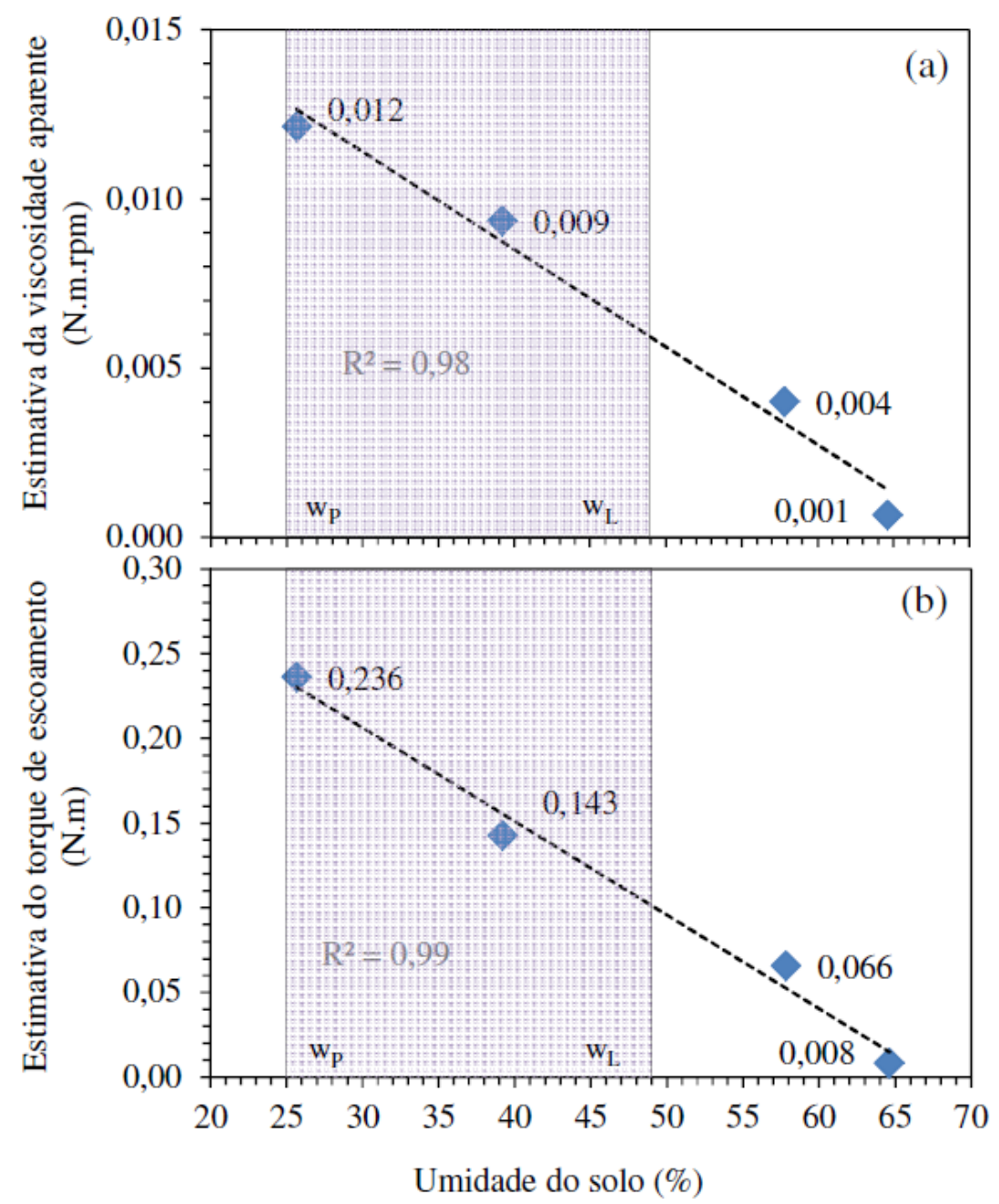

Figura 5.38 Relação entre: (a) viscosidade aparente e (b) estimativa de torque de escoamento com a umidade (Melo et al., 2012) 
O segundo ensaio realizado foi o squeeze flow, que é realizado através de uma prensa universal Instron, modelo 5569 com células de carga de $1 \mathrm{kN}$. O resultado obtido está apresentado na Figura 5.39. Foi observado que as amostras com os menores teores de umidade apresentaram regime elástico desde as menores deformações, comportamento típico de material sólido. Enquanto que as demais amostras, com maiores teores de água, apresentaram fluxo viscoso e atingiram maiores deformações sem aumento expressivo de carga (MELO et al., 2012). Os autores afirmaram que, novamente, a umidade governou o fluxo sob compressão, sendo observado que, quanto menor o teor de água maior a viscosidade elongacional e mais difícil é o espalhamento. Isso porque a aproximação e o rearranjo das partículas geram forças restritivas ao fluxo que dificultam a movimentação da massa. A área assinalada com o círculo na Figura 5.39 representa uma região onde foi encontrada maior resistência devido à presença de um aglomerado ou grão de areia sob a punção, como a Figura 5.13, porém a curva apresentou tendência normal. (MELO et al., 2012)

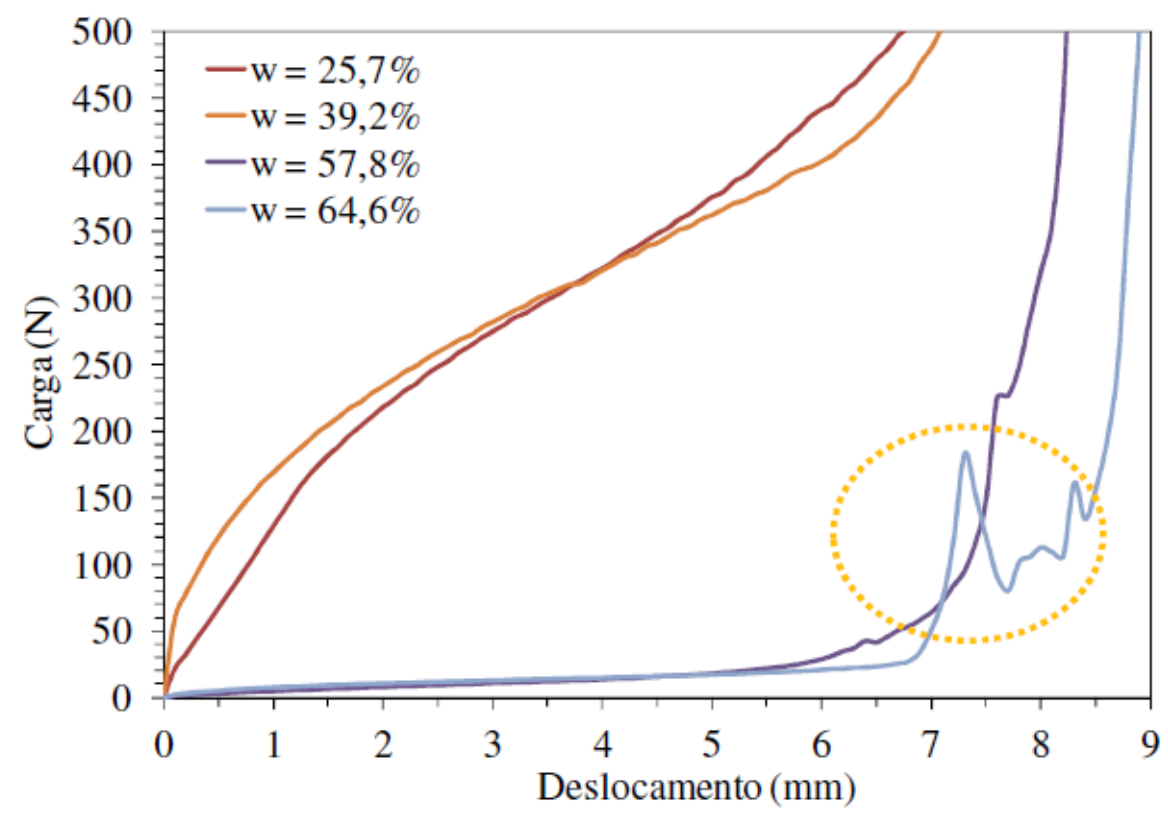

Figura 5.39 Perfil obtido no ensaio de squeeze flow (Melo et al., 2012)

Para exemplificar a dependência do teor de umidade no comportamento do solo, os autores apresentam a Figura 5.40. Para a construção dessa figura foi adotada uma deformação fixa de $15 \%$, para comparar qual a carga necessária para obter essa deformação em cada uma das amostras. Para a determinação da curva que representa essa relação são necessários mais pontos de ensaio, contudo 
ressaltam que um aumento de $19 \%$ no teor de água (de 39\% para 58\%) resultou em uma redução de mais de $95 \%$ no valor da carga compressiva.

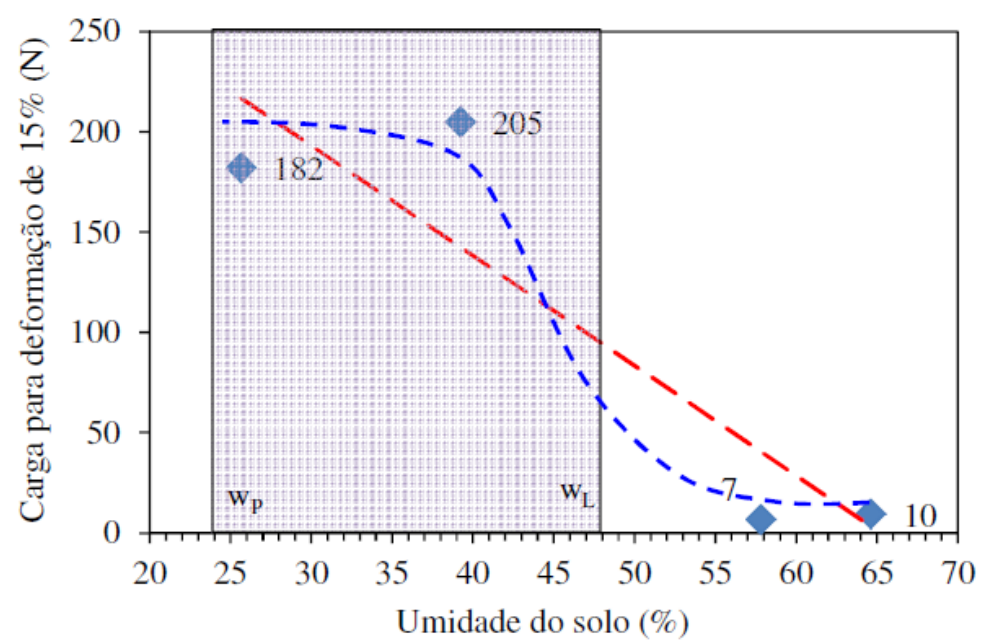

Figura 5.40 Relação entre umidade e carga em deformação constante (Melo et al., 2012)

Apesar dos autores terem afirmado que os ensaios são de fácil realização e apresentar repetitividade, ressaltaram que ainda é necessário um aprofundamento na teoria de reometria e a adequação dos modelos de previsão de comportamento dos fluidos para os solos. (MELO et al., 2012)

A partir dos artigos apresentados é possível realizar algumas observações:

- Philips e Davies (1991) apresentaram valores de tensão de escoamento entre 15 e $80 \mathrm{~Pa}$ e de viscosidade aparente entre 20 e 238 Pa.s para as amostras de Tarndale, para as amostras de Bullock Creek tensão de escoamento entre 45 e $300 \mathrm{~Pa}$ e viscosidade aparente entre 0,4 e 104 Pa.s;

- Coussot et al. (1992) apresentaram tensão de escoamento estática de $50 \mathrm{~Pa}$ e dinâmica de $15 \mathrm{~Pa}$;

- Coussot e Piau (1994) conseguiram comparar os resultados obtidos por um reômetro de pequena dimensão com o de grande dimensão não observando diferenciação no resultado obtido para amostras reconstituídas de argilas naturais com variação da umidade;

- Coussot e Piau (1994) e Coussou et al. (1998) adotaram o modelo de Herschel Bulkley para equalizar o comportamento reológico de debris flows. 
- Whipple (1997) adotou o modelo de Bingham para aproximação do comportamento do solo e apresenta gráfico da viscosidade como função da tensão de escoamento com grande dispersão;

Concluindo, tanto os valores de tensão de escoamento quanto os de viscosidade apresentam grande variação. Para o cálculo da viscosidade é necessário determinar quais as taxas de cisalhamento de interesse, já que esses parâmetros são dependentes. Os modelos adotados apesar de serem diferentes apresentam em comum a presença da tensão de escoamento, observada em todos os casos e a redução da viscosidade com o aumento da taxa de cisalhamento, indicando que os solos apresentaram um comportamento do tipo Pseudoplástico com tensão de escoamento.

Em relação aos resultados obtidos por Melo et al. (2012), foram realizados um número maior de ensaios de squeeze flow em diferentes umidades objetivando aferir o perfil de comportamento desse solo de Vila Albertina. Os ensaios foram realizados na velocidade de $0,1 \mathrm{~mm} / \mathrm{s}$ e o comportamento obtido está apresentado na Figura 5.41 , sendo que os resultados antigos estão em linha pontilhada e os novos em linha cheia.

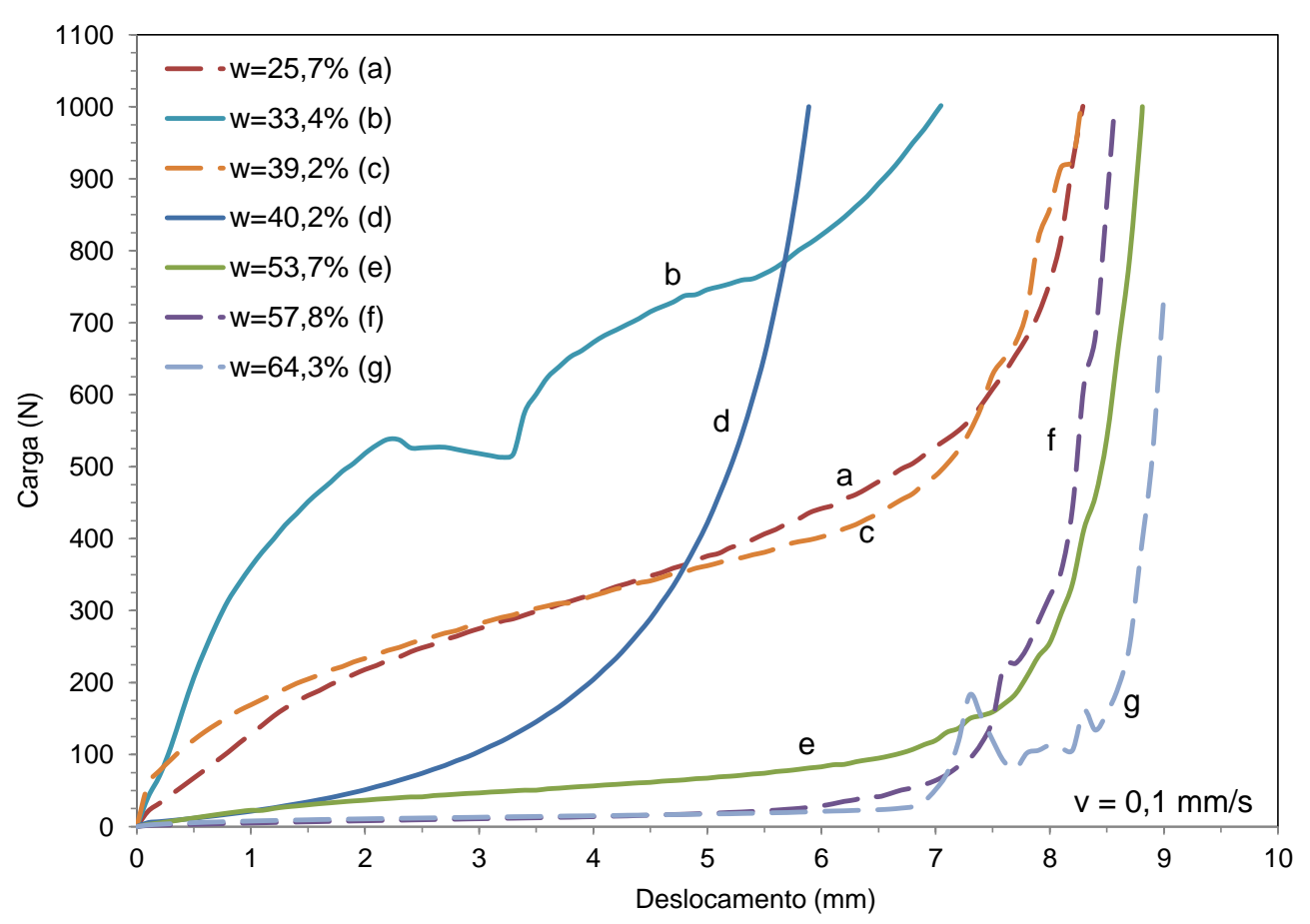

Figura 5.41 Novos resultados de squeeze flow de Vila Albertina

Observando o formato das curvas obtidas, é possível visualizar que o solo com o teor de umidade maior ou igual a 40,2 \% não apresentou comportamento 
elástico, e sim o de um líquido, valor próximo ao do limite de liquidez obtido, que foi de $48,9 \%$. O resultado obtido para a amostra com umidade de $33,4 \%$ será desprezado por apresentar uma resposta muito diferente da esperada, o que indica que esse resultado não é representativo do comportamento.

Com os novos resultados, obtidos para essa qualificação, foi possível calcular a tensão de escoamento para cada umidade e a carga para deformação de $15 \%$, para comparação com a Figura 5.40. Esses resultados estão apresentados na Figura 5.42 e na Figura 5.43, respectivamente.

Através da inserção dos novos dados nas curvas obtidas é possível visualizar uma mudança brusca de comportamento do solo, porém essa mudança não se deu na umidade correspondente ao $\mathrm{w}_{\mathrm{L}}$, mas em seu entorno, com umidade de $0,85 \mathrm{w}_{\mathrm{L}}$. Esses gráficos corroboram com o formato das curvas obtidas, Figura 5.41, indicando que o Limite de Liquidez definido pelo ensaio de Casagrande não indicou o limite para o comportamento fluido.

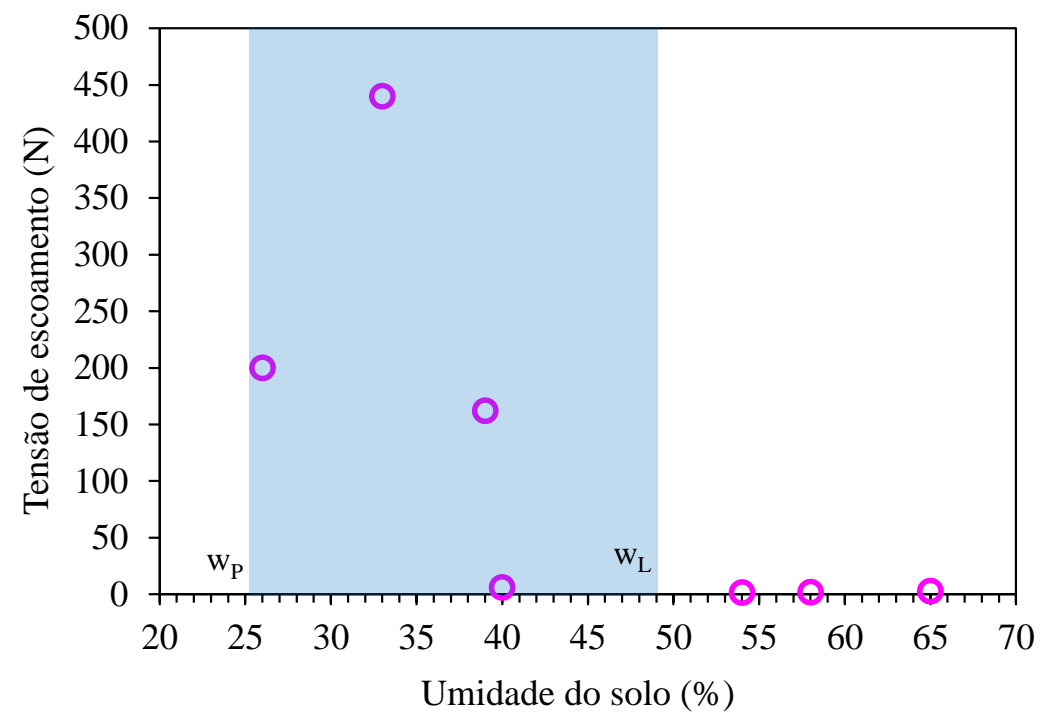

Figura 5.42 Variação da tensão de escoamento com a umidade para Vila Albertina 


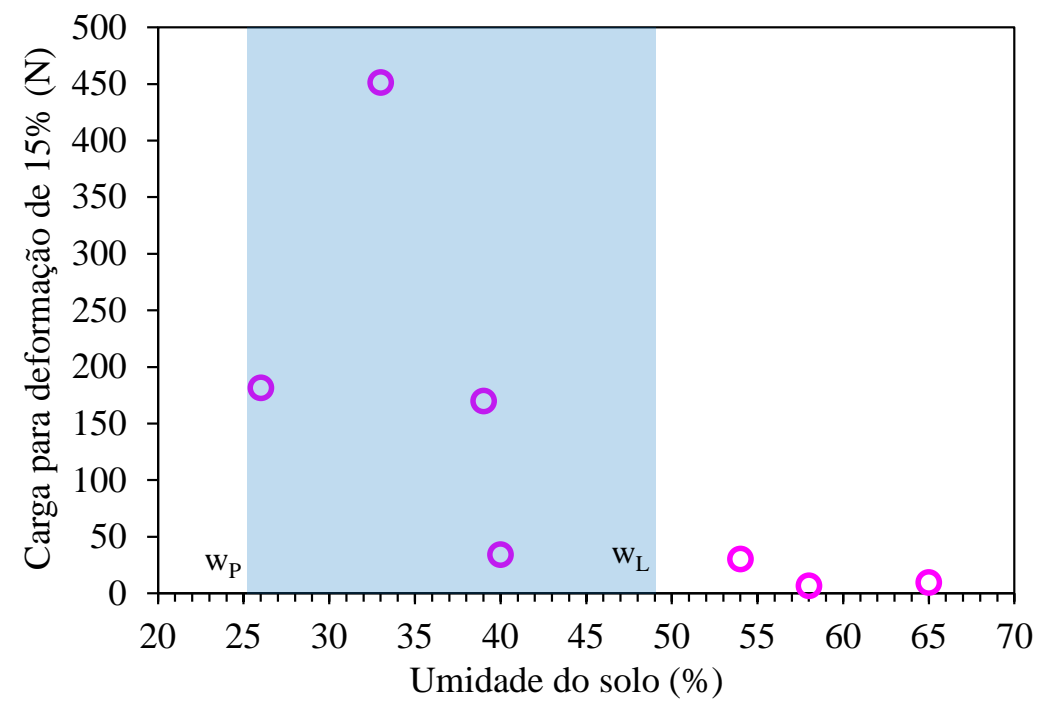

Figura 5.43 Relação entre umidade e carga em deformação constante para Vila Albertina

\subsection{Parâmetro de suavização}

A adoção de modelos de fluxo para descrever o comportamento observado é frequentemente empregada, a utilização de modelos facilita a comparação entre diferentes dados obtidos por diversos autores, através das constantes obtidas nas equações. Dos modelos reológicos, os mais utilizados na geotecnia para aproximar o comportamento observado são o modelo de Bingham e o modelo de Herschel Bulkley.

O modelo de Bingham é descrito pela já apresentada Equação 5.7 , com o índice $n$ igual a 1. A facilidade de aplicação deste modelo está intrinsicamente ligada a sua utilização mesmo quando a correlação não é muito alta. O modelo descreve um material que se comporta como um sólido rígido até que a tensão de escoamento seja excedida, e a partir daí através de um gráfico de variação linear entre a tensão de cisalhamento e a taxa de cisalhamento, indicando uma diminuição da viscosidade em relação à taxa de cisalhamento.

$$
\tau=\tau_{0}+k \dot{\gamma}^{n}
$$

Já o modelo de Herschel Bulkley (HB) descreve um material que apresenta o comportamento sólido até que a tensão de escoamento seja excedida, depois apresenta uma relação não linear entre a tensão de cisalhamento e a taxa de 
cisalhamento, podendo escoar, tanto como um fluido dilatante, como um fluido Pseudoplástico (viscosidade aumenta ou diminui em relação a taxa de cisalhamento, respectivamente).

Esses dois modelos serão utilizados para aproximação dos dados obtidos nessa dissertação Esses dois modelos apresentam o domínio caracterizado por duas regiões distintas: uma na qual a tensão aplicada é menor que a tensão de escoamento onde não ocorre fluxo e outra região na qual a tensão é maior que a tensão de escoamento, a transição entre essas duas regiões é denominada por superfície de escoamento. (Van Wazer, 1966)

A Equação 5.7 também consegue representar o modelo de HB, engloba três parâmetros reológicos, a tensão de escoamento e os índices $k$ e $n$. O índice $k$ representa o grau de resistência do fluido diante do escoamento e $n$ indica 0 afastamento do fluido do modelo Newtoniano. Quando $\tau<\tau_{0}, \dot{\gamma}=0$.

A partir do conceito de viscosidade aparente $(\eta=\tau / \dot{\gamma})$ e da Equação 5.7 , a viscosidade do modelo de HB é representada pela Equação 5.25.

$$
\eta(\dot{\gamma})=\frac{\tau_{0}}{\dot{\gamma}}+k \dot{\gamma}^{n-1}
$$

A aplicação do modelo de HB em dados experimentais não é uma tarefa simples como no modelo de Bingham, além da não linearidade nas relações constitutivas o modelo apresenta uma descontinuidade no campo de tensões cisalhantes, que é devido à presença de $\dot{\gamma}$ no denominador da Equação 5.25 que faz com que $\eta$ se torne ilimitada. Para superar essas dificuldades várias versões modificadas da Equação 5.25 foram propostas, tais como Papanastasiou (1987), Bercovier e Engelman (1980), O’Donovan e Tanner (1984), para que apresentassem o campo de tensões de cisalhamento contínuo assim as modificações são aplicáveis tanto nas regiões rígidas quanto no escoamento (BURGOS et al., 1999).

Neste trabalho, será utilizada a função regularizadora proposta por Papanastasiou (1987) na forma de uma função de viscosidade contínua, que é válida para ampla faixa de tensões superando as limitações impostas pelo caráter descontínuo do modelo clássico de HB. Para acabar o problema da descontinuidade, Papanastasiou introduziu um termo de suavização exponencial na 
expressão da viscosidade tornando a função viscosidade válida para as duas regiões do escoamento. A função é apresentada na Equação 5.26.

$$
\tau=k \dot{\gamma}^{n}+\tau_{0}\left(1-e^{-\alpha \dot{\gamma}}\right)
$$

O parâmetro a controla a taxa de crescimento da taxa de cisalhamento $(\dot{\gamma})$ na relação de deformação do material sendo que quanto maior o parâmetro $\alpha$, mais a função regularizadora de Papanastasiou se aproxima da função de HB. No entanto na aplicação do modelo, o parâmetro a não pode ser escolhido arbitrariamente porque altos valores de a podem causar problemas de convergência na Equação 5.26. Burgos et al. (1999) apresentaram estudo sobre a influência da variação do parâmetro a no modelo apresentado chegando a conclusão que para valores de $n$ de 1,5 é indicada a adoção de a de $10^{3}$, e para valores de $n$ menores que 0,5 indicam a adoção de $\alpha$ de 100.

A partir dos dados apresentados por Melo et al. (2012), foi possível realizar a aproximação por modelos de comportamento de fluxo, apresentados nas Figura 5.44 até a Figura 5.47, nas quais os dados em azul se referem ao modelo de Bingham, os dados em rosa ao modelo de Herschel Bulkley e os dados em verde ao modelo de Herschel Bulkley modificado por Papanastasiou (1987).

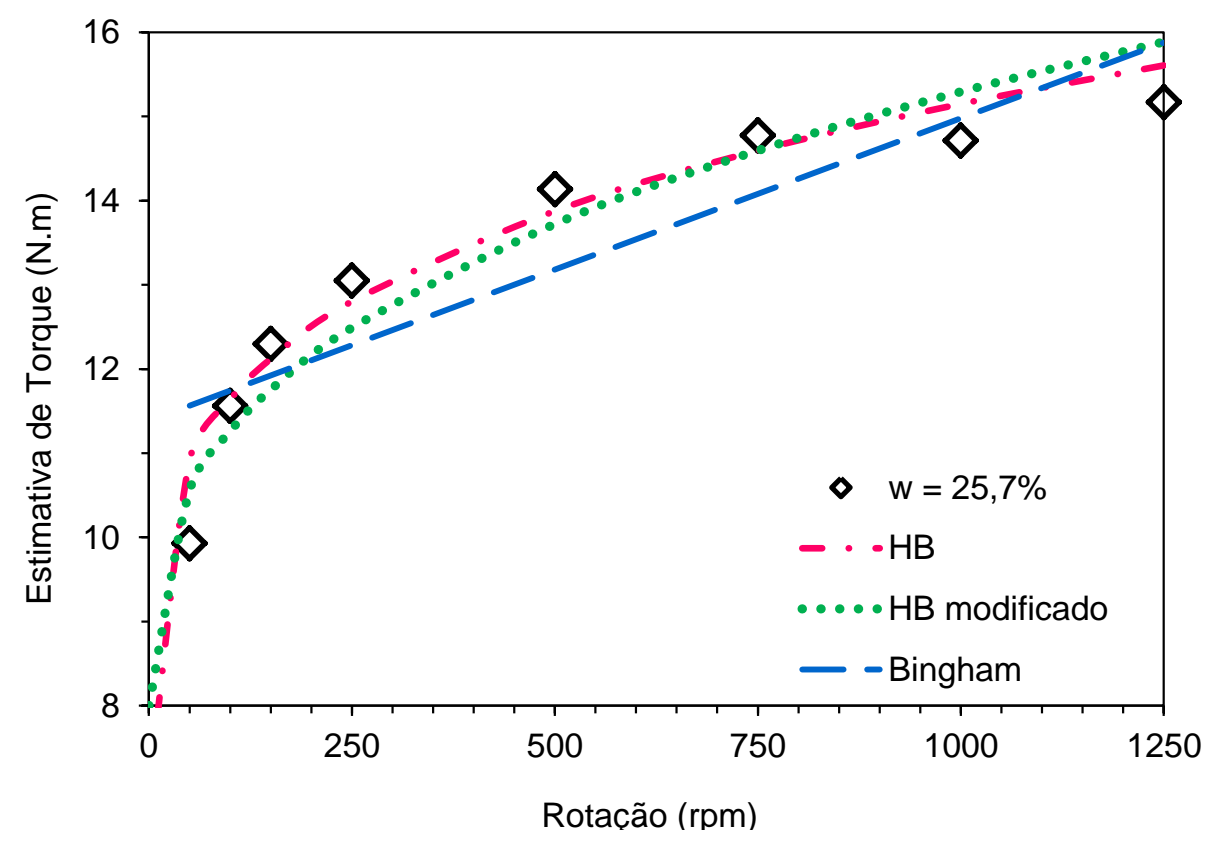

Figura 5.44 Aproximação por modelos dos dados obtidos por Melo et al. (2012), para a umidade de $25,7 \%$ 


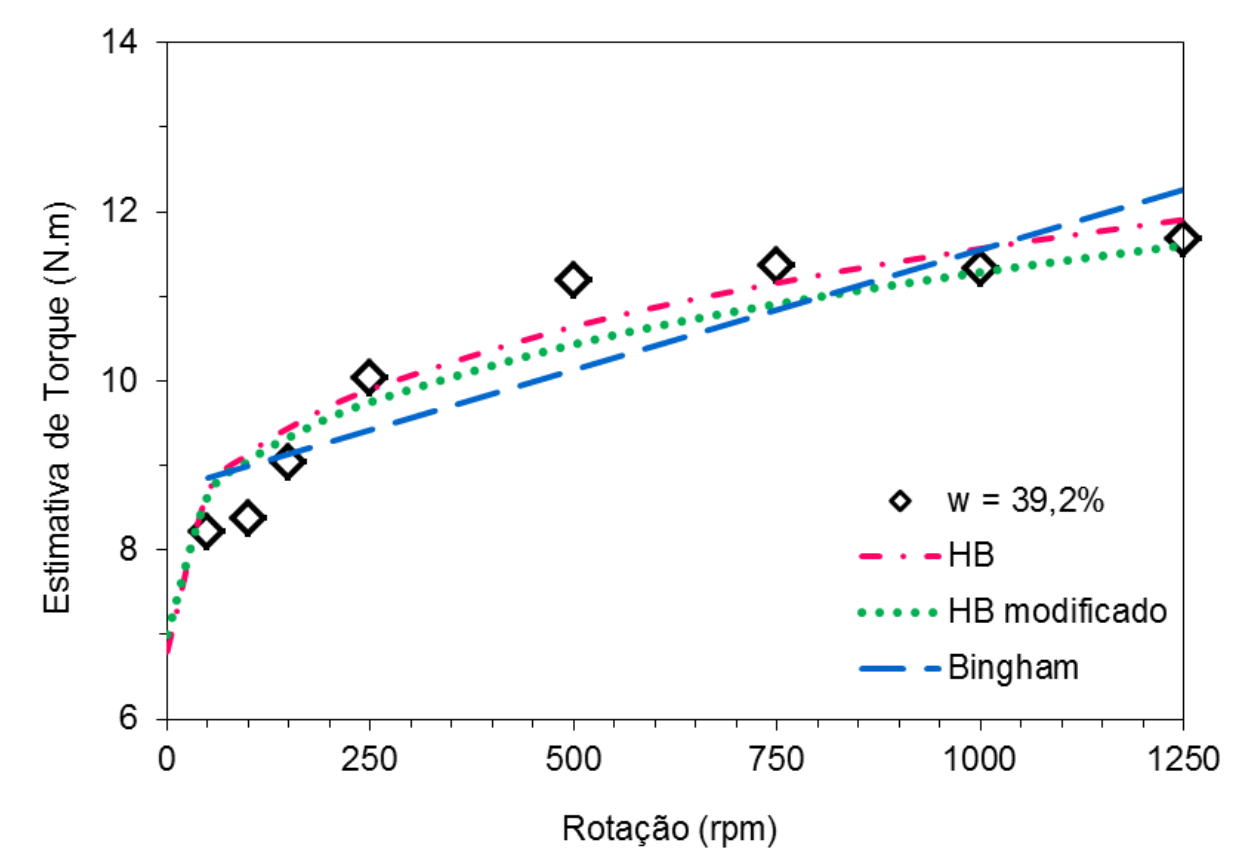

Figura 5.45 Aproximação por modelos dos dados obtidos por Melo et al. (2012), para a umidade de $39,2 \%$

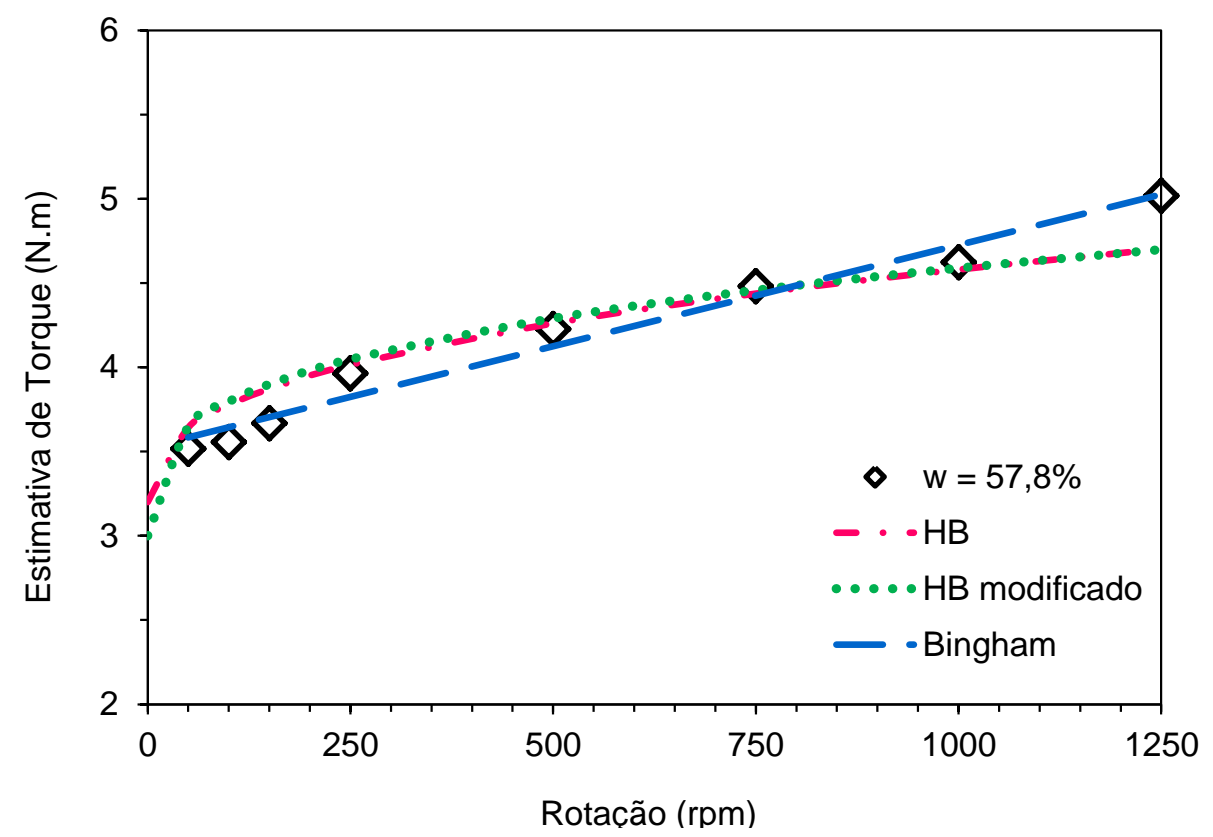

Figura 5.46 Aproximação por modelos dos dados obtidos por Melo et al. (2012), para a umidade de $57,8 \%$ 


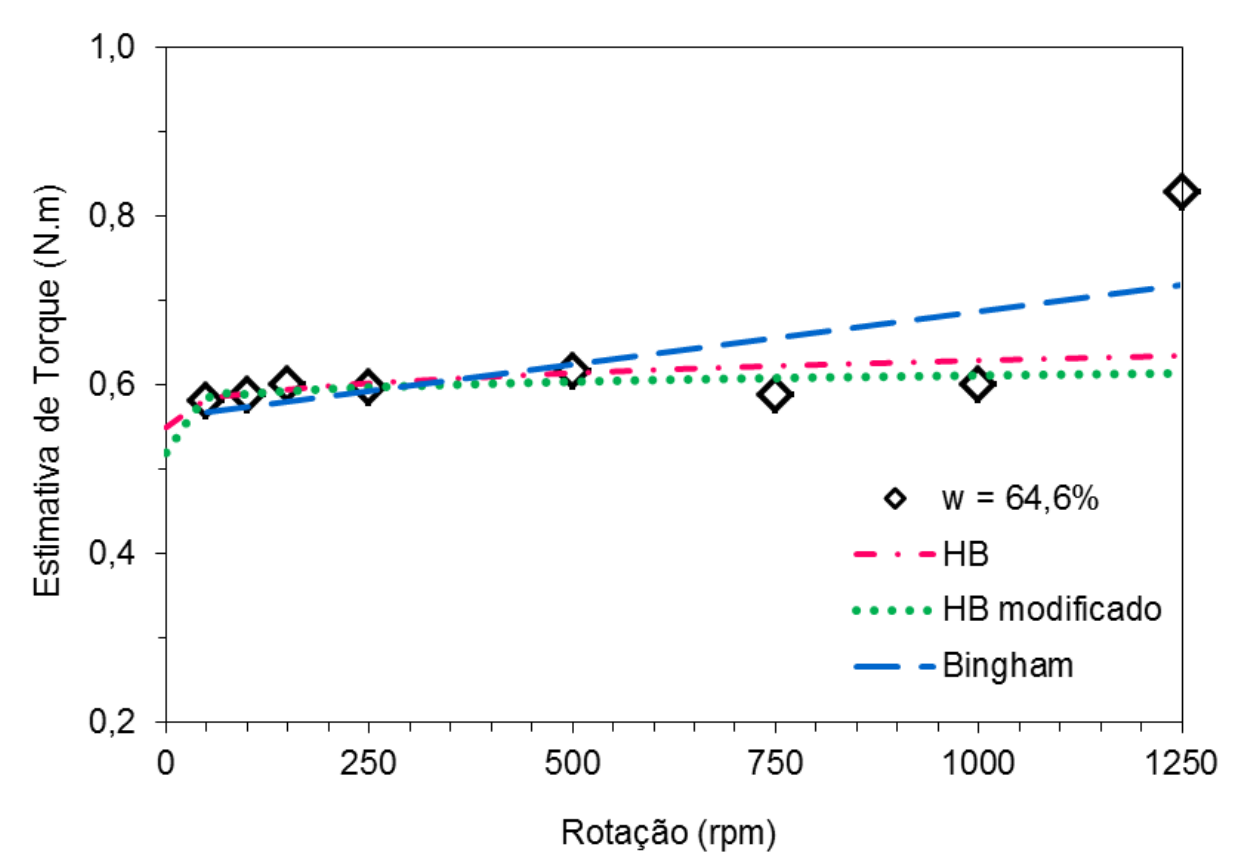

Figura 5.47 Aproximação por modelos dos dados obtidos por Melo et al. (2012), para a umidade de $64,6 \%$

Os resultados de Melo et al. (2012) apresentaram para cada uma das umidades isoladamente pequenas variações da estimativa de torque (ou da viscosidade) que não são previstas nos modelos teóricos. Esse fenômeno é nítido, por exemplo, quando o teor de umidade é de $64,6 \%$ no qual a última medida de torque apresenta um salto em relação às demais medidas, o que dificulta a utilização dos modelos.

A Tabela 5.6 apresenta a variação dos parâmetros de cada um dos modelos em relação à umidade para ilustrar a sensibilidade do modelo e inferir como cada parâmetro contribui no comportamento.

Para cada um dos modelos foi plotada a variação da tensão de escoamento e do parâmetro $\mathrm{k}$ com o aumento da umidade. Através dos gráficos é possível determinar qual teor de umidade equivaleria à anulação da tensão de escoamento, além de obter equações para essa variação. As Figuras $5.48,5.49$ e 5.50 apresentam o resultado obtido para os modelos de Bingham, HB e HB modificado, respectivamente. 
Tabela 5.6 Variação dos parâmetros dos modelos com a umidade

\begin{tabular}{|c|c|c|c|c|c|}
\hline & & $w=25,7 \%$ & $w=39,2 \%$ & $w=57,8 \%$ & $w=64,6 \%$ \\
\hline \multirow{3}{*}{ 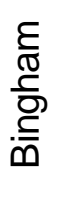 } & $\tau$ Tesc $(\mathrm{Nm})$ & 11,4 & 8,7 & 3,5 & 0,6 \\
\hline & k & 0,0036 & 0,0028 & 0,0012 & 0,00012 \\
\hline & $\mathrm{n}$ & 1 & 1 & 1 & 1 \\
\hline \multirow{3}{*}{$\stackrel{m}{\underline{I}}$} & $\tau$ Tesc $(\mathrm{Nm})$ & 7,00 & 6,80 & 3,20 & 0,55 \\
\hline & k & 1,50 & 0,56 & 0,10 & 0,01 \\
\hline & $\mathrm{n}$ & 0,25 & 0,31 & 0,38 & 0,30 \\
\hline \multirow{4}{*}{ 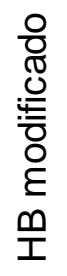 } & $\tau$ Tesc $(\mathrm{Nm})$ & 8,00 & 7,00 & 3,00 & 0,52 \\
\hline & $\mathrm{k}$ & 0,65 & 0,47 & 0,20 & 0,04 \\
\hline & $\mathrm{n}$ & 0,35 & 0,32 & 0,30 & 0,12 \\
\hline & $\alpha$ & 100 & 100 & 100 & 100 \\
\hline
\end{tabular}

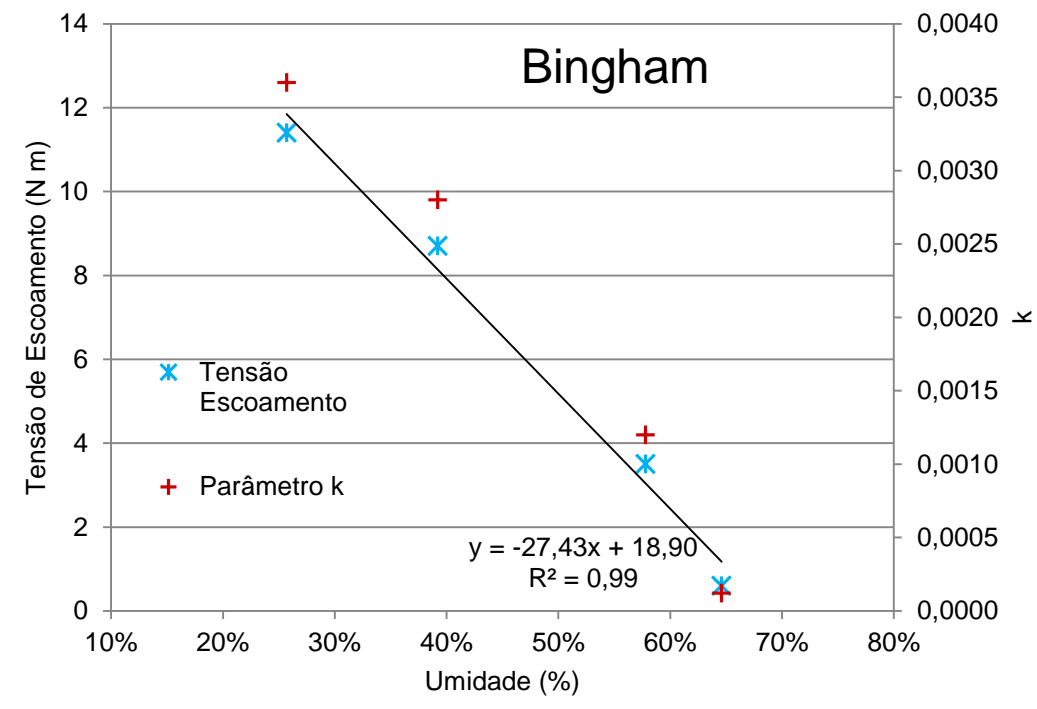

Figura 5.48 Variação da tensão de escoamento e do $\mathrm{k}$ coma umidade - Bingham 


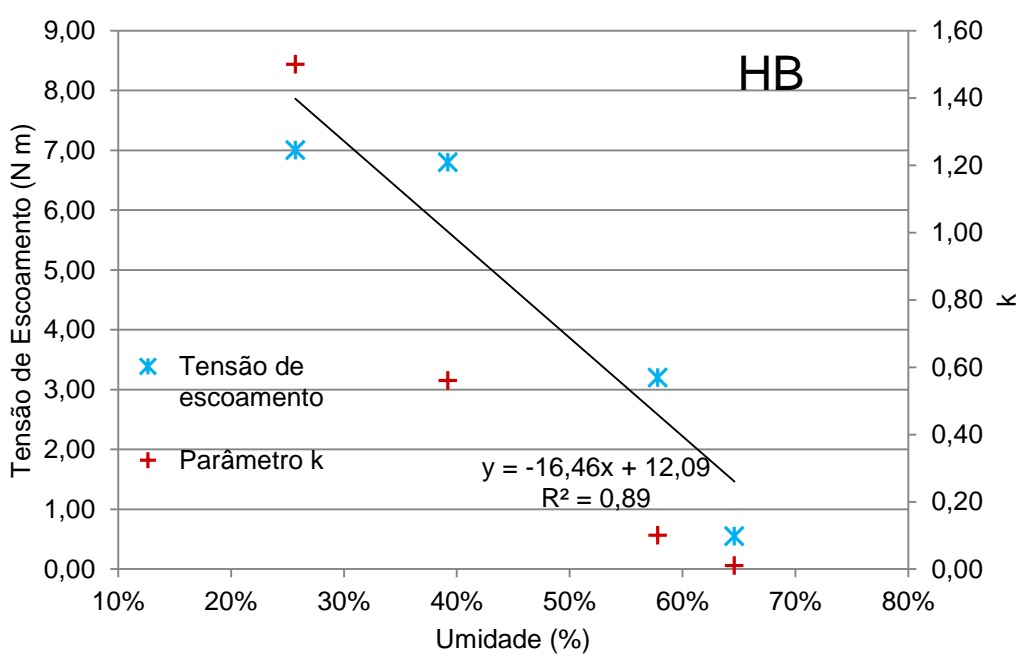

Figura 5.49 Variação da tensão de escoamento e do $\mathrm{k}$ coma umidade - HB

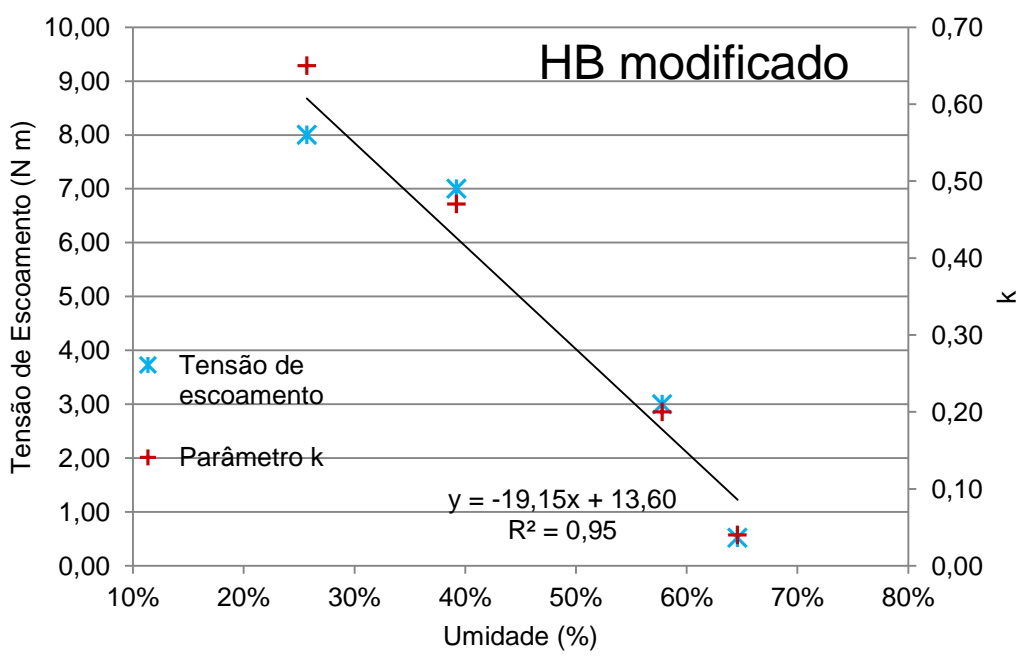

Figura 5.50 Variação da tensão de escoamento e do k coma umidade - HB modificado

Através de aproximações lineares, foi possível obter o valor de umidade para o qual a tensão de escoamento seria nula, que foram de 68,9\%, 73,5\% e 71,0\%, apresentando uma média de 71,1\%.

Ainda com os dados obtidos é possível apresentar a Figura 5.51, na qual é possível visualizar que os valores determinados para a tensão de escoamento apresentam menor variação quanto maior a umidade, o que acontece porque quanto maior o teor de umidade mais o solo se assemelha ao comportamento líquido, e isso faz com que os modelos se adequem melhor aos dados, resultando em aproximações mais fiéis aos dados e concordantes entre si. 


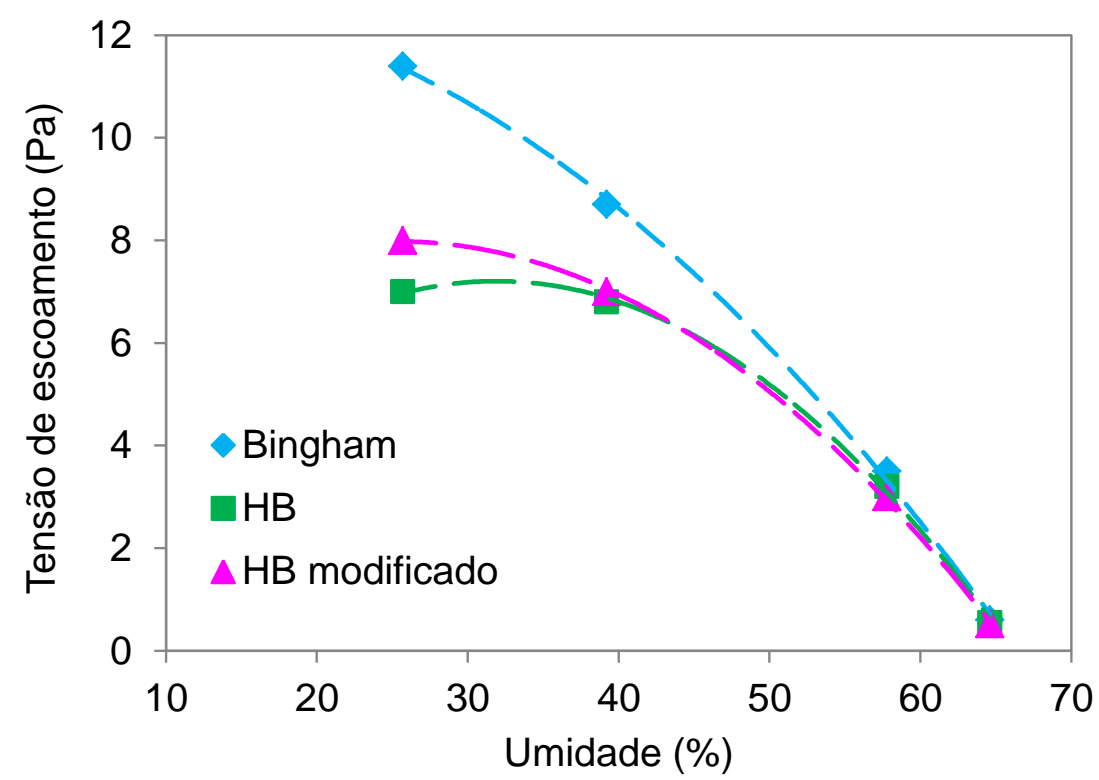

Figura 5.51 Variação da tensão de escoamento para os modelos estudados

Comparando esses resultados com os da Figura 5.42 é possível observar uma grande diferença entre os valores encontrados, sendo que através do ensaio de squeeze flow a umidade limite para liquefação foi de aproximadamente $41 \%$. Essa diferença nos valores observados indica que o tipo de solicitação imposta influencia nos parâmetros do solo. A discussão sobre qual ensaio é o mais representativo para a determinação desse limite em solos será feita com base nos resultados obtidos para esse trabalho, nos capítulos finais.

\subsection{Aplicação na Geotecnia}

Macias et al. (1997) aplicaram os conceitos da reologia na avaliação do comportamento de movimentações do tipo corridas, ocorridas em 1996, no Quitite, Papagaio e Vale Encantado, no Rio de Janeiro. Para isso, consideraram os modelos propostos por Bagnold (1954), que foi baseado no modelo reológico de Newton, e o modelo de Johnson (1970), baseado nos modelos de Saint Venan e Bingham. Além disso, utilizaram equação proposta por Mears (1981) para estimativa da velocidade de movimentação dos debris flows. 
Macias et al. (1997) consideraram que o debris flow é uma mistura de blocos rochosos envolvidos por uma matriz fina, sendo que foram realizadas medidas da geometria dos depósitos através da coleta de amostras em campo para determinar os parâmetros requeridos para cada análise e construídos perfis transversais em escala.

Através da utilização da equação de Mears (1981), e dos modelos propostos por Bagnold (1954) e Johnson (1970), Macias et al. (1997) objetivaram determinar as velocidades, o comportamento mecânico e os parâmetros reológicos das corridas de massa.

Macias et al. (1997) primeiro utilizaram a Equação 5.27, proposta por Mears (1981), desenvolvida para avalanches, para determinar a velocidade de movimentação das corridas de massa.

$$
v^{2}=\frac{\Delta h r g}{c b}
$$

Onde: $\Delta$ h é a diferença de elevação entre os extremos do canal $(\mathrm{m})$, r é o raio de curvatura $(\mathrm{m}), \mathrm{g}$ é a gravidade $\left(\mathrm{m} / \mathrm{s}^{2}\right)$, c é o fator de correção (adimensional), adotado como 2,5 e b a largura transversal da corrida $(\mathrm{m})$. Os valores de $\Delta \mathrm{h}, \mathrm{r}$ e b foram obtidos a partir de perfis desenhados em escala. Os resultados obtidos para a velocidade estão apresentados na Tabela 5.7.

Tabela 5.7 Parâmetros e Resultados da Aproximação segundo Mears (1981) (MACIAS et al., 1997)

\begin{tabular}{|cc|c|c|c|}
\hline \multicolumn{2}{|c|}{ Parâmetro } & Quitite & Papagaio & $\begin{array}{c}\text { Vale } \\
\text { Encantado }\end{array}$ \\
\hline$\Delta \mathrm{h}$ & $\mathrm{m}$ & 3,2 & 1,8 & 0,5 \\
\hline $\mathrm{b}$ & $\mathrm{m}$ & 61 & 29 & 19 \\
\hline $\mathrm{r}$ & $\mathrm{m}$ & 137 & 23,9 & 14,8 \\
\hline $\mathrm{c}$ & & 2,5 & 2,5 & 2,5 \\
\hline $\mathrm{v}$ & $\mathrm{m} / \mathrm{s}$ & 5,3 & 2,41 & 1,38 \\
\hline
\end{tabular}

A partir dos dados de velocidade, foi possível a utilização do modelo de Bagnold (1951), apresentados nas Equações 5.28 a 5.31. O modelo de Bagnold foi baseado em um estudo experimental realizado com esferas sólidas dispersas num líquido de comportamento Newtoniano, vaiando a concentração de partículas e determinando a relação adimensional entre a taxa de deformação (N) e o esforço cisalhante $\left(\mathrm{G}^{2}\right)$ atuante na mistura. (MACIAS et al., 1997) 


$$
\begin{gathered}
N=\frac{\lambda^{1 / 2} \Phi^{2} \sigma}{\mu} \frac{d v}{d z} \\
G^{2}=\frac{T \Phi^{2} \sigma}{\lambda \mu^{2}} \\
v=\frac{N}{G} \frac{T^{1 / 2}}{\sigma^{1 / 2} \Phi \lambda} \\
v=\frac{N}{G^{2}} \frac{T}{\lambda^{2 / 3}} \frac{1}{\mu} z
\end{gathered}
$$

Onde: $\lambda$ é o fator de concentração de partículas (adimensional), $\Phi$ é o diâmetro das partículas $(\mathrm{m}), \sigma$ é a massa específica das partículas $\left(\mathrm{kg} / \mathrm{m}^{3}\right), \mathrm{T}$ é o esforço cisalhante na mistura ( $\mathrm{kPa})$, vé a velocidade do fluido $(\mathrm{m} / \mathrm{s})$, z é a espessura do depósito da corrida $(\mathrm{m}), \mu$ é a viscosidade newtoniana do fluido (kPa.s), dv é o diferencial de velocidade e dz o diferencial de espessura.

Para determinar o comportamento mecânico das corridas, são utilizados os parâmetros $\mathrm{N} \mathrm{e} \mathrm{G}^{2}$, como pode ser observado na Figura 5.52.

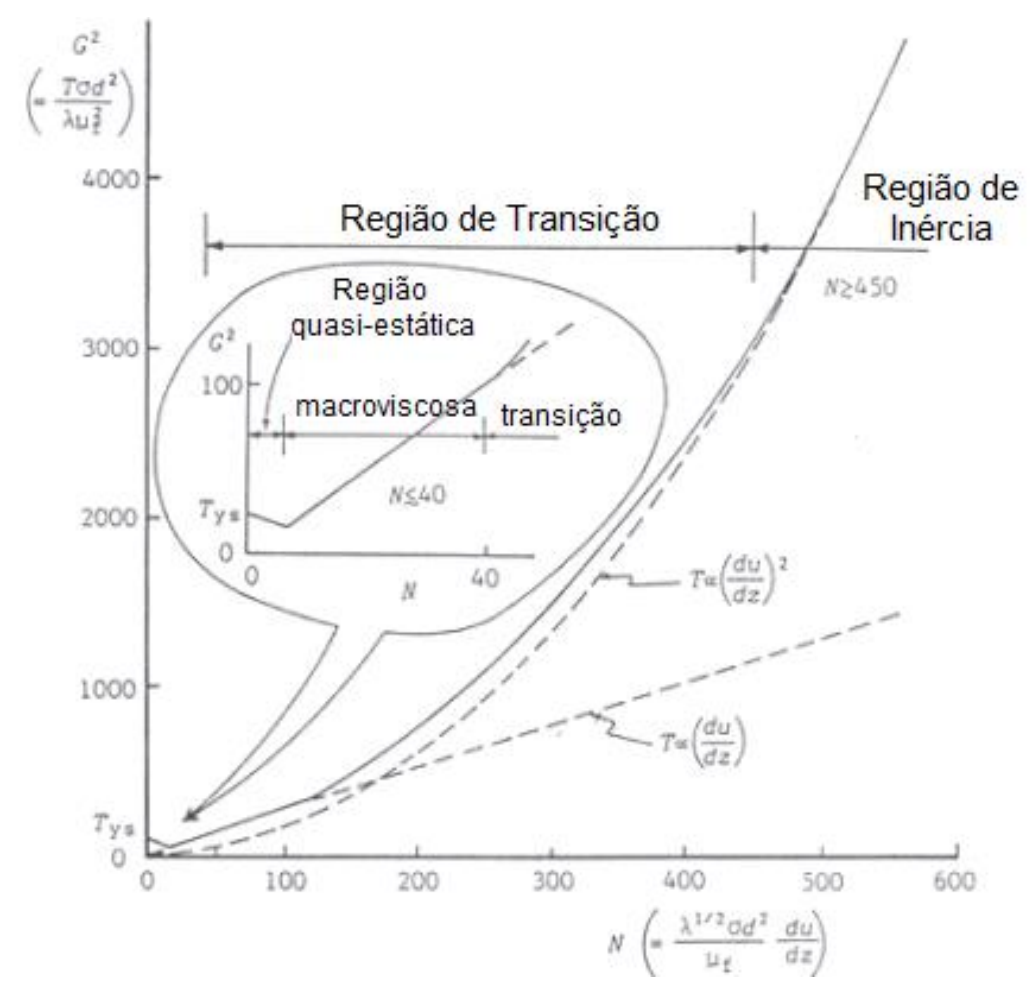

Figura 5.52 Taxa de deformação cisalhante $(\mathrm{N})$ versus esforço cisalhante $\left(\mathrm{G}^{2}\right)$ (TAKAHASHI, 1991) 
Bagnold (1954) definiu dois tipos de regimes de escoamento denominados por regime inercial e regime macro viscoso. No regime inercial a taxa de cisalhamento é alta e a inércia sobre o movimento dos grãos é dominante. No regime macro viscoso as taxas de cisalhamento são baixas e os efeitos do fluido intersticial viscoso dominam, ou seja, um fluido newtoniano com partículas sólidas inertes, na região macro viscosa, possui um comportamento newtoniano com um coeficiente de viscosidade modificado.

Os valores de $\lambda$ foram determinados a partir de seções transversais desenhadas em escala, os de $\Phi$ e $z$ foram medidos em campo e os valores de $\sigma$ determinados através de ensaios. Os resultados obtidos estão apresentados na Tabela 5.8 (MACIAS et al., 1997).

Os valores de $\mathrm{N}$ obtidos para as três localidades foi de $\mathrm{N}$ igual a 149 no Quitite, indicando um comportamento mecânico do tipo Transição, N de 39 na corrida do Papagaio indicando um comportamento do tipo Transição-Macroviscoso e $\mathrm{N}$ de 25 na corrida do Vale Encantado indicando um comportamento mecânico do tipo Macroviscoso (MACIAS et al., 1997).

Tabela 5.8 Parâmetros e resultados da análise segundo Bagnold (1954) (MACIAS et al., 1997)

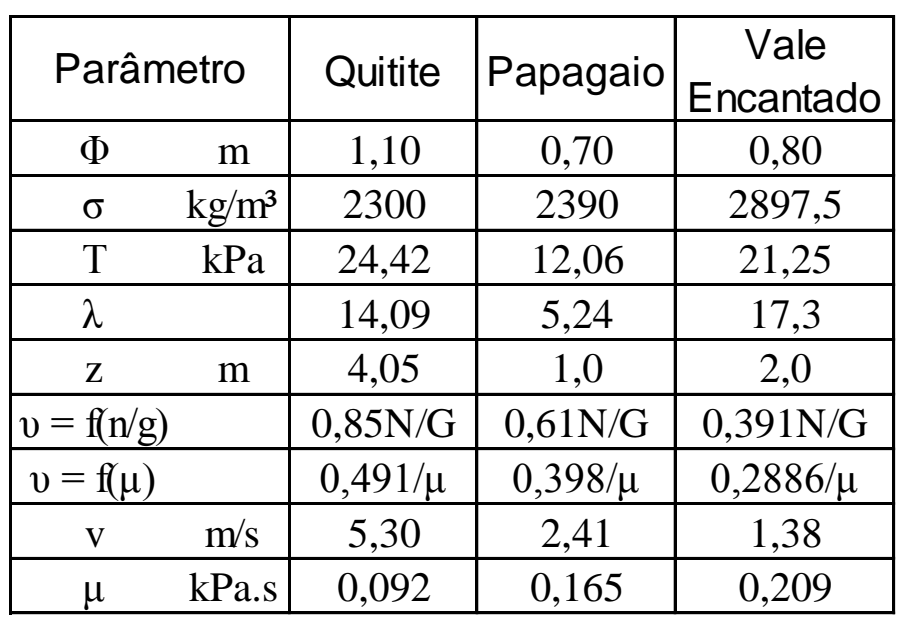

Johnson (1971) utilizou o modelo reológico de Bingham e obteve a Equação 5.32, tratando analiticamente o comportamento mecânico da corrida, com base na distribuição de sua velocidade ao longo do canal. (MACIAS et al., 1997)

$$
v=\frac{1}{\mu_{b}}\left[\frac{\gamma \sin \delta}{2\left[1+(a / b)^{2}\right]}\left\{b^{2}\left[\frac{k\left(1+(a / b)^{2}\right)}{\gamma \sin \delta}\right]\right\}-k b+\frac{k^{2}\left[1+(a / b)^{2}\right]}{\gamma \sin \delta}\right]
$$


Onde: $v$ é a velocidade da seção rígida $(\mathrm{m} / \mathrm{s}), \mu_{b}$ é a viscosidade do detrito para Bingham (kPa.s), $\gamma$ é o peso unitário do detrito $\left(\mathrm{kN} / \mathrm{m}^{3}\right), \delta$ a inclinação da superfície do fluxo, a é metade da largura transversal da corrida $(\mathrm{m})$, b é a espessura da corrida $(\mathrm{m})$ e k é a tensão de escoamento do detrito (kPa).

Os valores de $H_{S}, h_{c}, X_{0}, Y_{0}, a, b$ e $\delta$ foram obtidos por medição direta em campo, $\gamma$ por ensaios de laboratório e o valor de $k$ (tensão de escoamento) foi calculado a partir da média das Equações 5.33 e 5.34. Onde: $h_{c}$ é a espessura da seção rígida na frente da corrida e $\mathrm{H}_{\mathrm{S}}$ a altura da frente da corrida. A Tabela 5.9 apresenta os parâmetros e resultados da análise realizada de acordo com Johnson (1970).

$$
\begin{gathered}
k=h_{c} \gamma \sin \delta \\
k=\frac{H_{s} \gamma}{\pi\left(1-\left(\frac{\delta}{90}\right)\right)}
\end{gathered}
$$

Tabela 5.9 Parâmetros e resultados da análise segundo Johnson (1970) (MACIAS et al., 1997)

\begin{tabular}{|cc|c|c|}
\hline \multicolumn{2}{|c|}{ Parâmetro } & Quitite & Papagaio \\
\hline $\mathrm{K}$ & $\mathrm{kPa}$ & 24,42 & 12,06 \\
\hline $\mathrm{H}_{\mathrm{S}}$ & $\mathrm{m}$ & 4,8 & 2,4 \\
\hline $\mathrm{h}_{\mathrm{C}}$ & $\mathrm{m}$ & 3,3 & 1,2 \\
\hline$\delta$ & graus & 10 & 10 \\
\hline$\gamma$ & $\mathrm{kN} / \mathrm{m}^{3}$ & 20,92 & 22,61 \\
\hline $\mathrm{X}_{0}$ & $\mathrm{~m}$ & 26,0 & 9,0 \\
\hline $\mathrm{Y}_{0}$ & $\mathrm{~m}$ & 3,3 & 1,2 \\
\hline $\mathrm{a}$ & $\mathrm{m}$ & 30,5 & 14,5 \\
\hline $\mathrm{b}$ & $\mathrm{m}$ & 4,05 & 1,80 \\
\hline $\mathrm{a} / \mathrm{b}$ & & 7,53 & 8,05 \\
\hline $\mathrm{X}_{0} / \mathrm{b}$ & & 0,852 & 0,621 \\
\hline $\mathrm{K}$ & & 0,0148 & 0,0094 \\
\hline $\mathrm{K}^{*}$ & & 0,111 & 0,075 \\
\hline $\mathrm{v}^{*}$ & & 0,30 & 0,34 \\
\hline $\mathrm{v}=\mathrm{f}(\mu)$ & & $18,22 / \mu$ & $4,32 / \mu$ \\
\hline $\mathrm{V}$ & $\mathrm{m} / \mathrm{s}$ & 5,30 & 2,41 \\
\hline$\mu$ & $\mathrm{kPa} . \mathrm{s}$ & 3,44 & 1,79 \\
\hline
\end{tabular}

A partir de valores de velocidade obtidos através da equação de Mears (1981), Macias et al. (1997) calcularam a viscosidade dos materiais de cada corrida de massa e apresentaram na Figura 5.53 e na Figura 5.54 as relações da velocidade 
em função da viscosidade para as seções de comportamento rígido das corridas de massa do Papagaio e Quitite.

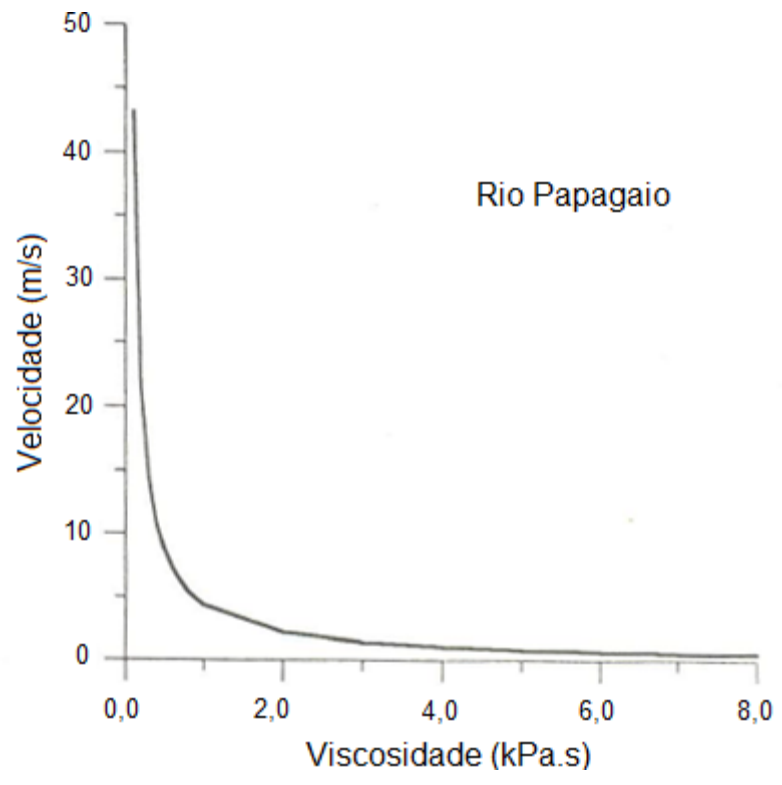

Figura 5.53 Relação da velocidade com a viscosidade na corrida do Papagaio segundo o modelo de Johnson (1970) (MACIAS et al., 1997)

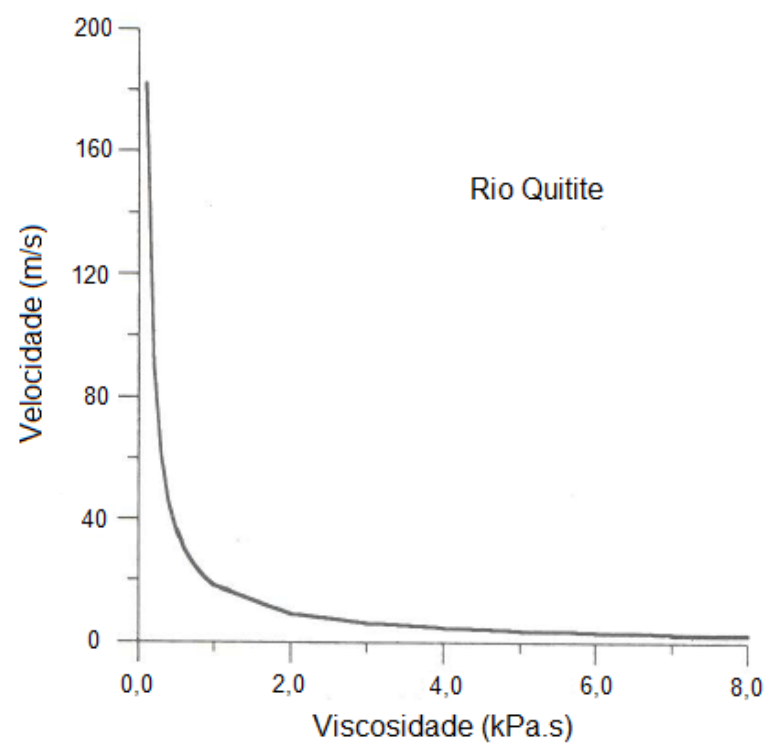

Figura 5.54 Relação da velocidade com a viscosidade na corrida do Quitite segundo o modelo de Johnson (1970) (MACIAS et al., 1997)

Esse trabalho foi um dos primeiros no país a relacionar a viscosidade com uma grandeza física de grande interessa na geotecnia que é a velocidade da corrida de massa. 


\section{ENSAIOS E RESULTADOS}

\section{1. Área de Estudo}

Nova Friburgo é um município localizado em região Serrana com altitude de $846 \mathrm{~m}$ no centro da cidade, com área total de $938,5 \mathrm{~km}^{2}$. Tem população em torno de 182.000 habitantes distribuídos em oito distritos (Nova Friburgo, Riograndina, Campo do Coelho, Amparo Lumiar, Conselheiro Paulino, São Pedro da Serra e Muri). A principal atividade econômica da cidade é o turismo. Apresenta um clima tropical de altitude com temperaturas amenas no verão e frias no inverno, com as quatro estações bem definidas (Prefeitura de Nova Friburgo).

A cidade de Nova Friburgo foi uma das mais afetadas no evento catastrófico de 2011. Objetivando investigar o desenvolvimento dos processos de ruptura que ocorreram no local foram coletadas duas amostras de solo na cidade nos dias $27 \mathrm{e}$ 28 de maio de 2011, ou seja, quatro meses e meio depois do evento.

O local de retirada das amostras é uma estrada secundária, sem pavimentação, localizada entre os municípios de Nova Friburgo e Teresópolis, no km 50 da RJ-130. A RJ-130 recebe o nome de Rodovia Dr. Rogério de Moura Estevão no município de Teresópolis e de Rodovia Antônio Mário de Azevedo em Nova Friburgo, sendo popularmente conhecida como Tere-Fri. Durante os $9 \mathrm{~km}$ percorridos na rodovia Teresópolis-Friburgo foi possível visualizar dezenas de escorregamentos, assim como na estrada secundária, tanto nas áreas habitadas quanto nas áreas aparentemente preservadas, alguns desses escorregamentos estão apresentados na Figura 6.1. 

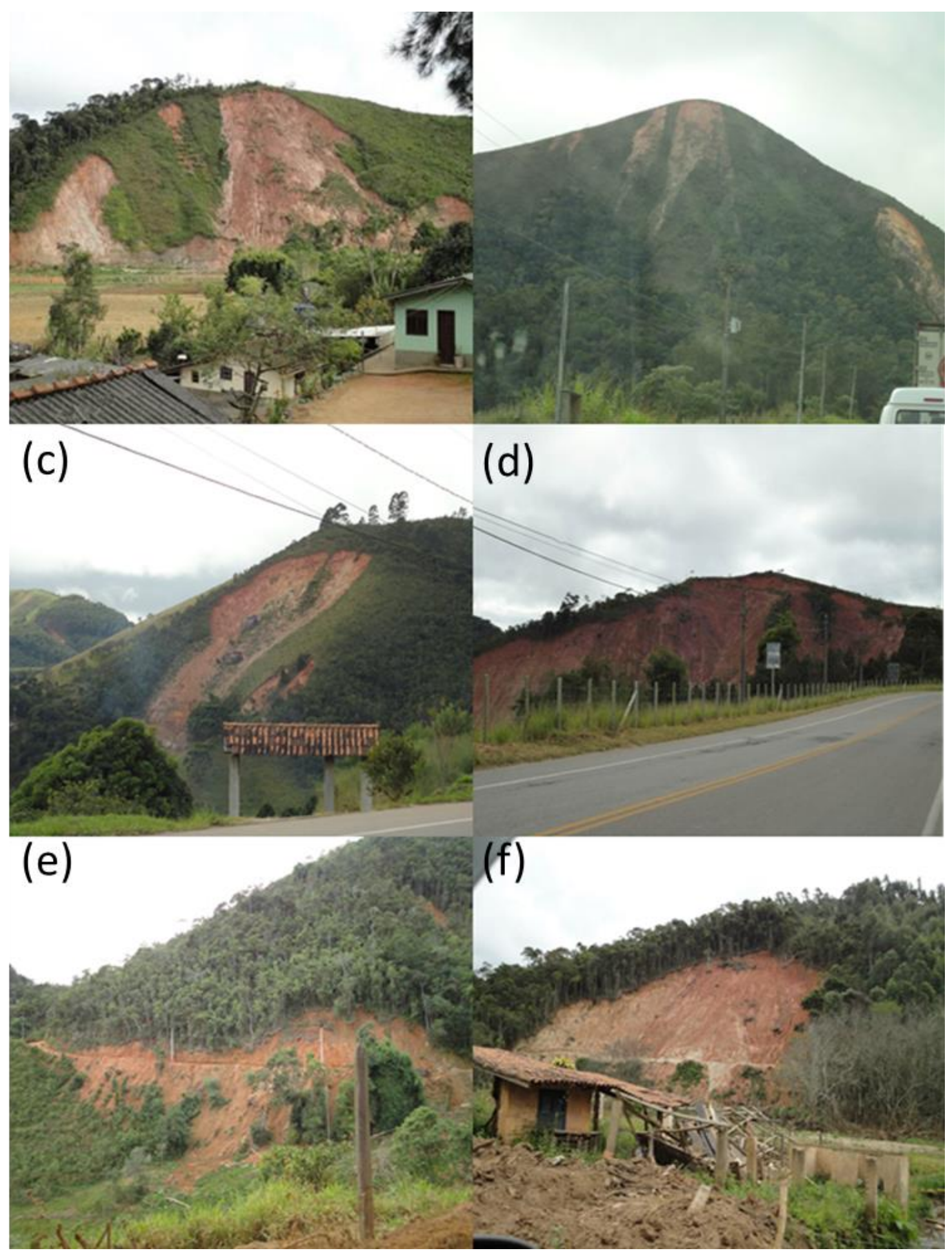

Figura 6.1 Diversos escorregamentos observados na rodovia RJ-130

\subsection{Amostragem}

Para determinar os locais de coleta das amostras foi observado que a maioria dos escorregamentos, na área à qual se teve acesso, havia ocorrido em perfil 
composto por dois solos visivelmente diferentes: o saprólito de coloração rosa que sofreu intenso intemperismo de granito e o colúvio de cor vermelha que sofreu intensa laterização, encontrado na cobertura de taludes, esses dois solos estão apresentados na Figura 6.2. Foram retirados dois blocos indeformados dos solos citados, que puderam ser retirados porque nos dois casos o talude foi cortado para a reconstrução da estrada que ficou completamente obstruída depois do evento de janeiro. Para facilitar a identificação das amostras estas passam a ser denominadas de residual e colúvio. O solo denominado por residual é um saprolítico de granito e o solo coluvionar é um colúvio de sopé que cobre os taludes e não dos fundos dos vales.

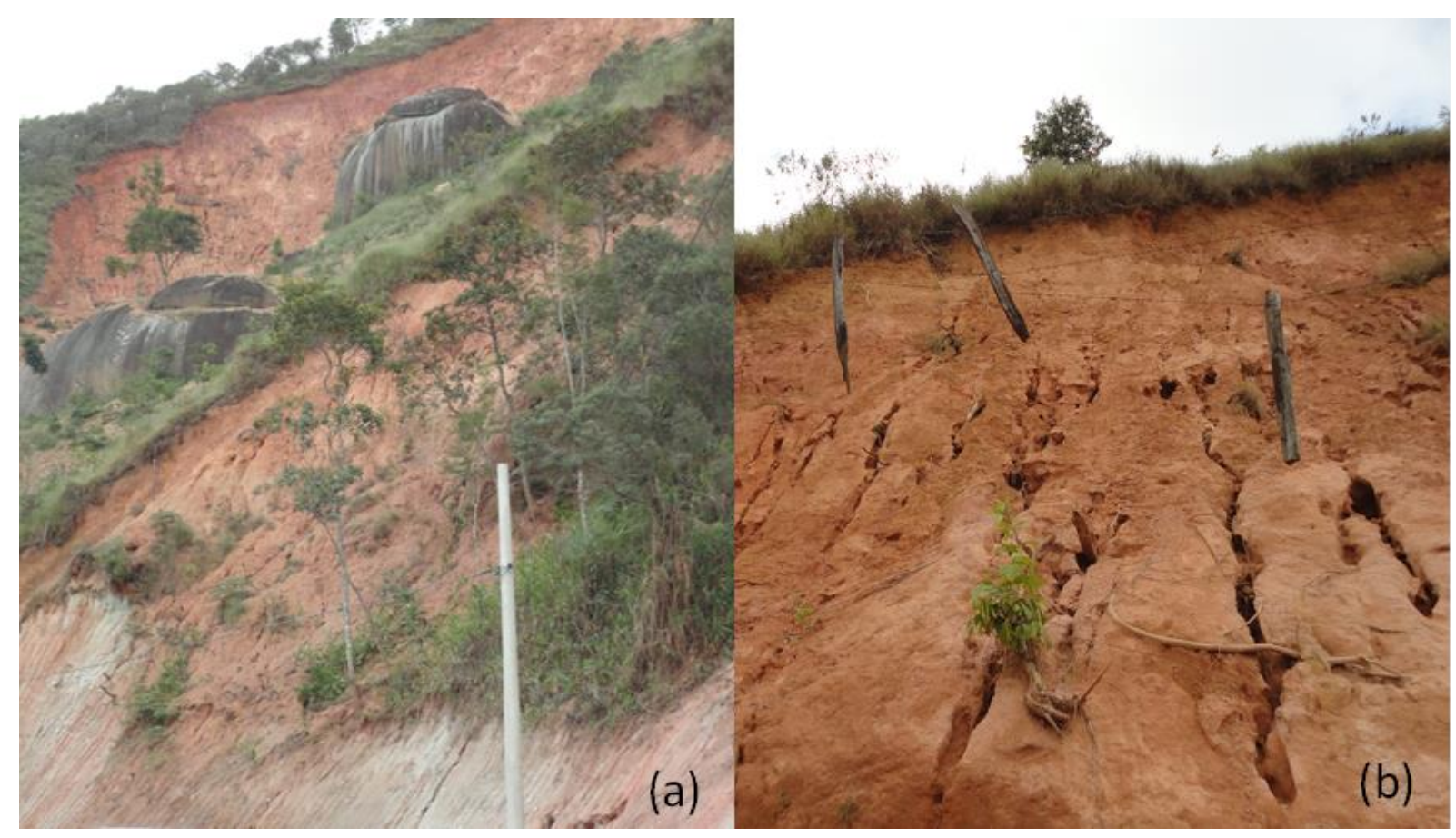

Figura 6.2 Solos predominantes nos escorregamentos (a) residual e (b) colúvio

A primeira amostra indeformada, de solo residual de granito, foi colhida a 700 $\mathrm{m}$ da rodovia $\mathrm{RJ}-130$ a partir da saída do $\mathrm{km} 50$. A profundidade do topo da amostra é de aproximadamente $6 \mathrm{~m}$, as dimensões da caixa coletora são $30 \mathrm{~cm} \times 30 \mathrm{~cm} \times 30$ $\mathrm{cm}$. Além do bloco, foram coletados $7 \mathrm{~kg}$ de material deformado em saco plástico. As coordenadas da posição do bloco são: $22^{\circ} 16^{\prime}$ 18,27' e $42^{\circ} 36^{\prime}$ 03,10". O procedimento de coleta da amostra está apresentado na Figura 6.3, na qual (a) representa o corte inicial do talude com as dimensões do bloco bem superiores às 
da caixa, (b) a adequação da dimensão que foi realizada com equipamento mais leve como espátulas e martelo geológico, (c) o bloco nas dimensões requeridas, (d) passou-se papel alumínio ao redor do bloco para protegê-lo da infiltração da parafina, (e) o bloco foi enrolado por faixas para preservar sua geometria e (f) a caixa foi suavemente colocada ao redor do bloco e jogou-se parafina líquida entre $o$ vão do bloco e da caixa. A coloração do solo residual nas imagens (c) a (f) está diferente das imagens (a) e (b), pois foi necessária a utilização do flash da máquina fotográfica.

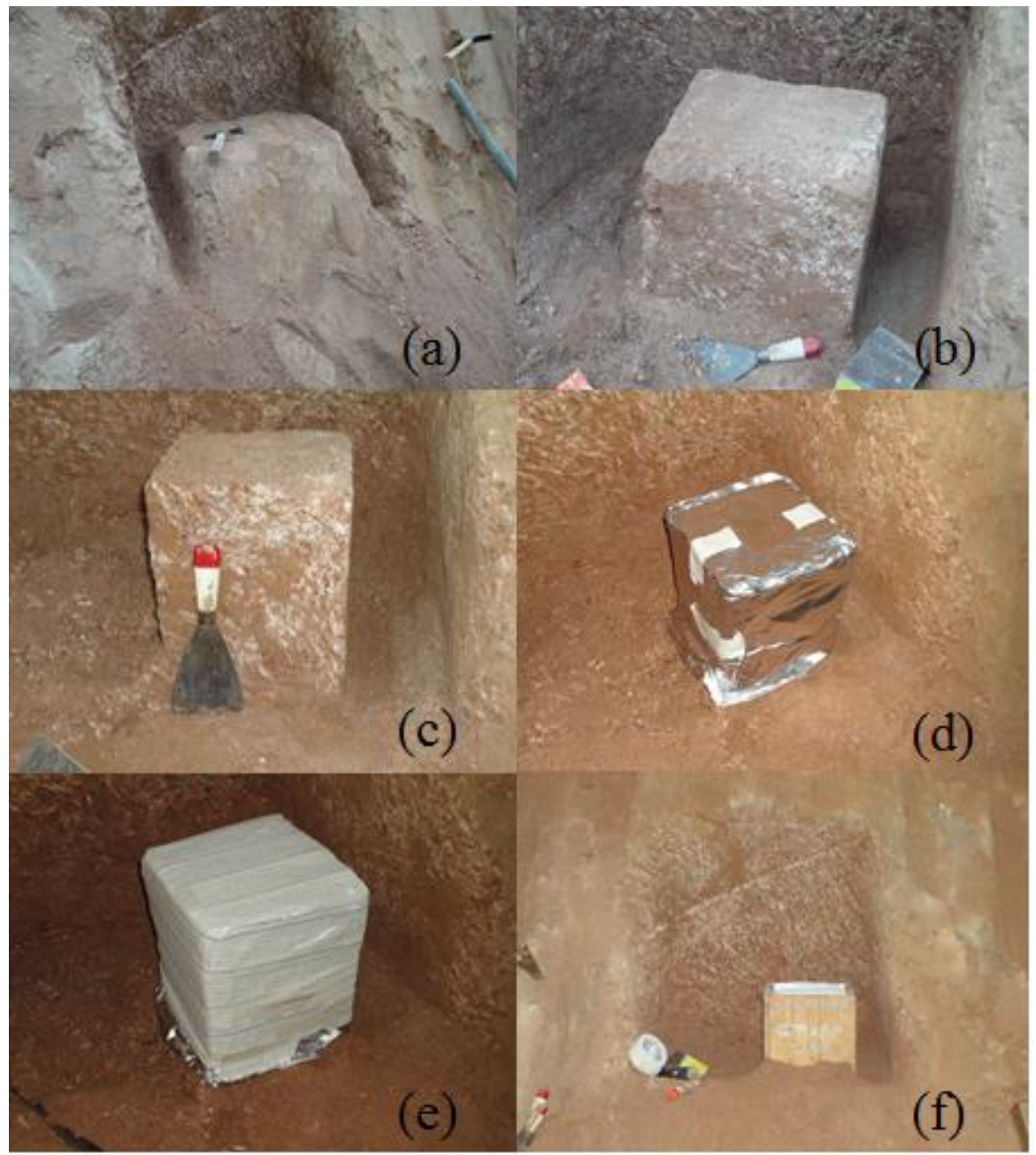

Figura 6.3 Procedimento de retirada de amostra indeformada - solo residual

Para a retirada do segundo bloco de solo indeformado, o colúvio, apresentado na Figura 6.4, foi necessário percorrer por $4 \mathrm{~km}$ pela estrada de terra além da RJ130 para localizar um ponto onde fosse possível coletar essa amostra. Isso por dois motivos: primeiro que a maioria dos escorregamentos era do solo residual de granito e segundo que os escorregamentos com colúvio estavam localizados em locais com 
difícil acesso pelas estradas de terra da região. A profundidade de topo da amostra foi de aproximadamente $3 \mathrm{~m}$, também foram coletados $7 \mathrm{~kg}$ de solo deformado.

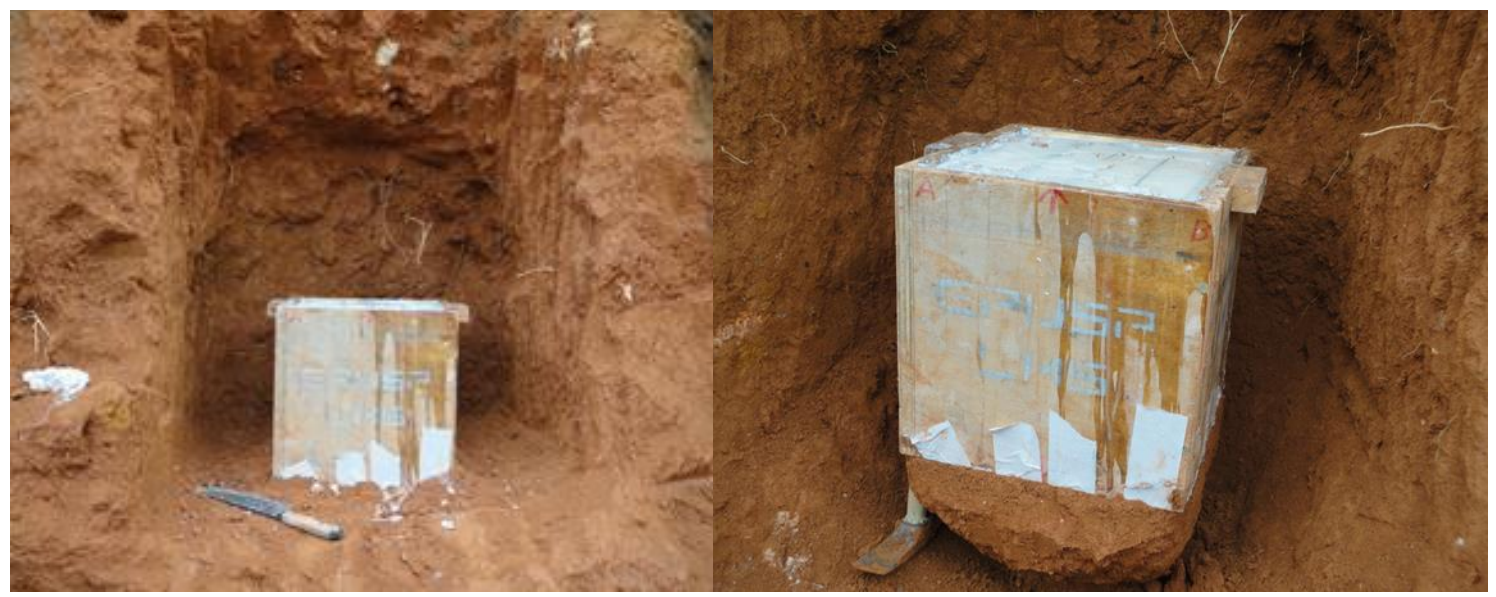

Figura 6.4 Amostragem do segundo bloco indeformado - colúvio

A localização dos dois pontos de amostragem, em relação aos escorregamentos ocorridos na região está apresentada na Figura 6.5.

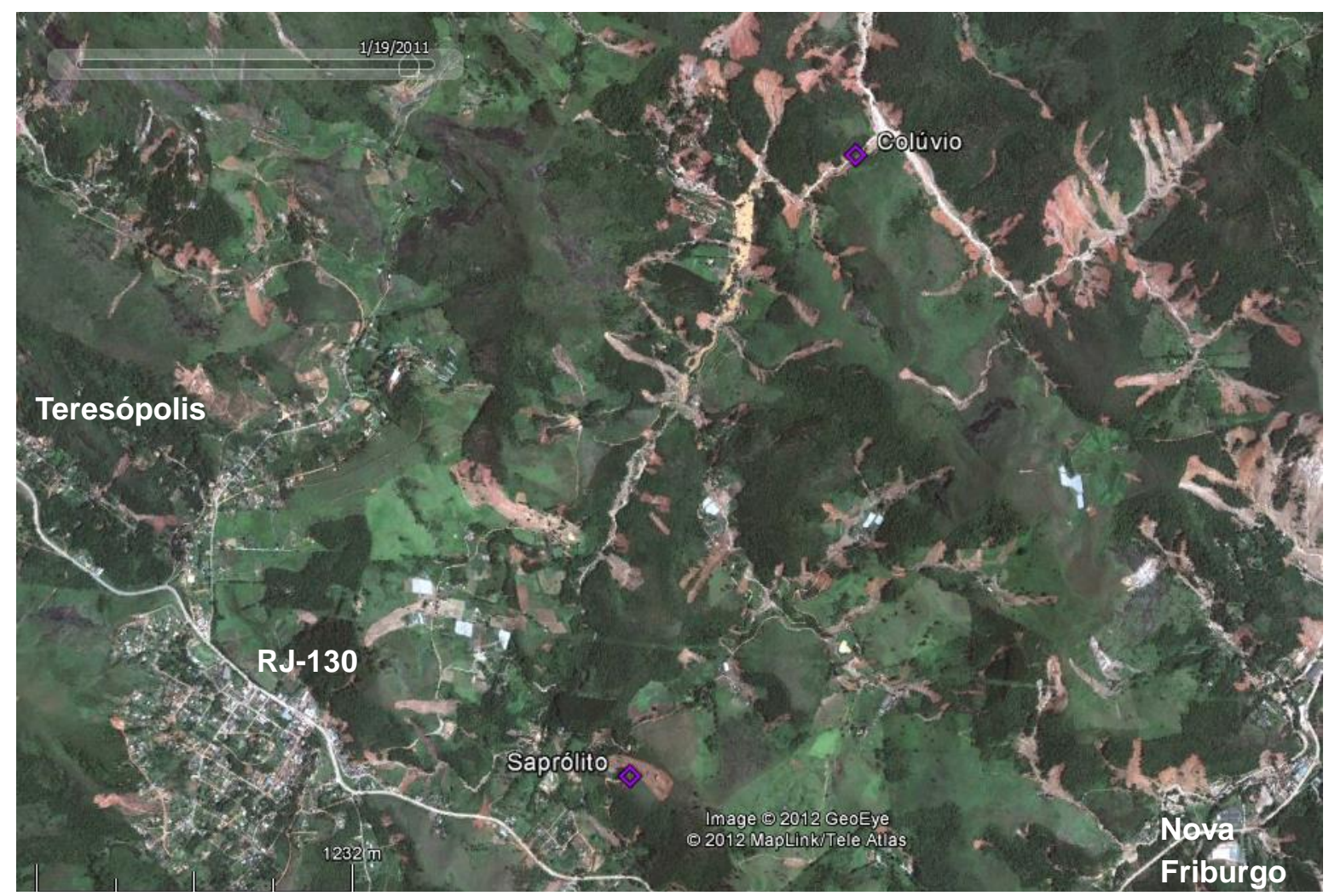

Figura 6.5 Localização dos pontos de coleta de amostra

As amostras foram levadas ao Laboratório de Mecânica dos Solos da Escola Politécnica da USP onde foram parafinadas novamente para cobrir quaisquer defeitos da parafina em campo e dispostas em câmara úmida, para se conservarem 
o mais original possível. Dos blocos indeformados foram moldados corpos de provas para os ensaios de cisalhamento direto e a amostra deformada foi utilizada nos ensaios de limites, granulometria e nos ensaios reométricos.

\subsection{Ensaios de Caracterização}

Para a realização dos ensaios de caracterização as amostras foram previamente secas ao ar, até a umidade higroscópica de acordo com a NBR 6457/1986 (Amostras de solo - Preparação para ensaios de compactação e ensaios de caracterização).

A granulometria foi determinada de acordo com a NBR 7181/1984 (Solo Análise Granulométrica), sendo realizado 0 ensaio por peneiramento e sedimentação. A determinação da massa específica foi realizada seguindo as recomendações da NBR 6508/1982 (Grãos de solos que passam na peneira de $4,8 \mathrm{~mm}$ - determinação da massa específica). A distribuição granulométrica obtida para os dois solos está apresentada na Figura 6.6. A partir do formato da curva é possível afirmar que os dois solos apresentam uma granulometria bem distribuída.

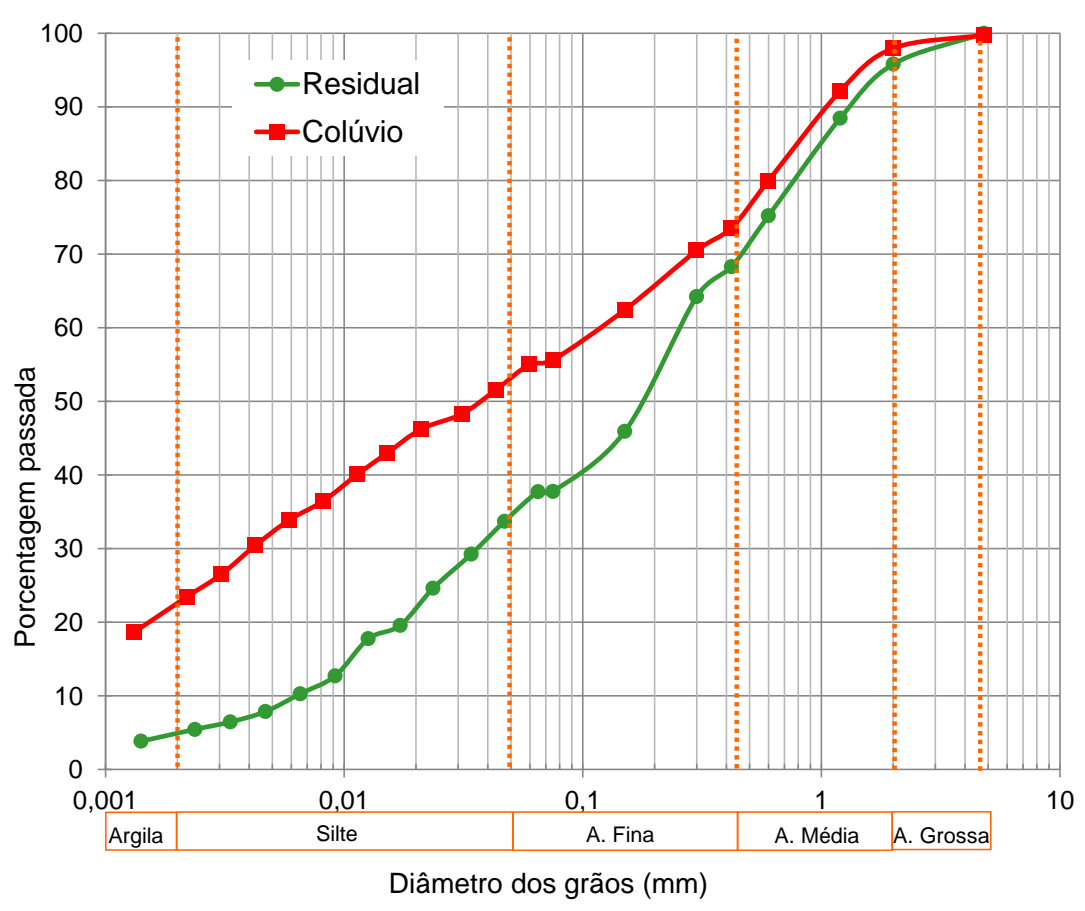

Figura 6.6 Distribuição granulométrica das amostras 
Os ensaios de determinação dos limites foram realizados de acordo com as NBR 7180/1984 (Solo - Determinação do Limite de Plasticidade) e NBR 6459/1984 (Solo - Determinação do Limite de Liquidez). O limite de plasticidade do solo residual foi realizado com aproximadamente $5 \mathrm{~mm}$ de diâmetro por causa da alta quantidade de areia e silte. A Tabela 6.1 apresenta os dados obtidos dos solos.

Tabela 6.1 Resumo dos dados obtidos

\begin{tabular}{|l|c|c|c|c|c|c|c|}
\cline { 2 - 8 } \multicolumn{1}{c|}{} & \% Areia & \% Silte & $\%$ Argila & $\begin{array}{c}\text { densidade } \\
\text { específica } \\
\mathbf{V}_{\mathbf{s}}\left(\mathbf{k N} / \mathbf{m}^{\mathbf{3}}\right)\end{array}$ & $\mathbf{w}_{\mathrm{L}}(\%)$ & $\mathbf{w}_{\mathbf{P}}(\%)$ & IP (\%) \\
\hline Colúvio & 47 & 30 & 23 & 26,56 & 53,6 & 36,3 & 17,3 \\
\hline Residual & 66 & 29 & 5 & 26,62 & 36,4 & 30,9 & 5,5 \\
\hline
\end{tabular}

\subsection{Resistência ao Cisalhamento Direto}

A resistência ao cisalhamento dos solos foi investigada através de ensaios de cisalhamento direto, que foram realizados com as amostras inundadas para que fosse possível investigar a condição de interesse, com o solo saturado ou próximo da saturação.

Os corpos de prova foram moldados com altura de $2,5 \mathrm{~cm}$ e seção quadrada com 6,0 cm de lado, passaram por processo de adensamento durante 24 horas, com medidas realizadas nas primeiras oito horas. No cisalhamento o deslocamento total foi de $8 \mathrm{~mm}$, com velocidade de 0,03 $\mathrm{mm} / \mathrm{min}$, para garantir a drenagem do corpo de prova. A prensa utilizada está apresentada na Figura 6.7. 


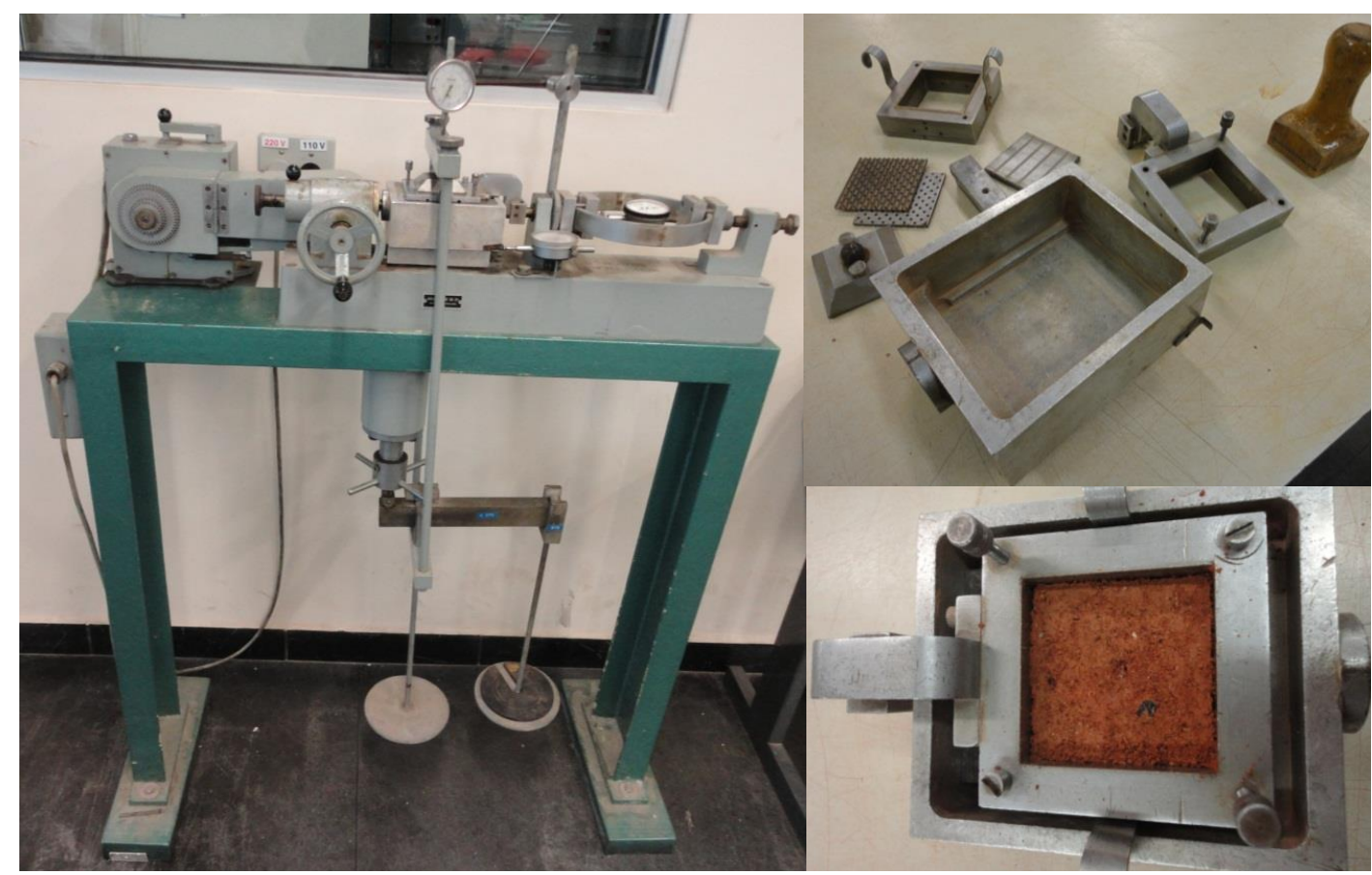

Figura 6.7 Prensa e componentes para o ensaio de cisalhamento direto

Os parâmetros dos corpos de prova e os dados obtidos do cisalhamento direto estão apresentados na Tabela 6.2 e nas Figuras 6.8 à 6.11 . A umidade de campo é aquela correspondente ao período seco da região, em maio, quando as amostras foram coletadas. A partir dos dados obtidos foi possível traçar a envoltória de resistência apresentada na Figura 6.12.

Tabela 6.2 Parâmetros do ensaio de cisalhamento direto

\begin{tabular}{|c|c|c|c|c|c|c|c|c|}
\hline & $\begin{array}{c}\sigma \\
(\mathrm{kPa})\end{array}$ & $\begin{array}{c}\mathrm{W}_{\text {inicial }} \\
(\%)\end{array}$ & $\begin{array}{c}V_{n} \\
\left(k N / m^{3}\right) \\
\end{array}$ & $\begin{array}{c}V_{d} \\
\left(k N / m^{3}\right)\end{array}$ & $e_{0}$ & $\begin{array}{c}S_{\text {inicial }} \\
(\%)\end{array}$ & $\begin{array}{c}S_{\text {final }} \\
(\%)\end{array}$ & $\begin{array}{c}\tau \\
(\mathrm{kPa})\end{array}$ \\
\hline \multirow{4}{*}{$\frac{\text { 응 }}{\text { 임 }}$} & 25 & 25,0 & 16,77 & 13,42 & 0,979 & 68 & 98 & 27,7 \\
\hline & 50 & 24,9 & 16,51 & 13,22 & 1,010 & 65 & 98 & 42,1 \\
\hline & 100 & 26,4 & 16,93 & 13,40 & 0,982 & 71 & 100 & 70,2 \\
\hline & 200 & 28,2 & 16,19 & 12,63 & 1,103 & 68 & 94 & 147,8 \\
\hline \multirow{4}{*}{$\begin{array}{l}\overline{\mathbb{T}} \\
\frac{0}{\mathscr{D}} \\
\stackrel{\mathbb{D}}{ } \\
\simeq\end{array}$} & 25 & 13,1 & 14,68 & 12,98 & 1,051 & 33 & 93 & 15,9 \\
\hline & 50 & 12,6 & 14,03 & 12,47 & 1,135 & 29 & 92 & 40,6 \\
\hline & 100 & 12,8 & 14,60 & 12,95 & 1,051 & 32 & 92 & 67,2 \\
\hline & 200 & 13,3 & 14,86 & 13,12 & 1,029 & 34 & 92 & 134,5 \\
\hline
\end{tabular}




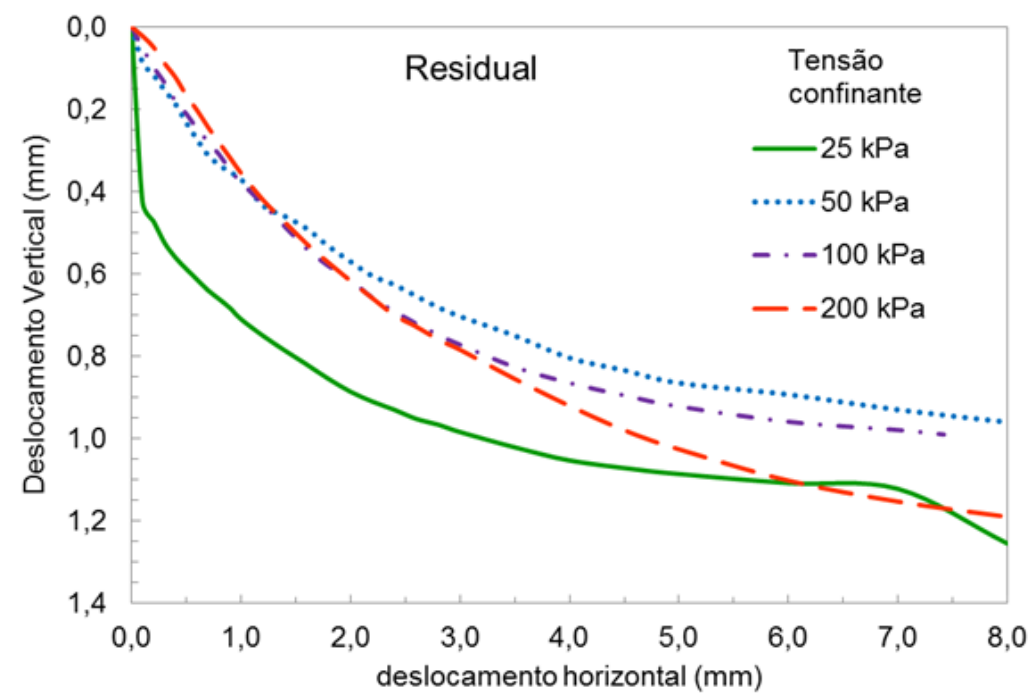

Figura 6.8 Recalque durante o ensaio de cisalhamento - Solo Residual

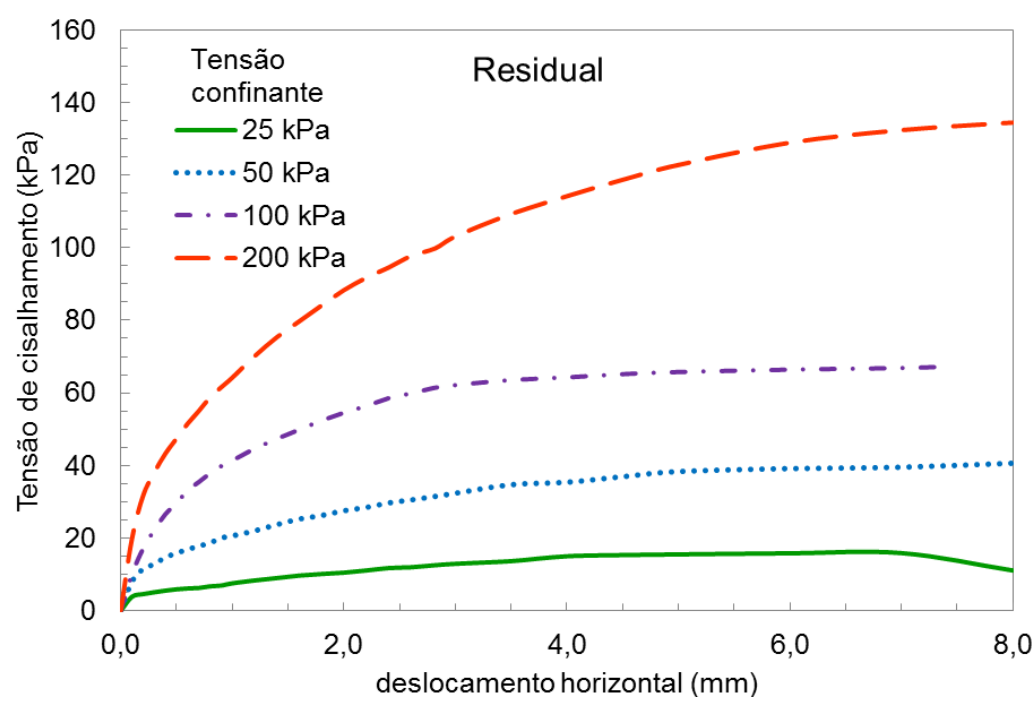

Figura 6.9 Tensão de cisalhamento obtida no ensaio - Solo Residual

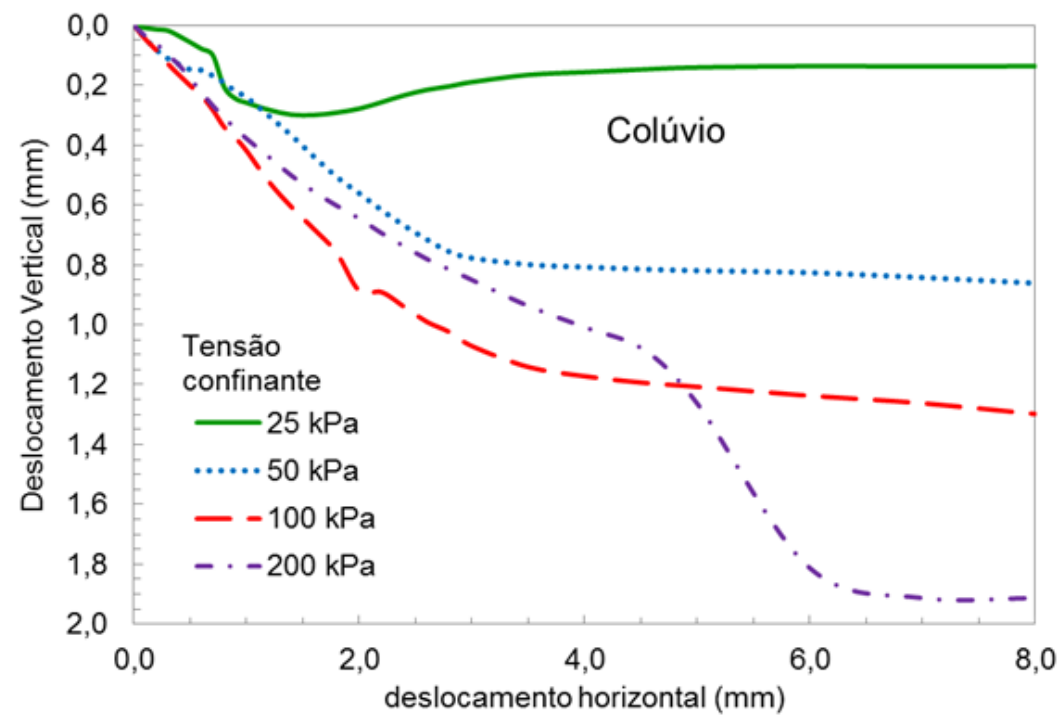

Figura 6.10 Recalque durante o ensaio de cisalhamento - Colúvio 


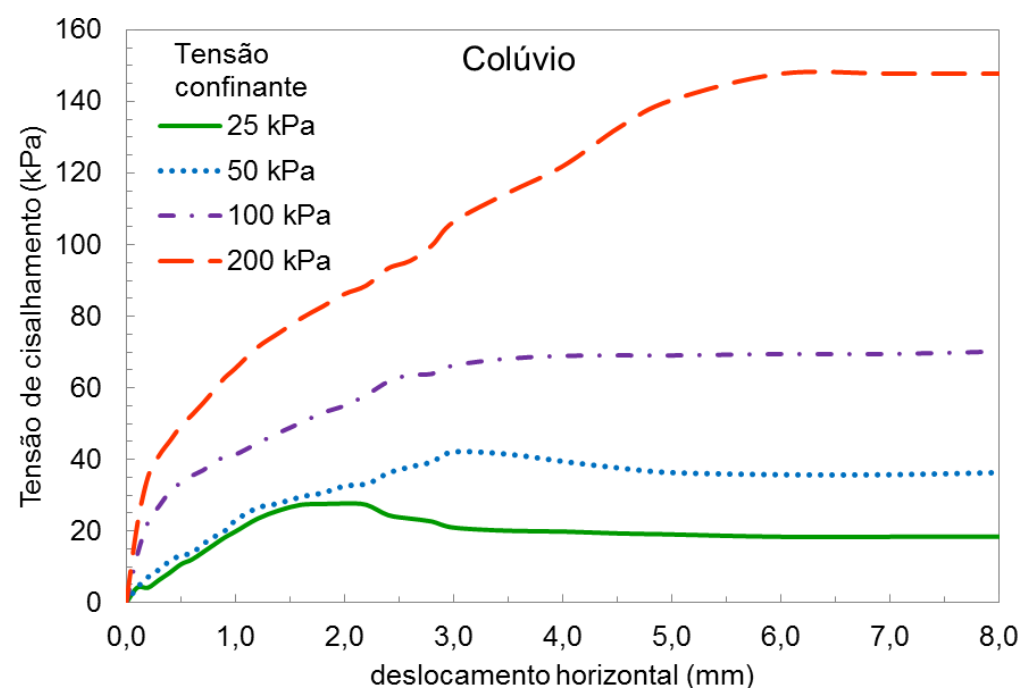

Figura 6.11 Tensão de cisalhamento obtida no ensaio - Colúvio

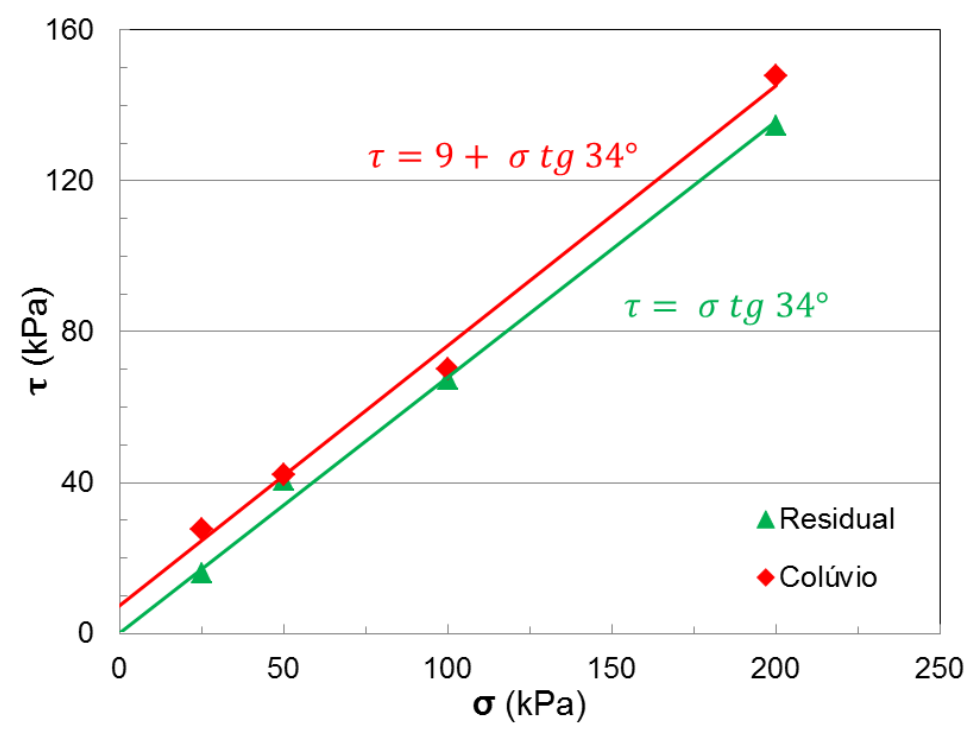

Figura 6.12 Resultado gráfico ensaio de cisalhamento

Avelar et al. (2011) realizou ensaios de cisalhamento em quatro amostras coletadas na região serrana, os resultados obtidos estão apresentados na Figura 6.13 em linha pontilhada, juntamente com os dados obtidos nas amostras coletadas em linha cheia, que se mostraram menores que os obtidos Avelar. 


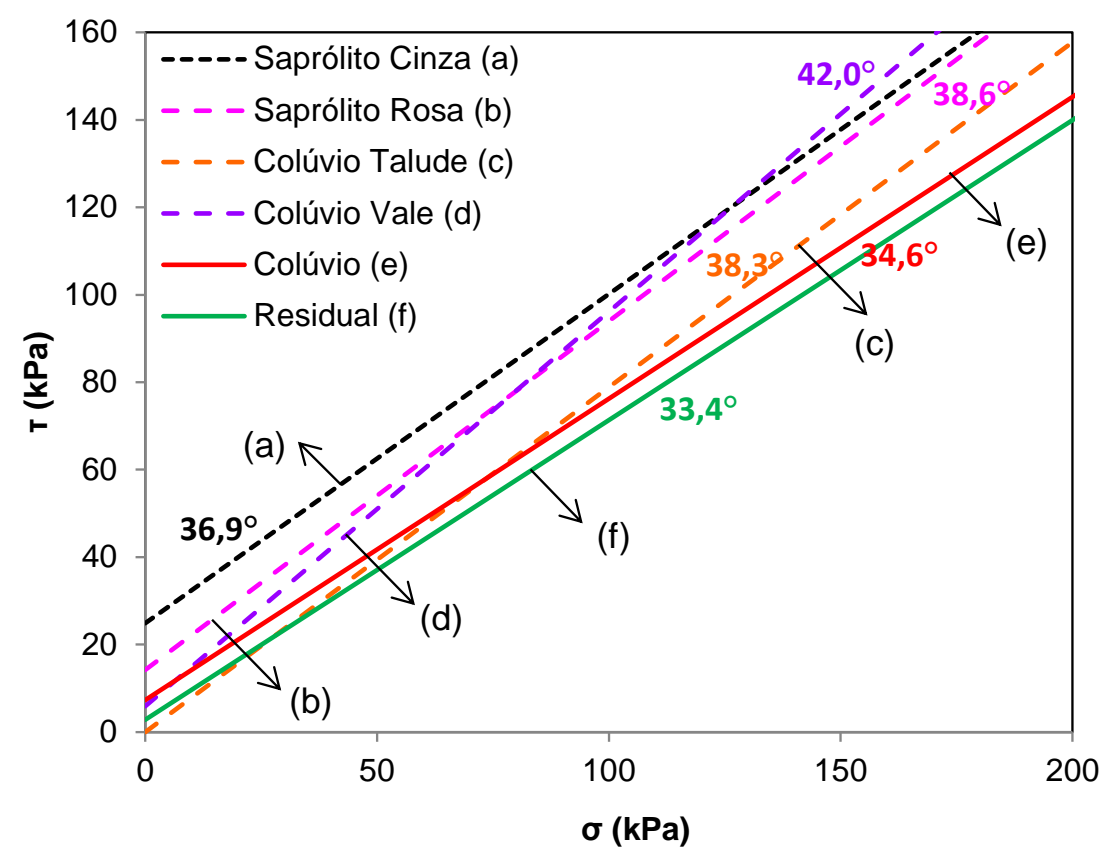

Figura 6.13 Comparação dos resultados obtidos com os de Avelar et al (2011)

Apesar dos valores determinados por Avelar et al. (2011) serem maiores que os valores determinados para as amostras, a diferença no ângulo de atrito e na coesão é esperada já que os solos em geral apresentam variações de composição e, principalmente, de estado de compacidade do solo. A Figura 6.14 apresenta uma imagem dos corpos de prova na qual é possível verificar a heterogeneidade das amostras.

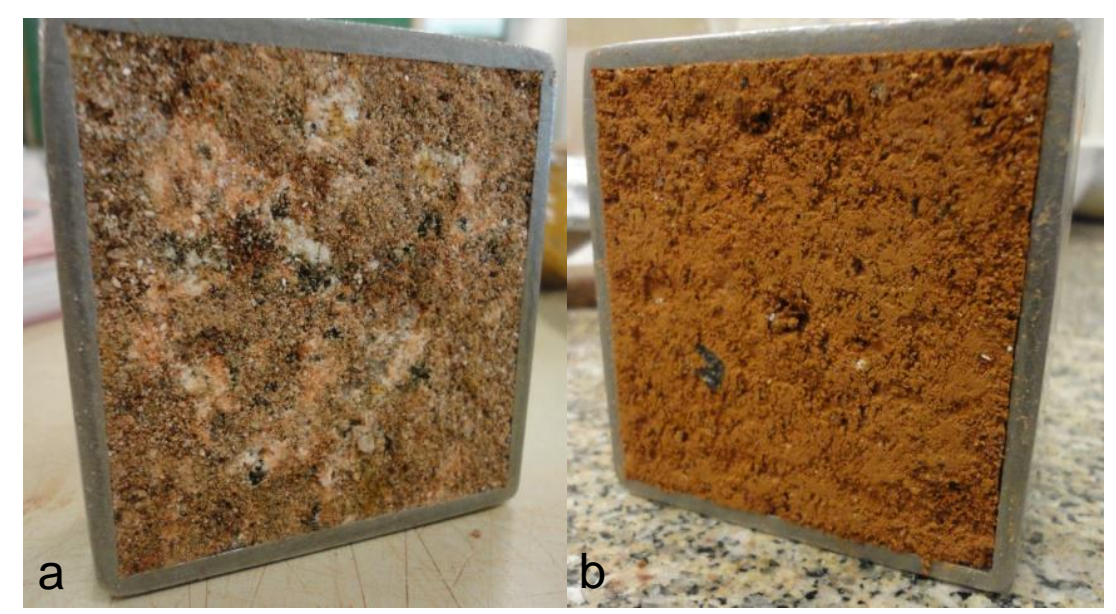

Figura 6.14 Corpos de prova: (a) residual e (b) colúvio 


\subsection{Reometria Rotacional de Torque}

Os ensaios de reologia foram realizados no Laboratório de Microestrutura da Escola Politécnica da USP, o aparelho utilizado foi o mesmo utilizado por Melo et al. (2012) já apresentado na Figura 5.9, o reômetro com geometria planetária.

Nesse reômetro rotacional foram realizados dois ensaios. O primeiro deles foi realizado com a amostra numa umidade constante durante o ensaio, com diversas amostras em diferentes umidades (sete amostras para o solo residual e oito amostras para o colúvio), sendo possível observar para cada um dos solos, as diferenças entre amostras com diferentes umidades. Esse ensaio tem como objetivo observar a queda de resistência e da tensão de escoamento do material em relação as amostras com diferentes umidades.

O segundo ensaio foi realizado para uma amostra de cada solo, com variação da umidade durante o ensaio, com o objetivo de determinar a tensão de escoamento do material ensaiado.

As amostras de solo utilizados no ensaio foram coletados em sacos plásticos. Para a realização dos dois ensaios o primeiro procedimento foi o peneiramento do material na peneira \#10, com abertura de $2,0 \mathrm{~mm}$.

As análises dos resultados obtidos e suas implicações estarão apresentadas no capítulo 7 da dissertação.

\subsubsection{Reometria Rotacional - Umidade Constante}

O solo residual de granito, para o primeiro ensaio, foi separado em duas amostras $(A$ e $B)$, sendo que o ensaio foi realizado com reaproveitamento de material. O peso de solo inicial de cada amostra foi de $3,5 \mathrm{~kg}$ sendo adicionada água destilada na quantidade necessária para alcançar a umidade programada de acordo com a Tabela 6.3. O mesmo procedimento foi realizado para o colúvio, ou seja, foram separadas duas amostras denominadas por $C$ e $D$ de $3,5 \mathrm{~kg}$ e adicionada água destilada. A dimensão da cuba utilizada é de $21 \mathrm{~cm}$ de diâmetro e $20 \mathrm{~cm}$ de profundidade, e essa quantidade de solo é suficiente para manter a haste em contato com o material durante o ensaio. 
Tabela 6.3 Programação da umidade das amostras

\begin{tabular}{|c|c|c|c|c|c|c|c|}
\hline & A1 & A2 & A3 & A4 & B1 & B2 & B3 \\
\hline Peso total am. Úmida (g) & 3500,0 & 3884,1 & 3974,1 & 4044,1 & 3500,0 & 4225,9 & 4225,9 \\
\hline Umidade inicial (\%) & $12,64 \%$ & $25,0 \%$ & $25,0 \%$ & $25,0 \%$ & $12,64 \%$ & $36,0 \%$ & $36,0 \%$ \\
\hline Água existente (g) & 392,8 & 776,8 & 776,8 & 776,8 & 392,8 & 1118,6 & 1118,6 \\
\hline Solo seco existente (g) & 3107,2 & 3107,2 & 3107,2 & 3107,2 & 3107,2 & 3107,2 & 3107,2 \\
\hline Umidade desejada (\%) & $25,0 \%$ & $27,9 \%$ & $30,1 \%$ & $33,0 \%$ & $36,0 \%$ & $40,0 \%$ & $44,0 \%$ \\
\hline Água total (g) & 776,8 & 866,8 & 936,8 & 1026,8 & 1118,6 & 1243,6 & 1368,6 \\
\hline Água adicional (g) & 684,06 & 90,00 & 160,00 & 250,00 & 725,85 & 125,00 & 250,00 \\
\hline Água adicional total (g) & 384,10 & 90,00 & 70,00 & 90,00 & 725,90 & 125,00 & 125,00 \\
\hline
\end{tabular}

Para cada uma das umidades adotadas, a homogeneização das amostras com a adição de água foi realizada no próprio reômetro, num ciclo de velocidade constante de $100 \mathrm{rpm}$ durante 2 minutos. Os ensaios de reometria foram realizados para sete umidades diferentes para o solo residual e em oito umidades para o colúvio, sendo que os valores de umidade adotados variam em torno dos limites de liquidez e plasticidade. Os ensaios foram realizados nas umidades apresentadas na Figura 6.15 .
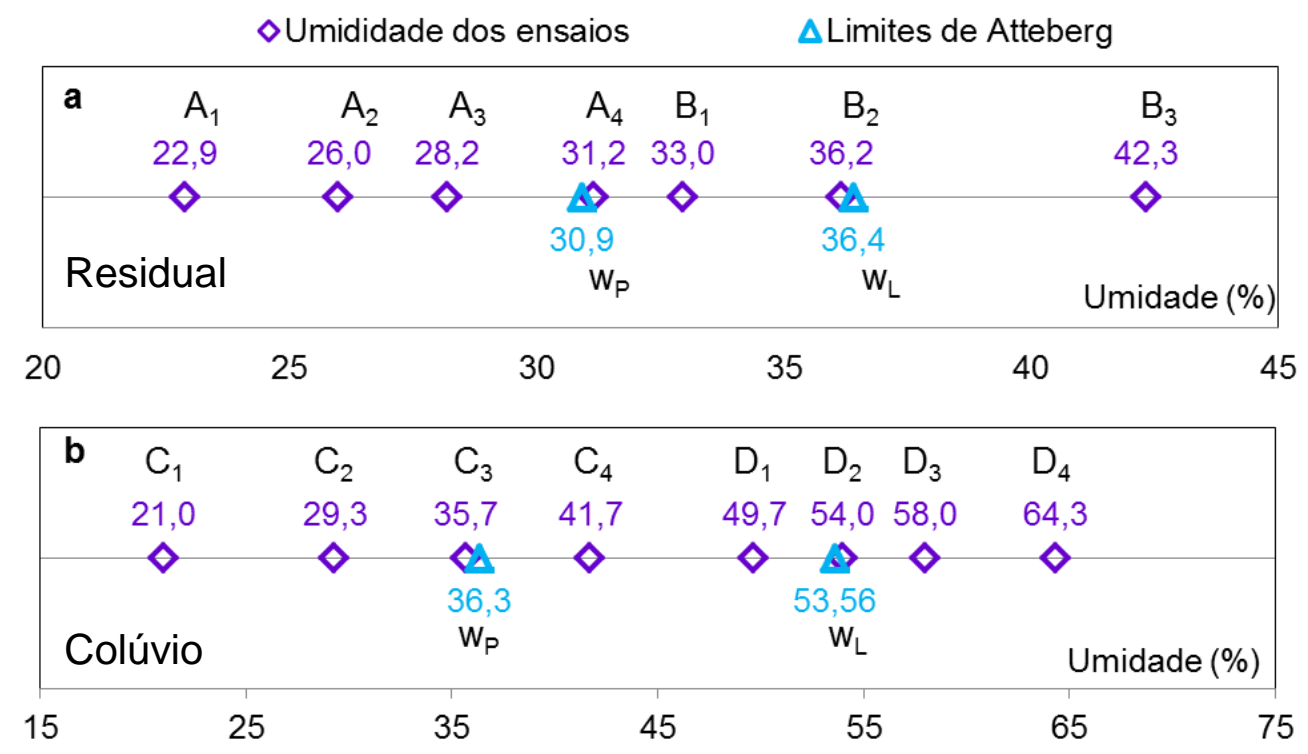

Figura 6.15 Umidade das amostras utilizadas em (a) o Solo Residual e em (b) o Colúvio

Para deixar claro o procedimento para definição das amostras está apresentada a Figura 6.16. As umidades apresentadas nesta Figura são referentes ao solo residual, para o solo coluvionar foi realizada a mesma separação. Então a diferença entre as amostras A e B é somente a umidade, já que foi realizado apenas 
a divisão da amostra coletada em duas partes, por quarteamento. $O$ mesmo raciocínio se aplica as amostras $\mathrm{C}$ e $\mathrm{D}$, que são do solo coluvionar.
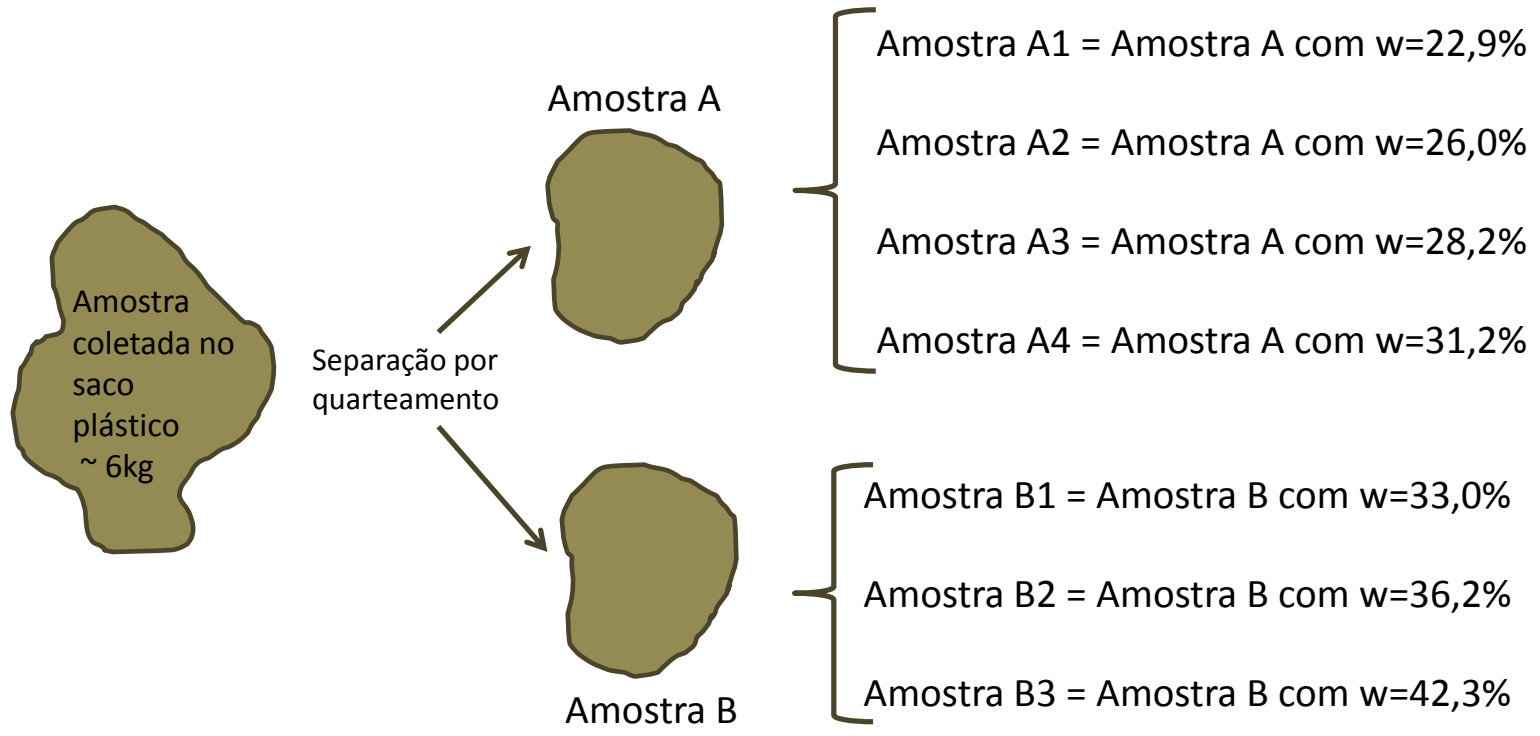

Figura 6.16 Diagrama com apresentação das amostras

O procedimento do ensaio é descrito com os seguintes procedimentos: primeiro o solo é colocado na cuba, depois a cuba é fixada na mesa do aparelho através de quatro grampos, o aparelho inicia a rotação e a cuba é posicionada automaticamente, para que todo o material entre em contato com a haste. Os dados são coletados pelo sistema de aquisição. Esse esquema está representado na Figura 6.17 .

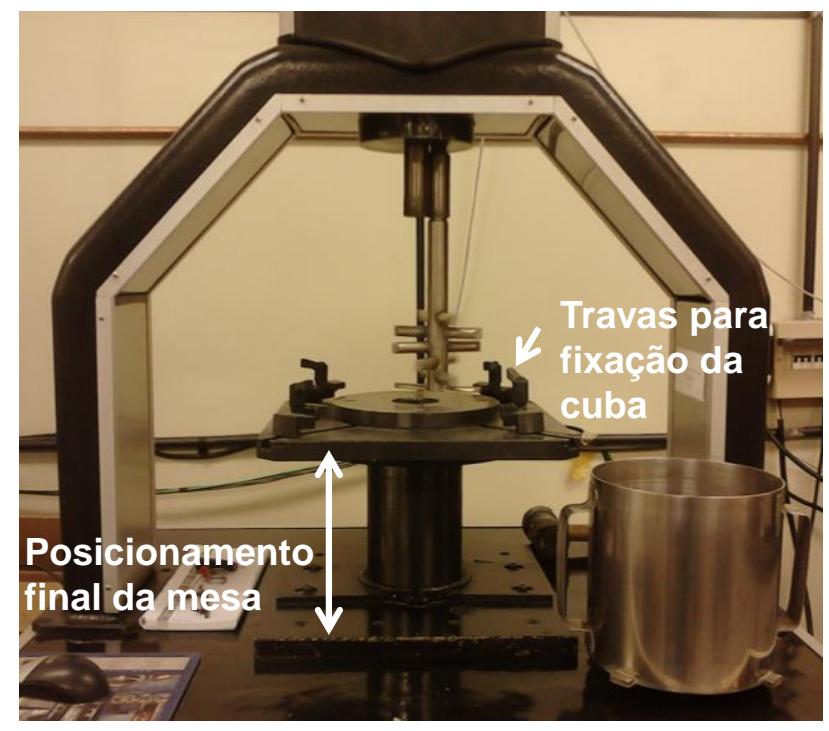

Figura 6.17 Esquema do ensaio no reômetro rotacional de torque 
Para cada uma das amostras o ensaio foi realizado da mesma maneira, com a aplicação de uma velocidade de rotação pré-determinada no solo e medida de torque realizada, aproximadamente, a cada 2 segundos. O ciclo de carregamento adotado é apresentado na Figura 6.18.

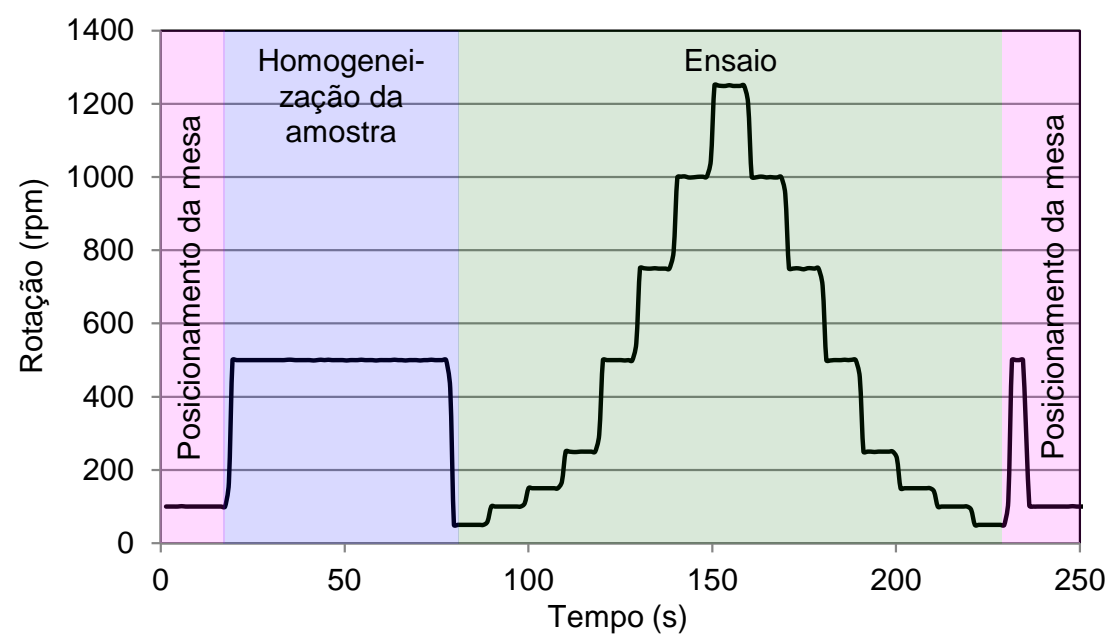

Figura 6.18 Ciclo de velocidade utilizado no reômetro rotacional

Com o final do ensaio, já com o ciclo realizado, a mesa volta à posição inicial e são retiradas amostras para o controle de umidade e também o material utilizado no ensaio de squeeze flow, que, depois da compressão no squeeze flow, reutilizado no reômetro de torque. Depois é adicionada a água destilada necessária para alcançar a umidade do próximo ponto e a amostra é homogeneizada antes da aplicação de um novo ciclo de carregamento, o resultado da adição de água pode ser observado na Figura 6.19 na qual são mostrados os três últimos pontos de umidade do solo residual e na Figura 6.20 que apresenta imagens do solo coluvionar para todos os pontos de umidade ensaiados. Para facilitar a apresentação dos dados, todas as amostras serão representadas pelos seus valores de umidade.

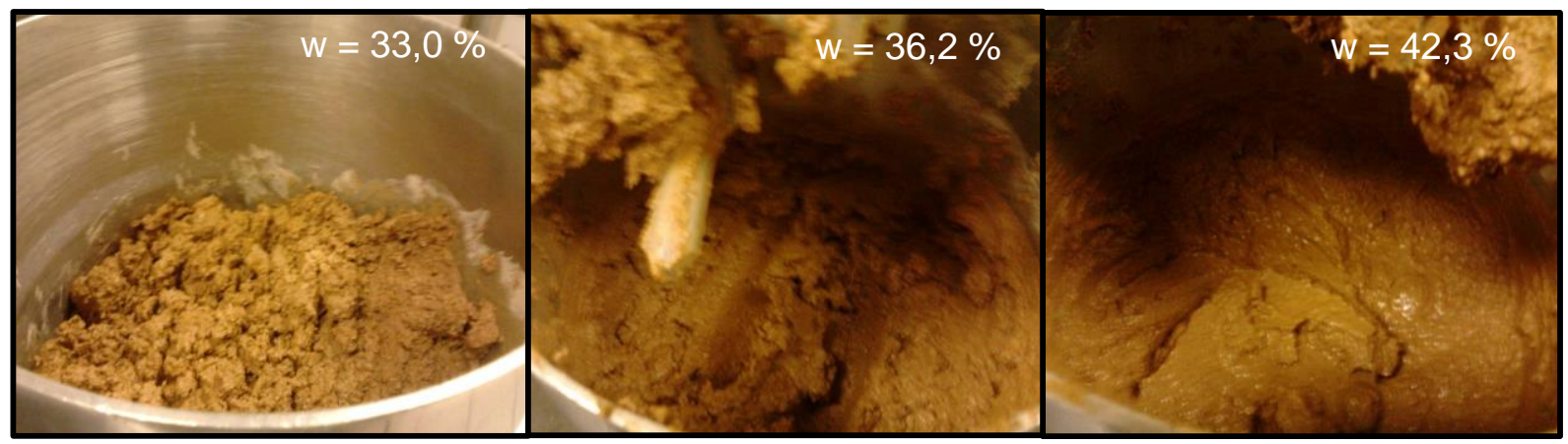

Figura 6.19 Apresentação das amostras de Solo Residual com diferentes umidades 


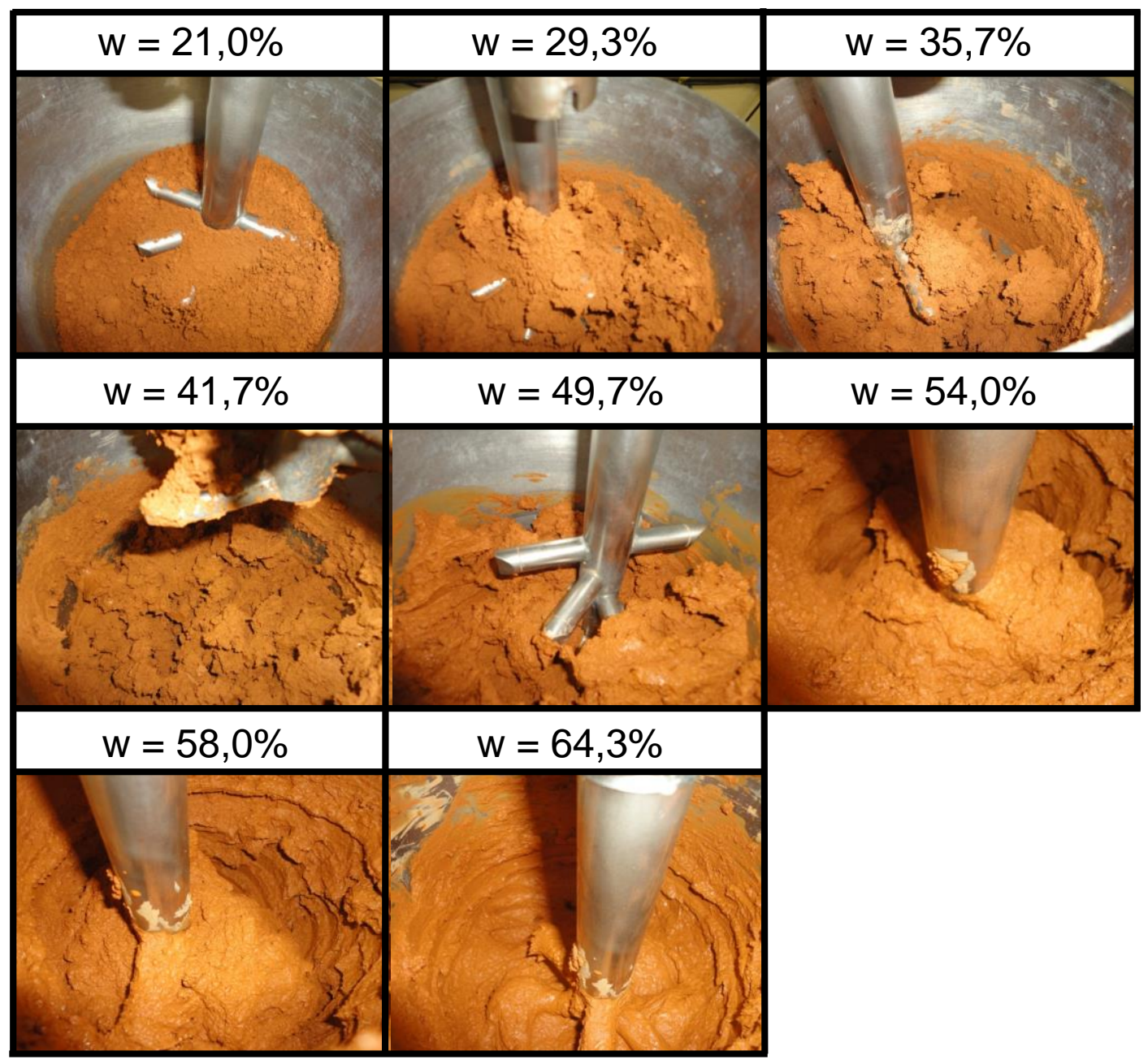

Figura 6.20 Apresentação das amostras do colúvio

As medidas tomadas nesse ensaio são a velocidade de rotação (rpm) e o torque (N.m). Como as medidas são tomadas a cada dois segundos, são medidos diversos valores para cada uma das velocidades, para a utilização dos dados esses valores são reduzidos para apenas um valor de torque para cada valor de rotação. $\mathrm{O}$ resultado do ensaio é apresentado em forma gráfica, onde é possível observar o torque para cada rotação adotada, nas sete umidades distintas para o solo residual na Figura 6.21 e oito umidades para o colúvio na Figura 6.22, sendo que a Figura 6.23 apresenta uma aproximação para os maiores valores de umidade do colúvio para facilitar a visualização do comportamento obtido. Nas Figuras 6.21 a 6.23 as linhas pontilhadas representam $o$ carregamento $e$ as linhas cheias 0 descarregamento no ciclo de cisalhamento. 


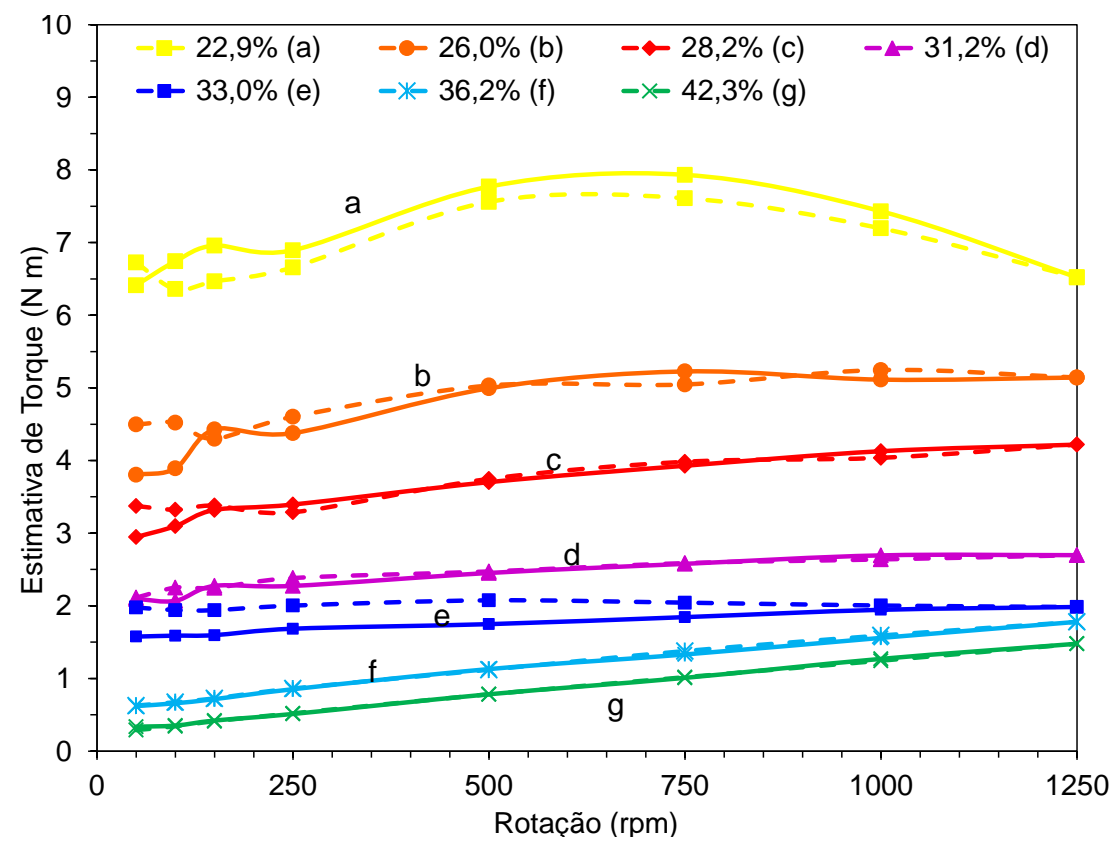

Figura 6.21 Resultado obtido no reômetro de torque para o Solo Residual

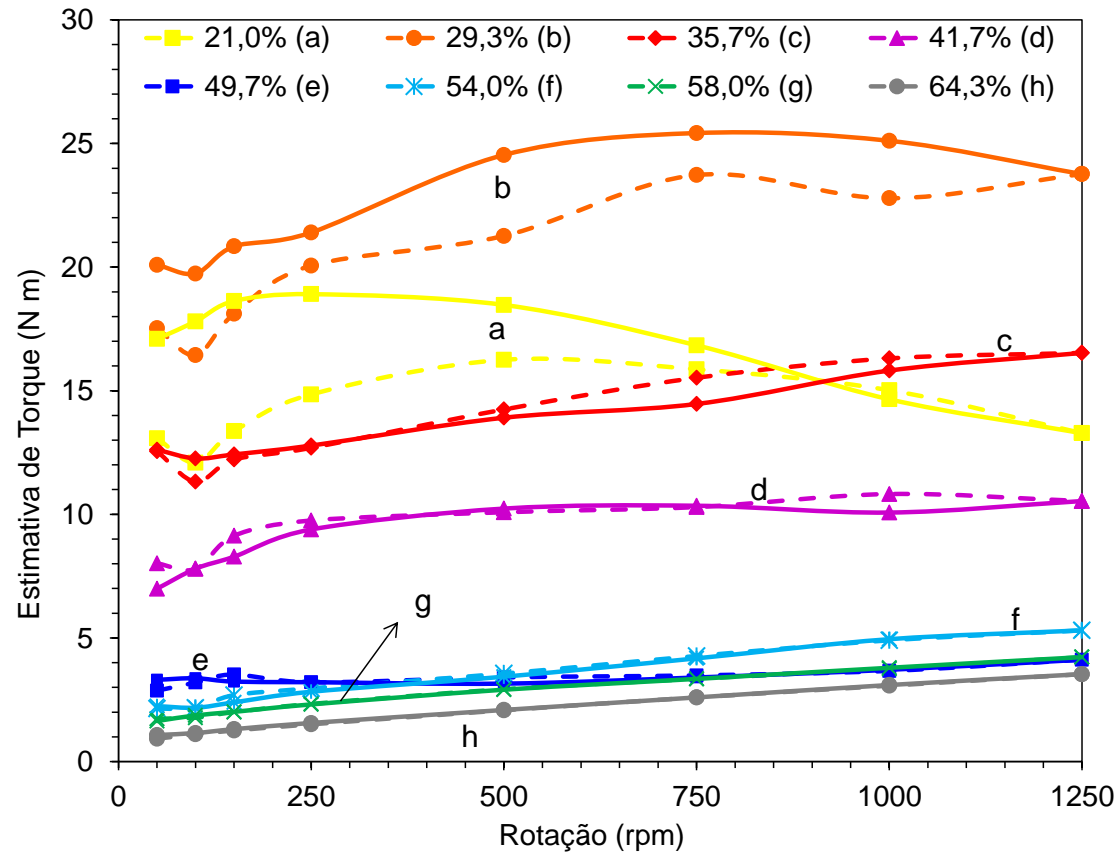

Figura 6.22 Resultado obtido no reômetro de torque para o Colúvio 


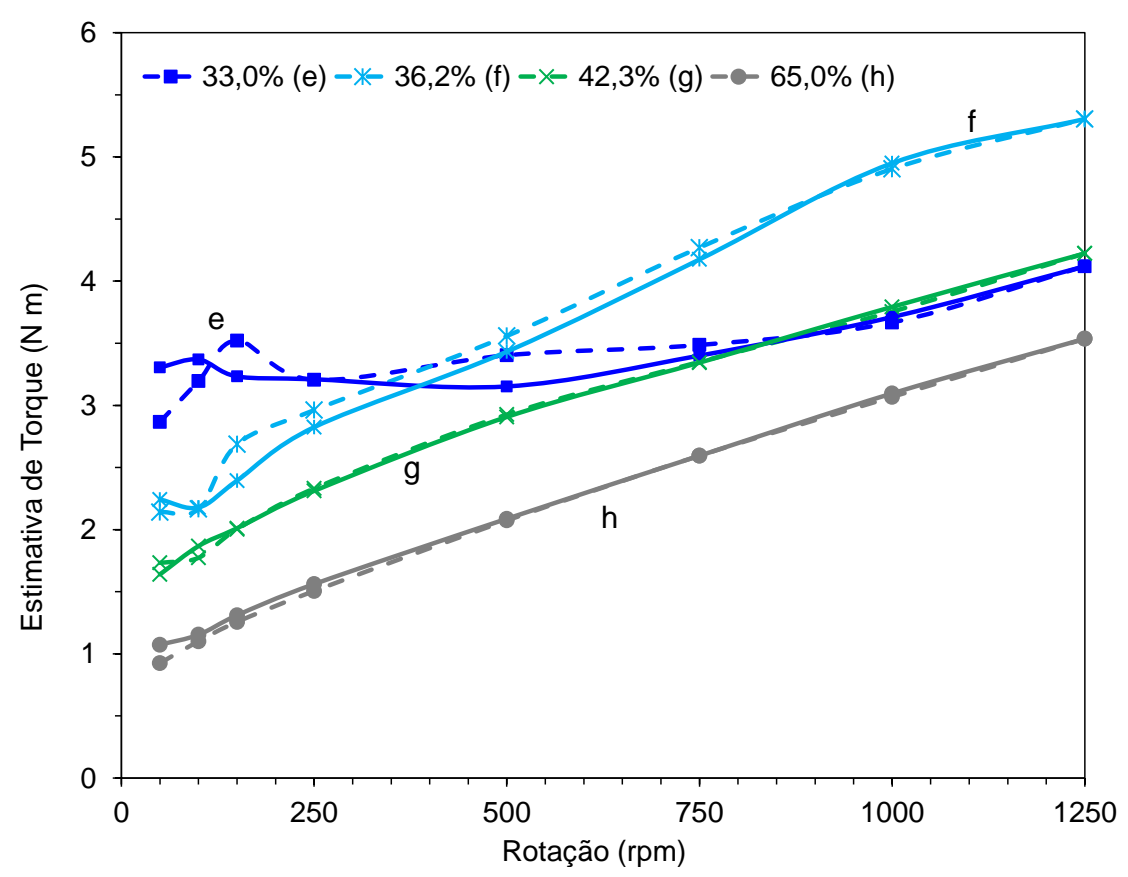

Figura 6.23 Aproximação de região do gráfico do resultado obtido no reômetro de torque para - Colúvio

Considerando a definição dada anteriormente, que a viscosidade caracteriza a resistência ao escoamento de um fluido para uma dada taxa de cisalhamento, é possível fazer uma estimativa da viscosidade do material ensaiado nesse aparelho. Para isso é preciso fazer duas considerações, primeiro que a imposição de uma velocidade de rotação na haste planetária provoque o cisalhamento contínuo do material e outra é que o torque equivalha a uma medida de resistência. Então a divisão do torque pela velocidade resulta em uma medida de resistência ao escoamento, que esta denominada aqui por 'estimativa de viscosidade' ( $\mathrm{N} \mathrm{m} / \mathrm{rpm}$ ). A variação desse parâmetro para os solos analisados estão apresentadas nas Figuras 6.24 e 6.25 . 


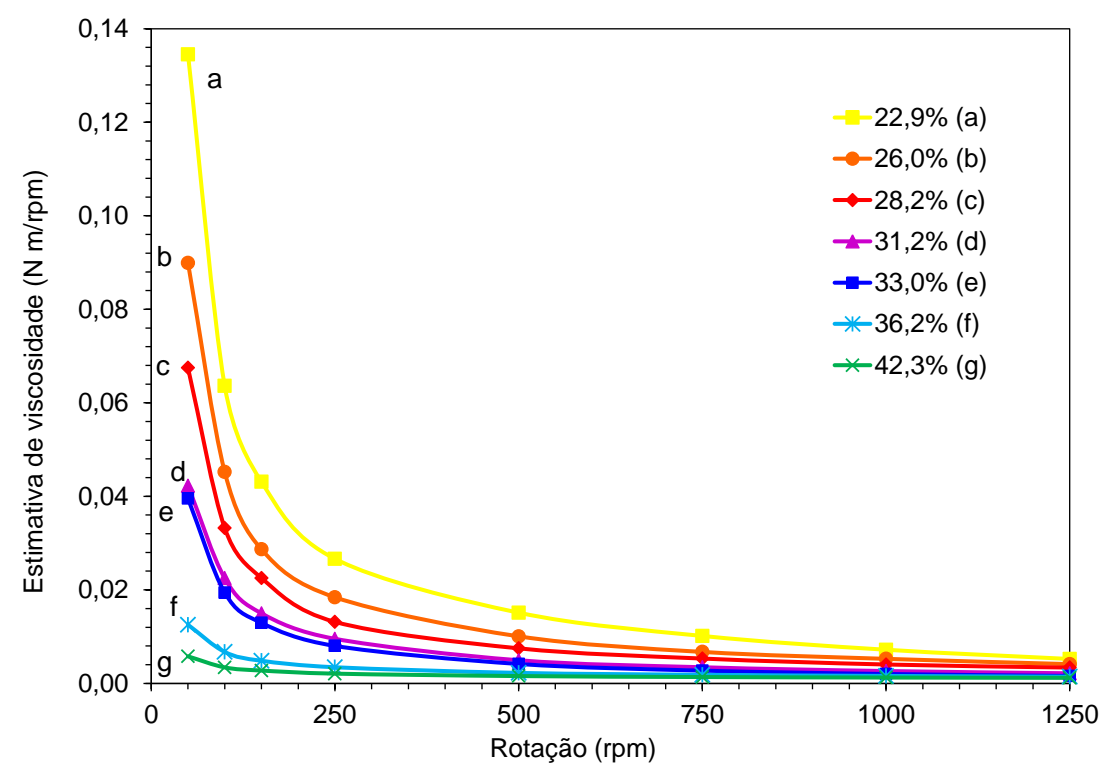

Figura 6.24 Variação da estimativa da viscosidade em relação à rotação para o Solo Residual

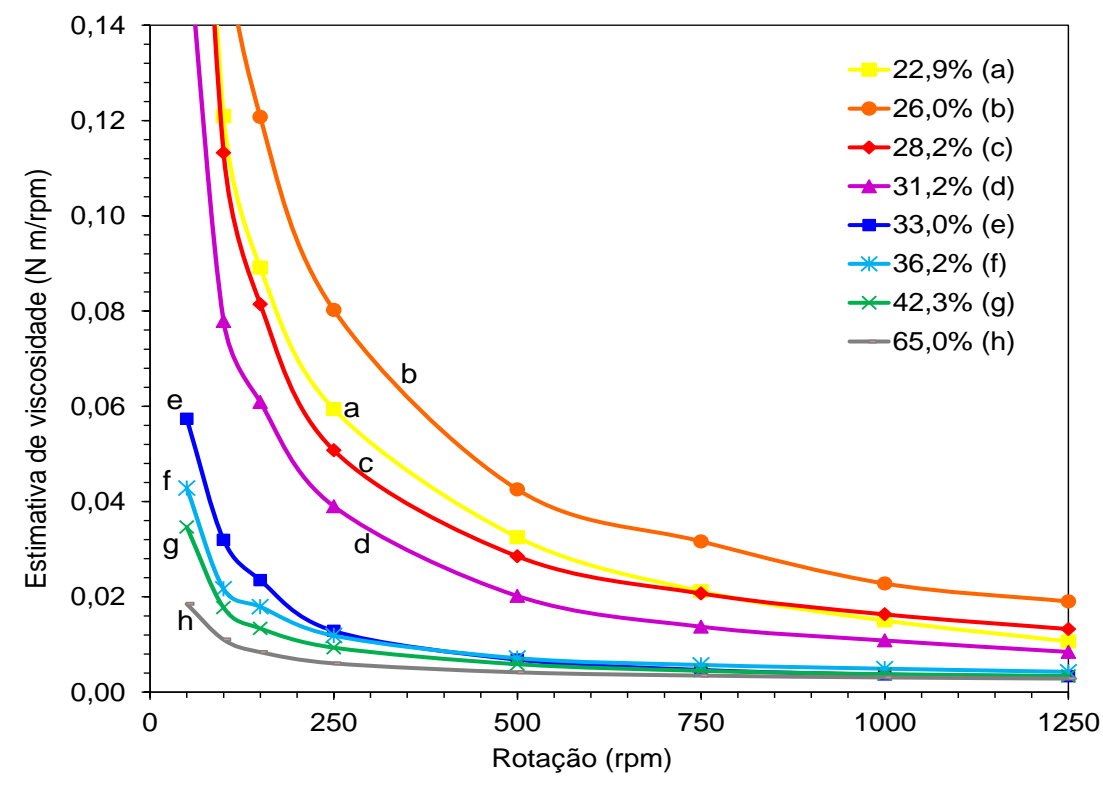

Figura 6.25 Variação da estimativa da viscosidade em relação à rotação para o Colúvio

\subsubsection{Reometria Rotacional - Umidade variável}

O segundo ensaio realizado no mesmo aparelho, o reômetro rotacional, foi para determinar qual a umidade e torque atuam na amostra quando ocorre a mudança de comportamento do solo. O procedimento de ensaio foi colocar $2 \mathrm{~kg}$ de solo seco na umidade higroscópica na cuba de ensaio, aplicar uma velocidade de 
rotação constante de 500 rpm, adicionar água na amostra gradualmente, medindo a quantidade de água adicionada à amostra.

Durante a realização do ensaio é medido o torque (N.m), que apresenta um comportamento ascendente mesmo com o aumento da umidade até alcançar um pico a partir do qual ocorre a mudança de comportamento. A água adicionada ao solo é medida tanto em quantidade como o tempo de adicionamento, para que seja possível a determinação da umidade durante toda a duração do ensaio.

Os resultados obtidos através desse ensaio estão apresentados nas Figuras 6.26 e 6.27, onde foi destacada a região na qual é possível observar a mudança do comportamento da mistura solo e água.

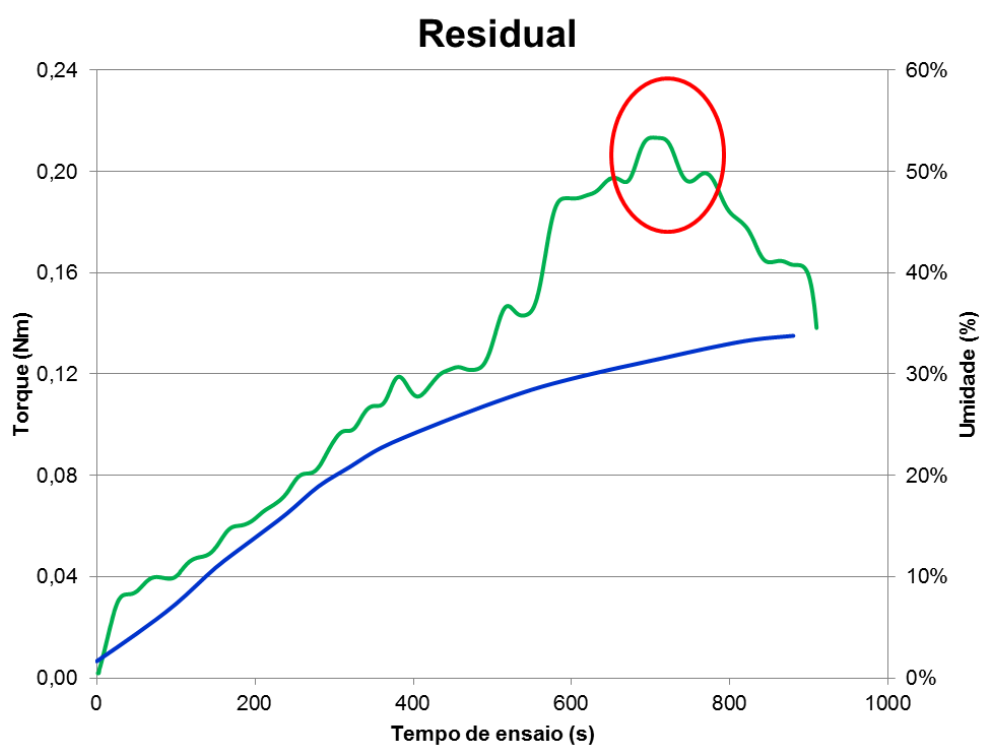

Figura 6.26 Resultado obtido para o solo Residual 


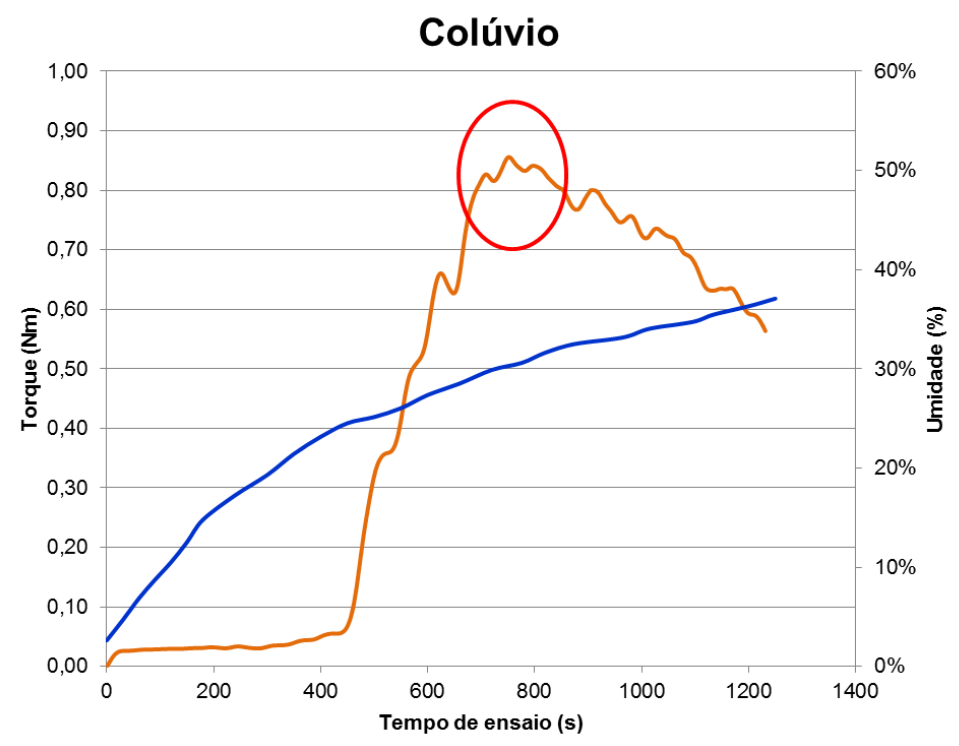

Figura 6.27 Resultado obtido para o Colúvio

\subsection{Reometria Rotacional - Placas Paralelas}

Como já mencionado, o corpo de prova para a realização do ensaio de reometria rotacional com geometria de placas paralelas, tem pequenas dimensões, com altura de $1 \mathrm{~mm}$ e diâmetro de $4 \mathrm{~cm}$. Para a montagem do ensaio, é adicionada uma quantidade da amostra de solo na prensa AR 550, então a torre superior desce até que o gap (distância entre as placas) seja de $1 \mathrm{~mm}$, comprimindo a amostra para isso, sendo que o excesso de amostra é retirado antes do início do ensaio. Esse esquema está apresentado na Figura 6.28 e Figura 6.29. 


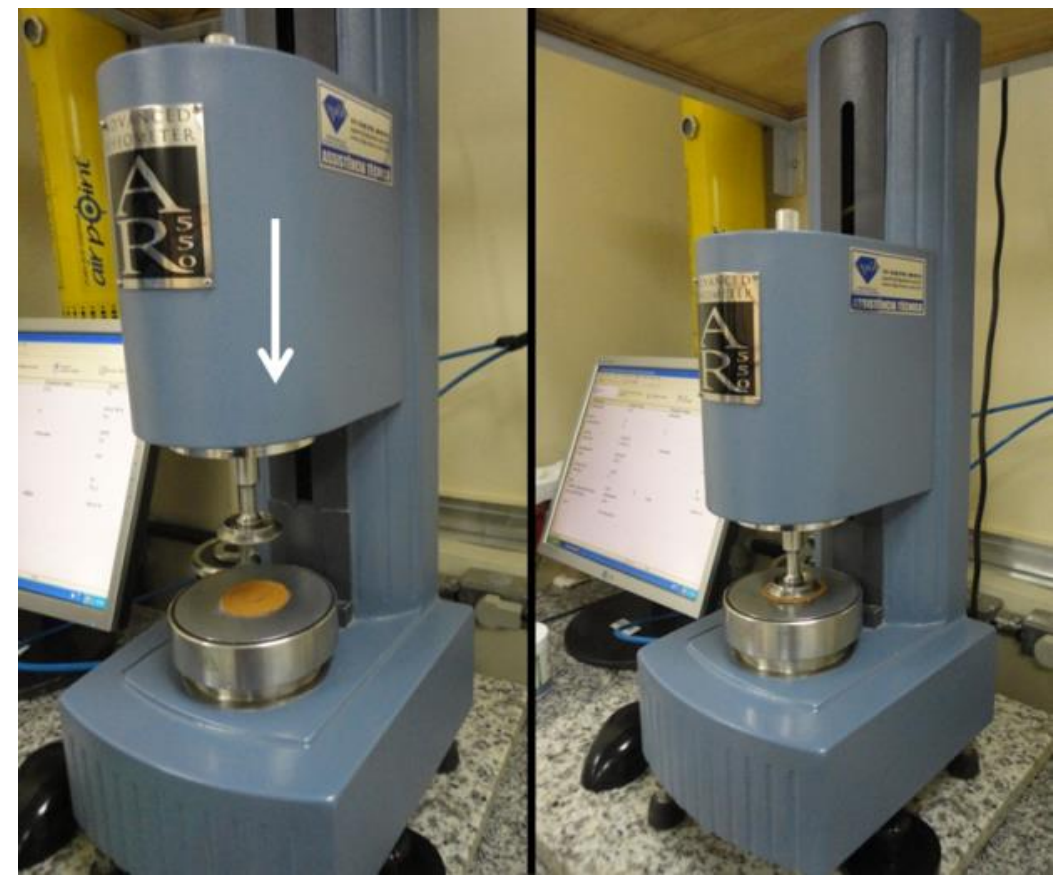

Figura 6.28 Posicionamento da AR 550 para ensaio

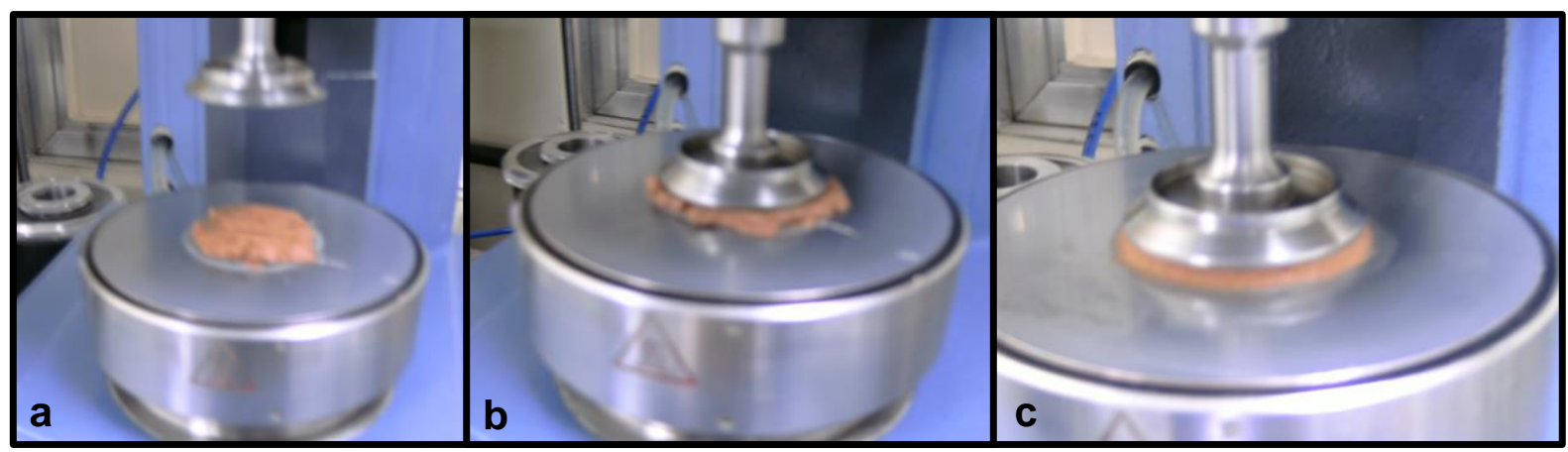

Figura 6.29 Procedimento de posicionamento da amostra para ensaio

Durante a descida da torre superior, a força normal aplicada no punção é controlada através de medidas simultâneas ao deslocamento. O limite de $50 \mathrm{~N}$ é adotado e quando a força excedia esse valor o posicionamento era cancelado, então a amostra era rompida, através de rotação, e, quando a força normal se anulava, o deslocamento era reiniciado fazendo-se nova tentativa de posicionamento até que fosse atingido o gap de $1 \mathrm{~mm}$.

As amostras de solo utilizadas no ensaio foram passadas na peneira \#100, com abertura de 0,15 mm. Considerando o gap de $1 \mathrm{~mm}$ essa granulometria se apresentou grossa e o equipamento não conseguiu alcançar o gap de $1 \mathrm{~mm}$ sem extrapolar a restrição da força normal de $50 \mathrm{~N}$, por isso teve que ser utilizado um gap de $2 \mathrm{~mm}$.

Outra restrição do ensaio é em relação à umidade da amostra, já que quando a umidade é baixa e a resistência do solo é maior e o equipamento não apresenta 
torque suficiente para iniciar o fluxo, por isso as umidades utilizadas nesse ensaio tiveram que ser elevadas. Portanto, os teores de umidade utilizados nesse ensaio diferem dos demais ensaios e estão apresentados na Tabela 6.4.

Tabela 6.4 Valores de umidade utilizados no reômetro com geometria placas paralelas

\begin{tabular}{|c|c|c|c|c|c|c|c|c|}
\cline { 2 - 9 } \multicolumn{1}{c|}{} & 1 & 2 & 3 & 4 & 5 & 6 & 7 & 8 \\
\hline Solo Residual & $46 \%$ & $52 \%$ & $54 \%$ & $55 \%$ & $57 \%$ & $59 \%$ & $61 \%$ & - \\
\hline Colúvio & $61 \%$ & $67 \%$ & $69 \%$ & $71 \%$ & $74 \%$ & $76 \%$ & $78 \%$ & $80 \%$ \\
\hline
\end{tabular}

O ensaio é dividido em duas partes, iniciou com uma taxa de cisalhamento nula que se incrementou até alcançar um valor da ordem de $400 \mathrm{~s}^{-1}$ e reduziu novamente para zero, denominado de Ciclo 1, e depois a taxa de cisalhamento se elevou novamente até $400 \mathrm{~s}^{-1}$ e reduziu a zero, sendo denominado de Ciclo 2, como esquematizado na Figura 6.30.

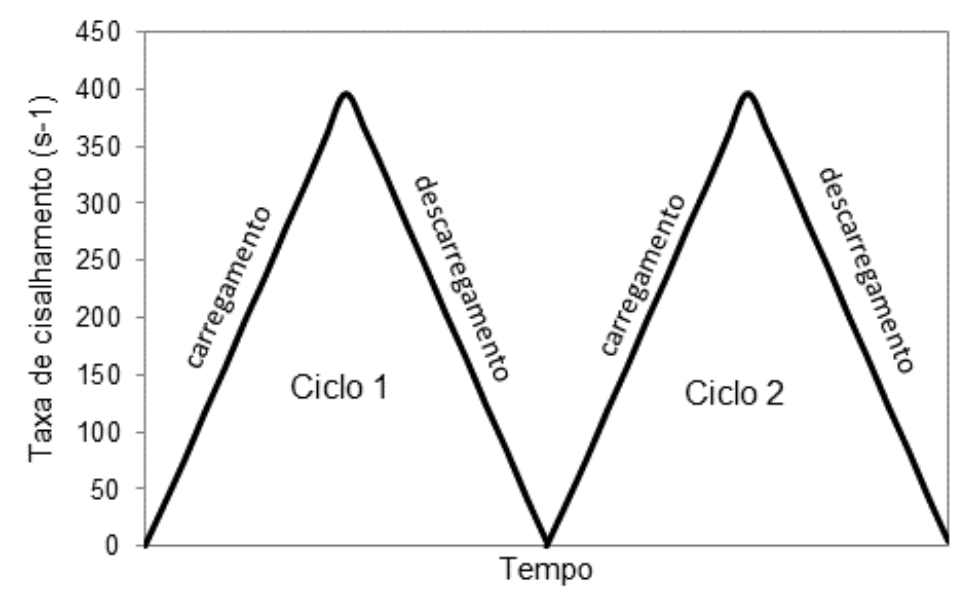

Figura 6.30 Esquema ensaio de reometria com placas paralelas

Os resultados obtidos nesse ensaio estão apresentados em forma de gráficos, um exemplo do resultado está apresentado na Figura 6.31, o restante dos resultados estão apresentados no Anexo dessa dissertação. Para cada solo são apresentados os resultados de cada ciclo em dois gráficos, sendo um deles a taxa de cisalhamento versus a tensão de cisalhamento e o outro a taxa de cisalhamento versus a viscosidade. Nas Figuras a linha cheia representa o carregamento e a pontilhada o descarregamento.

Os resultados desse ensaio são obtidos em unidades do SI, ou seja, a tensão de cisalhamento em $\mathrm{Pa}$, a taxa de cisalhamento em $\mathrm{s}^{-1}$ e a viscosidade em $\mathrm{Pa}$ s. 

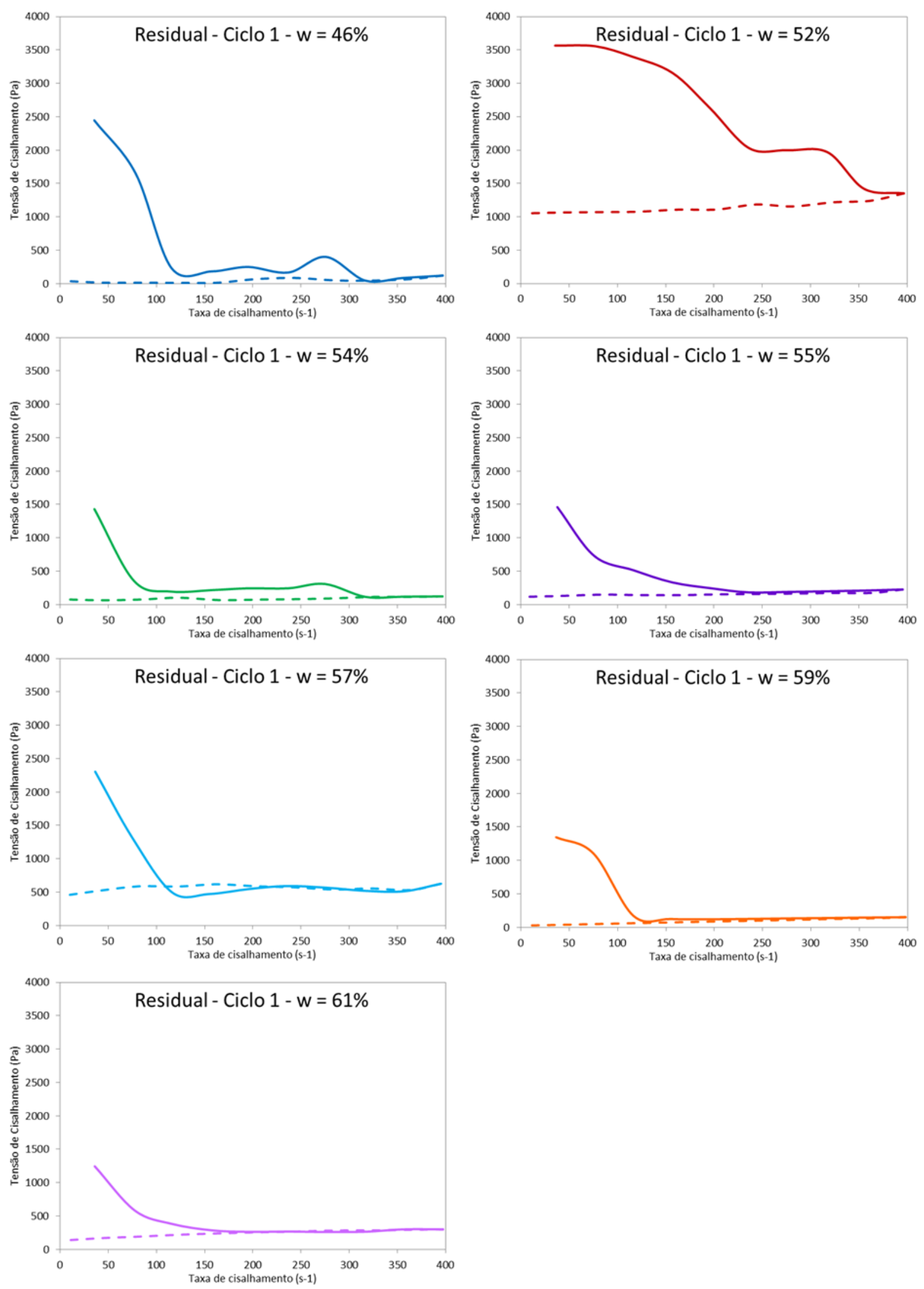

Figura 6.31 Curva de fluxo - Solo Residual - Ciclo 1 


\subsection{Reometria Compressiva (Squeeze-Flow)}

O material para a realização do squeeze flow foi coletado da amostra utilizada no reômetro rotacional para cada teor de umidade ensaiado, essa medida foi adotada para que as amostras analisadas nos dois ensaios fossem equivalentes. Para cada teor de umidade foram coletadas duas amostras de solo, uma amostra para cada velocidade de ensaio, que depois da realização do ensaio eram devolvidas à cuba de inox do ensaio de reometria de torque. O objetivo da realização desse ensaio é verificar, através da mudança de velocidade do ensaio e da variação da umidade, a separação de fases que é indicativo de movimentos e da aceleração de movimentos.

As ferramentas empregadas foram um punção de $50,05 \mathrm{~mm}$ de diâmetro, base metálica, anéis de PVC com $10 \mathrm{~mm}$ de altura e $101 \mathrm{~mm}$ de diâmetro. O programa de ensaio utilizado submete o material a uma compressão com deslocamento total de $9 \mathrm{~mm}$ e adoção de duas velocidades de ensaio $0,1 \mathrm{~mm} / \mathrm{s}$ e $3,0 \mathrm{~mm} / \mathrm{s}$. Para as condições de maior umidade seria necessária a utilização do molde de PVC. Então, para que não houvesse diferença nos resultados obtidos o molde foi utilizado em todas as amostras ensaiadas.

Para a montagem do corpo de prova existem alguns instrumentos auxiliares. O primeiro deles é a placa de aço inoxidável sob a qual o corpo de prova é montado, essa placa tem um rebaixo que encaixa na base rígida da prensa. São utilizados dois gabaritos plásticos para garantir que a amostra fique centralizada na placa, esses gabaritos são encaixados na placa e o molde de PVC é encaixado dentro do gabarito. A amostra é colocada em abundância dentro do molde de PVC e com o auxílio de uma espátula são retirados os excessos de solo até obter uma superfície lisa, é importante que a espátula seja maior que o diâmetro da amostra para que seja garantido o nivelamento da amostra, daí o gabarito é retirado e a amostra é levada à prensa para ser realizado o ensaio. A Figura 6.32 apresenta em (a) o anel de PVC centralizado com o auxílio do gabarito encaixado na placa de aço e em (b) o corpo de prova como é levado à prensa. 


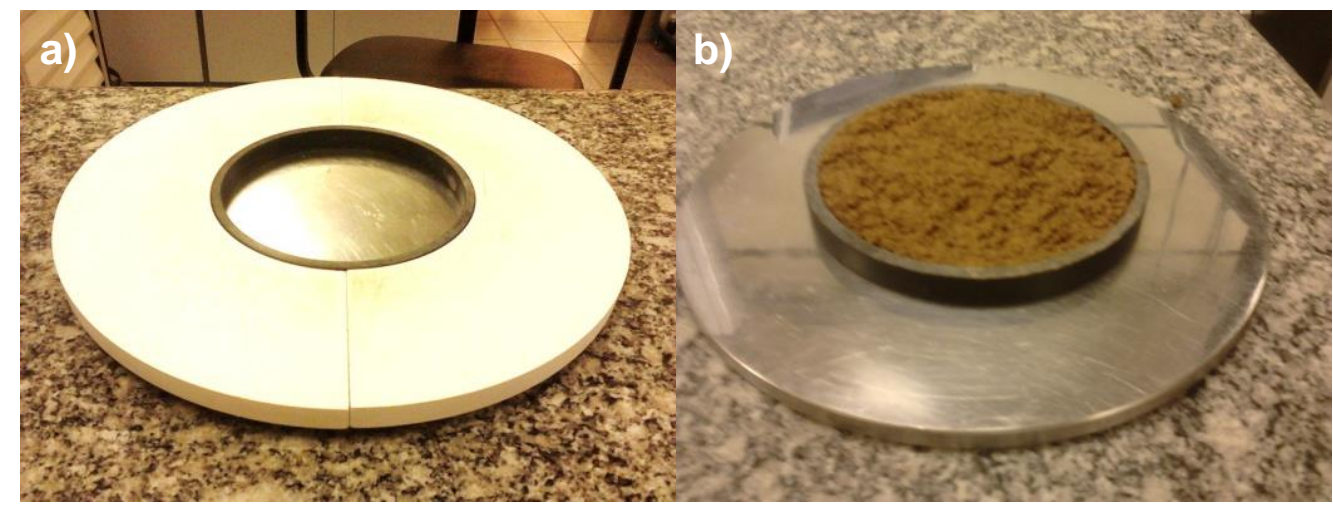

Figura 6.32 Corpo de prova pronto para ser ensaiado

Como resultado, são obtidos dados de força e deslocamento, que são medidos automaticamente a cada segundo. Os resultados do solo residual estão apresentados em forma de gráfico na Figura 6.33 e Figura 6.34, sendo realizada uma comparação entre as duas velocidades através de fotografias que foram retiradas logo após a execução do ensaio na Figura 6.35 .

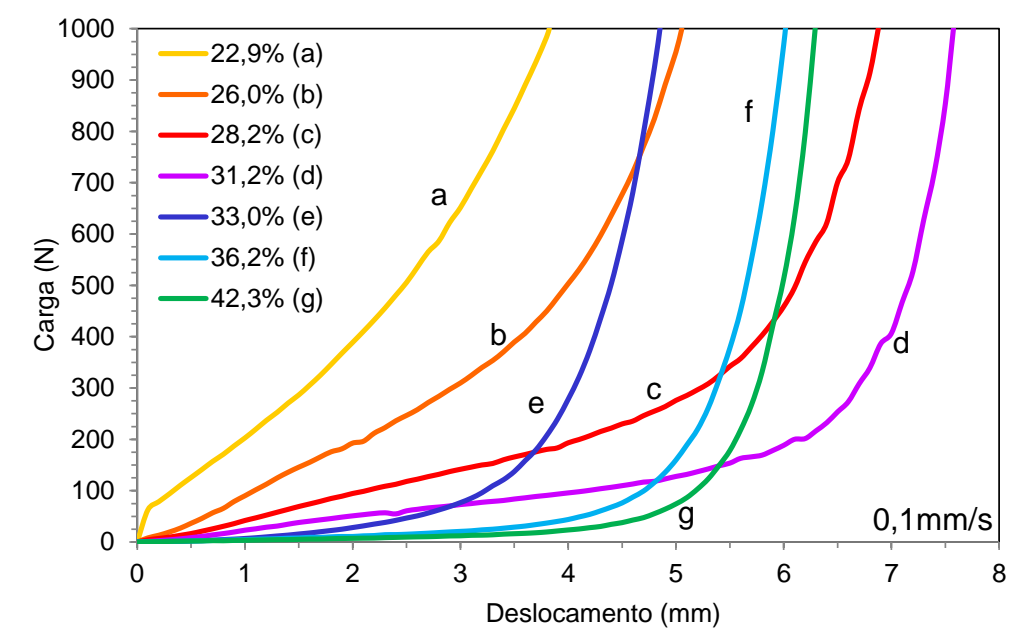

Figura 6.33 Resultado do squeeze flow realizado em $0,1 \mathrm{~mm} / \mathrm{s}$ para o Solo Residual

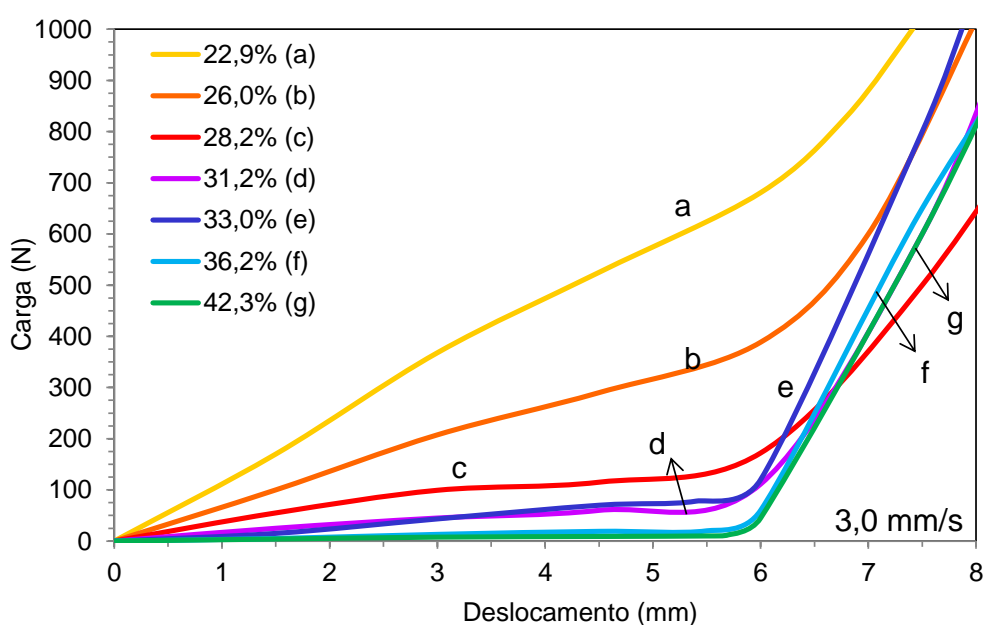

Figura 6.34 Resultado do squeeze flow realizado em $3,0 \mathrm{~mm} / \mathrm{s}$ para o Solo Residual 
No resultado apresentado na Figura 6.33 é visível que as amostras apresentaram comportamento semelhante, porém se entrelaçaram. Os quatro menores teores de umidade foram obtidos da primeira amostra $(A)$ e os três últimos da segunda amostra (B). Lembrando que o solo foi dividido em duas amostras para o reaproveitamento, denominadas por $A$ e $B$, sendo que a amostra $A$ foi utilizada para a realização de 4 ensaios, apresentados nas Figuras acima por (a), (b), (c) e (d) e a amostra B foi utilizada para 3 ensaios, denominados por (e), (f) e (g). O comportamento esperado seria que as curvas das amostras com maiores umidades apresentassem um maior deslocamento para determinada força aplicada. Esse resultado poderia indicar que existem diferenças em função do procedimento, como as amostras serem diferentes ou a existência de uma influência da umidade inicial e do reuso do material.

Entretanto, observando as fotos da Figura 6.35, entre as quatro umidades iniciais e as três umidades finais, há uma diferença clara de comportamento, sendo que nas três últimas umidades é visível a segregação da água na superfície e nas laterais da amostra. Então, a alta umidade dessas três amostras afetou o comportamento delas no ensaio com menor velocidade. Apesar disso, cada uma das amostras apresentou resultado coerente, e os resultados de tensão de escoamento e viscosidade também foram coerentes, o que valida a adoção desses dados. 


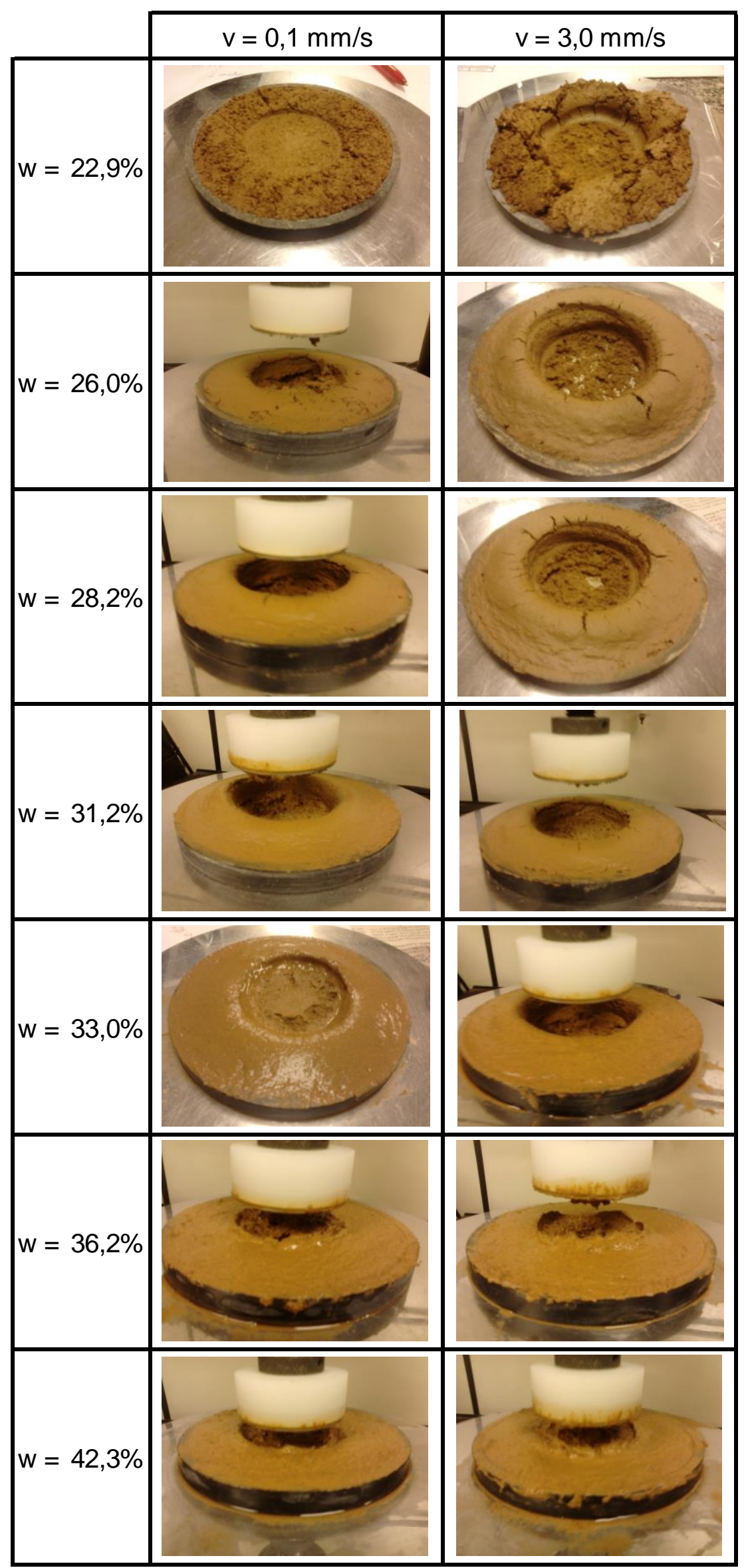

Figura 6.35 Fotos do ensaio squeeze flow - Solo Residual 
Os resultados obtidos para o colúvio estão apresentados nas Figuras 6.36 a 6.48. A amostra de solo utilizada também foi dividida em duas partes para 0 reaproveitamento do ensaio, denominadas por C e D. Sendo que da amostra C resultou os dados apresentados por (a), (b), (c) e (d) e da amostra D os dados (e), (f), (g) e (h). Nos gráficos é possível observar que o comportamento das amostras (a), (b) e (c) estão diferente das demais, o que pode ser explicado pela falta de umidade, levando a amostra a apresentar um comportamento sólido e não de uma pasta como as outras amostras.

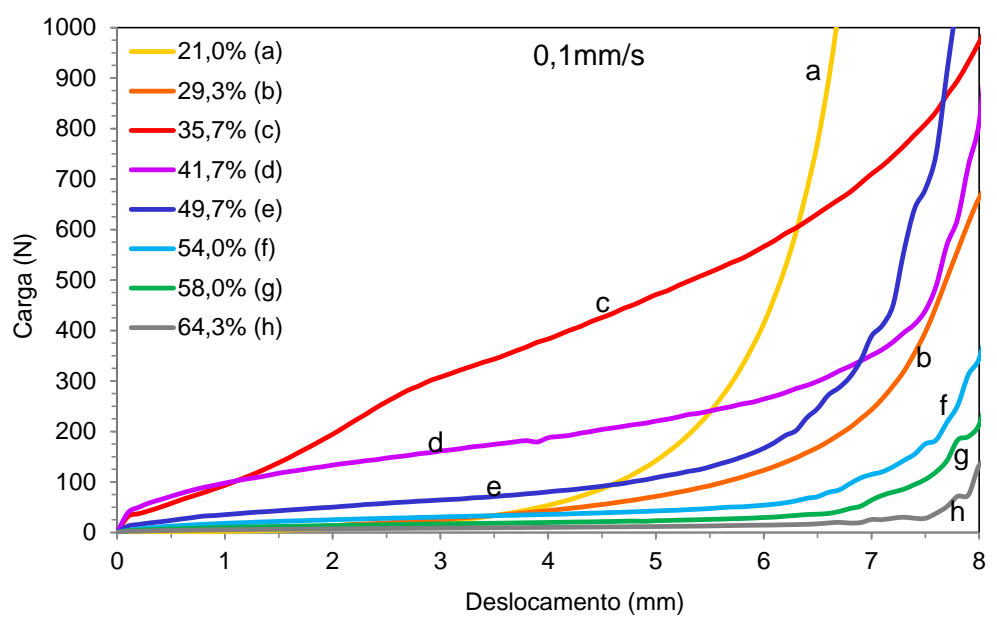

Figura 6.36 Resultado do squeeze flow realizado em $0,1 \mathrm{~mm} / \mathrm{s}$ para o Colúvio

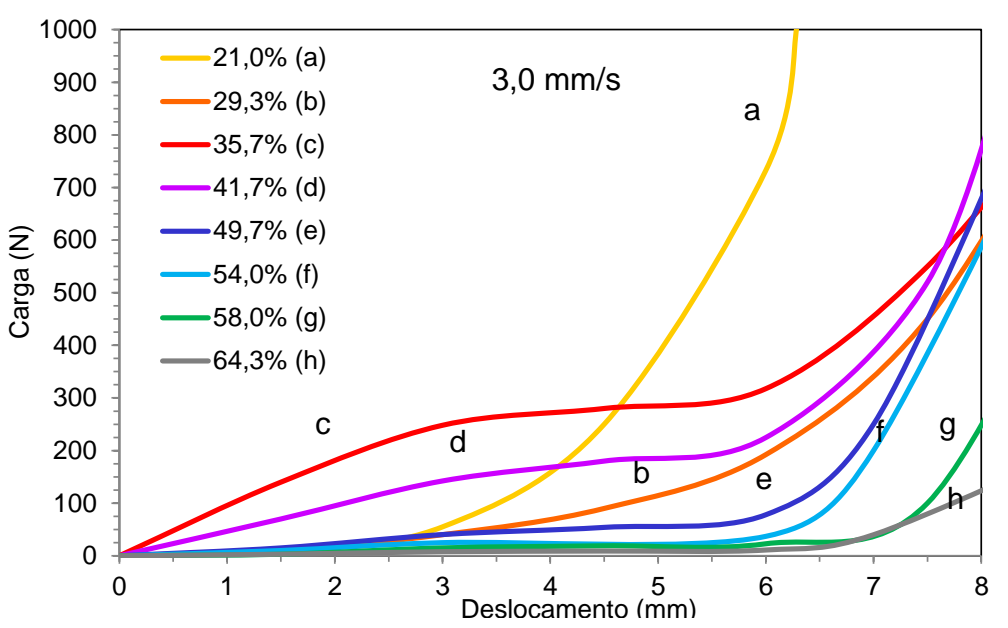

Figura 6.37 Resultado do squeeze flow realizado em $3,0 \mathrm{~mm} / \mathrm{s}$ para o Colúvio 


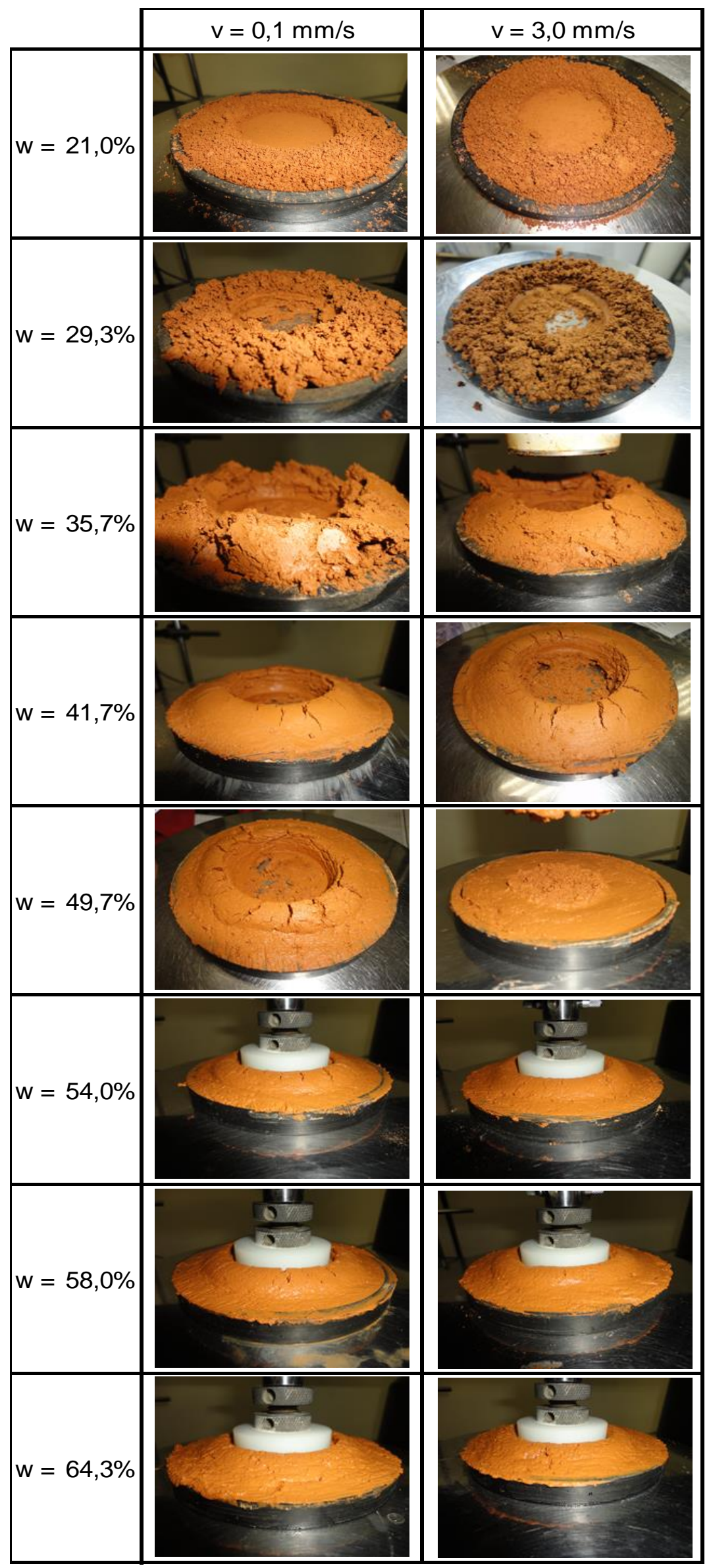

Figura 6.38 Fotos do ensaio squeeze flow - Colúvio 


\section{ANÁLISE DOS RESULTADOS DOS ENSAIOS REOLÓGICOS}

\subsection{Análise do ensaio Reometria Rotacional}

Para determinar o comportamento reológico apresentado pelo material é considerado que o formato do gráfico de taxa de cisalhamento versus tensão de cisalhamento é o mesmo apresentado no gráfico da rotação versus o torque, e o comportamento do gráfico de taxa de cisalhamento versus viscosidade equivale ao do gráfico de rotação versus estimativa de viscosidade. Essa medida é necessária já que os resultados obtidos nesse equipamento não são em unidades do SI e sua conversão não é uma tarefa simples e, apesar das unidades, o comportamento obtido é equivalente.

Os solos apresentaram tensão de escoamento e diminuição dos valores da viscosidade, ou seja, um fluido com comportamento não newtoniano, com comportamento independente do tempo e com tensão de cisalhamento inicial. Os dois principais modelos reológicos associados a esse tipo de comportamento são o de Bingham e o de Herschel Bulkley, que são os mesmos modelos adotados na classificação reológica de debris flow peneirados, como já era esperado. Aos dados obtidos no ensaio de "umidade constante" foram realizadas aproximações para os dois modelos reológicos citados e também para o modelo de Herschel Bulkley com a correção proposta por Papanastasiou.

\subsubsection{Ajuste dos modelos reológicos para os resultados dos ensaios de Geometria Planetária}

A utilização dos modelos reológicos para representação dos dados obtidos se mostrou bastante satisfatória, principalmente para os maiores teores de umidade. Os resultados estão apresentados da seguinte maneira: a aplicação do modelo para uma das umidades utilizadas para cada solo e depois uma tabela com o resumo dos parâmetros obtidos para cada teor de umidade de cada solo. Os gráficos obtidos para cada amostra de solo, cada teor de umidade e sua aproximação por cada um dos três modelos utilizados estão apresentados no Anexo dessa dissertação. 
Os resultados obtidos na aproximação através do modelo de Bingham, para a amostra com o maior teor de umidade, estão apresentados nas Figuras 7.1 e 7.2 , onde os dados estão representados pelos pontos e a previsão do modelo pela linha cheia. Para cada teor de umidade foram feitos ajustes em relação ao carregamento e ao descarregamento, sendo apresentado também o R2 obtido para cada um dos ajustes realizados. Para padronizar, os dados que se referem ao carregamento serão sempre representados por marcadores circulares enquanto os dados de descarregamento por losangos. Os parâmetros obtidos para todas as amostras, com a utilização do modelo de Bingham, estão apresentados nas Tabelas 7.1 e 7.2.
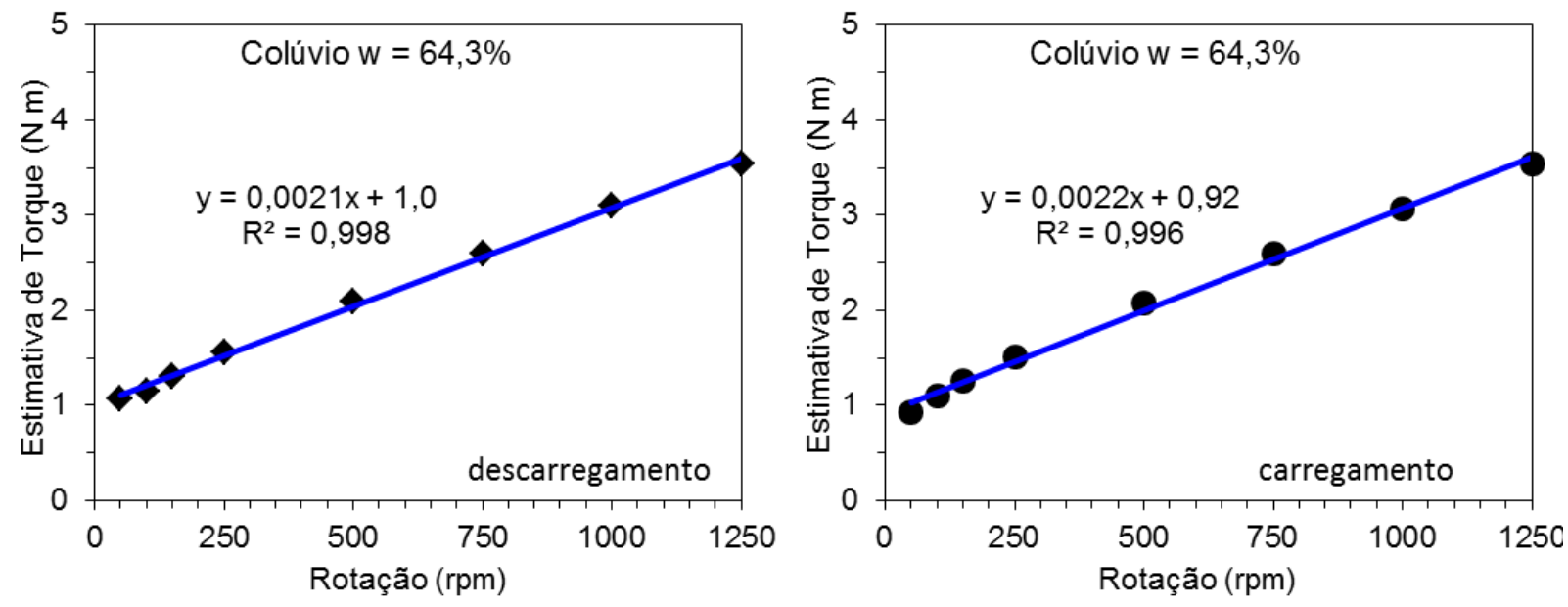

Figura 7.1 GP - Colúvio - Aproximação por Bingham - w = 64,3\%

Tabela 7.1 GP - Parâmetro obtidos - Colúvio - Aproximação por Bingham

\begin{tabular}{|c|c|c|c|c|c|c|}
\hline Colúvio & \multicolumn{3}{|c|}{ carregamento } & \multicolumn{3}{|c|}{ descarregamento } \\
\hline umidade & Tesc & $\mu$ & correlação & $\tau_{\text {esc }}$ & $\mu$ & correlação \\
\hline$(\%)$ & N.m & N.m.rpm & & N.m & N.m.rpm & \\
\hline 21,0 & 13,6 & 0,0011 & 0,12 & 18,9 & - & 0,72 \\
\hline 29,3 & 17,5 & 0,0058 & 0,84 & 20,5 & 0,0042 & 0,66 \\
\hline 35,7 & 11,7 & 0,0043 & 0,93 & 12,0 & 0,0036 & 0,98 \\
\hline 41,7 & 8,5 & 0,0021 & 0,72 & 7,9 & 0,0025 & 0,70 \\
\hline 49,7 & 3,1 & 0,0007 & 0,76 & 3,1 & 0,0006 & 0,70 \\
\hline 54,0 & 2,1 & 0,0027 & 0,98 & 2,0 & 0,0027 & 0,99 \\
\hline 58,0 & 1,7 & 0,0021 & 0,99 & 1,7 & 0,0021 & 0,99 \\
\hline 64,3 & 0,92 & 0,0022 & 0,99 & 1,0 & 0,0021 & 0,99 \\
\hline
\end{tabular}



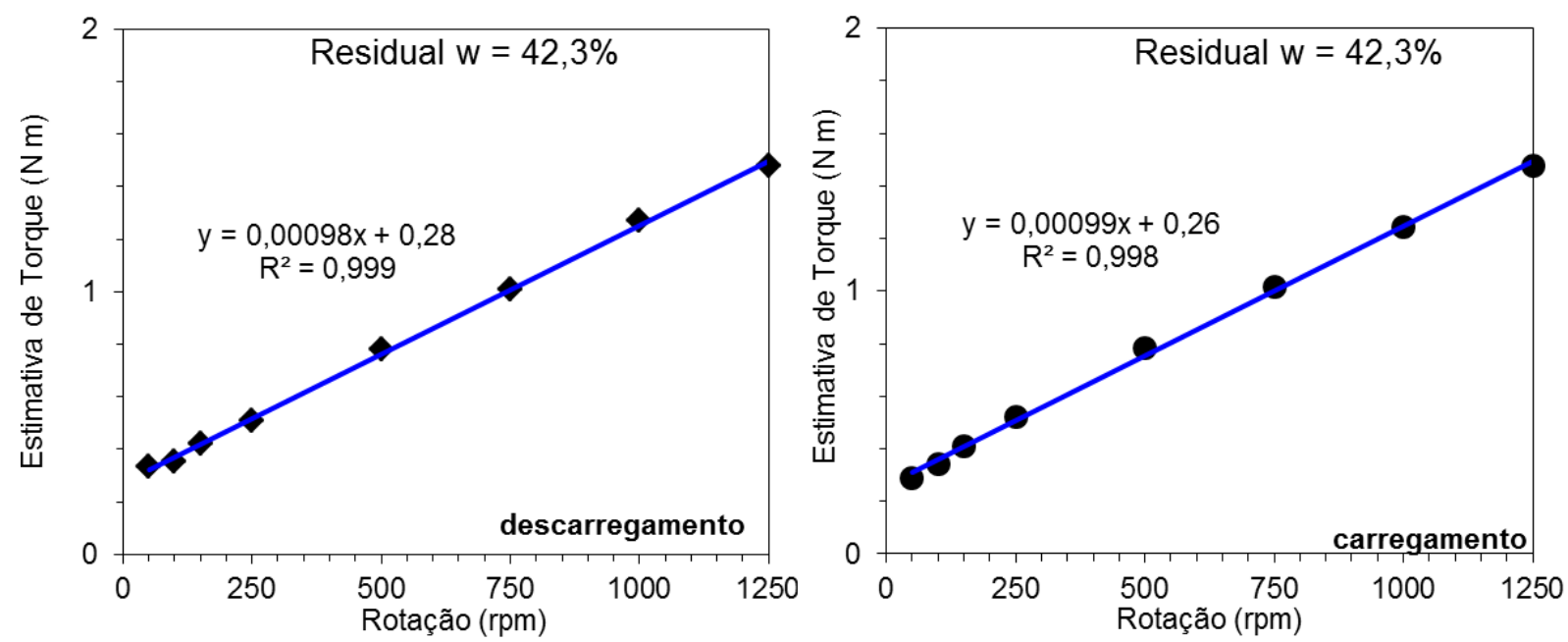

Figura 7.2 GP - Residual - Aproximação por Bingham - w = 42,3\%

Tabela 7.2 GP - Parâmetro obtidos - Residual - Aproximação por Bingham

\begin{tabular}{|c|c|c|c|c|c|c|}
\cline { 2 - 7 } Residual & \multicolumn{3}{|c|}{ carregamento } & \multicolumn{3}{c|}{ descarregamento } \\
\hline $\begin{array}{c}\text { umidade } \\
(\%)\end{array}$ & $\begin{array}{c}\tau_{\text {esc }} \\
\text { N.m }\end{array}$ & $\begin{array}{c}\mu . m . r p m \\
\text { N. correlação }\end{array}$ & $\begin{array}{c}\tau_{\text {esc }} \\
\text { N.m }\end{array}$ & $\begin{array}{c}\mu \\
\text { N.m. rpm }\end{array}$ & correlação \\
\hline 22,9 & 6,7 & 0,00040 & 0,12 & 6,9 & 0,0040 & 0,08 \\
\hline 26,0 & 4,4 & 0,00070 & 0,81 & 4,1 & 0,0011 & 0,75 \\
\hline 28,2 & 3,3 & 0,00080 & 0,94 & 3,1 & 0,0010 & 0,94 \\
\hline 31,2 & 2,2 & 0,00050 & 0,92 & 2,1 & 0,0005 & 0,92 \\
\hline 33,0 & 2,0 & 0,00004 & 0,14 & 1,6 & 0,0004 & 0,98 \\
\hline 36,2 & 0,6 & 0,00100 & 0,99 & 0,6 & 0,0010 & 0,99 \\
\hline 42,3 & 0,3 & 0,00100 & 0,99 & 0,3 & 0,0010 & 0,99 \\
\hline
\end{tabular}

As Figuras 7.3 e 7.4 apresentam a variação da tensão de escoamento e do parâmetro $\mu$ em relação à umidade para o colúvio e o solo residual, respectivamente. 


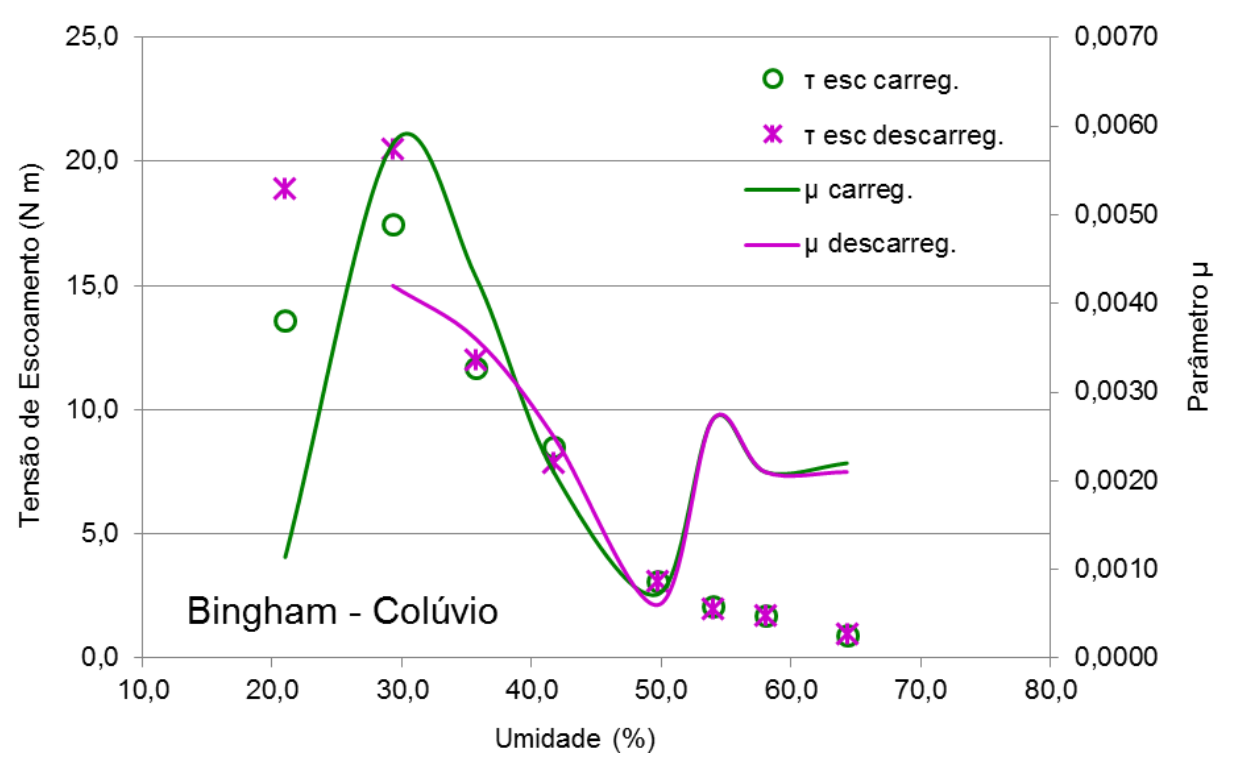

Figura 7.3 Variação dos parâmetros com a umidade - Bingham Colúvio

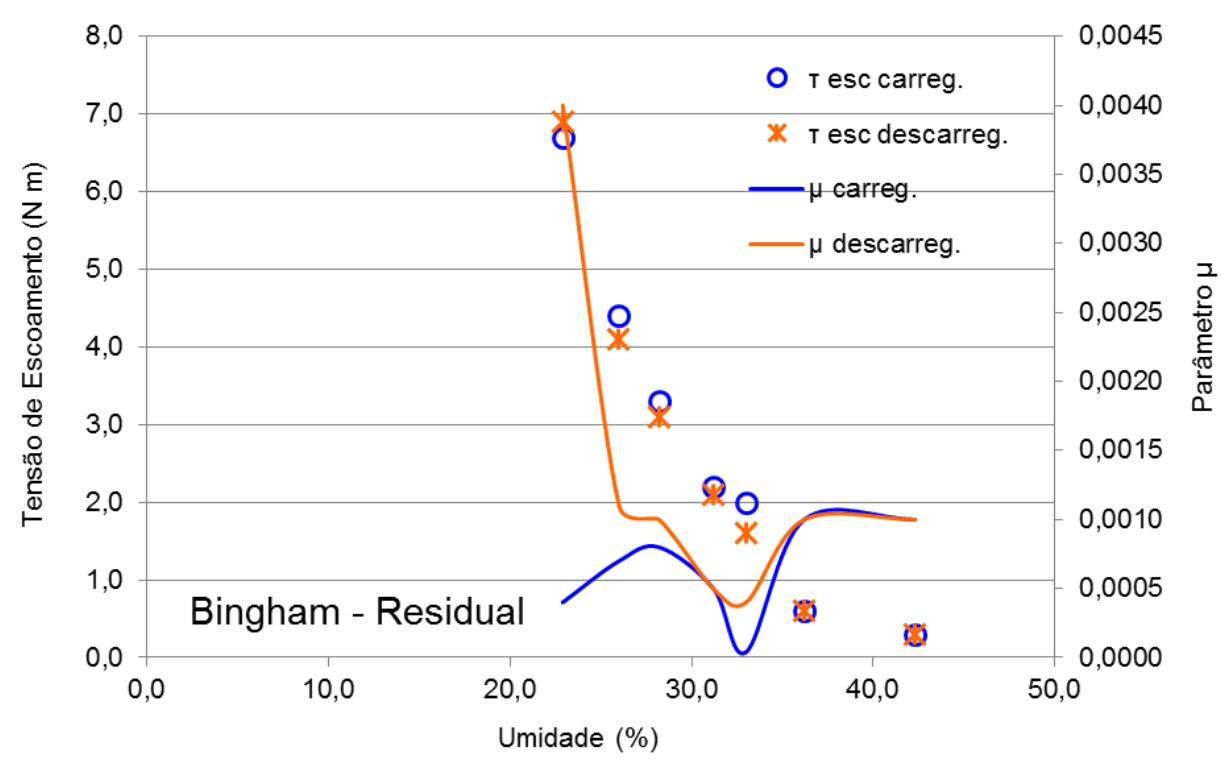

Figura 7.4 Variação dos parâmetros com a umidade - Bingham Residual

Para o colúvio, a primeira amostra, com umidade de $21,0 \%$, não apresentou correlação com o modelo devido a baixa umidade utilizada, a amostra não tem comportamento modelado como um fluido. Para as demais amostras do colúvio ocorre uma diminuição da viscosidade com o aumento da umidade até que o teor de umidade fique próximo do limite de liquidez e desse ponto em diante a viscosidade apresenta um valor que é aproximadamente constante. O mesmo comportamento foi observado para o solo residual. Esse comportamento será explorado adiante, depois da apresentação dos demais modelos. A diferença de valores obtida entre o 
carregamento e descarregamento é pequena, sendo que os parâmetros apresentam uma mesma tendência de comportamento.

O segundo modelo utilizado para a aproximação dos dados foi o de Herschel Bulkley. Os resultados obtidos estão exemplificados pela apresentação da Figura 7.5 e da Figura 7.6. Os parâmetros obtidos para todas as amostras estão apresentados na Tabela 7.3 e na Tabela 7.4 .
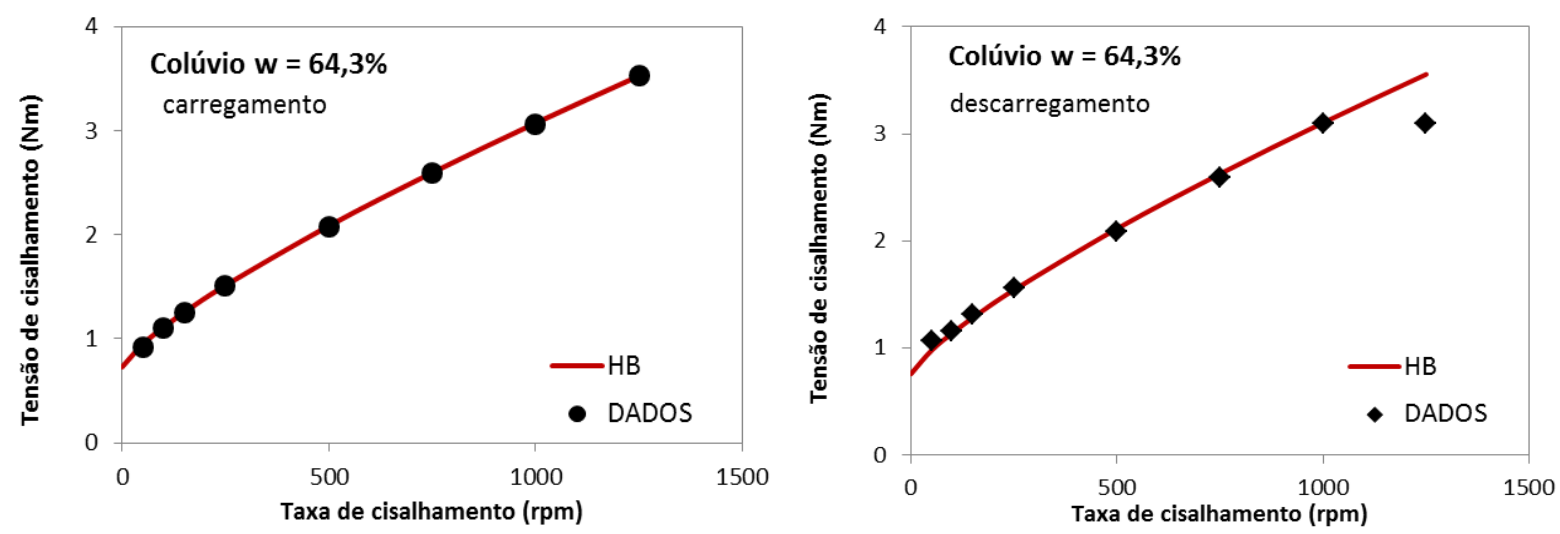

Figura 7.5 GP - Colúvio - Aproximação por Herschel Bulkley - w = 64,3\%

Tabela 7.3 GP - Parâmetro obtidos - Colúvio - Aproximação por Herschel Bulkley

\begin{tabular}{|c|c|c|c|c|c|c|c|}
\hline Colúvio & \multicolumn{3}{|c|}{ carregamento } & \multicolumn{3}{|c|}{ descarregamento } & \\
\hline $\begin{array}{c}\text { umidade } \\
(\%)\end{array}$ & k & $\mathrm{n}$ & $\begin{array}{l}\text { T esc } \\
\text { N.m }\end{array}$ & k & $\mathrm{n}$ & $\begin{array}{l}\tau \text { esc } \\
\text { N.m }\end{array}$ & correlação \\
\hline 21,0 & - & - & - & - & - & - & - \\
\hline 29,3 & 0,14 & 0,60 & 15,0 & 0,05 & 0,68 & 19,0 & 0,83 \\
\hline 35,7 & 0,13 & 0,55 & 10,0 & 0,13 & 0,55 & 10,0 & 0,88 \\
\hline 41,7 & 0,25 & 0,40 & 7,0 & 0,15 & 0,5 & 6,0 & 0,78 \\
\hline 49,7 & 0,25 & 0,30 & 2,0 & - & - & - & 0,51 \\
\hline 54,0 & 0,01 & 0,82 & 2,0 & 0,01 & 0,82 & 1,8 & 0,99 \\
\hline 58,0 & 0,01 & 0,79 & 1,4 & 0,01 & 0,79 & 1,4 & 0,99 \\
\hline 64,3 & 0,01 & 0,79 & 0,73 & 0,01 & 0,79 & 0,8 & 0,98 \\
\hline
\end{tabular}



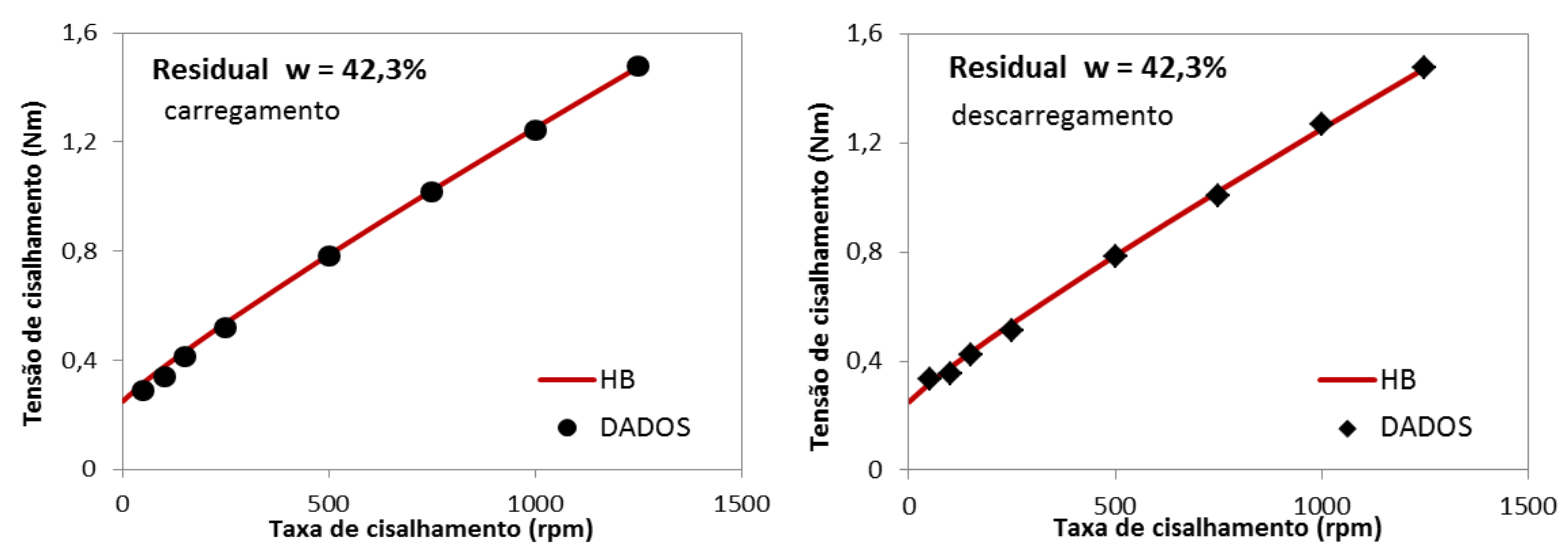

Figura 7.6 GP - Residual - Aproximação por Herschel Bulkley - w = 42,3\%

Tabela 7.4 GP - Parâmetro obtidos - Residual - Aproximação por Herschel Bulkley

\begin{tabular}{|c|c|c|c|c|c|c|c|}
\hline Residual & \multicolumn{3}{|c|}{ carregamento } & \multicolumn{3}{|c|}{ descarregamento } & \\
\hline $\begin{array}{c}\text { umidade } \\
\text { (\%) }\end{array}$ & k & $\mathrm{n}$ & $\begin{array}{l}\text { T esc } \\
\text { N.m }\end{array}$ & k & $\mathrm{n}$ & $\begin{array}{l}\text { Tesc } \\
\text { N.m }\end{array}$ & correlação \\
\hline 22,9 & 0,10 & 0,40 & 5,8 & 0,30 & 0,3 & 5,5 & 0,09 \\
\hline 26,0 & 0,15 & 0,30 & 4,0 & 0,27 & 0,3 & 3,0 & 0,87 \\
\hline 28,2 & 0,01 & 0,67 & 3,0 & 0,01 & 0,7 & 2,8 & 0,92 \\
\hline 31,2 & 0,01 & 0,60 & 2,0 & 0,01 & 0,6 & 2,0 & 0,93 \\
\hline 33,0 & 0,01 & 0,35 & 1,9 & 0,01 & 0,55 & 1,5 & 0,95 \\
\hline 36,2 & 0,004 & 0,80 & 0,6 & 0,004 & 0,8 & 0,5 & 0,99 \\
\hline 42,3 & 0,002 & 0,90 & 0,3 & 0,002 & 0,9 & 0,25 & 1,00 \\
\hline
\end{tabular}

As Figuras 7.7 e 7.8 apresentam a variação da tensão de escoamento e do parâmetro k em relação ao aumento do teor de umidade para o colúvio e o solo residual. 


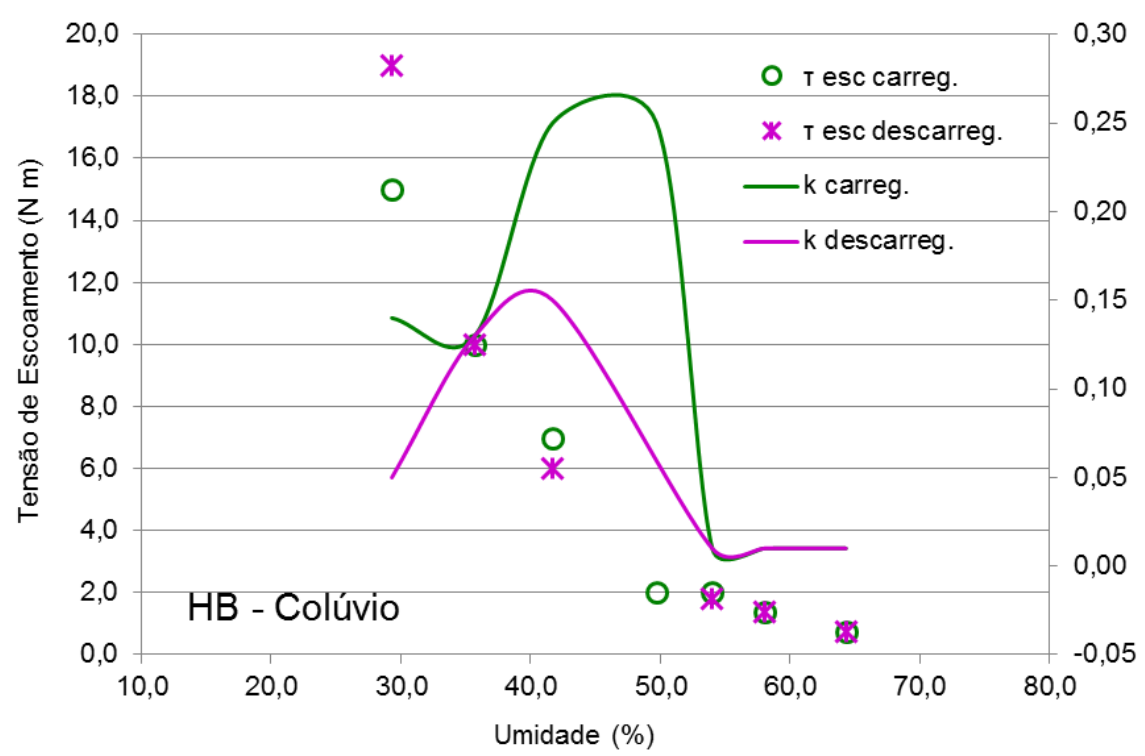

Figura 7.7 Variação dos parâmetros com a umidade - HB Colúvio

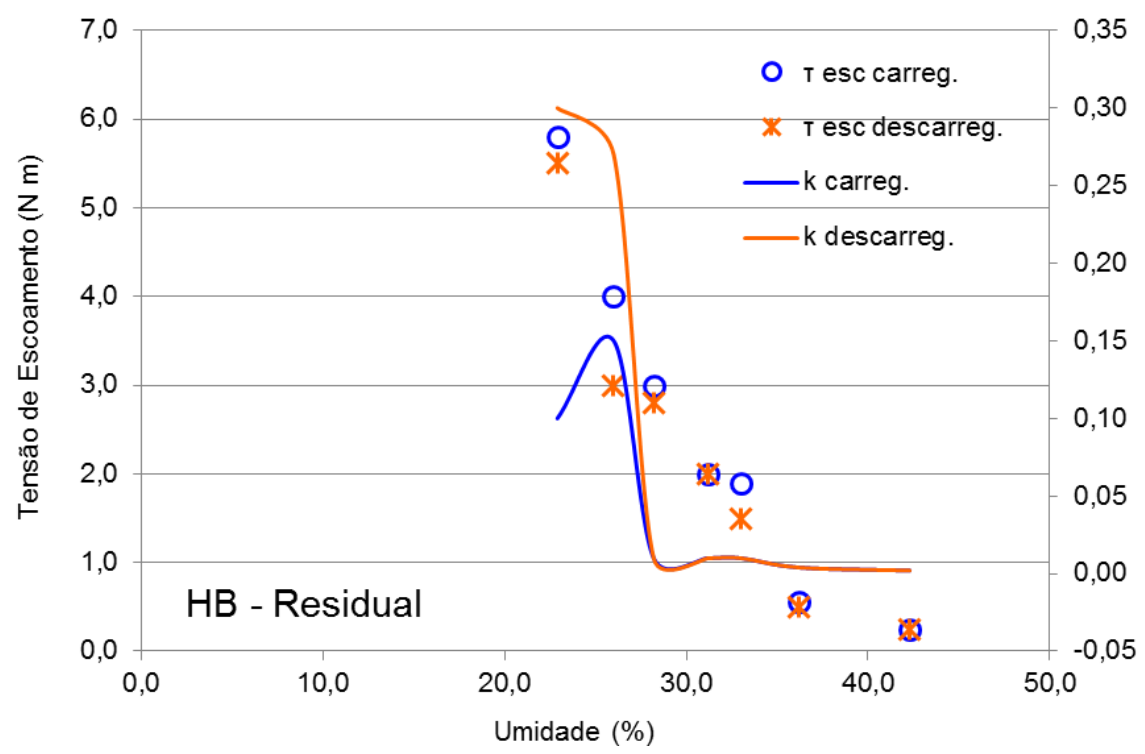

Figura 7.8 Variação dos parâmetros com a umidade - HB Residual

Nas amostras de colúvio com teores de umidade de $21,0 \%$ e de $49,7 \%$, 0 modelo não consegue representar os dados obtidos, já nas demais amostras apresentaram um índice de correlação alto. A amostra com teor de umidade de $22,9 \%$ de solo residual também não apresentou correlação com o modelo.

As Figuras 7.9 e 7.10 apresentam a variação da viscosidade aparente para cada solo, que foi calculada a partir dos dados obtidos com a utilização do modelo de Herschel Bulkley com a equação 5.2. 


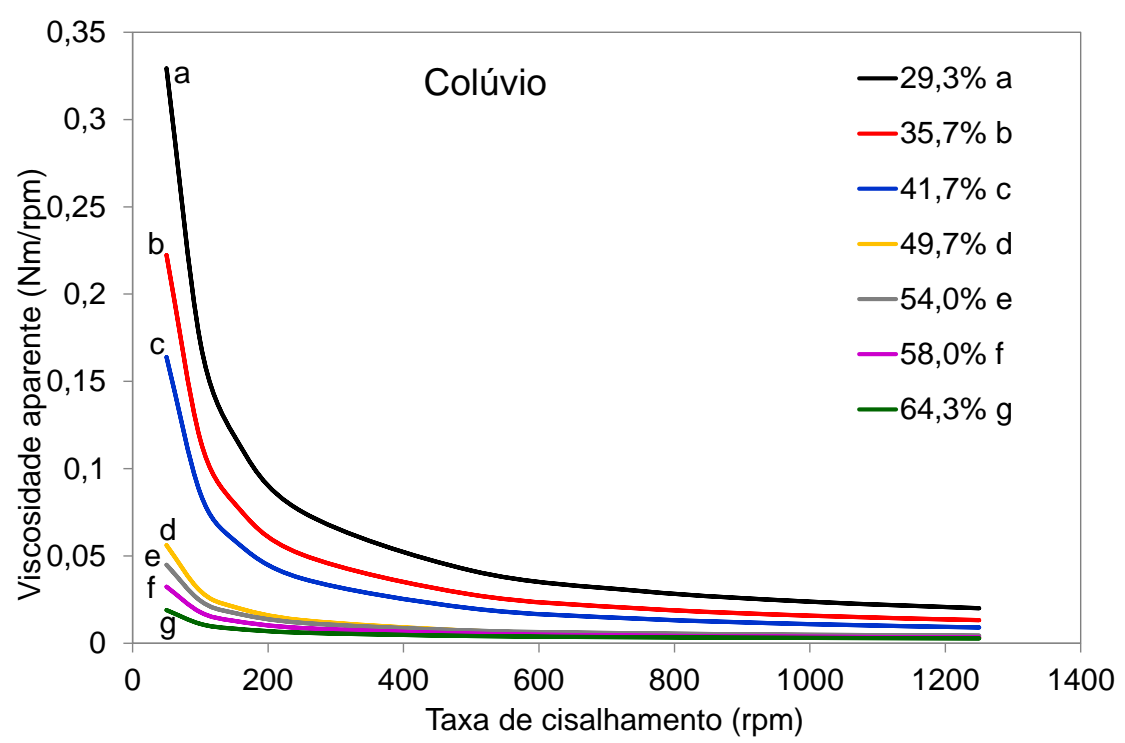

Figura 7.9 GP - Viscosidade aparente modelo de HB - Colúvio

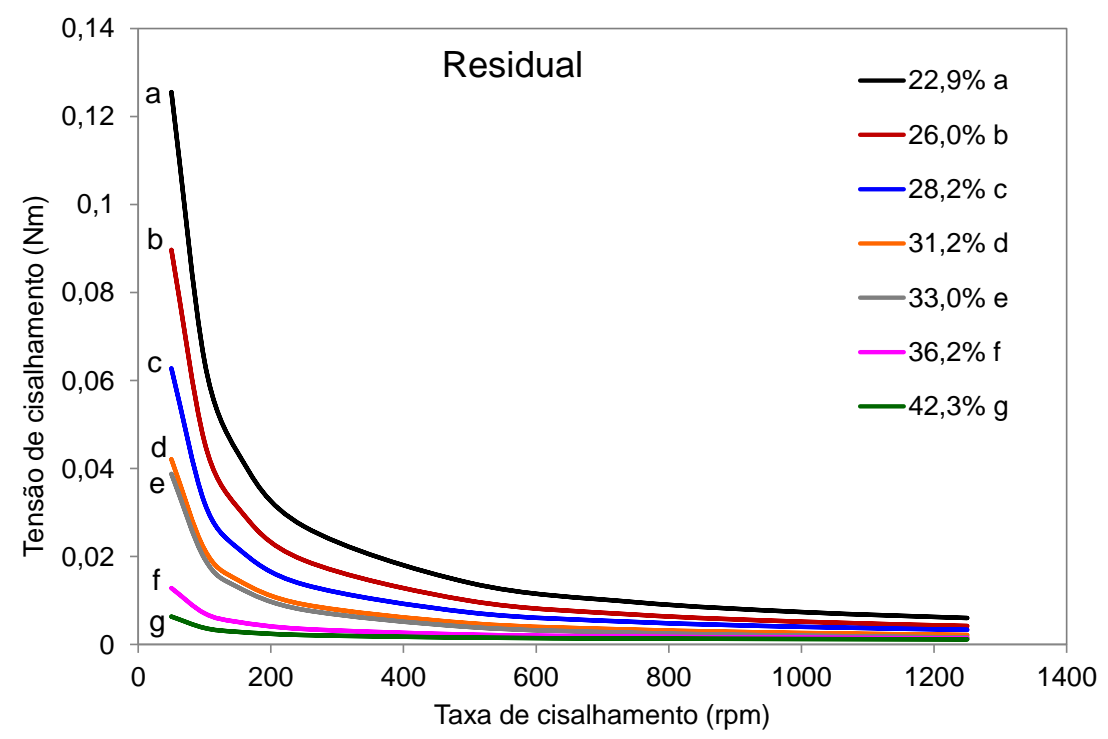

Figura 7.10 GP - Viscosidade aparente modelo de HB - Residual

O terceiro modelo de ajuste utilizado foi o de Herschel Bulkley corrigido por Papanastasiou, os resultados obtidos estão apresentados nas Figuras 7.11 e 7.12, e os parâmetros obtidos para as amostras estão apresentados nas Tabelas 7.5 e 7.6, para o colúvio e o solo residual, respectivamente. Para todos os dados analisados foi adotado o valor de 100 para o parâmetro alpha, conforme discutido no item 5.7. Também está apresentada a variação da viscosidade em relação a taxa de cisalhamento nas Figuras 7.13 e 7.14 . 

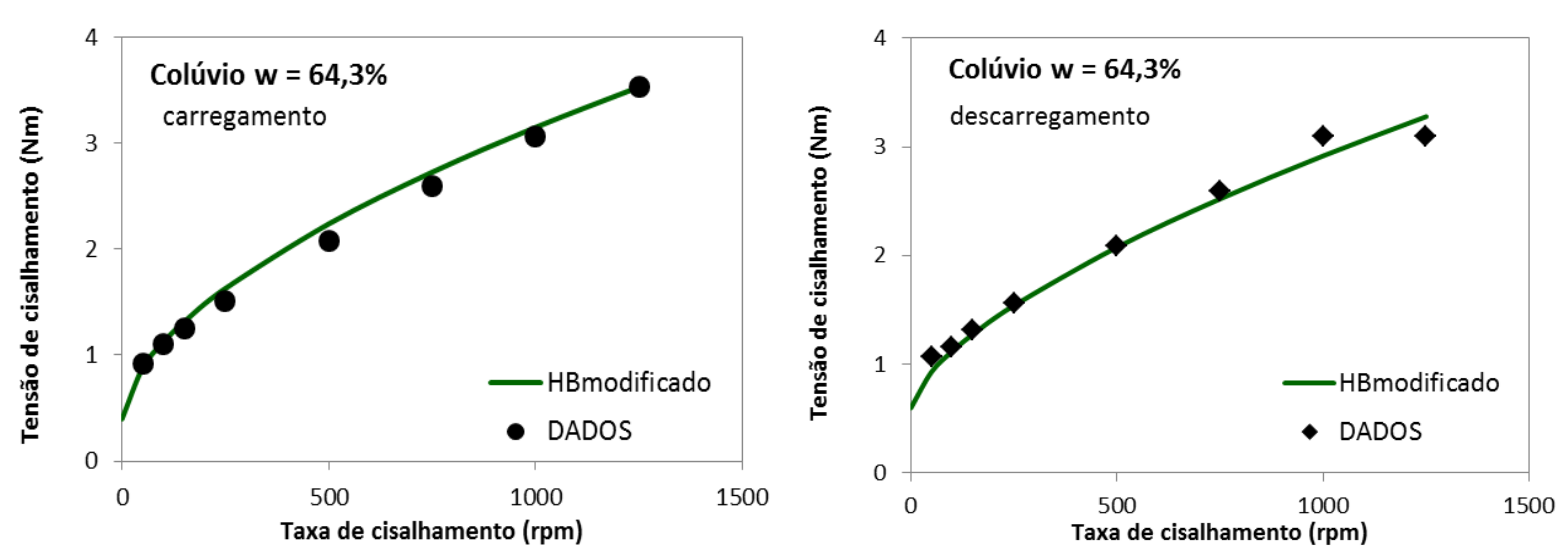

Figura 7.11 GP - Colúvio - Aproximação por Herschel Bulkley modificado - $w=64,3 \%$

Tabela 7.5 GP - Parâmetro obtidos - Colúvio - Aproximação por Herschel Bulkley modificado

\begin{tabular}{|c|c|c|c|c|c|c|c|}
\hline Colúvio & \multicolumn{3}{|c|}{ carregamento } & \multicolumn{3}{|c|}{ descarregamento } & \\
\hline $\begin{array}{c}\text { umidade } \\
(\%)\end{array}$ & k & $n$ & $\begin{array}{l}\text { T esc } \\
\text { N.m }\end{array}$ & k & $n$ & $\begin{array}{l}\tau \text { esc } \\
\text { N.m }\end{array}$ & correlação \\
\hline 21,0 & - & - & - & - & - & - & - \\
\hline 29,3 & 0,11 & 0,61 & 16,0 & 0,11 & 0,60 & 18,0 & 0,84 \\
\hline 35,7 & 0,14 & 0,53 & 10,0 & 0,14 & 0,55 & 9,8 & 0,87 \\
\hline 41,7 & 0,22 & 0,40 & 7,3 & 0,11 & 0,54 & 6,0 & 0,74 \\
\hline 49,7 & 0,15 & 0,30 & 2,5 & - & - & - & 0,70 \\
\hline 54,0 & 0,10 & 0,50 & 1,5 & 0,06 & 0,60 & 1,1 & 0,97 \\
\hline 58,0 & 0,10 & 0,50 & 0,7 & 0,04 & 0,60 & 1,3 & 0,99 \\
\hline 64,3 & 0,05 & 0,58 & 0,4 & 0,03 & 0,65 & 0,6 & 0,99 \\
\hline
\end{tabular}
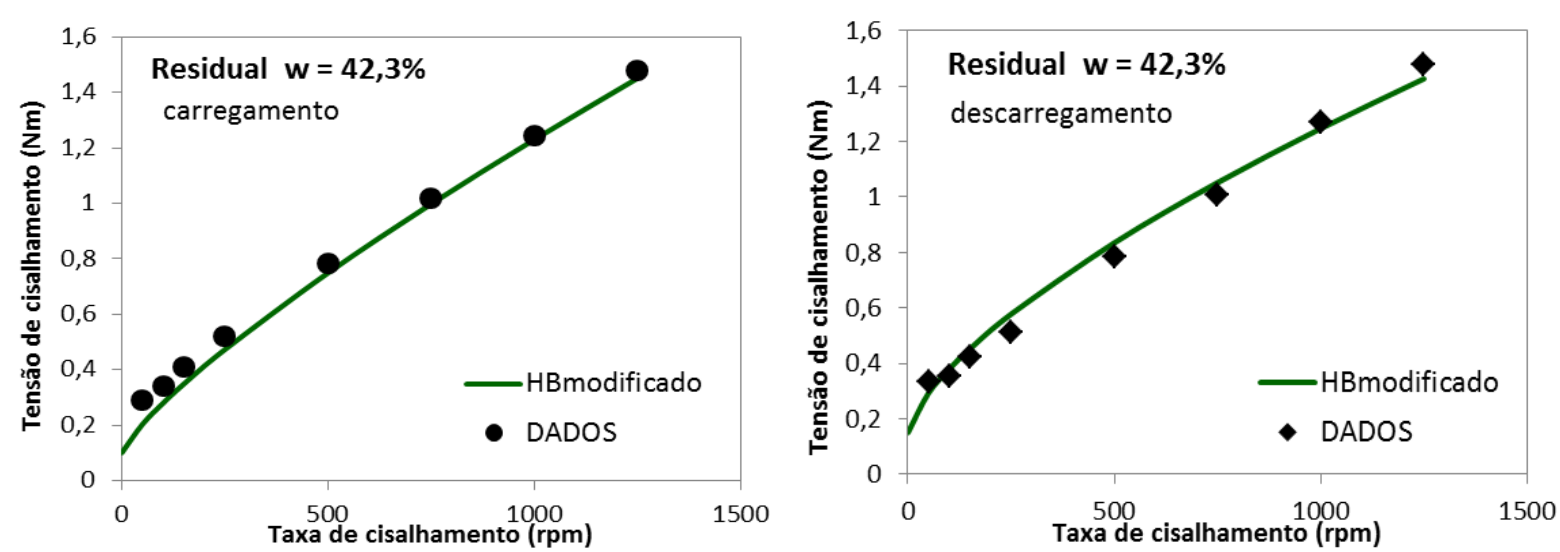

Figura 7.12 GP - Colúvio - Aproximação por Herschel Bulkley modificado - w = 42,3\% 
Tabela 7.6 GP - Parâmetro obtidos - Residual - Aproximação por Herschel Bulkley modificado

\begin{tabular}{|c|c|c|c|c|c|c|c|}
\cline { 2 - 7 } \multicolumn{1}{c|}{ Residual } & \multicolumn{3}{c|}{ carregamento } & \multicolumn{3}{c|}{ descarregamento } & \multicolumn{1}{c|}{} \\
\hline $\begin{array}{c}\text { umidade } \\
(\%)\end{array}$ & $\mathrm{k}$ & $\mathrm{n}$ & $\begin{array}{c}\tau \text { esc } \\
\mathrm{N} \cdot \mathrm{m}\end{array}$ & $\mathrm{k}$ & $\mathrm{n}$ & $\begin{array}{c}\tau \text { esc } \\
\text { N.m }\end{array}$ & correlação \\
\hline 22,9 & 0,15 & 0,30 & 5,8 & 0,30 & 0,30 & 5,5 & 0,07 \\
\hline 26,0 & 0,10 & 0,40 & 3,7 & 0,17 & 0,34 & 3,3 & 0,83 \\
\hline 28,2 & 0,10 & 0,40 & 2,5 & 0,01 & 0,70 & 2,8 & 0,88 \\
\hline 31,2 & 0,08 & 0,35 & 1,8 & 0,02 & 0,60 & 1,8 & 0,85 \\
\hline 33,0 & 0,01 & 0,35 & 1,9 & 0,02 & 0,47 & 1,4 & 0,96 \\
\hline 36,2 & 0,045 & 0,50 & 0,2 & 0,020 & 0,60 & 0,4 & 0,98 \\
\hline 42,3 & 0,005 & 0,80 & 0,1 & 0,010 & 0,68 & 0,15 & 0,99 \\
\hline
\end{tabular}

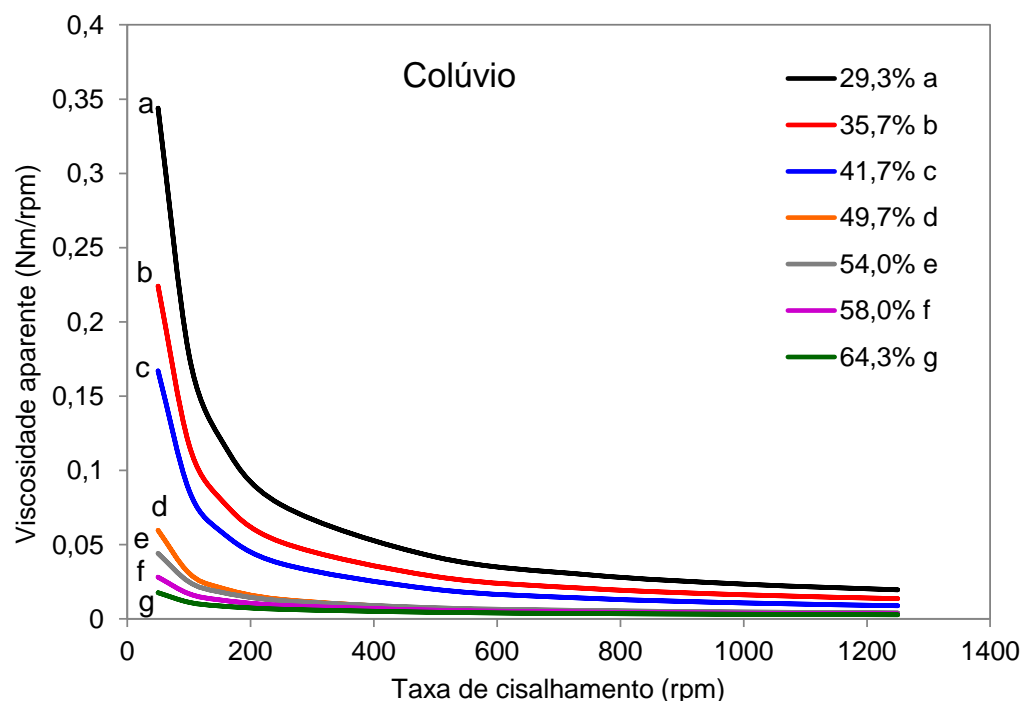

Figura 7.13 GP - Viscosidade aparente modelo de HB modificado - Colúvio

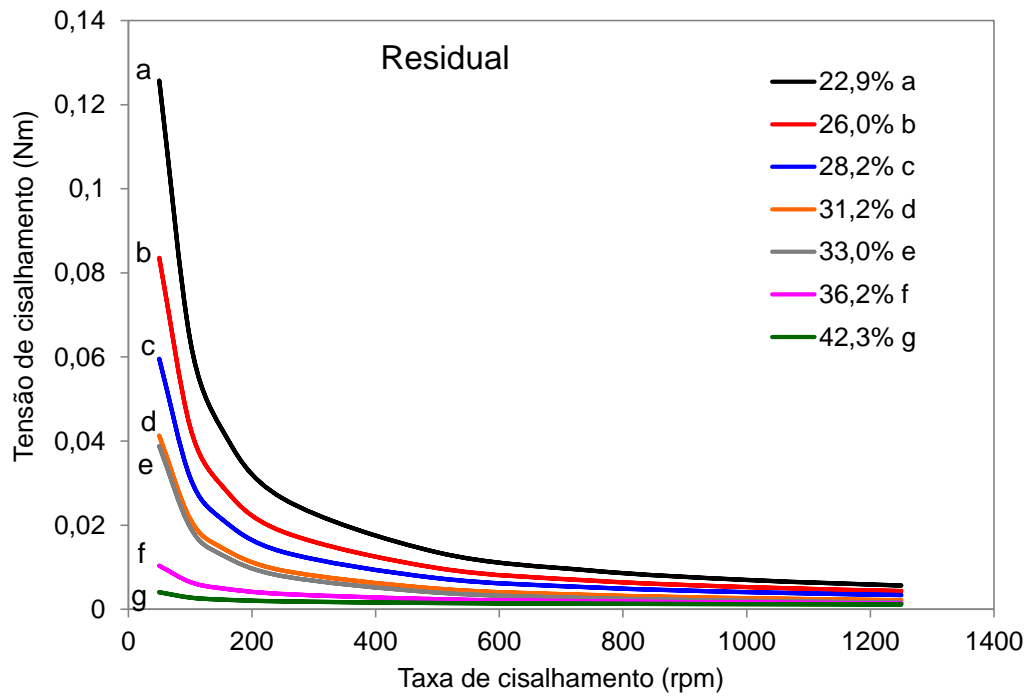

Figura 7.14 GP - Viscosidade aparente modelo de HB modificado - Residual 
As Figuras 7.15 e 7.16 apresentam a variação da tensão de escoamento e do parâmetro $\mathrm{k}$ em relação ao aumento do teor de umidade para o colúvio e o solo residual.

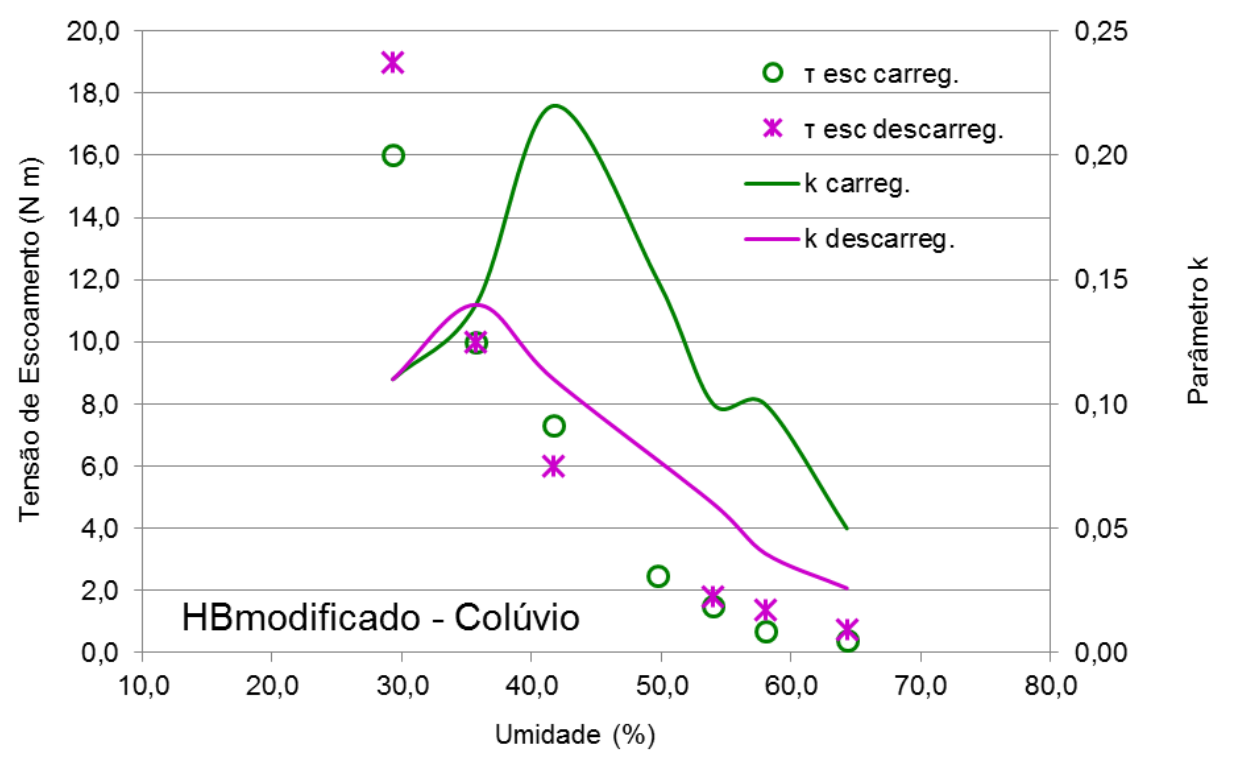

Figura 7.15 Variação dos parâmetros com a umidade - HB mod. Colúvio

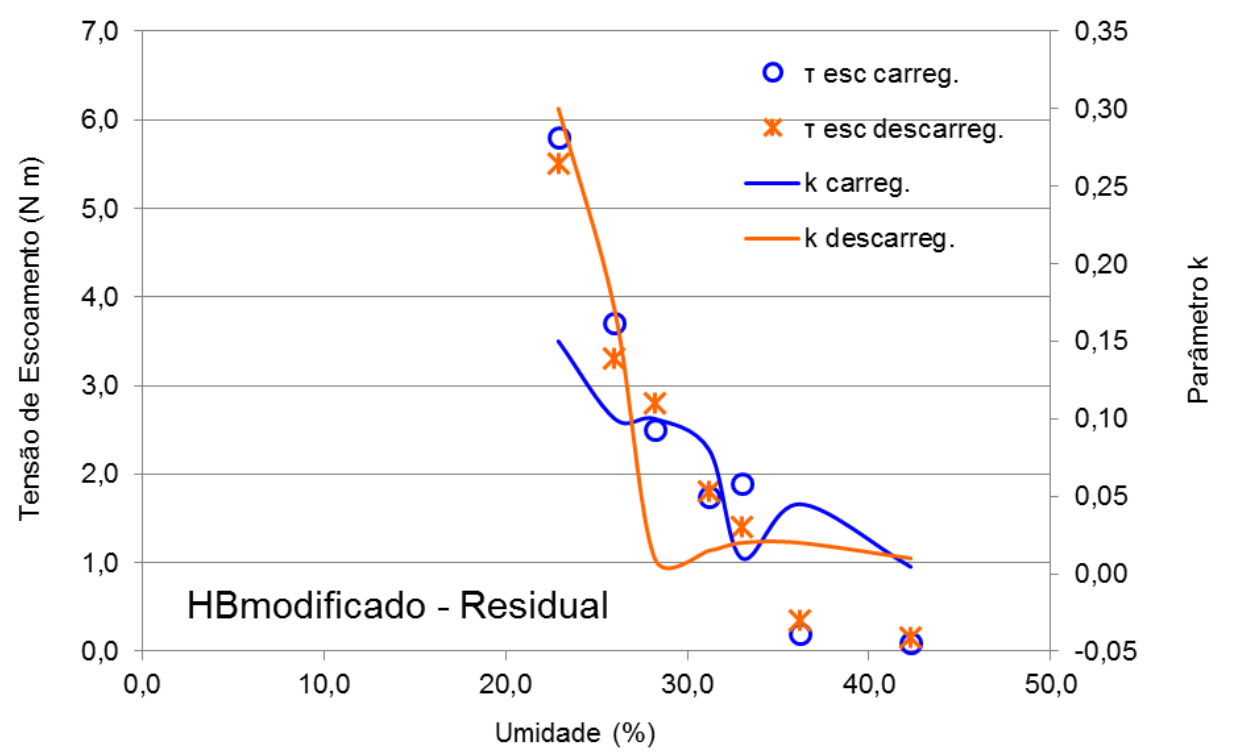

Figura 7.16 Variação dos parâmetros com a umidade - HB mod. Residual

Os ajustes obtidos através do modelo de Herschel Bulkley modificado para as amostras com menores teores de umidade também não foram satisfatórios. Em relação aos de dados de carregamento/descarregamento não foi possível observar diferença expressiva para aplicação do modelo.

Para o $2^{\circ}$ ensaio, realizado com a umidade variável e velocidade constante, foi possível obter a tensão de escoamento do solo e a umidade correspondente à 
essa tensão. A variação de umidade em relação ao torque aplicado está apresentada nas Figuras 7.17 e 7.18 .

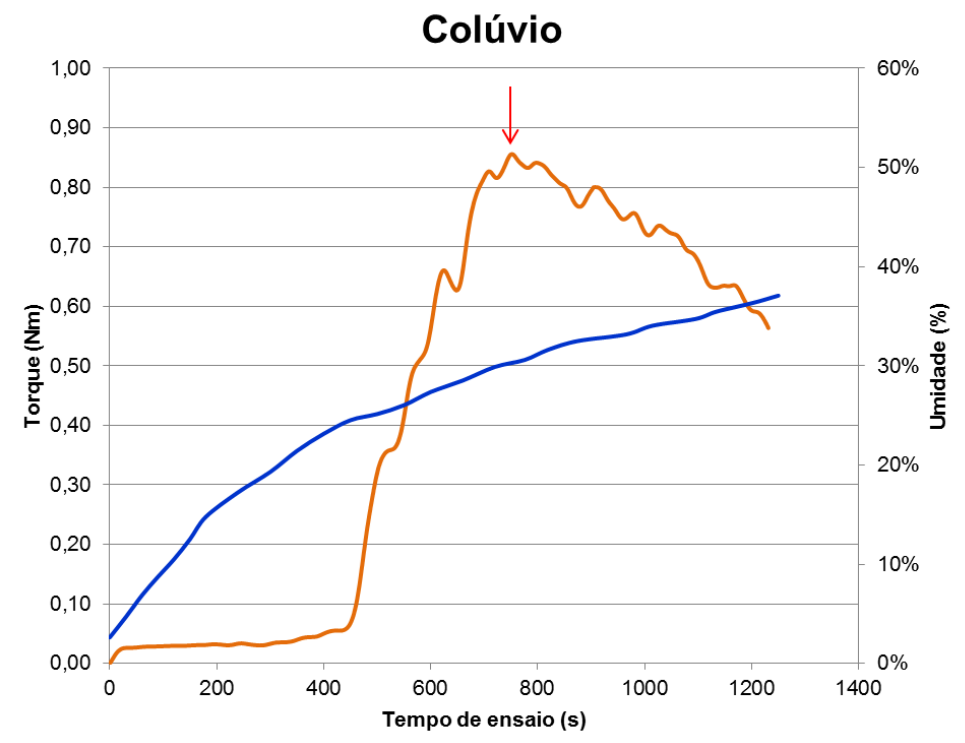

Figura 7.17 - Tensão de escoamento - Colúvio

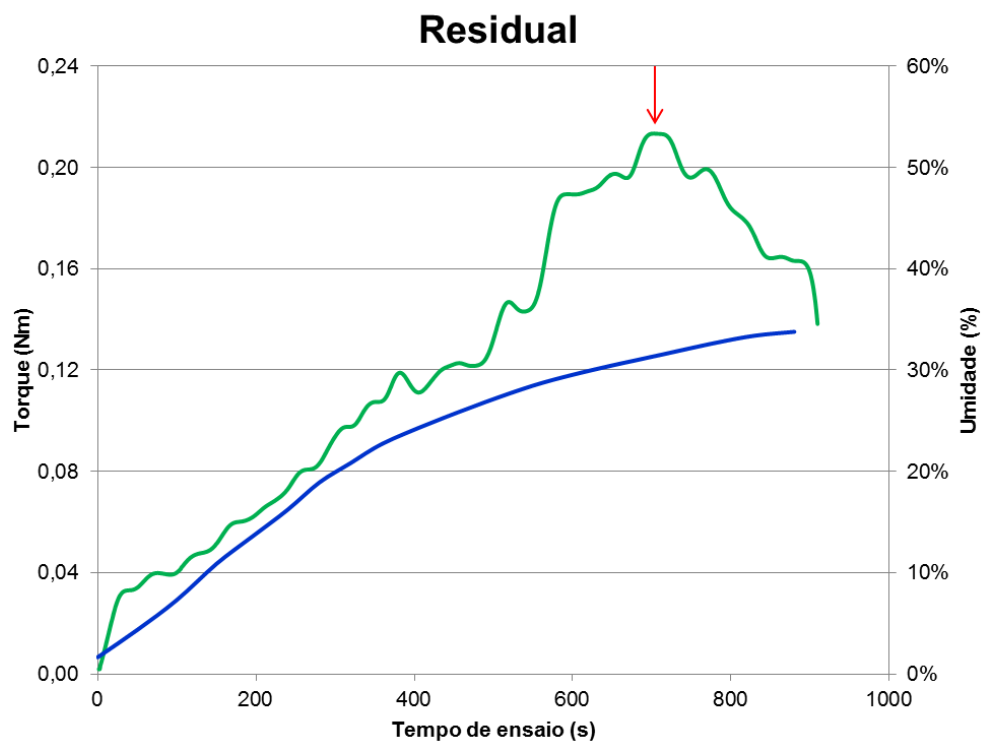

Figura 7.18 - Tensão de escoamento - Residual

De acordo com o ensaio realizado com "variação de umidade" é possível visualizar que a tensão de escoamento foi de 0,84 N.m para o colúvio e 0,21 Nm para o solo residual. E a umidade para que os solos atingissem essa tensão foi de $30,6 \%$ para o colúvio e $31,5 \%$ para o solo residual. 


\subsubsection{Conclusões do Ensaio de Geometria Planetária}

O reômetro rotacional com geometria planetária é de fácil utilização, os resultados obtidos são concordantes, apresentam repetibilidade e são confiáveis.

Os resultados de tixotropia pontam que as amostras com umidades intermediárias apresentaram comportamento tixotrópico enquanto as amostras de maior e menor umidade apresentaram reopexia. A Figura 7.19 apresenta a área de histerese dos solos. O comportamento obtido já era esperado tendo em vista que a área de histerese é um parâmetro de medição da homogeneização da amostra e sabendo que as amostras mais homogêneas são aquelas que estão sendo reutilizadas nos ensaios e também aquelas que apresentam o maior teor de umidade.
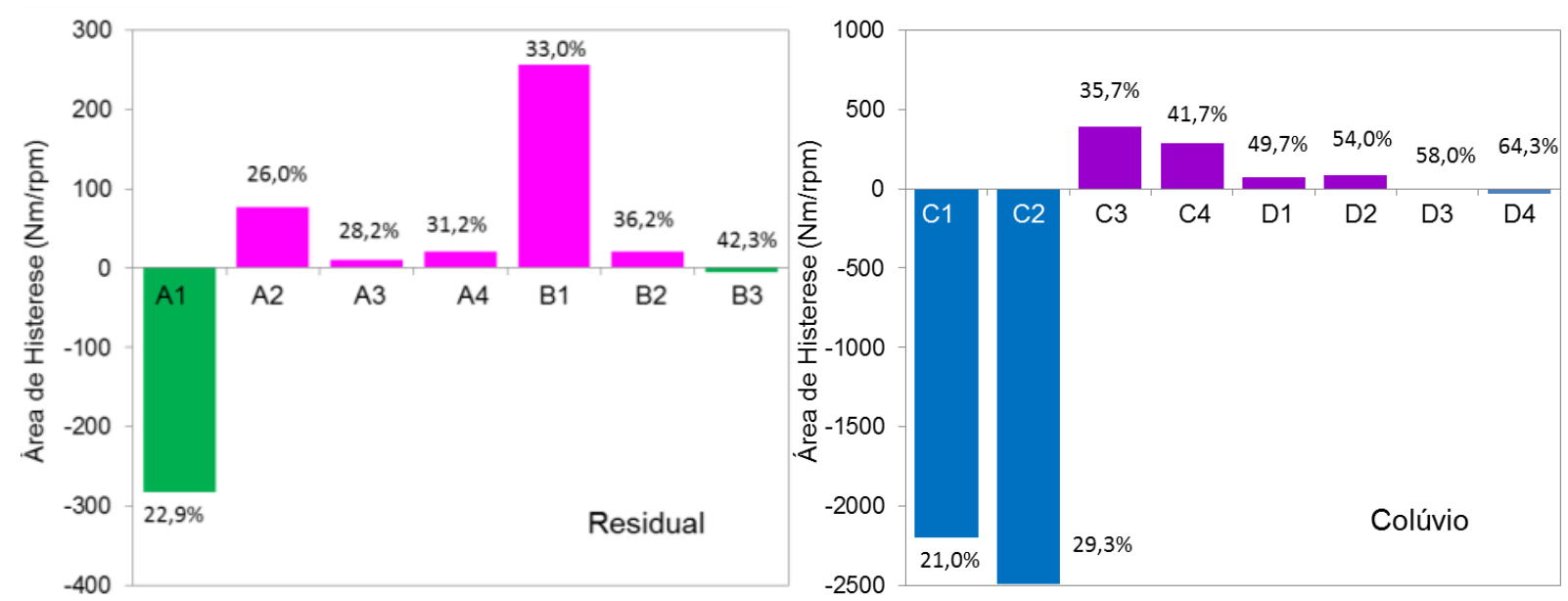

Figura 7.19 Área de histerese das amostras

O alto valor da tixotropia obtido na amostra com teor de umidade de $22,9 \%$ no solo residual e as amostras com umidade de $21,0 \%$ e $29,3 \%$ no colúvio é esperado porque como o solo está seco com essas baixas umidades, a amostra ensaiada tem um aspecto de grãos aglomerados, e não pode ser considerada como uma massa homogênea como nas amostras de maior umidade. Por esse motivo, o ajuste dos modelos utilizados com os dados obtidos para essas amostras não foram satisfatórios, o que pode ser observado nos índices de correlação obtidos apresentados nas Tabelas 7.1 a 7.6. Já a amostra de solo residual com $33,0 \%$ de umidade apresentou uma elevada área de histerese pela falta de homogeneização, explicada pelo fato dessa amostra ter sido misturada com água manualmente, sendo 
realizada uma homogeneização mecânica, no equipamento, por apenas 2 minutos, esse tempo deveria ter sido aumentado para que essa área de histerese diminuísse.

Para realizar uma comparação entre os ajustes realizados para cada modelo reológico são apresentadas as Figuras 7.21 à 7.23 , que compara os resultados obtidos para cada modelo de apenas um teor de umidade de cada solo.
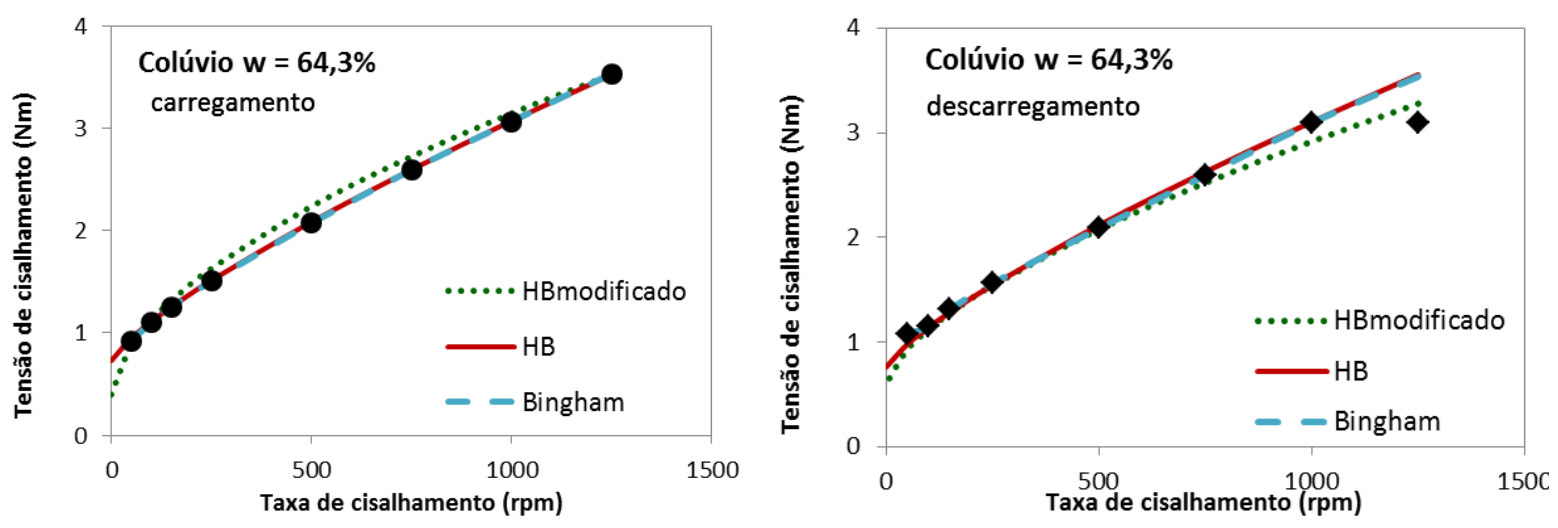

Figura 7.20 Colúvio - Comparação entre os modelos utilizados $-\mathrm{w}=64,3 \%$
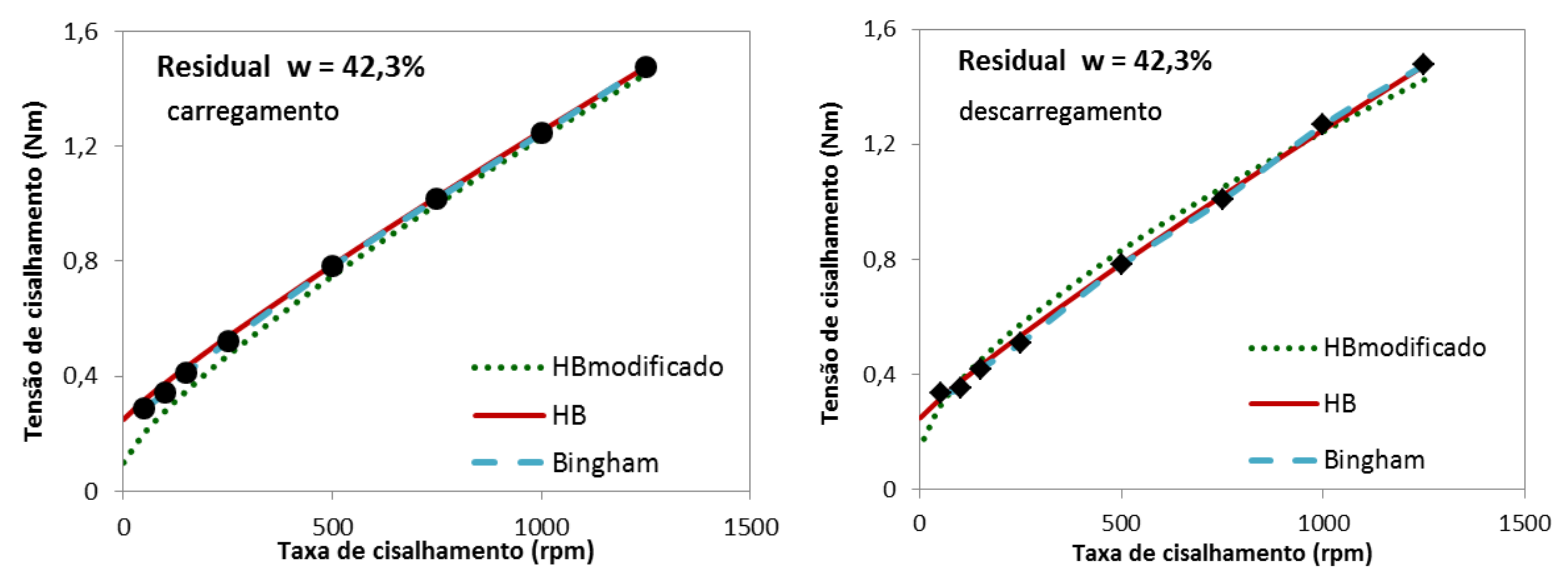

Figura 7.21 Residual - Comparação entre os modelos utilizados $-\mathrm{w}=\mathbf{4 2 , 3} \%$ 


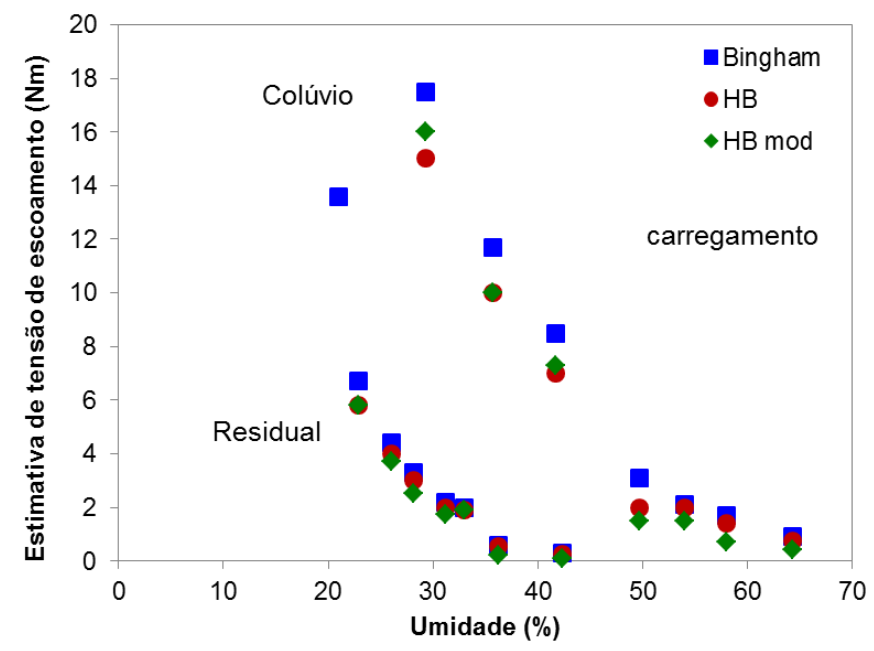

Figura 7.22 GP - Variação da tensão de escoamento - carregamento

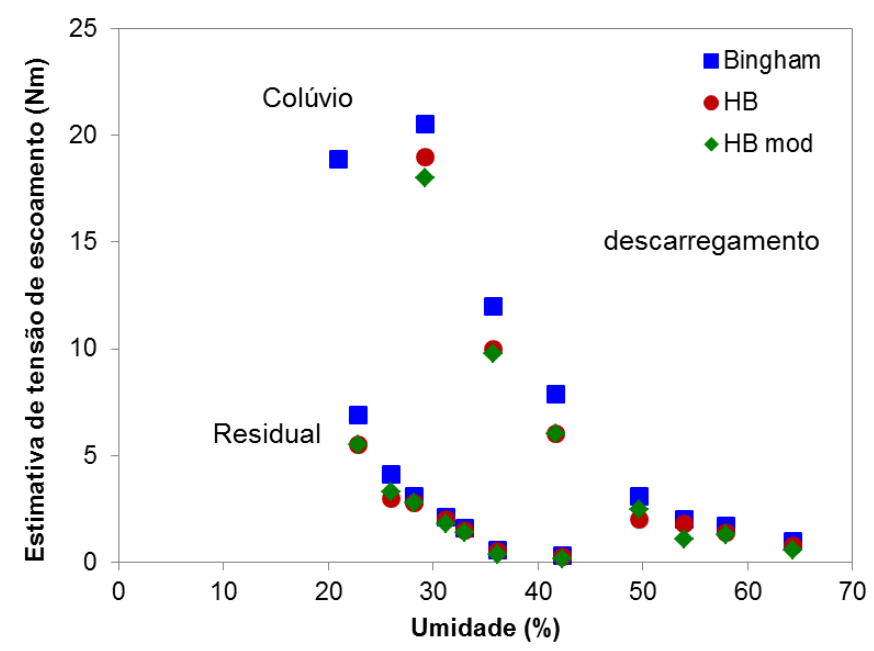

Figura 7.23 Variação da tensão de escoamento - descarregamento

Os três modelos adotados apresentaram valores dos parâmetros reológicos próximos e concordantes, a estimativa da tensão de escoamento, como pode ser vista nas Figuras 7.22 e 7.23, não apresentou diferenças significativas. Os gráficos obtidos da variação da viscosidade em relação à taxa de cisalhamento se mostraram concordantes entre os modelos analisados. As correlações, R2, obtidas foram mais altas utilizando o modelo de Bingham para o solo Residual e o modelo de Herschel Bulkley modificado para o Colúvio, entretanto todos os modelos obtiveram valores de correlações muito próximos.

Nenhum dos modelos consegue representar bem a situação menos úmida, o que já era esperado, porque com a umidade baixa o solo tem seu comportamento melhor aproximado por um sólido do que um fluido. Como a reologia é utilizada para a caracterização de fluidos, quanto maior a umidade, melhor a aproximação dos modelos com o comportamento observado. 
A inclusão do parâmetro alpha não aumentou significadamente as correlações obtidas, não melhorando os ajustes entre o modelo e os dados. Mesmo variando o valor desse parâmetro para 1000 não ocorreram mudanças significativas no comportamento. Considerando a média dos valores de correlação obtidos, houve uma diminuição da correlação utilizando o modelo modificado de $1 \%$ para o colúvio e 3\% para o solo residual, não se obtendo utilidade na correção do modelo.

Para uma umidade de campo os dois solos apresentam comportamentos distintos considerando, por exemplo, um teor de umidade de $40 \%$ o solo residual iria sofrer liquefação enquanto o colúvio não, só sofreria o fenômeno com um teor de umidade mais elevado, da ordem de $60-70 \%$.

Para resolver a utilização dos dados obtidos pelo carregamento ou descarregamento é necessário definir qual o tipo de solicitação que será imposta ao material. No caso dos escorregamentos, por exemplo, o solo se encontrava em seu estado natural, sem alterações enquanto ocorria o aumento da umidade, indicando que os dados do carregamento devam ser utilizados para as análises efetuadas.

Para investigar como os parâmetros reológicos variam em relação à umidade é feita uma reapresentação das Figuras 7.22 e 7.23, com a inclusão dos valores de limites de liquidez e plasticidade de cada solo, apresentada nas Figuras 7.24 e 7.25, onde é possível observar que o solo apresenta uma mudança brusca de comportamento, e o ponto de flexão está localizado em um teor de umidade da ordem de $90 \%$ do limite de liquidez. Considerando como $w_{r}$ o limite de liquidez calculado a partir da reometria (49\% para o solo coluvionar e $34 \%$ para o solo residual), os valores obtidos com a reometria, em comparação aos valores obtidos pelo aparelho de Casagrande (53,6\% para o solo coluvionar e $36,4 \%$ para o solo residual) a aproximação foi de $91,4 \%$ para o solo residual e de $93,4 \%$ para o solo coluvionar. 


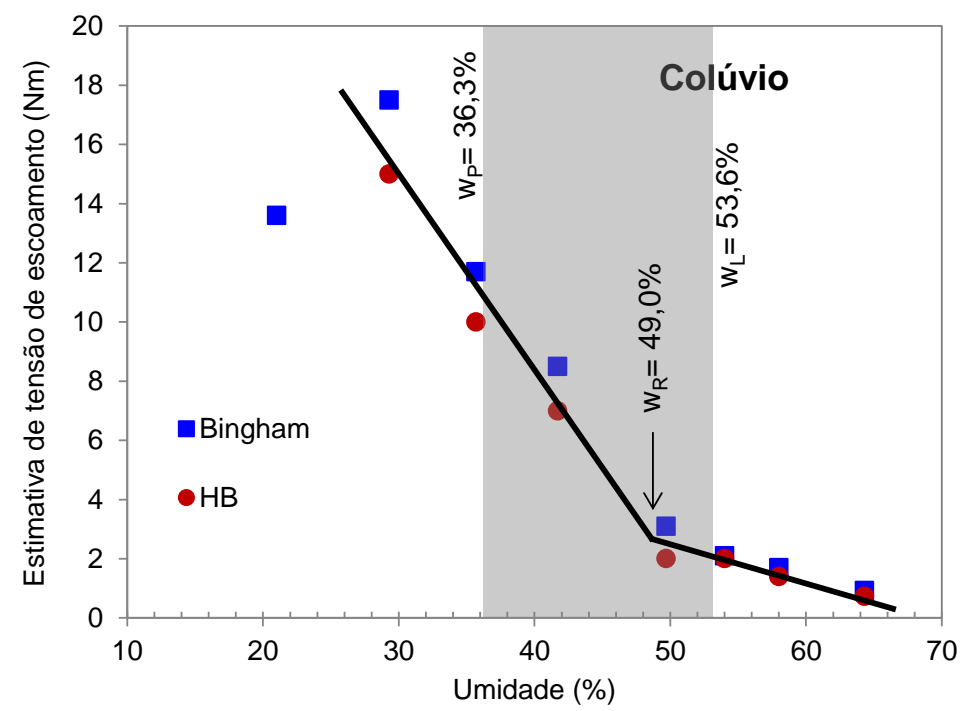

Figura 7.24 GP - Variação da Tensão de escoamento com a umidade - Colúvio

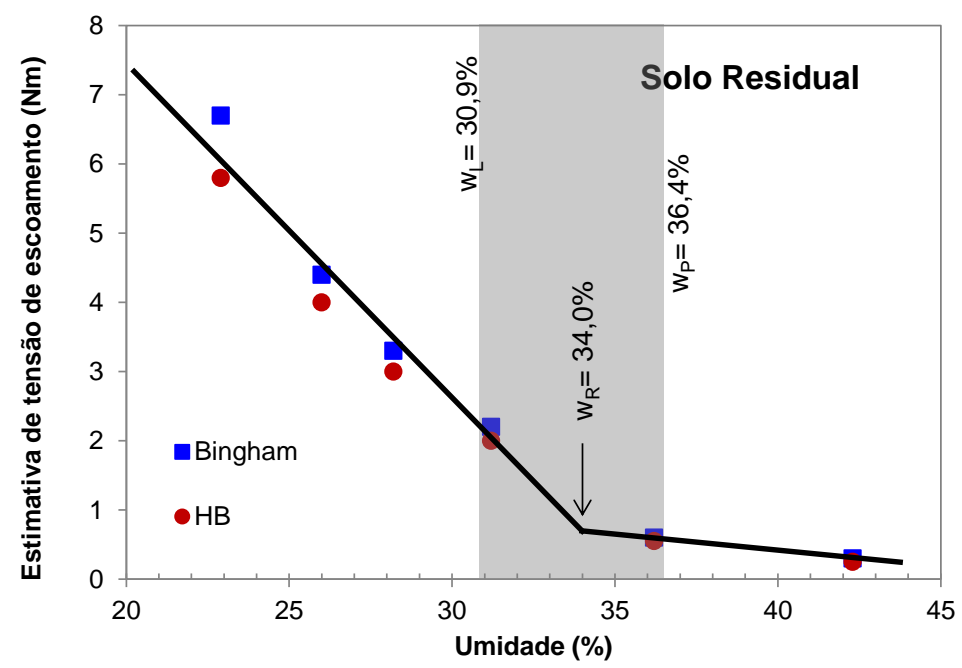

Figura 7.25 GP - Variação da tensão de escoamento com a umidade - Residual

Em relação ao comportamento da viscosidade é apresentada a Figura 7.26, com a variação da viscosidade aparente para 5 taxas de cisalhamento, com os valores calculados a partir da correlação de Herschel Bulkley, onde é possível visualizar a mesma mudança de comportamento observada para a tensão de escoamento. É apresentada também, na Figura 7.27, a viscosidade calculada pelo modelo de Bingham, que é independente da taxa de cisalhamento adotada. 

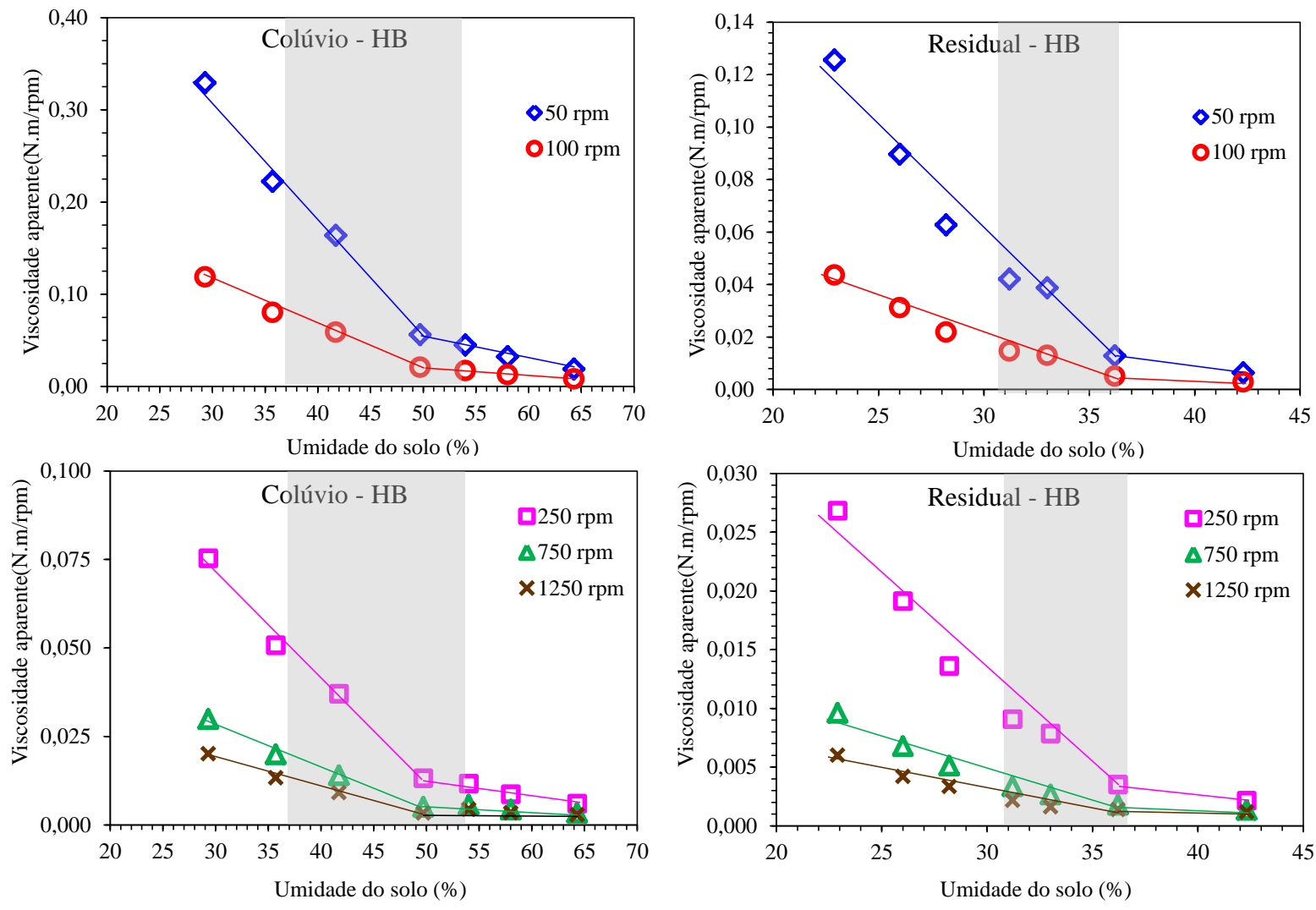

Figura 7.26 GP - Variação da viscosidade com a umidade para cinco taxas de cisalhamento
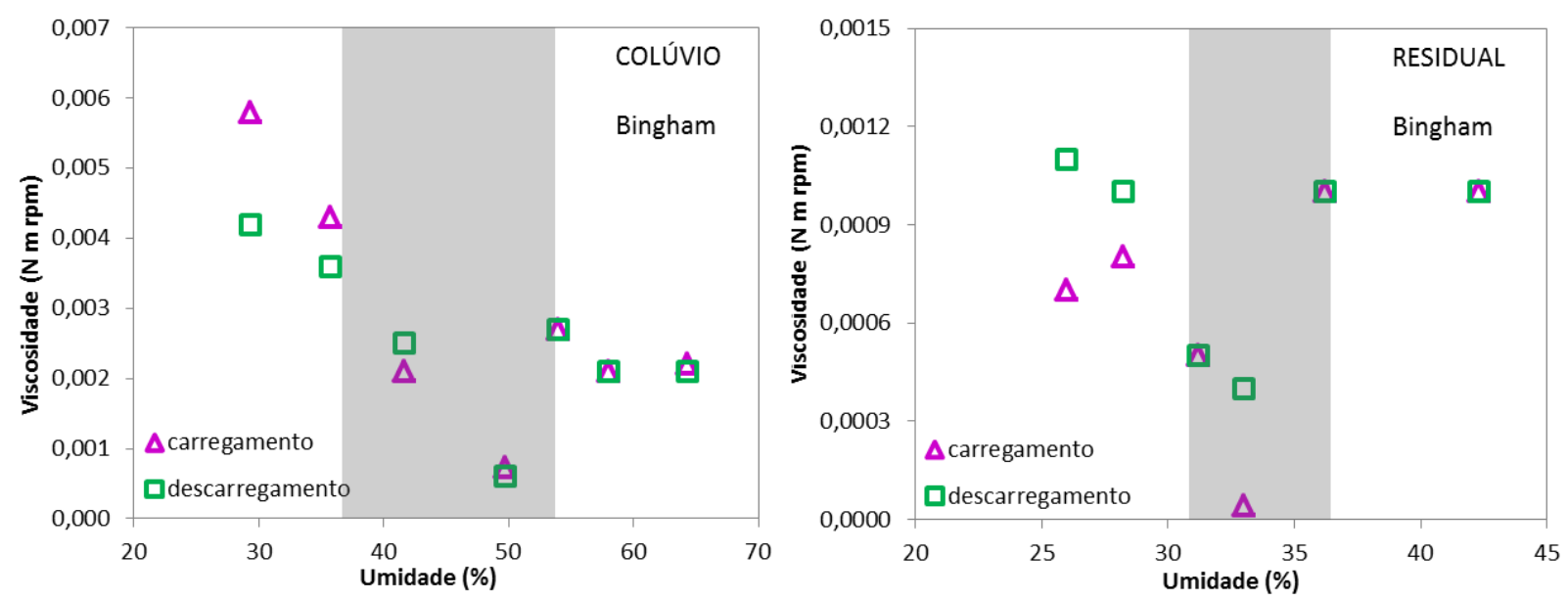

Figura 7.27 Variação da viscosidade em relação à umidade - Bingham

Na Figura 7.27 é possível observar que os valores de viscosidade apresentam dois comportamentos, antes do limite de liquidez a viscosidade diminui com o aumento da umidade e, depois do limite de liquidez a viscosidade sofre um brusco aumento e se mantém aproximadamente constante apesar do aumento da umidade.

O objetivo é determinar a partir de qual parâmetro o comportamento do solo pode ser definido como líquido. Com os dados obtidos desse ensaio é possível observar os pontos de inflexão onde tanto os valores de tensão de escoamento 
quanto os valores de viscosidade apresentam uma queda brusca, sendo possível definir que a partir do ponto de inflexão o comportamento do solo é puramente líquido.

As conclusões referentes ao primeiro ensaio, com as amostras de solos em umidades pré-determinadas, realizado no reômetro planetário são:

- O Colúvio apresenta os limites de liquidez e plasticidade mais altos do que o solo Residual, e essa diferença é sentida nos valores da tensão de escoamento, além disso, o colúvio apresenta o ângulo de atrito maior, sendo um solo mais resistente. Considerando os dois solos com a umidade no valor do limite de plasticidade, a tensão de escoamento do Colúvio é seis vezes maior que a tensão de escoamento do solo Residual.

- Os valores da viscosidade também foram mais altos para o Colúvio, indicando que esse solo, considerando os dois solos com a mesma umidade relativa, ou seja, os dois solos no limite de liquidez, por exemplo, o Colúvio oferece uma maior resistência à movimentação. Essa diferenciação entre os solos já era esperada considerando os resultados obtidos na análise da suscetibilidade à liquefação e nos ensaios de cisalhamento direto.

- O modelo de Bingham, apesar de apresentar uma correlação alta com os dados, tem sua limitação no fato de definir apenas um valor de viscosidade para cada umidade.

Os dados obtidos no segundo ensaio, com umidade variável durante o ensaio, não precisam ser comparados com modelos, porque são obtidos dados diretos de tensão de escoamento e a umidade referente à essa tensão. A situação do ensaio com a variação de umidade e aplicação de uma mesma rotação é mais representativa do comportamento real, onde os esforços que estão sendo aplicados em campo são praticamente os mesmos e a precipitação leva ao aumento de umidade do solo. Os resultados obtidos nesse ensaio estão apresentados na Tabela 7.7. 
Tabela 7.7 Resultado numérico ensaio.

\begin{tabular}{|c|c|c|}
\hline Solo & $\begin{array}{c}\tau_{\text {esc }} \\
(\mathrm{Nm} / \mathrm{rpm})\end{array}$ & $\begin{array}{c}\text { umidade } \\
(\%)\end{array}$ \\
\hline Colúvio & 0,83 & 30,6 \\
\hline Residual & 0,21 & 31,5 \\
\hline
\end{tabular}

Para essa situação a tensão de escoamento observada foi extremamente baixa para ambos os solos, quando comparada aos resultados do obtidos com $01^{\circ}$ ensaio, sendo que a umidade correspondente a tensão de escoamento também foi baixa, principalmente para o colúvio. O valor da tensão de escoamento pode ter sido afetado pelo longo tempo de ensaio, de 13 e 20 minutos para o solo residual e o colúvio, respectivamente, durante o qual o solo é continuamente amolgado perdendo sua resistência e apresentando esses valores baixos.

\subsection{Reometria Rotacional - Geometria Placas Paralelas (PP)}

Numa análise preliminar já é possível observar que os resultados apresentados no ensaio (exemplficado na Figura 6.31) se mostraram bastante dispersos e não seguiram uma tendência clara em relação à umidade. A necessidade de peneirar o solo na peneira \#100 é um grande empecilho para a utilização desse ensaio na caracterização reométrica de solos, a quantidade de solo que passa nessa peneira em relação a quantidade total de material para os solos estudados foi de $45,9 \%$ para o solo residual e de $62,4 \%$ para o colúvio. Devido a essa restrição do material, uma dúvida pertinente é se esse resultado é representativo do material que entra em movimento, principalmente na caracterização de solos mais grossos e com presença de detritos.

Outra restrição é que, durante o ensaio, uma pequena quantidade de material flui para fora da ferramenta de aplicação do cisalhamento, diminuindo a confiabilidade dos resultados obtidos, sendo neceed ssário fazer uma verificação visual para conferir se ainda havia amostra sob a punção ao final do ensaio, Figura 7.28, e se a amostra ensaiada apresentava linhas de fluxo, como a amostra apresentada na Figura 7.29. 


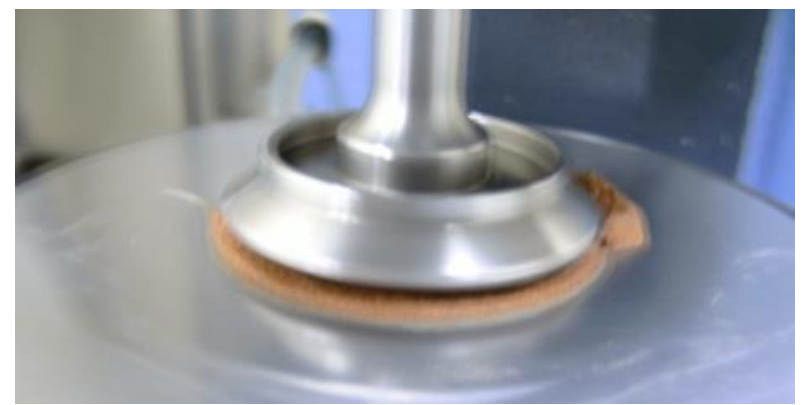

Figura 7.28 Perda de contato entre a amostra e a punção no final do ensaio

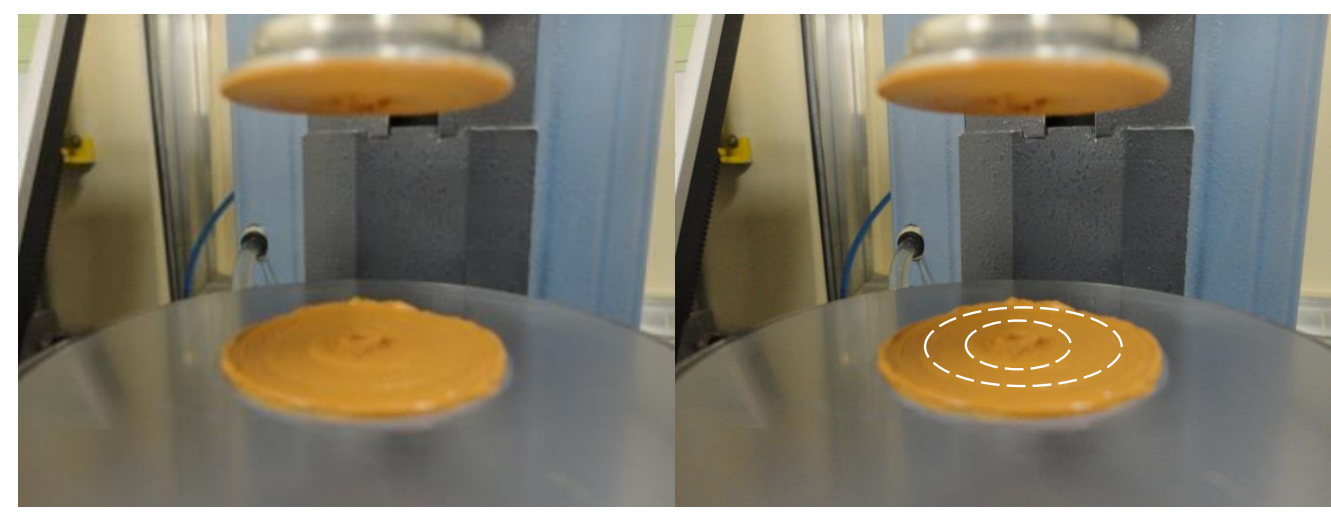

Figura 7.29 Linhas de fluxo observadas no final do ensaio

Entretanto, a utilização do ensaio é simples e rápida e os resultados são obtidos em unidade do SI facilitando a utilização e a comparação com os dados obtidos na literatura.

Aos dados obtidos foram realizadas aproximações utilizando os modelos de Bingham, Herschel Bulkley e Herschel Bulkley modificado por Papanastasiou, sendo que os resultados obtidos estão apresentados a seguir.

\subsubsection{Placas Paralelas (PP) - Aproximação por Modelos Reológicos}

A utilização do modelo de Bingham na aproximação dos resultados obtidos apresentou alguns resultados positivos, porém a maioria foi insatisfatória. A Figura 7.30 e a Figura 7.31 apresentam um dos resultados obtidos para cada um dos solos ensaiados e as demais amostras estão apresentadas no anexo da dissertação. 

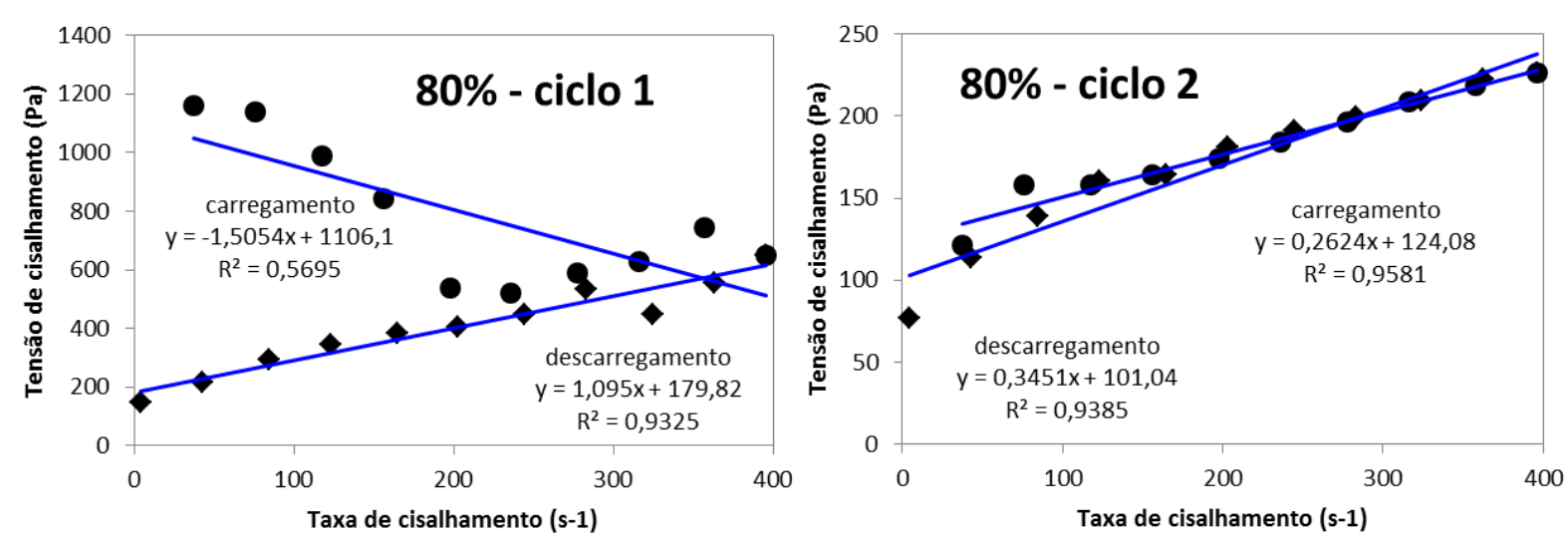

Figura 7.30 PP - Colúvio - Aproximação por Bingham - w = $80 \%$
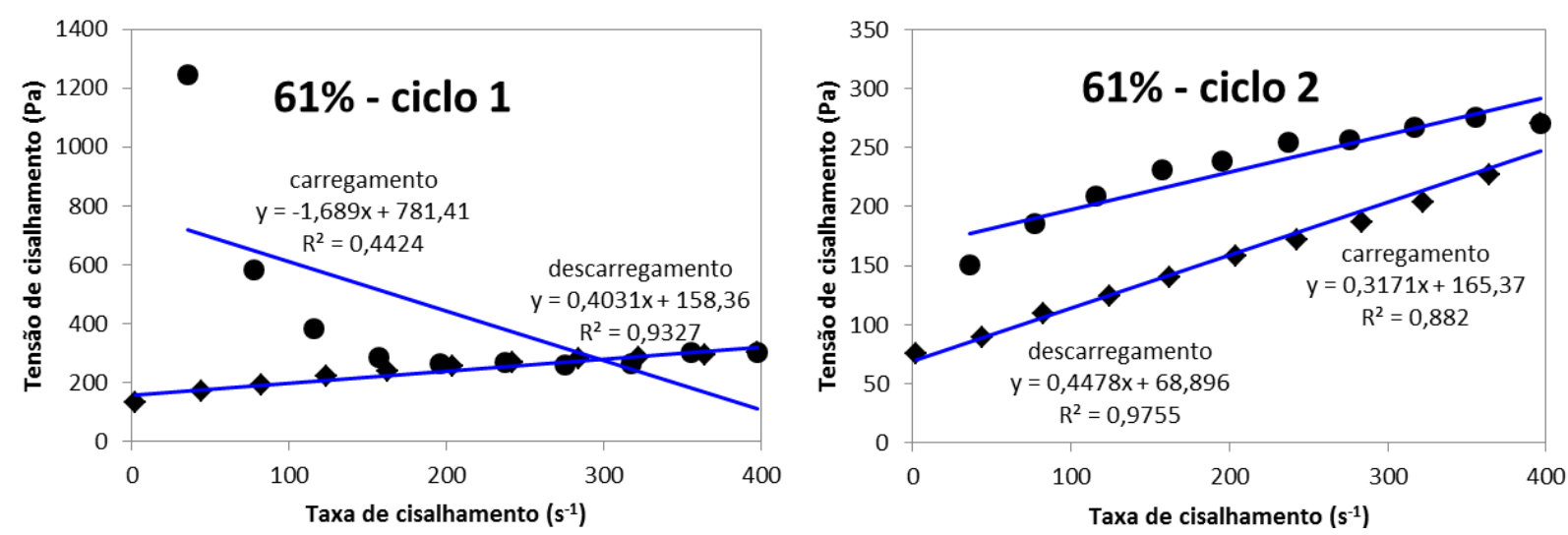

Figura 7.31 PP - Residual - Aproximação por Bingham - w = 61\%

A análise dos dados só é possível para o segundo ciclo de carregamento e descarregamento, isso porque todos os resultados obtidos no primeiro ciclo apresentaram algum parâmetro (tensão de escoamento ou viscosidade) com valor negativo, o que não tem sentido físico, desvalidando o resultado do primeiro ciclo, como pode ser observado nas Figuras 7.30 e 7.31.

Além disso, algumas amostras não apresentaram correlação com o modelo de Bingham, que são as amostras de solo residual com teor de umidade de $46 \%$ e $57 \%$ e a amostra do colúvio com $67 \%$, por isso essas amostras não terão seus dados analisados com esse modelo. As Tabelas 7.8 e 7.9 apresentam os resultados obtidos. 
Tabela 7.8 PP - Parâmetro obtidos - Colúvio - Aproximação por Bingham

\begin{tabular}{|c|c|c|c|c|c|c|}
\cline { 2 - 7 } \multicolumn{1}{c|}{ Colúvio } & \multicolumn{3}{|c|}{ carregamento } & \multicolumn{3}{c|}{ descarregamento } \\
\hline $\begin{array}{c}\text { umidade } \\
(\%)\end{array}$ & $\begin{array}{c}\text { Tesc } \\
\mathrm{Pa}\end{array}$ & $\begin{array}{c}\mu \\
\text { Pa.s }\end{array}$ & $\mathrm{R}^{2}$ & $\begin{array}{c}\text { T esc } \\
\mathrm{Pa}\end{array}$ & $\begin{array}{c}\mu \\
\text { Pa.s }\end{array}$ & $\mathrm{R}^{2}$ \\
\hline 61,0 & - & - & - & - & - & - \\
\hline 67,0 & 130,2 & 0,1110 & 0,33 & - & - & - \\
\hline 69,0 & 18,2 & 0,0550 & 0,94 & 4,6 & 0,079 & 0,67 \\
\hline 71,0 & 1,7 & 0,0050 & 0,95 & - & - & - \\
\hline 74,0 & 3,5 & 0,0156 & 0,87 & - & - & - \\
\hline 76,0 & 31,9 & 0,1554 & 0,78 & 28,0 & 0,164 & 0,95 \\
\hline 78,0 & 60,6 & 0,1169 & 0,62 & 14,7 & 0,208 & 0,62 \\
\hline 80,0 & 124,10 & 0,2624 & 0,96 & 101,0 & 0,345 & 0,94 \\
\hline
\end{tabular}

Tabela 7.9 PP - Parâmetro obtidos - Residual - Aproximação por Bingham

\begin{tabular}{|c|c|c|c|c|c|c|}
\cline { 2 - 7 } Residual & \multicolumn{3}{c|}{ carregamento } & \multicolumn{3}{c|}{ descarregamento } \\
\hline $\begin{array}{c}\text { umidade } \\
(\%)\end{array}$ & $\begin{array}{c}\text { esc } \\
\mathrm{Pa}\end{array}$ & $\begin{array}{c}\mu \\
\text { Pa.s }\end{array}$ & $\mathrm{R}^{2}$ & $\begin{array}{c}\tau \text { esc } \\
\mathrm{Pa}\end{array}$ & $\begin{array}{c}\mu \\
\mathrm{Pa} . \mathrm{s}\end{array}$ & $\mathrm{R}^{2}$ \\
\hline 46,0 & - & - & - & - & - & - \\
\hline 52,0 & - & - & - & - & - & - \\
\hline 54,0 & 74,2 & 0,1500 & 0,98 & 30,3 & 0,23 & 0,98 \\
\hline 55,0 & 183,4 & 0,0600 & 0,05 & 69,9 & 0,31 & 0,89 \\
\hline 57,0 & - & - & - & - & - & - \\
\hline 59,0 & 36,1 & 0,1900 & 0,99 & 33,0 & 0,20 & 0,98 \\
\hline 61,0 & 165,4 & 0,3200 & 0,88 & 68,9 & 0,45 & 0,97 \\
\hline
\end{tabular}

A utilização do modelo de Bingham no tratamento dos dados obtidos pelo reômetro rotacional com geometria de placas paralelas não se mostrou satisfatória, tendo em vista que mais da metade dos ensaios não foi capaz de produzir dados, além disso, os dados obtidos não apresentaram correlação com o teor de umidade, indicando claramente que existe influência de outro parâmetro, ou até que esse ensaio não é capaz de classificar um material coesivo como o solo.

Como os dados do primeiro ciclo desse ensaio com geometria de placas paralelas não apresentaram resultados coerentes, a aproximação pelos dois outros modelos foi realizada apenas para o segundo ciclo. As Figuras 7.32 e 7.33 exemplificam o resultado utilizando o modelo de Herschel Bulkley, e as Tabelas 7.10 e 7.11 apresentam os dados obtidos para as demais umidades. 

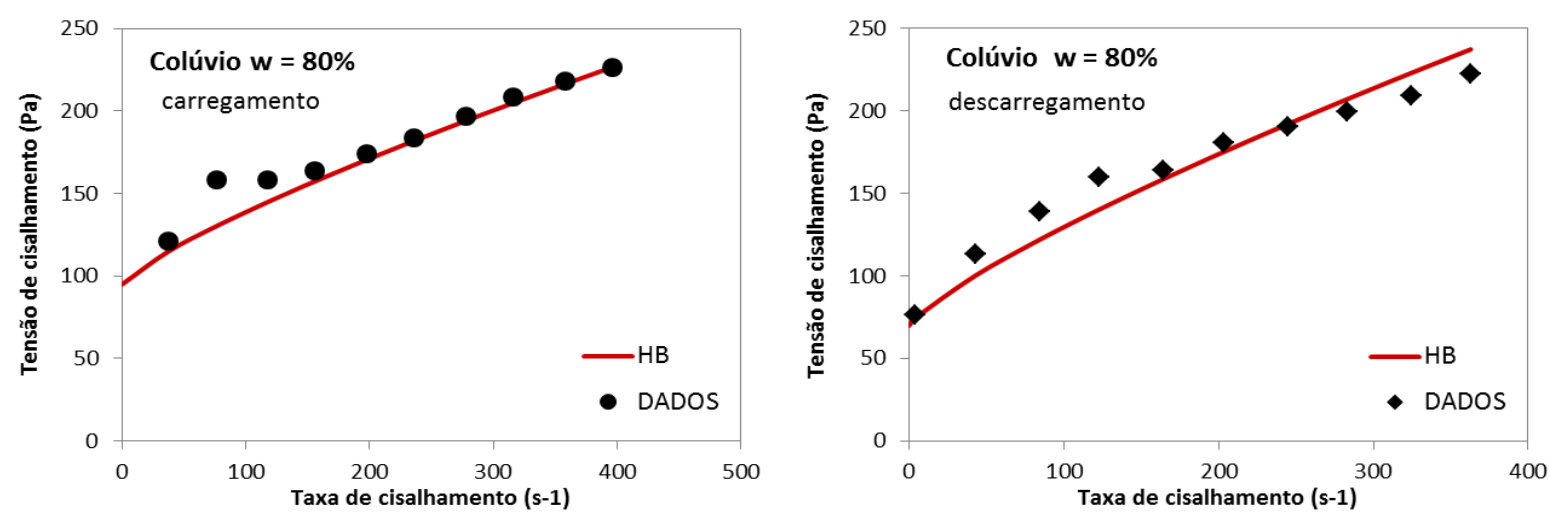

Figura 7.32 PP - Colúvio - Aproximação por Herschel Bulkley - $w=80 \%$

Tabela 7.10 PP - Parâmetro obtidos - Colúvio - Aproximação por Herschel Bulkley

\begin{tabular}{|c|c|c|c|c|c|c|c|}
\hline Colúvio & \multicolumn{3}{|c|}{ carregamento } & \multicolumn{3}{|c|}{ descarregamento } & \multirow[b]{2}{*}{$\mathrm{R}^{2}$} \\
\hline $\begin{array}{c}\text { umidade } \\
(\%)\end{array}$ & $\mathrm{k}$ & $\mathrm{n}$ & $\begin{array}{c}\tau \text { esc } \\
\mathrm{Pa}\end{array}$ & k & $\mathrm{n}$ & $\begin{array}{c}\tau \text { esc } \\
\mathrm{Pa}\end{array}$ & \\
\hline 61,0 & - & - & - & - & - & - & - \\
\hline 67,0 & 2,0 & 0,60 & 100,0 & - & - & - & 0,25 \\
\hline 69,0 & 0,8 & 0,61 & 9,0 & - & - & - & 0,89 \\
\hline 71,0 & 0,03 & 0,75 & 1,0 & - & - & - & 0,87 \\
\hline 74,0 & 0,06 & 0,81 & $2,, 2$ & 0,09 & 0,7 & 0,0 & 0,93 \\
\hline 76,0 & 1,3 & 0,68 & 15,0 & 1,0 & 0,7 & 20,0 & 0,82 \\
\hline 78,0 & 1,1 & 0,70 & 40,0 & 0,8 & 0,8 & 5,0 & 0,87 \\
\hline 80,0 & 1,1 & 0,80 & 95 & 1,5 & 0,8 & 70,0 & 0,92 \\
\hline
\end{tabular}
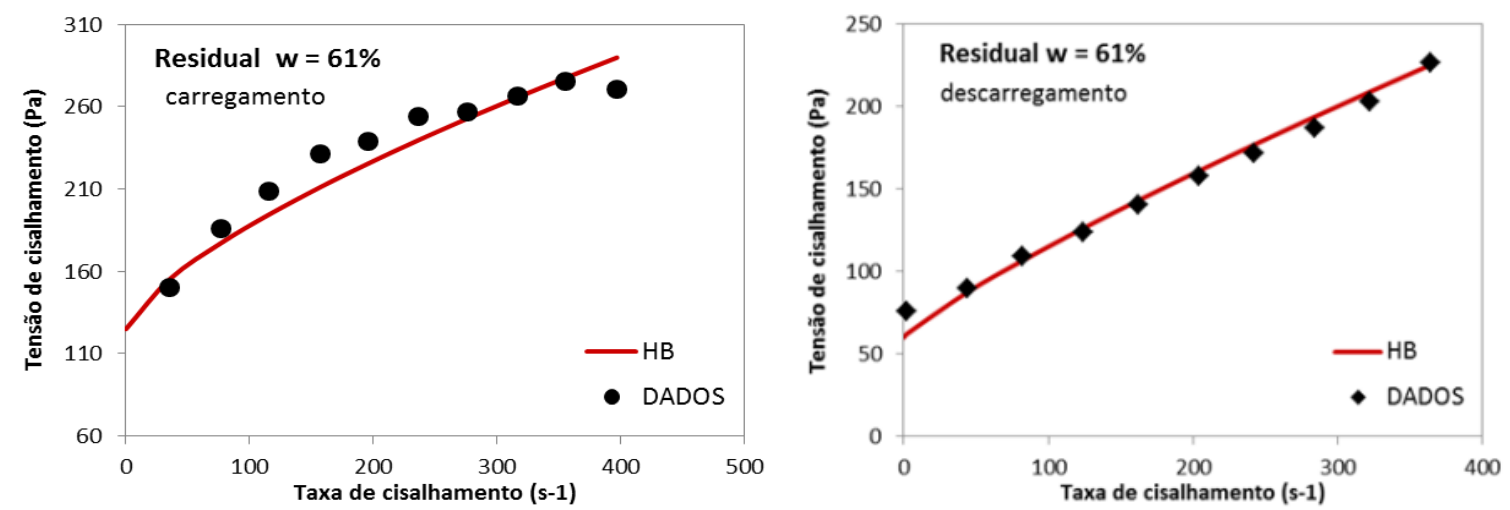

Figura 7.33 PP - Residual - Aproximação por Herschel Bulkley - $w=61 \%$ 
Tabela 7.11 PP - Parâmetro obtidos - Residual - Aproximação por Herschel Bulkley

\begin{tabular}{|c|c|c|c|c|c|c|c|}
\hline Residual & \multicolumn{3}{|c|}{ carregamento } & \multicolumn{3}{|c|}{ descarregamento } & \multirow[b]{2}{*}{$\mathrm{R}^{2}$} \\
\hline umidade & k & $\mathrm{n}$ & $\tau$ esc & k & $\mathrm{n}$ & $\tau$ esc & \\
\hline$(\%)$ & & & $\mathrm{Pa}$ & & & $\mathrm{Pa}$ & \\
\hline 46,0 & - & - & - & - & - & - & - \\
\hline 52,0 & - & - & - & - & - & - & - \\
\hline 54,0 & 0,55 & 0,80 & 65,0 & 1,4 & 0,70 & 21,0 & 0,983 \\
\hline 55,0 & 2,0 & 0,68 & 100,0 & 1,7 & 0,70 & 60,0 & 0,571 \\
\hline 57,0 & - & - & - & - & - & - & - \\
\hline 59,0 & 1,0 & 0,75 & 23,0 & 1,0 & 0,75 & 21,0 & 0,992 \\
\hline 61,0 & 2,5 & 0,70 & 125,0 & 1,1 & 0,85 & 60,0 & 0,975 \\
\hline
\end{tabular}

Para a aplicação do modelo de Herschel Bulkley modificado foi adotado o valor de 100 para o parâmetro alpha, assim como no ensaio com a geometria planetária. Os valores obtidos para o modelo estão apresentados nas Tabelas 7.12 e 7.13, e as Figuras 7.34 e 7.35 exemplificam a aplicação do modelo.
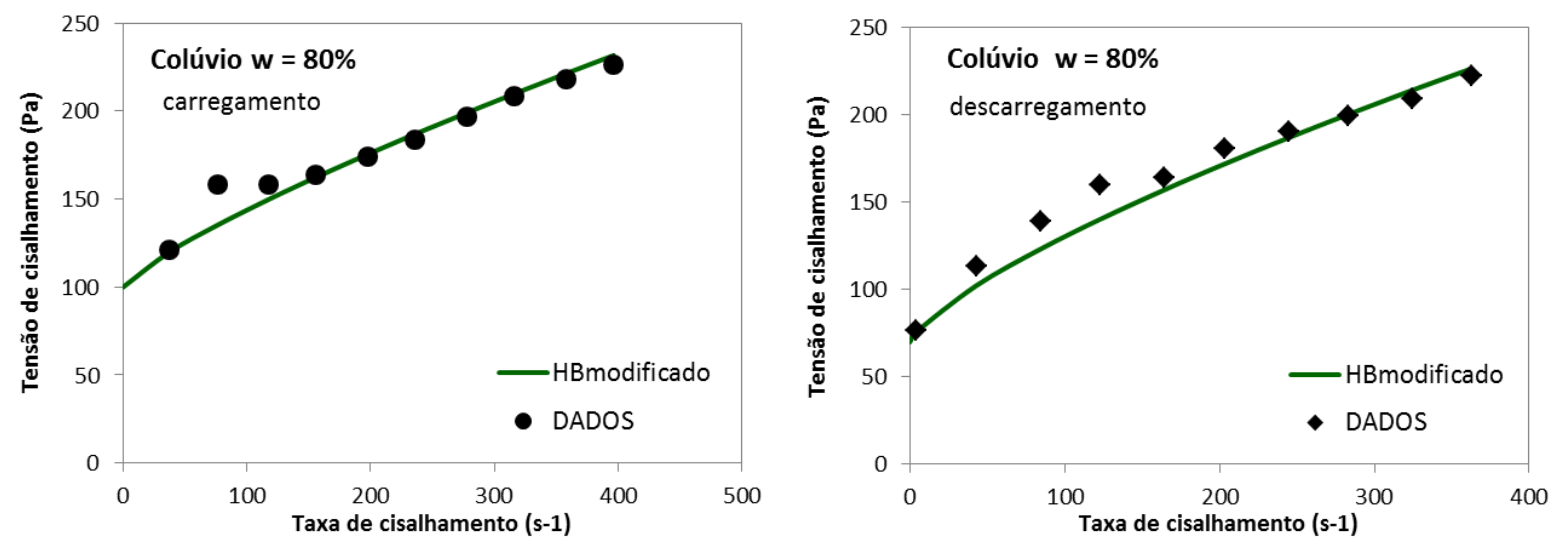

Figura 7.34 PP - Colúvio - Aproximação por Herschel Bulkley modificado - $\mathbf{w}=\mathbf{8 0} \%$

Tabela 7.12 PP - Parâmetro obtidos - Colúvio - Aproximação por Herschel Bulkley modificado

\begin{tabular}{|c|c|c|c|c|c|c|c|}
\hline Colúvio & \multicolumn{3}{|c|}{ carregamento } & \multicolumn{3}{|c|}{ descarregamento } & \multirow[b]{2}{*}{$\mathrm{R}^{2}$} \\
\hline $\begin{array}{c}\text { umidade } \\
(\%)\end{array}$ & $\mathrm{k}$ & $\mathrm{n}$ & $\begin{array}{c}\text { Tesc } \\
\mathrm{Pa}\end{array}$ & k & $\mathrm{n}$ & $\begin{array}{c}\text { Tesc } \\
\mathrm{Pa}\end{array}$ & \\
\hline 61,0 & - & - & - & - & - & - & - \\
\hline 67,0 & 2,0 & 0,60 & 100,0 & - & - & - & 0,250 \\
\hline 69,0 & 0,8 & 0,61 & 9,0 & - & - & - & 0,893 \\
\hline 71,0 & 0,04 & 0,68 & 1,2 & - & - & - & 0,937 \\
\hline 74,0 & 0,06 & 0,81 & 2,3 & 0,09 & 0,7 & 0,0 & 0,964 \\
\hline 76,0 & 1,4 & 0,68 & 20,0 & 1,0 & 0,7 & 20,0 & 0,855 \\
\hline 78,0 & 1,6 & 0,60 & 45,0 & 0,8 & 0,8 & 5,0 & 0,935 \\
\hline 80,0 & 1,1 & 0,80 & 100 & 2,0 & 0,74 & 70,0 & 0,897 \\
\hline
\end{tabular}



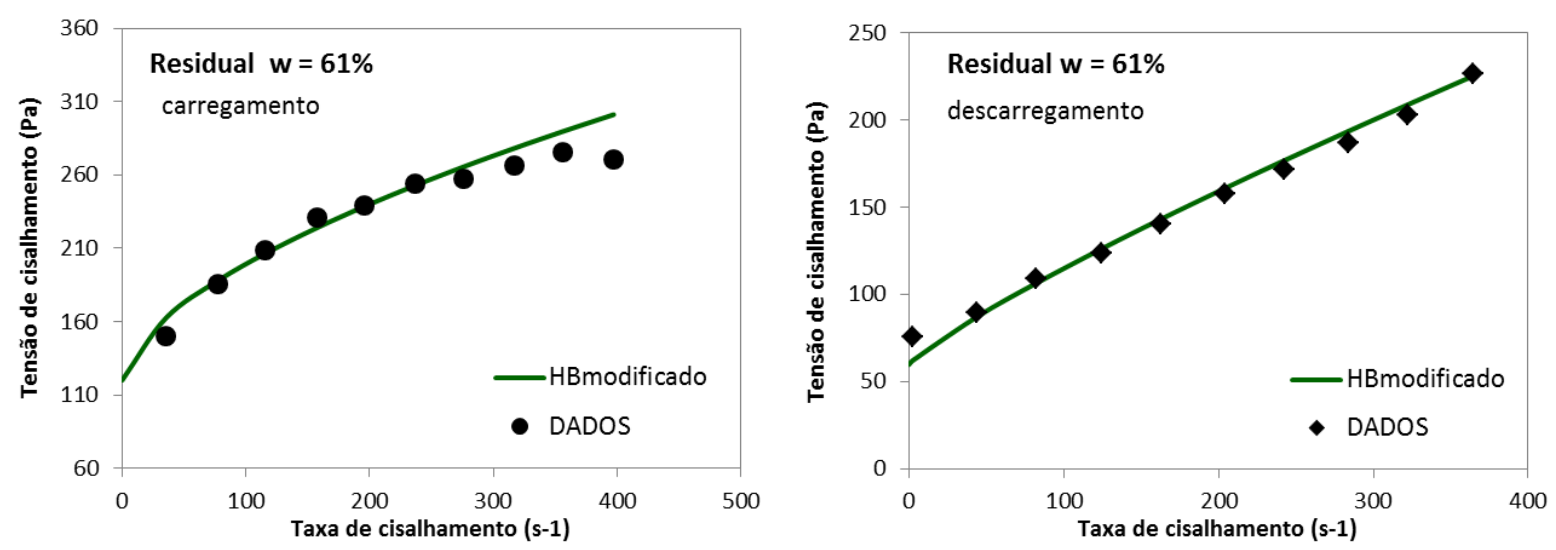

Figura 7.35 PP - Residual - Aproximação por Herschel Bulkley modficado - $w=61 \%$

Tabela 7.13 PP - Parâmetro obtidos - Residual - Aproximação por Herschel Bulkley modificado

\begin{tabular}{|c|c|c|c|c|c|c|c|}
\hline Residual & & egam & & & arrega & & \\
\hline umidade & $\mathrm{k}$ & $n$ & $\tau$ esc & $\mathrm{k}$ & $n$ & $\tau$ esc & $\mathrm{R}^{2}$ \\
\hline (\%) & & & $\mathrm{Pa}$ & & & $\mathrm{Pa}$ & \\
\hline 46,0 & - & - & - & - & - & - & - \\
\hline 52,0 & - & - & - & - & - & - & - \\
\hline 54,0 & 0,55 & 0,80 & 65,0 & 1,4 & 0,70 & 21,0 & 0,983 \\
\hline 55,0 & 2,00 & 0,68 & 100,00 & 1,7 & 0,70 & 60,0 & 0,571 \\
\hline 57,0 & - & - & - & - & - & - & - \\
\hline 59,0 & 1,0 & 0,75 & 23,0 & 1,0 & 0,75 & 21,0 & 0,992 \\
\hline 61,0 & 5,0 & 0,60 & 120,0 & 1,1 & 0,85 & 60,0 & 0,975 \\
\hline
\end{tabular}

\subsubsection{Conclusões Ensaio de Placas Paralelas}

Os resultados obtidos com a utilização desse equipamento não foram satisfatórios. A dispersão de valores foi alta e os valores obtidos não apresentaram relação com a variação de umidade do solo, como era esperado. Resultados obtidos para umidades muito próximas do mesmo solo (54\% e 55\%), por exemplo, não apresentaram concordância.

Diversas amostras apresentaram dados incoerentes, como valores negativos para grandezas físicas como a viscosidade e a tensão de escoamento, o que não tem sentido físico. Devido a esse fato a utilização dos modelos, mesmo quando apresentaram uma correlação satisfatória, pode não ser correspondente ao comportamento real e para sua utilização teria que ser realizada uma investigação 
dos parâmetros que estão influenciando os resultados. Uma alternativa seria a desconsideração dos pontos que causam essa inconsistência, no entanto teria que ser realizada uma investigação para determinar o quanto esses pontos que serão cortados influenciam no comportamento, já que a desconsideração de dados até o resultado obtido ser coerente com o esperado não é razoável.

Uma explicação para as distorções encontradas pode ser a restrição da força Normal na montagem do ensaio quando é colocada uma quantidade de material sob a punção e essa desce comprimindo o material até atingir a espessura desejada para o ensaio. A restrição da força Normal faz com que a compressão seja realizada em várias etapas e entre as etapas é necessário forçar um cisalhamento da amostra, rotacionando manualmente o equipamento para que o contato entre a amostra e o equipamento seja refeito, e esse cisalhamento pode estar provocando uma mudança estrutural da amostra, causando as dispersões encontradas.

Quando o ensaio foi realizado com teores de umidade mais baixos, o equipamento não apresentou torque suficiente para iniciar a rotação, ou seja, não alcança um valor de torque que ultrapasse a tensão de escoamento, o que dificulta a utilização desse equipamento, já que restringe bastante o número de pontos passíveis de utilização.

A vantagem de utilização seria a facilidade e rapidez no manuseio do equipamento e na obtenção dos dados, principalmente porque os dados estão em unidades do Sistema Internacional, facilitando sua utilização e comparação com outros pesquisadores.

Em relação aos modelos adotados e desconsiderando os dados que não apresentaram coerência, a melhor aproximação foi observada na utilização do modelo de Herschel Bulkley modificada por Papanastasiou para o colúvio, e para o solo residual o modelo de Bingham.

Todas as amostras utilizadas apresentam valores para o teor de umidade muito acima dos limites de liquidez calculados por Casagrande ou os obtidos pelo ensaio de reometria rotacional, apresentados no item anterior. Então os valores de tensão de escoamento, obtidos como resultados desse ensaio deveriam ser extremamente reduzidos, o que não foi observado. Essa situação pode ser advinda da ocorrência de segregação da amostra, uma possível explicação é que a argila 
saiu da área de contato do equipamento, restando apenas os grãos de areia, elevando os valores de tensão de escoamento obtidos.

\subsection{Reometria Compressiva - Squeeze flow}

A partir dos dados obtidos através do ensaio de squeeze flow, são apresentadas as Figuras 7.36 e 7.37 para a comparação entre as duas velocidades de ensaio utilizadas $(0,1 \mathrm{~mm} / \mathrm{s}$ e $3,0 \mathrm{~mm} / \mathrm{s})$. As figuras foram divididas em dois gráficos para que os resultados ficassem visíveis e claros, nos quais as linhas cheias representam os dados obtidos na velocidade de $0,1 \mathrm{~mm} / \mathrm{s}$ e as linhas pontilhadas os dados obtidos com velocidade de $3,0 \mathrm{~mm} / \mathrm{s}$. O resultado para cada umidade está legendado de a até $\mathrm{h}$ indicando o aumento da umidade, a letra entre parênteses de (A) à (D) indica a qual das amostras iniciais cada umidade pertence.

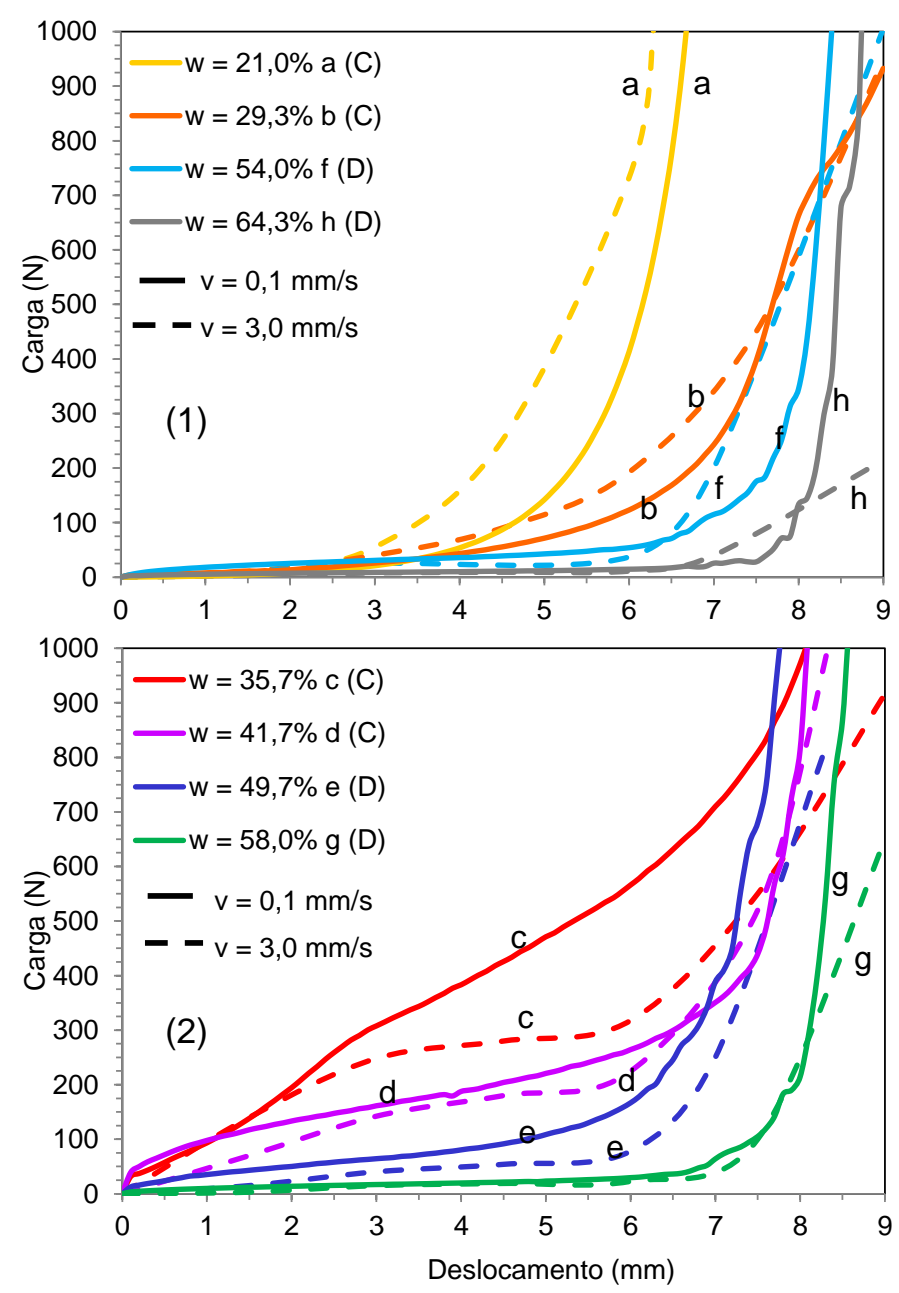

Figura 7.36 Comparação entre as velocidades de $0,1 \mathrm{~mm} / \mathrm{s}$ e $3,0 \mathrm{~mm} / \mathrm{s}$ - Colúvio 

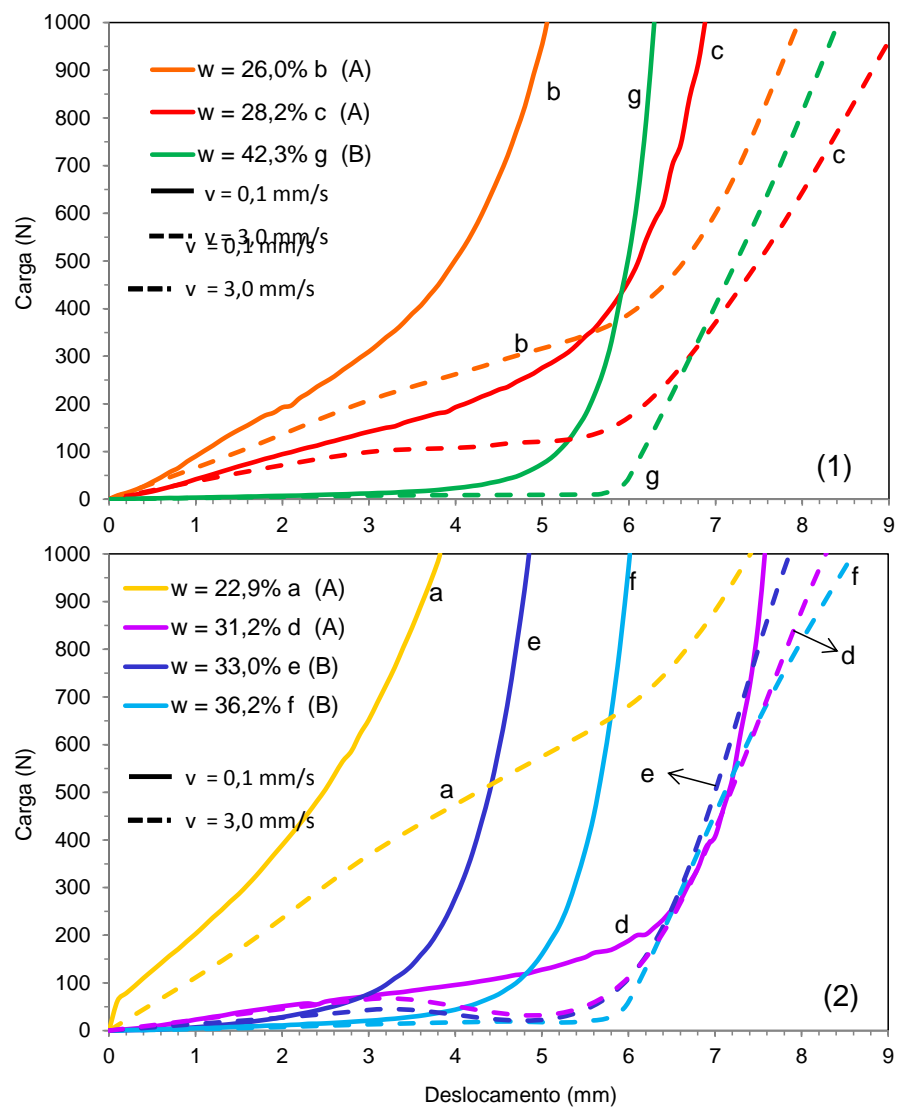

Figura 7.37 Comparação entre as velocidades de $0,1 \mathrm{~mm} / \mathrm{s}$ e $3,0 \mathrm{~mm} / \mathrm{s}$ - Solo Residual

Com as curvas obtidas é possível observar que as amostras apresentaram algumas características distintas, que podem ser comparadas de duas maneiras, a primeira considerando um teor de umidade fixo, qual a diferença existente entre as velocidades de compressão e a segunda maneira, para uma velocidade fixa, qual a influência causada pelo aumento do teor de umidade.

\section{- Teor de umidade fixo}

Os resultados obtidos para o Colúvio demonstram que a diferença entre as velocidades não seguiu um padrão, sendo possível observar no primeiro gráfico da Figura 7.36 as amostras que apresentaram deslocamentos maiores na velocidade de $0,1 \mathrm{~mm} / \mathrm{s}$ e no segundo gráfico da Figura 7.36 as amostras que apresentaram maior deslocamento com a velocidade de ensaio de $3,0 \mathrm{~mm} / \mathrm{s}$.

Para o solo residual, Figura 7.37, a diferença de comportamento entre as velocidades é nítida e repetitiva, sendo que o ensaio realizado com a velocidade mais alta apresentou uma deformação mais expressiva. Esse aumento de deslocamento indica que, para a velocidade mais alta, o processo de segregação de 
fases é mais intensificado. O que significa que, quando ocorre um incremento da velocidade de movimentação ocorre também uma intensificação no processo de segregação do material, o que eleva ainda mais a velocidade. Esse fenômeno é mais uma evidência de que esse solo sofre o fenômeno da liquefação quando cisalhado, já que vai apresentar maiores deformações e maiores velocidades de deslocamento, o que coloca o solo residual com maior potencial para liquefazer em relação ao colúvio.

\section{- Velocidade fixa}

Analisando as curvas obtidas para a velocidade de compressão constante de $0,1 \mathrm{~mm} / \mathrm{s}$, é possível observar que existe uma gama de quatro perfis que foram observados como resposta de comportamento, em relação aos estágios apresentados na Figura 5.13. São esses perfis: amostras que apresentaram todos os estágios (colúvio w $=41,7$ e 49,7\%), amostras que apresentam apenas o estágio 1 e 3 (colúvio $w=35,7 \%$ e residual $w=22,9$ e $26,0 \%$ ), amostras que apresentam os estágios 2 e 3 (colúvio $w=21,0 ; 29,3 ; 54,3 ; 58,0$ e 64,3\% e residual $w=31,2 ; 36,2$ e $42,3 \%$ ), amostras que apresentam somente o estágio 3 (residual $w=28,2$ e $33,0 \%$ ).

O estágio 1 é ausente ou bem curto, restrito aos 2 primeiros $\mathrm{mm}$ de deslocamento em todas as amostras; o que é esperado já que o solo nas condições analisadas não deve mesmo apresentar comportamento elástico. Todas as amostras apresentaram o estágio 3 , indicando que em determinado momento, algumas amostras antes outras depois, a resistência imposta pelo solo ao fluxo se eleva exponencialmente, o que pode ser explicado devido ao aumento da interação entre as partículas que gera forças de atrito entre os grãos do solo, quando esse movimento cessaria.

O estágio 2 é o que representa o movimento de massa, no caso a liquefação, quando o material se encontra em comportamento viscoso e sofre grandes deformações sem um correspondente aumento de força. Portanto as amostras que apresentaram o estágio 2 maior são aquelas mais suscetíveis a sofrer o fenômeno de liquefação naquela determinada umidade. Foram as amostras de colúvio com umidade de 54,$0 ; 58,0$ e $64,3 \%$ e as amostras de solo residual com umidade de 31,$2 ; 33,0 ; 36,3$ e $42,3 \%$. As amostras apresentaram uma acentuação do estágio 2 
na velocidade mais alta, indicando que com o aumento da velocidade é mais fácil para o solo apresentar o comportamento viscoso.

Com as curvas obtidas no ensaio de squeeze flow realizado com velocidade de $0,1 \mathrm{~mm} / \mathrm{s}$, apresentados nas Figuras 6.39 à 6.42, no capítulo anterior, também é possível determinar a tensão de escoamento para cada umidade ensaiada, através da metodologia proposta no item 5.4.3, os valores de tensão de escoamento estão apresentados na Tabela 7.14. Plotando os valores de tensão de escoamento em relação à umidade é obtida a Figura 7.38 para o colúvio e a Figura 7.39 para o solo residual, com uma indicação dos valores obtidos para os limites de liquidez e plasticidade de cada solo.

Tabela 7.14 Tensão de escoamento obtida pelo squeeze flow

\begin{tabular}{|c|c|c|c|c|c|}
\hline Colúvio & Umidade & $\begin{array}{c}\text { Tensão de } \\
\text { escoamento }(\mathrm{N})\end{array}$ & Residual & Umidade & $\begin{array}{c}\text { Tensão de } \\
\text { escoamento }(\mathrm{N})\end{array}$ \\
\hline $\mathrm{C} 1$ & $21,0 \%$ & - & $\overline{A 1}$ & $22,9 \%$ & 62,0 \\
\hline $\mathrm{C} 2$ & $29,3 \%$ & 3,5 & $\mathrm{~A} 2$ & $26,0 \%$ & 9,0 \\
\hline C3 & $35,7 \%$ & 28,0 & A3 & $28,2 \%$ & 5,0 \\
\hline C4 & $41,7 \%$ & 46,0 & A4 & $31,2 \%$ & 0,9 \\
\hline D1 & $49,7 \%$ & 13,0 & B1 & $33,0 \%$ & 1,0 \\
\hline D2 & $54,0 \%$ & 9,0 & B2 & $36,2 \%$ & 0,7 \\
\hline D3 & $58,0 \%$ & 4,0 & B3 & $42,3 \%$ & 1,4 \\
\hline D4 & $64,3 \%$ & 3,5 & & & \\
\hline
\end{tabular}

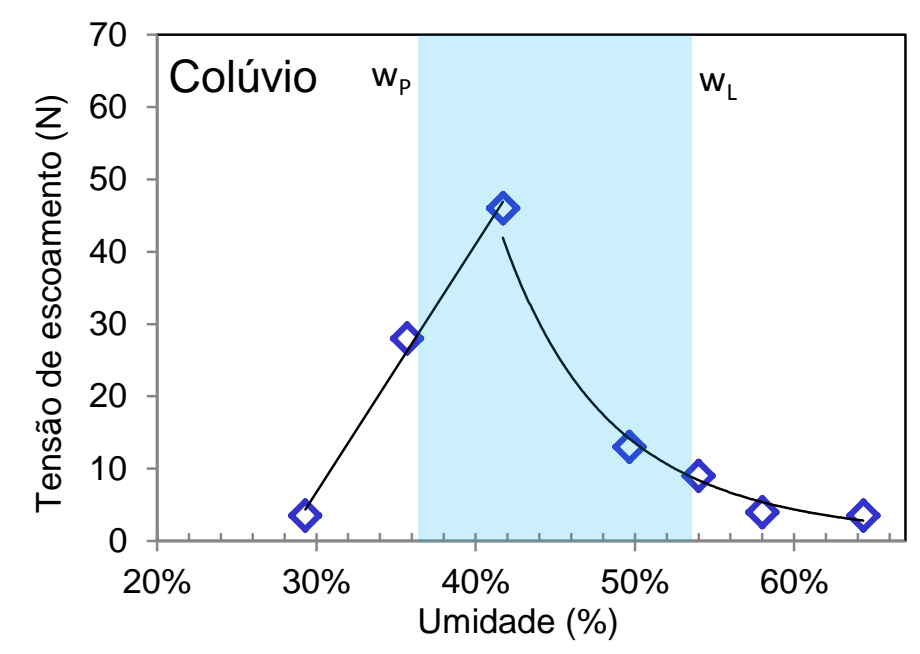

Figura 7.38 Variação da tensão de escoamento em relação à umidade - colúvio 


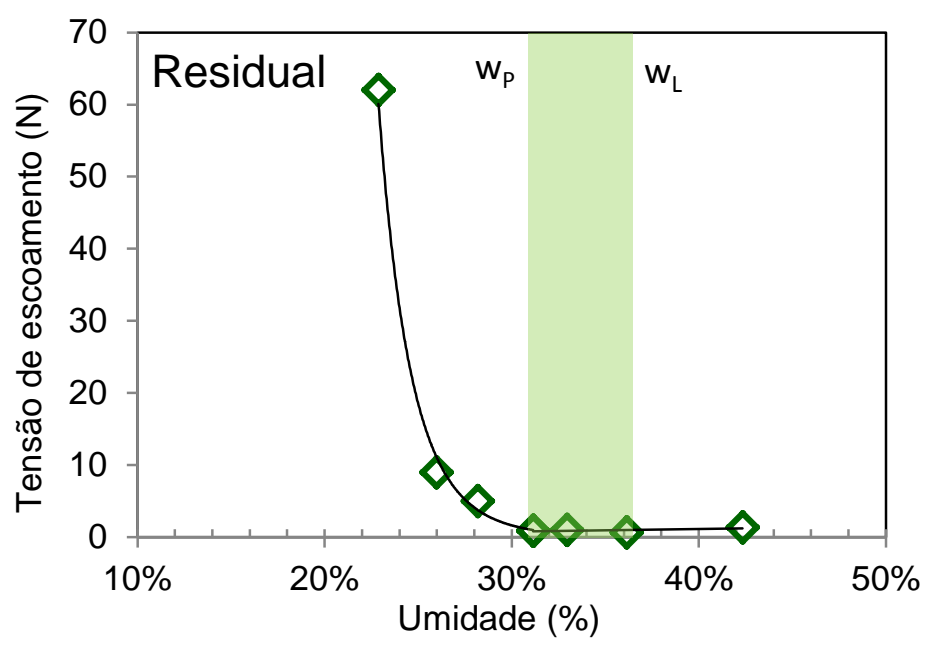

Figura 7.39 Variação da tensão de escoamento em relação à umidade - residual

Os solos apresentaram comportamentos distintos entre si. Os baixos valores de tensão de escoamento medidos nos solos coluvionares para os menores teores de umidade $(29,3 \%$ e $35,7 \%)$ podem ser explicados pelo fato das amostras apresentarem o aspecto de uma farofa e não de uma pasta, como pode ser visto na Figura 7.40․ Aumentando da umidade da amostra ocorreu a ligação entre os grãos e o solo se comportou como uma massa contínua, elevando os valores de tensão de escoamento (Figura 7.40b). Depois com a continuação do aumento da umidade o comportamento tende ao comportamento de um líquido viscoso, fazendo com que os valores de tensão de escoamento diminuam bruscamente, Figura 7.40c.

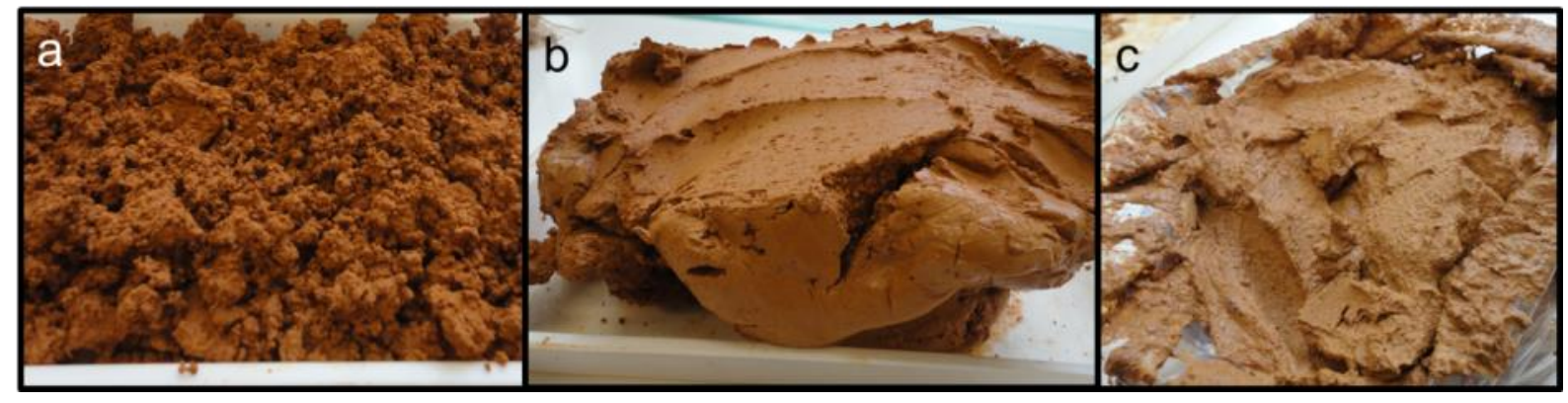

Figura 7.40 Esquema ilustrativo comportamento do colúvio

O solo residual apresentou comportamento no qual os valores de tensão de escoamento decrescem com o aumento da umidade, e para valores de umidade acima do limite de plasticidade o solo já apresentava uma tensão de escoamento em torno de zero. Esse tipo de comportamento corrobora com a hipótese de que o solo residual é muito mais sensível ao aumento da umidade, apresentando valores de tensão de escoamento baixos quando o teor de umidade atinge o limite de 
plasticidade. O valor observado está um pouco abaixo do apresentado na Figura 7.25, mas está coerente.

A partir dos resultados do ensaio de squeeze flow também é possível analisar de que forma o aumento da umidade influi na resistência à movimentação do solo através da comparação de qual a carga necessária para causar uma deformação fixa em cada teor de umidade do solo. Essa análise foi realizada considerando uma deformação fixa de 30\% para as duas velocidades de ensaio e está apresentada na Figura 7.41 para o colúvio e na Figura 7.42 para o solo residual, tanto em escala logarítmica quanto em escala aritmética. Vale ressaltar que os valores obtidos para as duas amostras de menores umidades do colúvio pode não ser representativo, como já discutido.

Para os dois solos foi possível observar uma curva exponencial como resposta de comportamento, e a diferença de comportamento causada pela velocidade foi desprezível. Interessante notar que, para o solo residual, Figura 7.42, a queda da força já se acentua antes mesmo do valor da umidade atingir o limite de plasticidade, pelo solo ser sensível ao incremento da umidade.
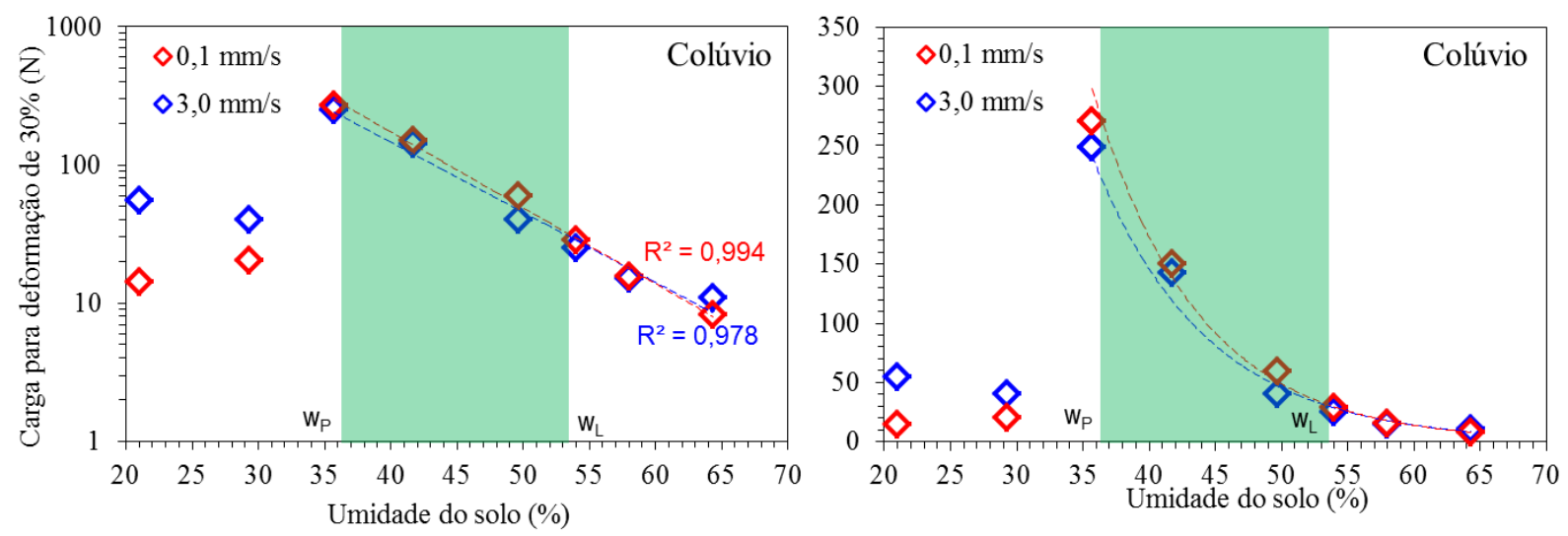

Figura 7.41 Carga necessária para deformação fixa - colúvio 

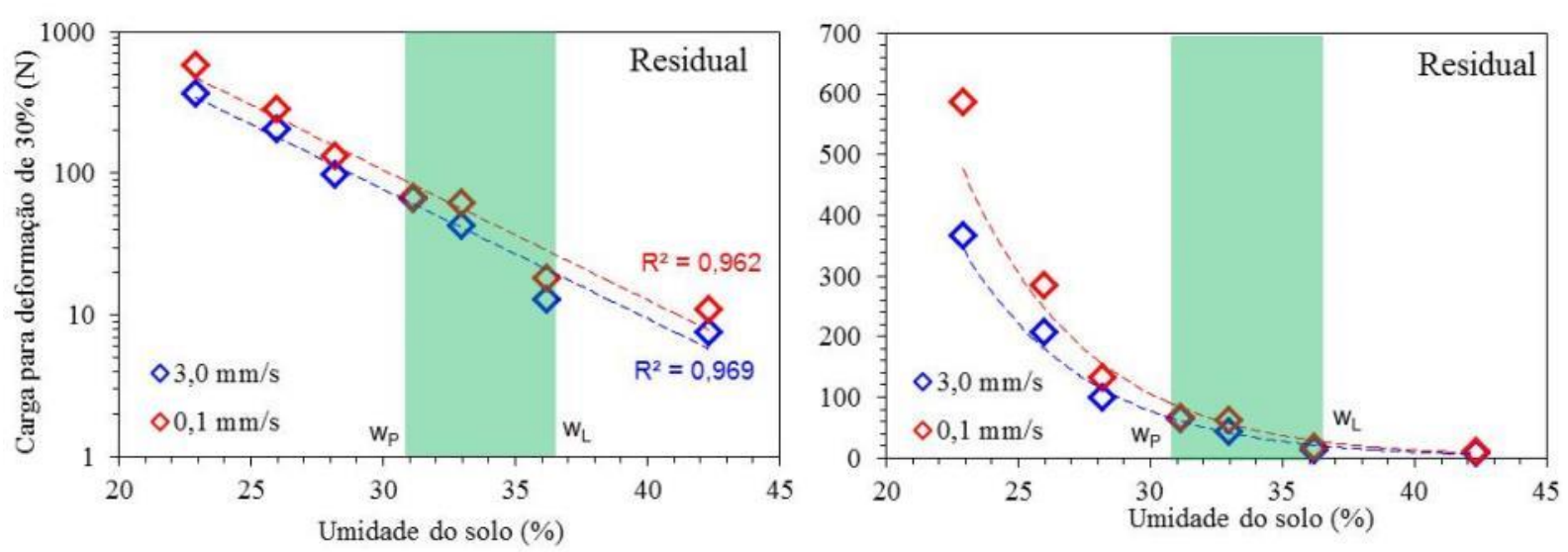

Figura 7.42 Carga necessária para deformação fixa - residual

Com os dados do squeeze flow realizado para a velocidade de $0,1 \mathrm{~mm} / \mathrm{s}$, foi possível calcular a viscosidade elongacional para cada taxa de cisalhamento, a variação dessa viscosidade está apresentada na Figura 7.43 e na Figura 7.44. Viscosidade obtida por Steffe (1996), conforme Equação 5.20.

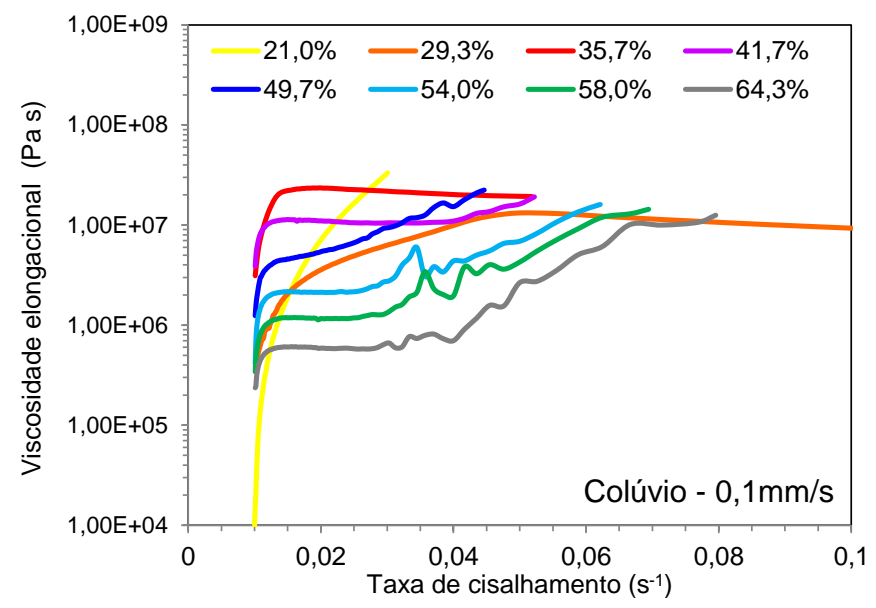

Figura 7.43 Variação da viscosidade elongacional com a taxa de cisalhamento - colúvio

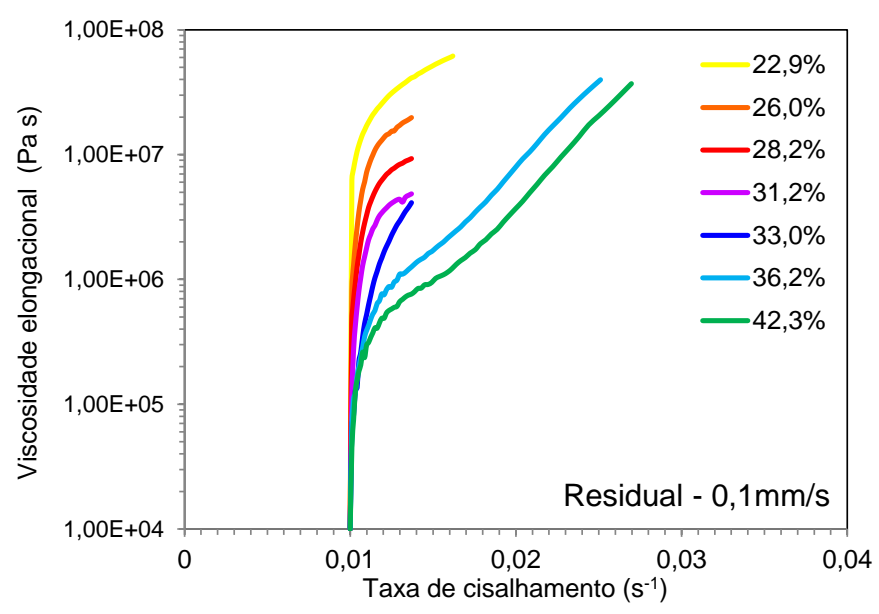

Figura 7.44 Variação da viscosidade elongacional com a taxa de cisalhamento - residual 
No colúvio a maior parte dos valores se encontra numa faixa de valores compreendida entre $3 \times 10^{5}$ e $3 \times 10^{7}$ Pa.s. No solo residual os valores de viscosidade elongacional não apresentaram um patamar claro, sendo impossível definir uma faixa padrão. O comportamento desse solo indica que mesmo para um pequeno incremento na taxa de cisalhamento já ocorrem grandes mudanças nos valores de viscosidade.

Para facilitar a comparação dos valores obtidos para a viscosidade elongacional, são expostas as Figuras 7.45 e 7.46, nas quais é apresentada a variação da viscosidade em função da umidade, para quatro taxas de cisalhamento fixas $\left(1,01 ; 1,10 ; 1,20\right.$ e $1,3710^{-2}$ Pa.s), definidas a partir dos dados obtidos, entre a menor taxa da qual se tem medida e a maior taxa na qual todas as amostras apresentaram dados.

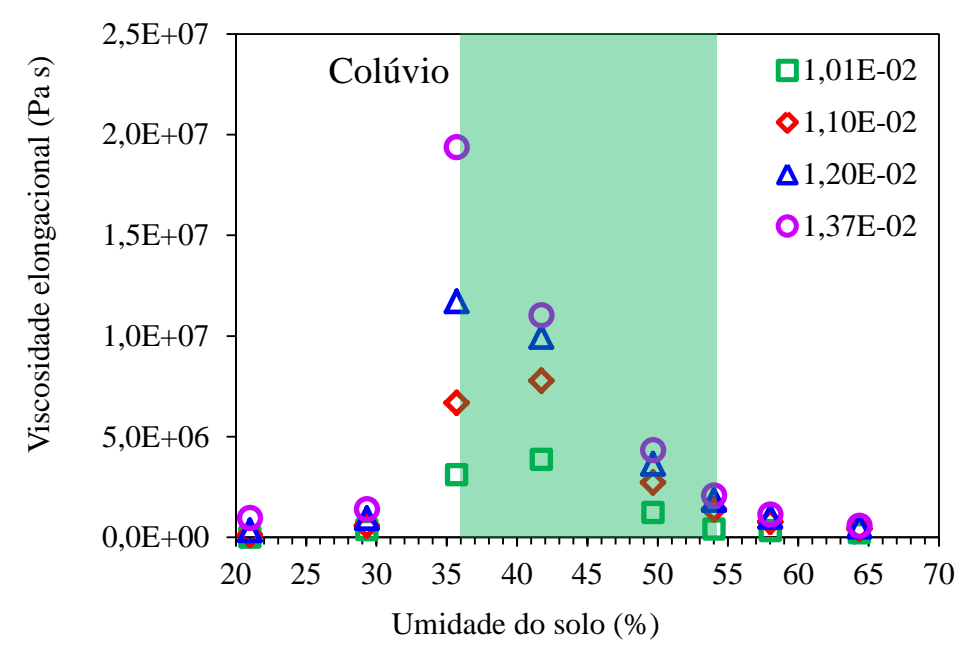

Figura 7.45 Variação da viscosidade elongacional para 4 taxas de cisalhamento - colúvio

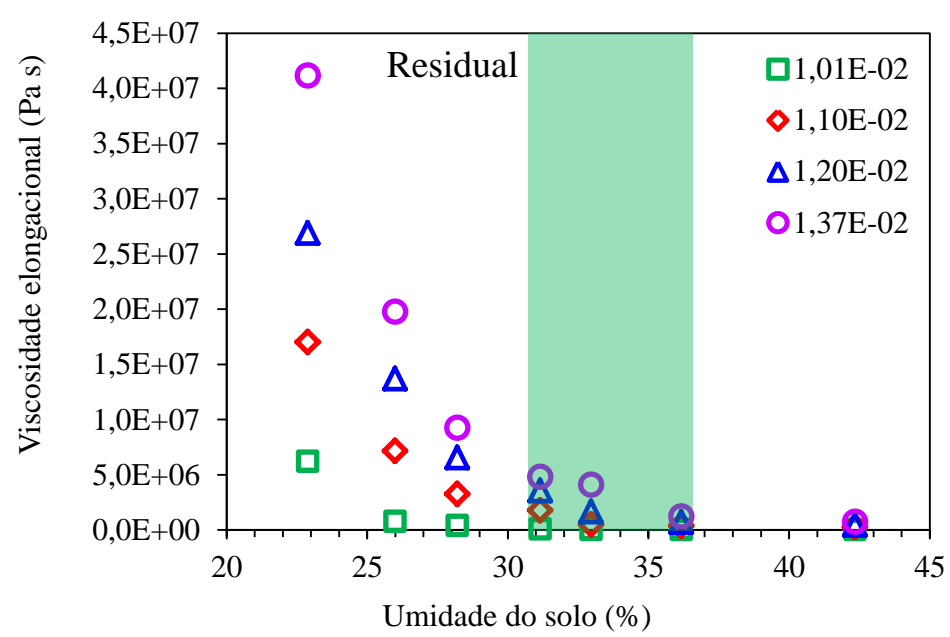

Figura 7.46 Variação da viscosidade elongacional para 4 taxas de cisalhamento - residual 
Como pode ser observado nas Figuras 7.45 e 7.46, quanto menor a taxa de cisalhamento menor a viscosidade elongacional para cada uma das umidades, nos dois solos ensaiados. O colúvio apresentou, para umidades menores que o $\mathrm{w}_{\mathrm{P}}$, uma viscosidade baixa, que sofreu um brusco aumento quando a umidade do solo alcançou o $\mathrm{w}_{\mathrm{P}}$, que ainda se manteve por mais um ponto e somente com a umidade mais próxima do $w_{L}$ que a viscosidade apresentou uma diminuição com o aumento da umidade. Já o solo residual apresentou uma diminuição da viscosidade com o aumento da umidade.

\subsubsection{Conclusões Reometria Compressiva}

O ensaio de Squeeze flow se mostrou coerente com os resultados esperados. Sua utilização na caracterização reológica é expressiva por ser um ensaio com as seguintes características: rapidez na execução do ensaio e na obtenção dos dados, diversas configurações do equipamento, automatização do ensaio e diversas possibilidades de aplicação dos resultados. Entretanto, é necessário o desenvolvimento de uma formulação matemática para que seja viável o cálculo da viscosidade cisalhante, para facilitar a aplicação na geotecnia.

Através da utilização do ensaio foi possível visualizar as diferenças nas características das duas amostras ensaiadas, ressaltando o comportamento de cada uma delas sob solicitação, principalmente quanto à segregação da amostra que representa o fenômeno natural durante a movimentação.

A diminuição da viscosidade para o aumento da umidade é esperada já que com o aumento da umidade o material perde resistência.

Em relação ao colúvio, comparando visualmente os valores de tensão de escoamento obtidos com o squeeze flow e com o reômetro planetário no 1ํe ensaio, é possível afirmar que os pontos com os maiores teores de umidade ( $w>45 \%$ ) apresentaram o mesmo comportamento enquanto que os pontos mais secos apresentaram dois comportamentos distintos.

A grande dificuldade para uma comparação direta entre os ensaios são as unidades, principalmente no quesito viscosidade, já que além dos valores em si as 
taxas de cisalhamento devem ser compatíveis para uma comparação. Entretanto, observando os resultados é possível visualizar um padrão no comportamento, embora as amostras com menores teores de umidade no squeeze flow não apresentaram um resultado comum.

Considerando o solo residual, a tensão de escoamento obtida entre os dois equipamentos não foram coincidentes mas também não foram discrepantes. Enquanto que o squeeze flow apresentou comportamento aproximado um uma curva logarítmica o reômetro apresentou duas retas. Já em relação à viscosidade o formato dos gráficos obtidos foi praticamente o mesmo.

\subsection{Conclusões da reometria aplicada a solos}

Em relação aos ensaios reométricos é possível obter as seguintes conclusões:

O ensaio de reometria rotacional com geometria de placas paralelas não foi útil para a caracterização do solo. Como esse tipo de ensaio já foi utilizado por outros pesquisadores (como Coussot e Piau, 1994) é possível que o equipamento utilizado nessa pesquisa não seja 0 mais adequado para solos, devido, principalmente, a restrição da força normal. Como os resultados não foram satisfatórios foi realizado uma segunda rodada de ensaios cujos resultados também não seguiram nenhuma tendência, o que indica claramente que existem outros parâmetros que estão influenciando nos resultados.

Considerando então, apenas os resultados obtidos por meio da reometria rotacional com geometria planetária e os resultados da reometria compressiva (squeeze flow), serão tomadas algumas conclusões.

O principal resultado obtido com o ensaio de squeeze flow é a observação da segregação de fases a partir do aumento da umidade e também com o aumento da velocidade de ensaio. Esse comportamento observado no ensaio reflete o que pode ser observado em eventos de movimentação causados por precipitação intensa, onde o movimento se acelera, devido a declividade das encostas, e ocorre a 
segregação de fases, sendo um processo cíclico que tende a majorar a velocidade do movimento.

O aparelho de squeeze flow é automatizado, o que facilita a obtenção dos dados, a moldagem do corpo de prova é simples e rápida, assim como a obtenção dos resultados. Os resultados obtidos apresentaram coerência com o que pode ser observado em movimentos de solo. No entanto, para o cálculo da tensão de escoamento esse ensaio não é o mais indiciado, e ainda é preciso o desenvolvimento de uma formulação matemática para o cálculo da viscosidade cisalhante que ocorre na amostra.

O ensaio pode ser utilizado para a observação da mudança de comportamento do solo. Além disso, o ensaio permite a utilização de diversas configurações de diâmetro e altura do corpo de prova, além da possibilidade da configuração da punção para aplicação de força com velocidade constante ou variável, ou até mesmo a aplicação de força constante ou variável, permitindo diversas aplicações na geotecnia.

O aparelho reômetro com geometria planetária apresentou bons resultados. Os ensaios que foram realizados nesse aparelho são rápidos, assim como a obtenção dos dados, além de apresentar repetibilidade e uma maior representatividade do solo por causa da quantidade de solo utilizada no ensaio. Para os dois ensaios o equipamento aplica uma rotação através de sua haste medindo a força resistente do solo ao movimento, essa idealização do ensaio se encaixa perfeitamente com o estudo dos movimentos de solo.

Existem algumas diferenças entre os dois ensaios realizados no reômetro rotacional de torque, a principal delas é em relação à amostra, sendo que para o primeiro ensaio as amostras foram com uma umidade fixa, pré-determinada enquanto que no segundo ensaio a umidade varia durante a aplicação de uma rotação fixa. Além disso, o tempo de ensaio do segundo ensaio é cerca de 5 vezes maior que o primeiro ensaio. Essas diferenças causam uma discrepância entre os dois resultados obtidos, sendo que foram observados valores para a tensão de escoamento e para a viscosidade bem maiores no primeiro ensaio.

A única dificuldade de aplicação do ensaio realizado com o reômetro rotacional de torque para a Geotecnia é a dificuldade para transformar as unidades 
observadas para o SI. No entanto o ensaio apresentou uma alta correlação com os modelos aplicados, modelos que estão sendo utilizados para a determinação do comportamento reológico de solos em diversos dos estudos apresentados na revisão bibliográfica.

Dos resultados obtidos com o reômetro rotacional de torque podemos destacar a possibilidade de observação do comportamento da tensão de escoamento em relação aos Limites de Atteberg, sendo possível observar a queda da resistência com o acréscimo da umidade. Outra observação é como se dá a variação da viscosidade para um taxa de cisalhamento pré-fixada, que apresenta o mesmo comportamento da tensão.

O segundo ensaio, apresar de apresentar valores significadamente menores, também apresentou gráficos coerentes, indicando que os dois solos apresentam sim uma tensão de escoamento e que a partir dessa tensão de escoamento o comportamento da mistura solo e água perde a resistência e mesmo para a manutenção de um torque constante a resistência continua a cair. Os dois solos apresentaram o mesmo comportamento.

A aproximação dos comportamentos observados pelo modelos reológicos foi satisfatória, sendo que o modelo que apresentou os melhores resultados foi o de Herschel Bulkley, apresentando altos valores de correlações e fácil aplicabilidade.

A partir dos resultados obtidos e das conclusões apresentadas é possível afirmar que o ensaio do reômetro rotacional de torque é o que mais representa 0 comportamento dos solos, sendo mais indicado para o estudo proposto nessa dissertação. 


\section{APLICAÇÃO À GEOTECNIA}

Para verificar a suscetibilidade do solo a sofrer o fenômeno de liquefação, os dados obtidos nos ensaios de caracterização foram comparados com os fatores que determinam se determinado solo pode ou não sofrer tal fenômeno. São os seguintes fatores: granulometria, limite de liquidez versus o índice de plasticidade, condição de saturação e estado do solo.

A granulometria dos solos, apresentada na Figura 6.6, foi comparada com a Figura 4.1.1, e está apresentada na Figura 8.1. É possível observar que os dois solos analisados apresentam uma curva granulométrica bem mais ampla, indicando que os solos são bem graduados, indicando que os solos não são suscetíveis à liquefação segundo esse critério.

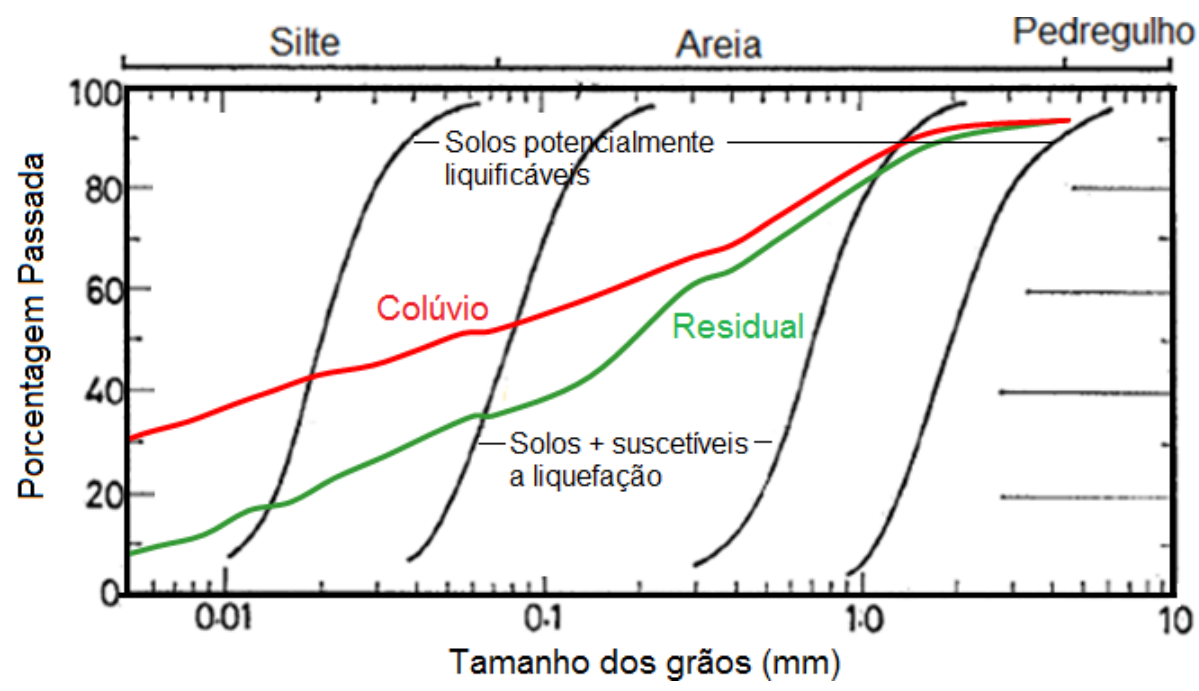

Figura 8.1 Análise de suscetibilidade: curva granulométrica

Outro ponto analisado para avaliar o potencial de liquefação do solo é a saturação em campo. Martin (1999) afirmou que um grau de saturação entre 80 e $100 \%$ é suficiente para causar a liquefação, e considerando o período chuvoso da região Serrana do Rio de Janeiro, com precipitação acumulada de 30 dias de 380 $\mathrm{mm}$ no dia 10 de Janeiro e as chuvas deflagradoras de $170 \mathrm{~mm}$ nos dias 11 e 12, é razoável admitir que os dois solos estivessem saturados ou próximos da saturação.

Para avaliar o Limite de Liquidez e Índice de Plasticidade, de acordo com o critério proposto por Seed et al. (2003), os valores encontrados para esses índices foram inseridos no gráfico proposto, apresentada na Figura 8.2. É possível visualizar que o colúvio se encontra fora da área de suspeita de liquefação, porém o solo 
residual se encontra em área com potencial para sofrer liquefação quando a umidade em campo for maior que 0,88 do $w \mathrm{~L}$, ou seja, maior que $32 \%$.

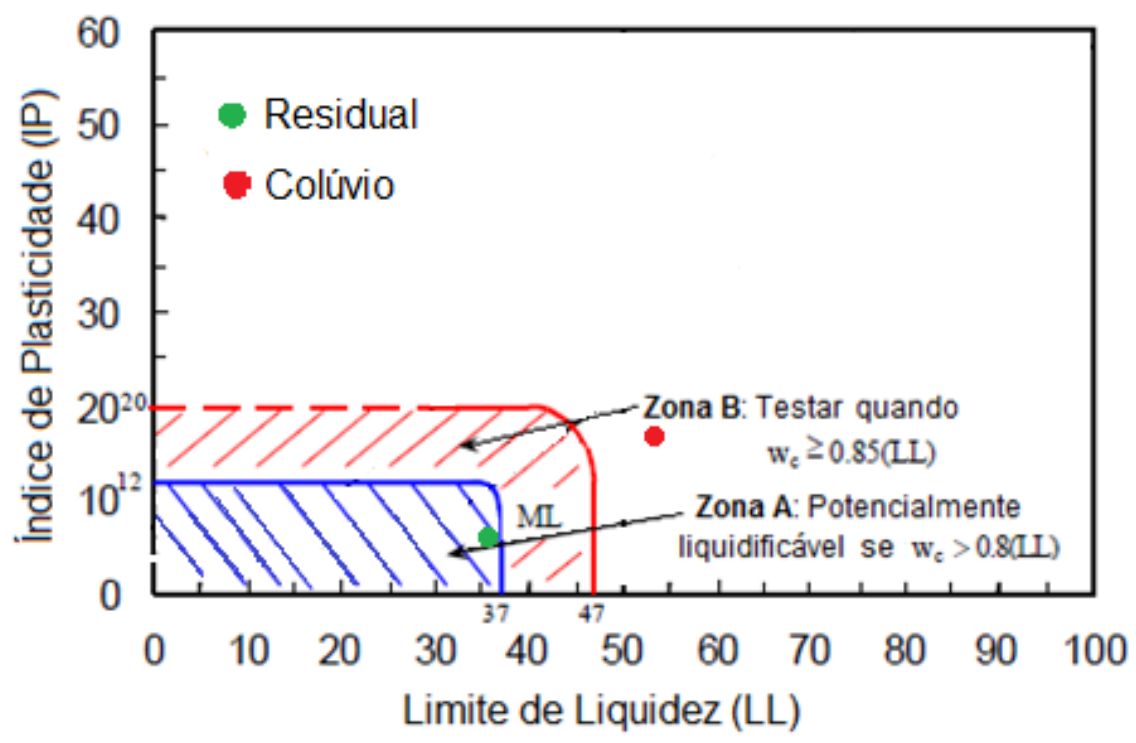

Figura 8.2 Análise de suscetibilidade: Limites de Atteberg

Para determinação do estado do solo foi considerado o resultado do ensaio de cisalhamento direto dos blocos indeformados. Os resultados do ensaio de cisalhaemnto foram apresentados nas Figuras 6.10 e 6.11, nas quais é possível observar que os dois solos apresentam compressão.

Quanto a granulometria, saturação e comportamento sob solicitação os dois solos são equivalentes, apresentando diferença no critério dos limites de Atteberg. Apenas com essas comparações não é possível definir se ocorrerá liquefação, mesmo porque o tipo de fenômeno pode ser diferente em alguns casos. Analisando as imagens obtidas por satélite dos pontos de coleta de amostra, é possível visualizar que o local onde foi retirada a amostra de colúvio não apresentou desenvolvimento da ruptura, Figura 8.3. No local da amostra de solo residual é possível observar o desenvolvimento da ruptura com a ocorrência da liquefação, Figura 8.4, fazendo com que o movimento se transformasse em uma corrida. É apresentado também na Figura 8.4 o perfil de elevação do caminho percorrido pela corrida de solo, sendo possível observar que o solo liquefeito só parou seu movimento porque a topografia foi um fator limitante. 


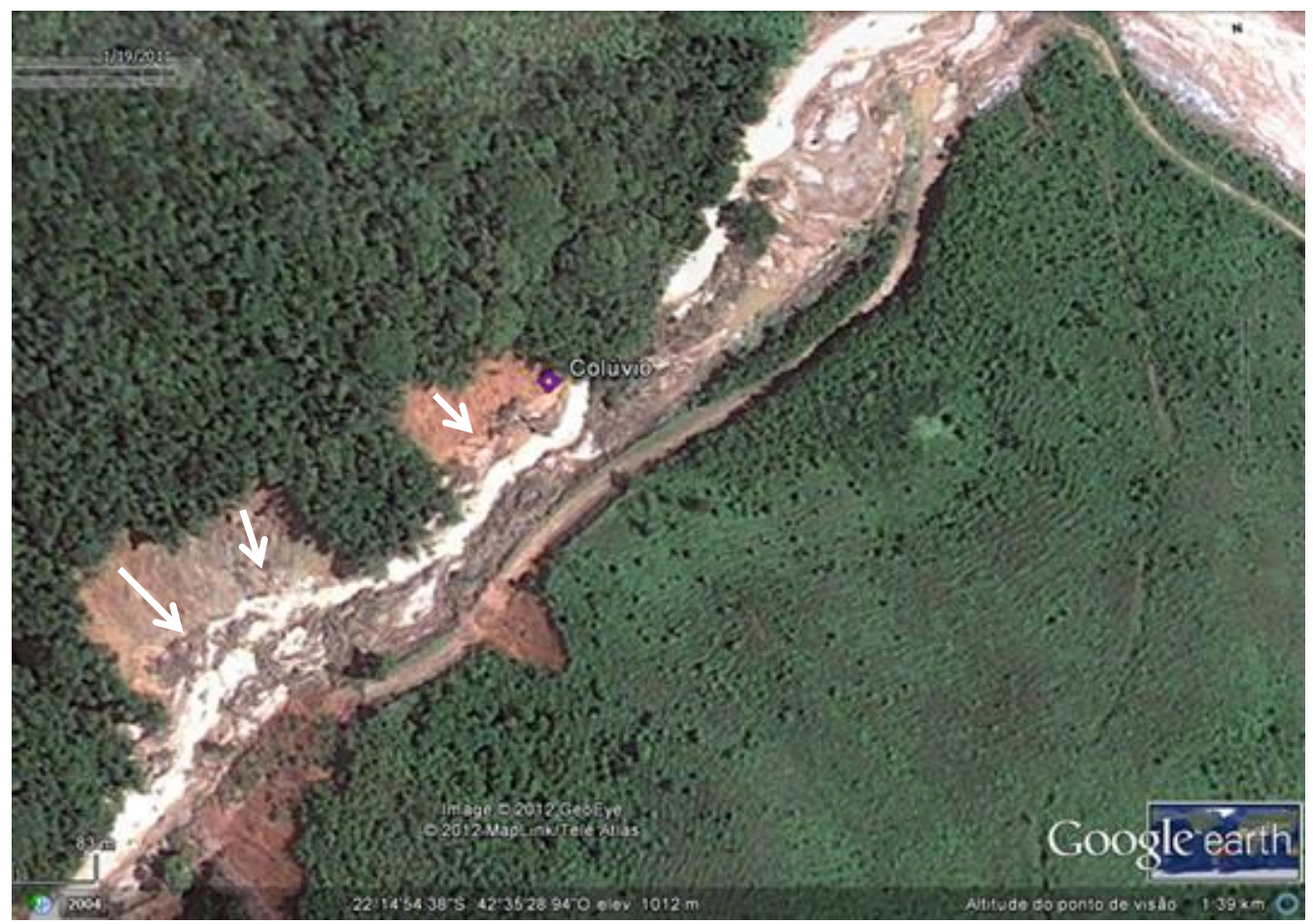

Figura 8.3 Local de coleta do Colúvio

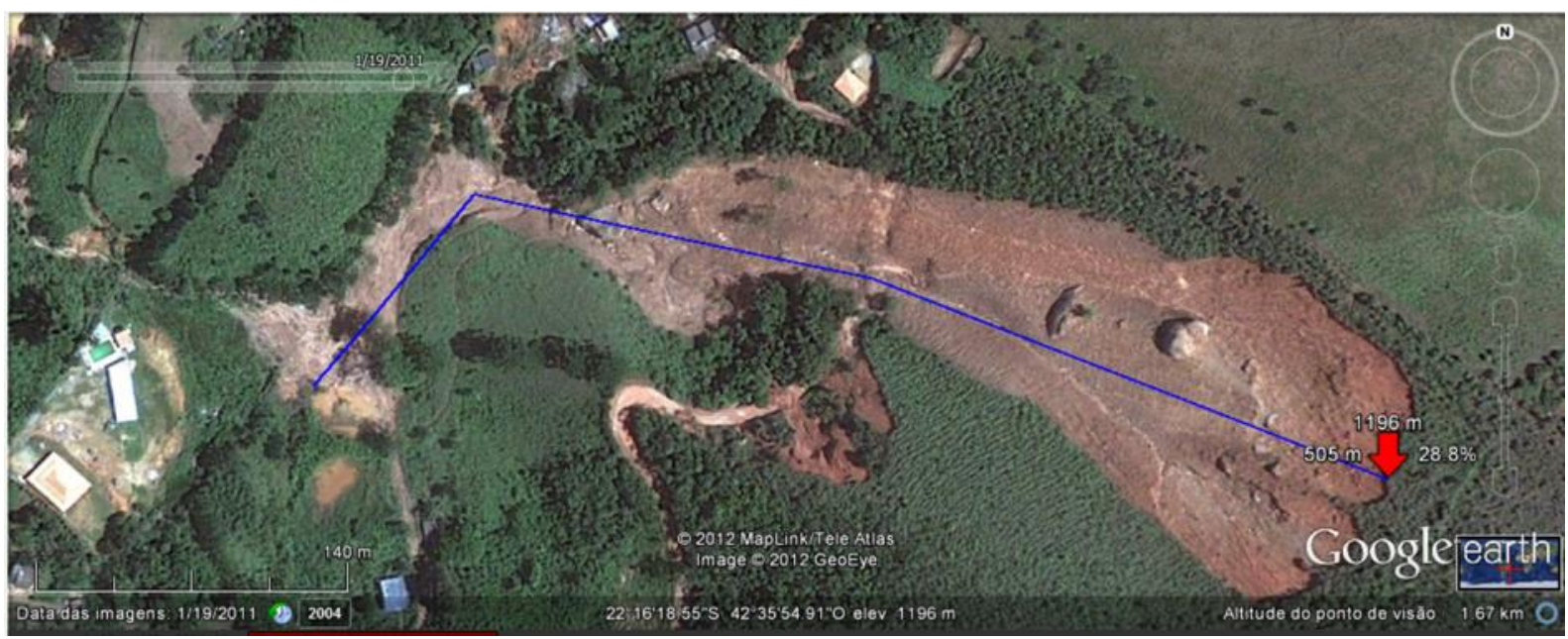

Figura 8.4 Perfil de elevação do local de coleta do solo residual (Google Earth, 2011)

Observando os critérios de liquefação e a umidade em campo na ocasião do megadesastre era de esperar que ocorressem centenas de liquefações na região, o que não foi observado. A liquefação observada é resultado não só das características do solo, mas também do fenômeno de ruptura ocorrido. Esse solo tem sua ruptura definida pela elevação do nível d'água no solo com consequente perda de sucção e de tensão efetiva. A perda da resistência é causada pela água e esse solo, saturado pela infiltração do excesso de chuvas, sofre ruptura, e a partir da ruptura o movimento é bruscamente acelerado, e, como o solo é suscetível, ocorre a liquefação. 
Essa liquefação ocorre apenas nas condições propostas na Figura 3.5, 0 fluxograma proposto para o caso italiano, ou seja, além da saturação e da susceptibilidade à liquefação é necessário que a ruptura se dê em condição não drenada. Para que a liquefação ocorra após a ruptura é necessário que esses fatores sejam obedecidos, caso contrário os taludes vão sofrer apenas o movimento de escorregamento propriamente dito. Sendo que através da reologia foi possível definir um novo critério para o fluxograma, que está reapresentado na Figura 8.5.

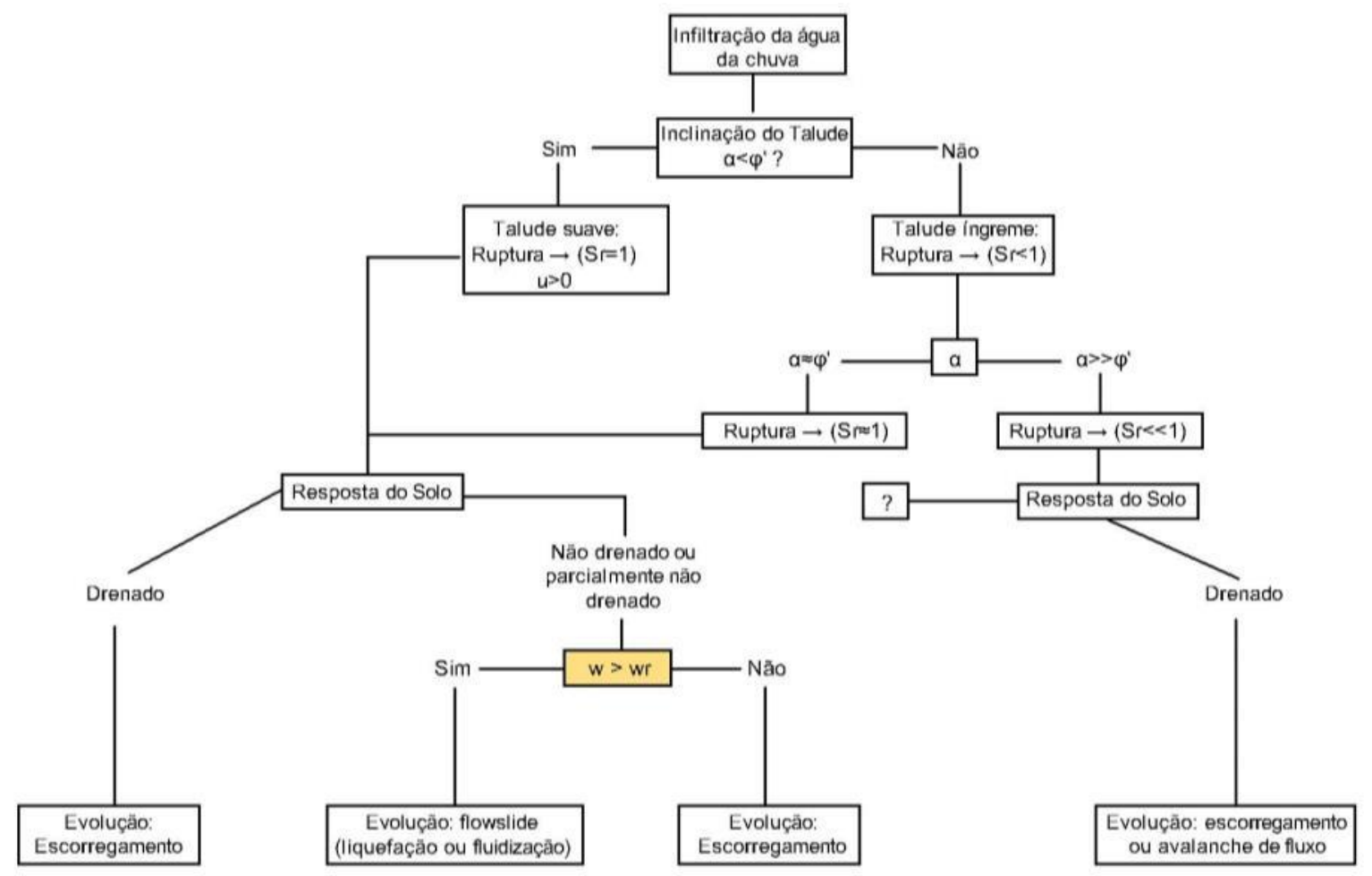

Figura 8.5 Fluxograma modificado com a contribuição da pesquisa (modificado de Olivares e Damiano, 2007)

Adotando um valor médio para o índice de vazios obtido das amostras indeformadas, apresentados na Tabela 6.2, juntamente com os resultados apresentados na Tabela 6.1 foi possível calcular o teor de umidade para a saturação para os dois solos, que foram de $38,34 \%$ para o colúvio e de $40,06 \%$ para o solo residual. Considerando os resultados obtidos nas Figuras 7.24 e 7.25 foi possível observar que o valor de umidade que separa o comportamento líquido do sólido, denominada doravante por $\mathrm{w}_{\mathrm{R}}$ (umidade para o limite de liquidez obtida pela reometria), foi de $49 \%$ para o colúvio e $34 \%$ para o solo residual. Essas informações estão esquematizadas na Figura 8.6, juntamente com a umidade obtida em campo para as amostras coletadas, sendo que a coletada foi realizada 5 meses após a ocorrência dos deslizamentos, quando a região já estava em seu período seco, não 
sendo representativa da umidade em campo dos dias 11 e 12 de janeiro de 2012 . Importante ressaltar que a umidade de saturação depende diretamente do índice de vazios, quanto mais fofo o solo estiver em campo, maior a umidade de saturação e maior a possibilidade de sofrer liquefação.
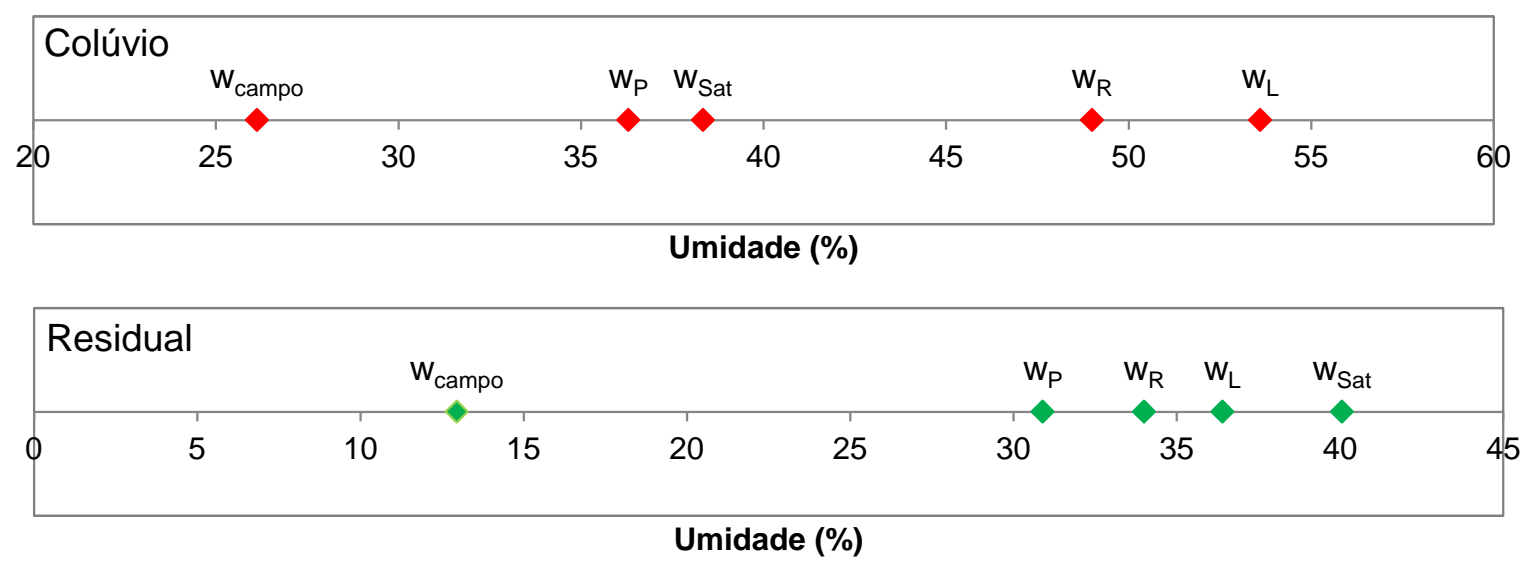

Figura 8.6 Resumo dos teores de umidade para os solos

A partir do exposto na Figura 8.6 é observado que quando o solo residual escorrega saturado estará com uma umidade acima do limite de liquidez e do limite de liquefação, ou seja, a estrutura do solo o mantém estável em condição natural, mas depois do escorregamento ele pode sofrer liquefação. O solo coluvionar quando escorrega saturado está com umidade abaixo do limite de liquefação, por isso o movimento pós-escorregamento não evolui para uma corrida. Importante ressaltar que a umidade de saturação depende diretamente do índice de vazios, quanto mais fofo o solo estiver em campo, maior a umidade de saturação e maior a possibilidade de sofrer liquefação. Essa é uma nova forma de avaliar o potencial do solo sofrer liquefação.

Para a aplicação no solo residual, que apresenta potencial de sofrer liquefação, foram realizadas simulações, considerando a geometria dos taludes existentes na região serrana, para avaliar a influência da altura do nível d'água e da inclinação nos locais onde ocorrem escorregamento.

Para avaliar os resultados de forma simplificada, foi considerado que a ruptura do solo pode ser analisada com a hipótese de talude infinito com fluxo paralelo a encosta.

A inclinação do talude estudado foi analisada por Machado et. al (2013), sendo aferido que a inclinação da cicatriz após o escorregamento apresentada

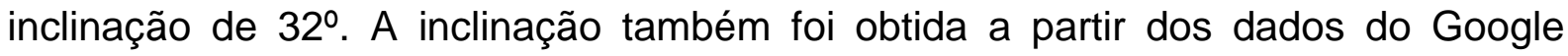


Earth, sendo de $15^{\circ}$. Portanto foi considerado uma faixa de inclinação entre $10^{\circ} \mathrm{e}$ 35․ A altura da camada de solo foi considerada como 2 metros, que é um valor típico dos escorregamentos translacionais ocorridos na Região Serrana do Rio de Janeiro), sendo utilizado também os dados obtidos no ensaio de cisalhamento direto $\left(c^{\prime}=0, \varphi=34^{\circ}\right)$. O resultado obtido está apresentado na Tabela 8.1.

Tabela 8.1 Valores obtidos para coeficiente de seguança

\begin{tabular}{|c|c|c|}
\hline N.A. & F.S. & $\begin{array}{c}\text { inclinação } \\
\text { (graus) }\end{array}$ \\
\hline 2,0 & 1,28 & 10 \\
\hline 2,0 & 1,00 & 12,7 \\
\hline 1,8 & 1,00 & 15 \\
\hline 1,4 & 1,00 & 20 \\
\hline 0,9 & 1,00 & 25 \\
\hline 0,4 & 1,00 & 30 \\
\hline 0,0 & 1,00 & 34,0 \\
\hline 0,0 & 0,96 & 35 \\
\hline
\end{tabular}

Observando os resultados é possível visualizar que para inclinações maiores que 34으 o talude vai romper sem saturação, então não há ocorrência de liquefação. Para inclinações de até $12,7^{\circ}$ o talude não rompe, mesmo estando saturado. Aliando essas informações com a umidade para o limite de liquefação (do ensaio reométrico) chega-se na conclusão de que os taludes com inclinação entre $12,7^{\circ}$ e $34^{\circ}$ está em condição que pode ocorrer liquefação. Os solos que se encontram no mesmo estado da amostra analisada devem sofrer liquefação, no entanto o estado dos solos na natureza é bastante variado, e esse estado é extremamente importante para a determinação da ocorrência de liquefação. Resumindo, os resultados indicam que o solo residual da região, com espessura média de 2 metros, em inclinações maiores que $15^{\circ}$ tem grande potencial para sofrer liquefação, transformando os movimentos de escorregamento em corridas.

Esse resultado é corroborado com o que foi observado em campo, a corrida formada pelo solo residual foi rasa, tanto que no meio do talude existia uma estrada que praticamente não foi mobilizada, evidenciando a espessura baixa do solo que ocorre a liquefação. 


\section{CONCLUSÕES E SUGESTÕES}

Os eventos extremos de chuva estão ocorrendo com uma frequência cada vez mais alta, sendo noticiadas as tragédias causadas por essas chuvas a cada estação chuvosa. $O$ conhecimento do solo e do mecanismo que levam as grandes movimentações é essencial para que essas tragédias sejam eventos cada vez mais previsíveis, causando menos danos.

Essa dissertação é apenas o início desse estudo que precisa ser realizado para a caracterização geotécnica e reológica desses movimentos complexos de solo, nos quais o solo muda de comportamento elástico para fluido-viscoso. O ideal é determinar, com certa precisão, quando o escorregamento irá se desenvolver gerando uma corrida e quando esse escorregamento vai simplesmente parar. Para isso é necessário um número maior de amostras que sejam representativas do solo regional, além de um levantamento preciso das inclinações e situações de solicitações das encostas, sendo necessário um investimento governamental e um acompanhamento técnico efetivo e rotineiro.

Com a aplicação dos conceitos da reologia foi definido o modelo de Herschel Bulkley para representar o comportamento do solo, sendo possível definir a tensão de escoamento em relação à umidade. $O$ valor da tensão de escoamento define se o solo vai ter um comportamento sólido ou líquido. Com os valores da tensão de cisalhamento atuante na encosta e da tensão de escoamento, determinada pelo modelo, pode ser possível definir um fator de segurança.

A tensão de cisalhamento atuante no talude é determinável, considerando a hipótese de talude infinito, que se aplica a região da Serra do Mar. A velocidade do escorregamento, equivalente à taxa de cisalhamento, é um parâmetro que pode ser estimado a partir de fórmulas conhecidas baseadas em retro análises. Com as estimativas de velocidades do debris flow é possível também definir qual a viscosidade da massa em movimento. Ainda não é possível definir como as condições de campo influenciariam na reologia, no entanto a ocorrência da liquefação está diretamente relacionada com o estado do solo em campo. 
O fenômeno de liquefação dos solos vem sendo estudado já há algum tempo, a reologia vem para complementar esses estudos, já que o solo apresenta os dois comportamentos (sólido e líquido). Para que seja possível a aplicação dos dois conceitos é necessário considerar que existiu a ruptura do solo, dominada pelos mecanismos já conhecidos da Geotecnia, e a partir dos conhecimentos das condições do solo em campo (saturação, índice de vazios, umidade e se a ruptura é não drenada) é possível determinar se o solo tem potencial para liquefazer ou não. Se o solo tiver esse potencial os modelos reológicos podem ser aplicados tendo sua utilidade para determinar qual a tensão de escoamento que faz esse solo se mover, sendo ainda possível determinar a velocidade e a viscosidade do fluido em relação a sua umidade.

Esse campo da reologia ainda merece atenção por parte dos engenheiros geotécnicos, através do estudo das possibilidades de utilização dos ensaios e equipamento já existentes para uma nova interpretação dos fenômenos observados em campo. Ainda é necessário um desenvolvimento em relação aos equipamentos utilizados, que devem ser adaptados para a utilização em solos, já que foram elaboradas inicialmente para a caracterização de materiais de construção.

A partir dos resultados dos ensaios realizados foi possível observar:

- O solo tem uma mudança de comportamento (sólido para líquido) a partir de uma determinada umidade, denominada por $\mathrm{w}_{\mathrm{r}}$;

- Essa umidade está intimamente realicioanada com o a definição do limite de lqiuidez, e seu valor é da ordem de $90 \%$ do $w_{L}$;

- $O$ aumento da umidade causa uma segregação das fases sob solicitação, o que, na natureza, eleva a velocidade do movimento;

- A ocorrência da liquefação é facilmente avaliada com os resultados reométricos, enquanto que os critérios tradicionais não conseguem caracterizar solos tropicais.

Considerando os solos estudados, o colúvio de sopé e o solo residual, os resultados demonstram que o solo coluvionar não vai sofrer liquefação, o que pode ser confirmado com o observado em campo. Para o solo residual, os resultados demonstraram que ocorre liquefação para taludes com inclinações maiores que 15으, em solos rasos, o que também pode ser confirmado com o observado em campo. 
Tendo em vista o estado inicial em que se encontra esse estudo, por causa desta nova modalidade de trabalho, alguns tópicos merecem uma maior investigação e são sugeridos como futuros estudos, para contribuir com o aumento do conhecimento na área, apresentados a seguir:

- Realização de ensaios triaxiais em corpos de prova indeformados e com o grau de saturação controlado para simular a ocorrência da liquefação de solos;

- Realizar o ensaio de squeeze flow em diferentes velocidades para conseguir determinar até que ponto a velocidade influi na segregação das fases;

- Adaptar o aparelho de reômetro de torque planetário com uma gemetria capaz de simular o cisalhamento contínuo da amostra;

- Utilização de um reômetro de placas paralelas com uma maior capacidade de carga;

- Adaptar os equipamentos para a aplicação de tensão confinante tanto no reômetro quanto no squeeze flow. 


\section{REFERÊNCIAS BIBLIOGRÁFICAS}

ALLEN, J. R. L. Sedimentary Structures: their character and physical basis. Elsevier, Amsterdam, 663p., 1984.

AUGUSTO FILHO, O. Caracterização geológica - geotécnica voltada à estabilização de encostas: uma proposta metodológica. Conferência Brasileira sobre estabilidade de encostas. Rio de Janeiro, 1992.

- Mass movements identification, modeling, analysis and mapping: some experiences in the southern of Brazil, São Paulo state. Landslides: Evaluation and stabilization, proceedings of the $9^{\circ}$ international symposium on landslides, Rio de Janeiro, 2004.

AVELAR, A. S. Iniciação e desenvolvimento de fluxos detríticos em encosta: ensaios triaxiais de choque e em caixa experimental a bordando o caso do Soberbo (RJ). Tese de Doutoramento, Universidade Federal do Rio de Janeiro, COPPE, Rio de Janeiro, 2003.

AVELAR, A. S.; LACERDA, W. A.; NETTO, A. L. C. Mecanismos de iniciação de fluxos detríticos no maciço da Tijuca, Rio de Janeiro (RJ): o caso da encosta do soberbo. Revista Brasileira de Geomorfologia, ano 7, n. 1, p. 73 - 83, 2006.

; NETTO, A. L. C.; LACERDA, W. A.; BECKER, L. B.; MENDONÇA, M. B. Mechanisms of the recent catastrophic landslides in the mountainous range of Rio de Janeiro, Brazil. Proceedings of the $2^{\circ}$ World Landslide Forum, Rome, 2011.

AVELAR, A. S. Algumas Fotos - Movimentos de Massa da Região Serrana RJ [mensagem pessoal]. Mensagem recebida por e-mail em 28/01/2011, 2011.

BAGGIO, H.; HORN, H. A. Geological risks in Brazil: The mountainous region of Rio de Janeiro. Geo-risk management - a German Latin American approach. Heidelberg, p. 55-63, 2-7 April 2011.

BAGNOLD, R. Experiments on a gravity free dispersion of large solid spheres in a Newtonian fluid under shear. Proceedings of the Royal Society of London, series A, 225, p. 49-63, 1954.

BANFIL, P. F. G. Rheological methods for assessing the flow properties of mortar and related materials. Construction and Building Materials, v. 8, n. 1, p. $43-50$, 1994.

BARATA, F. E. Landslides in the tropical region of Rio de Janeiro, Proceedings 7th International Conference on Soil Mechanics and Foundation Engineering, Mexico City, Sociedad Mexicana de Mecánica de Suelos, v. 2, p. 507-516, 1969. 
BARBOSA, W. S. Alteração do comportamento reológico da suspensão cimentícia aplicada sobre substratos porosos. Dissertação (Mestrado), Escola Politécnica da Universidade de São Paulo, 152 p., 2010.

BEEN, K.; JEFFERIES, M. G.; HACHEY, J. The critical state of sands. Géotechnique, vol. 41, n. 3, p. $365-381,1991$.

BERCOVIER, M.; ENGELMAN, M. A finite element method for incompressible nonNewtonian flows, Journal of Computational Physics, vol. 36, 313-326, 1980.

BETIOLI, A. M.; JOHN, V. M.; GLEIZE, P. J. P.; PILEGGI, R. G. Caracterização reológica de pasta cimentícia: associação de técnicas complementares. Revista Ambiente Construído, Porto Alegre, v. 9, n. 4, p. 37 - 48, 2009.

CPTEC INPE - Boletim ClimAnálise - CPTEC INPE VOL 26, N.1 JANEIRO DE 2011.

BURGOS, G. R.; ALEXANDROU, A.N.; ENTOV, V. On the determination of yield surfaces in Herschel-Bulkley fluids. Journal of Rheology, vol. 43, p 463 - 483, 1999.

CARREAU, P. J. Ph.D. Dissertation. Dept. of Chemical Engineering, University of Wisconsin, Madison, 1968.

CASCINI, L., SORBINO, G. The contribution of soil measurements to the analysis of flowslide triggering. Invited Lecture, Proc. Of the Int. Workshop "Flows 2003 Occurrence and Mechanisms of Flows in Natural Slopes and Earthfill", Sorrento, Patron Ed, pp. 77-86, 2003.

CASCINI, L., CUOMO, S., SORBINO, G. Flow-like mass movements in pyroclastic soils: remarks on the modeling of triggering mechanisms. Rivista Italiana di Geotecnica, abril 2005.

CARDOSO, F. A. Método de formulação de argamassas de revestimento baseado em distribuição granulométrica e comportamento reológico, Tese (Doutorado), Escola Politécnica da Universidade de São Paulo, São Paulo, 2009.

; PILEGGI, R. G.; JOHN, V. M. Caracterização Reológica de Argamassas pelo Método de Squeeze-Flow. VI Simpósio Brasileiro de Tecnologia de Argamassas, Florianópolis, 2005.

Squeeze-Flow aplicado a argamassas de revestimento: Manual de utilização. Material Didático Escola Politécnica da Universidade de São Paulo, 2007.

CASTRO, G. Liquefaction of Sands. Thesis (Doctor of Philosophy in the subject of Engineering), Division of Engineering and Applied Physics, Harvard University, Cambridge, Massachusetts, 1969.

CASTRO, A. L. Aplicação de conceitos reológicos na tecnologia dos concretos de alto desempenho. Tese (Doutorado) em Ciência e Engenharia de Materiais, Universidade de São Paulo, São Carlos/SP, 302p, 2007. 
CHENG, D. C. H. Further observations on the rheological behavior of dense suspensions. Powder Technology, vol. 37, p. 255 - 273, 1984.

COELHO NETO, A. L.; SATO, A. M.; AVELAR, A. S.; VIANNA, L. G. G.; ARAÚJO, I. S.; FERREIRA, D. L. C.; LIMA, P. H.; SILVA, A. P. A.; SILVA, R. P. January 2011: the extreme landslide disaster in Brazil. Proceedings of the 20 World Landslide Forum, Rome, 2011.

COSTA NUNES, A. J., Landslides in soils of decomposed rock due to intense rainstorms. Proceedings 7th International Conference on Soil Mechanics and Foundation Engineering, Mexico City, Sociedad Mexicana de Mecánica de Suelos, v. 2, p. 554-574, 1969.

COUSSOT, P., LEONOV, A. I., PIAU, J-M. Rheological modeling and peculiar properties of some debris flows. Proceedings of the Chengdu Symposium - Debris Flows and Environment in Mountain Regions, IAHS Publ n 209, 1992.

; PIAU, J-M. A large-scale field coaxial cylinder rheometer for the study of the rheology of natural coarse suspensions. Journal Rheology, 39, 1994.

; BOYER, S. Determination of yield stress fluid behavior from inclined plane test. Rheologica Acta vol. 34, p. 534 - 543, 1995.

; MEUNIER, M. Recognition, classification and mechanical description of debris flows. Earth-Science Reviews, v. 40, n. 3, p 209-277, Elsevier, 1996.

; LAIGLE, D.; ARATTANO, M.; DEGANUTTI, A.; MARCHI, L. Direct Determination of Rheological Characteristics of Debris Flow. Journal of Hydraulic Engineering, vol. 124, n. 8, 1998.

CROSS, M. M. Rheology of non-Newtonian flow: equation for pseudoplastic systems. J. Colloid Sci., 20, p. 417 - 437, 1965.

DAMIANO, E., OLIVARES, L. The role of infiltration process in steep slope stability of pyroclastic granular soils: laboratory and numerical investigation. Natural Hazards, 2010.

DRM - RJ. Megadesastre da Serra Jan 2011, Departamento de Recursos Minerais Serviço Geológico do Estado do Rio de Janeiro, 2011.

DMR - RJ. Mapa Geológico Simplificado do Estado do Rio de Janeiro - As rochas nos contam sua história. Projeto Caminhos Ecológicos, Departamento de Recursos Minerais - Serviço Geológico do Estado do Rio de Janeiro, 2008.

DRUMMOND, J. A. Devastação e Preservação Ambiental - Os parques nacionais do Estado do Rio de Janeiro - Editora da Universidade Federal Fluminense, Niterói RJ, 1997.

ELLIS, S. B. Thesis, Lafayette College, Pa. (1927) Citado em: Whorlow, R. W. Rheological Techniques. Halsted Press (Div. of John Wiley \& Sons), New York, 1980. 
ENGMANN, J.; SERVAIS, C.; BURBIDGE, A. S. Squeeze flow theory and applications to rheometry: A review. Journal of Non-Newtonian Fluid Mechanics, 132, p. $1-27,2005$.

FECOMERCIO - FIRJAN, <www.fecomercio-rj.org.br>, acessado em outubro de 2011.

FAIRCHILD, L. H. Lahars at Mount St. Helens: Unpub. Ph.D. Thesis, University of Washington, Seattle, 374 p., 1985.

FREDLUND, D. G.; MORGENSTERN, N. R.; WIDGER, R. S. The Shear Strength of Unsaturated Soils. J. Geot. Div. ASCE, v. 103, p. 447 - 446, 1978.

FUTAI, M. M.; MELO, D. F. M.; CARDOSO JR, C. R.; DUEÑAS, V. Z. Estabilidade de Encostas em Condições Não Saturadas. VII Simpósio Brasileiro de Solos Não Saturados, 2011.

GODOIS, J. V. S. Estudo do comportamento de um escorregamento ativo na Serra da Cantareira - SP. Dissertação de Mestrado, Escola Politécnica da Universidade de São Paulo, São Paulo, 2011.

GUIDICINI, G.; IWASA, O. Y. Ensaio de correlação entre pluviosidade e escorregamento em meio tropical úmido. São Paulo: IPT. 48 p. (IPT pub. 1080), 1976.

GUIDICINI, G.; NIEBLE, C. M. Estabilidade de Taludes Naturais e de Escavação. Edgard Blucher, São Paulo, 1983, 2. ed.

GUILLÉN, J. L. C. Modelagem elasto-plástica da liquefação dinâmica de solos. Tese (Doutorado em Engenharia Civil), Pontifícia Universidade Católica do Rio de Janeiro, Rio de Janeiro, 2008.

INMET. Instituto Nacional de Meteorologia. http://www.inmet.gov.br, acesso ao BDMEP - Banco de Dados Meteorológicos para Ensino e Pesquisa em 04/07/2012.

IVERSON. R. M. The Physics of Debris Flows. Geophysics, 35, p. 245 - 296, 1997.

ISHIARA, K.; TRONCOSO, J.; KAWASE, Y. Cyclic strength characteristics of tailing materials. Soils and Foundations, vol. 20, n. 4, 1980.

IPCC, Painel Intergovernamental Sobre Mudanças Climáticas. Mudança do Clima 2007: Mitigação da Mudança do Clima, 2007.

JHONSON, A. M. Physical Processes in Geology: San Francisco, Freeman, Cooper \& Company, 576p, San Francisco, California, 1970.

JONES, F. O. Landslides of Rio de Janeiro and the Serra das Araras Escarpment, Brazil. Geological Survey Professional Paper, 697, Washington, 1973.

KANJI, M. A. ; MASSAD, F. ; CRUZ, P. T. . Debris Flows in Areas of Residual Soils: Occurrence and Characteristics. In: International Workshop on Occurrence and 
Mechanism of Flows in Natural Slopes and Earthfills, 2003, Sorrento. International Workshop on Occurrence and Mechanism of Flows in Natural Slopes and Earthfills. Napoles : Associacione Geotecnica Italiana, 2003. v. 2. p. 1-11

KEEDWELL, M.J. Rheology and Soils Mechanics. Elsevier Applied Science Publishers LTD, 1984, 323p.

KRAMER, S. L. Geotechnical earthquake engineering. Prentice-Hall Civil Engineering Mechanics Series, Upper Saddle River, N. J., 1996.

LARRAD, F.; SEDRAN, T. Mixture Proportioning of high performance concrete. Cement and Concrete Research, v. 32, n. 11, p. 1699-1704, 2002.

LARRAD F. et al. A new rheometer for soft-to-fluid concrete. ACI Materials Journal, v. 94, p. $234-243,1997$.

LI, J.; YUAN, J.; BI, C.; LUO, D. The main features of the mudflow in Jiang-Jia Ravine: Zeits. Geomorphology, v. 27, p. 325-341, 1983.

LYRA, J. S. Estudo da influência de policarboxilato comercial na hidratação, reologia e físico-química de superfície do cimento. Dissertação (Mestrado) Escola Politécnica da Universidade de São Paulo, 2010.

MACHADO, K.M.; BECKER, L.B.; AVELAR, A.S.; GUIMARÃES, G.V.M.. Retroanálise de um deslizamento de encosta em solo residual em Campo do Coelho, Nova Friburgo/RJ. VI Conferência Brasileira de Encostas, Angra dos Reis, pp. $282-288$, Outubro de 2013.

MACIAS, J.; AMARAL, C.; VARGAR Jr., E. Retroanálise do Comportamento Mecânico das Corridas de Massa de 1996 no Rio de Janeiro: Determinação da velocidade de deslocamento e da viscosidade dos materiais envolvidos. Anais: $2^{\circ}$ Conferência Brasileira sobre Estabilidade de Taludes, Rio de Janeiro, 1997.

MAGALHÃES FREIRE, E. S. Movimentos coletivos de solos e rochas e sua moderna sistemática. Construção, n.8, p.10-18, 1965.

MAJOR, J. J.; PIERSON, T. C. Debris flow rheology: Experimental analysis of finegrained slurries, Water Resources Research, 28 (3), p. 841 - 857, 1992.

MARTIN, T.E. Characterization of pore pressure conditions in upstream tailings dams. Proceedings, Tailings \& Mine Waste '99, Fort Collins, Colorado, pp. 303-313, 1999.

MEARS, A. Design criteria for avalanche control structures in the runout zone. US Department of Agriculture, Forest Service General Technical Report, RM-84, 82p., 1981.

MELO, D. F. M.; ROMANO, R. C. O.; PILEGGI, R. G.; JOHN, V. M.; FUTAI, M. M. Caracterização reológica de encosta em Vila Albertina - São Paulo, Congresso Brasileiro de Mecânica dos Solos, Recife, 2012. 
MESCHYAN, S. R. Experimental Rheology of Clayey Soils. Balkema Publishers. USA, 1995, 448p.

MIN, B. H.; ERWIN, L.; JENNINGS, H. M. Rheological behavior of fresh cement paste as measured by squeeze flow. Journal of Materials Science, 29, p. 1374 1381, 1994.

MIZRAHI, S.; BERK, Z. Flow behavior of concentrated Orange juice: mathematical treatment. Journal Texture Stud. 3, p. 69-79, 1972.

O'DONOVAN, E. J.; TANNER, R. I. Numerical study of the Bingham squeeze film problem. Journal Non-Newtonian Fluid Mechanics. 15, 75-83, 1984.

OFOLI, R. Y.; MORGAN, R. G.; STEFFE, J. F. A generalized rheological model for inelastic fluid foods. Journal Texture Stud. 18, p. 213-230, 1987.

OLIVARES, L., DAMIANO, E. Postfailure mechanics of landslides: laboratory investigation of flowslide in pyroclastic soils. Journal of geotechnical and geoenvironmental engineering, v. 133, n. 1, 2007.

OLIVEIRA, I. R.; STUDART, A.R.; PILEGGI, R.G.; PANDOLFELLI, V.C. Dispersão e empacotamento de partículas - Princípios e aplicações em processamento cerâmico. Fazendo arte editorial. São Paulo, 224 p., 2000.

PAPANASTASIOU, T. C. Flows of materials with yield. Journal of Rheology, vol. 31, p. $385-404,1987$.

PARZONKA, W.; VOCADLO, J. Méthode de la caractéristique du comportement rhéologique des substances viscoplastiques d'après les mesures au viscomimètre de Couette (modele nouveau à trois paramèters). Rheol. Acta., 7, p. 260-265, 1968.

PEREIRA, E. L. Estudo do potencial de liquefação de rejeitos de minério de ferro sob carregamento estático. Dissertação de Mestrado, Programa de Pós-graduação em Engenharia Geotécnica, Universidade Federal de Ouro Preto, Ouro Preto-MG, 2005.

PHILIPPOFF, W. Kolloid-Zeit, 71, 1-16, 1935. Citado em: Brodkey, R. S. The Phenomena of Fluid Motions, Addison-Wesley Publishing Co., Menlo Park, California, 1967.

PHILLIPS, C.J., DAVIES, T. R. H. Determining rheological parameters of debris flow material. Geomorphology, 4, p. 101-110, Elsevier Science Publishers, Amsterdam, 1991.

PIERSON, T. C. Erosion and Deposition by debris flows at Mount Thomas, North Canterbury, New Zealand: Earth Surf. Proc., v. 5, p. 227-247, 1980.

; SCOTT, K. M. Downstream dilution of a lahar: transition from debris flow to hyperconcentrated streamflow. Water Resources Research, 21 (10), p. 1511-1524, 1985. 
PILEGGI, R. G. Ferramentas para o estudo e desenvolvimento de concretos refratários. Tese (Doutorado em Ciência e Engenharia de Materiais), Universidade Federal de São Carlos, São Carlos-SP, 187 p., 2001.

POWELL, R. E.; EYRING, H. J. Mechanisms for the relaxation theory of viscosity. Nature, 154, $427-428,1944$.

Prefeitura de Nova Friburgo, disponível em <http://www.novafriburgo.rj.gov.br>, acesso em 24 de janeiro de 2012.

Reprodução/TV Globo, disponível em <http://g1.globo.com/rio-de-janeiro/chuvas-norj/fotos/2011/01/veja-imagens-da-tragedia-no-rj.html>, acesso em 30 março de 2011.

SCHOFIELD, A.N.; WROTH, C.P. A critical state soil mechanics, McGraw-Hill, London. 1968.

SEED, R. B.; CETIN, K. O.; MOSS, R. E. S.; KAMMERER, A. M.; WU, J.; PESTANA, J. M.; RIEMER, M. F.; SANCIO, R. B.; BRAY, J. D.; KAYEN, R. E.; FARIS, A. Recent advances in soil liquefaction engineering: a unified and consistent framework. 26th Annual ASCE Los Angeles Geotechnical Spring Seminar, California, 2003.

SETOR 1, Página da internet <http://www.setor1.com.br>, acessada em 06/08/2012.

STEFFE, J. F. Rheological Methods in Food Process Engineering. 2nd edition. East Lansing: Freeman Press, 1996, 418p.

ŠUKLJE, L. Rheological Aspects of Soils Mechanics, Wiley-Interscience, 1969, 571p.

TANNER, R. I. Engineering rheology. Ed. Rev. New York: Oxford University Press, 451 p., 1988.

TATTERSAL, G. H.; BANFIL, P. F. G. The rheology of fresh concrete. Pitman Advanced Publishing Program, 1983.

TATIZANA, C.; OGURA, A. T.; CERRI, L. E. S.; ROCHA, M. C. M. Análise de correlação entre Chuvas e Escorregamentos - Serra do Mar, Município de Cubatão. Congresso Brasileiro de Geologia de Engenharia (CBGE), V. 2, P. 225 - 236, 1987.

UKRAINICIK, V. Study on fresh concrete flow curves. Cement and Concrete Research, 10, 1980, p. $111-115$.

VAN WAZER, J. R.; LYONS, J. W.; KIM, K. Y.; COLWELL, R.E. Viscosity and Flow Measurement - A Laboratory Handbook of Rheology. John Wiley \& Sons, USA, 1966, 406p.

VARGAS Jr. et al. A study of the Relationship between the stability of slopes in residual soils and rain intensity. International Symposium on Environmental Geotechnology, Bethlehem, USA, P. 491 - 500, 1986. 
VARNES, D.J., 1978, Slope movements and types and processes, cap.2, in: SCHUSTER, R.L \& KRIZER, R.J (eds.), Landslides: analysis and control. Transportation Research Board, National Academy of Sciences, Washington DC, Special Report 176, pp. 11-33, 1978.

WALLEVIK, O. H.; GJØRV, O. E. Development of a coaxial cylinders viscometer for fresh concrete. In: Properties of fresh concrete, 1990, Hanover/Germany. Proceedings... London: Chapman and Hall, p. 213 - 224, 1990.

WALLEVIK, O. H.; WALLEVIK, J. E. Rheology as a tool in concrete science: The use of rheographs and workability boxes. Cement and Concrete Research, v. 41, p. 1279 $-1288,2011$.

WIGMOSTA, M. S. Rheology and flow dynamics of the Toutle debris flows from Mount St. Helens: Unpub. M.S. Thesis, University of Washington, Seattle, 184p., 1983.

WHIPPLE, K. X. Open-Channel Flow of Bingham Fluids: Applications in Debris-Flow Research. The Journal of Geology, v. 105, p. 243 - 262, 1997.

; MOHRIG, D.; PARKER, G.; HONDZO, M.; ELLIS, C. Experimental study of subaqueous debris flows, Geol. Soc. America, Abst. With Prog., v. 27, n. 6, p. A127, 1995.

WHORLOW, R. W. Rheological Techniques (Second Edition). Ellis Horwood, New York, 1992.

WOLLE, C.M. Taludes naturais - mecanismos de instabilização e critérios de segurança. Dissertação (Mestrado), Escola Politécnica, Universidade de São Paulo, São Paulo, 345 p, 1980.

WOLLE, C.M. Análise dos Escorregamentos Translacionais numa Região da Serra do Mar no contexto de uma Classificação de Mecanismos de Instabilização de Encostas. Tese (Doutorado), Escola Politécnica, Universidade de São Paulo, São Paulo, 1988.

\section{. Disciplina PEF 5827 - Estabilidade de Taludes em Solo, 2011}

YOSHIMI, Y.; TANAKA, K.; TOKIMATSU, K. Liquefaction resistance of a partially saturated sand. Soils and Foundations, vol. 29, n. 3, 157-162, 1989.

Youtube, reportagem Tragédia na Região Serrana exibida em 13/01/2011, disponível em <http://www.youtube.com/watch?v=yyEo7a7utz0\& > acessado em 14 de maio de 2012.

ZNAMENSKY, D. Corridas de Detritos ou "Debris Flows" - Avaliação de Parâmetros. Dissertação (Mestrado), Escola Politécnica, Universidade de São Paulo, 2001. 
A. ANEXOS 


\section{A.1. Resultados obtidos no Reômetro Rotacional de Placas Paralelas}
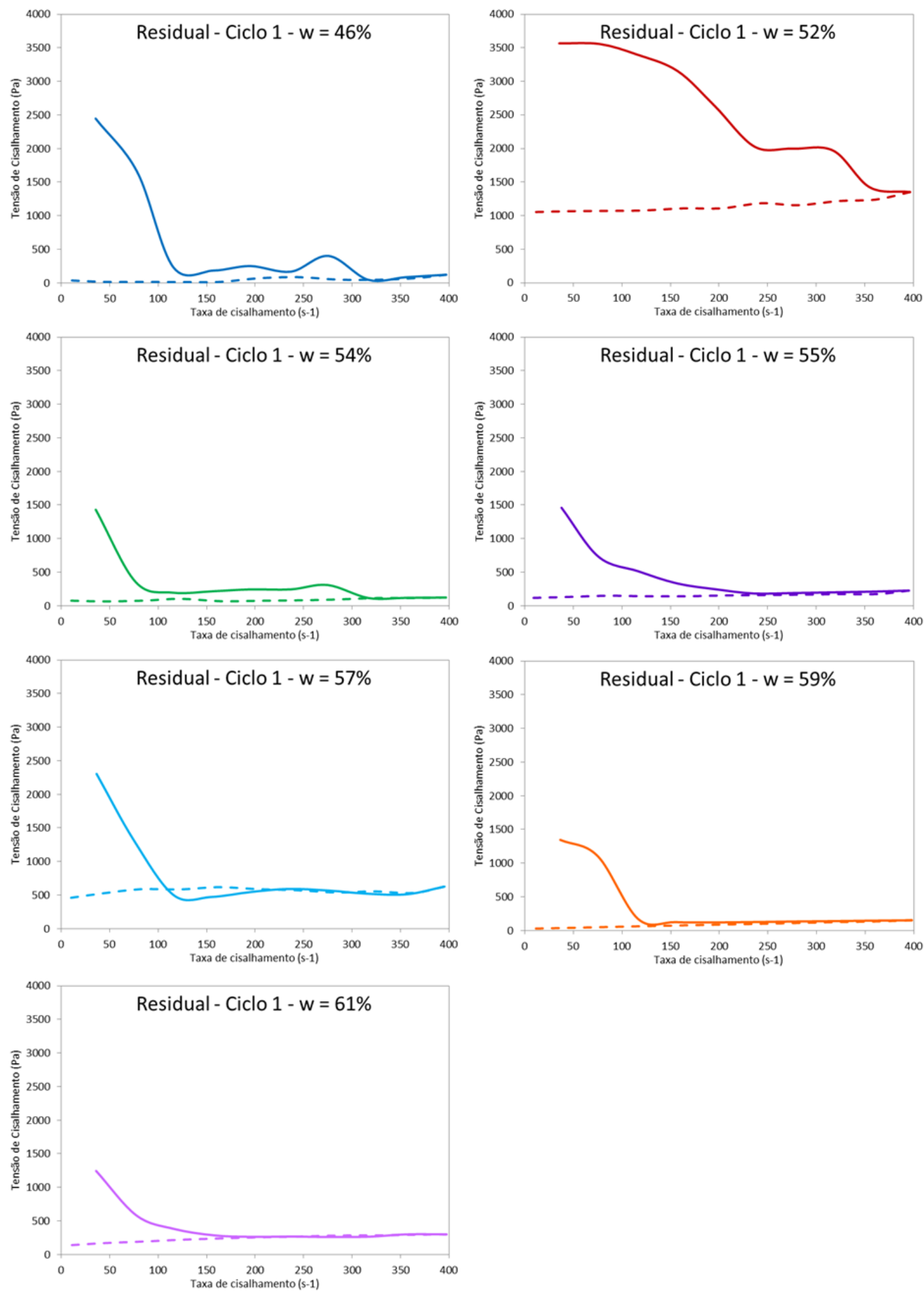

Figura A.1 Curva de fluxo - Solo Residual - Ciclo 1 

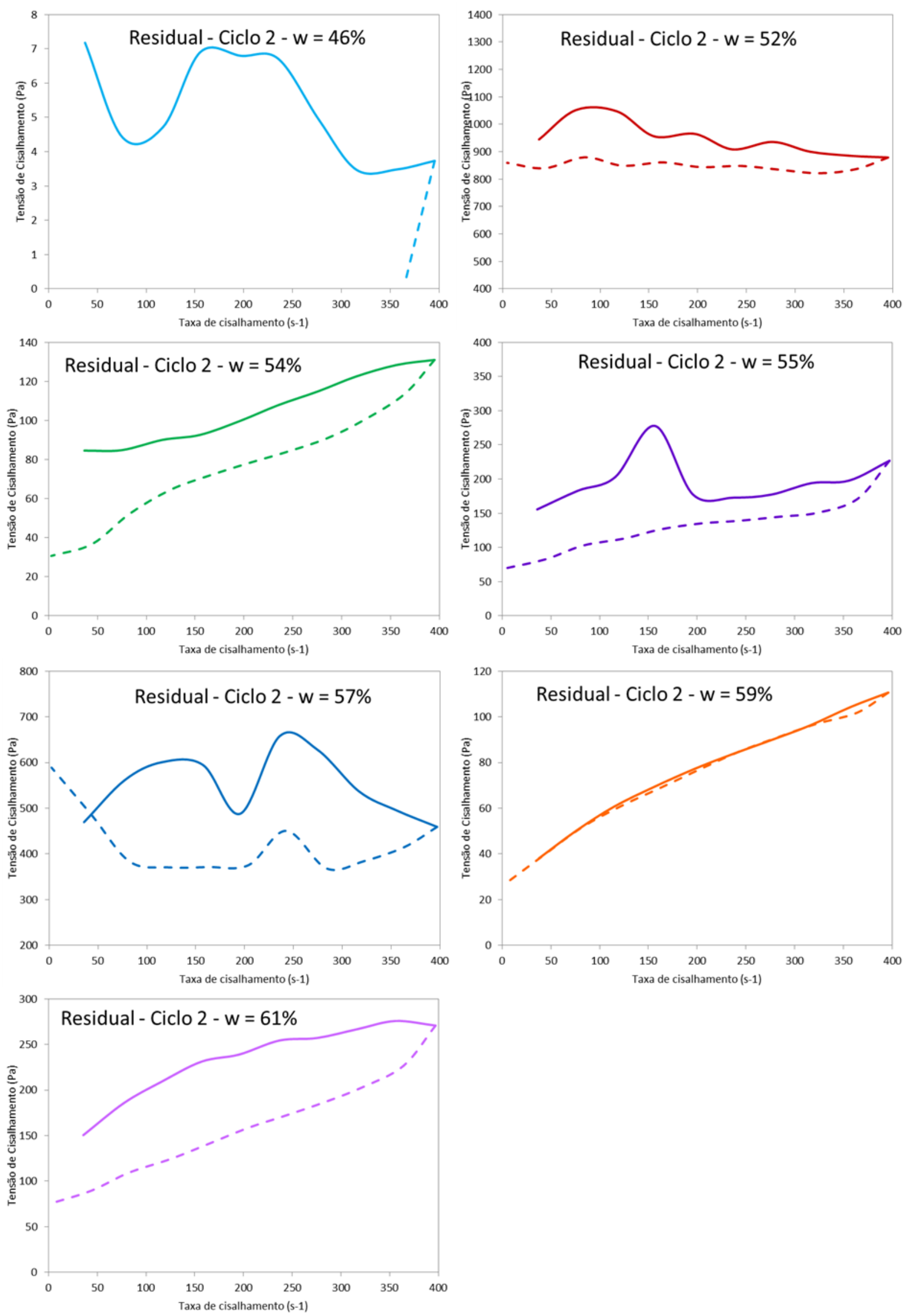

Figura A.2 Curva de fluxo - Solo Residual - Ciclo 2 

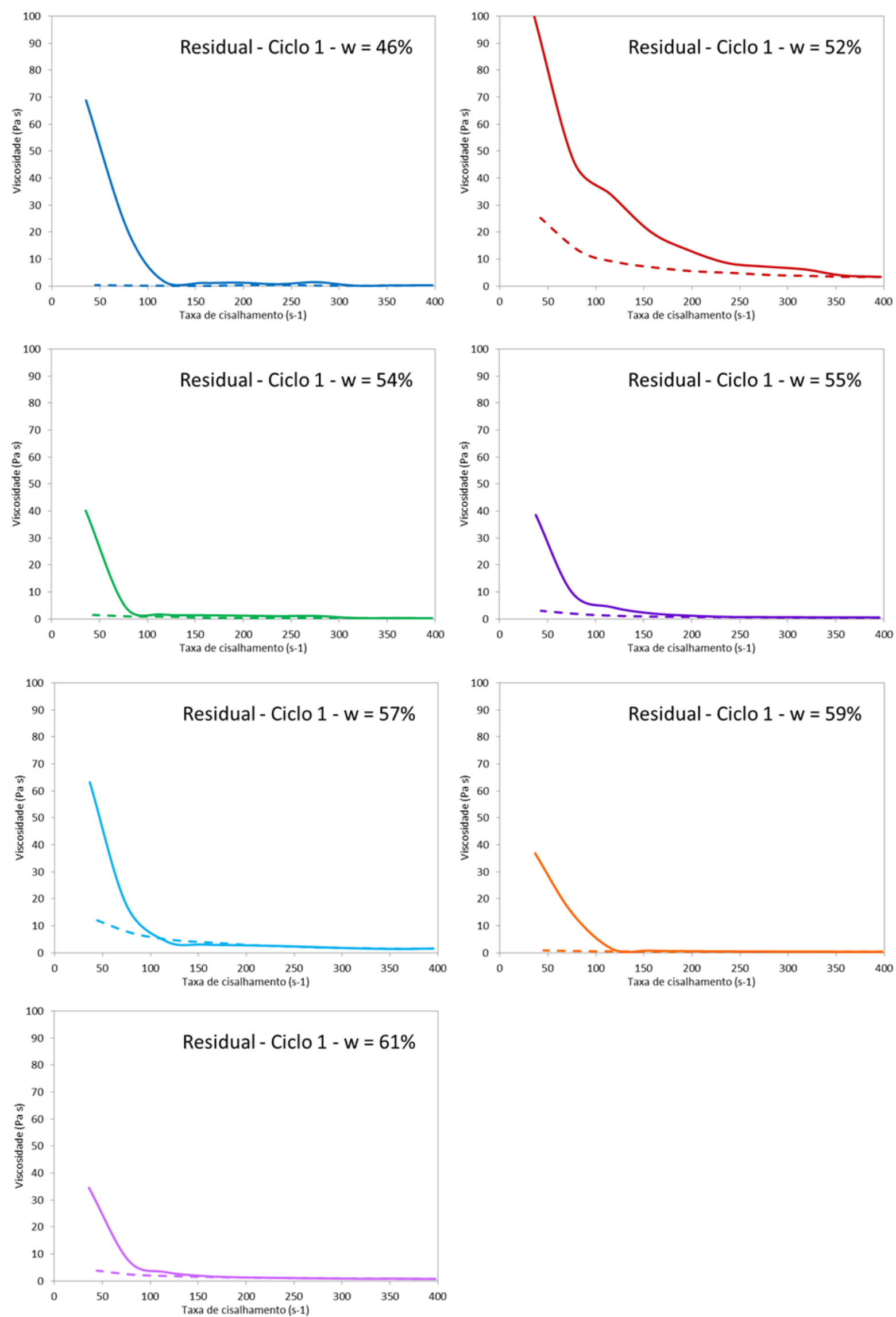

Figura A.3 Variação da viscosidade com taxa de cisalhamento - Solo Residual - Ciclo 1 

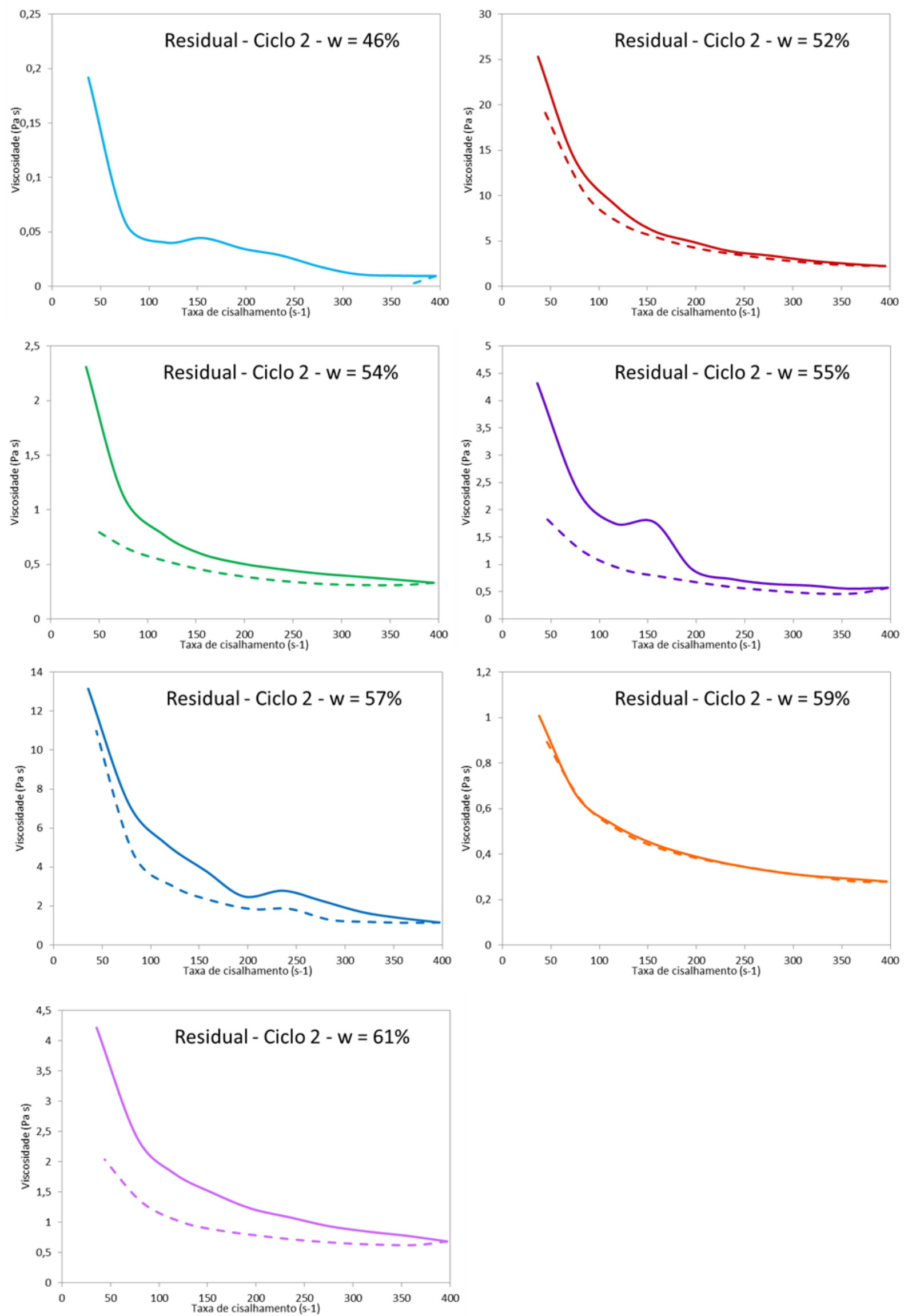

Figura A.4 Variação da viscosidade com taxa de cisalhamento - Solo Residual - Ciclo 2 

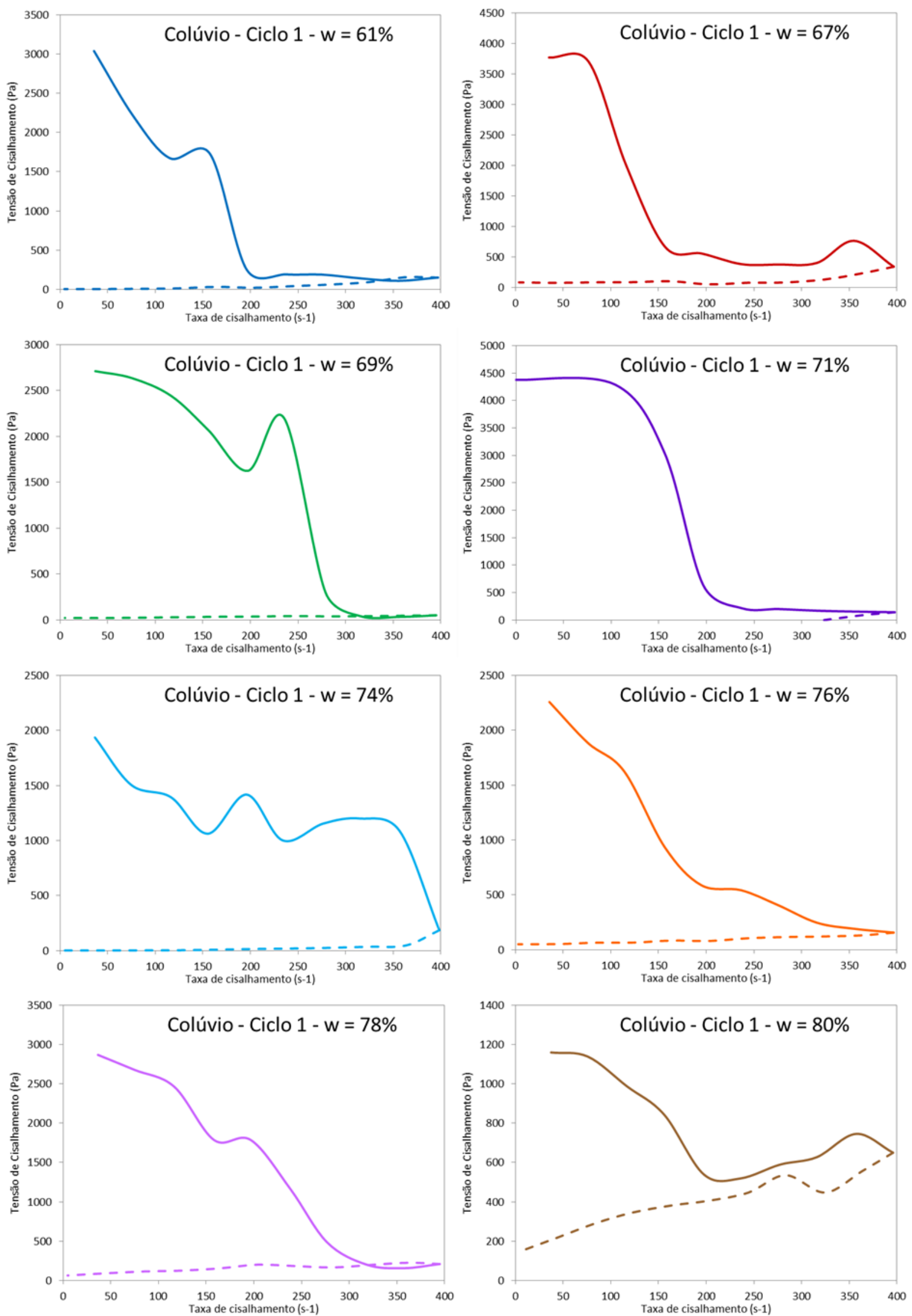

Figura A.5 Curva de fluxo - Colúvio - Ciclo 1 

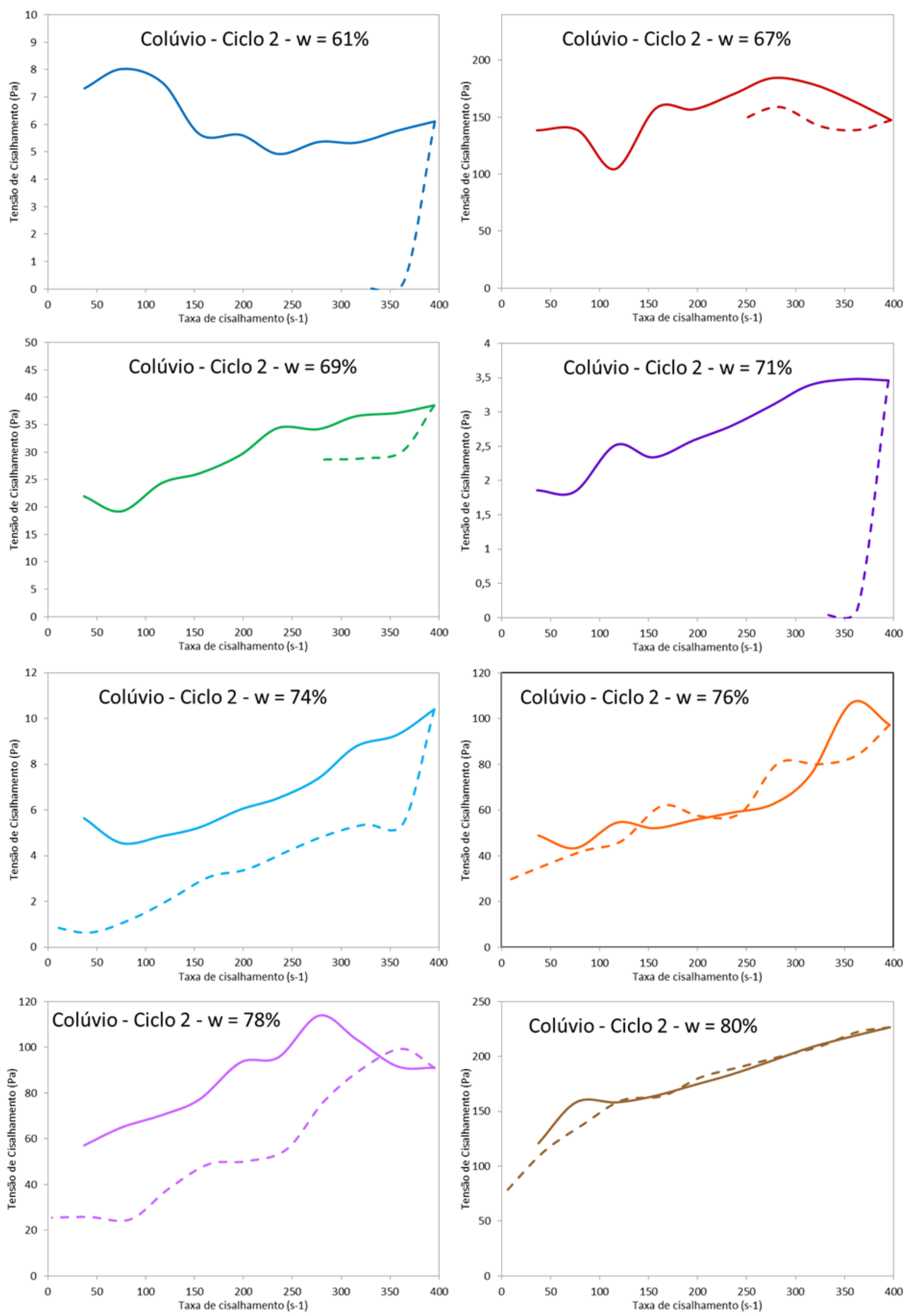

Figura A.6 Curva de fluxo - Colúvio - Ciclo 2 

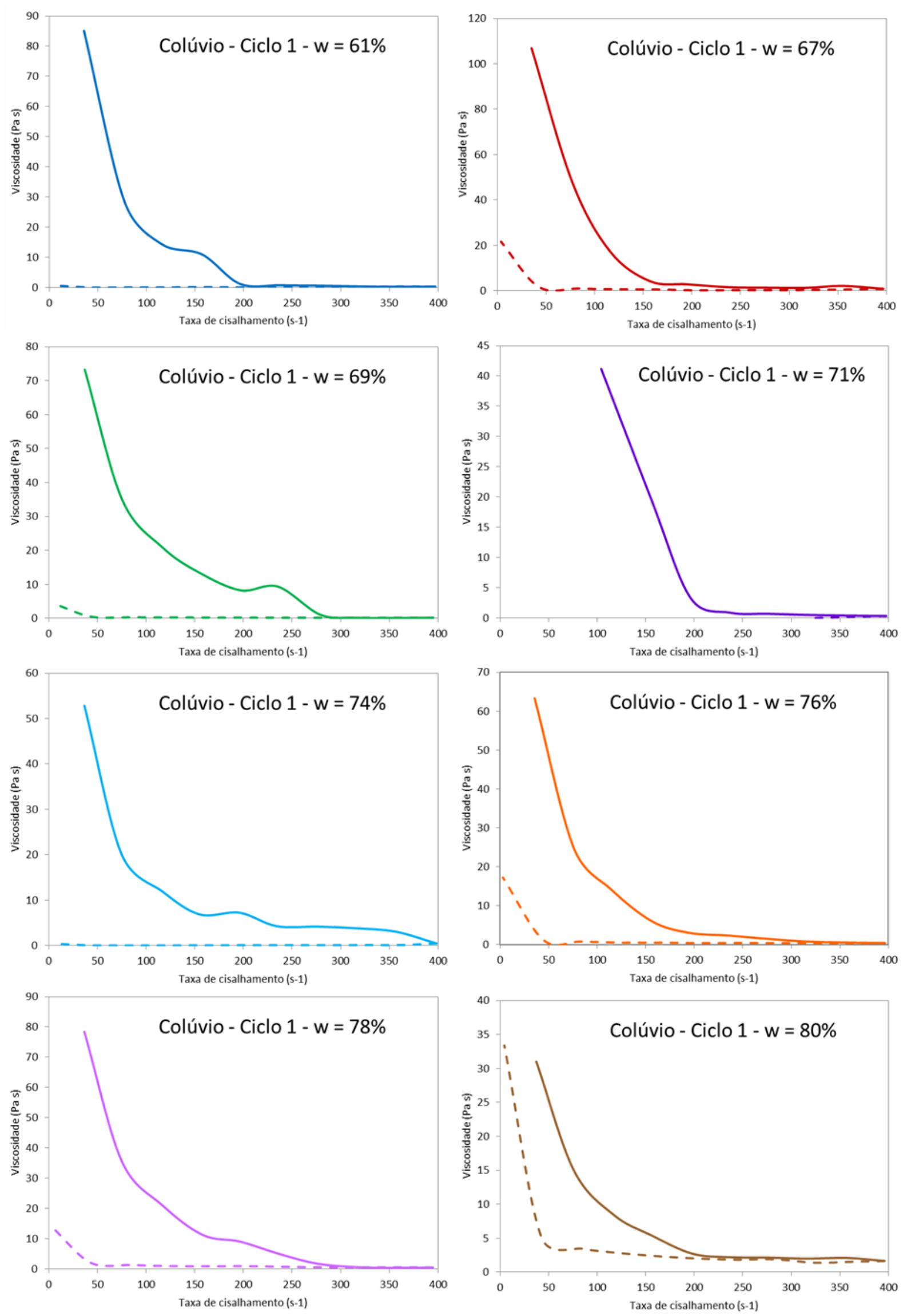

Figura A.7 Variação da viscosidade com taxa de cisalhamento - Colúvio - Ciclo 1 

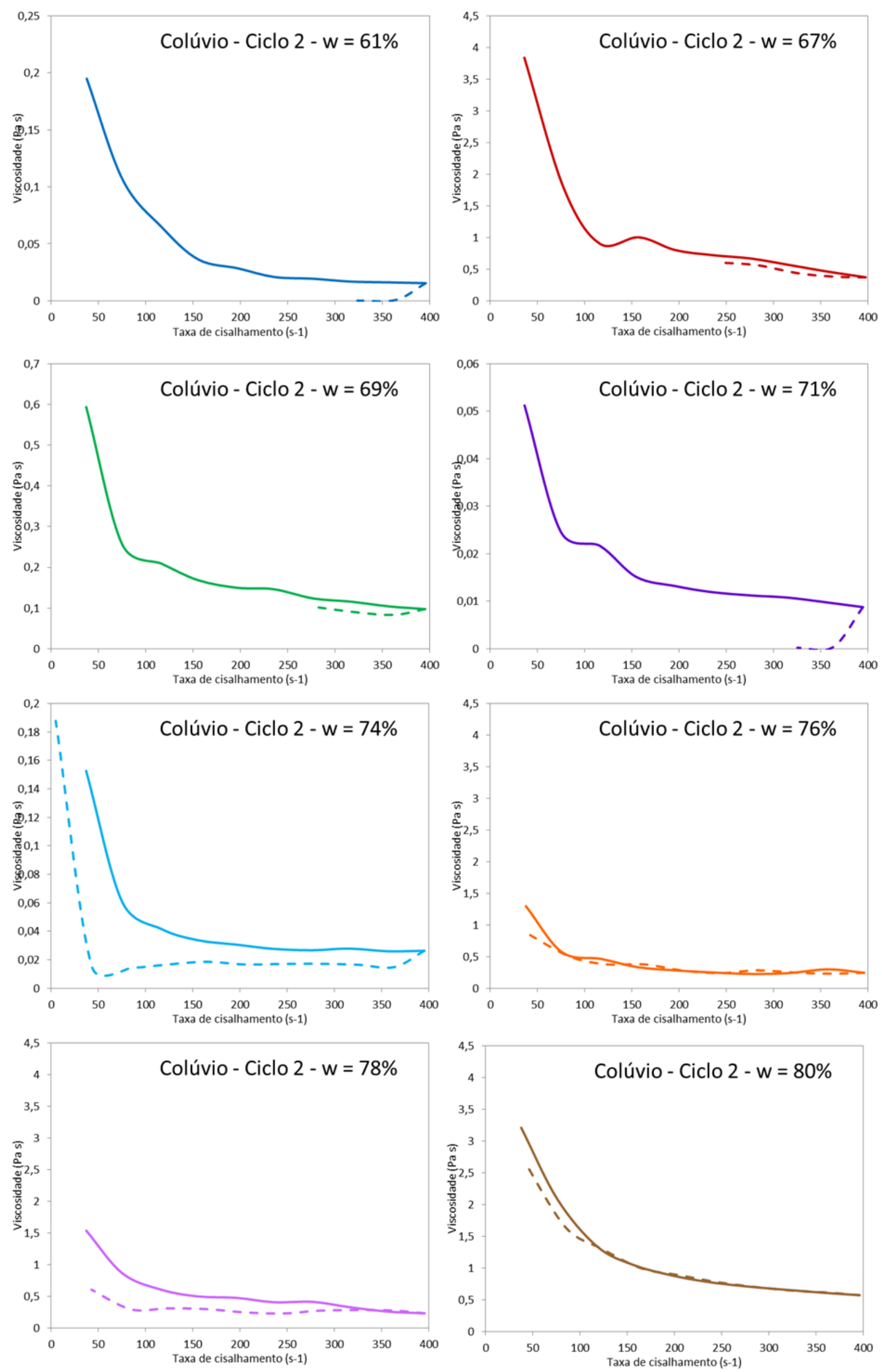

Figura A.8 Variação da viscosidade com taxa de cisalhamento - Colúvio - Ciclo 2 


\section{A.2. Reômetro de Torque com Geometria Planetária - Aproximação por Modelos Reológicos}

Tabela A.1 Valores de Torque( $\mathrm{Nm})$ obtidos ensaio com Geometria Planetária - Colúvio

\begin{tabular}{|c|c|c|c|c|c|c|c|c|}
\hline $\begin{array}{c}\text { Velocidade } \\
\text { (rpm) }\end{array}$ & $21,0 \%$ & $29,3 \%$ & $35,7 \%$ & $41,7 \%$ & $49,7 \%$ & $54,0 \%$ & $58,0 \%$ & $64,3 \%$ \\
\hline 50 & 13,08 & 17,53 & 12,55 & 8,01 & 2,87 & 2,14 & 1,73 & 0,92 \\
\hline 100 & 12,09 & 16,44 & 11,32 & 7,79 & 3,20 & 2,17 & 1,77 & 1,10 \\
\hline 150 & 13,36 & 18,11 & 12,22 & 9,13 & 3,52 & 2,69 & 2,00 & 1,26 \\
\hline 250 & 14,85 & 20,06 & 12,69 & 9,75 & 3,21 & 2,96 & 2,33 & 1,51 \\
\hline 500 & 16,25 & 21,26 & 14,24 & 10,08 & 3,40 & 3,56 & 2,93 & 2,07 \\
\hline 750 & 15,87 & 23,73 & 15,52 & 10,29 & 3,49 & 4,27 & 3,35 & 2,59 \\
\hline 1000 & 15,02 & 22,79 & 16,31 & 10,82 & 3,67 & 4,90 & 3,75 & 3,07 \\
\hline 1250 & 13,28 & 23,76 & 16,53 & 10,54 & 4,12 & 5,31 & 4,22 & 3,54 \\
\hline 1000 & 14,65 & 25,11 & 15,81 & 10,07 & 3,71 & 4,95 & 3,79 & 3,10 \\
\hline 750 & 16,84 & 25,42 & 14,46 & 10,35 & 3,40 & 4,17 & 3,34 & 2,59 \\
\hline 500 & 18,47 & 24,54 & 13,91 & 10,23 & 3,15 & 3,43 & 2,91 & 2,09 \\
\hline 250 & 18,91 & 21,40 & 12,78 & 9,39 & 3,21 & 2,82 & 2,31 & 1,56 \\
\hline 150 & 18,63 & 20,84 & 12,42 & 8,29 & 3,23 & 2,39 & 2,01 & 1,31 \\
\hline 100 & 17,80 & 19,74 & 12,26 & 7,80 & 3,37 & 2,18 & 1,87 & 1,15 \\
\hline 50 & 17,09 & 20,09 & 12,61 & 6,99 & 3,31 & 2,24 & 1,64 & 1,07 \\
\hline
\end{tabular}

Tabela A.2 Valores de Viscosidade(Nm/rpm) obtidos ensaio com Geometria Planetária -

Colúvio

\begin{tabular}{|c|c|c|c|c|c|c|c|c|}
\hline $\begin{array}{c}\text { Velocidade } \\
\text { (rpm) }\end{array}$ & $21,0 \%$ & $29,3 \%$ & $35,7 \%$ & $41,7 \%$ & $49,7 \%$ & $54,0 \%$ & $58,0 \%$ & $64,3 \%$ \\
\hline 50,0 & 0,262 & 0,351 & 0,251 & 0,160 & 0,057 & 0,043 & 0,035 & 0,018 \\
\hline 100,0 & 0,121 & 0,164 & 0,113 & 0,078 & 0,032 & 0,022 & 0,018 & 0,011 \\
\hline 150,0 & 0,089 & 0,121 & 0,081 & 0,061 & 0,023 & 0,018 & 0,013 & 0,008 \\
\hline 250,0 & 0,059 & 0,080 & 0,051 & 0,039 & 0,013 & 0,012 & 0,009 & 0,006 \\
\hline 500,0 & 0,033 & 0,043 & 0,028 & 0,020 & 0,007 & 0,007 & 0,006 & 0,004 \\
\hline 750,0 & 0,021 & 0,032 & 0,021 & 0,014 & 0,005 & 0,006 & 0,004 & 0,003 \\
\hline 1000,0 & 0,015 & 0,023 & 0,016 & 0,011 & 0,004 & 0,005 & 0,004 & 0,003 \\
\hline 1250,0 & 0,011 & 0,019 & 0,013 & 0,008 & 0,003 & 0,004 & 0,003 & 0,003 \\
\hline 1000,0 & 0,015 & 0,025 & 0,016 & 0,010 & 0,004 & 0,005 & 0,004 & 0,003 \\
\hline 750,0 & 0,022 & 0,034 & 0,019 & 0,014 & 0,005 & 0,006 & 0,004 & 0,003 \\
\hline 500,0 & 0,037 & 0,049 & 0,028 & 0,020 & 0,006 & 0,007 & 0,006 & 0,004 \\
\hline 250,0 & 0,076 & 0,086 & 0,051 & 0,038 & 0,013 & 0,011 & 0,009 & 0,006 \\
\hline 150,0 & 0,124 & 0,139 & 0,083 & 0,055 & 0,022 & 0,016 & 0,013 & 0,009 \\
\hline 100,0 & 0,178 & 0,197 & 0,123 & 0,078 & 0,034 & 0,022 & 0,019 & 0,012 \\
\hline 50,0 & 0,342 & 0,402 & 0,252 & 0,140 & 0,066 & 0,045 & 0,033 & 0,021 \\
\hline
\end{tabular}


Tabela A.3 Valores de Torque(Nm) obtidos ensaio com Geometria Planetária - Residual

\begin{tabular}{|c|c|c|c|c|c|c|c|}
\hline $\begin{array}{c}\text { Velocidade } \\
\text { (rpm) }\end{array}$ & \multicolumn{7}{|c|}{ Umidade } \\
\hline & $22,9 \%$ & $26,0 \%$ & $28,2 \%$ & $31,2 \%$ & $33,0 \%$ & $36,2 \%$ & $42,3 \%$ \\
\hline 50,0 & 6,73 & 4,50 & 3,37 & 2,11 & 1,98 & 0,63 & 0,29 \\
\hline 100,0 & 6,36 & 4,52 & 3,32 & 2,25 & 1,94 & 0,67 & 0,34 \\
\hline 150,0 & 6,47 & 4,30 & 3,38 & 2,25 & 1,94 & 0,73 & 0,41 \\
\hline 250,0 & 6,66 & 4,60 & 3,29 & 2,38 & 2,00 & 0,86 & 0,52 \\
\hline 500,0 & 7,56 & 5,03 & 3,75 & 2,47 & 2,08 & 1,12 & 0,78 \\
\hline 750,0 & 7,61 & 5,05 & 3,98 & 2,59 & 2,04 & 1,38 & 1,02 \\
\hline 1000,0 & 7,20 & 5,25 & 4,04 & 2,64 & 2,00 & 1,59 & 1,24 \\
\hline 1250,0 & 6,52 & 5,14 & 4,22 & 2,70 & 1,98 & 1,78 & 1,48 \\
\hline 1000,0 & 7,43 & 5,11 & 4,13 & 2,69 & 1,94 & 1,56 & 1,27 \\
\hline 750,0 & 7,93 & 5,23 & 3,93 & 2,58 & 1,84 & 1,33 & 1,01 \\
\hline 500,0 & 7,77 & 4,99 & 3,70 & 2,45 & 1,75 & 1,13 & 0,78 \\
\hline 250,0 & 6,90 & 4,38 & 3,39 & 2,27 & 1,68 & 0,85 & 0,51 \\
\hline 150,0 & 6,96 & 4,43 & 3,32 & 2,27 & 1,60 & 0,72 & 0,42 \\
\hline 100,0 & 6,74 & 3,89 & 3,10 & 2,07 & 1,59 & 0,66 & 0,35 \\
\hline 50,0 & 6,41 & 3,80 & 2,95 & 2,09 & 1,58 & 0,62 & 0,34 \\
\hline
\end{tabular}

Tabela A.4 Valores de Viscosidade(Nm/rpm) obtidos ensaio com Geometria Planetária Residual

\begin{tabular}{|c|c|c|c|c|c|c|c|}
\hline $\begin{array}{c}\text { Velocidade } \\
\text { (rpm) }\end{array}$ & $\mathbf{2 2 , 9 \%}$ & $\mathbf{2 6 , 0} \%$ & $\mathbf{2 8 , 2 \%}$ & $\mathbf{3 1 , 2 \%}$ & $\mathbf{3 3 , 0 \%}$ & $\mathbf{3 6 , 2 \%}$ & $\mathbf{4 2 , 3 \%}$ \\
\hline 50,0 & 0,135 & 0,090 & 0,067 & 0,042 & 0,040 & 0,013 & 0,006 \\
\hline 100,0 & 0,064 & 0,045 & 0,033 & 0,022 & 0,019 & 0,007 & 0,003 \\
\hline 150,0 & 0,043 & 0,029 & 0,023 & 0,015 & 0,013 & 0,005 & 0,003 \\
\hline 250,0 & 0,027 & 0,018 & 0,013 & 0,010 & 0,008 & 0,003 & 0,002 \\
\hline 500,0 & 0,015 & 0,010 & 0,007 & 0,005 & 0,004 & 0,002 & 0,002 \\
\hline 750,0 & 0,010 & 0,007 & 0,005 & 0,003 & 0,003 & 0,002 & 0,001 \\
\hline 1000,0 & 0,007 & 0,005 & 0,004 & 0,003 & 0,002 & 0,002 & 0,001 \\
\hline 1250,0 & 0,005 & 0,004 & 0,003 & 0,002 & 0,002 & 0,001 & 0,001 \\
\hline 1000,0 & 0,007 & 0,005 & 0,004 & 0,003 & 0,002 & 0,002 & 0,001 \\
\hline 750,0 & 0,011 & 0,007 & 0,005 & 0,003 & 0,002 & 0,002 & 0,001 \\
\hline 500,0 & 0,016 & 0,010 & 0,007 & 0,005 & 0,003 & 0,002 & 0,002 \\
\hline 250,0 & 0,028 & 0,018 & 0,014 & 0,009 & 0,007 & 0,003 & 0,002 \\
\hline 150,0 & 0,046 & 0,030 & 0,022 & 0,015 & 0,011 & 0,005 & 0,003 \\
\hline 100,0 & 0,067 & 0,039 & 0,031 & 0,021 & 0,016 & 0,007 & 0,004 \\
\hline 50,0 & 0,128 & 0,076 & 0,059 & 0,042 & 0,032 & 0,012 & 0,007 \\
\hline
\end{tabular}




\section{A.2.1.Modelo de Bingham}

\section{COLÚVIO}
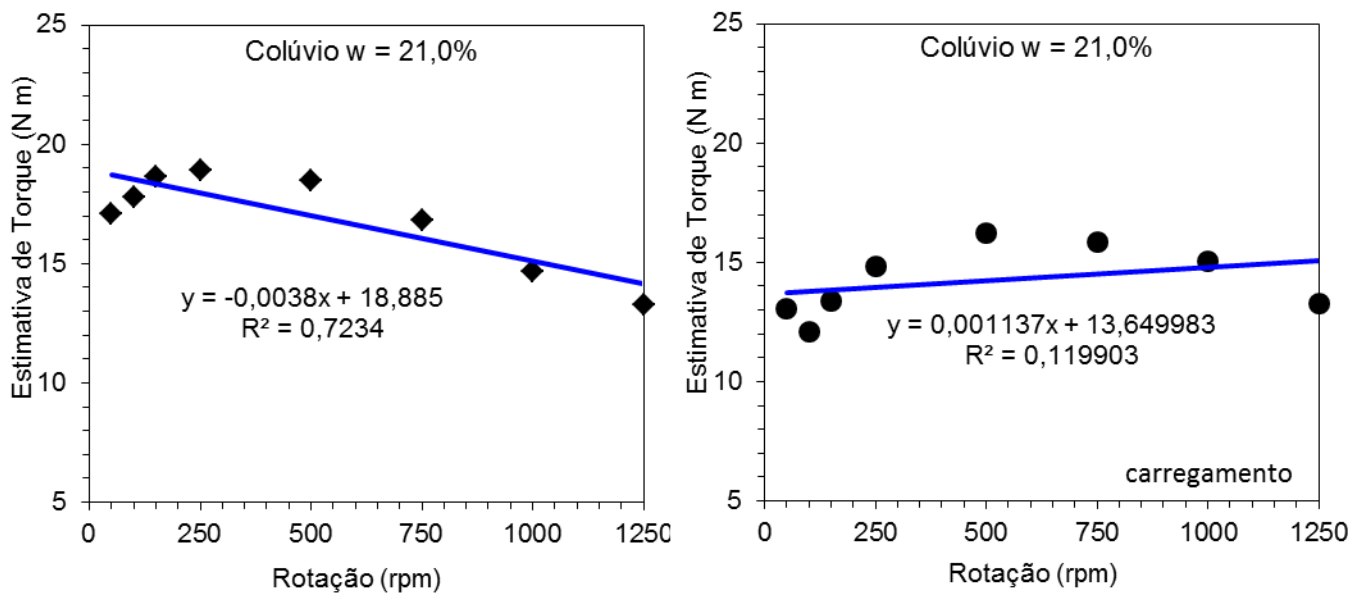

Figura A.9 GP - Bingham - colúvio - $w=21,0 \%$
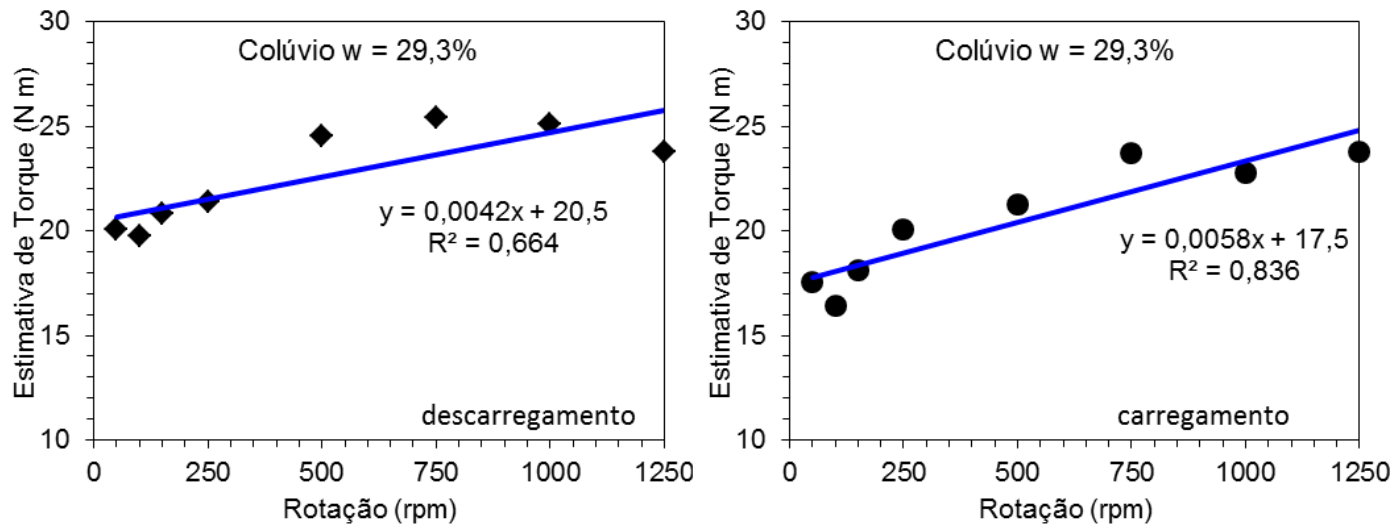

Figura A.10 GP - Bingham - colúvio - w = 29,3\%
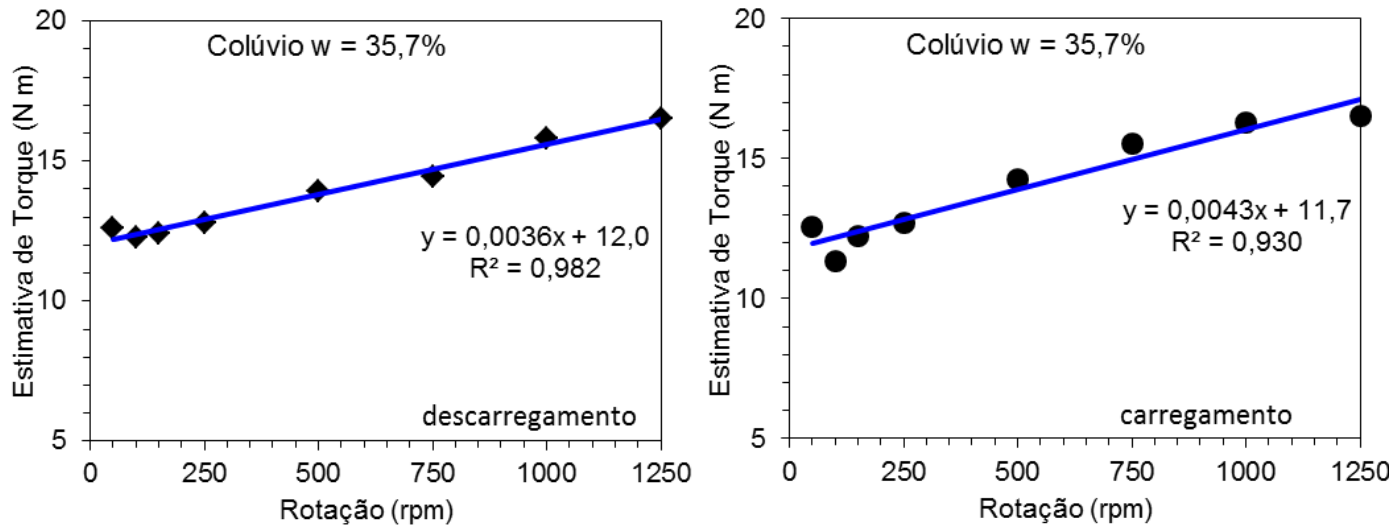

Figura A.11 GP - Bingham - colúvio - w = 35,7\% 

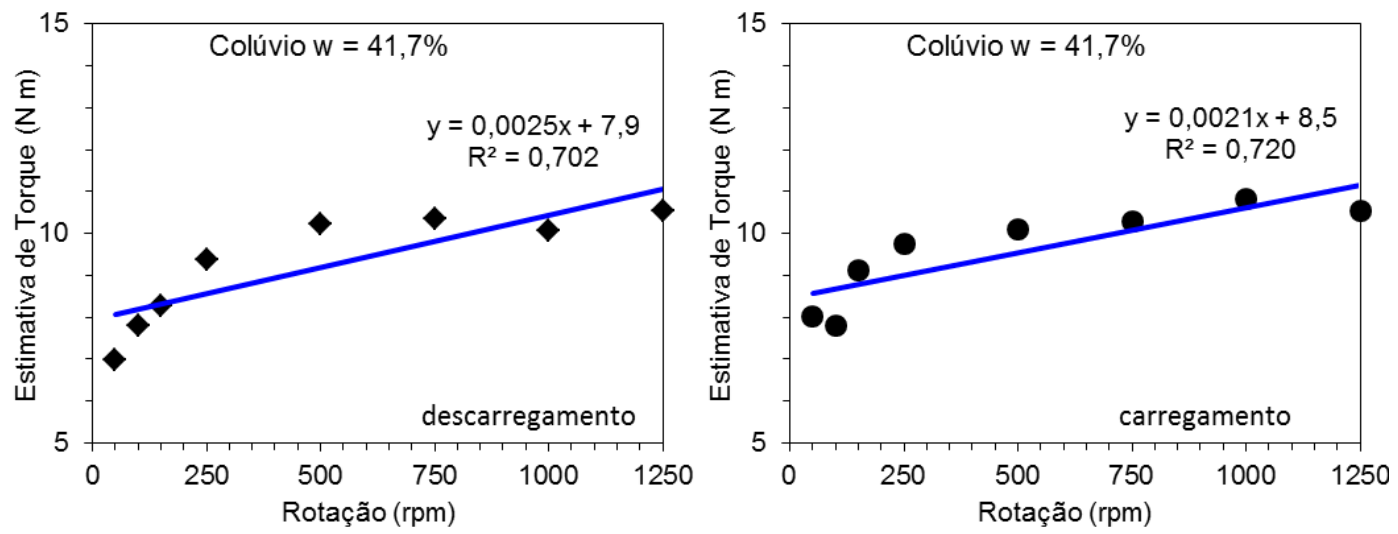

Figura A.12 GP - Bingham - colúvio - $w=41,7 \%$
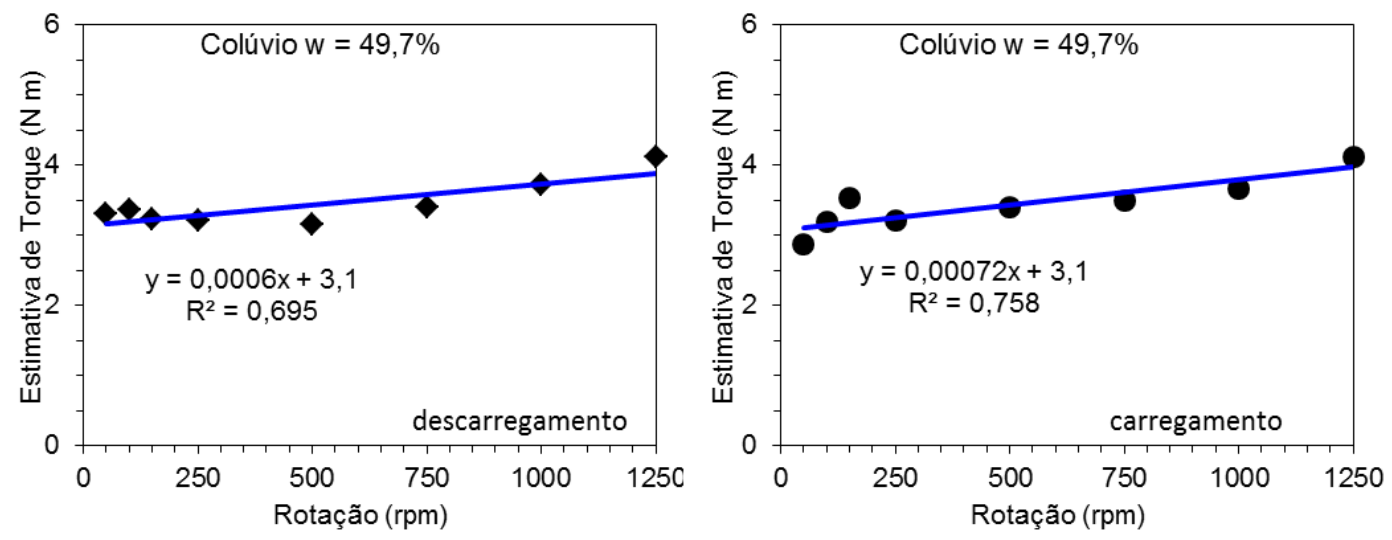

Figura A.13 GP - Bingham - colúvio - w = 49,7\%
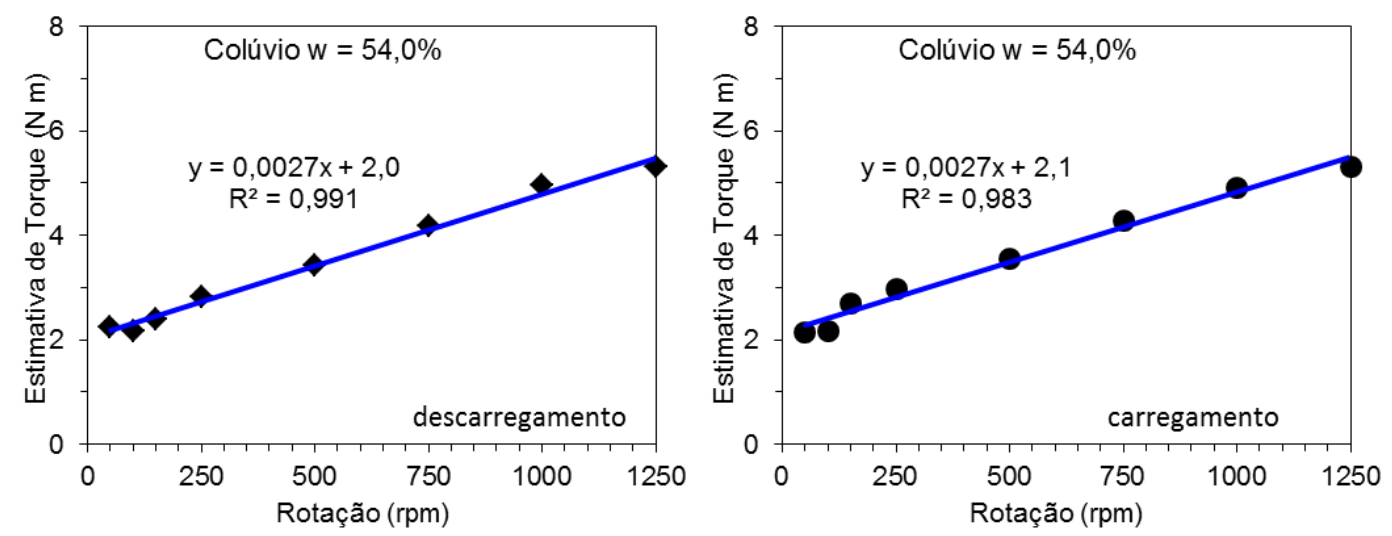

Figura A.14 GP - Bingham - colúvio - w = 54,0\% 

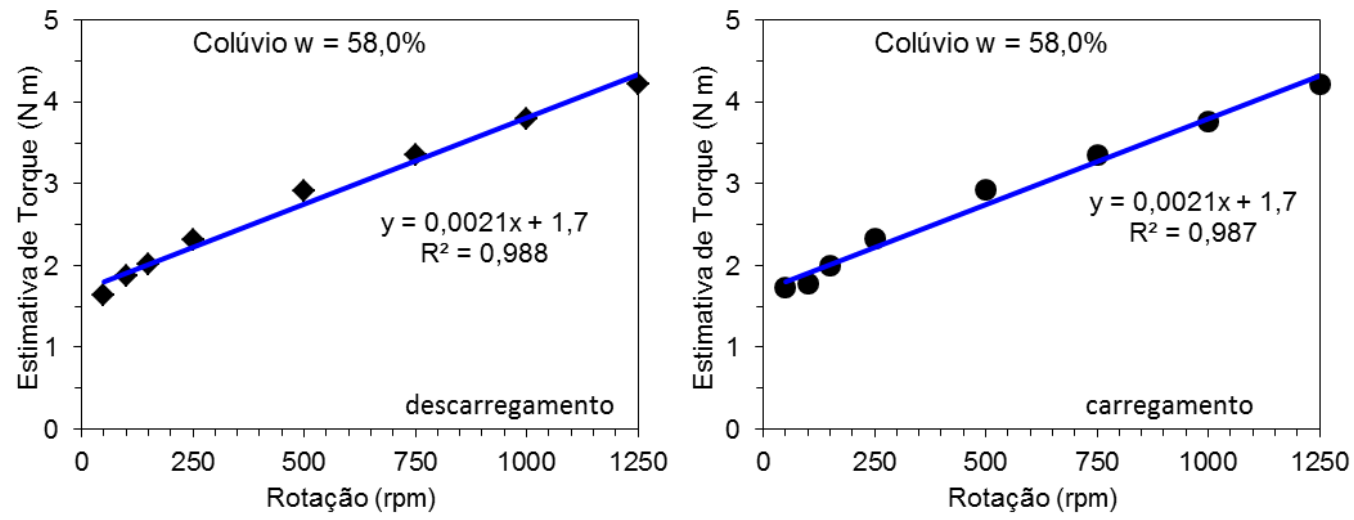

Figura A.15 GP - Bingham - colúvio - $w=58,0 \%$
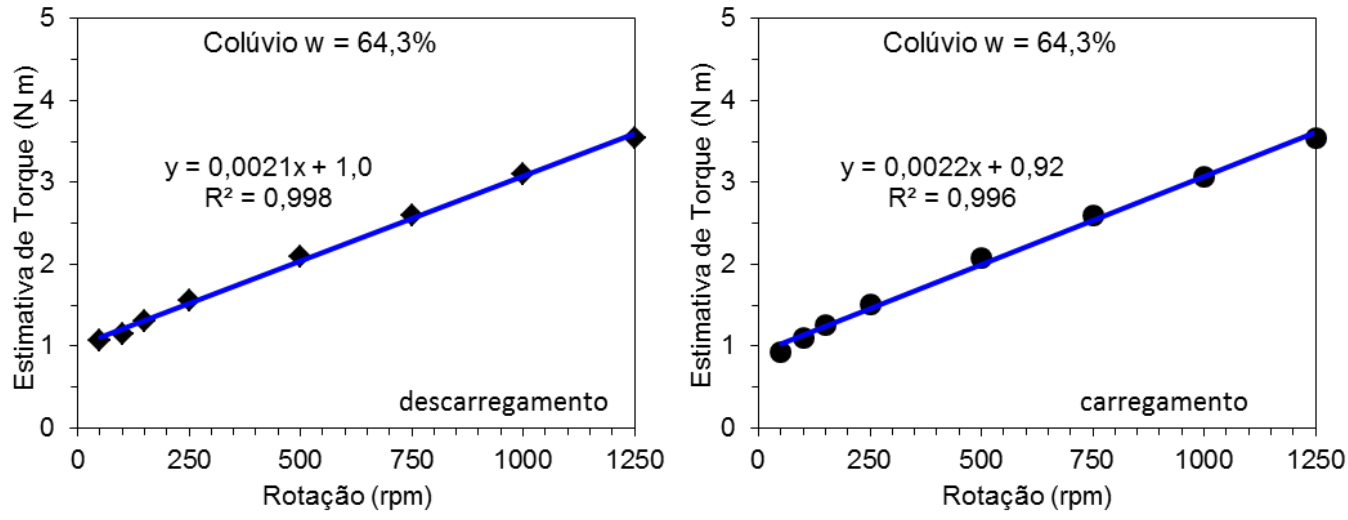

Figura A.16 GP - Bingham - colúvio - w = 64,3\%

\section{SOLO RESIDUAL}
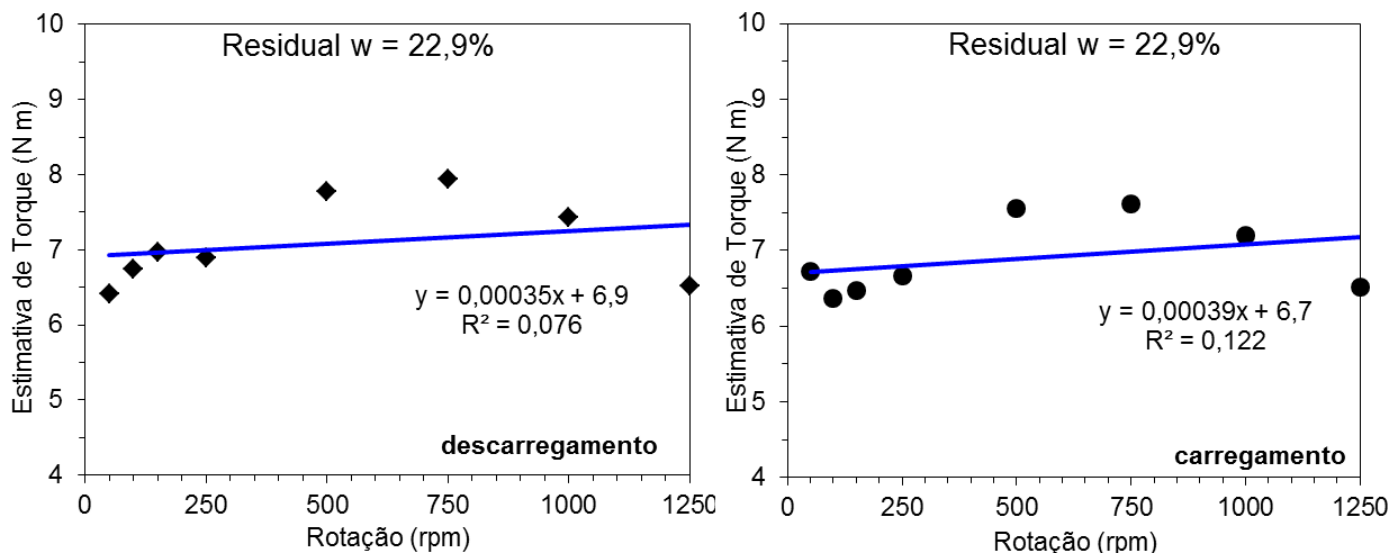

Figura A.17 GP - Bingham - residual - w = 22,9\% 

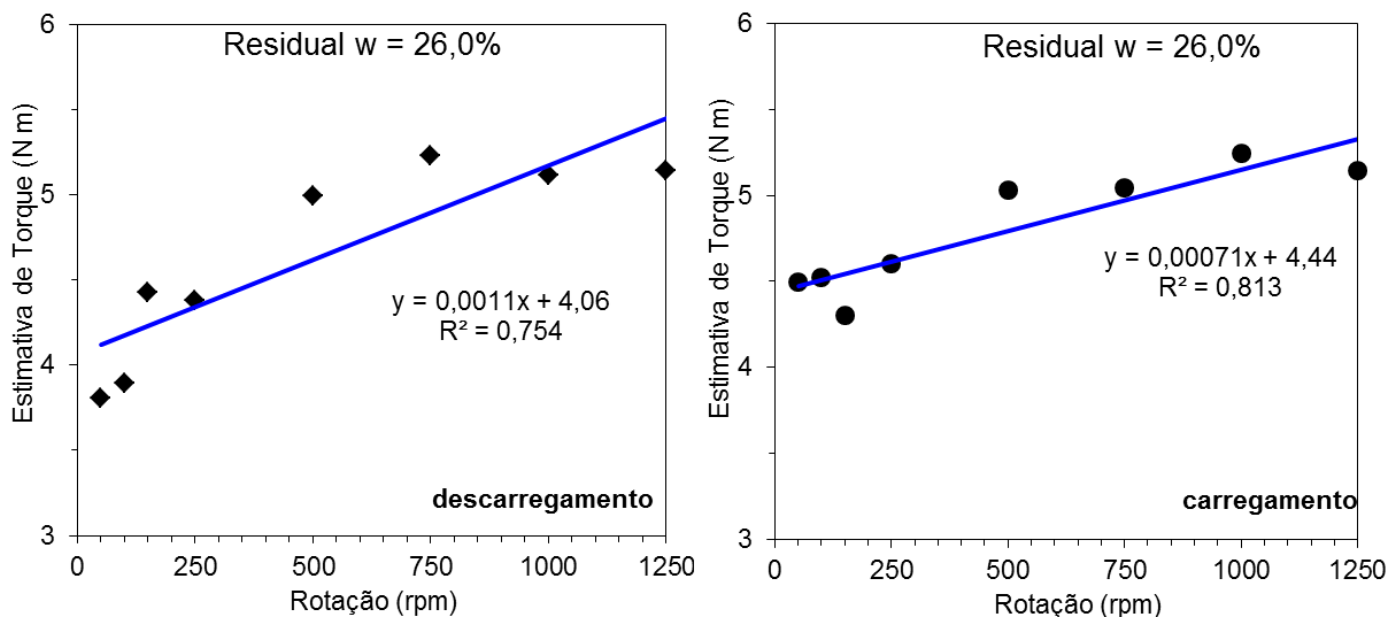

Figura A.18 GP - Bingham - residual - $w=26,0 \%$
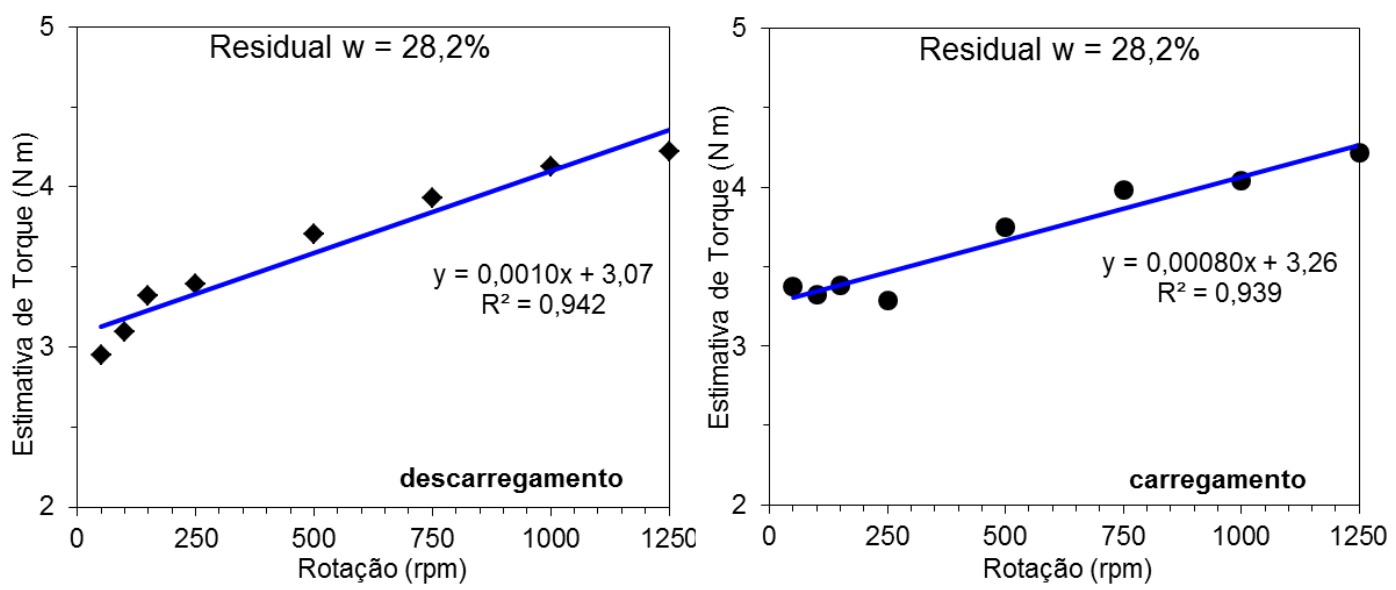

Figura A.19 GP - Bingham - residual - $w=28,2 \%$
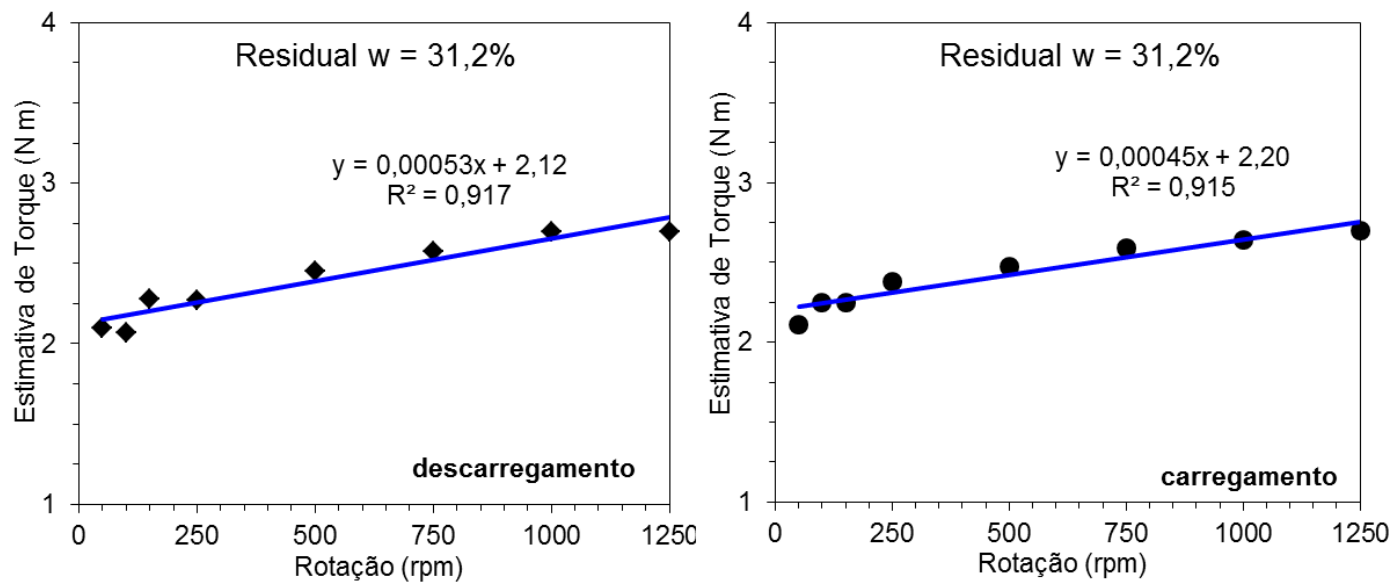

Figura A.20 GP - Bingham - residual - $w=31,2 \%$ 

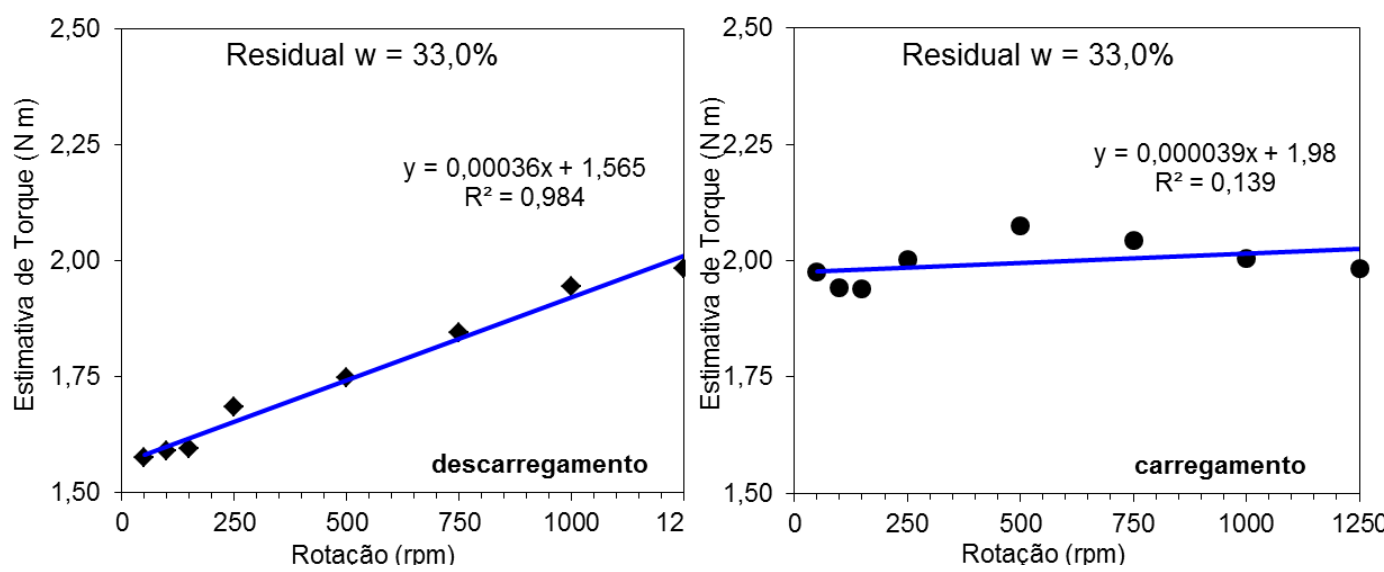

Figura A.21 GP - Bingham - residual - w = 33,0\%
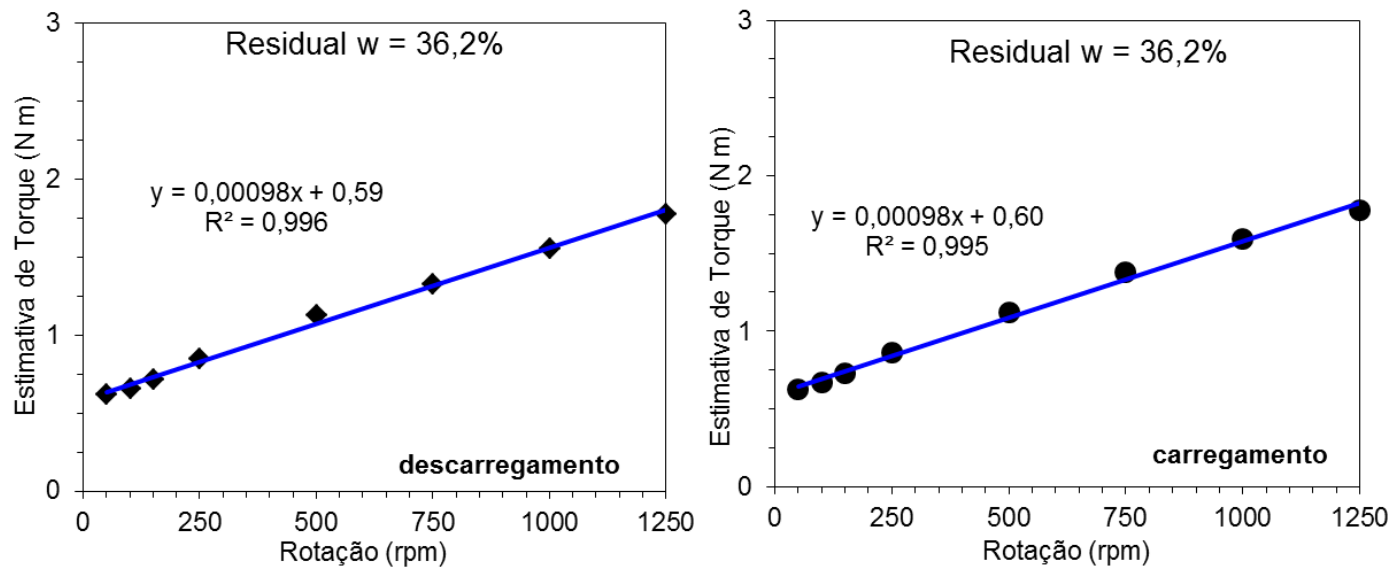

Figura A.22 GP - Bingham - residual - $w=36,2 \%$
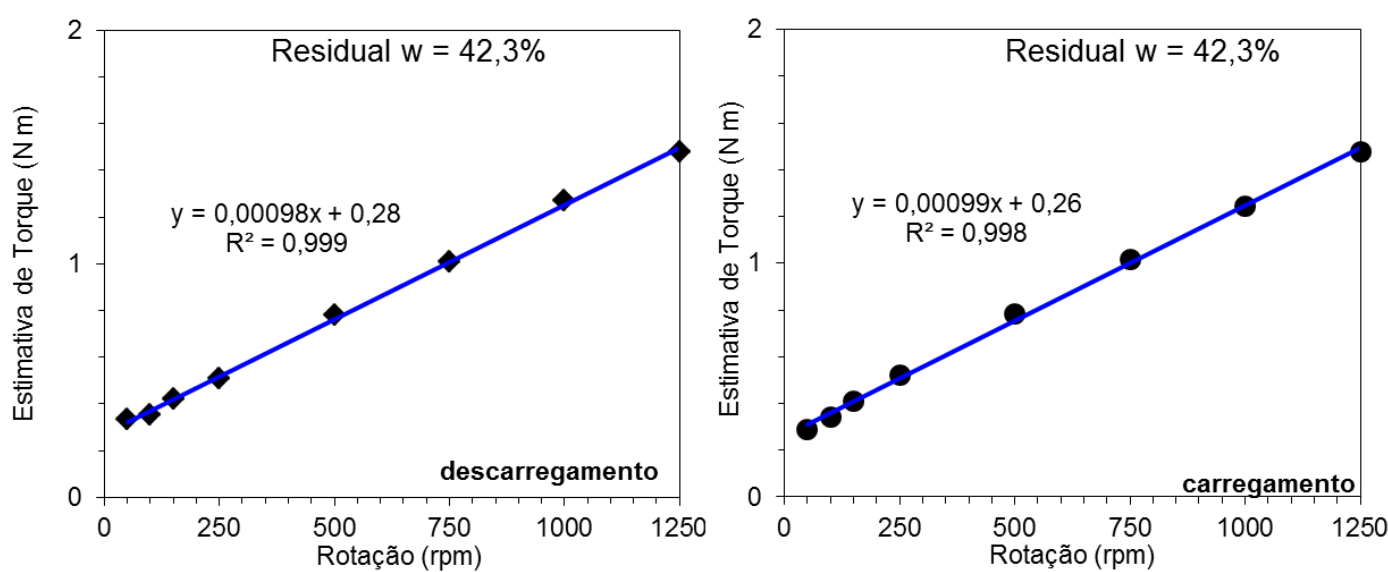

Figura A.23 GP - Bingham - residual - $w=42,3 \%$

\section{A.2.2.Modelo de Herschel Bulkley}




\section{COLÚVIO}

Os dados obtidos para o teor de umidade de $21,0 \%$ não apresentaram correlação com o modelo, como pode ser observado na Figura A.24.
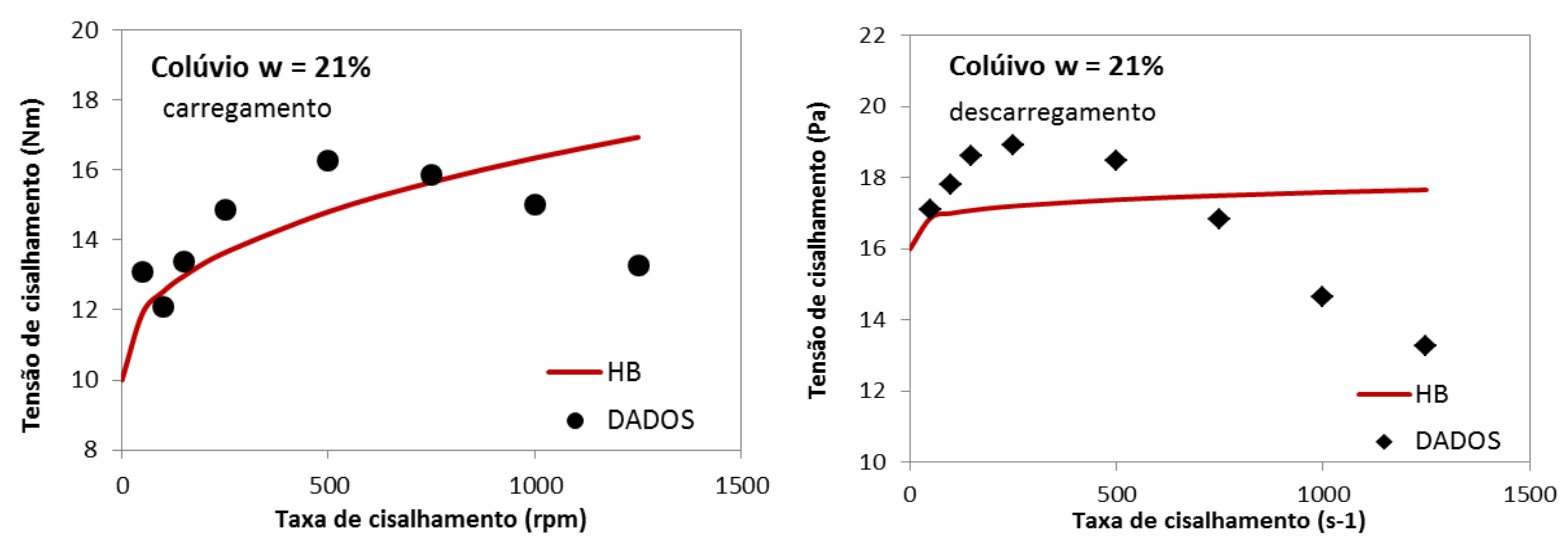

Figura A.24 GP - Herschel Bulkley - colúvio - w = 21,0\%
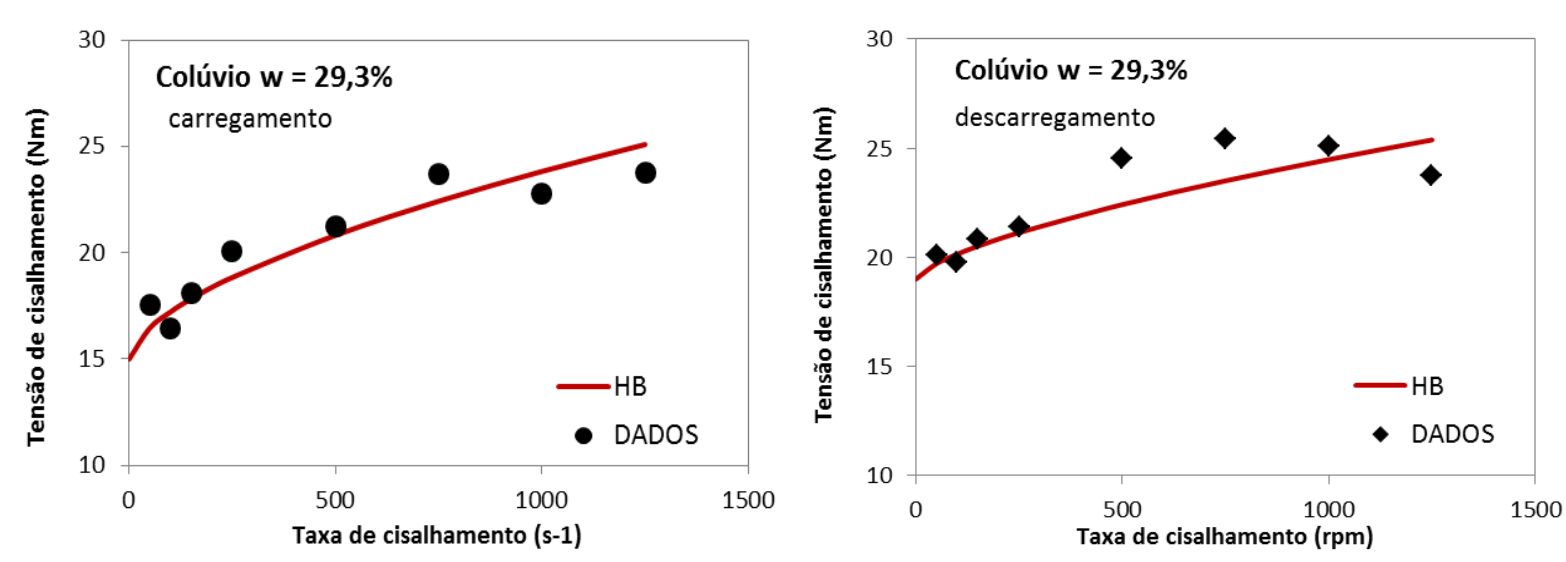

Figura A.25 GP - Herschel Bulkley - colúvio - w = 29,3\%
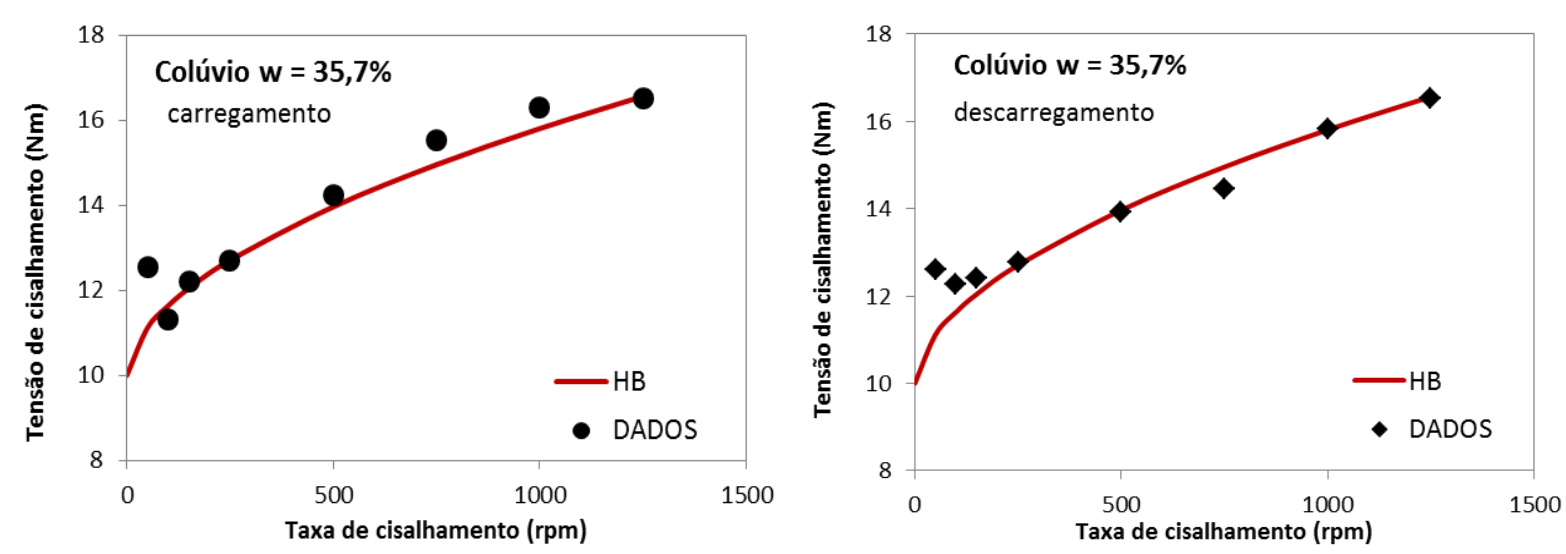

Figura A.26 GP - Herschel Bulkley - colúvio - w = 35,7\% 

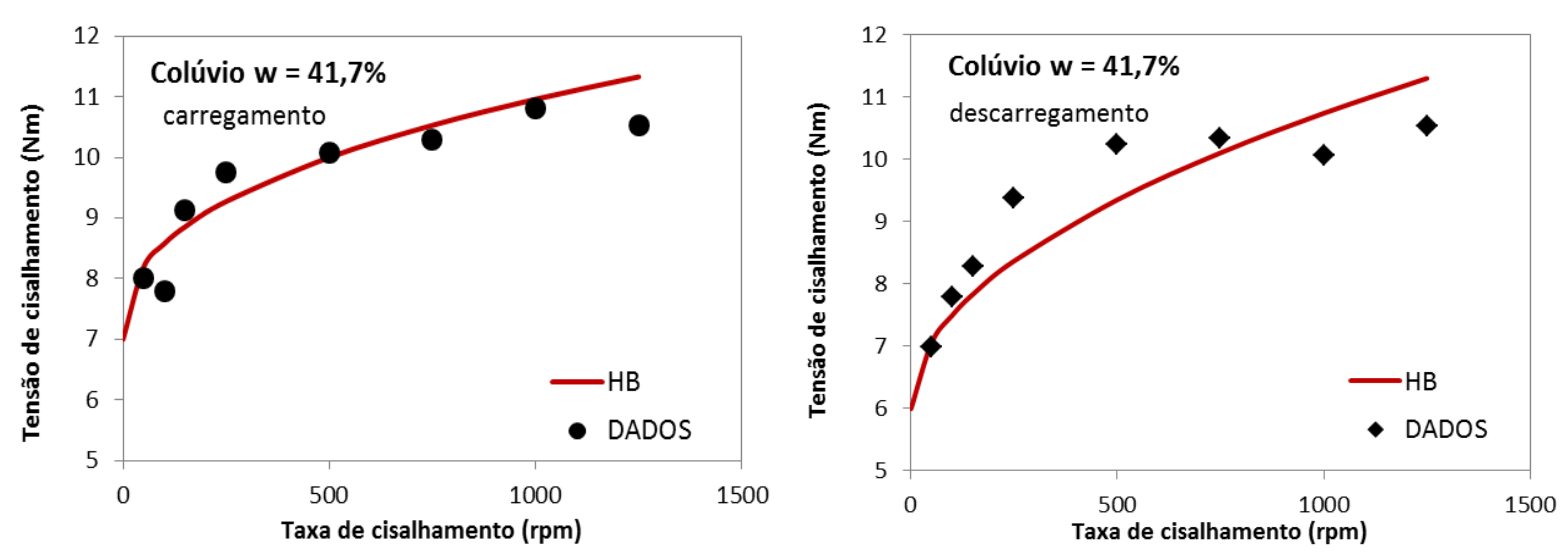

Figura A.27 GP - Herschel Bulkley - colúvio - w = 41,7\%

Os dados obtidos para o descarregamento da amostra com teor de umidade de 49,7\% não apresentou correlação com o modelo, Figura A.28.
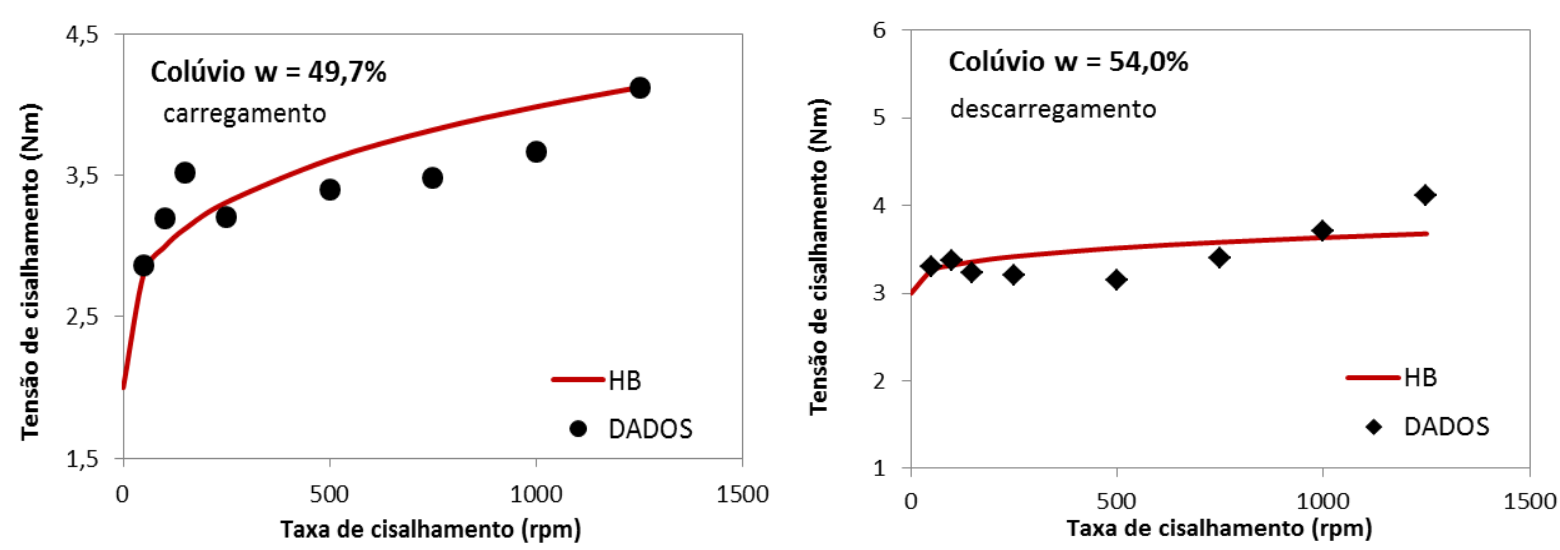

Figura A.28 GP - Herschel Bulkley - colúvio - w = 49,7\%
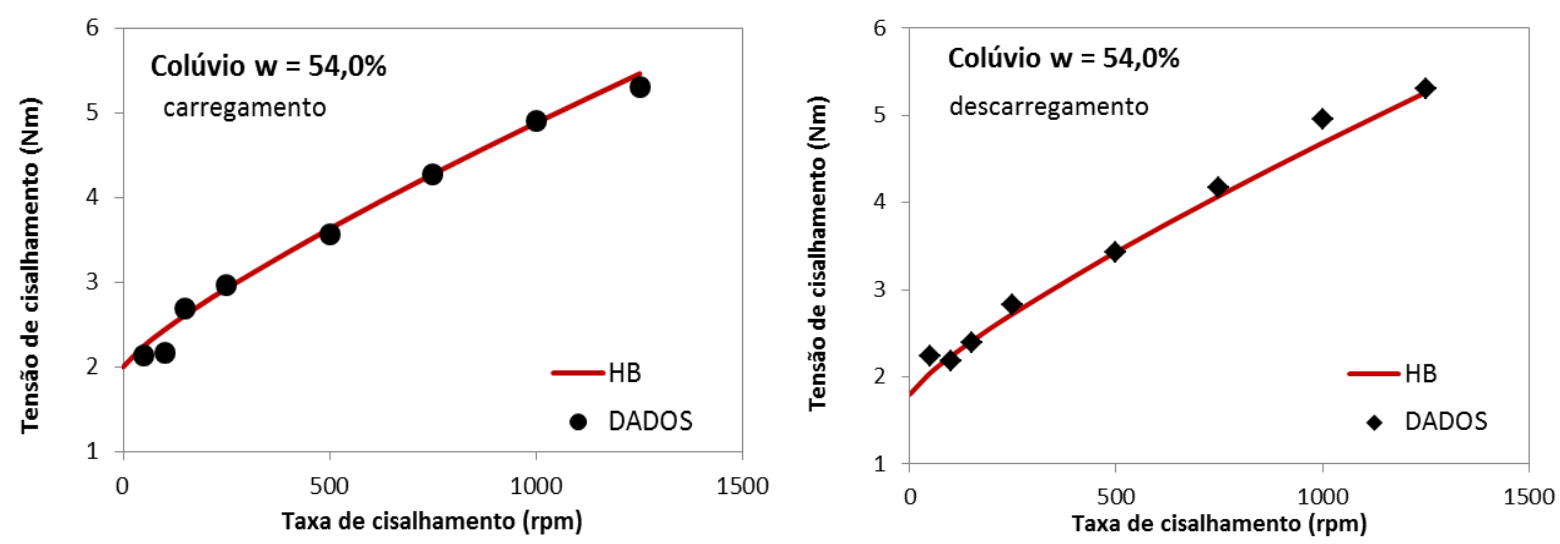

Figura A.29 GP - Herschel Bulkley - colúvio - w = 54,0\% 

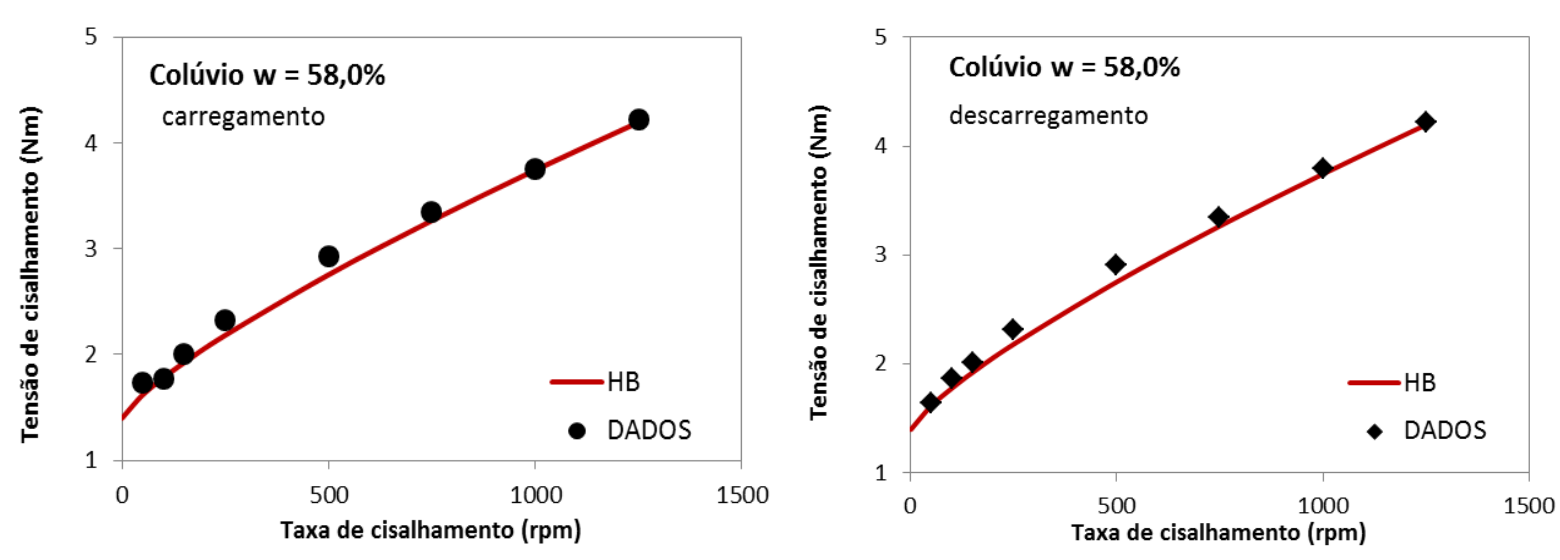

Figura A.30 GP - Herschel Bulkley - colúvio - w = 58,0\%
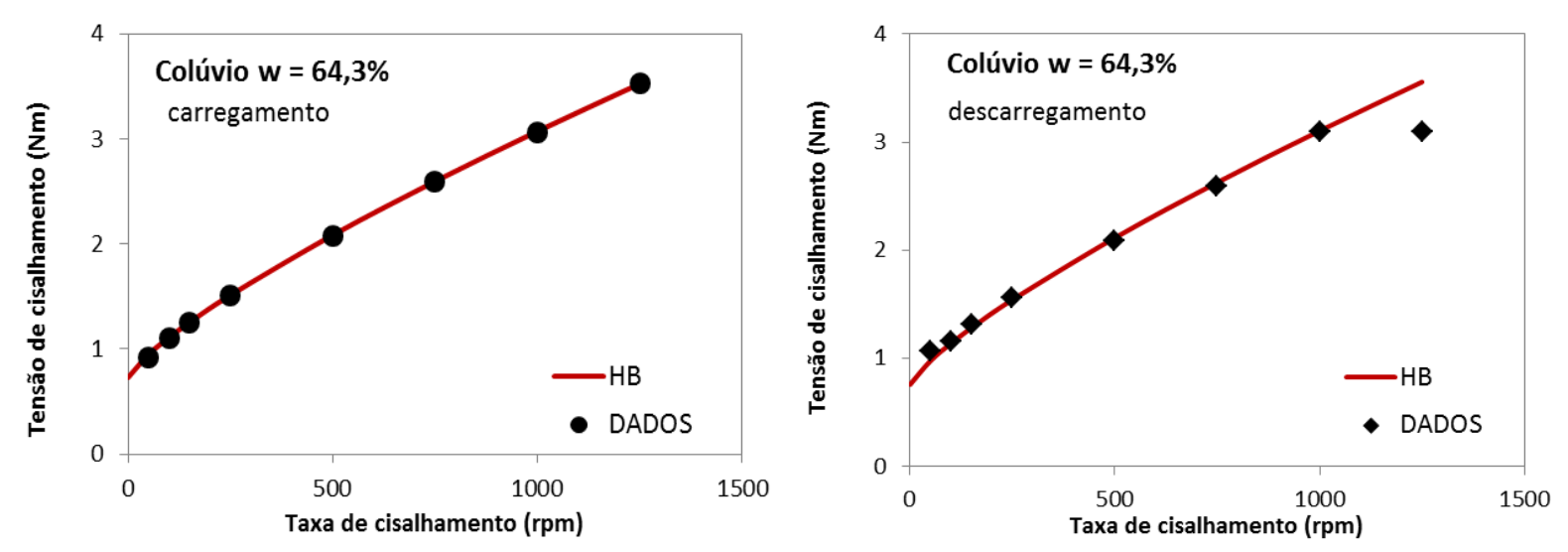

Figura A.31 GP - Herschel Bulkley - colúvio - w = 64,3\%

\section{SOLO RESIDUAL}
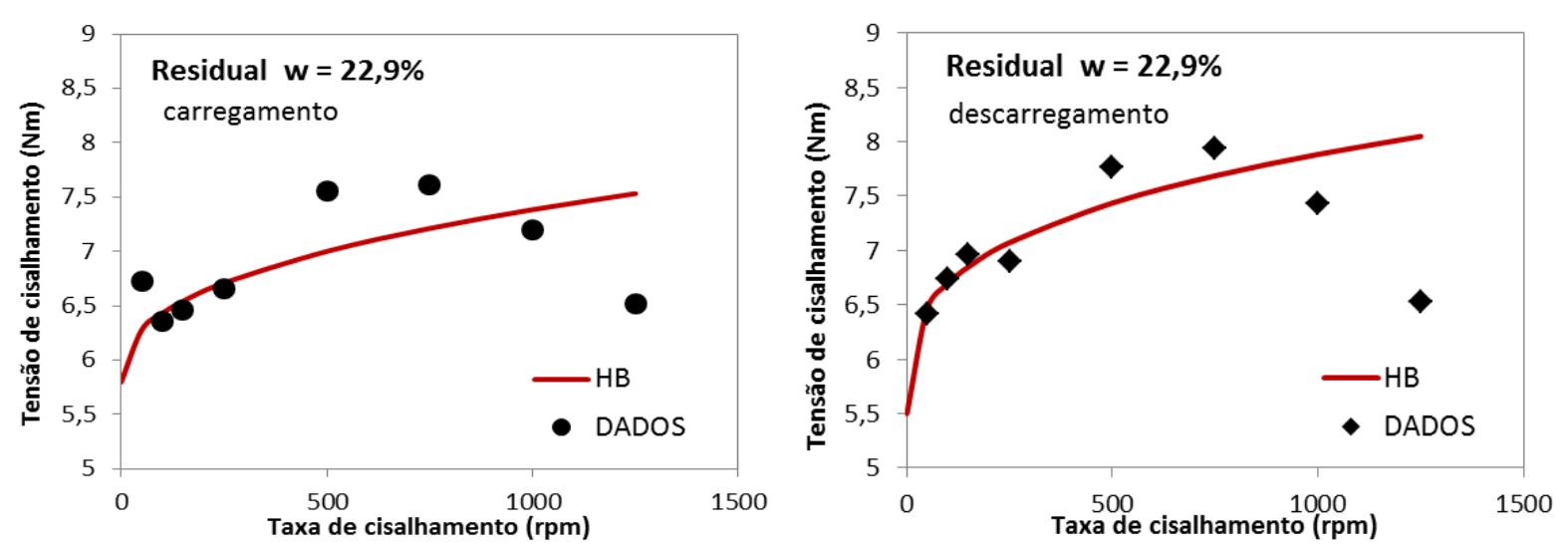

Figura A.32 GP - Herschel Bulkley - residual - w = 22,9\% 

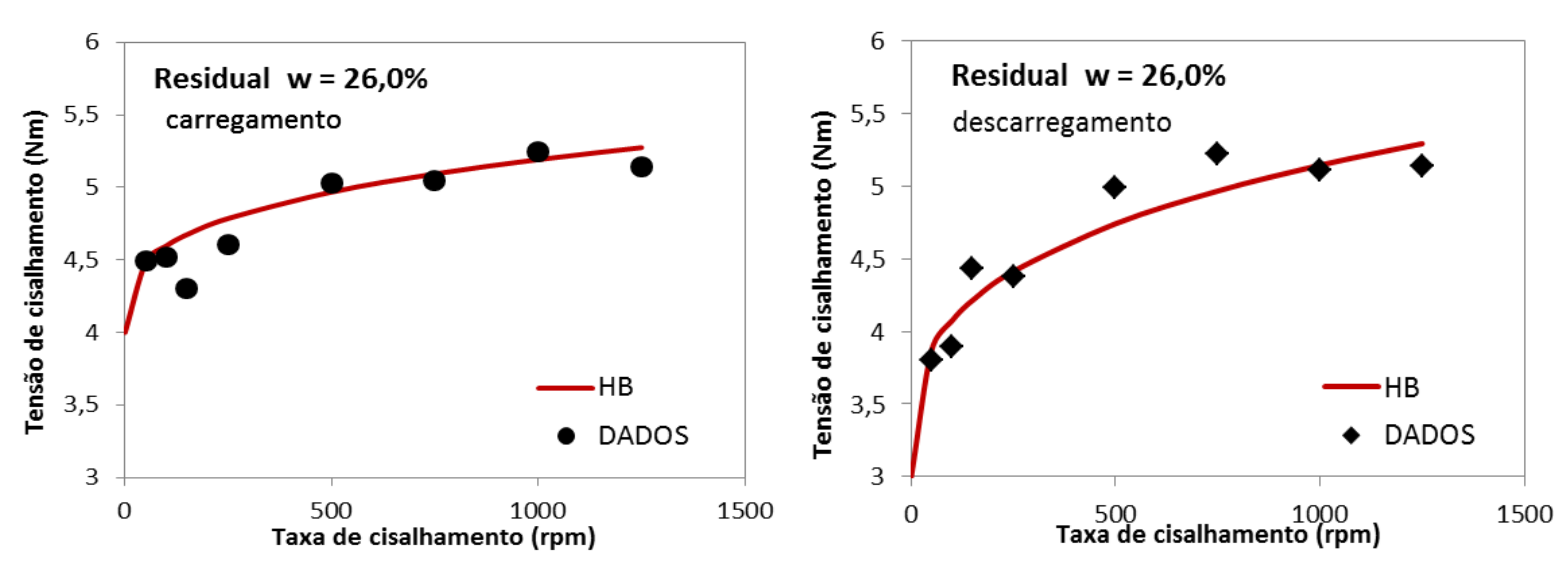

Figura A.33 GP - Herschel Bulkley - residual - w = 26,0\%
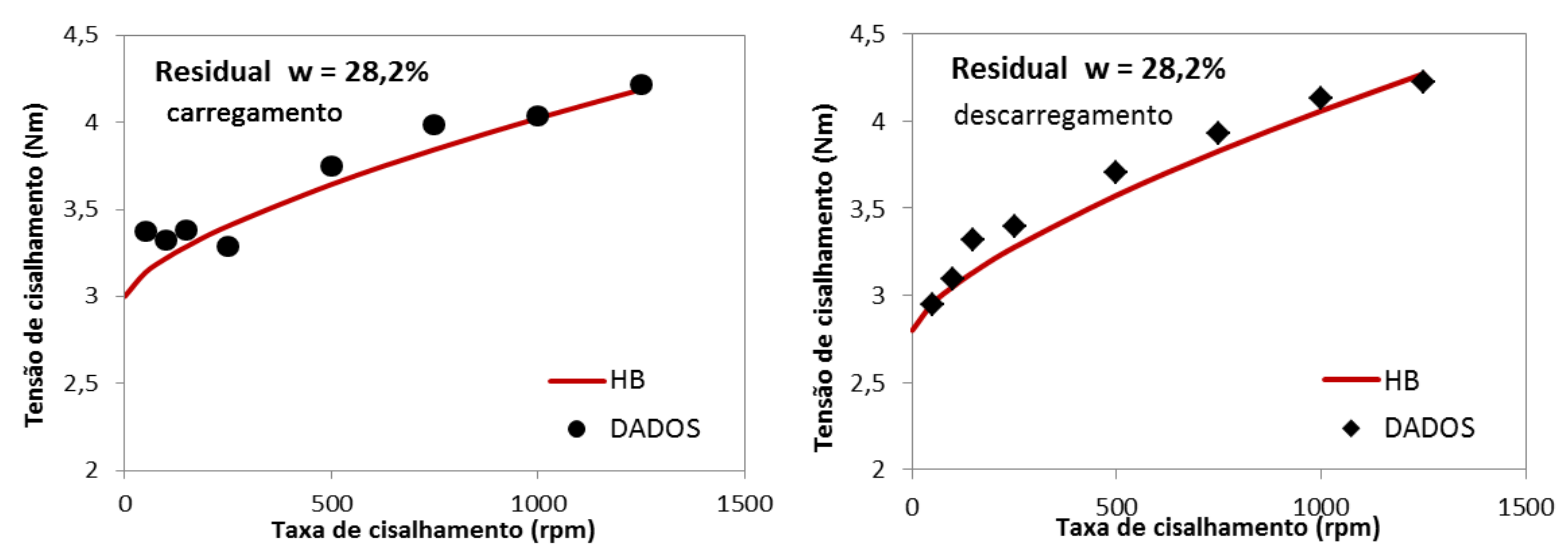

Figura A.34 GP - Herschel Bulkley - residual - $w=28,2 \%$
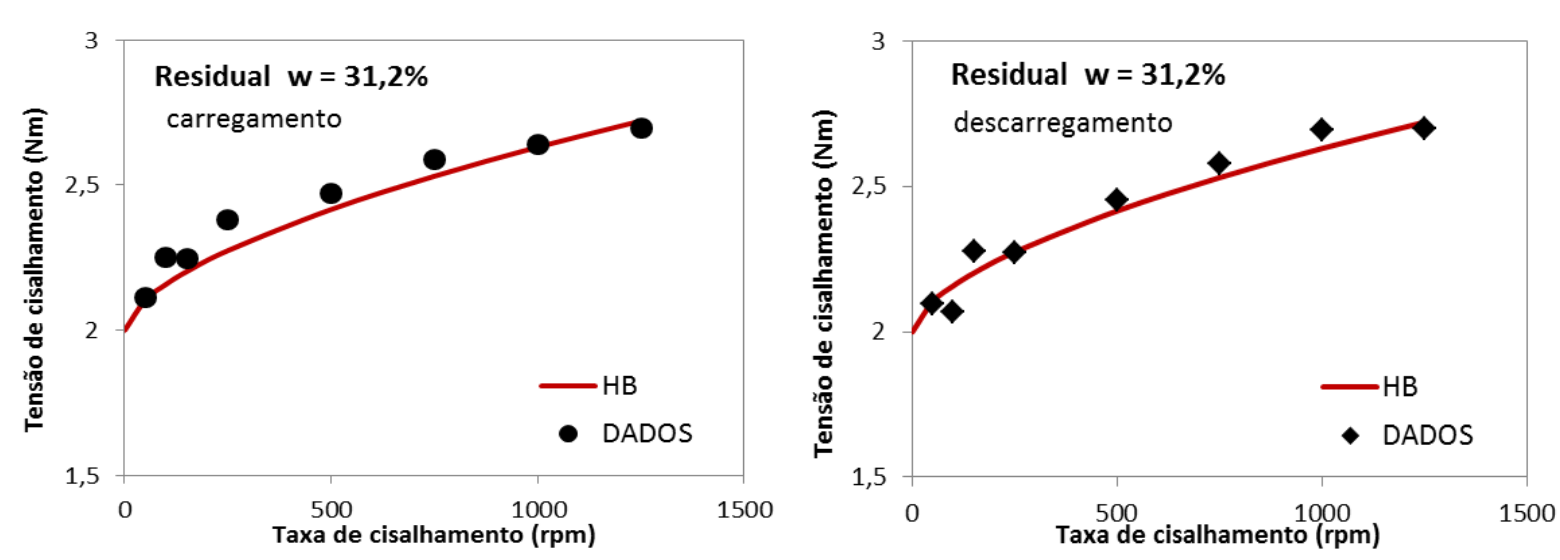

Figura A.35 GP - Herschel Bulkley - residual - $w=31,2 \%$ 

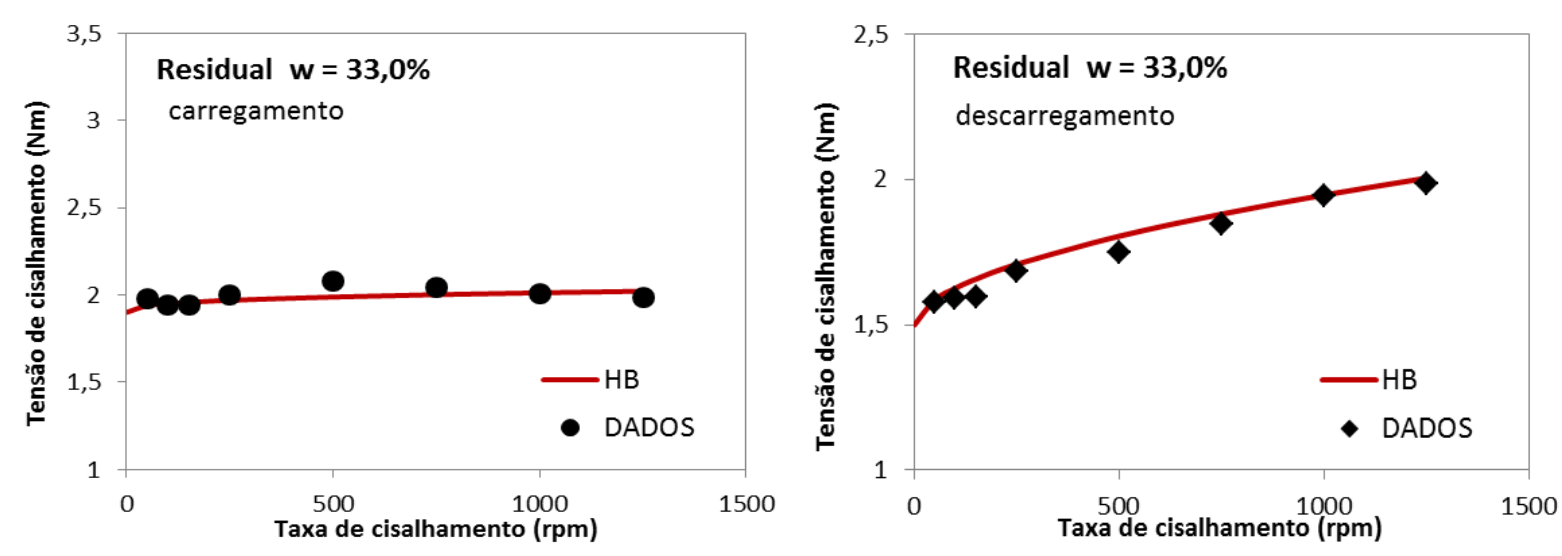

Figura A.36 GP - Herschel Bulkley - residual - w = 33,0\%
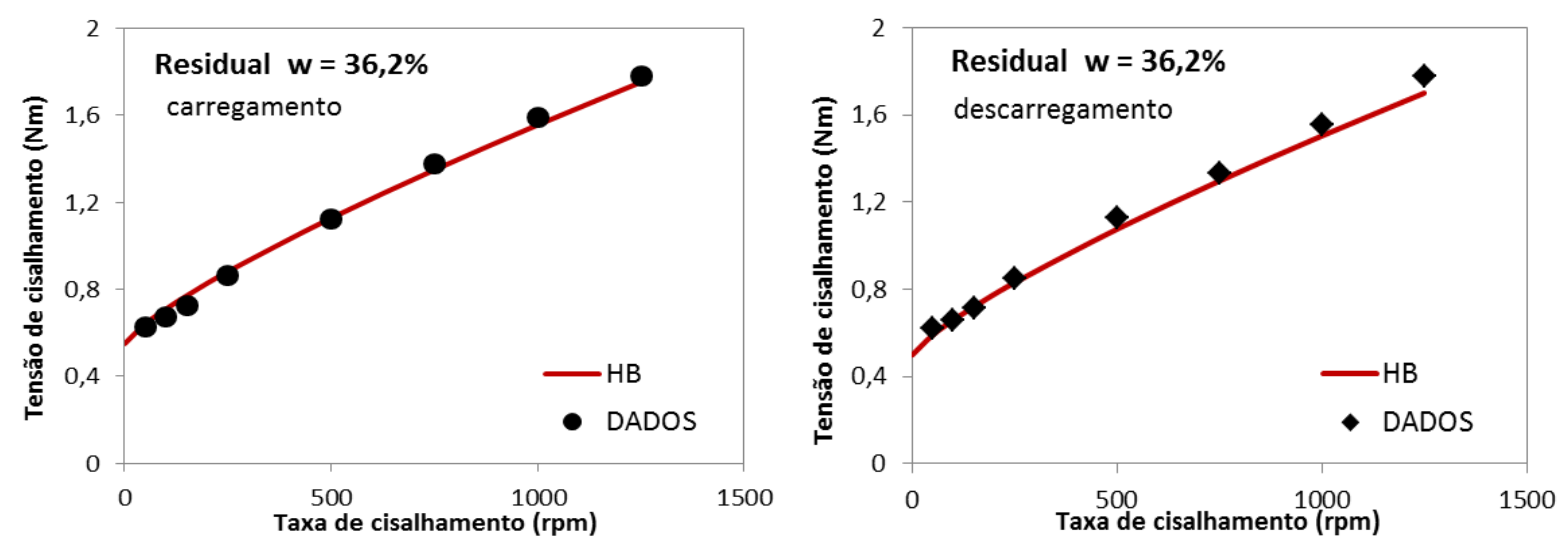

Figura A.37 GP - Herschel Bulkley - residual - w = 36,2\%
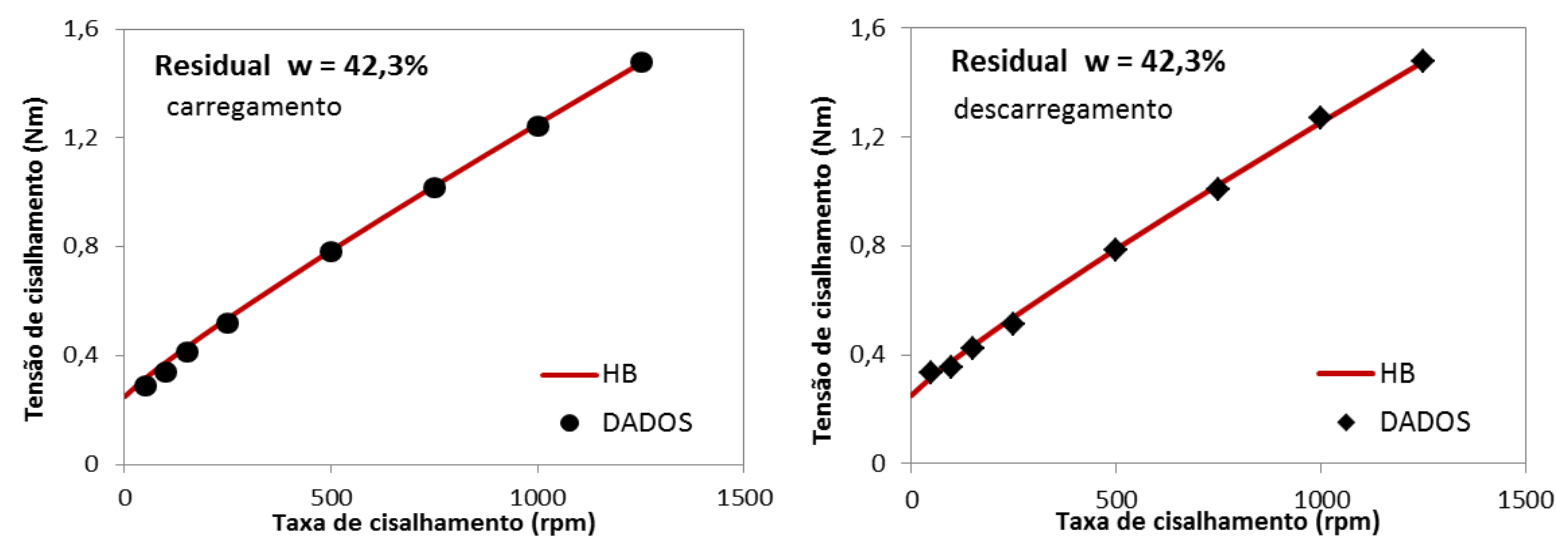

Figura A.38 GP - Herschel Bulkley - residual - w = 42,3\% 


\section{A.2.3.Modelo de Herschel Bulkley modificado por Papanastasiou}

\section{COLÚVIO}

A amostra com teor de umidade $21,0 \%$ não apresentou relação com o modelo, Figura A.39.
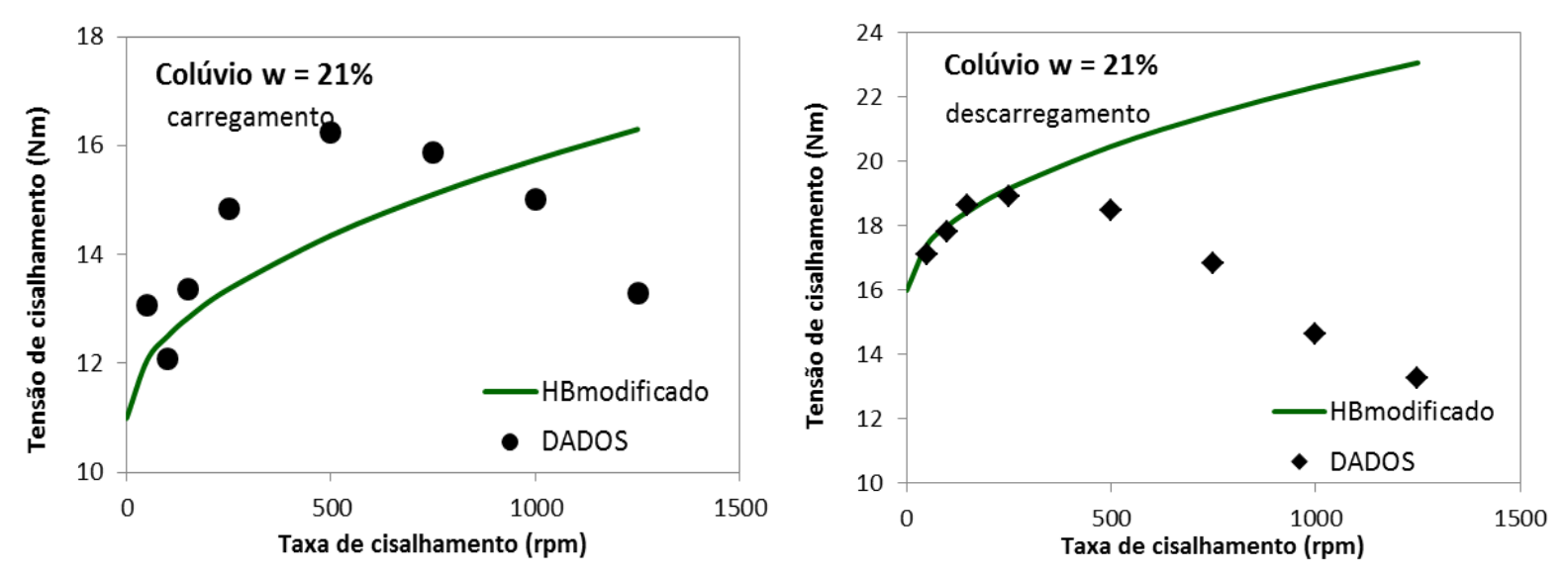

Figura A.39 GP - Herschel Bulkley modificado- colúvio - w = 21,0\%
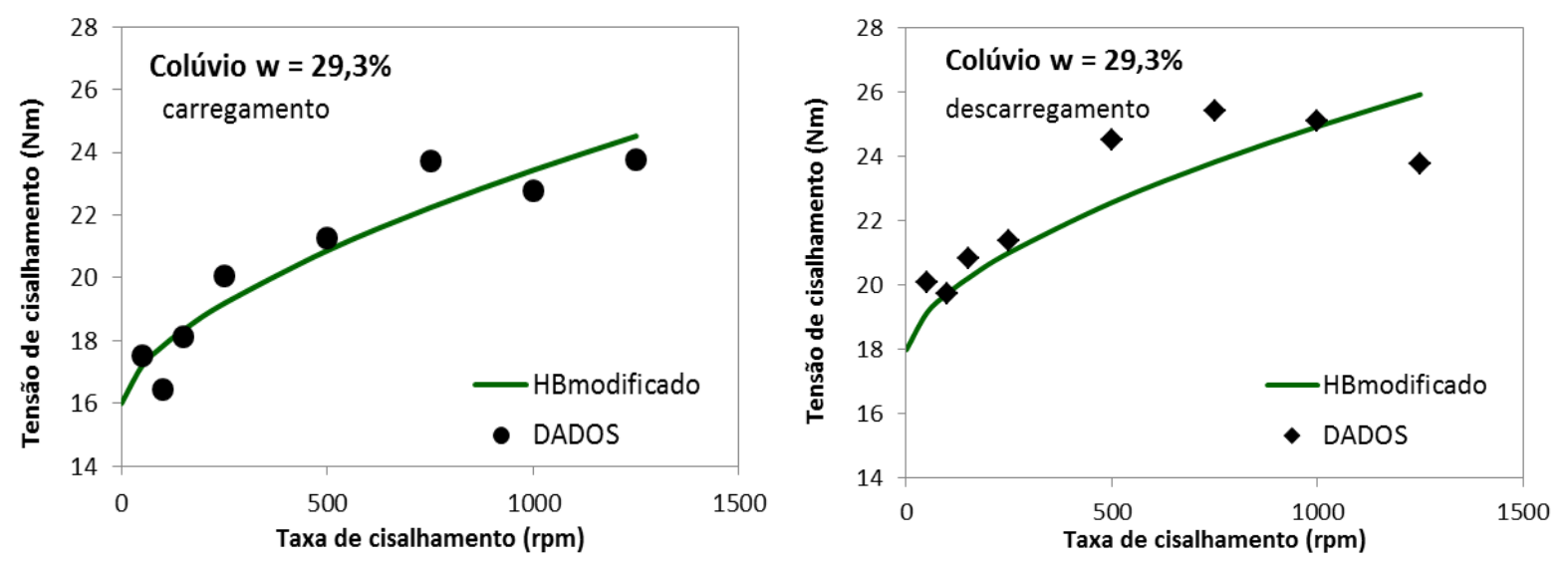

Figura A.40 GP - Herschel Bulkley modificado- colúvio - w = 29,3\% 

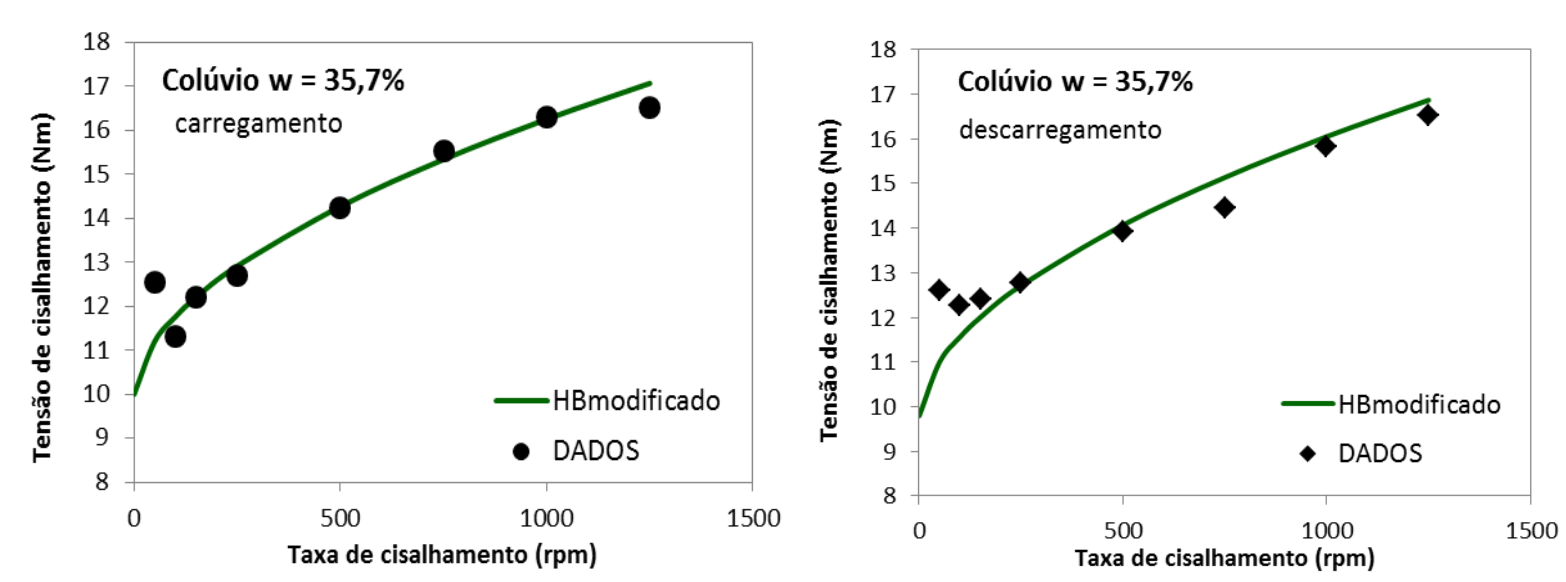

Figura A.41 GP - Herschel Bulkley modificado- colúvio - w = 35,7\%
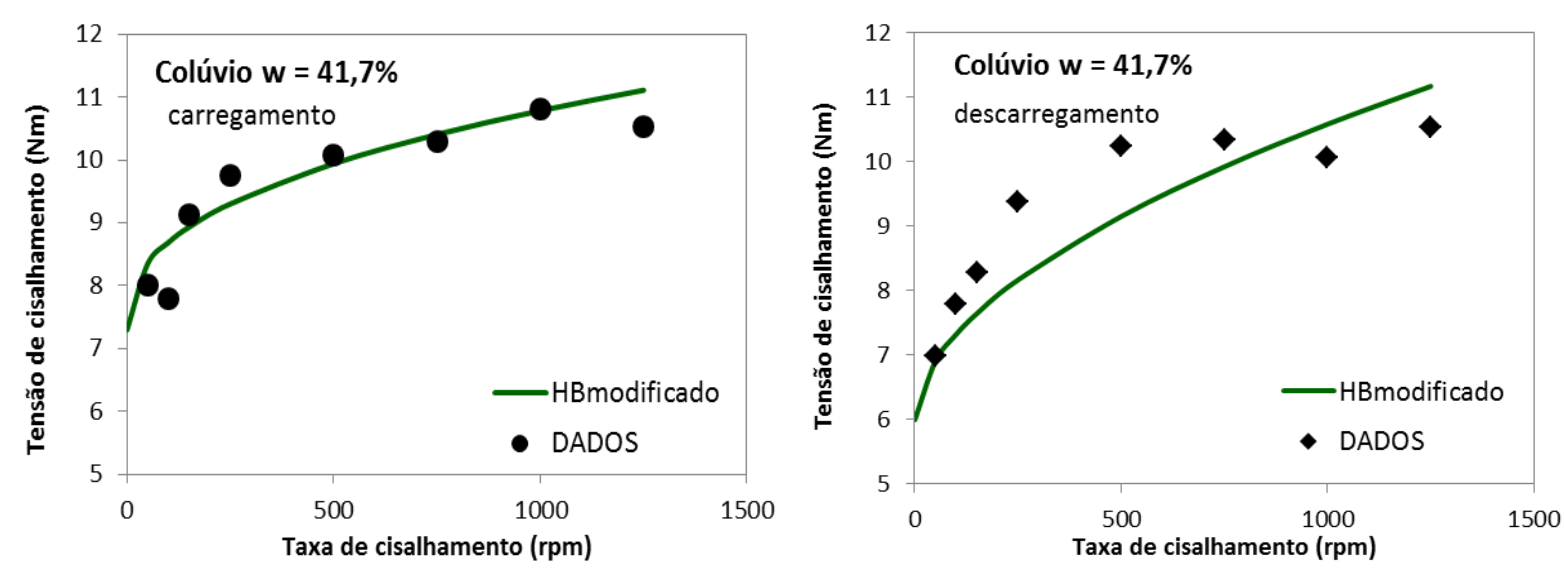

Figura A.42 GP - Herschel Bulkley modificado- colúvio - w = 41,7\%

A amostra com teor de umidade de $49,7 \%$ não apresentou relação com o modelo para o descarregamento, como pode ser observado na Figura A.43.
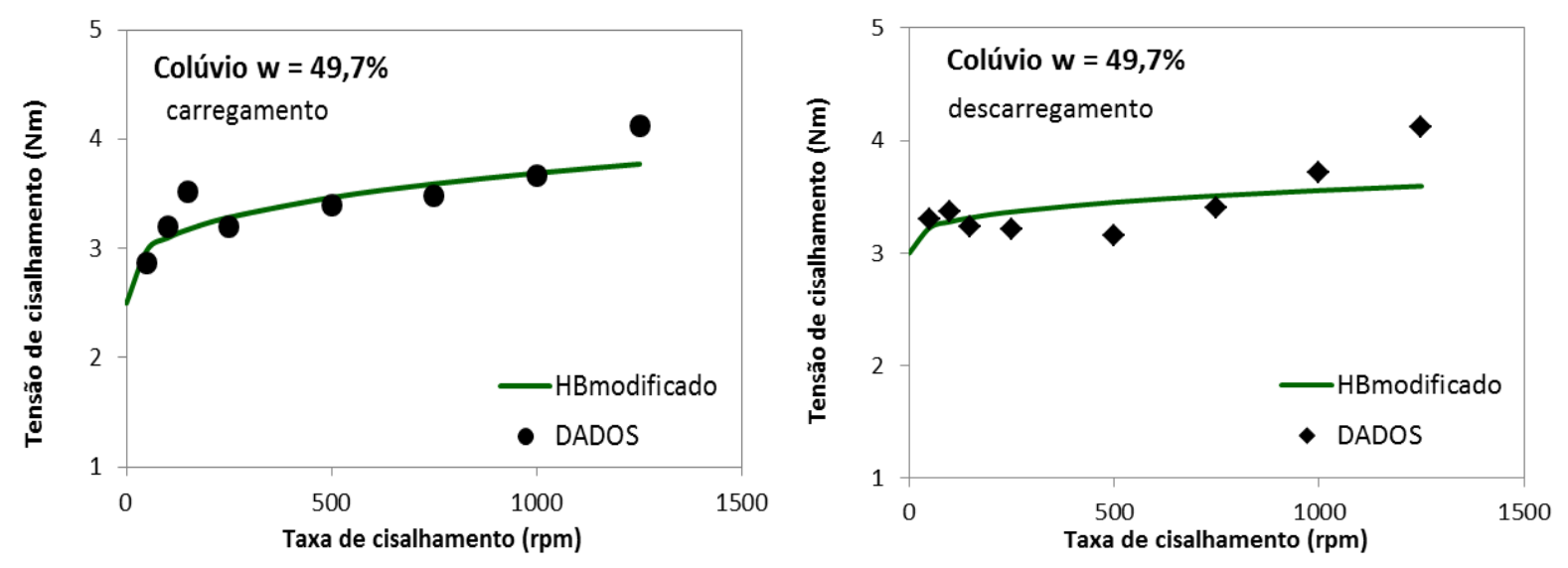

Figura A.43 GP - Herschel Bulkley modificado- colúvio - w = 49,7\% 

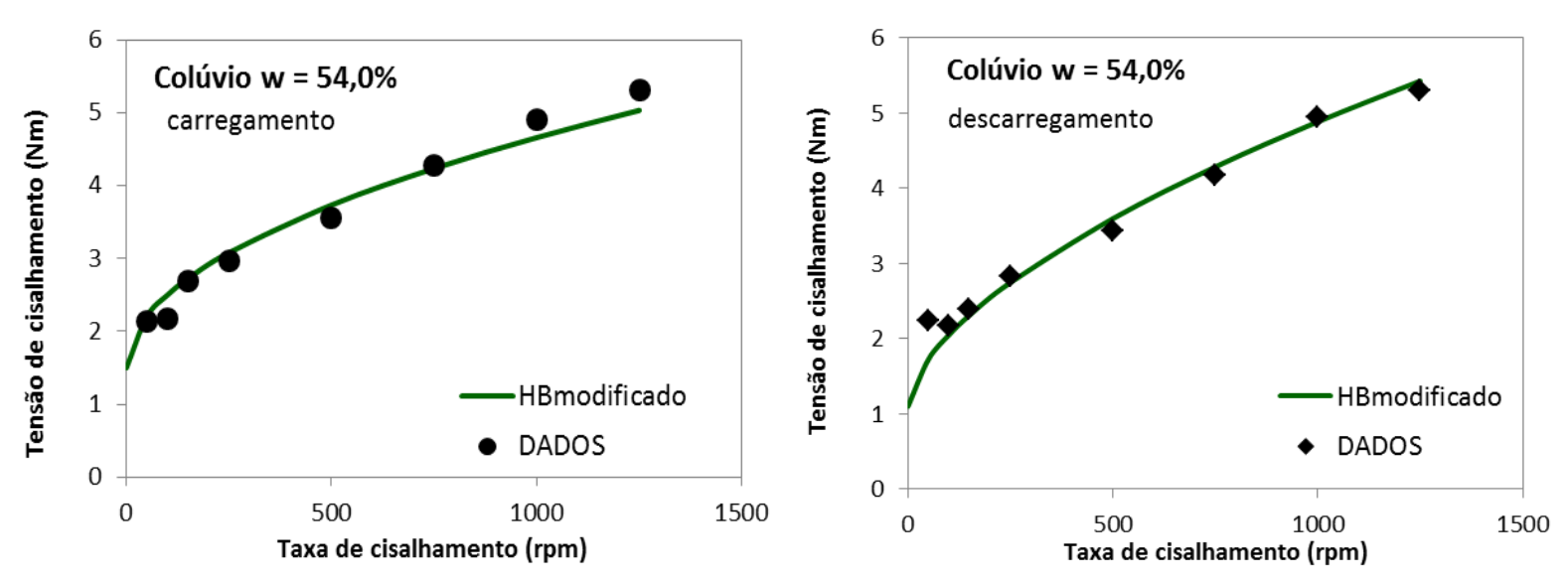

Figura A.44 GP - Herschel Bulkley modificado- colúvio - w = 54,0\%
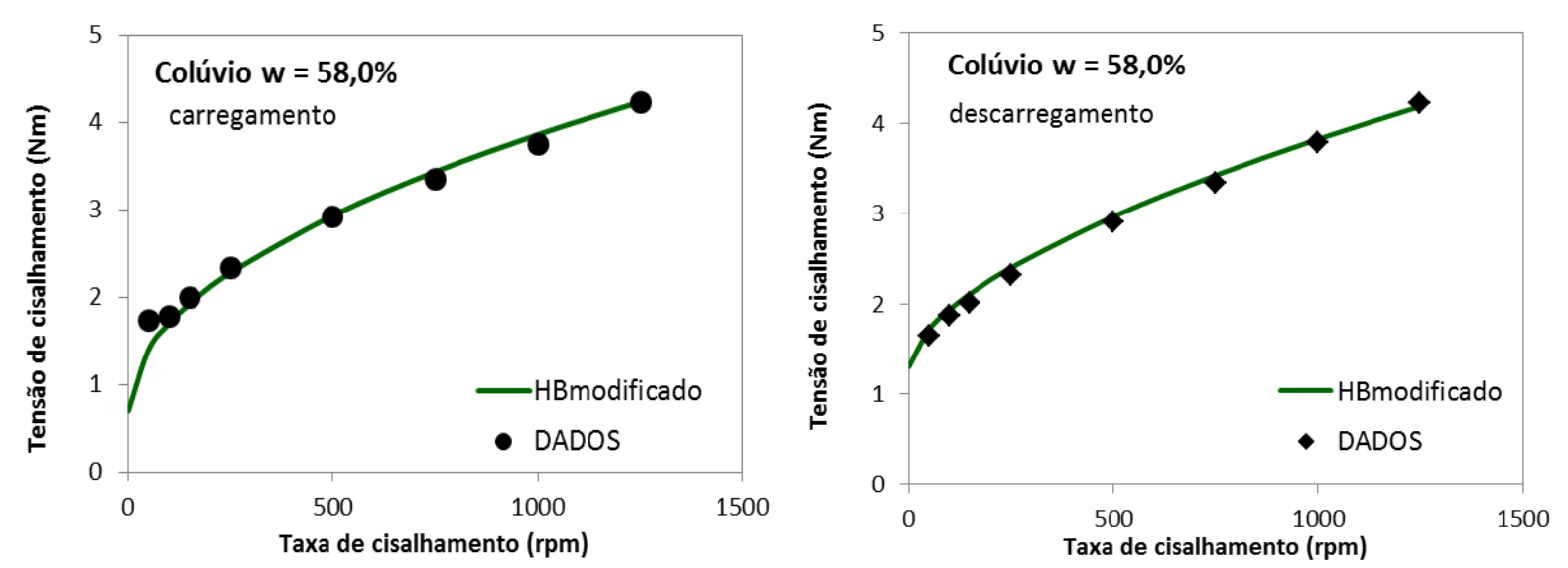

Figura A.45 GP - Herschel Bulkley modificado- colúvio - w = 58,0\%
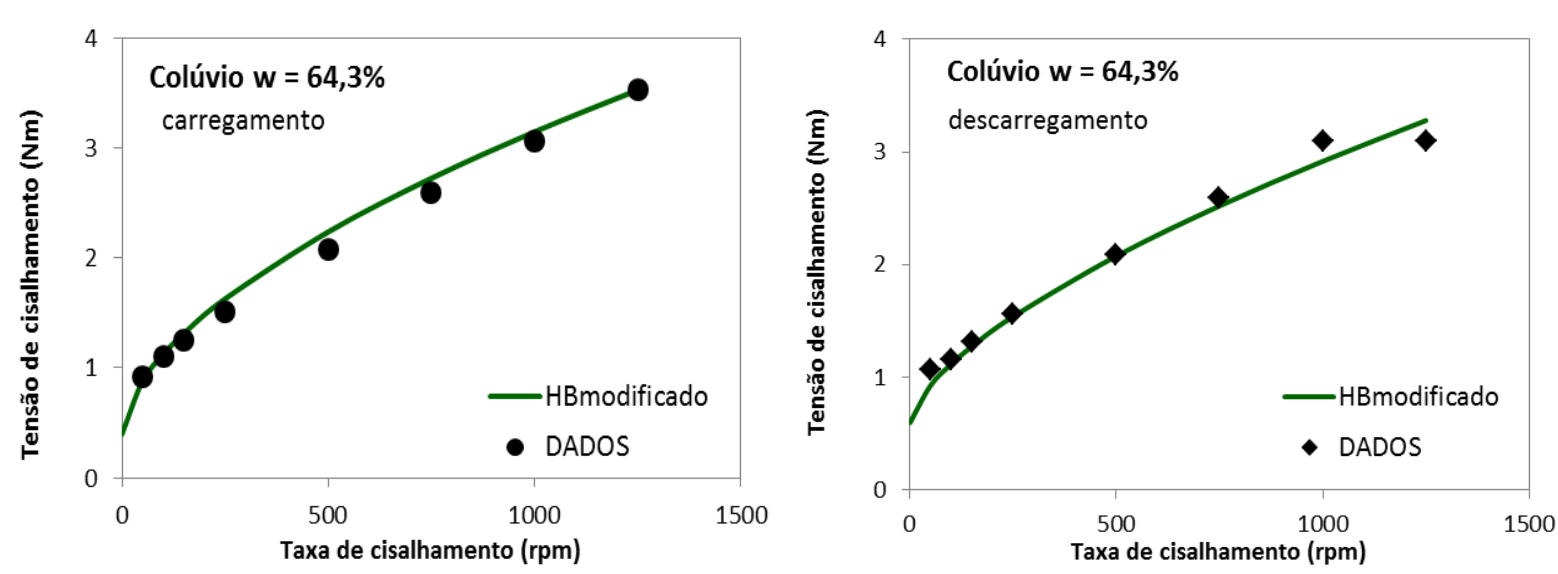

Figura A.46 GP - Herschel Bulkley modificado- colúvio - w = 64,3\% 


\section{SOLO RESIDUAL}
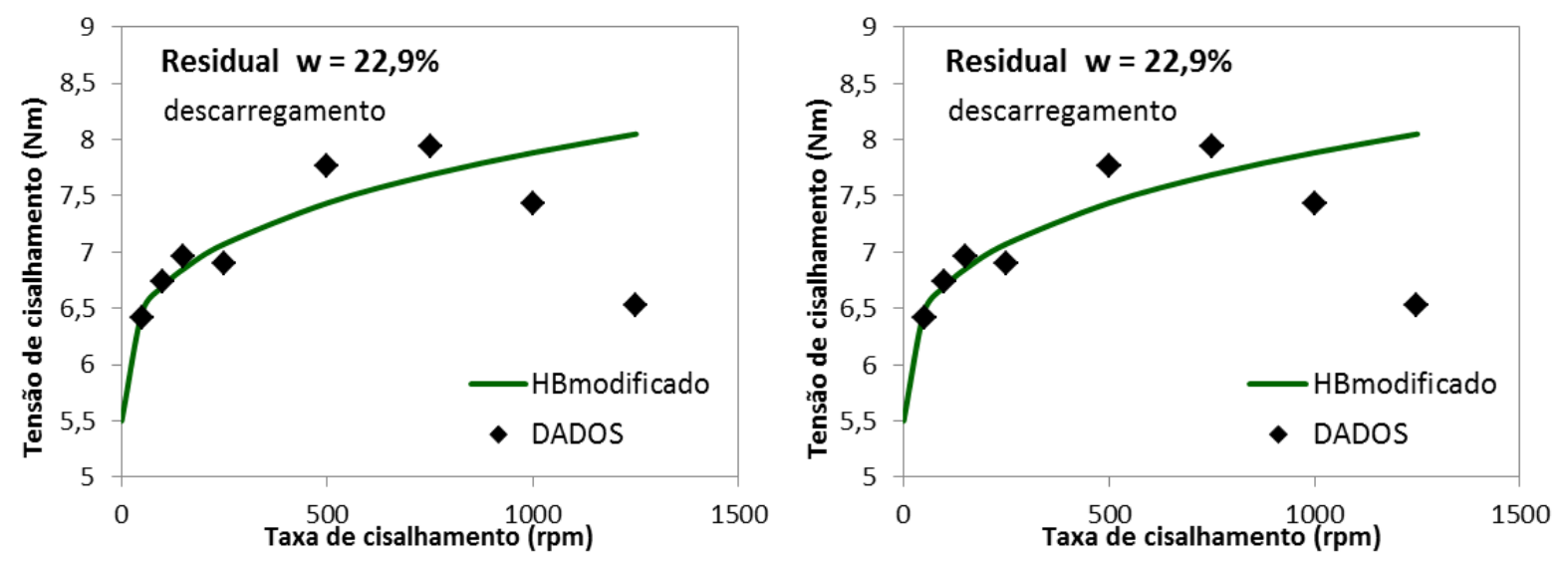

Figura A.47 GP - Herschel Bulkley modificado- residual - w = 22,9\%
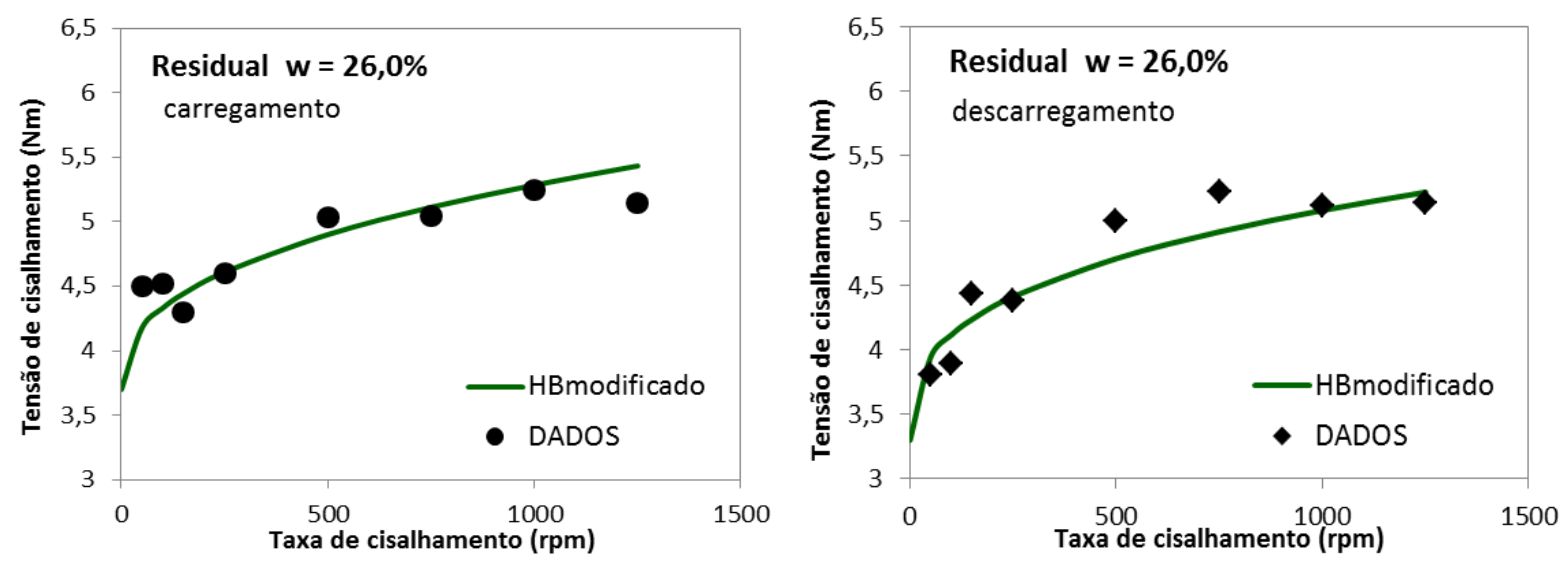

Figura A.48 GP - Herschel Bulkley modificado- residual - w = 26,0\%
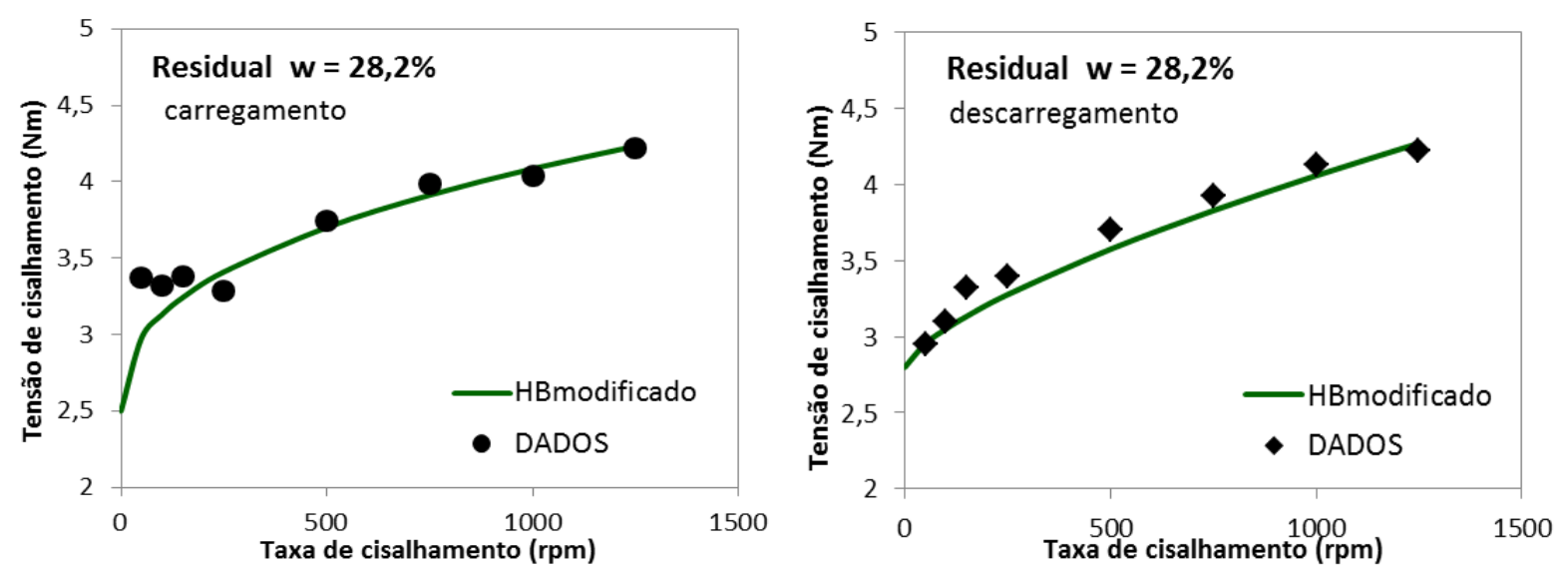

Figura A.49 GP - Herschel Bulkley modificado- residual - $w=28,2 \%$ 

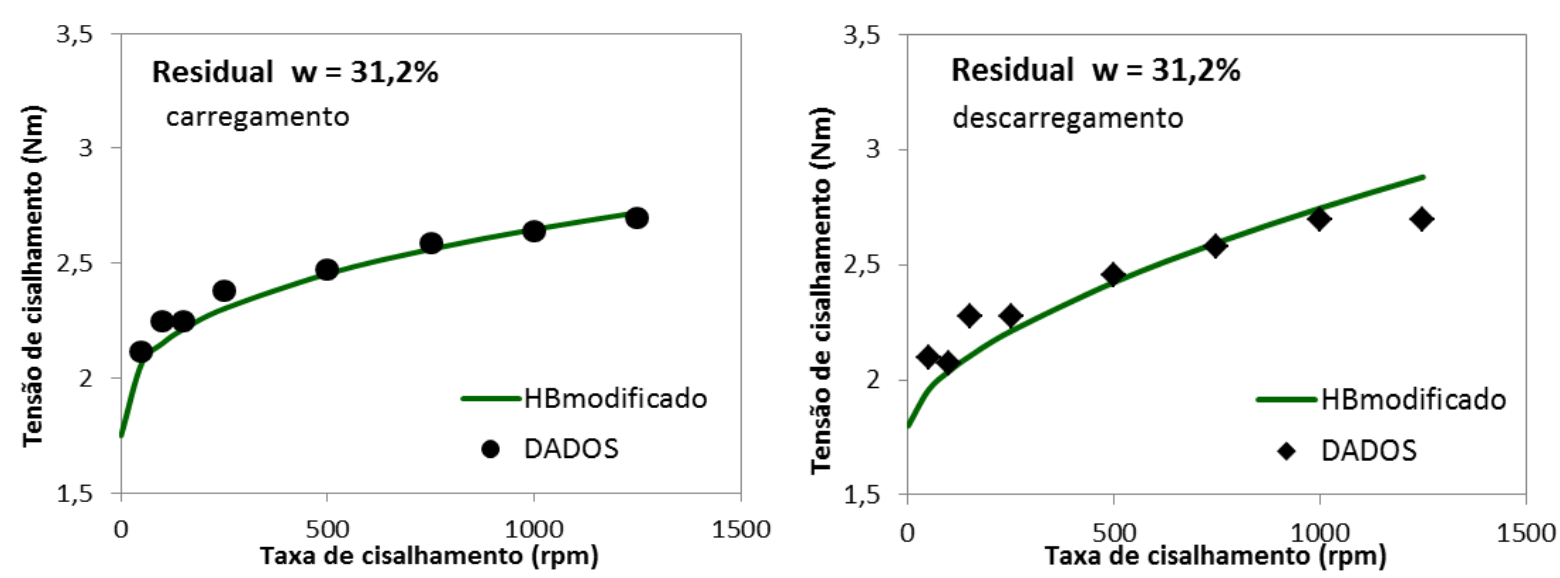

Figura A.50 GP - Herschel Bulkley modificado- residual - $w=31,2 \%$
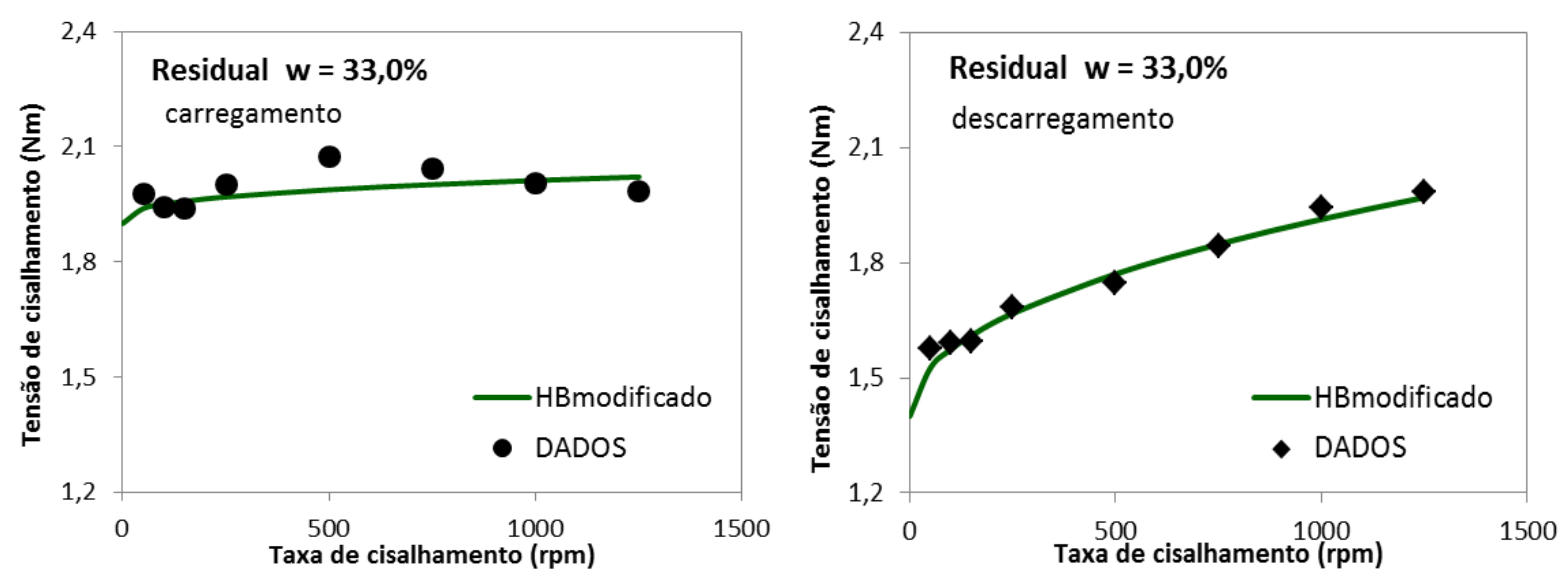

Figura A.51 GP - Herschel Bulkley modificado- residual - w = 33,0\%
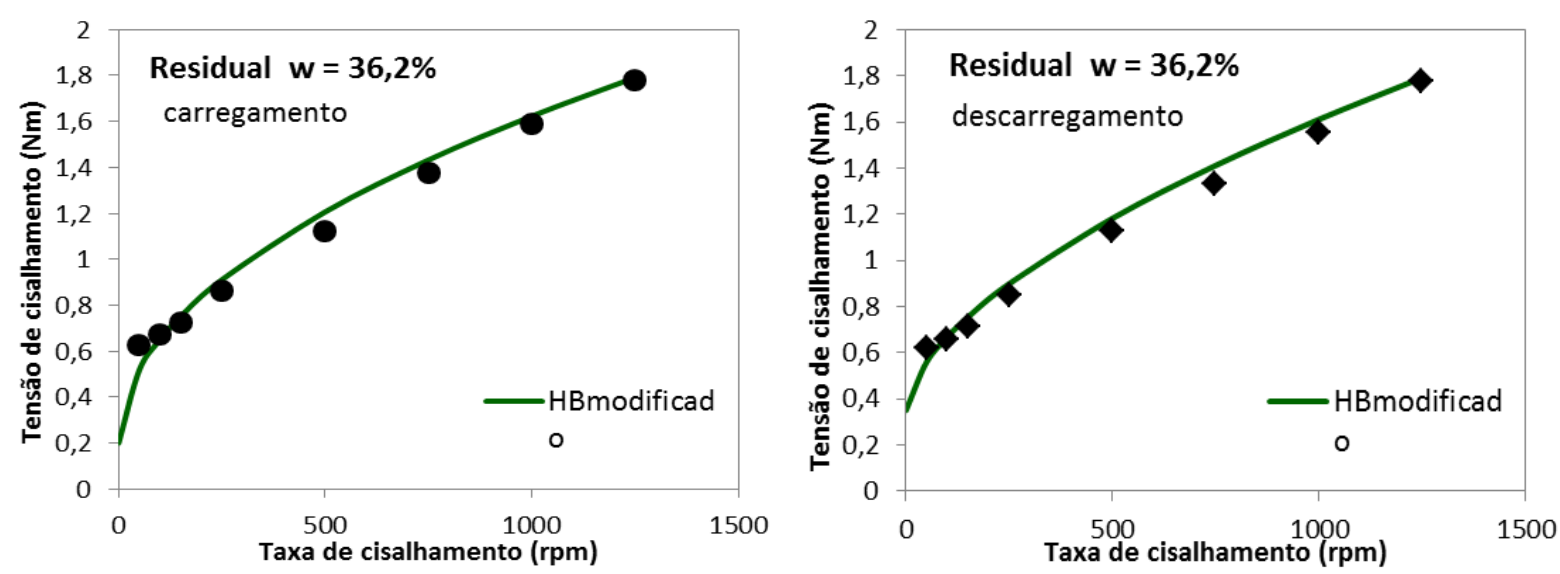

Figura A.52 GP - Herschel Bulkley modificado- residual - w = 36,2\% 

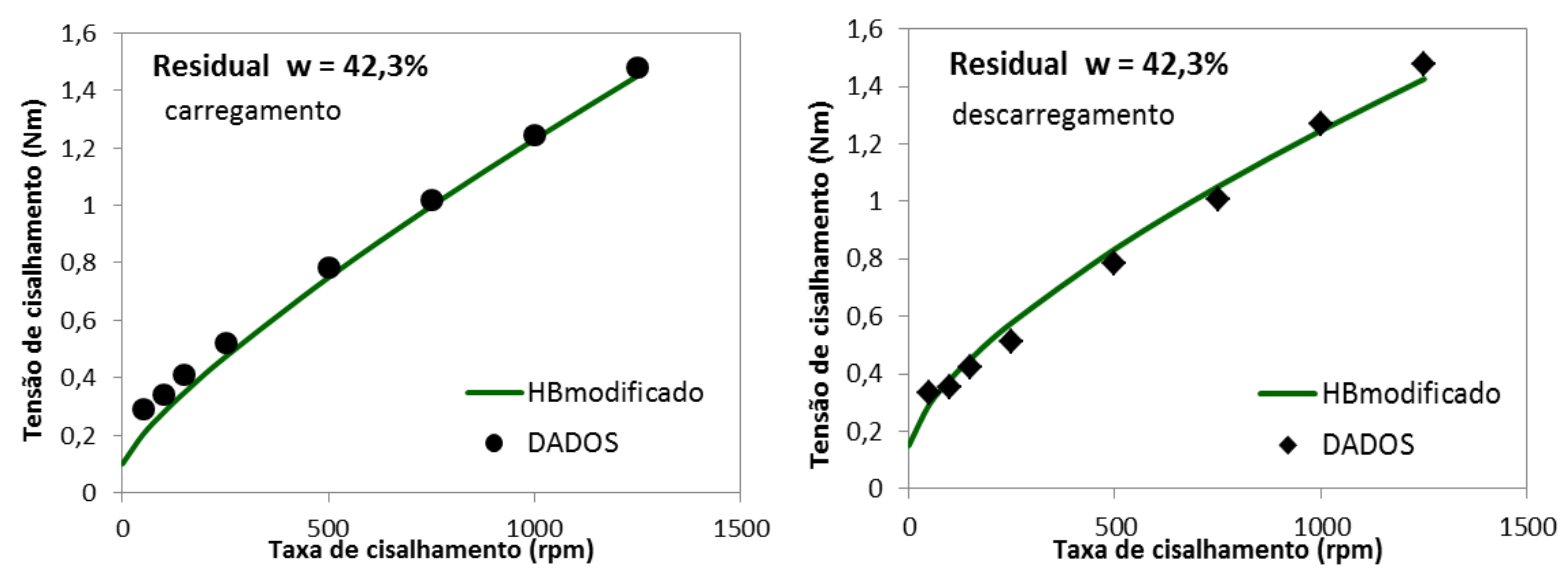

Figura A.53 GP - Herschel Bulkley modificado- residual - w = 42,3\%

\section{A.3. Reômetro Placa a Placa - Aproximação por Modelos Reológicos}

Tabela A.5 Dados Reômetro Placa a Placa - solo residual $-w=46 \%$ e w= $52 \%$

\begin{tabular}{|c|c|c|c|c|c|c|c|c|c|c|c|}
\hline \multicolumn{6}{|c|}{ SOLO RESIDUAL } & \multicolumn{6}{|c|}{ SOLO RESIDUAL } \\
\hline \multicolumn{3}{|c|}{$46 \%$ - ciclo 1} & \multicolumn{3}{|c|}{$46 \%$ - ciclo 2} & \multicolumn{3}{|c|}{$52 \%$ - ciclo 1} & \multicolumn{3}{|c|}{$52 \%$ - ciclo 2} \\
\hline Tensão & Taxa & Viscosidade & Tensão & Taxa & Viscosidade & Tensão & Taxa & Viscosidade & Tensão & Taxa & Viscosidade \\
\hline 2446,0 & 35,55 & 68,81 & 7,177 & 37,42 & 0,192 & 3565,0 & 35,58 & 100,20 & 944,6 & 37,31 & 25,320 \\
\hline 1648,0 & 78,55 & 20,98 & 4,415 & 75,86 & 0,058 & 3556,0 & 77,11 & 46,12 & 1052,0 & 75,36 & 13,960 \\
\hline 232,5 & 115,70 & 2,009 & 4,720 & 117,40 & 0,040 & 3400,0 & 115,40 & 34,000 & 1047,0 & 117,30 & 8,928 \\
\hline 184,9 & 157,50 & 1,174 & 6,904 & 155,50 & 0,044 & 3155,0 & 157,20 & 20,080 & 956,0 & 155,30 & 6,156 \\
\hline 251,1 & 195,00 & 1,288 & 6,795 & 197,40 & 0,034 & 2631,0 & 195,70 & 13,440 & 965,0 & 197,10 & 4,897 \\
\hline 168,1 & 237,00 & 0,709 & 6,706 & 235,50 & 0,028 & 2028,0 & 236,60 & 8,571 & 908,4 & 235,50 & 3,858 \\
\hline 402,0 & 275,90 & 1,457 & 4,917 & 277,30 & 0,018 & 1998,0 & 275,50 & 7,253 & 935,6 & 277,10 & 3,376 \\
\hline 46,2 & 316,70 & 0,146 & 3,470 & 315,60 & 0,011 & 1968,0 & 317,70 & 6,195 & 900,0 & 315,40 & 2,853 \\
\hline 85,7 & 355,40 & 0,241 & 3,485 & 357,20 & 0,010 & 1422,0 & 355,30 & 4,003 & 885,1 & 356,90 & 2,480 \\
\hline 122,2 & 397,10 & 0,308 & 3,733 & 395,50 & 0,009 & 1353,0 & 396,60 & 3,412 & 878,8 & 395,30 & 2,223 \\
\hline 71,5 & 365,40 & 0,196 & 0,224 & 365,60 & 0,001 & 1241,0 & 361,70 & 3,430 & 836,7 & 362,80 & 2,306 \\
\hline 46,0 & 323,70 & 0,142 & $-0,040$ & 324,60 & 0,000 & 1220,0 & 323,80 & 3,769 & 821,5 & 324,70 & 2,531 \\
\hline 49,4 & 285,10 & 0,173 & $-0,257$ & 283,00 & $-0,001$ & 1157,0 & 281,50 & 4,110 & 834,6 & 283,20 & 2,947 \\
\hline 86,7 & 243,40 & 0,356 & $-0,465$ & 244,60 & $-0,002$ & 1186,0 & 243,40 & 4,871 & 848,1 & 244,70 & 3,465 \\
\hline 67,5 & 201,90 & 0,334 & $-0,571$ & 206,20 & $-0,003$ & 1110,0 & 202,30 & 5,487 & 843,8 & 203,10 & 4,154 \\
\hline 14,8 & 163,80 & 0,090 & $-1,174$ & 164,10 & $-0,007$ & 1110,0 & 163,80 & 6,778 & 861,2 & 164,70 & 5,229 \\
\hline 13,3 & 122,10 & 0,109 & $-1,042$ & 125,60 & $-0,008$ & 1078,0 & 122,10 & 8,827 & 849,0 & 122,90 & 6,910 \\
\hline 15,2 & 83,64 & 0,181 & $-1,147$ & 84,08 & $-0,014$ & 1072,0 & 83,73 & 12,800 & 879,7 & 84,38 & 10,430 \\
\hline 15,5 & 45,15 & 0,343 & $-1,454$ & 45,46 & $-0,032$ & 1067,0 & 42,22 & 25,280 & 839,7 & 43,01 & 19,520 \\
\hline 41,9 & 3,52 & & $-1,703$ & 3,78 & $-0,451$ & 1052,0 & 3,60 & & 859,5 & 4,61 & \\
\hline
\end{tabular}


Tabela A.6 Dados Reômetro Placa a Placa - solo residual - $\mathbf{w}=54 \%$ e w= 55\%

\begin{tabular}{|c|c|c|c|c|c|c|c|c|c|c|c|}
\hline \multicolumn{6}{|c|}{ SOLO RESIDUAL } & \multicolumn{6}{|c|}{ SOLO RESIDUAL } \\
\hline \multicolumn{3}{|c|}{$54 \%$ - ciclo 1} & \multicolumn{3}{|c|}{$54 \%$ - ciclo 2} & \multicolumn{3}{|c|}{$55 \%$ - ciclo 1} & \multicolumn{3}{|c|}{$55 \%$ - ciclo 2} \\
\hline Tensão & Taxa & Viscosidade & Tensão & Taxa & Viscosidade & Tensão & Taxa & Viscosidade & Tensão & Taxa & Viscosidade \\
\hline 1431,0 & 35,7 & 40,150 & 84,6 & 36,62 & 2,309 & 1460,0 & 37,84 & 38,570 & 155,6 & 36,03 & 4,318 \\
\hline 351,8 & 77,0 & 4,571 & 84,8 & 74,90 & 1,132 & 729,5 & 76,06 & 9,591 & 182,9 & 77,62 & 2,356 \\
\hline 195,5 & 115,4 & 1,695 & 90,1 & 116,50 & 0,773 & 514,4 & 116,80 & 4,404 & 202,7 & 115,90 & 1,749 \\
\hline 217,3 & 157,0 & 1,383 & 92,6 & 154,80 & 0,598 & 333,8 & 156,70 & 2,130 & 277,7 & 156,90 & 1,770 \\
\hline 244,7 & 195,1 & 1,254 & 99,8 & 196,50 & 0,508 & 244,0 & 197,80 & 1,234 & 177,1 & 196,00 & 0,904 \\
\hline 244,9 & 236,9 & 1,034 & 107,8 & 234,90 & 0,459 & 183,9 & 235,80 & 0,780 & 172,8 & 237,50 & 0,728 \\
\hline 309,9 & 274,8 & 1,128 & 115,0 & 276,50 & 0,416 & 190,7 & 277,50 & 0,687 & 177,2 & 275,90 & 0,642 \\
\hline 116,3 & 316,8 & 0,367 & 122,5 & 314,80 & 0,389 & 200,0 & 315,90 & 0,633 & 194,1 & 317,50 & 0,611 \\
\hline 118,8 & 355,3 & 0,334 & 128,4 & 356,40 & 0,360 & 211,6 & 357,40 & 0,592 & 197,8 & 356,00 & 0,556 \\
\hline 123,4 & 396,8 & 0,311 & 131,0 & 395,00 & 0,332 & 226,9 & 395,40 & 0,574 & 226,8 & 397,40 & 0,571 \\
\hline 116,6 & 363,2 & 0,321 & 113,6 & 364,60 & 0,312 & 175,0 & 363,10 & 0,482 & 171,0 & 364,60 & 0,469 \\
\hline 115,6 & 325,0 & 0,356 & 100,3 & 323,10 & 0,310 & 174,6 & 324,90 & 0,537 & 150,6 & 323,10 & 0,466 \\
\hline 93,9 & 283,5 & 0,331 & 90,8 & 284,60 & 0,319 & 165,9 & 283,20 & 0,586 & 145,0 & 284,70 & 0,509 \\
\hline 82,1 & 245,0 & 0,335 & 83,7 & 242,80 & 0,345 & 159,6 & 244,80 & 0,652 & 139,0 & 243,00 & 0,572 \\
\hline 74,7 & 203,4 & 0,367 & 78,1 & 204,60 & 0,382 & 153,8 & 203,10 & 0,757 & 135,2 & 204,50 & 0,661 \\
\hline 68,1 & 165,0 & 0,412 & 71,5 & 162,90 & 0,439 & 141,9 & 164,90 & 0,861 & 126,6 & 163,00 & 0,777 \\
\hline 104,0 & 123,5 & 0,842 & 64,4 & 124,40 & 0,518 & 142,8 & 123,10 & 1,160 & 112,9 & 124,80 & 0,904 \\
\hline 77,6 & 85,0 & 0,913 & 52,2 & 82,75 & 0,631 & 150,4 & 84,68 & 1,777 & 102,8 & 83,09 & 1,237 \\
\hline 65,6 & 43,3 & 1,517 & 36,7 & 44,46 & 0,826 & 131,1 & 43,16 & 3,038 & 82,7 & 44,67 & 1,852 \\
\hline 79,2 & 4,9 & & 30,7 & 2,68 & & 116,9 & 4,62 & & 69,3 & 2,94 & \\
\hline
\end{tabular}

Tabela A.7 Dados Reômetro Placa a Placa - solo residual $-\mathbf{w}=\mathbf{5 7 \%}$ e w= $59 \%$

\begin{tabular}{|c|c|c|c|c|c|c|c|c|c|c|c|}
\hline \multicolumn{6}{|c|}{ SOLO RESIDUAL } & \multicolumn{6}{|c|}{ SOLO RESIDUAL } \\
\hline \multicolumn{3}{|c|}{$57 \%$ - ciclo 1} & \multicolumn{3}{|c|}{$57 \%$ - ciclo 2} & \multicolumn{3}{|c|}{$59 \%$ - ciclo 1} & \multicolumn{3}{|c|}{$59 \%$ - ciclo 2} \\
\hline Tensão & Taxa & Viscosidade & Tensão & Taxa & Viscosidade & Tensão & Taxa & Viscosidade & Tensão & Taxa & Viscosidade \\
\hline 2305,0 & 36,48 & 63,190 & 469,6 & 35,72 & 13,150 & 1346,0 & 36,49 & 36,890 & 38,1 & 37,83 & 1,008 \\
\hline 1314,0 & 75,03 & 17,520 & 561,4 & 77,29 & 7,263 & 1103,0 & 75,12 & 14,680 & 50,2 & 76,24 & 0,659 \\
\hline 495,2 & 116,40 & 4,256 & 600,7 & 115,50 & 5,199 & 170,4 & 116,60 & 1,461 & 60,7 & 114,70 & 0,529 \\
\hline 472,5 & 154,70 & 3,055 & 594,8 & 157,40 & 3,779 & 125,2 & 154,80 & 0,809 & 69,4 & 156,10 & 0,444 \\
\hline 548,0 & 196,50 & 2,788 & 488,0 & 195,50 & 2,497 & 121,6 & 196,30 & 0,619 & 77,3 & 197,80 & 0,391 \\
\hline 592,0 & 234,90 & 2,521 & 658,4 & 236,30 & 2,786 & 126,3 & 234,80 & 0,538 & 83,7 & 236,30 & 0,354 \\
\hline 567,2 & 276,70 & 2,050 & 627,5 & 274,90 & 2,283 & 134,2 & 276,30 & 0,486 & 90,1 & 277,80 & 0,324 \\
\hline 521,4 & 315,10 & 1,655 & 536,7 & 317,30 & 1,691 & 139,7 & 314,50 & 0,444 & 96,3 & 316,10 & 0,305 \\
\hline 512,4 & 356,40 & 1,438 & 495,5 & 355,40 & 1,394 & 146,8 & 356,30 & 0,412 & 104,3 & 357,60 & 0,292 \\
\hline 626,6 & 395,20 & 1,585 & 459,3 & 397,10 & 1,157 & 152,9 & 397,90 & 0,384 & 110,6 & 396,10 & 0,279 \\
\hline 532,3 & 363,70 & 1,464 & 415,5 & 364,00 & 1,142 & 136,3 & 365,10 & 0,373 & 101,8 & 364,20 & 0,280 \\
\hline 555,5 & 322,30 & 1,723 & 384,5 & 322,60 & 1,192 & 127,0 & 323,70 & 0,393 & 96,9 & 322,20 & 0,301 \\
\hline 539,4 & 283,70 & 1,901 & 368,3 & 284,00 & 1,297 & 113,6 & 285,30 & 0,398 & 91,2 & 283,80 & 0,321 \\
\hline 573,4 & 242,20 & 2,368 & 450,7 & 242,70 & 1,857 & 100,9 & 243,60 & 0,414 & 84,6 & 242,30 & 0,349 \\
\hline 588,4 & 203,00 & 2,899 & 375,6 & 204,10 & 1,840 & 89,5 & 205,20 & 0,436 & 77,3 & 203,90 & 0,379 \\
\hline 619,4 & 162,30 & 3,817 & 371,5 & 162,70 & 2,283 & 77,4 & 163,50 & 0,473 & 68,9 & 162,30 & 0,425 \\
\hline 585,1 & 123,80 & 4,724 & 370,6 & 124,20 & 2,983 & 65,7 & 125,10 & 0,525 & 61,3 & 123,90 & 0,495 \\
\hline 587,8 & 81,91 & 7,176 & 383,1 & 82,66 & 4,635 & 52,7 & 83,54 & 0,631 & 51,8 & 82,35 & 0,629 \\
\hline 527,3 & 43,56 & 12,110 & 483,7 & 44,06 & 10,980 & 40,0 & 45,16 & 0,885 & 39,8 & 43,81 & 0,909 \\
\hline 443,7 & 1,92 & & 588,9 & 2,43 & & 27,0 & 3,47 & & 26,6 & 2,19 & \\
\hline
\end{tabular}


Tabela A.8 Dados Reômetro Placa a Placa - solo residual $-\mathrm{w}=61 \%$

\begin{tabular}{|c|c|c|c|c|c|}
\hline \multicolumn{6}{|c|}{ SOLO RESIDUAL } \\
\hline \multicolumn{3}{|c|}{$61 \%$ - ciclo 1} & \multicolumn{3}{|c|}{$61 \%$ - ciclo 2} \\
\hline Tensão & Taxa & Viscosidade & Tensão & Taxa & Viscosidade \\
\hline 1245,0 & 36,01 & 34,580 & 150,5 & 35,70 & 4,216 \\
\hline 582,8 & 77,53 & 7,517 & 185,7 & 77,34 & 2,401 \\
\hline 382,5 & 116,00 & 3,298 & 208,9 & 115,60 & 1,807 \\
\hline 286,0 & 157,60 & 1,814 & 231,2 & 157,10 & 1,472 \\
\hline 263,7 & 196,00 & 1,346 & 238,9 & 195,50 & 1,222 \\
\hline 267,2 & 237,40 & 1,125 & 254,3 & 236,90 & 1,073 \\
\hline 260,8 & 275,80 & 0,946 & 257,1 & 275,70 & 0,933 \\
\hline 265,4 & 317,30 & 0,836 & 266,8 & 317,10 & 0,841 \\
\hline 300,8 & 355,80 & 0,846 & 275,7 & 355,80 & 0,775 \\
\hline 300,2 & 397,40 & 0,755 & 270,7 & 397,00 & 0,682 \\
\hline 294,5 & 364,40 & 0,808 & 226,6 & 364,20 & 0,622 \\
\hline 284,6 & 322,60 & 0,882 & 203,2 & 322,40 & 0,630 \\
\hline 282,5 & 284,20 & 0,994 & 187,0 & 284,00 & 0,658 \\
\hline 267,3 & 242,50 & 1,102 & 171,7 & 242,40 & 0,708 \\
\hline 256,6 & 204,30 & 1,256 & 158,2 & 204,00 & 0,775 \\
\hline 239,3 & 162,60 & 1,472 & 140,2 & 162,50 & 0,863 \\
\hline 220,6 & 124,30 & 1,774 & 123,9 & 124,10 & 0,999 \\
\hline 192,4 & 82,66 & 2,328 & 109,4 & 82,43 & 1,328 \\
\hline 170,3 & 44,23 & 3,851 & 89,6 & 43,97 & 2,038 \\
\hline 133,2 & 2,47 & & 75,6 & 2,28 & \\
\hline
\end{tabular}

Tabela A.9 Dados Reômetro Placa a Placa - colúvio - w = $61 \%$ e w= $67 \%$

\begin{tabular}{|c|c|c|c|c|c|c|c|c|c|c|c|}
\hline \multicolumn{6}{|c|}{ COLÚVIO } & \multicolumn{6}{|c|}{ COLÚVIO } \\
\hline \multicolumn{3}{|c|}{$61 \%$ - ciclo 1} & \multicolumn{3}{|c|}{$61 \%$ - ciclo 2} & \multicolumn{3}{|c|}{$67 \%$ - ciclo 1} & \multicolumn{3}{|c|}{$67 \%$ - ciclo 2} \\
\hline Tensão & Taxa & Viscosidade & Tensão & Taxa & Viscosidade & Tensão & Taxa & Viscosidade & Tensão & Taxa & Viscosidade \\
\hline 3040,0 & 35,72 & 85,110 & 7,3 & 37,49 & 0,195 & 3770,0 & 35,28 & 106,900 & 138,5 & 36,08 & 3,840 \\
\hline 2197,0 & 77,66 & 28,290 & 8,0 & 75,65 & 0,106 & 3702,0 & 76,80 & 48,200 & 138,7 & 77,55 & 1,789 \\
\hline 1671,0 & 115,70 & 14,440 & 7,5 & 117,40 & 0,064 & 2020,0 & 115,70 & 17,460 & 104,5 & 115,90 & 0,902 \\
\hline 1729,0 & 157,50 & 10,980 & 5,6 & 155,60 & 0,036 & 664,3 & 156,90 & 4,234 & 157,9 & 157,50 & 1,003 \\
\hline 250,8 & 196,10 & 1,279 & 5,6 & 197,50 & 0,028 & 556,0 & 195,40 & 2,846 & 156,9 & 196,00 & 0,801 \\
\hline 190,9 & 237,20 & 0,805 & 4,9 & 235,70 & 0,021 & 382,0 & 236,80 & 1,613 & 170,6 & 237,60 & 0,718 \\
\hline 188,0 & 275,40 & 0,682 & 5,4 & 277,10 & 0,019 & 376,0 & 274,50 & 1,369 & 184,3 & 276,00 & 0,668 \\
\hline 138,8 & 316,80 & 0,438 & 5,3 & 315,70 & 0,017 & 402,2 & 316,10 & 1,272 & 179,0 & 317,50 & 0,564 \\
\hline 108,5 & 356,00 & 0,305 & 5,8 & 357,00 & 0,016 & 764,0 & 354,90 & 2,153 & 165,4 & 356,00 & 0,465 \\
\hline 150,4 & 397,10 & 0,379 & 6,1 & 395,70 & 0,015 & 339,4 & 396,60 & 0,856 & 147,5 & 397,50 & 0,371 \\
\hline 153,8 & 361,90 & 0,425 & 0,3 & 364,20 & 0,000 & 227,2 & 362,10 & 0,627 & 138,8 & 363,50 & 0,382 \\
\hline 92,3 & 324,80 & 0,284 & 0,0 & 323,50 & 0,000 & 130,2 & 324,00 & 0,402 & 142,1 & 325,10 & 0,437 \\
\hline 61,0 & 283,00 & 0,216 & $-0,2$ & 285,10 & 0,000 & 81,5 & 282,40 & 0,289 & 159,0 & 283,40 & 0,561 \\
\hline 41,1 & 244,60 & 0,168 & $-0,6$ & 243,50 & 0,000 & 76,8 & 244,00 & 0,315 & 147,4 & 244,90 & 0,602 \\
\hline 20,5 & 203,20 & 0,101 & $-0,9$ & 205,10 & 0,000 & 50,3 & 202,50 & 0,248 & 7,2 & 203,70 & 0,035 \\
\hline 31,4 & 164,60 & 0,191 & $-1,2$ & 163,50 & $-0,010$ & 100,7 & 164,00 & 0,614 & $-1,0$ & 162,40 & $-0,006$ \\
\hline 12,8 & 123,30 & 0,104 & $-1,3$ & 124,50 & $-0,010$ & 86,1 & 122,40 & 0,703 & $-1,9$ & 123,60 & $-0,015$ \\
\hline 7,1 & 84,66 & 0,084 & $-2,0$ & 82,64 & $-0,020$ & 83,6 & 83,92 & 0,996 & $-1,8$ & 85,29 & $-0,022$ \\
\hline 3,6 & 43,01 & 0,084 & $-1,9$ & 44,19 & $-0,040$ & 75,5 & 42,44 & 1,779 & $-2,6$ & 43,64 & $-0,059$ \\
\hline 3,5 & 4,59 & 0,751 & $-2,6$ & 2,56 & $-1,020$ & 82,9 & 3,83 & 21,660 & $-2,4$ & 5,04 & $-0,474$ \\
\hline
\end{tabular}


Tabela A.10 Dados Reômetro Placa a Placa - colúvio - w = 69\% e w= 71\%

\begin{tabular}{|c|c|c|c|c|c|c|c|c|c|c|c|}
\hline \multicolumn{6}{|c|}{ COLÚVIO } & \multicolumn{6}{|c|}{ COLÚVIO } \\
\hline \multicolumn{3}{|c|}{$69 \%$ - ciclo 1} & \multicolumn{3}{|c|}{$69 \%$ - ciclo 2} & \multicolumn{3}{|c|}{$71 \%$ - ciclo 1} & \multicolumn{3}{|c|}{$71 \%$ - ciclo 2} \\
\hline Tensão & Taxa & Viscosidade & Tensão & Taxa & Viscosidade & Tensão & Taxa & Viscosidade & Tensão & Taxa & Viscosidade \\
\hline 2712,0 & 37,03 & 73,240 & 22,0 & 36,94 & 0,594 & 4377,0 & 0,04 & 106032,0 & 1,9 & 36,26 & 0,051 \\
\hline 2637,0 & 75,47 & 34,940 & 19,2 & 75,20 & 0,255 & 4377,0 & 3,44 & 1273,9 & 1,8 & 74,79 & 0,025 \\
\hline 2444,0 & 116,60 & 20,950 & 24,4 & 116,70 & 0,209 & 4291,0 & 104,20 & 41,180 & 2,5 & 116,20 & 0,022 \\
\hline 2074,0 & 155,40 & 13,350 & 26,1 & 155,20 & 0,168 & 3044,0 & 156,10 & 19,500 & 2,3 & 154,60 & 0,015 \\
\hline 1626,0 & 197,30 & 8,241 & 29,4 & 196,70 & 0,150 & 638,2 & 196,60 & 3,246 & 2,6 & 196,10 & 0,013 \\
\hline 2198,0 & 235,50 & 9,336 & 34,4 & 235,10 & 0,146 & 215,5 & 237,30 & 0,908 & 2,8 & 234,30 & 0,012 \\
\hline 301,9 & 278,80 & 1,083 & 34,2 & 276,80 & 0,124 & 200,7 & 275,80 & 0,728 & 3,1 & 276,20 & 0,011 \\
\hline 42,2 & 315,30 & 0,134 & 36,6 & 315,20 & 0,116 & 170,3 & 317,00 & 0,537 & 3,4 & 314,50 & 0,011 \\
\hline 33,5 & 356,80 & 0,094 & 37,1 & 356,70 & 0,104 & 154,9 & 354,60 & 0,437 & 3,5 & 356,20 & 0,010 \\
\hline 51,0 & 395,10 & 0,129 & 38,5 & 395,10 & 0,097 & 142,6 & 397,70 & 0,359 & 3,5 & 394,70 & 0,009 \\
\hline 47,1 & 363,60 & 0,130 & 30,2 & 362,60 & 0,083 & 91,3 & 365,00 & 0,250 & 0,1 & 363,00 & 0,000 \\
\hline 42,5 & 325,20 & 0,131 & 28,9 & 324,00 & 0,089 & 0,5 & 323,50 & 0,002 & 0,1 & 325,20 & 0,000 \\
\hline 39,2 & 283,70 & 0,138 & 28,7 & 282,50 & 0,101 & $-0,1$ & 286,00 & 0,000 & $-0,2$ & 283,60 & $-0,001$ \\
\hline 42,7 & 245,10 & 0,174 & $-0,3$ & 244,20 & 0,000 & $-0,4$ & 244,30 & $-0,002$ & $-0,4$ & 245,20 & $-0,002$ \\
\hline 37,2 & 203,60 & 0,183 & $-0,9$ & 203,40 & 0,000 & $-0,7$ & 206,00 & $-0,003$ & $-0,7$ & 203,60 & $-0,004$ \\
\hline 35,1 & 165,10 & 0,213 & $-1,2$ & 165,10 & $-0,010$ & $-1,2$ & 164,00 & $-0,007$ & $-1,2$ & 164,80 & $-0,008$ \\
\hline 30,1 & 123,70 & 0,244 & $-1,3$ & 122,70 & $-0,010$ & $-1,2$ & 125,20 & $-0,010$ & $-1,0$ & 123,00 & $-0,008$ \\
\hline 24,9 & 85,17 & 0,292 & $-1,8$ & 84,40 & $-0,020$ & $-1,6$ & 83,76 & $-0,019$ & $-1,4$ & 84,69 & $-0,016$ \\
\hline 21,2 & 43,48 & 0,487 & $-1,9$ & 42,58 & $-0,040$ & $-1,4$ & 45,33 & $-0,031$ & $-1,5$ & 42,75 & $-0,036$ \\
\hline 22,3 & 5,12 & 4,369 & $-2,8$ & 4,03 & $-0,700$ & $-1,8$ & 3,41 & $-0,527$ & $-1,8$ & 4,35 & $-0,407$ \\
\hline
\end{tabular}

Tabela A.11 Dados Reômetro Placa a Placa - colúvio - w = 74\% e w= 76\%

\begin{tabular}{|c|c|c|c|c|c|c|c|c|c|c|c|}
\hline \multicolumn{6}{|c|}{ COLÚVIO } & \multicolumn{6}{|c|}{ COLÚVIO } \\
\hline \multicolumn{3}{|c|}{$74 \%$ - ciclo 1} & \multicolumn{3}{|c|}{$74 \%$ - ciclo 2} & \multicolumn{3}{|c|}{$76 \%$ - ciclo 1} & \multicolumn{3}{|c|}{$76 \%$ - ciclo 2} \\
\hline Tensão & Taxa & Viscosidade & Tensão & Taxa & Viscosidade & Tensão & Taxa & Viscosidade & Tensão & Taxa & Viscosidade \\
\hline 1937,0 & 36,66 & 52,830 & 5,6 & 37,00 & 0,153 & 2258,0 & 35,67 & 63,300 & 48,9 & 37,67 & 1,298 \\
\hline 1505,0 & 75,00 & 20,070 & 4,6 & 75,37 & 0,060 & 1887,0 & 75,82 & 24,890 & 43,4 & 75,94 & 0,571 \\
\hline 1394,0 & 116,60 & 11,950 & 4,9 & 117,00 & 0,042 & 1626,0 & 114,10 & 14,250 & 54,5 & 117,60 & 0,464 \\
\hline 1063,0 & 155,20 & 6,848 & 5,2 & 155,30 & 0,034 & 934,9 & 156,60 & 5,972 & 52,1 & 156,00 & 0,334 \\
\hline 1418,0 & 196,00 & 7,237 & 6,0 & 196,70 & 0,031 & 589,4 & 194,80 & 3,026 & 55,8 & 197,50 & 0,283 \\
\hline 1002,0 & 233,90 & 4,286 & 6,5 & 235,20 & 0,028 & 543,5 & 236,50 & 2,298 & 58,9 & 235,70 & 0,250 \\
\hline 1155,0 & 276,50 & 4,175 & 7,4 & 276,70 & 0,027 & 409,2 & 274,90 & 1,489 & 62,7 & 277,20 & 0,226 \\
\hline 1201,0 & 314,90 & 3,816 & 8,8 & 315,20 & 0,028 & 247,8 & 315,80 & 0,785 & 75,7 & 315,60 & 0,240 \\
\hline 1089,0 & 356,60 & 3,053 & 9,3 & 356,80 & 0,026 & 192,7 & 354,60 & 0,543 & 107,0 & 357,40 & 0,300 \\
\hline 186,1 & 398,40 & 0,467 & 10,4 & 395,20 & 0,026 & 157,4 & 396,50 & 0,397 & 97,3 & 396,00 & 0,246 \\
\hline 48,3 & 363,70 & 0,133 & 5,4 & 363,40 & 0,015 & 132,9 & 364,90 & 0,364 & 83,9 & 362,20 & 0,232 \\
\hline 36,4 & 325,10 & 0,112 & 5,4 & 325,20 & 0,017 & 121,9 & 323,30 & 0,377 & 80,0 & 324,00 & 0,247 \\
\hline 26,5 & 283,60 & 0,093 & 4,9 & 283,60 & 0,017 & 116,9 & 284,60 & 0,411 & 80,5 & 282,30 & 0,285 \\
\hline 20,1 & 245,40 & 0,082 & 4,2 & 245,10 & 0,017 & 105,5 & 243,10 & 0,434 & 58,7 & 243,90 & 0,241 \\
\hline 15,9 & 203,90 & 0,078 & 3,4 & 203,40 & 0,017 & 81,5 & 204,80 & 0,398 & 57,4 & 202,30 & 0,284 \\
\hline 9,8 & 165,20 & 0,059 & 3,1 & 165,00 & 0,019 & 84,5 & 163,10 & 0,518 & 61,9 & 163,90 & 0,378 \\
\hline 4,0 & 123,80 & 0,033 & 2,1 & 123,40 & 0,017 & 66,5 & 124,80 & 0,533 & 46,5 & 122,40 & 0,380 \\
\hline 3,2 & 85,38 & 0,037 & 1,2 & 84,97 & 0,014 & 64,7 & 83,11 & 0,779 & 42,2 & 84,04 & 0,503 \\
\hline 2,2 & 43,63 & 0,051 & 0,6 & 43,31 & 0,015 & 52,7 & 44,68 & 1,180 & 35,5 & 42,25 & 0,841 \\
\hline 2,1 & 5,13 & 0,406 & 0,9 & 4,80 & 0,188 & 51,1 & 2,96 & 17,250 & 28,7 & 3,77 & \\
\hline
\end{tabular}


Tabela A.12 Dados Reômetro Placa a Placa - colúvio - w = 78\% e w= $80 \%$

\begin{tabular}{|c|c|c|c|c|c|c|c|c|c|c|c|}
\hline \multicolumn{6}{|c|}{ COLÚVIO } & \multicolumn{6}{|c|}{ COLÚVIO } \\
\hline \multicolumn{3}{|c|}{$78 \%$ - ciclo 1} & \multicolumn{3}{|c|}{$78 \%$ - ciclo 2} & \multicolumn{3}{|c|}{$80 \%$ - ciclo 1} & \multicolumn{3}{|c|}{$80 \%$ - ciclo 2} \\
\hline Tensão & Taxa & Viscosidade & Tensão & Taxa & Viscosidade & Tensão & Taxa & Viscosidade & Tensão & Taxa & Viscosidade \\
\hline 2869,0 & 36,59 & 78,420 & 57,1 & 37,19 & 1,536 & 1160,0 & 37,42 & 30,990 & 120,9 & 37,66 & 3,211 \\
\hline 2678,0 & 75,01 & 35,700 & 65,0 & 75,54 & 0,860 & 1139,0 & 75,92 & 15,010 & 158,3 & 76,10 & 2,080 \\
\hline 2464,0 & 116,60 & 21,140 & 70,4 & 117,10 & 0,602 & 986,9 & 117,20 & 8,417 & 158,2 & 117,60 & 1,345 \\
\hline 1786,0 & 158,30 & 11,280 & 77,3 & 155,40 & 0,498 & 843,4 & 156,00 & 5,405 & 164,0 & 156,00 & 1,051 \\
\hline 1787,0 & 196,80 & 9,078 & 93,4 & 197,00 & 0,474 & 539,1 & 197,60 & 2,728 & 174,3 & 197,60 & 0,882 \\
\hline 1163,0 & 238,30 & 4,879 & 95,6 & 235,70 & 0,406 & 518,7 & 235,60 & 2,202 & 184,0 & 236,00 & 0,780 \\
\hline 485,7 & 276,70 & 1,755 & 113,9 & 277,30 & 0,411 & 589,4 & 277,40 & 2,125 & 196,7 & 277,70 & 0,708 \\
\hline 202,2 & 318,00 & 0,636 & 103,5 & 315,60 & 0,328 & 627,6 & 316,10 & 1,985 & 208,5 & 316,00 & 0,660 \\
\hline 155,8 & 356,60 & 0,437 & 91,7 & 357,10 & 0,257 & 745,8 & 357,20 & 2,088 & 218,3 & 357,50 & 0,611 \\
\hline 209,1 & 394,80 & 0,530 & 91,0 & 395,40 & 0,230 & 650,1 & 395,90 & 1,642 & 226,6 & 396,10 & 0,572 \\
\hline 225,8 & 363,30 & 0,622 & 99,4 & 362,80 & 0,274 & 555,0 & 363,10 & 1,529 & 222,3 & 362,90 & 0,613 \\
\hline 200,3 & 325,00 & 0,616 & 91,5 & 324,30 & 0,282 & 447,4 & 324,50 & 1,379 & 209,1 & 324,40 & 0,645 \\
\hline 165,6 & 283,20 & 0,585 & 76,6 & 282,80 & 0,271 & 535,4 & 283,30 & 1,890 & 199,6 & 282,90 & 0,706 \\
\hline 183,0 & 244,70 & 0,748 & 55,5 & 244,40 & 0,227 & 446,7 & 244,10 & 1,830 & 190,7 & 244,60 & 0,780 \\
\hline 200,6 & 203,50 & 0,986 & 50,2 & 202,90 & 0,247 & 405,9 & 202,90 & 2,001 & 181,0 & 203,10 & 0,892 \\
\hline 154,8 & 164,90 & 0,939 & 48,9 & 164,40 & 0,297 & 382,1 & 164,60 & 2,321 & 164,0 & 164,40 & 0,998 \\
\hline 125,3 & 123,30 & 1,017 & 37,9 & 122,80 & 0,308 & 345,7 & 123,00 & 2,810 & 160,1 & 122,80 & 1,304 \\
\hline 114,6 & 84,82 & 1,351 & 24,8 & 84,53 & 0,293 & 292,1 & 84,65 & 3,451 & 138,8 & 84,49 & 1,643 \\
\hline 90,3 & 43,23 & 2,088 & 25,8 & 42,70 & 0,604 & 216,0 & 42,90 & 5,036 & 113,2 & 42,97 & 2,633 \\
\hline 63,8 & 4,73 & 13,480 & 25,5 & 4,26 & & 147,1 & 4,41 & 33,380 & 76,7 & 4,34 & \\
\hline
\end{tabular}

\section{A.3.1.Modelo de Bingham}

\section{COLÚVIO}
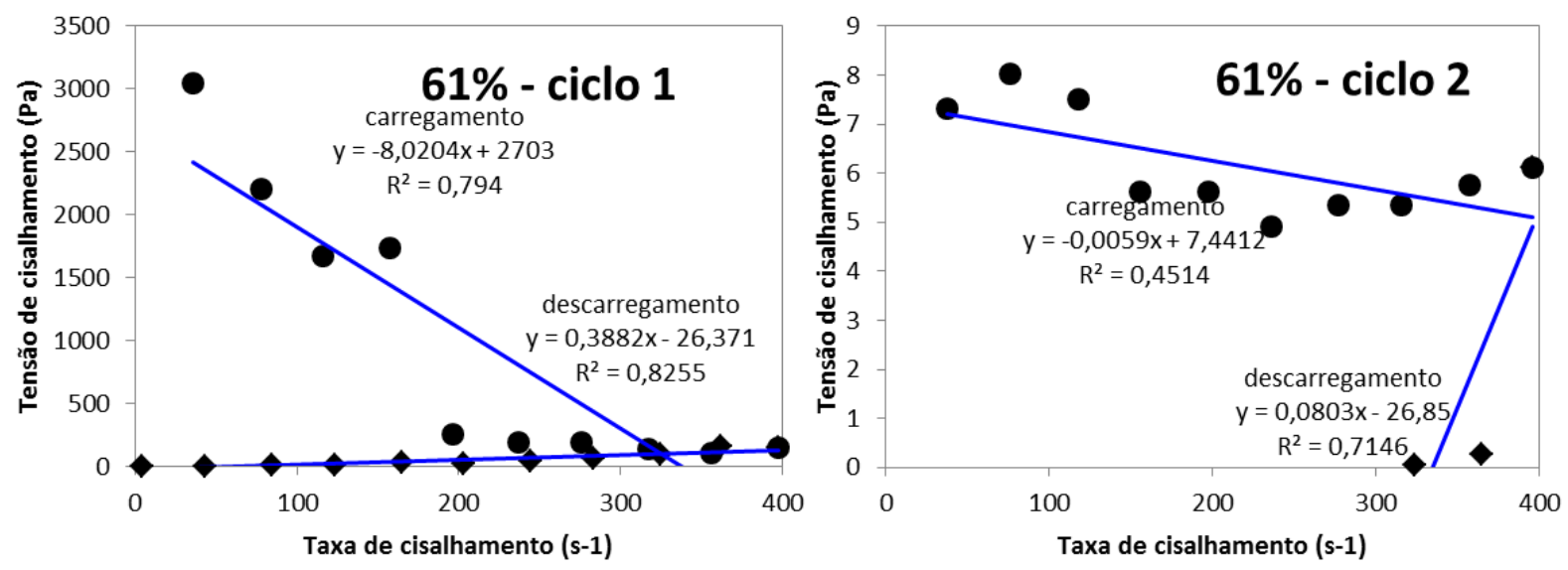

Figura A.54 PP - Bingham - colúvio - w = 61\% 

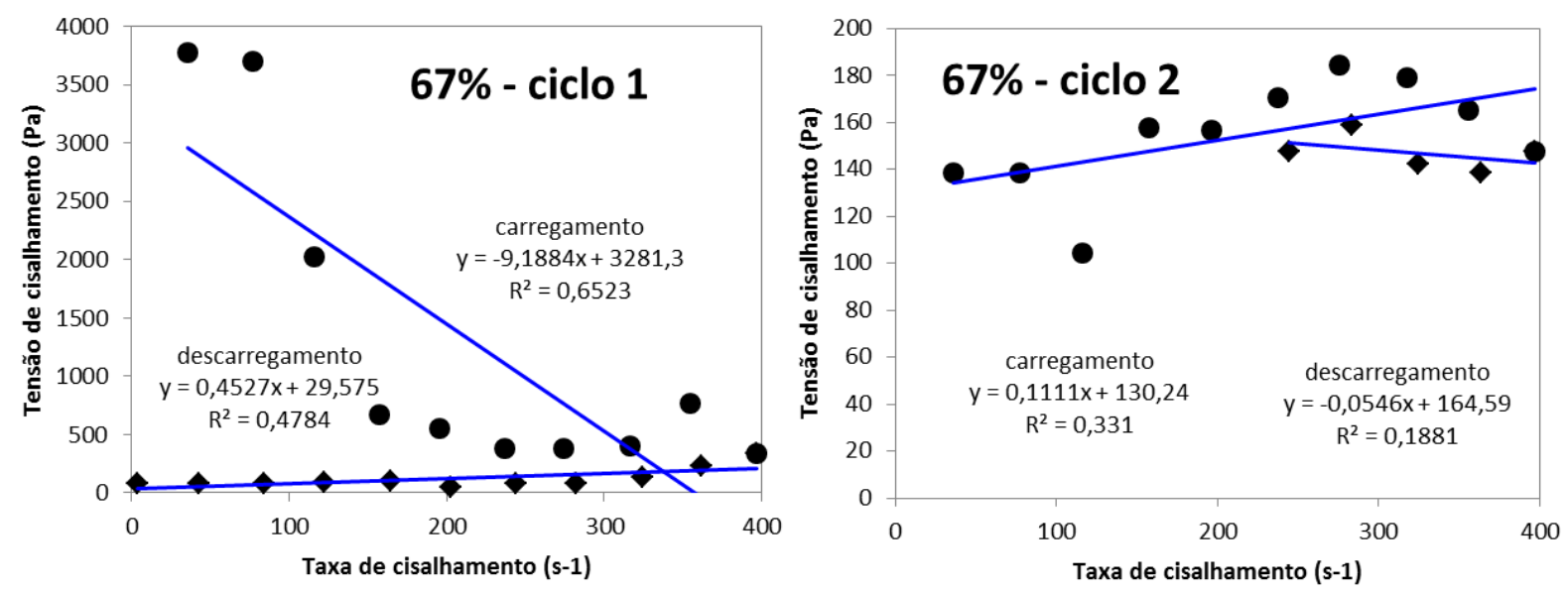

Figura A.55 PP - Bingham - colúvio - w = 67\%
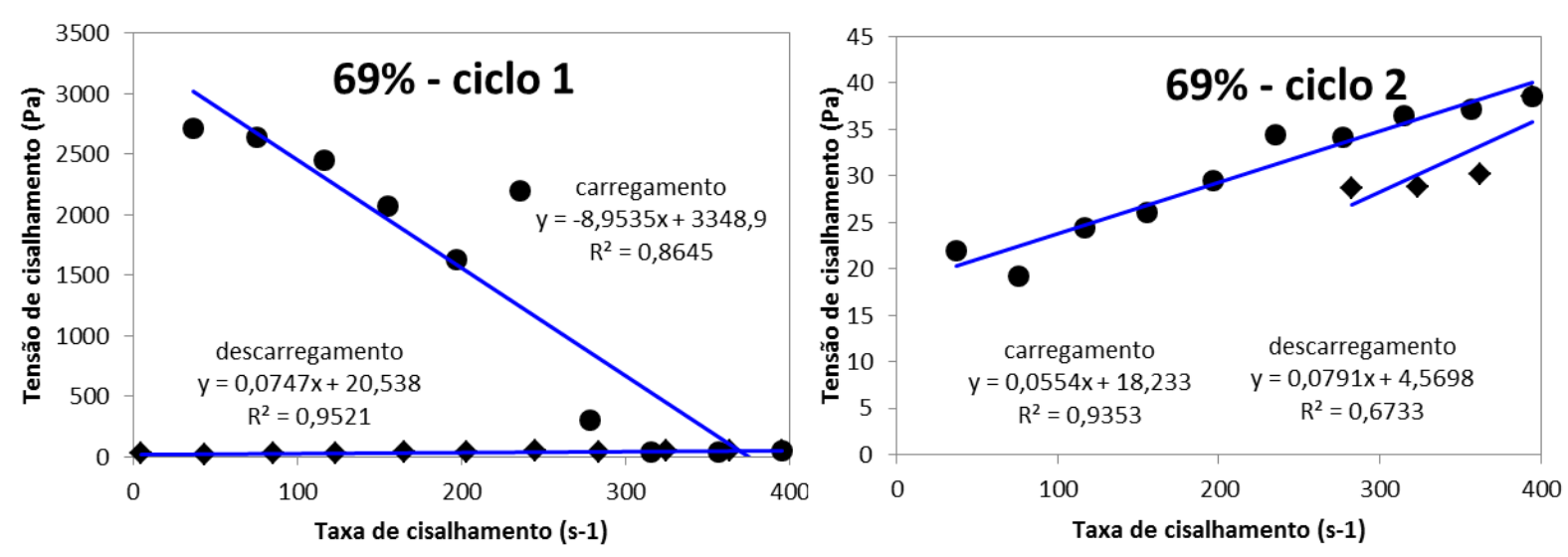

Figura A.56 PP - Bingham - colúvio - w = 69\%
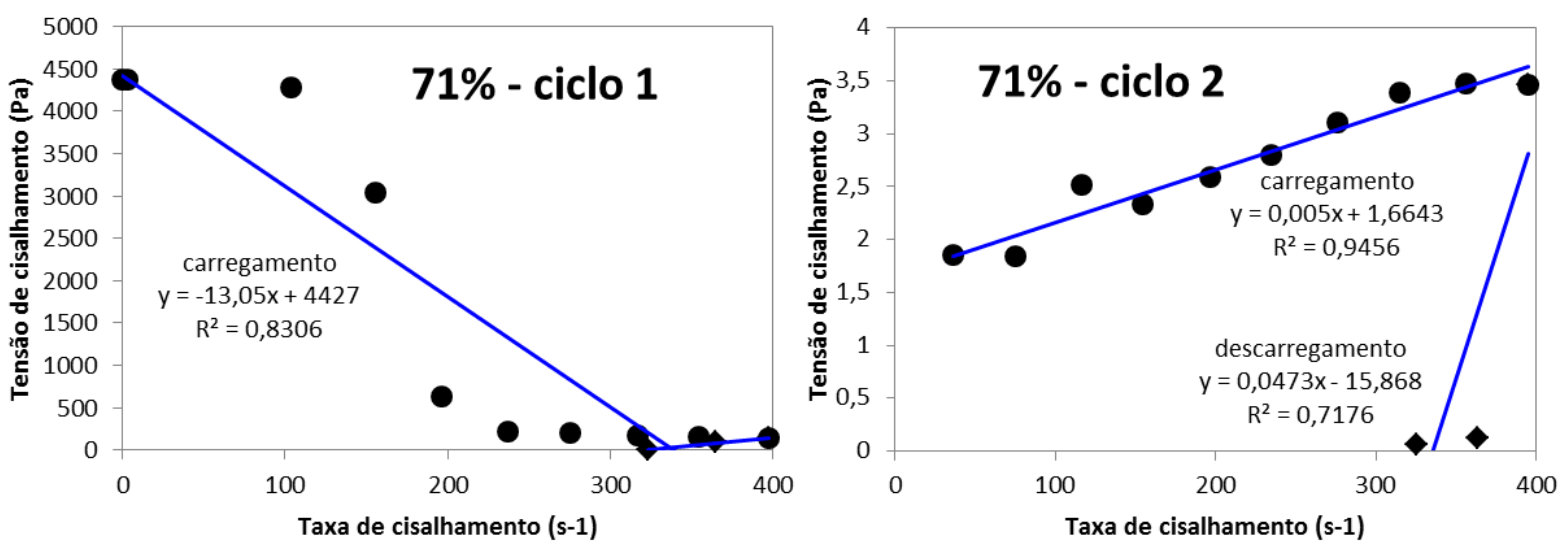

Figura A.57 PP - Bingham - colúvio - w = 71\% 

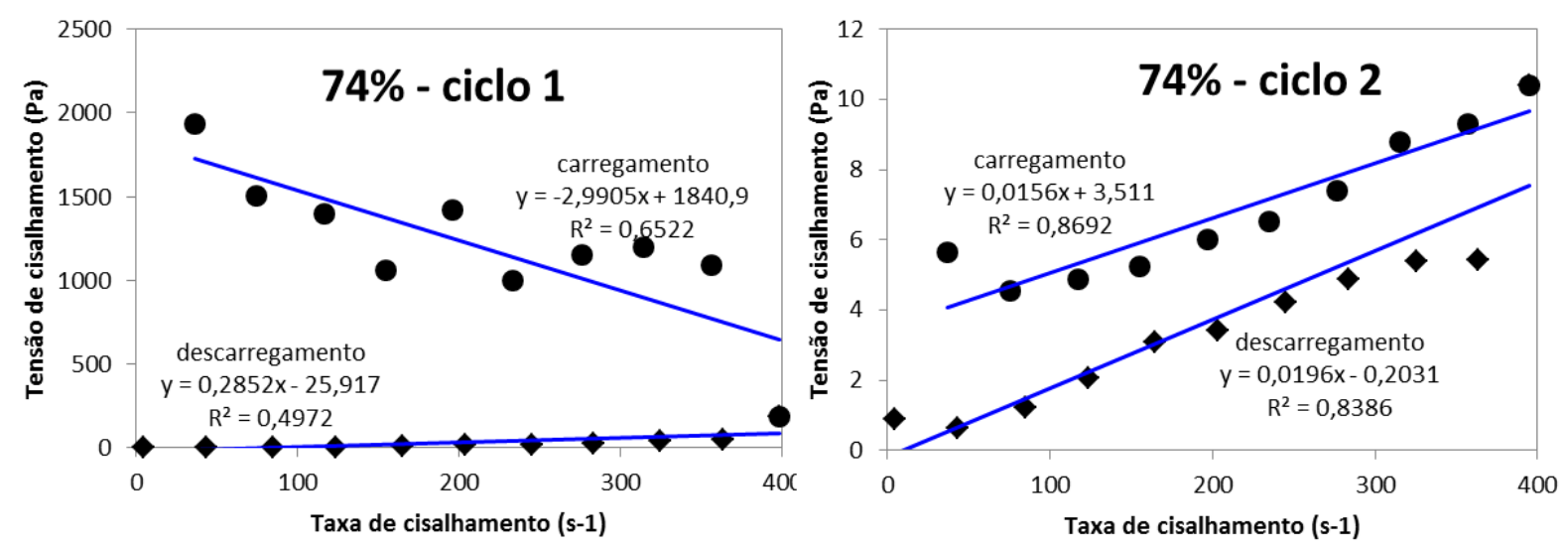

Figura A.58 PP - Bingham - colúvio - $w=74 \%$
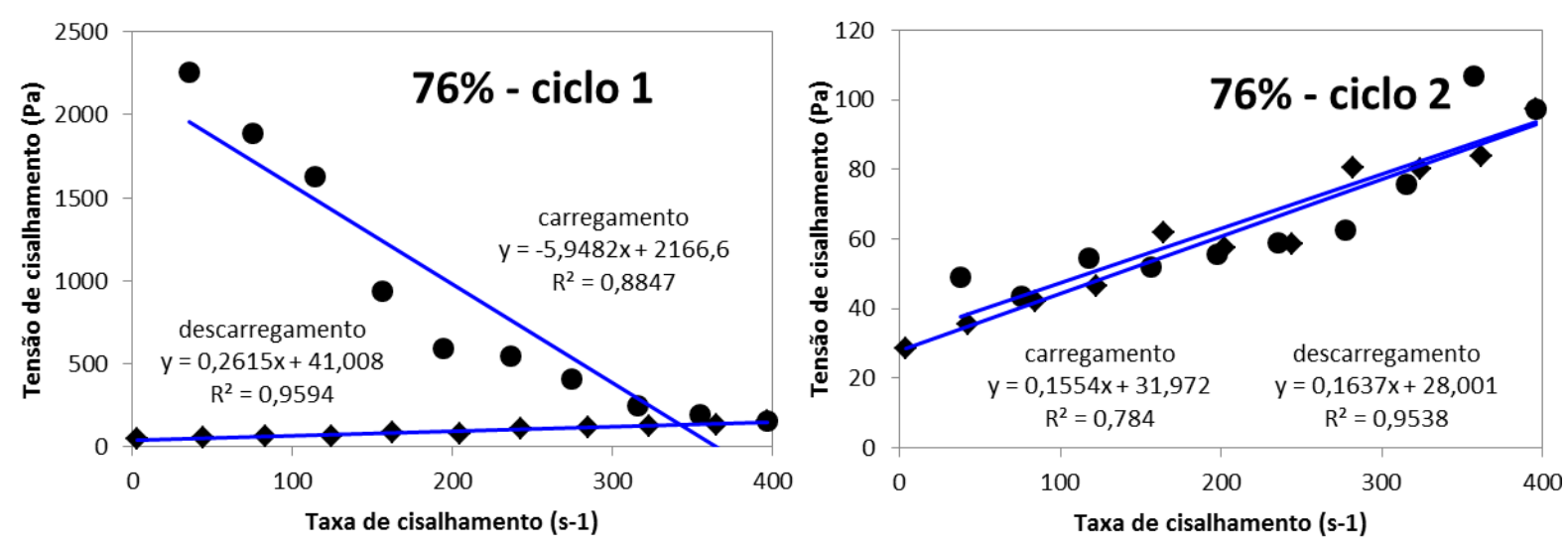

Figura A.59 PP - Bingham - colúvio - $w=76 \%$
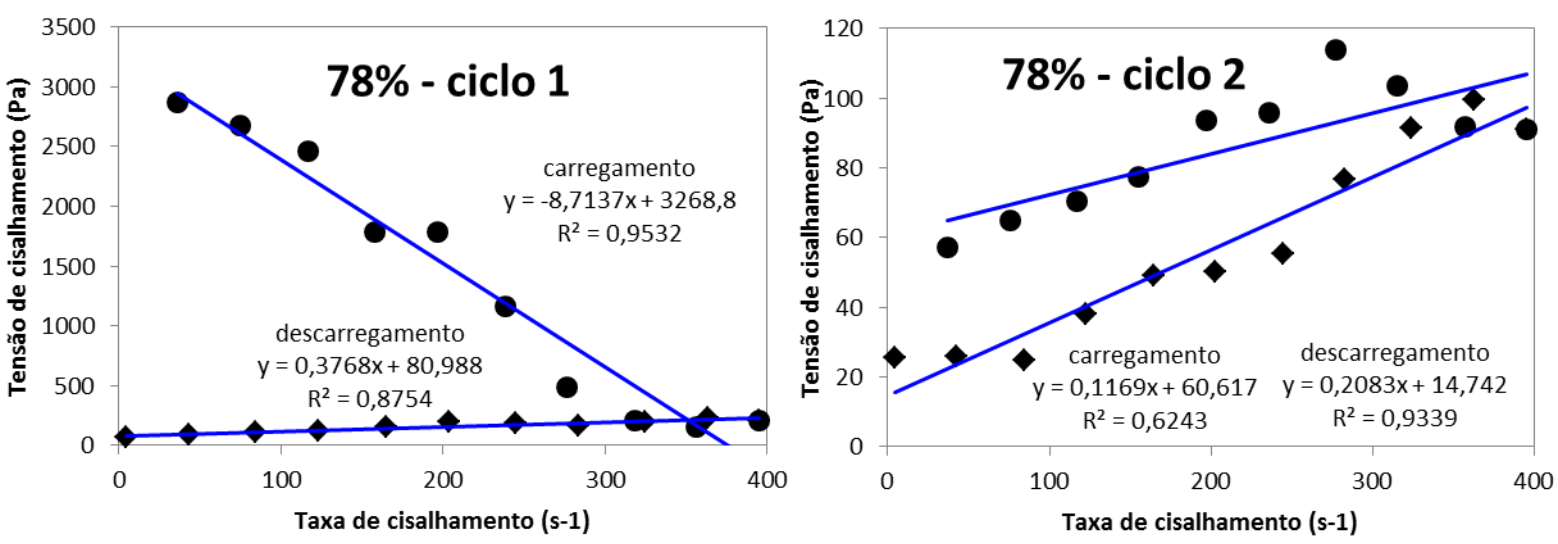

Figura A.60 PP - Bingham - colúvio - $w=79 \%$ 

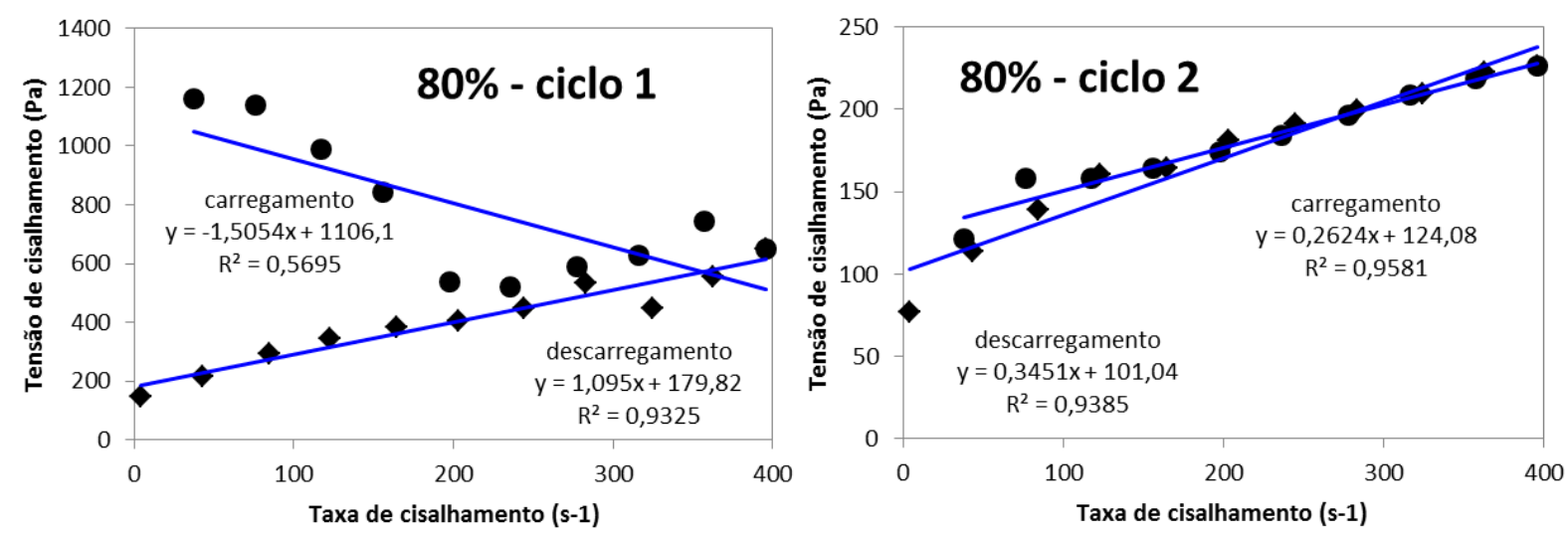

Figura A.61 PP - Bingham - colúvio - $w=80 \%$

\section{SOLO RESIDUAL}
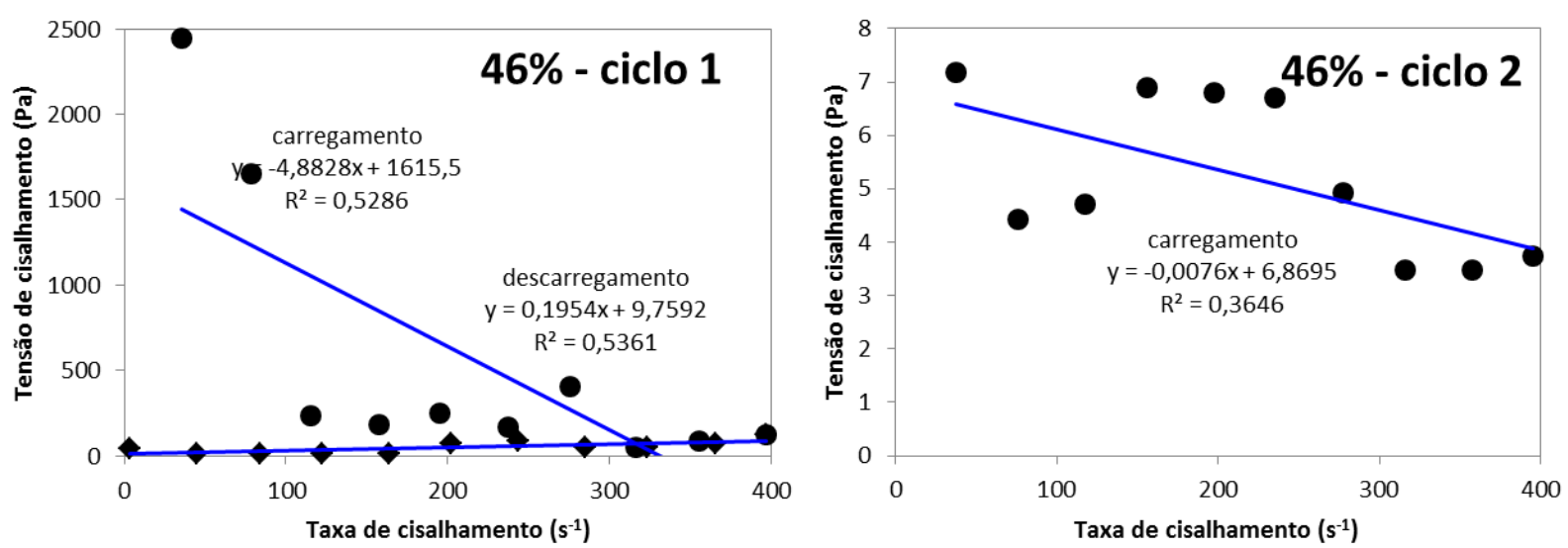

Figura A.62 PP - Bingham - residual - $w=46 \%$
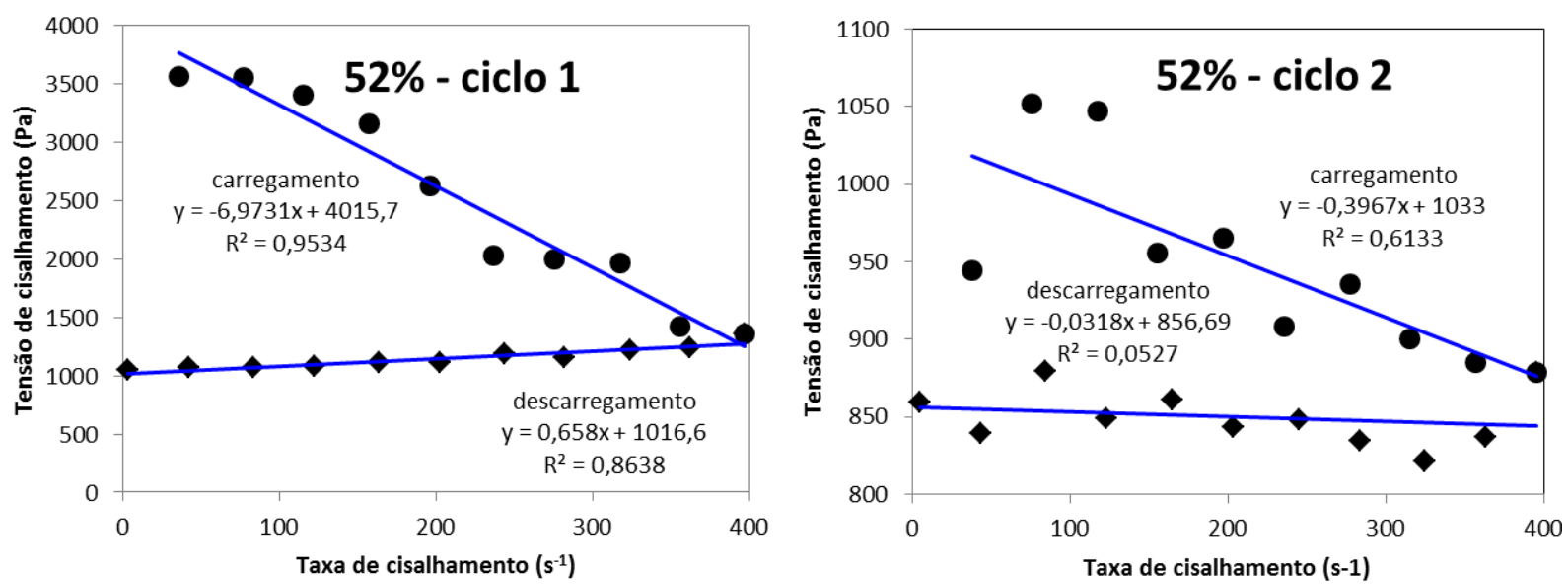

Figura A.63 PP - Bingham - residual - $w=52 \%$ 

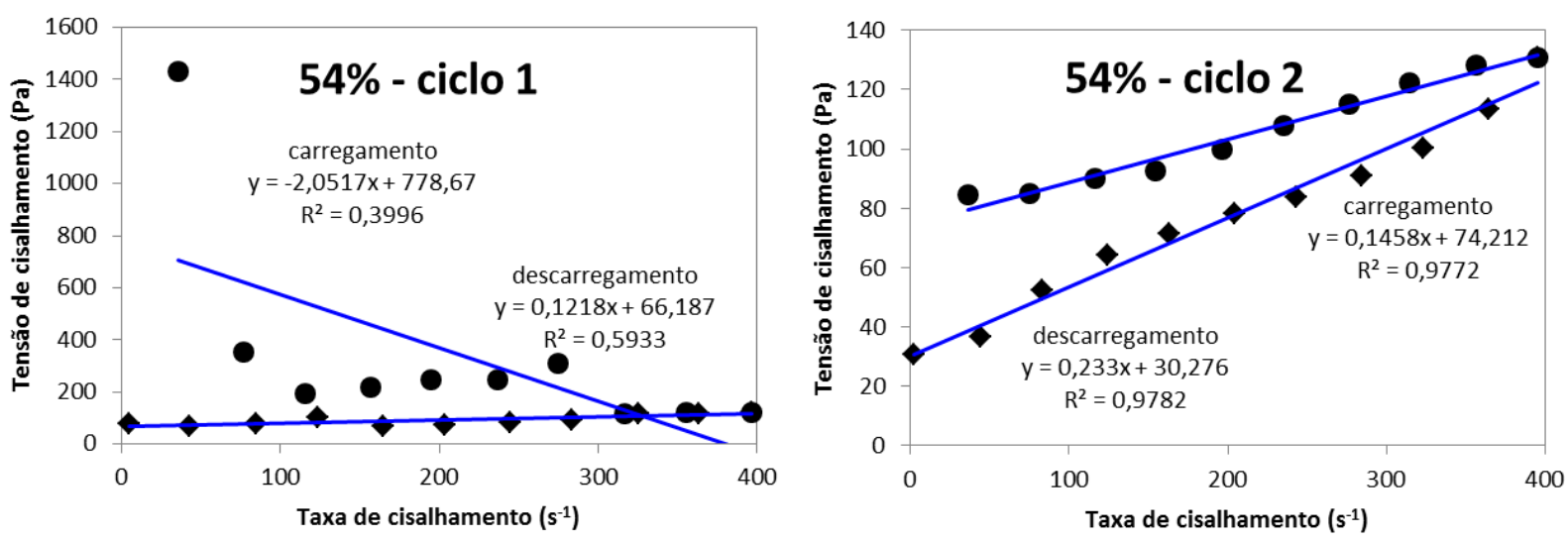

Figura A.64 PP - Bingham - residual - $w=54 \%$
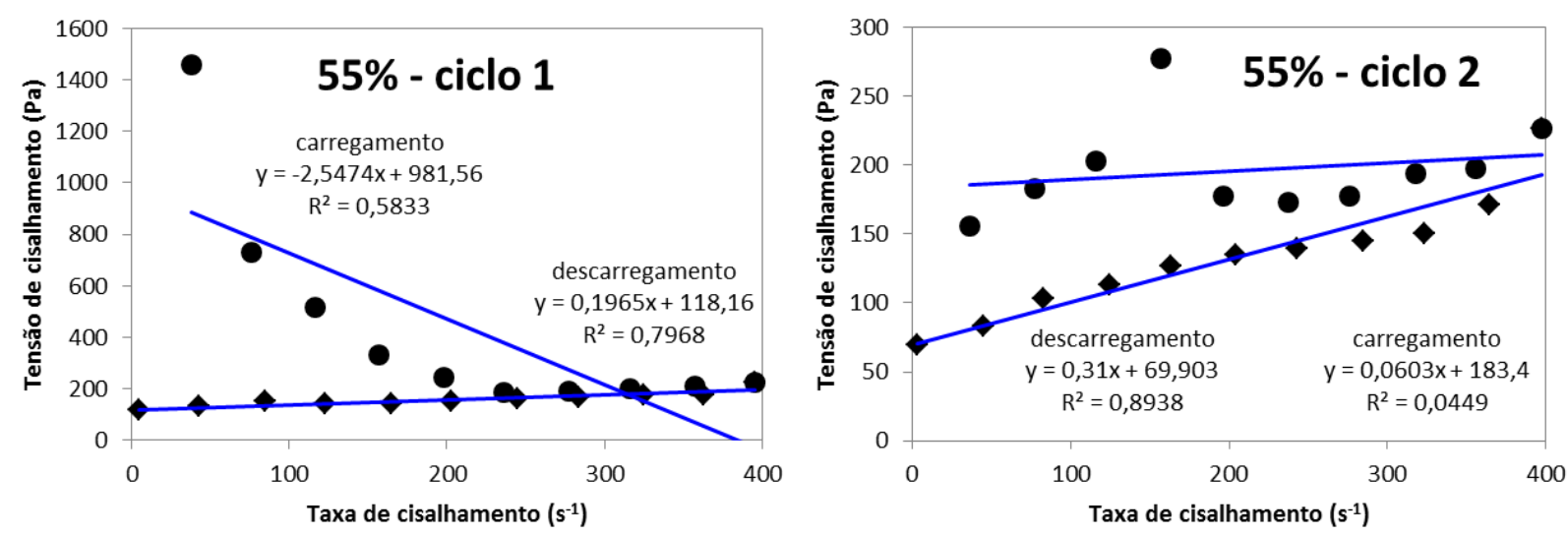

Figura A.65 PP - Bingham - residual - $w=55 \%$
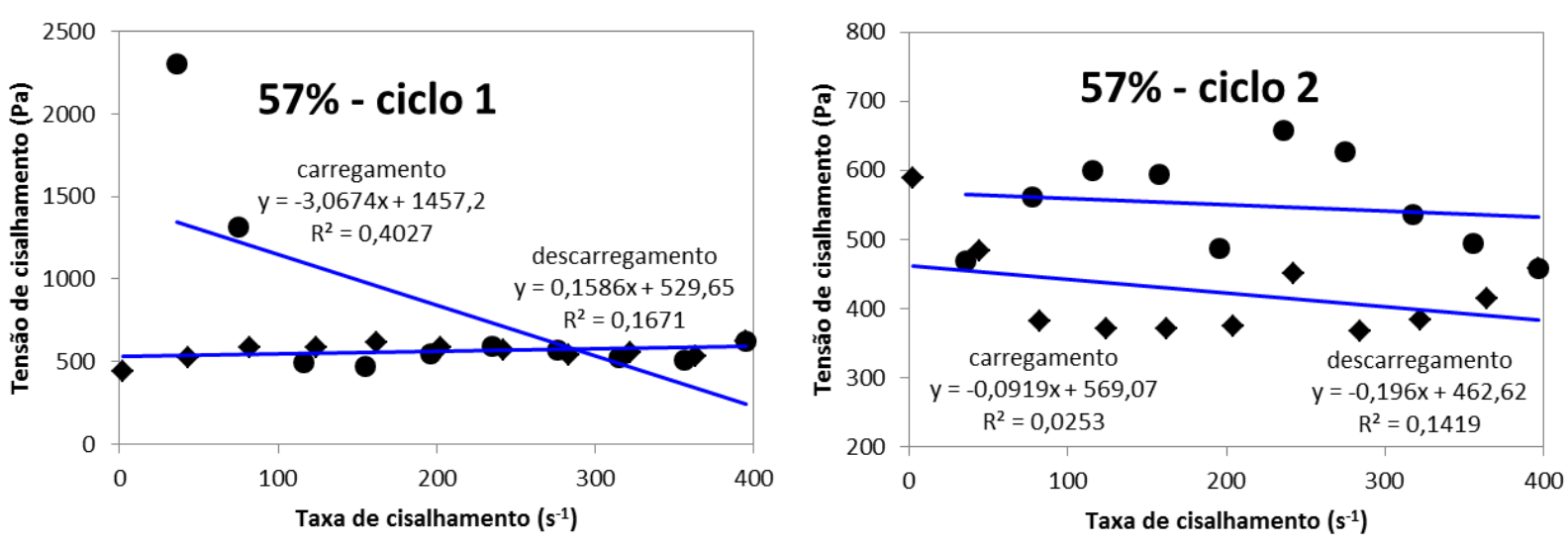

Figura A.66 PP - Bingham - residual - w $=57 \%$ 

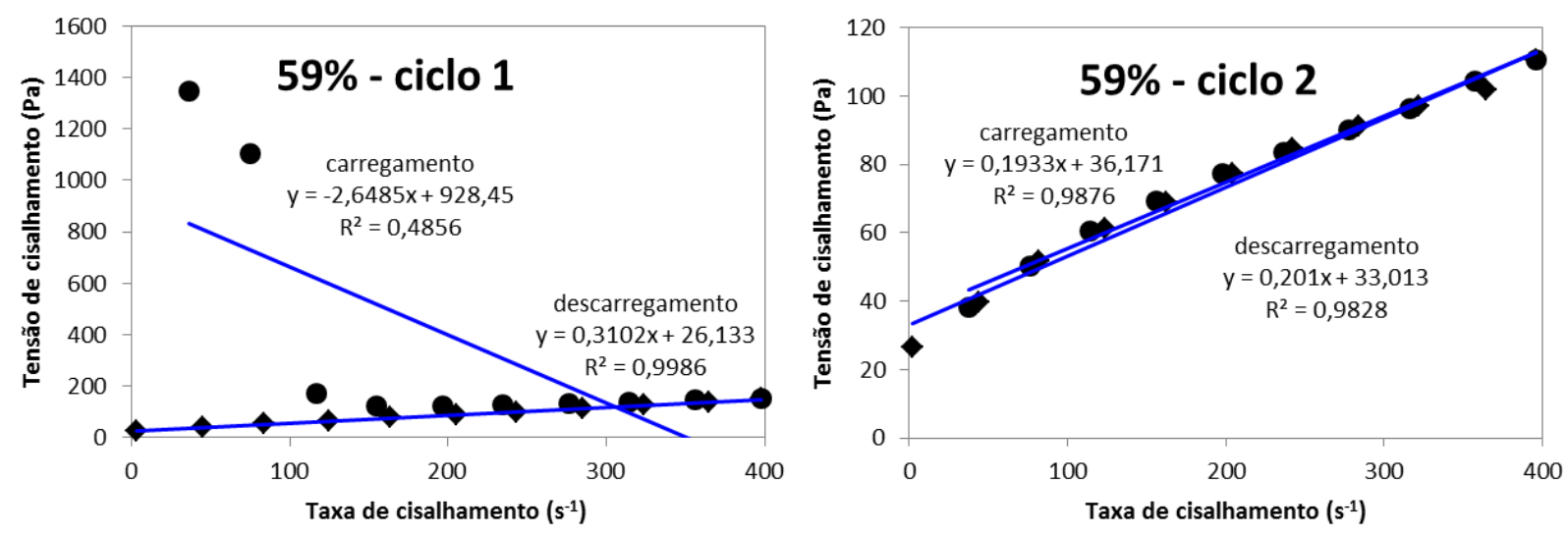

Figura A.67 PP - Bingham - residual $-\mathrm{w}=59 \%$
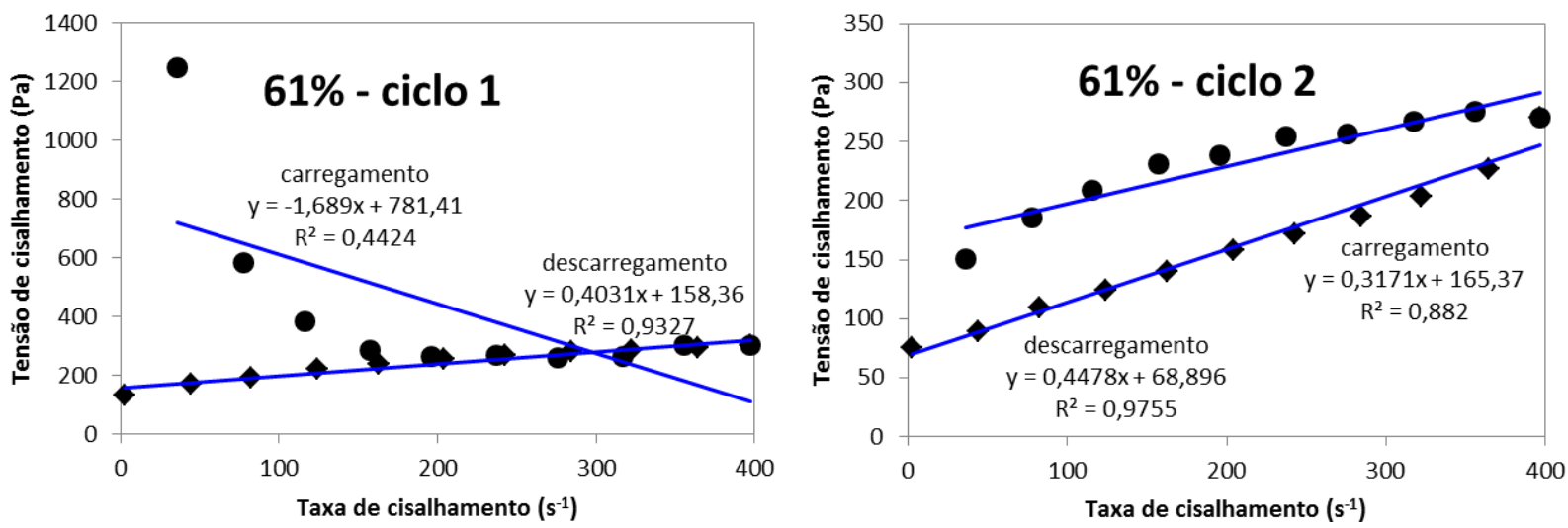

Figura A.68 PP - Bingham - residual $-\mathrm{w}=61 \%$

\section{A.3.2.Modelo de Herschel Bulkley}

O ajuste pelos modelos seguintes foi realizado apenas para o segundo ciclo de aplicação de carregamento/descarregamento. Alguns dos dados obtidos apresentaram valores negativos e não foram analisados o descarregamento das amostras com os seguintes teores de umidade do colúvio: $67 \%, 69 \%$ e $71 \%$. 


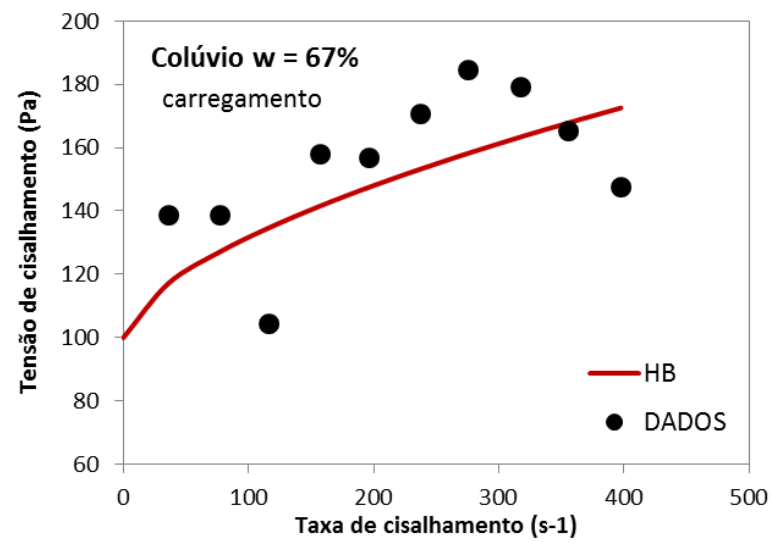

Figura A.69 PP - Herschel Bulkley - colúvio - w = 67\%

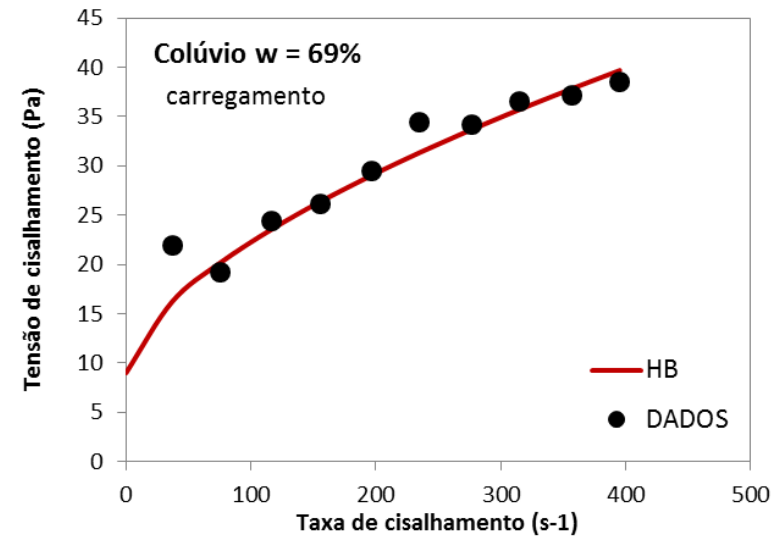

Figura A.70 PP - Herschel Bulkley - colúvio - w = 69\%

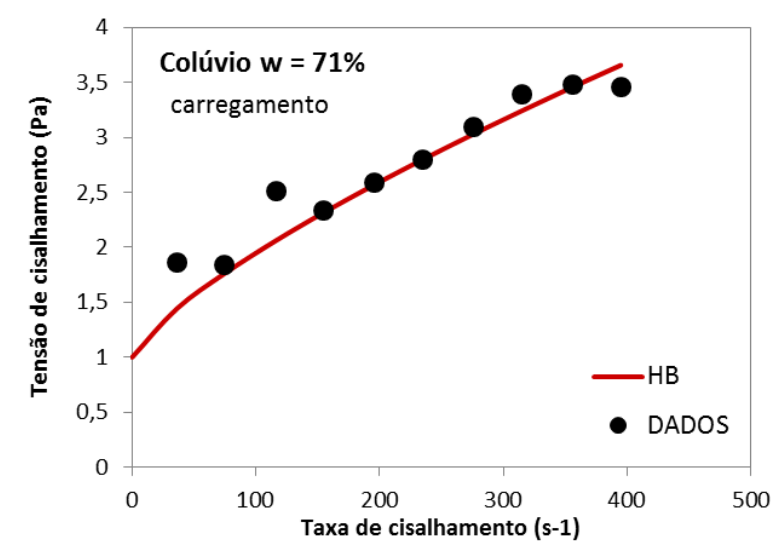

Figura A.71 PP - Herschel Bulkley - colúvio - w = 71\% 

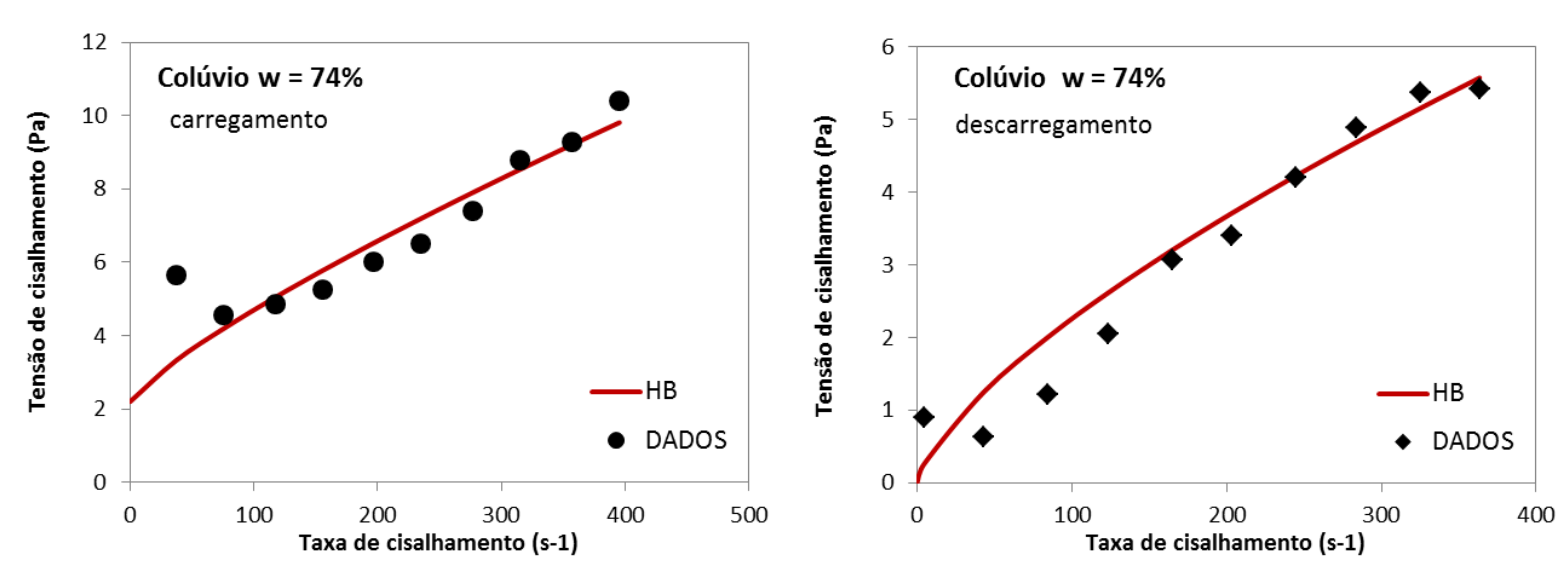

Figura A.72 PP - Herschel Bulkley - colúvio - w = 74\%
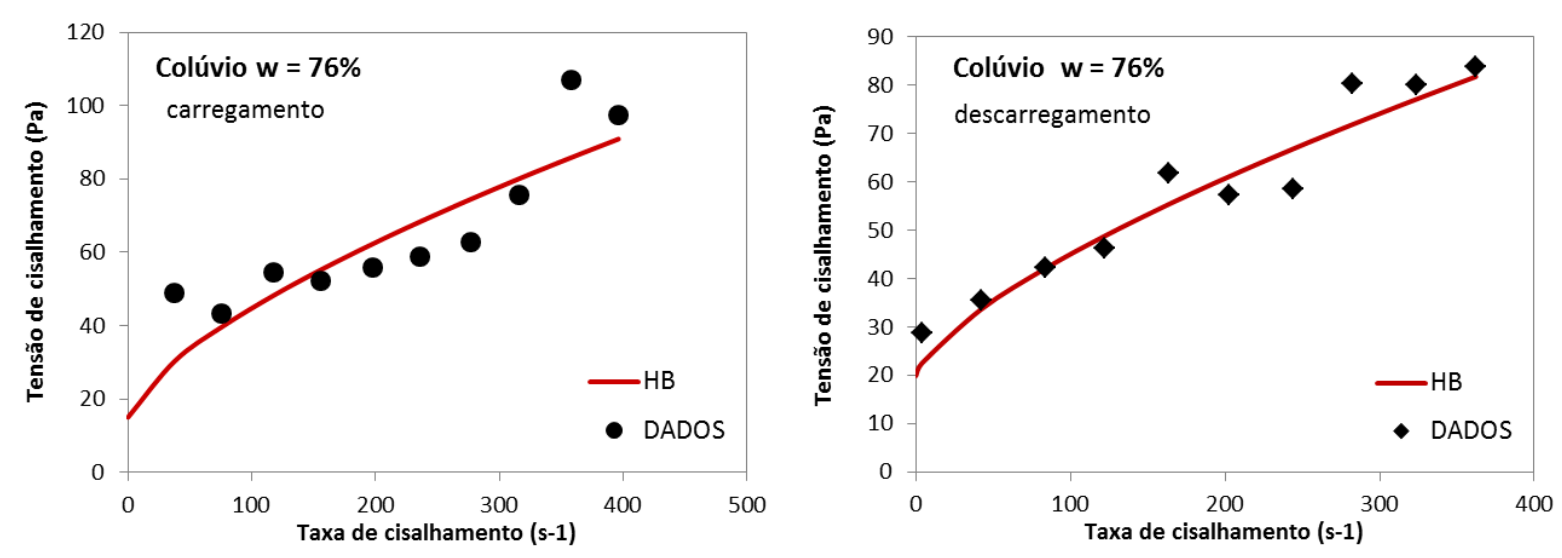

Figura A.73 PP - Herschel Bulkley - colúvio - w = 76\%
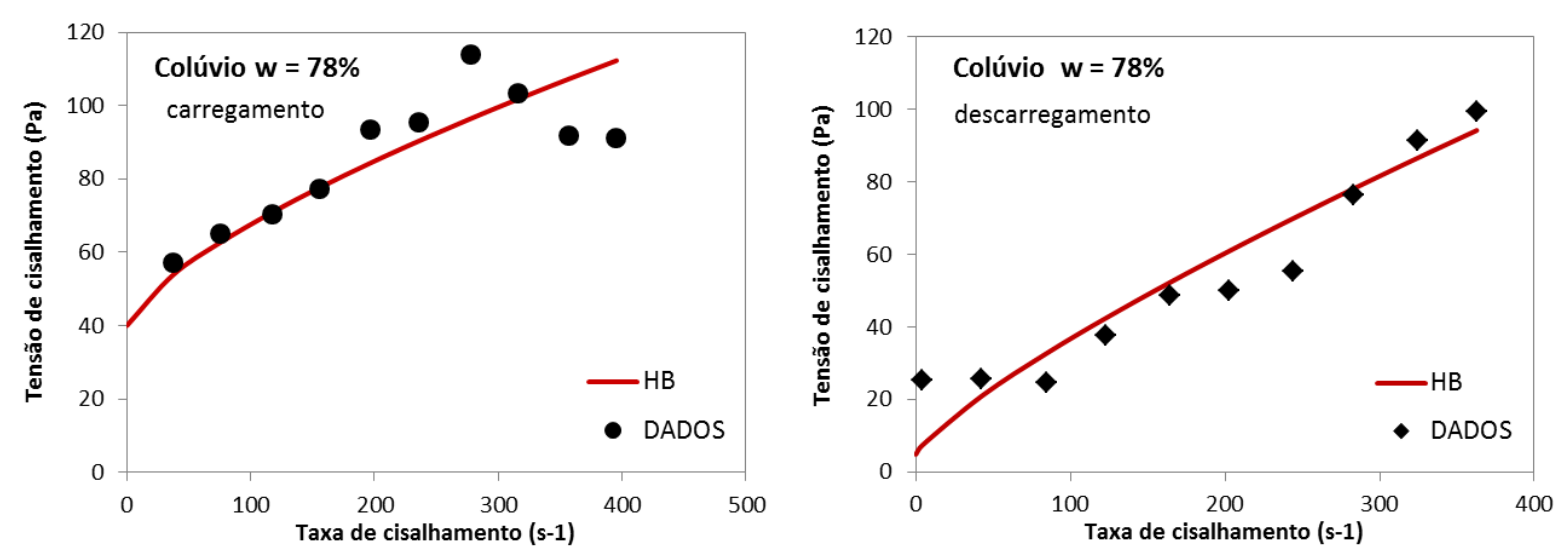

Figura A.74 PP - Herschel Bulkley - colúvio - w = 78\% 

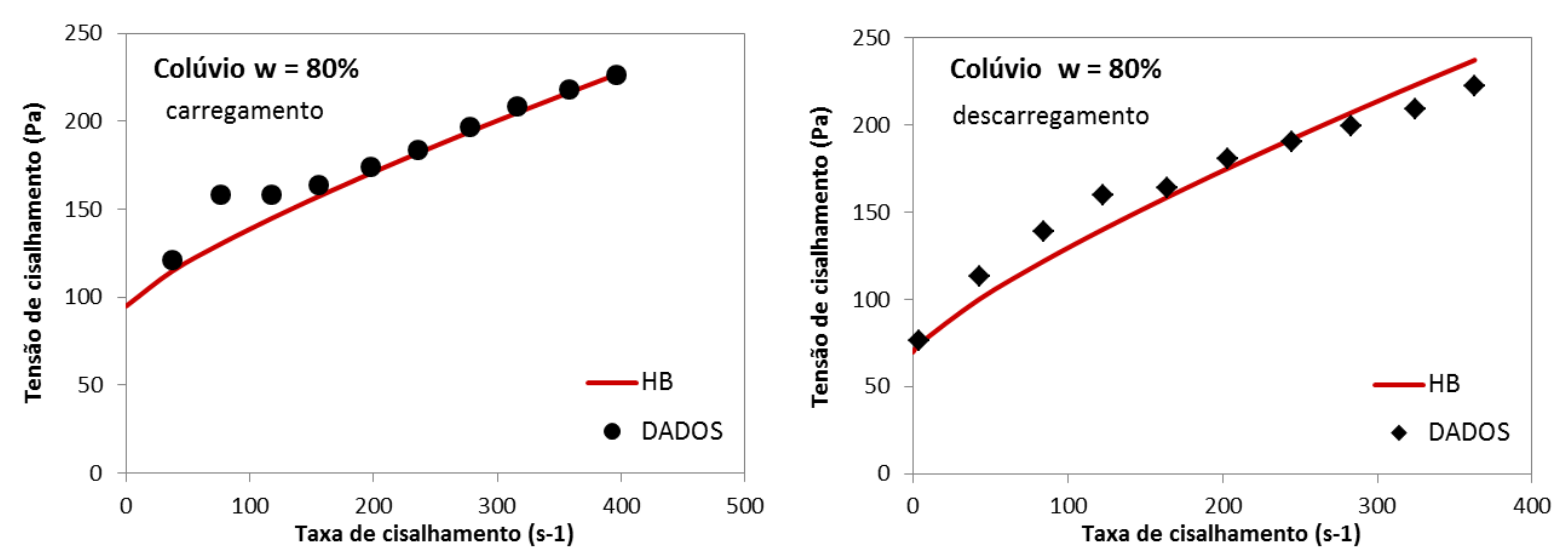

Figura A.75 PP - Herschel Bulkley - colúvio - w = 80\%

\section{SOLO RESIDUAL}
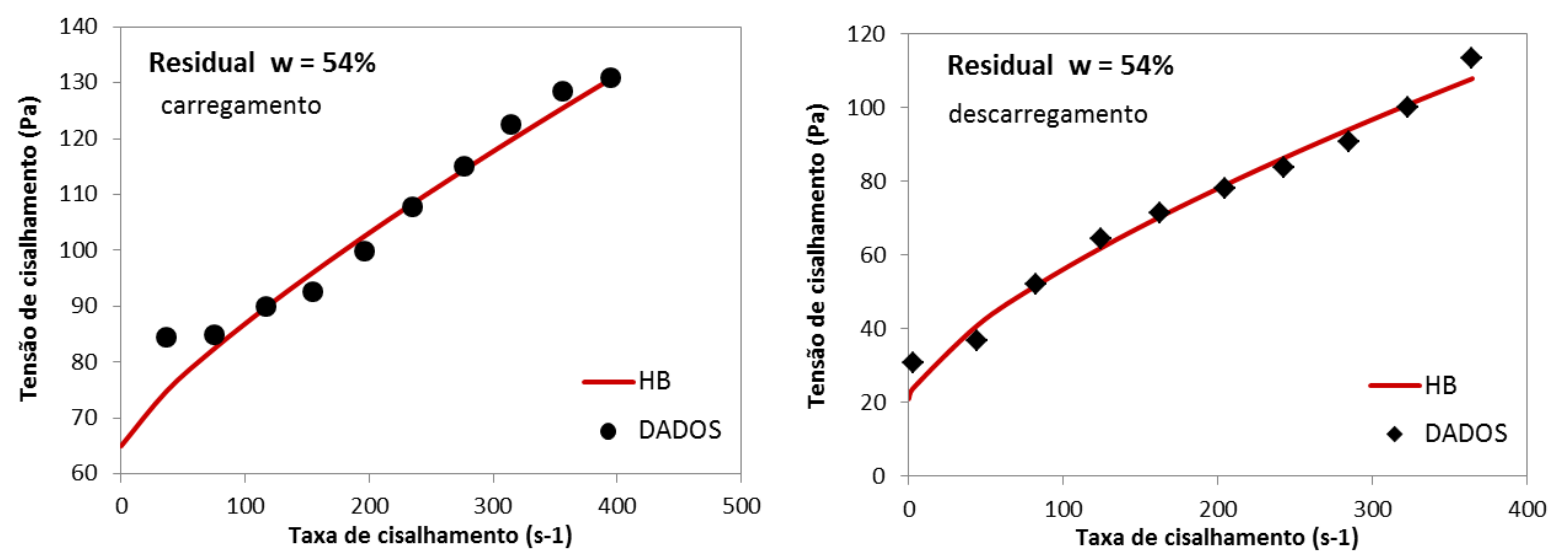

Figura A.76 PP - Herschel Bulkley - residual - w = 54\%
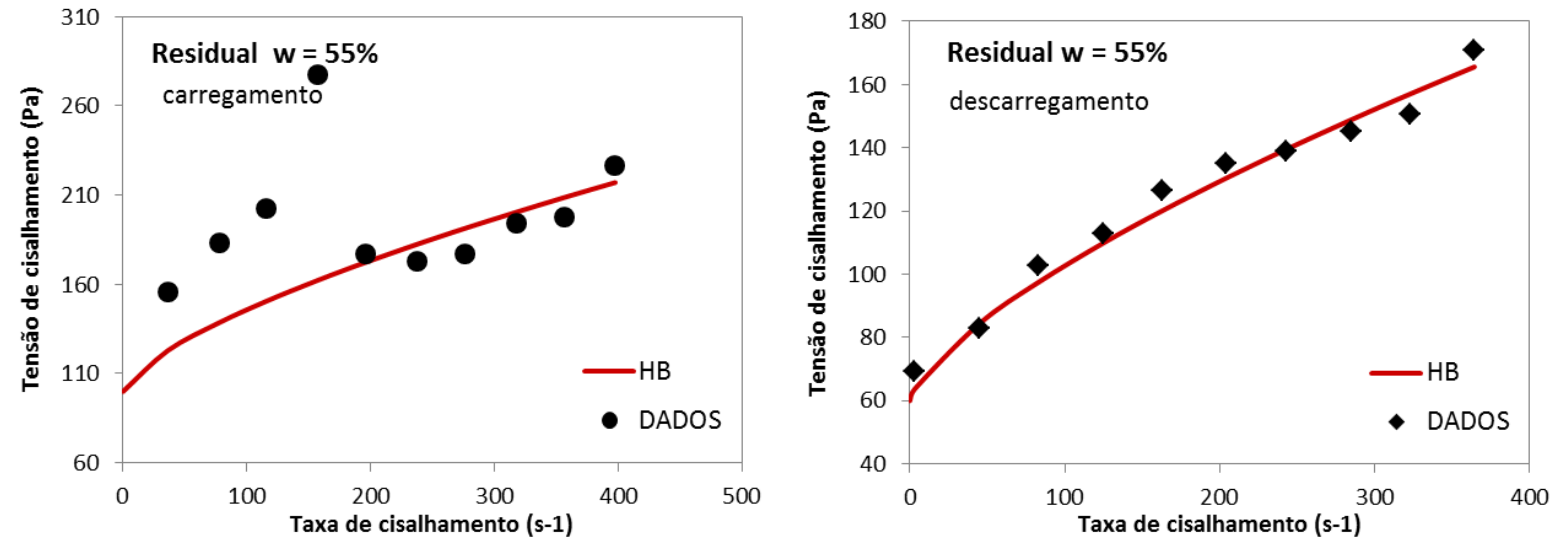

Figura A.77 PP - Herschel Bulkley - residual - $w=55 \%$ 

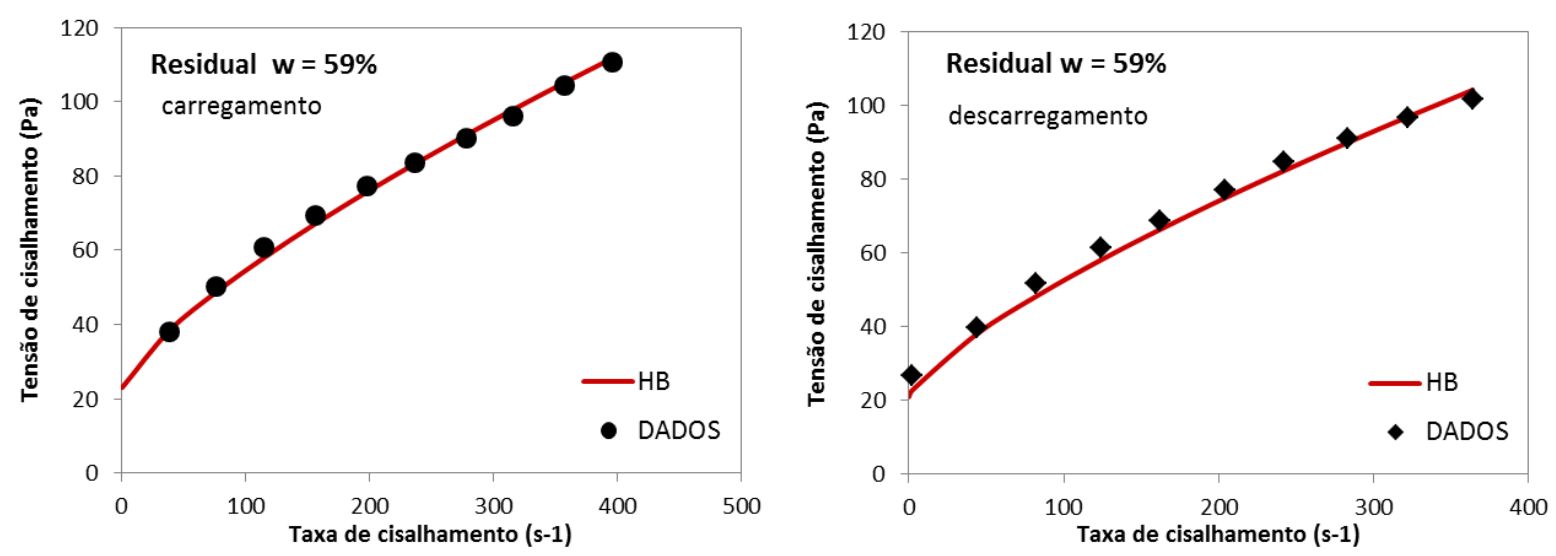

Figura A.78 PP - Herschel Bulkley - residual - w = 59\%
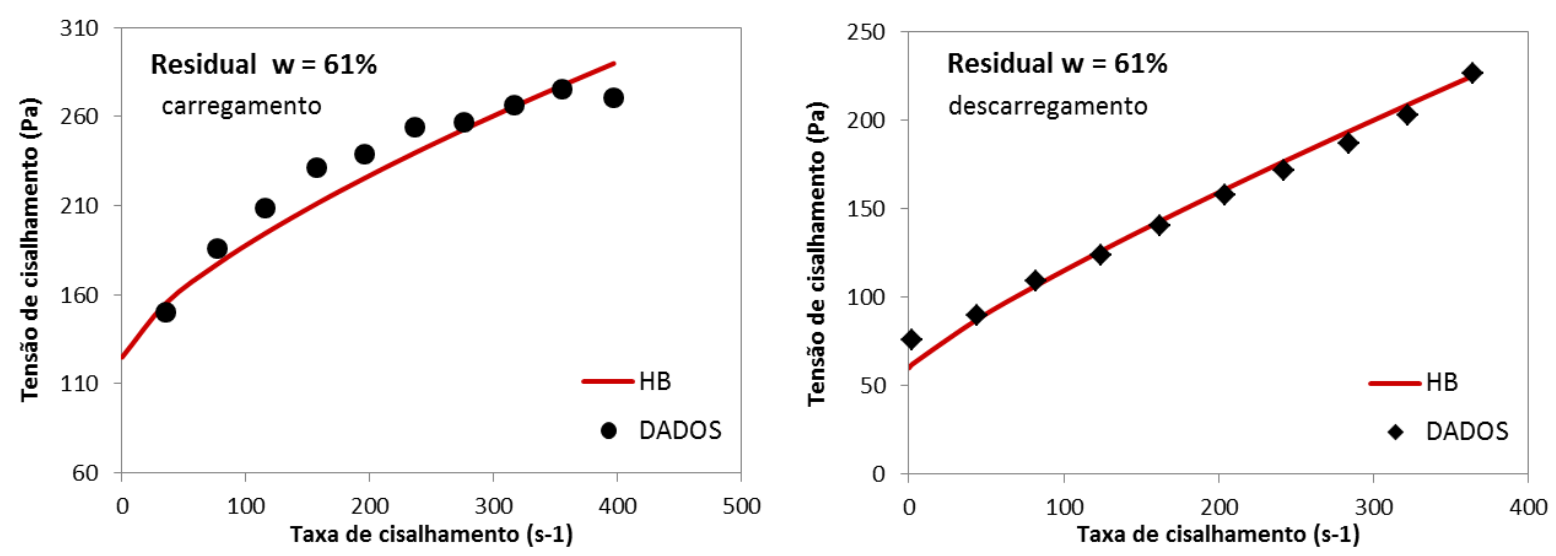

Figura A.79 PP - Herschel Bulkley - residual $-\mathrm{w}=61 \%$

\section{A.3.3.Modelo de Herschel Bulkley corrigido por Papanastasiou}

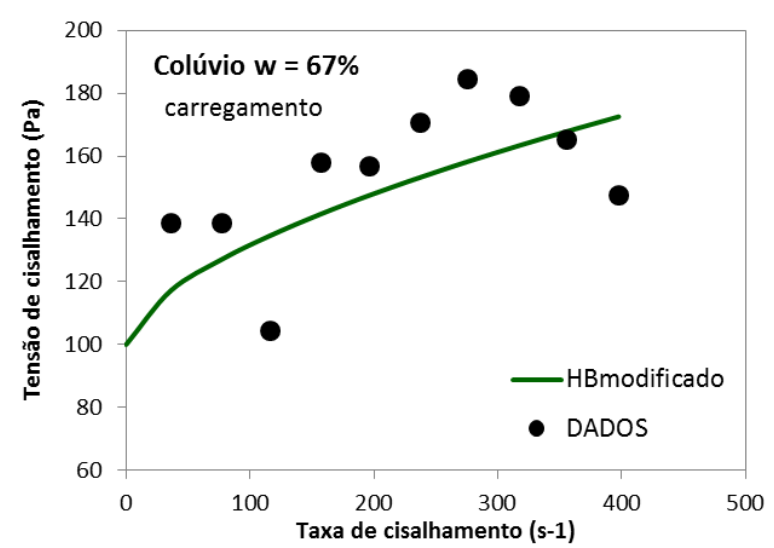

Figura A.80 PP - Herschel Bulkley modificado- colúvio - w = 67\% 


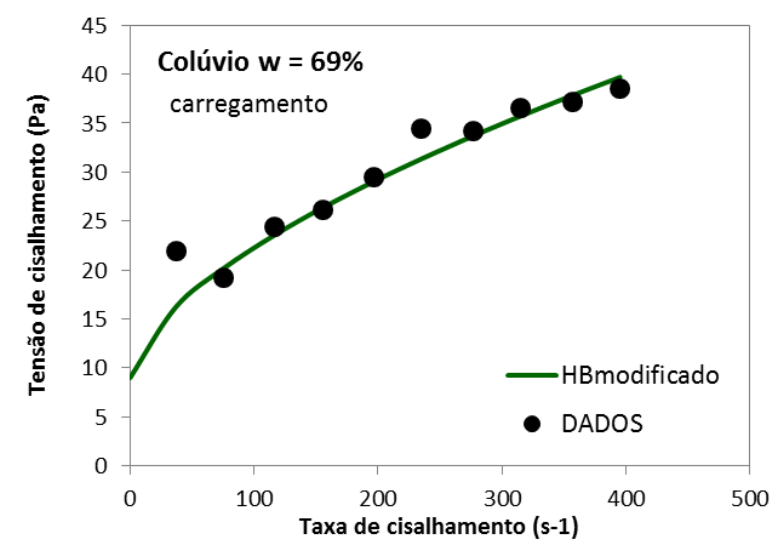

Figura A.81 PP - Herschel Bulkley modificado- colúvio - w = 69\%

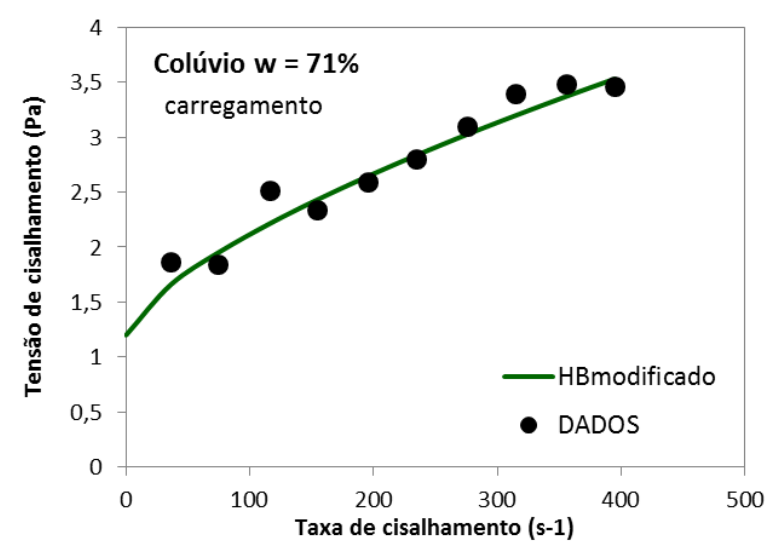

Figura A.82 PP - Herschel Bulkley modificado- colúvio - $w=71 \%$
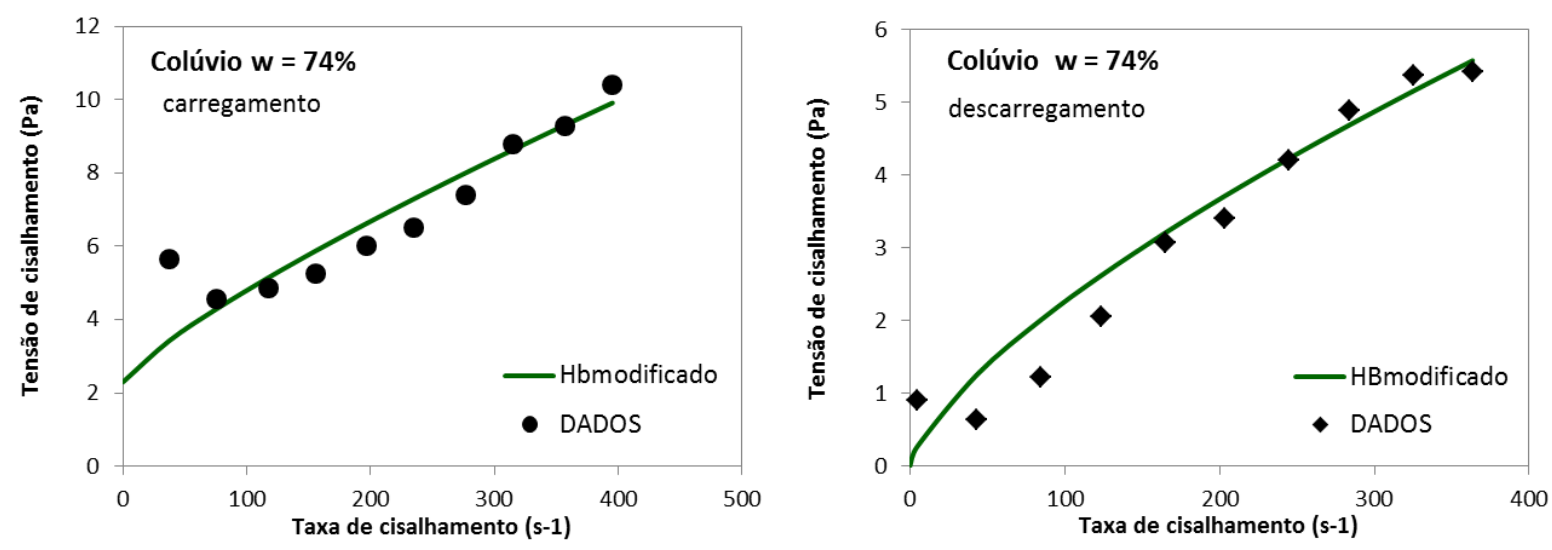

Figura A.83 PP - Herschel Bulkley modificado- colúvio - $\mathbf{w}=\mathbf{7 4} \%$ 

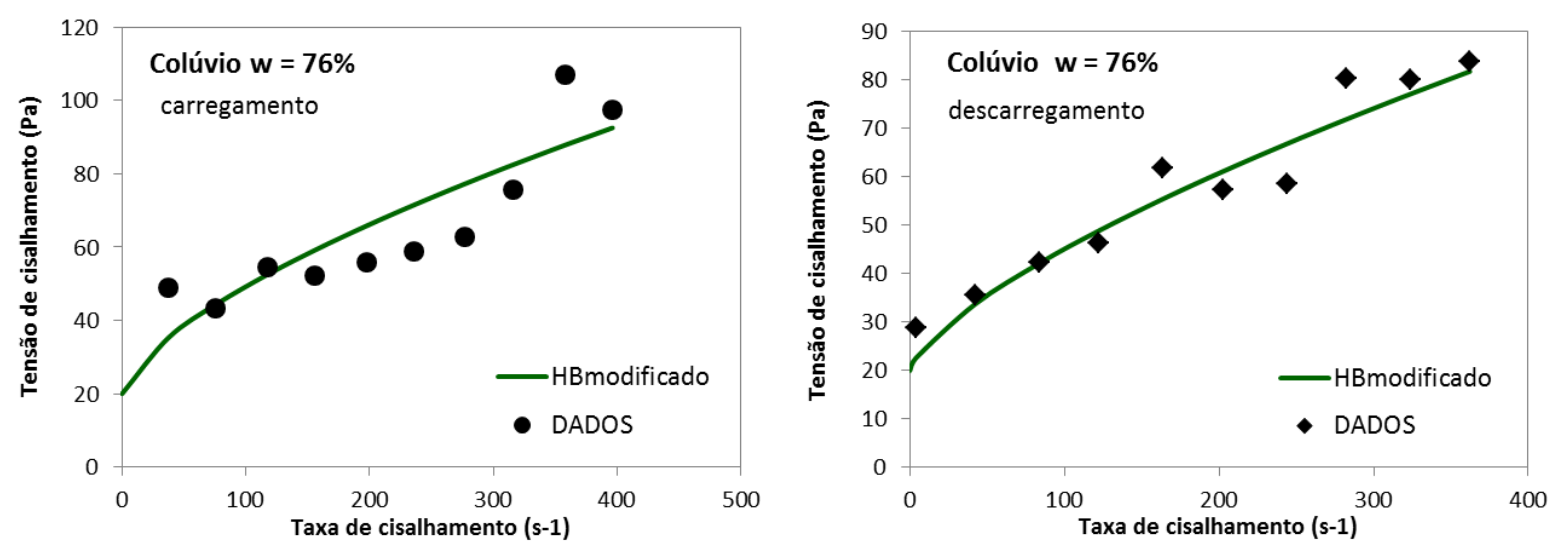

Figura A.84 PP - Herschel Bulkley modificado- colúvio - w = 76\%
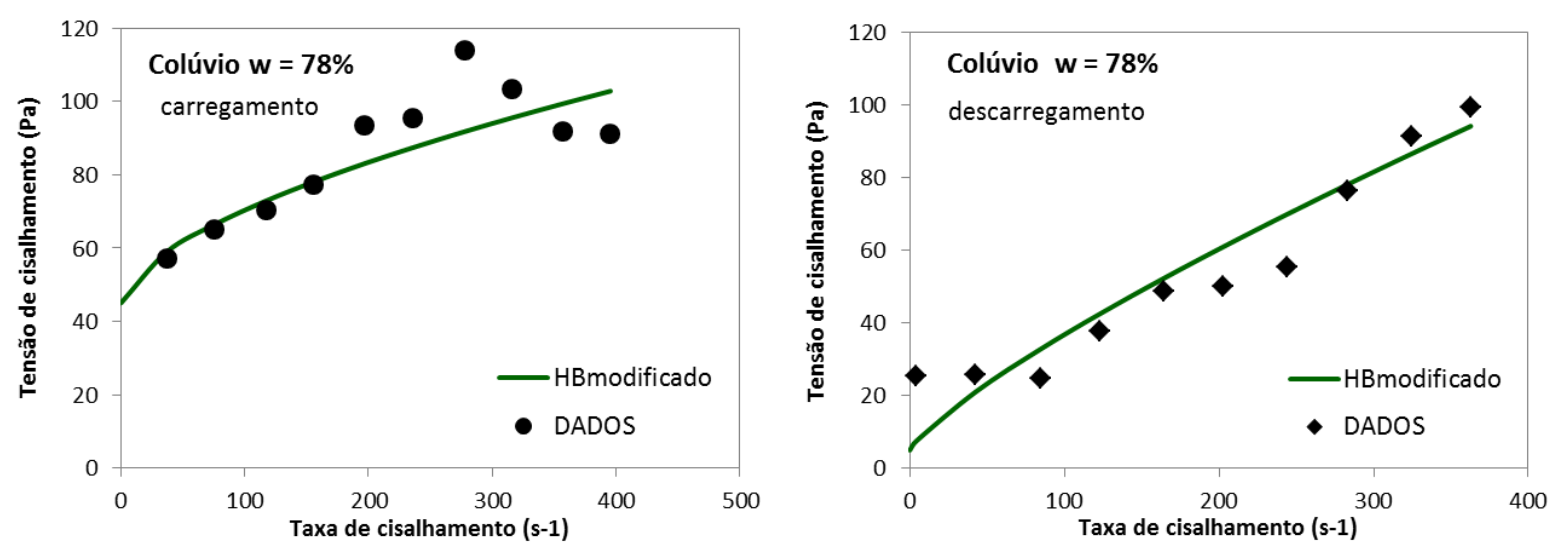

Figura A.85 PP - Herschel Bulkley modificado- colúvio - $\mathbf{w}=\mathbf{7 8} \%$
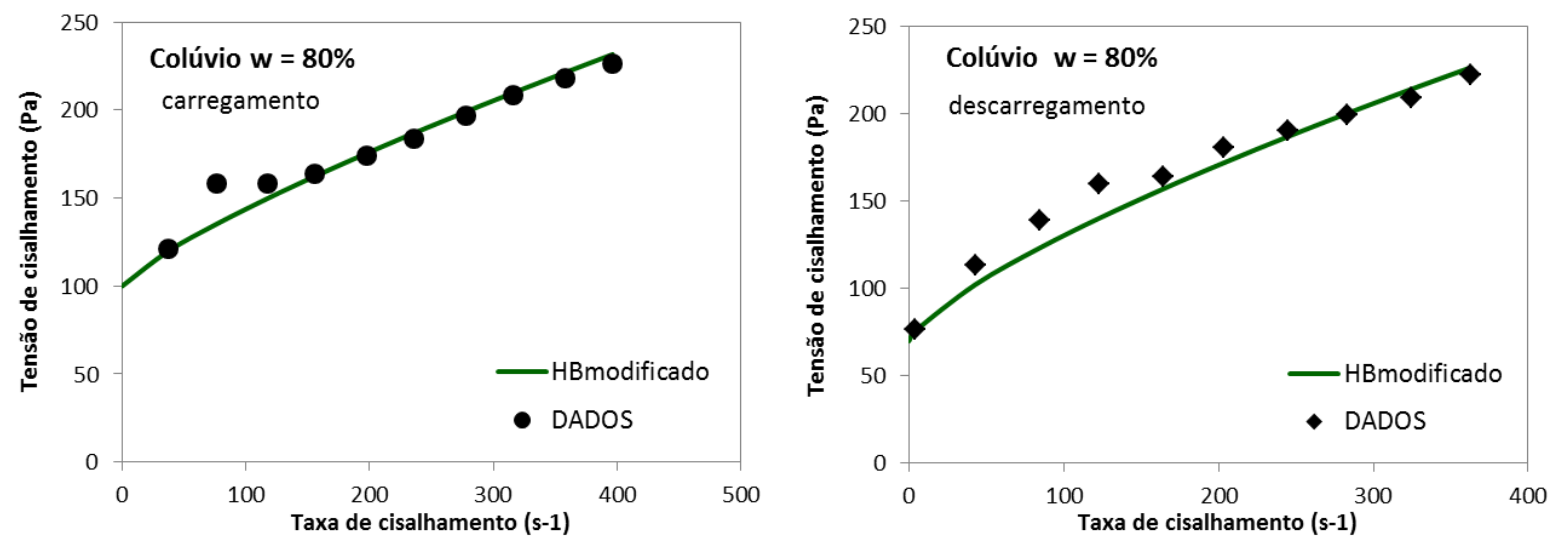

Figura A.86 PP - Herschel Bulkley modificado- colúvio - $\mathbf{w}=\mathbf{8 0} \%$ 

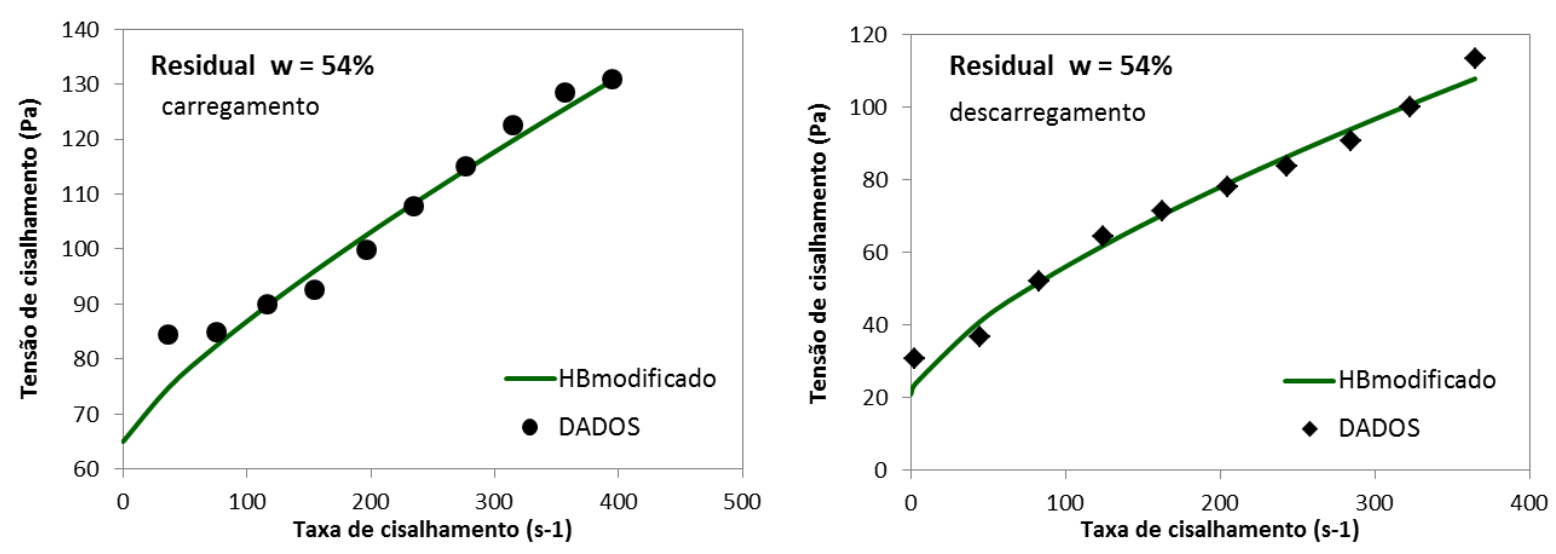

Figura A.87 PP - Herschel Bulkley modificado- residual - $w=54 \%$
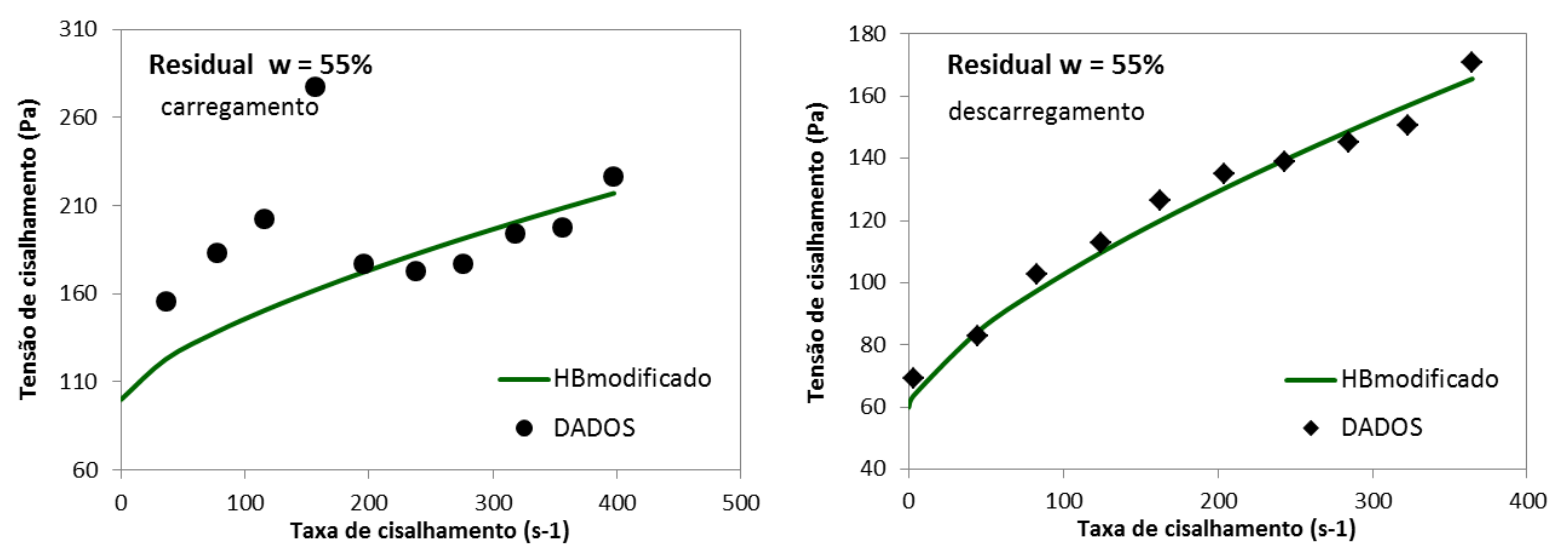

Figura A.88 PP - Herschel Bulkley modificado- residual - $\mathbf{w}=55 \%$
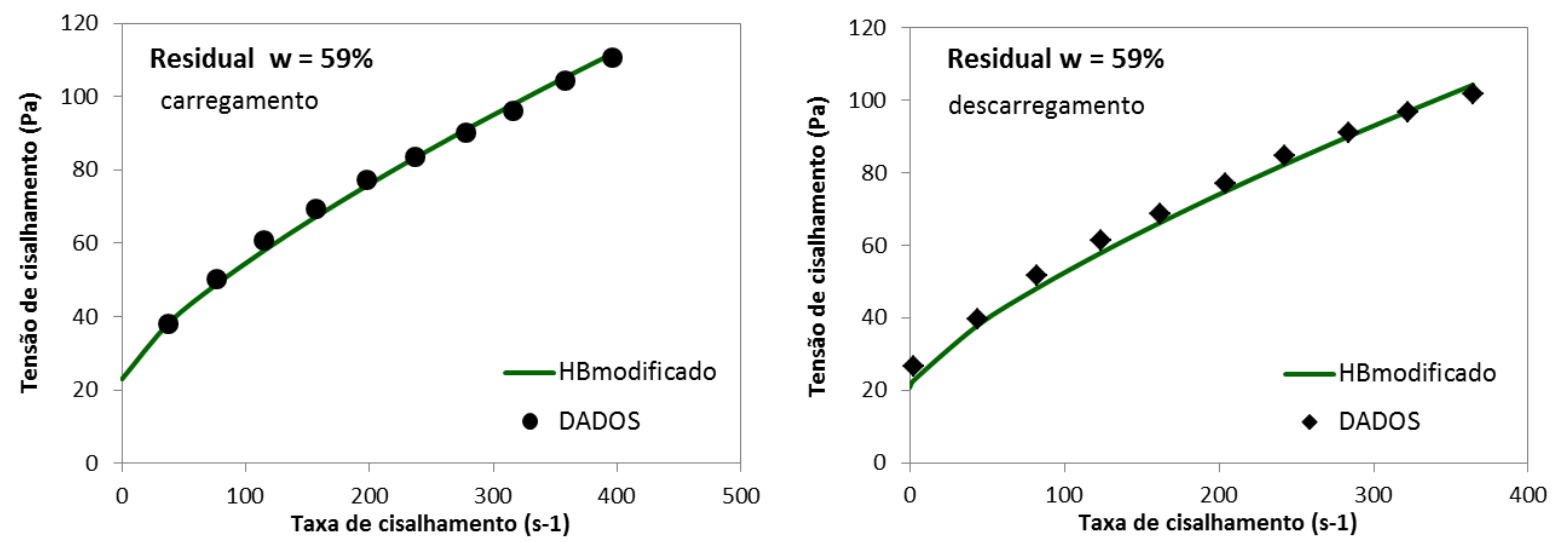

Figura A.89 PP - Herschel Bulkley modificado- residual - $w=59 \%$ 

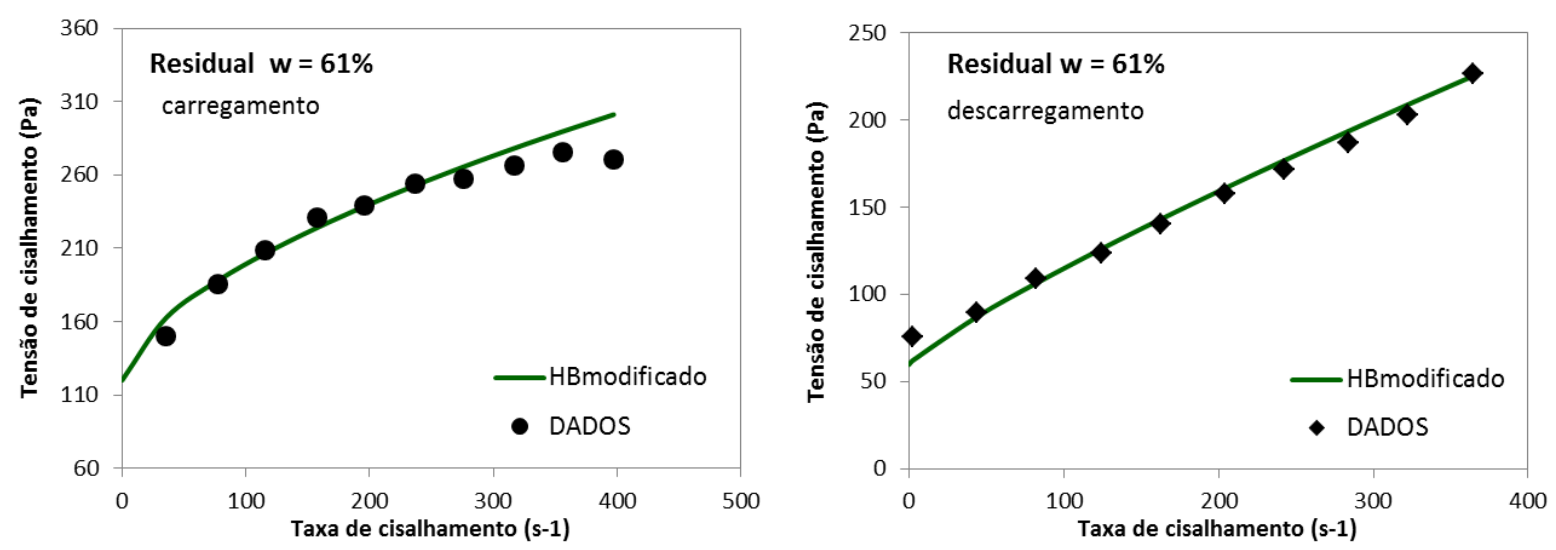

Figura A.90 PP - Herschel Bulkley modificado- residual - $w=61 \%$ 